

\section{På liv og død}

Palliasjon til alvorlig syke og døende

Utredning fra utvalg oppnevnt ved kongelig resolusjon 11. mai 2016.

Avgitt til Helse- og omsorgsdepartementet 20. desember 2017. 
ISSN 0333-2306

ISBN 978-82-583-1343-1

07 Media AS 


\section{Til Helse- og omsorgsdepartementet}

Ved kongelig resolusjon 11. mai 2016 oppnevnte regjeringen Solberg et utvalg som skal gjennomgå og vurdere dagens palliative tilbud. I mandatet ble utvalget bedt om å vurdere innholdet i tjenestene, uavhengig av diagnose, alder eller andre forhold, gjennom hele sykdomsperioden og frem til livets avslutning. På denne bakgrunn ble utvalget bedt om å foreslå tiltak som skal bidra til å styrke kvalitet, kompetanse, samhandling, faglig omstilling og nye arbeidsformer samt tverrfaglig samarbeid. Pasientenes og de pårørendes behov skal stå i sentrum. Opprinnelig medlem Ann Ragnhild Broderstad trakk seg i august 2017. Sigve Andersen ble oppnevnt som nytt medlem i april 2017.

Oslo, 20. desember 2017

Stein Kaasa, leder

Sigve Andersen

Marianne Klungland Bahus

Peder Broen

Helge Farsund

Anne Marie Flovik

Søren Vincent Hagerup

Bodil Husby

Natasha Pedersen

Astrid Rønsen

Borrik Schjødt

Joran Slaaen

Ann Kristin Andresen

(sekretariatsleder)

Hilde Marie Rognlie

Sjur Bjørnar Hanssen 


\section{DØDEN}

Døden er ikke slik:

En knokkelmann

som kveler ditt siste, ville skrik

med heslig hand.

Døden er ikke angst og ljå

og djevlekrav,

ikke måneskygger

rundt ei ribbet grav.

Nei, døden er fjell som løfter sin svale snø over vegen du drar.

Der skal du stå den siste kveld, og se i skjær av solfalls-eld hvor vakkert livet var.

Hans Børli 


\section{Innhold}

\section{4}

4.1

4.2
Innledning

9

Hva er pallisjon?

Rett kompetanse på rett sted til

rett tid

9

Den doende pasienten ...

Planlegging og pasient-

medvirkning

Organisering

Pasienttilpassede forløp

Noen grunnelementer for å kunne

gi god palliativ behandling

\section{Sammendrag}

Kapittel 4 Verdier

Kapittel 5 Perspektiv

Kapittel 6 Pasienttilpassede forløp 13

Kapittel 7 Palliasjon

i utdanningene

Kapittel 8 Forskning

Kapittel 9 Organisering, struktur

og kompetanse

Kapittel 10 Pårørende

Kapittel 11 Frivillig innsats på

palliasjonsfeltet

Kapittel 12 Andre land

Kapittel 13 Balansen mellom

helsepersonells inngrepsplikt og

pasientenes selvbestemmelsesrett

Kapittel 14 Økonomiske og

administrative konsekvenser

Utvalgets arbeid

Oppnevning og sammensetning

av utvalget

Utvalgets mandat

Utvalgets forståelse av mandatet

og avgrensning av utvalgets

arbeid

Utvalgets bruk/forståelse av

enkelte sentrale begreper

Møter og arbeidsform i utvalget ...

Utvalgets innhenting av ulike

perspektiv

\section{Verdier}

Verdigrunnlag

Kommunikasjon og pasienters

rett til medvirkning - hva er

viktig for meg?

Etiske utfordringer: pasientenes

preferanser og rett behandlingsnivå .
4.3.1 Rett behandlingsnivå og

kvalitetsindikatorer

4.3.2 Pasientenes preferanser -

forhåndssamtaler

Etiske vurderinger ved palliasjon

til barn

Tiltak

Perspektiv

Et tilbakeblikk 34

Tidligere utredninger og

stortingsmeldinger

Økt medbestemmelse - fra

paternalistisk tilnærming til «pasientens helsetjeneste» og pasientens behov som utgangs-

punkt 35

Den internasjonale utviklingen .... 36

5.1 .4

5.1 .5

Utviklingen i Norge og Norden .... 37

Paradigmeskifte - fra kreft til andre diagnoser og integrasjon i hele sykdomsforløpet

Palliasjon til flere pasientgrupper

Framtidens utfordringer og behov

Kulturelle faktorer

Demografi og sykdomsutvikling .. 44

\section{6}

6.1

6.2

6.2 .1
Pasienttilpassede forløp ........... 50

Innledning ........................................ 50

Dagens situasjon ............................... 50

Hva er standardiserte pasientforløp?

Retningslinjer, planer og verktøy

for palliative forløp

Bruk av pasientforløp innen

palliasjon

Vurdering og drøfting av dagens praksis ....

Manglende samhandling og

fragmenterte tjenester

Manglende integrasjon av

palliasjon i behandlingen

Pasientmedvirkning i de palliative pasientforløpene

Tiltak

Palliasjon i utdanningene ........ 64

Innledning ......................................... 64

Dagens situasjon ............................... 65

Sentrale dokumenter ......................... 65

Palliasjon i utdanningene ............... 66 
7.3 Vurdering av omfang og innhold av palliasjon i utdanningene .......... 72

$7.4 \quad$ Tiltak ............................................. 74

$8 \quad$ Forskning …................................. 76

8.1 Innledning ...................................... 76

8.1.1 Kvaliteten på forskning

i palliasjonsfeltet

8.1.2 Økende behov for palliativ

forskning

8.2 Dagens status nasjonalt og

internasjonalt

8.2 .1

8.2 .2

8.3

8.3.1

8.3.2

8.3 .3

8.3.4

8.4

9

9.1

9.2

9.2 .1

9.2 .2

9.2 .3

9.2 .4

9.3

9.3 .1

9.3 .2

9.4

10

10.1

10.2

10.2.1

10.2 .2

10.2 .3

10.2 .4

10.2 .5

Historikk

Forskning internasjonalt og

i Norge

Vurdering og drøfting av dagens

forskning

Behov for forskning i palliasjon ....

Hva og hvem bør det forskes på? ..

Utvikling og styrking av palliativ

forskning

Finansiering

Konkrete forslag til tiltak -

forskning

\section{Organisering, struktur og}

kompetanse

Innledning

Dagens situasjon

Dagens organisering, struktur

og kompetanse i palliasjon

i spesialisthelsetjenesten

Dagens organisering av det

palliative tilbudet i den

kommunale helse- og omsorgs-

tjenesten

95

Barn og unge .................................... 100

Utskrivningsklare pasienter .......... 102

Vurdering og drøfting av dagens

praksis

102

6 sentrale målsettinger for

palliasjon

102

Framtidens modell: en integrert

palliativ modell

110

Tiltak

119

Pårørende

120

Innledning

120

Dagens situasjon

120

Sentrale dokumenter og føringer .. 120

Pårørende i et samfunns-

perspektiv

Informasjon og veiledningsplikt ... 121

Barn og unge som pårørende ....... 121

Pårørendes behov
10.2.6 Når pasienten ønsker å være

hjemme så lenge som mulig 123

10.2.7 Kontakten mellom pårørende og

helse- og omsorgstjenestene ........ 123

10.2.8 Pårørende til syke barn ................ 124

10.2.9 Velferdsordninger for pårørende .. 125

10.3 Vurdering og drøfting av dagens

praksis .

10.3.1 Kartlegging av pårørendes

omsorgsbyrde ................................. 127

10.3.2 Velferdsordninger for pårørende .. 127

10.4

11

11.1

11.2

11.2 .1

11.2 .2

11.2 .3

11.2 .4

Tiltak 128

Frivillige 129

Innledning 129

Dagens situasjon 129

Sentrale dokumenter og

anbefalinger for frivillig innsats ... 129

Tradisjon for frivillig arbeid .......... 130

Livsberikelse og livsstøtte ............ 130

Formelle forhold/rammer rundt

frivillige

131

11.3

11.4

Frivillighet i framtiden

132

Tiltak 132

\section{2}

12.1

12.2

12.3

12.4

12.5

12.6

12.7

Erfaringer fra andre land

133

Innledning

133

Danmark

133

Sverige

135

Finland

Storbritannia

138

Irland 139

Oppsummering - hva kan vi lære av våre naboland? 140

\section{3}

\section{Balansen mellom helse-}

personells inngrepsplikt

og pasientenes selv-

bestemmelsesrett ........................ 141

$13.1 \quad$ Mandat ............................................ 141

13.2 Avgrensing ...................................... 141

13.3 Dagens lovregler om inngreps-

plikt og selvbestemmelsesrett ...... 141

13.3.1 Inngrepsplikt - hjemmelsgrunnlag 141

13.3.2 Inngrepsvilkåret «påtrengende

nødvendig»

13.3.3

Unntak fra hjelpeplikten -

begrepet «døende»

13.3.4

Pasientens selvbestemmelsesrett

- pasientautonomi ........................... 143

13.3.5

13.3.6

Alvorlig syke barn

«Barnets beste» som et grunn-

leggende hensyn

13.3.7

Folkerettslige forpliktelser

145

13.4

Nordisk lovgivning 
13.4.1 Finsk rett

147

14.1

Innledning 155

13.4 .2

Svensk rett

147

14.2

Uendret ressursbruk

155

13.4 .3

Dansk rett

149

13.4 .4

Islandsk rett

14.3

13.4.5 Oppsummering av nordisk rettstilstand 150

13.5

En vurdering av om dagens

lovregler innebærer en riktig

150

14.4

Forslag som omhandler den

kommunale helse- og omsorgs-

tjenesten

grensedragning mellom helse-

personellets inngrepsplikt og

pasienters rett til å nekte liv-

reddende og livsforlengende

behandling

Mandat

13.5.2 Lovtekniske betraktninger

13.5.3 Utvalgets vurderinger av om dagens regler bør videreføres

Tiltak

\section{5}

Forslag som omhandler

14.6

spesialisthelsetjenesten

Utdanning

Forskning

Barn og unge 



\section{Kapittel 1 Innledning}

I palliasjon er den pasientsentrerte tilnærmingen en av hjørnesteinene. I all behandling, pleie og omsorg, skal pasientene tas med i beslutninger. Dette prinsippet bør gjelde uavhengig om målsettingen er å kurere, forlenge livet, lindre plager eller å ivareta pasienter som er døende. Dette er ikke tilfelle i Norge i dag. Derfor er det nødvendig med et utvidet perspektiv, bort fra en ensidig sykdomssentrert tilnærming, til å ta pasientperspektivet inn i alle områder i helse og omsorgstjenestene.

Det sykdomsrettede perspektivet kan forklares ved at leger ønsker pasientene det beste, fordi de er opplært til å behandle sykdommen gjennom studiene. Dette ønsker også pasientene, og derfor er og skal den sykdomssentrerte tilnærmingen fortsatt være sentral. Men i 2017 må en slik tilnærming suppleres med en helse- og omsorgstjeneste som er involverer pasientene. Dette er særlig viktig i palliasjon, og må tydeliggjøres i utdanningene $o g$ i forskningen. Videre må det gjøres organisatoriske endringer som må følges opp med nye økonomiske incentiver. Verdens Helseorganisasjon (WHO) endret sin definisjon av palliasjon i 2002. Da ble det presisert at palliasjon skal inn tidlig $\mathrm{i}$ pasientforløpene: «Palliative care is an approach that improves the quality of life for patients and their families facing the problem associated with life-threatening illness, to the prevention and relief of suffering by means of early identification and impeccible assesment and treatment of pain and other problems, physical, psychosocial and spiritual» (WHO, 2017).

Med denne nye definisjonen ble samtidig oppmerksomheten rettet mot viktige elementer av et pasientsentrert helsetilbud: «supportive care», «psychological care» og «social care». Noen steder ble to ulike paradigmer satt opp mot hverandre: sykdomsrettet tilnærming vs pasientrettet tilnærming. Dette ledet frem til diskusjoner og løsningsforslag om hvordan en pasientsentrert tilnærming kunne bli en del av den tradisjonelle sykdomssentrerte behandlingskulturen.

Flere studier har dokumentert at tidlig integrasjon av palliasjon kan bedre livskvaliteten til

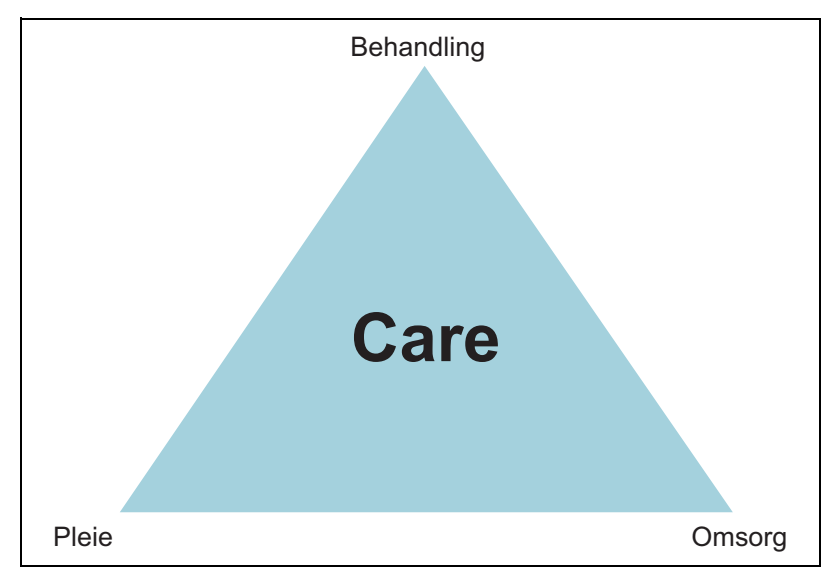

Figur 1.1 Palliasjon består av behandling, pleie og omsorg

både pasienter og pårørende, redusere bruk av unødvendig behandling mot livets slutt, begrense uhensiktsmessig bruk av intensivmedisin, og bidra til at flere kan dø hjemme og og være lengre og oftere hjemme.

Cecily Saunders, som etablerte det første moderne hospicet i London på 60-tallet, foreslo å bruke det grunnleggende begrepet «total pain». I dette ligger at man skal ivareta fire hovedområder for palliasjon: det fysiske, det psykiske, det sosiale og det åndelige/eksistensielle. For å lykkes med en slik bred tilnærming til pasienten og familien, kreves det en tverrfaglig kompetanse. Den tverrfaglige innsatsen, ofte i form av team, vil inneholde forskjellige yrkesgrupper avhengig av hvor pasienten er i helse- og omsorgstjenesten og hvilken pasientpopulasjon man ivaretar.

\subsection{Hva er pallisjon?}

Ordet palliative care er vanskelig å oversette direkte til norsk. «Care» har ofte blitt oversatt og forstått som behandling, pleie og omsorg. Ordet «palliasjon» kommer fra ordet «palliative care» og er stadig oftere brukt sammen med og i stedet for lindrende behandling og omsorg og hospice. Det spesielle med palliasjon er at tilnærmingen som 


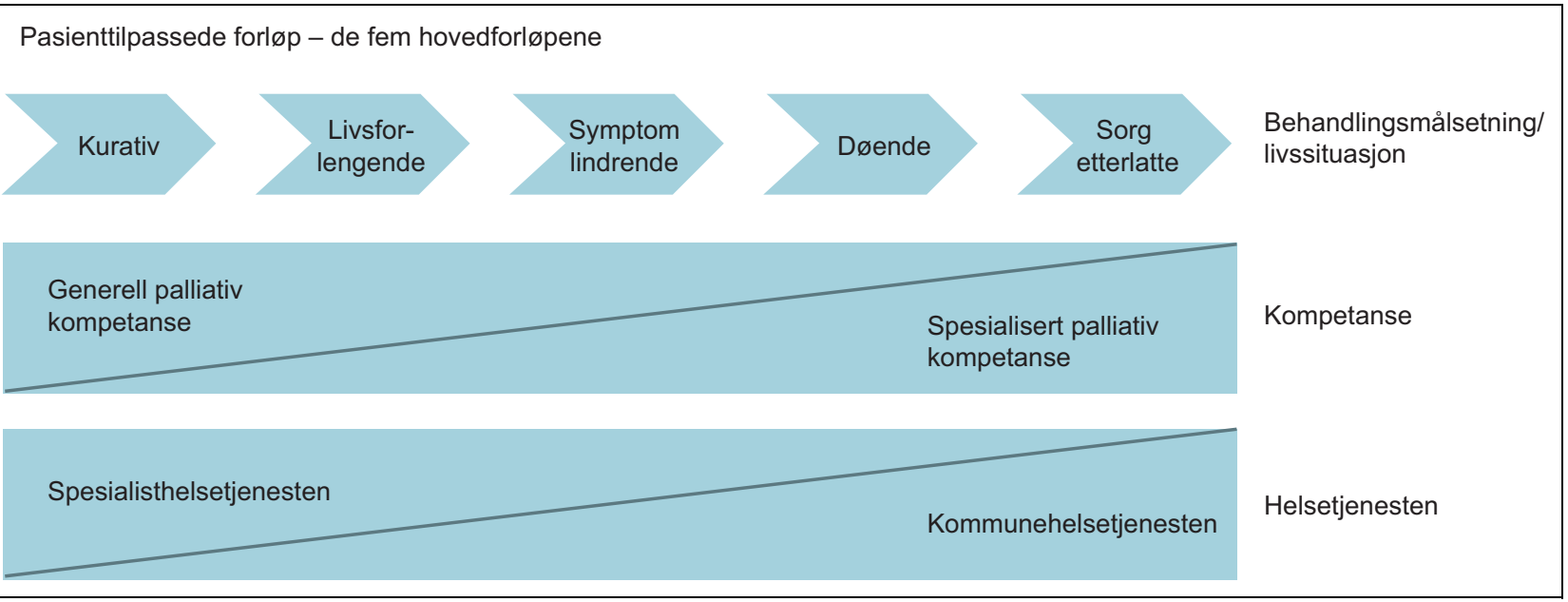

Figur 1.2 Behovet for spesialisert kompetanse

ligger til grunn for behandlingen og omsorgen er rettet mot den alvorlig syke og døende pasienten og hans/hennes reaksjoner på sykdom; fysisk, psykisk, sosialt og åndelig/eksistensielt. Integrasjon av palliasjon $\mathrm{i}$ tradisjonell somatisk medisin har som mål å gi et pasienttilpasset helsetilbud som kombinerer den sykdomsrettede tilnærmingen med den pasientsentrerte.

\subsection{Rett kompetanse på rett sted til rett tid}

Behandling kan kategoriseres ut ifra intensjon, det vil si hva man forventer å oppnå med behandlingen. Det er vanlig å bruke tre hovedkategorier for behandling (se figur 1.2). Kurativ, hvor målet er å helbrede, livsforlengende, hvor målet er å forlenge livet og symptomlindrende, hvor målsettingen er å lindre plager. Siden pasienter som trenger palliative tjenester nesten alltid har sammensatte behov, er det også nødvendig å koordinere den samlede kompetansen.

Figur 1.2 illustrerer at behovet for den spesialiserte palliative kompetansen skal være tilstede også når målsettingen er kurativ (helbredende) og livsforlengende. Figuren illustrerer også at alt helsepersonell skal ha generell palliativ kompetanse.

\subsection{Den døende pasienten}

Tradisjonelt har palliasjon vært forbundet med ivaretakelse av den døende pasienten og pårørende og sorgarbeid for etterlatte. Disse to områdene er og skal fortsatt være sentrale, slik det er illustrert i figur 1.2. De fleste pasienter i Norge dør på en helseinstitusjon, sykehus eller sykehjem, mens omkring 15 prosent dør hjemme. Mange pasienter ønsker å være hjemme så mye og så lenge som mulig mot livets slutt. En tverrfaglig tilnærming til pasient og pårørende er sentral. En tydelig etisk bevissthet hos helse og omsorgspersonell er en forutsetning for pasientens og pårørendes tillit til helse- og omsorgstjenesten, og det nasjonale likeverdige tilbudet den norske helse- og omsorgstjenesten er fundert på.

\subsection{Planlegging og pasientmedvirkning}

Pasientens behov i en sammensatt helse- og omsorgstjeneste kan lett bli uoversiktlig. Derfor har mange tatt til orde for og tatt konsekvensene av at «pasientens reise» i helse- og omsorgstjenestene må planlegges godt. Gode planer skal baseres på en analyse av den eksisterende organisasjonsstrukturen, ressursene og kompetansen man har tilgjengelig, den beste kunnskapen om hvordan pasienten skal behandles og dialog med pasient og pårørende. Pasienter som trenger palliativ behandling har ofte komplekse hjelpebehov. Derfor stilles det spesielle krav til gode analyser, god planlegging og stor grad av medvirkning fra pasient og pårørende.

\subsection{Organisering}

Hvordan helse- og omsorgstjenesten er organisert og ledet, er avgjørende for hvordan man evner å planlegge og implementere et kontinuerlig forbedringsarbeid. Flere av tiltakene som dette utvalget foreslår, vil kreve tilpasninger og endringer basert 
på den nåværende struktur innen helse- og omsorgstjenesten i sin alminnelighet og palliasjonen spesielt. Det er pasientens «reise i helse- og omsorgstjenesten» som skal være retningsgivende for hvordan struktur, organisering og ledelse er satt sammen.

\subsection{Pasienttilpassede forløp}

Muligheter til og forventninger om helsehjelp er raskt økende hos befolkningen. Samtidig er det økte forventninger om pasientinvolvering i viktige beslutninger - «shared decision making» og at man som pasient ikke skal behøve å vente på utredning, behandling, pleie og omsorg. God planlegging og forutsigbarhet er viktig, spesielt når sykdommen er sammensatt, slik som i palliasjon. Når kompleksiteten øker, slik den gjør under livsforlengende behandling, symptomlindrende behandling og ved livets slutt, settes det enda større krav til planene, de må være detaljerte og de pasienttilpassede forløpene tydelige. Metodikken pasientforløp har som et grunnleggende mål å lage en plan for pasienten. Dette «planarbeidet» skal være kunnskapsbasert. På den ene siden må planen tilpasses struktur og organisering i helseog omsorgstjenesten, på den andre siden må forbedring i helse- og omsorgstjenesten gjennomfø- res for å bidra til gode pasientforløp. En sentral målsetting er «rett kompetanse på rett sted til rett tid».

Pakkeforløp, slik de er utviklet i Norge i dag, er et godt eksempel på pasientforløp for å påse at pasientene ikke behøver å vente unødvendig fra mistanke om alvorlig sykdom er tilstede til diagnostikk og gjennomføring av første behandlingstiltak er igangsatt.

\subsubsection{Noen grunnelementer for å kunne gi god palliativ behandling}

For å tilby pasienter palliativ behandling, pleie og omsorg på høyt internasjonalt nivå, er det noen grunnelementer som må være på plass: Kliniske forskningsresultater, optimal organisering av helse- og omsorgstjenestene, palliasjon i alle helse- og sosialfaglige utdanninger der profesjonene møter pasienter som trenger palliativ behandling, kompetanse hos helsepersonell, tilretteleggelse for pasientmedvirkning, respekt for pasientens integritet og informerte valg, samt grunnholdninger der et pasientsentrert fokus er sidestilt med sykdomssentrert. Derfor er områdene kompetanse, utdanning, organisering, pasienttilpassede forløp, verdier og pasientmedvirkning sentrale i denne offentlige utredningen. 


\section{Kapittel 2 Sammendrag}

\subsection{Kapittel 4 Verdier}

Palliasjon som fag må bygge på et oppdatert vitenskapelig grunnlag. Samtidig må faget ha en tydelig verdimessig forankring som reflekterer de grunnleggende verdiene samfunnet er bygget på. Helsetjenesten har ansvar for å gi god behandling og omsorg, fra diagnose stilles, gjennom sykdomsperioden og fram til livets avslutning. For pasientene er det viktig å bli hørt, forstått, inkludert og respektert. Pasientens erfaringer, som er forbundet i et komplekst nett av følelser, meninger og uttrykk, er utgangspunktet for yrkesutøvelsen hos helse- og omsorgspersonell som ivaretar pasienter med behov for palliasjon.

Utvalget har valgt å ha en pasientsentrert tilnærming som grunnlag for arbeidet. Dette valget er også et verdivalg. En pasientsentrert tilnærming søker å se pasienten ut fra hans eller hennes perspektiv og å bekrefte den enkelte pasient som et unikt menneske, og ikke bare som et av mange individer i et behandlingssystem.

I kapittelet omtales videre hospicefilosofiens verdigrunnlag, som har en sentral plass når helseog omsorgspersonell ivaretar pasienter med behov for palliasjon. På 1990-tallet ble begrepet «hospice» i økende grad erstattet med begreper som blant annet lindrende behandling og palliativ medisin. En hovedintensjon med begrepsendringen er å vektlegge moderne medisinske behandlingsprinsipper og vitenskapsbasert behandling i kombinasjon med de verdiene som ligger i hospicefilosofien (NOU 1999: 2).

Omtale av forhåndssamtaler, kommunikasjon og medbestemmelse, menneskerettslige forpliktelser og verdier som følger, og som gjenfinnes i den norske velferdslovgivningen er også sentrale områder i kapittelet. Utvalget omtaler også helsepersonellets etiske ansvar, og nødvendigheten av en tydelig etisk bevissthet hos helse- og omsorgspersonell som en forutsetning for pasienters og pårørendes tillit.

\subsection{Kapittel 5 Perspektiv}

I dette kapittelet settes palliasjon inn i både et historisk og et framtidsrettet perspektiv. Den internasjonale utviklingen innen palliasjon spenner fra de første hospicene som ble etablert i Lyon i $1842 \mathrm{og}$ i Dublin i 1879, fram til etableringen av St. Christopher's Hospice i London i 1967 og den videre utvikling de siste 20-25 årene. Etableringen av St. Christopher's Hospice markerte starten på en ny æra, både innen hospicefeltet generelt og som en begynnelse på fagfeltet palliativ medisin. Tidligere ble det lagt mest vekt på pleie og omsorg for den døende, og det var liten eller ingen medisinsk tilnærming. En av hovedmålsettingene med å etablere St. Christopher's Hospice var å drive klinisk forskning. Med etableringen av St. Christopher's Hospice ble begrepet «total pain» (total smerte) introdusert for å understreke behovet for en bred faglig tilnærming til pasienter med behov for palliasjon. Både fysiske symptomer, psykiske plager, sosiale, åndelige og eksistensielle problemer regnes som utgangspunkt for den moderne hospicebevegelsen (Strømskag, 2012). Internasjonalt har det vært en bevegelse for utvikling av palliasjon til barn og unge siden tidlig på 2000-tallet, med engasjement over hele verden.

Fra 1970-tallet begynte arbeidet for de alvorlig syke og døende for alvor å bli mer koordinert i Norge. Det ble etablert kreftavdelinger i Bergen, Trondheim og Tromsø, og også tverrfaglige rådgivningsgrupper for omsorg ved livets slutt. Palliasjon i Norge og i Norden har i hovedsak fulgt den samme utviklingen som i Nord-Europa på 1980og 1990-tallet. På 1990-tallet ble det en rask utvikling av palliasjon i Norge.

Tradisjonelt var man i begynnelsen av palliasjonens historie mest opptatt av symptomkontroll og støtte for kreftpasienter. Palliasjon ble inkludert som tema i undervisning i onkologi, men den samme historiske satsingen har ikke funnet sted for de store indremedisinske sykdommene som lungesykdommer, hjertesykdommer, nevrolgiske sykdommer og nyresykdommer. Studier og erfa- 
ringer viser at pasienter med en jevn forverring av funksjon og symptomer ofte har behov for palliasjon ut over det grunnleggende nivå. Dette gjelder pasienter med uhelbredelig kreftsykdom og pasienter med langtkommen hjerte-, lunge- og nyresykdom, pasienter med nevrologiske sykdommer og pasienter med demens.

Nyere litteratur understreker at kultursensitivitet og kulturkompetanse ikke utelukkende handler om å ha kjennskap til «den andres» kultur, men i like stor grad handler om å reflektere over eget ståsted og egen forståelse (Blix, 2016). Kultursensitivitet og kulturkompetanse må ligge til grunn for å utvikle palliative tjenester til alle som trenger det, uavhengig av kulturell og etnisk bakgrunn.

I Meld. St. 29 (2016-2017) Perspektivmeldingen 2017 går det fram at aldringen i befolkningen gir økt behov for helse- og omsorgstjenester i årene framover. De aller eldste blir flere. Bedre helse blant eldre kan dempe, men ikke fjerne det økte behovet for helse- og omsorgstjenester. Noe av det viktigste som kan gjøres for å sikre rasjonell bruk av medisinske ressurser er å unngå å bruke ressurser der de ikke har effekt. Integrasjon av palliasjon tidlig i sykdomsforløpet, vil kunne bidra til å redusere unødvendige sykehusopphold, samt unngå overflødig utredning/ behandling.

\subsection{Kapittel 6 Pasienttilpassede forløp}

En av hovedutfordringene i helsetjenesten i dag, er at mange pasienter opplever en helsetjeneste som er fragmentert, med mangelfull samhandling innad i og mellom den kommunale helse- og omsorgstjenesten og spesialisthelsetjenesten (St.meld. nr. 47 (2008-2009). Dette medfører forsinket og dårlig planlagt utredning og behandling. Pasienter med behov for palliasjon får hjelp fra mange enheter $\mathrm{i}$ helse- og omsorgstjenesten, ofte fra flere aktører samtidig.

Når kompleksiteten øker i behandlingsforløpene og behovet for helsetjenester varierer over tid, slik situasjonen er for pasienter som trenger palliativ behandling, er det nødvendig med gode forutsigbare planer, tilpasset pasientens behov. Det er behov for systemer som understøtter pasientens behov for helhet i de palliative pasientforløpene. Dette er spesielt viktig for pasienter med komplekse palliative behov, da de ofte trenger tjenester både fra spesialisthelsetjenesten og den kommunale helse- og omsorgstjenesten. Dessu- ten kan flere sykehus være involvert, i tillegg til både fastlege, sykehjem og hjemmesykepleie.

Utvalget mener metoden pasientforløp bør brukes og tilpasses den enkelte pasients behov, slik at hver enkelt pasient får en plan - et pasienttilpasset forløp. Denne planen må revideres etter behov, basert på endringer i sykdommen og hos pasienten. På denne måten vil det hele tiden være et pasientsentrert og pasienttilpasset forløp som danner grunnlaget for den palliative behandlingen, pleien og omsorgen.

Godt organiserte pasientforløp vil kunne bedre logistikk og samhandling, redusere risikonivået for uønskede hendelser og derved øke pasientsikkerheten. Slike pasientforløp kan i tillegg gi pasienter og pårørende bedre oversikt, forutsigbarhet og forståelse for de ulike trinnene i behandlingen og dermed økt trygghet. Derfor bruker utvalget gjennomgående begrepet «pasienttilpassede forløp».

\subsection{Kapittel 7 Palliasjon i utdanningene}

For å møte pasientenes behov, trenger helse- og omsorgspersonell både kompetanse om grunnsykdommen og om palliasjon. I tillegg er det nødvendig å ha kompetanse til å gjenkjenne når det er behov for andre faggrupper og annen kompetanse enn den man selv har. Å møte en pasient med livstruende sykdom fordrer kompetanse i å kommunisere med pasienter og pårørende som er i en sårbar situasjon.

Den grunnleggende kompetansen i palliasjon bør helsepersonell få gjennom sin grunnutdanning. Helsepersonell som arbeider ved enheter med behandling og oppfølging av pasienter som trenger palliativ behandling, både i den kommunale helse- og omsorgstjenesten og i spesialisthelsetjenesten, bør ha spesialisert kompetanse i palliasjon. Dette gjelder helsepersonell som arbeider ved palliative enheter eller i palliative team, der pasienter med komplekse palliative behov er.

Omfanget av undervisning i palliasjon varierer både innad og mellom de ulike utdanningene og utdanningsstedene. Noen steder er det i lite omfang undervisning i palliasjon. Det er derfor viktig at utdanningen i palliasjon styrkes i helseog sosialfaglige utdanninger, både teoretisk og praktisk. Innholdet i undervisningen i palliasjon bør omfatte palliasjon til alle som har behov, uavhengig av diagnose og alder, og den må ivareta tidlig integrasjon av palliasjon, samt ha et tverrfaglig perspektiv. 
Kompetansen i palliasjon er styrket de siste 15 årene. Vi har i Norge mange gode utdanninger og en god struktur for å videreutvikle kompetansegrunnlag i palliasjon. Det er nødvendig for å imøtekomme økte behov hos befolkningen og styrke kvaliteten for alle pasienter som trenger palliative tjenester.

\subsection{Kapittel 8 Forskning}

Forskning bør danne grunnlaget for klinisk praksis. Dette gjelder også for palliasjon. Normer for pasientbehandling i Norge finnes i nasjonale faglige retningslinjer som utarbeides av Helsedirektoratet i samarbeid med fagmiljøene. Kvaliteten på og omfanget av klinisk forskning innen palliasjon som skal danne grunnlaget for de nasjonale retningslinjene, er svakt. De fleste anbefalingene er basert på laveste evidensnivå (nivå IV), ekspertgruppeuttalelser, og kvaliteten er ofte på laveste nivå (nivå C). Dette gjelder også et av de mest utforskede områdene innen palliasjon, smertebehandling hos kreftpasienter.

Kvaliteten og omfanget av den palliative forskningen står i sterk kontrast til det raskt økende behovet. Befolkningen blir eldre, det palliative behovet øker, samtidig som kompleksiteten for behandling, pleie og omsorg øker. Eldre mennesker har mer sammensatte sykdomsbilder og hjelpebehov, og hjelpen som kreves fra helse- og omsorgstjenestene blir mer krevende og sammensatt. Det betyr at svært store ressurser benyttes på pasientene det siste leveåret og spesielt de tre siste månedene. Denne utviklingen forventes å bli forsterket.

For å styrke kompetansen og kvaliteten i helse- og omsorgstjenesten er det et stort behov for bedre og mer forskning innen palliasjon på mange områder. Utvalget vil særlig rette oppmerksomheten mot tre områder som dekker viktige pasientnære forskningsområder og som raskt kan bidra til bedre behandlingsresultater:

- Klinisk forskning for å utvikle og forbedre pasientbehandling, pleie og omsorg og få kunnskap om sykdommers påvirkning på pasienten.

- Helsetjenesteforskning for å evaluere og prøve ut ulike modeller for organisering av de palliative tjenestene, for eksempel gjennom pasientforløpsmodeller.

- Få bedre kunnskap om hvilken behandling og omsorg som er best for den enkelte pasient, blant annet gjennom forskning på pasienters og pårørendes preferanser.
Samarbeid mellom forskningsmiljøer og en større satsning på miljøer som har forskningskompetanse på høyt nivå bør prioriteres. Slik kan de sterke miljøene gis vekstmuligheter, men under forutsetning av at de samtidig skal bidra til å løfte og inkludere svakere miljøer. Ved en slik dreining kan det etableres bedre samarbeid innen forskning nasjonalt ved at noen miljøer er «drivere», og at også mindre miljøer styrkes, slik at disse sammen kan bidra til mer og bedre forskning innen palliasjon nasjonalt og internasjonalt. Det er viktig at forskning i palliasjon også omhandler forskning på palliasjon i kommunene.

\subsection{Kapittel 9 Organisering, struktur og kompetanse}

Pasienter med behov for palliasjon finnes $\mathrm{i}$ alle deler av helsetjenesten. De vil vekselvis ha behov for tilbud fra fastlege, den kommunale helse- og omsorgstjenesten og spesialisthelsetjenesten. Palliative forløp utvikler seg ofte ikke likt. Utfordringene pasient og pårørende står overfor er sammensatte, da den palliative fasen i sykdomsforløpet kjennetegnes ved et komplekst sykdomsbilde.

Pasienter med mindre komplekse palliative behov vil ivaretas i den kommunale helse- og omsorgstjenesten. Noen pasienter vil, i spesielle situasjoner når komplikasjoner oppstår, ha behov for behandling fra enheter som har spesialisert kompetanse i palliasjon, enten ved poliklinisk behandling eller ved konsultasjon fra palliativt team i hjemmet. Noen få pasienter vil ha så komplekse palliative behov at de trenger innleggelse $\mathrm{i}$ palliativ enhet i kortere eller lengre tid. Pasienter med behov for palliasjon bør få hjelp i den ordinære helse- og omsorgstjenesten for å sikre helhetlige og koordinerte forløp og et likeverdig palliativt tilbud uavhengig av diagnose. Utvalgets flertall anbefaler at de palliative tjenestene, herunder palliasjon i livets aller siste fase, organiseres integrert og ikke som en særomsorg på siden av den ordinære helse- og omsorgstjenesten. Internasjonalt og nasjonalt anbefaler fagmiljøene at palliasjon må komme inn i pasientforløpet så snart en diagnose er gitt, og at palliasjon integreres i den øvrige kliniske aktiviteten, både i spesialisthelsetjenesten, hos fastlegen og i den kommunale helse- og omsorgstjenesten (Helsedirektoratet, 2015a, Hui og Bruera, 2016).

For å innfri pasientenes behov og målsettingene i helse- og omsorgstjenesten, må det stilles krav til hvordan de palliative tjenestene organiseres. Innholdet i og organiseringen av de palliative 
tjenestene påvirker hvordan pasientens behov blir ivaretatt. Kvaliteten i tilbudet til pasientene kan kun i begrenset grad måles gjennom resultater på enhetsnivå. Forskning og utvikling, undersøkelser og analyser av hva som samlet gir de beste tjenestene for pasientene bør danne grunnlag for tjenesteutvikling hvor hele bredden av tjenester inngår.

Selv om det er store geografiske og volummessige forskjeller innad og mellom de enkelte kommuner og sykehus, er det fortsatt de samme prinsippene som skal legges til grunn for organiseringen av de palliative tjenestene. Det er en målsetting å få sammenhengende pasientforløp og tidlig integrasjon av de palliative tjenestene med de øvrige helse- og omsorgstjenestene. For å nå disse målsettingene er det nødvendig at helsepersonell har høy kompetanse i palliasjon.

Mange pasienter som trenger palliativ behandling kan ønske å være hjemme så lenge som mulig og å dø hjemme. Det gis anbefalinger som skal bidra til at pasienten kan være hjemme lengst mulig og om ønskelig dø hjemme. Integrasjon av palliasjon bør skje tidlig i forløpene og palliasjon bør gis til alle som har behov, uavhengig av diagnose. Det er også sentralt at det palliative tilbudet til barn må styrkes.

\subsection{Kapittel 10 Pårørende}

Livstruende sykdom rammer ikke bare den som er syk, men også de som er nær. Å være pårørende til en som er alvorlig syk kan bidra til å knytte sterkere bånd og samtidig kan det være belastende. Pårørende vil oftest støtte den syke, både fysisk og psykisk. Tilstedeværelse og omsorg fra pårørende kan være av avgjørende betydning for pasientene. Det er vanligvis de pårørende som kjenner pasienten best og som kan bistå pasientene med å tydeliggjøre ønsker og behov når de ikke lenger klarer det selv. Det er derfor viktig å trekke pårørende inn tidlig i pasientforløpet. Pårørendes egne behov må også anerkjennes og ivaretas.

\subsection{Kapittel 11 Frivillig innsats på palliasjonsfeltet}

De demografiske framskrivningene innebærer at behovet for frivillig innsats på helse- og omsorgsfeltet vil øke. Det må derfor legges til rette for rekruttering av frivillige og for et systematisk samarbeid mellom frivillige og helse- og omsorgs- tjenestene i kommunen og i spesialisthelsetjenesten. Et godt systematisk samarbeid mellom frivillige og helse- og omsorgstjenesten kommer ikke av seg selv. Pasientens behov skal være retningsgivende for den frivillige innsatsen på palliasjonsfeltet. Gjennom den meningsfulle aktiviteten frivillig innsats er, kan den frivillige oppleve mestring og sosial inkludering. I dag har enkelte kommuner og institusjoner samarbeid med frivillige som gjør en innsats overfor alvorlig syke og døende og deres pårørende, og det er frivillige organisasjoner på palliasjonsfeltet som arbeider for å styrke de palliative tjenestene til pasientene og for å ivareta pårørendes behov.

\subsection{Kapittel 12 Andre land}

I følge mandatet skal utredningen «også bygge på erfaringer fra andre land, for eksempel om hospice, og det må vurderes om erfaringene er relevante for Norge.»

Verdens helseorganisasjon (WHO) og European Association for Palliative Care (EAPC) har gitt anbefalinger for organisering av palliasjon $\mathrm{i}$ sine medlemsland. Det finnes likevel mange ulike organisatoriske modeller, da anbefalingene skal tilpasses de ulike lands helsesystemer. For Norge er det mest aktuelt å se på forholdene i Norden, og da særlig Danmark og Sverige. Utvalget har også ønsket å innhente informasjon fra Finland, Irland og Storbritannia, som har en sterk hospicetradisjon, men som ellers har en organisering av helsetjenesten som er ganske ulik den norske.

\subsection{Kapittel 13 Balansen mellom helsepersonells inngrepsplikt og pasientenes selvbestemmelsesrett}

I følge mandatet skal utvalget vurdere balansen mellom helsepersonells inngrepsplikt som reguleres av helsepersonelloven $\S 7$, og pasientenes selvbestemmelsesrett som følger av pasient- og brukerrettighetsloven kapittel 4. Utvalget har i utredningen framhevet at pasientforløp bør brukes og tilpasses den enkelte pasients behov, slik at hver enkelt pasient får en plan - et pasienttilpasset forløp. I en behandlingsplan står pasientens ønsker sentralt, og for at ønskene skal respekteres må man ha rettsregler som sikrer selvbestemmelsesretten også når den helsehjelpen pasienten har takket nei til fremstår påtrengende nødvendig, noe som er inngrepsvilkåret for helsepersonells hjelpeplikt. 
Utvalget mener at det bør sikres en reell rett til å bestemme over egen kropp for alvorlig syke pasienter som har en sykdom de vil dø av, uavhengig av om de er døende. Det er samtidig et klart behov for en pliktbestemmelse som gir helsepersonell lovhjemmel til å agere i øyeblikkelig hjelpsituasjoner. Utvalget er derfor av den oppfatning at man må opprettholde bestemmelsen i helsepersonelloven $\S 7$ for å sikre pasienter hjelp i øyeblikkelig hjelp-situasjoner. Det er imidlertid behov for å tolke øyeblikkelig hjelp-bestemmelsen innskrenkende slik at den fanger opp situasjoner hvor pasienten blir vurdert av helsepersonell som ikke samtykkekompetent, og hvor det ellers ikke er uttrykt et klart forhåndsønske som bør respekteres for den oppståtte situasjonen. En innskrenkende tolkning av øyeblikkelig hjelp-bestemmelsen innebærer at balansen mellom helsepersonells inngrepsplikt og pasientenes selvbestemmelsesrett skyves i retning av økt selvbestemmelsesrett for pasienter med progredierende sykdommer som de vil dø av. Utvalget mener derfor at en styrket selvbestemmelsesrett krever økt samtalefrekvens mellom den uhelbredelig syke pasienten og helsepersonell. Et viktig tiltak i utredningen er derfor å sette forhåndssamtaler om blant annet behandlingsnivå og behandlingsintensitet i system. Det er videre et sentralt tiltak å heve den juridiske kompetansen hos helsepersonell som har ansvar for pasienter med behov for palliativ behandling, slik at de har nødvendig kunnskap om balansen mellom hjelpeplikt og selvbestemmelsesrett.

For barn som trenger palliativ behandling gjør det seg gjeldende særlige hensyn. I følge barnekonvensjonen artikkel 3 og Grunnloven artikkel 104 andre ledd skal «barnets beste» være et grunnleggende hensyn ved alle handlinger som berører barn. Barnets beste, både som prinsipp, rettighet og prosedyreregel, skal være styrende for alle beslutninger, blant annet valg av helse- hjelp, ved forhåndssamtaler, ved utformingen av behandlingsplaner, og ved utskriving. For å tydeliggjøre ansvaret som påhviler helsepersonell om å foreta en konkret vurdering av barnets beste, mener utvalget at «barnets beste» som et grunnleggende hensyn bør framgå både av pasient- og brukerrettighetsloven og av helsepersonelloven.

\subsection{Kapittel $14 \varnothing$ konomiske og administrative konsekvenser}

Økonomiske konsekvenser av utvalgets forslag er omtalt i kapittel 14. Enkelte av utvalgets forslag kan realiseres uten økt ressursbruk for kommuner og helseforetak. Utvalgets forslag vil samlet sett gi et løft for pasienter som har behov for palliative tjenester. Mange av forslagene er knyttet til økt kompetanse innen palliasjon både i den kommunale helse- og omsorgstjenesten og i spesialisthelsetjenesten, med en særlig innsats rettet mot palliasjon i kommunene. Strukturert, proaktiv palliasjon med oppmerksomhet mot funksjon hos pasienten kan bidra til forebygging av problemer og komplikasjoner. Dette kan samlet sett være ressursbesparende både for den kommunale helse- og omsorgstjenesten og spesialisthelsetjenesten. Bedre organisering på begge nivåer vil gi en bedre utnyttelse av de samlede ressursene. Utvalget mener at en økt innsats innen palliasjon i kommunene er en forutsetning for å kunne løfte omsorgen til alvorlig syke og døende til et reelt godt tilbud som ivaretar både brukere og deres pårørende. Palliasjon er et relativt nytt felt innen forskning, og det er nødvendig med økt forskningsinnsats innenfor flere store sykdomsgrupper, og for å utvikle palliative helsetjenester både i spesialisthelsetjenesten og i den kommunale helse- og omsorgstjenesten. 


\section{Kapittel 3 Utvalgets arbeid}

\subsection{Oppnevning og sammensetning av utvalget}

Ved kongelig resolusjon 11. mai 2016 oppnevnte regjeringen Solberg et utvalg som skal gjennomgå og vurdere dagens palliative tilbud.

Utvalget ble oppnevnt med følgende sammensetning:

- Professor Stein Kaasa, Oslo (leder)

- Førsteamanuensis Marianne Klungland Bahus, Kristiansand

- Overlege Ann Ragnhild Broderstad, Skånland

- Overlege Peder Broen, Klæbu

- Pensjonist Helge Farsund, Lørenskog

- Sykepleier Anne Marie Flovik, Bærum

- Teolog Søren Vincent Hagerup, Sandefjord

- Pensjonist Bodil Johanne Husby, Oslo

- Organisasjonsleder Natasha Pedersen, Kristiansand

- Førstelektor Astrid Rønsen, Lørenskog

- Senior psykologspesialist Borrik Schjødt, Bergen

- Sykepleier Joran Slaaen, Lørenskog

Utvalgsmedlem Ann Ragnhild Broderstad måtte av personlige grunner trekke seg fra utvalget $\mathrm{i}$ august 2017. Overlege Sigve Andersen, Tromsø, ble oppnevnt som nytt medlem 24. april 2017.

Utvalgets sekretariat har bestått av seniorrådgiver Ann Kristin Andresen, Helse- og omsorgsdepartementet (leder), seniorrådgiver Hilde Marie Rognlie, Helse- og omsorgsdepartementet og seniorrådgiver Sjur Bjørnar Hanssen, Helsedirektoratet. Seniorkonsulent Mette Andrea Jensen, Helse- og omsorgsdepartementet, har bistått utvalget og sekretariatet.

\subsubsection{Utvalgets mandat}

\section{Bakgrunn}

Av den politiske plattformen for regjeringen Solberg 2013 følger det at regjeringen ønsker å styrke kompetansen og tilbudet innen palliasjon, også for barn, og legge til rette for et mangfold av tilbud.

Ved Stortingets behandling av Dokument 8:92 S (2014-2015) om en plan for å sikre retten til livshjelp ved livets slutt, jf. Innst. 379 S (2014-2015), ble det fremmet følgende anmodningsvedtak: «Stortinget ber regjeringa gjennomføre en offentlig utredning (NOU) av palliasjonsfeltet, med bredt sammensatt representasjon fra ulike fagmiljøer, hvor barnepalliasjon er en del av arbeidet».

Det er 18 år siden forrige offentlige utredning på feltet, NOU 1999: 2 Livshjelp - Behandling, pleie og omsorg for uhelbredelig syke og døende. Det er derfor behov for en utredning som fanger opp utviklingen i de palliative tjenestene, som tar hensyn til dagens utfordringsbilde og som foretar en helhetlig vurdering av palliasjonsfeltet.

\section{Utvalgets hovedoppgaver}

Utvalget skal gjennomgå og vurdere dagens palliative tilbud. På denne bakgrunn skal utvalget foreslå tiltak for å imøtekomme brukernes/pasientenes og de pårørendes behov og ønsker, uavhengig av diagnose, alder, bosted eller andre forhold. Utvalget skal vurdere hele pasientforløpet fra diagnosen stilles, gjennom sykdomsperioden og frem til livets avslutning.

Utvalget skal foreslå tiltak som skal bidra til å styrke kvalitet, kompetanse, samhandling, faglig omstilling og nye arbeidsformer samt tverrfaglig arbeid. Palliasjon skal gis som en integrert del av de ordinære helse- og omsorgstjenestene. Utvalgets forslag skal være gjennomførbare innenfor denne rammen. Barn og unge skal gis særskilt oppmerksomhet.

Utvalget skal blant annet:

- Foreslå modeller for flerfaglig samarbeid og gode pasientforløp på palliasjonsfeltet

- Gi forslag til hvordan vi kan inkludere brukeres, pårørendes $\mathrm{og}$ frivilliges erfaringer $\mathrm{og}$ kunnskap for å tilrettelegge for individuelle behov gjennom hele sykdomsforløpet 
- Identifisere særskilte forskningsbehov og komme med forslag som kan styrke utviklingsarbeidet i de kommunale helse- og omsorgstjenestene

- Utrede reglene om helsepersonells inngrepsplikt i helsepersonelloven $\S 7$ og pasienters rett til å nekte livreddende og livsforlengende behandling. Utvalget skal vurdere om dagens regler bør videreføres eller foreslå nødvendige endringer.

- Drøfte når pasienter som trenger palliative tjenester, bør regnes for utskrivingsklare eller ikke

\section{Mandat}

Det er et mål at god palliativ behandling og omsorg kan gis til alle som har behov for det.

Verdens helseorganisasjons definisjon av palliasjon skal legges til grunn: «Palliativ behandling, pleie og omsorg er en tilnærmingsmåte som har til hensikt å forbedre livskvaliteten til pasienter og deres familier i møte med livstruende sykdom, gjennom forebygging og lindring av lidelse, ved hjelp av tidlig identifisering, grundig kartlegging, vurdering og behandling av smerte og andre problemer av fysisk, psykososial og åndelig art». God palliativ behandling og omsorg ivaretar den som trenger det på en helhetlig måte, fysisk, psykisk, sosialt og åndelig. Den tar hensyn til brukerens og pårørendes behov gjennom en kontinuerlig dialog under hele sykdomsforløpet.

I dag klarer vi ikke å gi gode palliative tjenester til alle som trenger det. Dette gjelder også i sykehjem, som er stedet hvor ca. 50 prosent dør. Omkring 15 prosent dør hjemme, og undersøkelser viser at flere ønsker å være lenger hjemme og dø hjemme enn de som får tilbud om dette. Varierende kapasitet og kompetanse i den kommunale helse- og omsorgstjenesten, kanskje særlig i sykehjemmene, i hjemmetjenesten og hos fastlegene/ allmennlegene, kan være forklaringer på dette. Andre forklaringer kan være uhensiktsmessig organisering og suboptimale arbeidsformer. Samhandlingen innad $\mathrm{i}$ den kommunale helse- og omsorgstjenesten og i spesialisthelsetjenesten og samhandlingen mellom nivåene fungerer ikke alltid tilfredsstillende. Nyere data peker på at lindrende behandling og omsorg bør komme tidlig inn i sykdomsforløpet, og at det også er behov for å styrke inkluderingen av pasienter med andre sykdommer enn kreft i et palliativt tilbud.

Utvalget skal gjennomgå og vurdere dagens palliative tilbud. På denne bakgrunn skal utvalget foreslå tiltak for å imøtekomme brukernes/pasi- entenes og de pårørendes behov og ønsker for innhold i, organisering av og sted for behandling, pleie og omsorg i livets sluttfase, uavhengig av diagnose eller prognose, alder, bosted eller andre forhold, fra diagnosen stilles, gjennom sykdomsperioden og frem til livets avslutning. Utvalget skal foreslå tiltak som skal bidra til å styrke kvalitet, kompetanse, samhandling, faglig omstilling og nye arbeidsformer samt tverrfaglig samarbeid. Lindrende behandling og omsorg skal gis som en integrert del av den ordinære helse- og omsorgstjenesten.

Utvalgets forslag skal være gjennomførbare innenfor denne rammen. Hvordan pasient/bruker og pårørende blir møtt den siste tiden er avgjørende for opplevelsen av omsorgen. Utvalget skal foreslå modeller for flerfaglig samarbeid og gode pasientforløp på palliasjonsfeltet som har nasjonal overføringsverdi. Det vises til Meld. St. 26 (20142015) Fremtidens primorhelsetjeneste - noerhet og helhet om team i den kommunale helse- og omsorgstjenesten.

Utvalget skal gi forslag til hvordan vi kan inkludere brukeres, pårørendes og frivilliges erfaringer og kunnskap for å tilrettelegge for individuelle behov gjennom hele sykdomsforløpet. Barn og unge som pårørende skal inngå i utredningsarbeidet.

Barn og unge er sårbare grupper og må få en spesiell oppmerksomhet i utvikling av tjenestene.

I sine forslag til løsning skal utvalget også ta hensyn til minoritetsgrupper og kulturelle forskjeller i befolkningen.

Med henblikk på planlegging av fremtidens palliative tilbud, skal utvalget identifisere særskilte forskningsbehov og komme med forslag som kan styrke utviklingsarbeidet i den kommunale helse- og omsorgstjenesten.

Utredningen skal også bygge på erfaringer fra andre land, for eksempel om hospice, og det må vurderes om erfaringene er relevante for Norge.

Utvalget skal legge en helhetlig og bred forståelse av palliasjon til grunn og se arbeidet $i$ lys av langsiktige hovedlinjer og utviklingstrekk, blant annet den demografiske utviklingen. I et helse- og sosialfaglig perspektiv skal utvalget også ta hensyn til kulturelle forskjeller, opplevelsen og bearbeidelsen av sorg og tap, og muligheten for å planlegge resten av livet.

Utvalget skal utrede reglene om helsepersonells inngrepsplikt i helsepersonelloven $\S 7$ og pasienters rett til å nekte livreddende og livsforlengende behandling. Utvalget skal vurdere om dagens lovregler innebærer en riktig grensedragning mellom helsepersonellets hjelpeplikt og pasi- 
entenes autonomi, blant annet når pasienten motsetter seg helsehjelpen. Utvalget skal vurdere om dagens regler bør videreføres, eller foreslå nødvendige endringer. Utvalgets arbeid skal avgrenses mot endringer i lovreglene om rett til nødvendig helsehjelp i pasient- og brukerrettighetsloven kapittel 2.

Regjeringen er imot aktiv dødshjelp, og utvalget skal ikke vurdere spørsmål vedrørende eutanasilovgivningen.

Innenfor rammen av palliative tjenester skal utvalget også drøfte når disse pasientene bør regnes for utskrivningsklare eller ikke, slik at man unngår uverdige utskrivninger motivert i en kommunal betalingsplikt.

Utvalget skal vurdere om det skal se på hvilke implikasjoner forslag i meldingen om prioritering, som etter planen legges frem i 2016, har for palliasjonsfeltet.

På eget initiativ kan utvalget også reise spørsmål og foreslå tiltak med sikte på å styrke helseog omsorgstjenestene til personer med behov for lindrende behandling og omsorg.

Departementet forutsetter at utvalget legger opp til en åpen arbeidsform og kan ta imot innspill og drøfte sentrale tema med ulike fagmiljøer, statlige råd og interesseorganisasjoner.

Utvalget skal utrede økonomiske, administrative og andre vesentlige konsekvenser av sine forslag i samsvar med Utredningsinstruksen kapittel 2. Minst ett av utvalgets forslag skal baseres på uendret ressursbruk.

Det bør være et siktemål at utvalget kan komme frem til forslag som kan samle bredest mulig oppslutning.

Utvalget skal levere sin endelige utredning og innstilling innen utgangen av 2017.

\subsubsection{Utvalgets forståelse av mandatet og avgrensning av utvalgets arbeid}

Slik utvalgets mandat er utformet, skal utvalget foreslå tiltak som skal bidra til å styrke kvalitet, kompetanse, samhandling, faglig omstilling og nye arbeidsformer samt tverrfaglig samarbeid. Det er presisert i mandatet at lindrende behandling skal gis som en integrert del av den ordinære helse- og omsorgstjenesten. Utvalgets flertall tolker dette slik at det ikke skal etableres tjenester på siden av de ordinære tjenestene, som ikke er en del av den eksisterende organisatoriske strukturen.

Utvalget har lagt vekt på å finne løsninger som skal bidra til økt grad av tverrfaglighet, et godt samarbeid mellom tjenestenivåene og gode helhetlige pasientforløp, med utgangspunkt i pasienten og de pårørendes behov.

Utvalget har fått et svært vidt mandat som omfatter palliasjon gjennom hele livsløpet, fra diagnosen stilles, gjennom sykdomsperioden og fram til livets avslutning. Utvalget skal ta opp temaer som spenner fra tiltak for å imøtekomme brukernes/pasientenes og de pårørendes behov og ønsker for innhold i, organisering av og sted for behandling, pleie og omsorg i livets sluttfase, uavhengig av diagnose eller prognose, alder, bosted eller andre forhold. Utvalget mener det er behov for å styrke kompetansen på begge nivåer $\mathrm{i}$ helsetjenesten, men har særlig sett behov for å løfte kompetansen i den kommunale helse- og omsorgstjenesten. Det er i kommunen pasienten tilbringer den største delen av sykdomsperioden, enten det er i en heldøgns pleie- og omsorgsbolig eller i sitt eget hjem.

\subsubsection{Utvalgets bruk/forståelse av enkelte sentrale begreper}

Utvalget trekker fram følgende sentrale begreper som er brukt i utredningen: 
Tabell 3.1 Sentrale begrep på palliasjonsfeltet

\begin{tabular}{lll}
\hline Begrep & Kortversjon & Lang versjon \\
\hline Palliasjon & Palliasjon er behandling av plag- & Palliasjon er aktiv behandling, pleie og omsorg for \\
& somme symptomer samt annen & pasienter med uhelbredelig sykdom og kort for- \\
hjelp og støtte ved alvorlig/livstru- & ventet levetid. Lindring av pasientens fysiske smer- \\
ende sykdom. & ter og andre plagsomme symptomer står sentralt, \\
& Omtales også som palliativ behand- & sammen med tiltak rettet mot psykiske, sosiale og \\
ling eller lindrende behandling. & $\begin{array}{l}\text { åndelige/eksistensielle problemer. Målet med all } \\
\text { behandling, pleie og omsorg er best mulig livskva- }\end{array}$ \\
& $\begin{array}{l}\text { litet for pasienten og de pårørende. Palliativ } \\
\text { behandling og omsorg verken fremskynder døden } \\
\text { eller forlenger selve dødsprosessen, men ser på }\end{array}$ \\
& døden som en del av livet.
\end{tabular}

Livets slutt- $\quad$ Når det er overveiende sannsynlig fase at gjenværende levetid er betydelig begrenset, ofte definert som uker eller dager.

Omsorg ved livets slutt Livshjelp

$\mathrm{ACP}-$ Advance care planning

Behandling, pleie og omsorg i de siste dager eller uker av livet ser, med minst mulig plager.
Tiltak for at den enkelte skal få hjelp Med livshjelp menes at det enkelte mennesket skal til å leve best mulig i egne omgivel- bli møtt med så god behandling, pleie og omsorg at livet kan oppleves meningsfullt og verdifullt tross begrenset levetid og store endringer i funksjonsdyktighet. Den enkelte skal få hjelp til å leve best mulig i egne omgivelser, med minst mulig angst og fysiske plager, og til å møte døden på sine egne premisser.

Forhåndssamtaler. En planlegging $\quad$ En kontinuerlig prosess hvor nåværende og fremtifor livets siste fase basert på pasien- dige ønsker og preferanser for videre medisinsk tens ønsker, verdier og preferanser. Planen er først og fremst ment å være i forkant av en situasjon der pasienten ikke selv lenger er i stand til å ta avgjørelser.

behandling og pleie blir diskutert mellom personen og helsepersonell, spesielt med tanke på en situasjon hvor man ikke lenger selv kan uttrykke sine ønsker eller preferanser. ACP gjøres på bakgrunn av forhåndssamtaler, og kan inneholde for-
Når det er overveiende sannsynlig at gjenværende er betydelig begrenset på grunn av høy Det finnes ingen entydig definisjon på dette. Både i forskningssammenheng og andre sammenhenger (økonomiske ytelser og stønader, forsikringssammenheng etc.) ser vi at dette gjerne defineres som maksimalt 6-12 måneder, av og til kortere. I klinisk sammenheng vil man ofte definere det som uker eller dager. håndsdirektiv $(\mathrm{AD})$ knyttet til beslutninger om begrensning av medisinsk behandling, f.eks. gjenoppliving ved hjertestans, bruk av respirator, antibiotika eller kunstig væske og ernæring, eller at pasienten gir fullmakt til en annen person som kan ta behandlingsbeslutninger dersom man ikke selv er i stand til det. ACP kan også omfatte preferanser for hvor man ønsker å motta pleie i sluttfasen eller ønsker å dø. 
Tabell 3.1 Sentrale begrep på palliasjonsfeltet

\begin{tabular}{lll}
\hline Begrep & Kortversjon & Lang versjon \\
\hline Døende & Med døende forstås at pasienten vil & Når pasienten lider av en uhelbredelig sykdom og \\
& dø i løpet av kort tid, det vil si i løpet & trolig vil dø i nær fremtid (timer eller få dager). \\
av timer eller få dager. & Når døden nærmer seg, ser en ofte en del typiske \\
& endringer hos pasienten som økt søvnbehov, tilta- \\
& gende fysisk svekkelse, økende behov for senge- \\
& leie, avtakende interesse for omgivelsene, mindre \\
& respons til de nærmeste, svekket orienteringsevne, \\
& ofte periodevis forvirring, tiltakende redusert \\
& interesse for å ta til seg mat og drikke og proble- \\
& mer med å svelge tabletter. \\
\hline
\end{tabular}

Utvalget har lagt begrepslisten til Norsk Palliativ Forening og Norsk forening for palliativ medisin til grunn.

\subsubsection{Møter og arbeidsform i utvalget}

Utvalget hadde sitt første møte 17. juni 2016. Det siste møtet ble holdt 2. november 2017. Til sammen har utvalget hatt 13 møter. Seks av disse har vært dagsmøter og syv møter har gått over to dager. Møtene har vært holdt i Oslo (eller i nærheten av Oslo), Jevnaker, Trondheim, Bergen, Kristiansand og Tromsø.

Utvalget bestilte to kartlegginger og en kunnskapsoppsummering:

- Kompetansesenter for lindrende behandling Helseregion Sør-Øst: Kartlegging av befolkningens ønsker for hvor man ønsker å motta behandling og pleie den siste tiden

- Kompetansesenter i lindrande behandling Helseregion Vest, i samarbeid med Senter for omsorgsforskning Øst: Kunnskapsoppsummering om palliasjon $\mathrm{i}$ andre land

- Kompetansesenter i lindrende behandling Helseregion Nord: Kartlegging av innholdet av palliasjon i helse- og sosialfaglige utdanninger

\subsubsection{Utvalgets innhenting av ulike perspektiv}

Utvalget har på flere av sine møter invitert sentrale personer/aktører til å holde innlegg om aktuelle temaer.

\section{Trondheim 28. november 2016}

Nils Kvernmo, administrerende direktør St. Olavs hospital: Forbedringsprogram og standardiserte pasientforlop. Kreftilbud noer pasienten - oppgavedeling mellom Trondheim og Orkdal

Jo-Åsmund Lund, tidligere klinikksjef Kreftklinikken og leder av arbeidet med standardiserte pasientforløp og Birger Endreseth, klinikksjef
Kirurgisk klinikk ved St. Olavs hospital: Hvorfor St. Olavs hospital har satset på standardiserte pasientforlop som metodikk

Morten Thronæs, avdelingssjef Seksjon lindrende behandling, Kari Hanne Gjeilo, forskningssykepleier Hjertemedisinsk klinikk og Anne Hildur Henriksen, klinikksjef Klinikk for lunge/ arbeidsmedisin og medisin, Orkdal Sjukehus: Organisering av det palliative tilbudet ved St. Olavs hospital

Hilde Grimstad, prodekan utdanning, Fakultet for medisin og helsefag, NTNU: Hvordan utvikles og ivaretas kompetansen om palliasjon $i$ utdanningen?

Anne Grete Skaar, enhetsleder Øya helsehus, Peder Broen, overlege Øya Helsehus, Anne Kvikstad, overlege Kreftklinikken, Marte Walstad, kommuneoverlege, tidligere fastlege i Trondheim, Inger Lise Wille, kreftkoordinator, ressursnettverk i kreftomsorg og palliasjon: Erfaringer med palliasjonstilbudet $i$ Trondheim kommune, historien, ståsted og tanker for videre drift og utvikling av tilbudet. Samarbeid mellom Trondheim kommune og St. Olavs hospital

Orkdal 29. november 2016

Anne Tove Brenne, overlege Orkdal sjukehus: Poliklinikk

Eli Crozier, kommuneoverlege på Frøya: Fastlegens rolle $i$ palliasjonsarbeidet

Liv Ågot Hågensen, kreftkoordinator: Samhandling $i$ palliasjonsarbeidet

Berit Drugli Blokkum, kreftsykepleier: Palliasjon $i$ helse- og omsorgstjenesten

Laila Skjelvan, prosjektkoordinator/sykepleier Kompetansesenter i lindrende behandling Helse-Midt: Samhandling gjennom oppgaveglidning $i$ Orkdalsmodellen 
Bergen 25. januar 2017

Ingvil Austbø, lege Askøy kommune: Askøymodellen

Brigt Bovim, lege Søreide legekontor: Fastlegens rolle

Hilde Lisbet Heggelien, etatsdirektør for hjemmebaserte tjenester: Det palliative tilbudet for hjemmeboende $i$ Bergen kommune

Rune Eidset, spesialrådgiver i Etat for alders- og sykehjem: Palliative tjenester $i$ sykehjem. Status og utfordringer $i$ Bergen

Alf Henrik Andreassen, fagdirektør, Helse Bergen: Strategiplan for lindrende behandling. Borrik Schjødt, psykologspesialist og Olav Hevrøy, Seksjon smertebehandling og palliasjon, Haukeland universitetssjukehus: Pasientforlop internt $i$ HFet og mot kommunen. Palliativt team. Hjemmedød

Ove Arne Fondenæs, overlege, Nasjonal kompetansetjeneste for hjemmerespiratorbehandling: Hjemmerespiratorbehandling ved ALS

Jan Henrik Rosland, professor, Sunniva senter for lindrende behandling, Haraldsplass Diakonale Sykehus og Universitetet i Bergen: Pasientforlopsmodeller. Bruk av frivillige

Dagny Faksvåg Haugen, professor, Kompetansesenter i lindrande behandling Helseregion Vest, Haukeland universitetssjukehus og Universitetet i Bergen: Ressursnettverk og kompetanseheving $i$ Helse Vest. Desentralisert modell. Palliative tiltak for funksjonshemmede $i$ samarbeid med Bergen kommune

Ingrid $\mathrm{O}$. Torsteinson, studieleder og rådgiver, VID vitenskapelige høgskole, Bergen og Dagny Faksvåg Haugen, Universitetet i Bergen: Hvordan utvikles og ivaretas kompetansen om palliasjon $i$ utdanningene?

Paal Naalsund, overlege, Haraldsplass Diakonale sykehus, Silje Eikemo, leder for Kompetanseutvikling - Omsorg ved livets slutt, Verdighetsenteret og Christine Gulla, stipendiat, Senter for alders- og sykehjemsmedisin, Universitetet i Bergen: Integrerte palliative tjenester til personer med demens, erfaringer og synspunkter

\section{Oslo 28. februar 2017}

Innlegg om hospice: Astrid Rønsen utvalgsmedlem og styreleder Hospiceforum Norge og Ellen Halvorsen, nestleder Hospiceforum Norge, Hospiceforum Norge, Joran Slaaen, seksjonsleder og Are Normann, avdelingsoverlege, Hospice Lovisenberg, Sonja Welde institusjonssjef og Henriette Høyskel, Hospice Sta- $b e k k$, Sissel Braaten, avdelingsleder og Anne Marie Thomle Brager, enhetsleder, Hospice Austjord, Bente Sydtangen og Grethe Brendløkken Nilsen, Hospice Sangen, Tormod HaaviChristensen, generalsekretær og Tor-Arne Henningsen, fagansvarlig og sykepleier, Fransiskushjelpen

Innlegg om barnepalliasjon: Vigdis Ziener, seksjonsleder ved Avansert hjemmesykehus, Oslo universitetssykehus: Avansert hjemmesykehus, palliasjon og hospice

Kristin Brække, overlege ved nyfødtavdelingen, Oslo universitetssykehus: Nyfødt - palliasjon

Birgit Kristiansen, lege, Seksjon for nevrohabilitering - barn, Oslo universitetssykehus: Barnehabilitering og nevrologi

Natasha Pedersen, leder og fagansvarlig, Foreningen for barnepalliasjon: Hvordan leve et liv med et barn som skal dø?

Jens Grogaard, pediater og Bodil Stokke seniorrådgiver, Helsedirektoratet: Utfordringer og tiltak på barnepalliasjonsfeltet. Gjennomgang av pasientforlop

Dagny Faksevåg Haugen, leder på Kompetansesenter for lindrande behandling Helseregion Vest, deltok på møtet

Kristiansand 8. mars 2017

Odd Kjøstvedt, fastlege Kristiansand kommune: En fastleges synspunkt på samhandling

Eva Albert, overlege, Lindrende enhet, Sørlandet sykehus: Presentasjon av lindrende enhet og team ved Sørlandet sykehus

Cathrine Humlen Ruud, fagkoordinator i lindring i Kristiansand kommune: Kommunens organisering av tilbudet til pasienter med behov for palliasjon - pasientforlopsarbeid

Svein Mjåland, avdelingsleder, Senter for kreftbehandling, Sørlandet sykehus: Er palliasjon en integrert del av onkologien?

Merethe Akselsen, overlege Kirurgisk avdeling, Sørlandet sykehus: Integrasjon av palliasjon $i$ kirurgisk avdeling

Lisbeth Bergstøl, virksomhetsleder, Kristiansand kommune: Integrering av palliasjon i den kommunale helse- og omsorgstjenesten

Pål Friis, overlege, Geriatrisk avdeling, Sørlandet sykehus: Palliasjonens plass i geriatrien. Bruk av forhåndssamtaler

Ørnulf Paulsen, overlege og Torunn Haugstøl, kreftsykepleier, Palliativ enhet, Sykehuset Telemark, Skien: Presentasjon av organiseringen av det palliative senteret. Samhandling med kommunene - fokus på ambulant modell 
Hildegunn Sønning, fagansvarlig, Universitetet i Agder: Formell utdanning $i$ regi av utdanningsinstitusjonene Bente Abrahamsen, Sørlandet sykehus: Gjensidig hospitering

Wenche Tetlie, sykepleier, Sørlandet sykehus og Cathrine Humlen Ruud: Samarbeid om kompetanseheving gjennom ressursnettverk/fagnettverk

Beate Sørensen, fagkoordinator, Utviklingssenter for sykehjem og hjemmetjenester, Vest Agder og Cathrine Humlen Ruud: Utviklingssenterets rolle innen kompetanseheving inkl. basiskompetanse

Kamilla Steinsvåg, Songdalen kommune: Livets siste dager - eksempel på prosjektarbeid som kompetansespredning

Inger Johanne Bolstad, Utviklingssenter for sykehjem og hjemmetjenester i Aust- Agder: Frivillighet $i$ palliativ omsorg - FRIPO - Presentasjon av prosjektet

Bente Abrahamsen, enhetsleder, Sørlandet sykehus: Organisering av frivillig arbeid ved lindrende enhet, Sørlandet sykehus

\section{Oslo 28. mars 2017}

Magne Hustavenes, seksjonssjef, Byrådsavdeling eldre, helse og sosiale tjenester, Aldring og helse: Hvordan løser Oslo kommune behovet for palliative tjenester $i$ kommunen? En storbys utfordringer og løsninger $i$ dag og $i$ fremtiden

Sølvi Karlstad, seniorkonsulent, Sykehjemsetaten: Lindrende enhet $i$ sykehjem og kompetanseoverforing fra denne enheten til andre sykehjem $i$ kommunen

Kathrine Brenne, palliativt team, Akershus universitetssykehus: Lindrende behandling og omsorg til personer med minoritetsbakgrunn

Anne Kittelsen, Sykehjemsetaten/Senter for fagutvikling og forskning/Utviklingssenter for sykehjem og hjemmetjenesten, Aker universitetssykehus: Utviklingssenterets rolle $i$ utviklingen av palliasjon inn mot den kommunale helse- og omsorgstjenesten nå og $i$ fremtiden

Kristin Weng, sykepleier, Hjemmetjenesten Bydel Østensjø: Hjemmetjenestens tilbud til pasienter med behov for palliative tjenester

Giske Jægtnes, kreftkoordinator, Bydel Østensjø: Koordinators/kreftkoordinators rolle overfor pasienter med behov for palliativ pleie og omsorg

Petter Brelin, leder, Norsk forening for allmennmedisin: Fastlegens rolle $i$ et palliativt pasientforlop

Sølvi Karlstad, Sykehjemsetaten og Jomar Skovholt Bjørge, Akerselva sykehjem, Oslo kom- mune: Hvordan har kommunen organisert palliative tjenester til mennesker med rusproblemer og psykiske helseproblemer?

Tromsø 16. august 2017

Sissel Andreassen, kreftsykepleier og koordinator, Vadsø kommune: Organisering av tjenester til personer med behov for palliative tjenester $i$ en liten kommune

Ann-Eli Edvardsen, avdelingssykepleier, Skånland kommune, hjemmesykepleien, avdeling Nord: Organisering av tjenester til personer med behov for palliative tjenester i en mindre kommune

Gunnar Hartviksen, professor, Nasjonalt senter for e-helseforskning: Kompetanseoverforing og den direkte kliniske bruken

Gro Rosvold Berntsen, sjefsforsker ved Nasjonalt senter for e-helseforskning: Pasientsentrert team

Bente Ervik, leder, Regionalt kompetansesenter for lindrende behandling i Nord- Norge: Kompetanseoverforing

Kristine Grønmo, prosjektleder, Utviklingssenter for sykehjem og hjemmetjenester til den samiske befolkningen: Palliasjon fra et samisk ståsted

Bodil Blix, postdoktor, Senter for omsorgsforskning Nord: Forskning

På møtene i Trondheim, Bergen, Kristiansand og Tromsø har den lokale pressen blitt kontaktet før utvalgsmøtene, og utvalgsleder har gitt flere intervjuer om utvalgets arbeid. Dette har resultert i flere oppslag i lokalpressen og i riksdekkende media, inkludert sak i Dagsrevyen. Dette har bidratt til å sette palliasjon på dagsorden og skape oppmerksomhet om temaer som blant annet palliasjon i den siste levetiden, palliasjon versus overbehandling og gode pasientforløp.

\section{Møter utover ordinære utvalgsmøter}

I tråd med utvalgets mandat ble det lagt opp til en åpen arbeidsform der utvalget har tatt imot innspill og drøftet sentrale temaer med ulike fagmiljøer og interesseorganisasjoner. Utvalgsleder, sekretariatet og enkeltmedlemmer fra utvalget har hatt møter med ulike aktører i Sverige og Danmark for innhenting av kunnskap og erfaringer. I tillegg har utvalgsleder, sekretariatet og enkeltmedlemmer fra utvalget hatt møter med frivillige organisasjoner, representanter fra det pastoralkliniske miljøet og representanter fra det sosialfaglige miljøet (sosionomer). På utvalgsmøtet 23. mai 
2017 presenterte Christy Whitney, Hope West og Constance Holden, Colorado USA erfaringer med hospice i Colorado.

I henhold til mandatet skal utvalget utrede reglene om helsepersonells inngrepsplikt i helsepersonelloven $\S 7$ og pasienters rett til å nekte livreddende og livsforlengende behandling. Utvalget skal vurdere om dagens lovregler innebærer en riktig grensedragning mellom helsepersonellets hjelpeplikt og pasientenes autonomi, blant annet når pasienten motsetter seg helsehjelpen. Utvalget skal vurdere om dagens regler bør videreføres eller foreslå nødvendige endringer. Utvalgets arbeid skal avgrenses mot endringer i lovreglene om rett til nødvendig helsehjelp i pasient- og brukerrettighetsloven kapittel 2. For å få bistand til å vurdere dette, har utvalgsleder, sekretariatet og enkelte utvalgsmedlemmer hatt et møte med representanter fra det juridiske miljøet i Oslo, og fra blant annet Senter for medisinsk etikk.

Møte med det juridiske miljøet 6. april 2017

Møtedeltakere:

- Jørgen Dahlberg, stipendiat, Institutt for klinisk medisin, Det medisinske fakultet, Universitetet i Oslo

- Reidun Førde, professor, Senter for medisinsk etikk, Det medisinske fakultet, Universitetet i Oslo

- Marit Halvorsen, professor, Institutt for offentlig rett, Det juridiske fakultet, Universitetet i Oslo

- Petter Andreas Steen, professor i emeritus, Institutt for klinisk medisin, Det medisinske fakultet, Universitetet i Oslo

- Aslak Syse, professor emeritus, Institutt for offentlig rett, Det juridiske fakultet, Universitetet i Oslo

- Stein Kaasa, utvalgsleder palliasjonsutvalget

- Marianne Klungland Bahus, medlem palliasjonsutvalget

- Søren Vincent Hagerup, medlem palliasjonsutvalget

- Astrid Rønsen, medlem palliasjonsutvalget

- Ann Kristin Andresen, leder sekretariatet palliasjonsutvalget

- Sjur Bjørnar Hanssen, sekretariatet palliasjonsutvalget

- Hilde Marie Rognlie, sekretariatet palliasjonsutvalget

Innlegg:

- Jørgen Dahlberg
Hensikten med møtet var å drøfte utvalgets oppgave i mandatet om å utrede reglene om helsepersonells inngrepsplikt i helsepersonelloven $\S 7$ og pasienters rett til å nekte livreddende og livsforlengende behandling. Utvalget ønsket å drøfte behovet for en endret ordlyd i helsepersonelloven $\S 7$.

Møte med det pastoralkliniske miljøet 10.mai 2017

Møtedeltakere:

- Aud Irene Svartvasmo, sykehusprest Diakonhjemmet Sykehus, Oslo

- Hilde Halsteinli Unsvåg, seksjonsleder og sykehusprest ved Akershus universitetssykehus, tilknyttet palliativt team

- Odd Arne Skogen, sykehusprest Ålesund sjukehus og medlem av styret i Norsk Palliativ Forening

- Eirik Os, hovedsykehusprest ved Lovisenberg Diakonale Sykehus, Oslo

- Terje Talseth Gundersen, sykehusprest ved sykehuset Telemark og palliativt team i Skien

- Anne Hirsch Tiller, tidligere diakon St. Olavs Hospital, Trondheim

- Svein Bjarte Mangersnes, sykehusprest ved Lovisenberg Diakonale sykehus, Oslo

- Guttorm Eidslott, sykehusprest Sykehuset Innlandet

- Ingun Fossland, Universitetssykehuset NordNorge og Fagutvalg for prester i helsesektoren, Presteforeningen

- Søren Vincent Hagerup, medlem palliasjonsutvalget

- Natasha Pedersen, medlem palliasjonsutvalget

- Hilde Marie Rognlie, sekretær palliasjonsutvalget

Innlegg:

- Odd Arne Skogen og Hilde Halsteinli Unsvåg

Deltakerne ble på forhånd bedt om å besvare følgende spørsmål $i$ innleggene sine:

1. Mandatets mål: Det er et mål at palliativ behandling og omsorg kan gis til alle som har behov for det. Spørsmål:

a. Hvordan opplever du at pasientens og pårørendes helhetlige behov blir ivaretatt?

b. Hvordan blir du som fagperson involvert i omsorgen for og støtten til både pasient og pårørende?

c. Med tanke på pasientens og pårørendes eksistensielle/åndelige behov - på hvilken måte blir 
i. Behovene og ønskene til mennesker fra minoriteter og andre kulturer ivaretatt

ii. Ressurspersoner fra andre kulturer, minoriteter og andre tros- og livssynsamfunn involvert på din arbeidsplass?

d. Har du forslag til tiltak som vil kunne forbedre det helhetlige tilbudet til pasienter og pårørende?

2. I mandatet heter det at Verdens helseorganisasjons definisjon av palliasjon skal legges til grunn i utredningen. I mandatet heter det videre: «God palliativ behandling og omsorg ivaretar den som trenger det på en helhetlig måte, fysisk, psykisk, sosialt og åndelig. Den tar hensyn til brukerens og pårørendes behov gjennom en kontinuerlig dialog under hele sykdomsforløpet». Spørsmål:

a. Sett ut fra din praktiske arbeidshverdag, hvilke refleksjoner gjør du deg i møte med setningen: «god palliativ behandling og omsorg tar hensyn til brukerens og pårørendes behov gjennom en kontinuerlig dialog under hele sykdomsforløpet?»

b. Hvordan/på hvilken måte, og når kommer din rolle og tjeneste inn i et pasientforløp?

c. Har du tanker om samhandling (rutiner, samarbeidsmåter) som bør forbedres, og har du forslag til tiltak?

3. Utvalget skal komme med forslag til tiltak som skal bidra til å styrke kvalitet og kompetanse innen palliasjon. Spørsmål: Med tanke på ditt fagområde, og ut fra det du vet:

a. På hvilken måte gjør den praktiske grunnutdanningen prester/diakoner i stand til å yte eksistensiell/åndelig omsorg og støtte til pasienter som har behov for palliasjon, samt deres pårørende? Har du tanker om $o g$ forslag til forbedringer?

b. Innenfor hvilken videreutdanning er «eksistensiell/åndelig omsorg og støtte til pasienter som har behov for palliasjon, samt deres pårørende» en integrert del? Har du tanker om endringer/forbedringer?

4. Ut fra ditt faglige ståsted, har du andre refleksjoner/innspill du vil gi utvalget?

\section{Møte om frivillighet og palliasjon 19. juni 2017}

Møtedeltakere

- Lill Ann Aanes, daglig leder Termik Vefsn

- Tormod Haavi-Christensen, generalsekretær Fransiskushjelpen

- Aksel Øhrn, Fransiskushjelpen

- Ida Marie Holmin, assisterende generalsekretær Frivillighet Norge
- Stein Kaasa, utvalgsleder palliasjonsutvalget

- Helge Farsund, medlem palliasjonsutvalget

- Joran Slaaen, medlem palliasjonsutvalget

- Ann Kristin Andresen, leder sekretariatet palliasjonsutvalget

Innlegg

- Fransiskushjelpen, Termik Vefsn og Frivillighet Norge. Organisasjonene ble på forhånd bedt om å besvare følgende spørsmål i innleggene sine:

- Hvordan kan vi rekruttere, beholde og utvikle samarbeidet mellom frivillige og helse- og omsorgstjenestene på palliasjonsfeltet i fremtiden? (Blant annet samhandling mellom frivillige aktører og kommunen (kommunal frivillighetspolitikk) og statens rolle.

- Frivillighetens rolle i helse- og omsorgstjenestene. Har frivilligheten noen unike karakteristika som er viktige i palliasjonsfeltet?

- Erfaringer fra andre land om frivillighet og palliasjon?

- Tiltak for å styrke frivillig innsats på palliasjonsfeltet.

Møte med det sosialfaglige miljøet 22. august 2017

Møtedeltakere:

- Sissel Harlo, sosionom, Kompetansesenter for lindrende behandling, Oslo universitetssykehus

- Una Stenberg, seniorforsker, Nasjonal kompetansetjeneste for læring og mestring innen helse, Oslo universitetssykehus

- Heidi Hansen, sosionom, Akershus universitetssykehus

- Ragnhild Askheim Ustaheim, sosionom, Lovisenberg Diakonale Sykehus

- Pia Kjøs Utengen, sosionom, Kreftforeningen

- Bente Øverli, sosiolog, Kreftforeningen

- Marit Gudim, sosionom, Radiumhospitalet, Oslo universitetssykehus

- Tove Bring Solum, sosionom, Vestre Viken HF var invitert, men deltok ikke. Bidro med skriftlig innspill i etterkant av møtet

- Borrik Schjødt, medlem palliasjonsutvalget

- Bodil Husby, medlem palliasjonsutvalget

- Anne Marie Flovik, medlem palliasjonsutvalget

- Helge Farsund, medlem palliasjonsutvalget

- Sjur Bjørnar Hanssen, sekretariatet palliasjonsutvalget

- Hilde Marie Rognlie, sekretariatet palliasjonsutvalget 
Innlegg:

- Una Stenberg, Sissel Harlo, Bente Øverli og Pia Kjøs Utengen

Deltakerne ble på forhånd bedt om å besvare følgende spørsmål i sine innlegg:

- Den sosialfaglige miljøet - er det entydig hvem som hører til denne gruppen?

- Hvordan vil/kan det sosialfaglige miljøet bidra klinisk, undervisningsmessig, forskningsmessig og organisatorisk inn i palliasjonsfeltet?

- Hva er de største barrierer i dag for å utøve klinisk praksis?

- Hvilke tiltak bør inn i NOUen for å bedre dette?

\section{Møte i Sverige}

1. juni 2017 besøkte utvalgsmedlemmene Anne Marie Flovik og Sigve Andersen, utvalgsleder
Stein Kaasa og sekretariatet Socialdepartementet og Socialstyrelsen i Stockholm. Temaet for møtet var å få informasjon om svenske helsemyndigheters erfaringer med kompetansetiltak og organisatoriske løsninger innen palliasjon.

\section{Møte i Danmark}

11. oktober 2017 hadde utvalgsmedlemmene Joran Slaaen, Anne Marie Flovik og Sigve Andersen, utvalgsleder Stein Kaasa og sekretariatet møte med Sundheds- og Eldreministeriet og Sundhedsstyrelsen i København. Temaet for møtet var å få informasjon om danske helsemyndigheters erfaringer med organisering, kompetanse og klinisk forskning innen palliasjon. 


\section{Kapittel 4 \\ Verdier}

Viktigere enn å vite hvilken sykdom et menneske har, er det å vite hvilket menneske som har sykdommen.

Hippokrates

\subsection{Verdigrunnlag}

Palliasjon som fag må bygge på et oppdatert vitenskapelig grunnlag. Samtidig må faget ha en tydelig verdimessig forankring som reflekterer de grunnleggende verdiene som samfunnet er bygget på. Helsetjenesten har ansvar for å gi god behandling og omsorg, fra diagnose stilles, gjennom sykdomsperioden og frem til livets avslutning. For pasientene er det viktig å bli hørt, forstått, inkludert og respektert. Pasientens erfaringer, som er forbundet i et komplekst nett av følelser, meninger og uttrykk, er utgangspunktet for yrkesutøvelsen hos helse- og omsorgspersonell som ivaretar pasienter med behov for palliasjon.

Norge er tilsluttet FNs verdenserklæring om menneskerettigheter og en rekke konvensjoner som skal verne om våre friheter og rettigheter. De slår blant annet fast at alle mennesker har en iboende verdighet og at «enhver har rett til å ha den høyest oppnåelige helsestandard» både fysisk og psykisk. Mange av våre menneskerettslige forpliktelser og de grunnleggende verdiene som følger, er tatt inn i den norske velferdslovgivningen.

Når utvalget velger å ha pasientsentrert tilnærming som et utgangspunkt, skal det også forstås som et verdivalg. En pasientsentrert tilnærming søker å se pasienten ut fra hans eller hennes perspektiv og å bekrefte den enkelte pasient som et unikt menneske, og ikke bare som et av mange individer i et behandlingssystem.

Hospicefilosofiens verdigrunnlag har en sentral plass når helse- og omsorgspersonell ivaretar pasienter med behov for palliasjon. Det er et overordnet mål at den alvorlig og uhelbredelig syke pasienten skal få hjelp til å leve den siste tiden så normalt, aktivt og meningsfullt som mulig. I hospicefilosofien står pasientens liv og verdier sentralt, sammen med den medisinske behandlingen av sykdommen. En åpen og ærlig dialog mellom helsepersonell, pasient og pårørende om livet og døden er både en forutsetning og en del av selve behandlingen. Målet er best mulig livskvalitet for pasient og pårørende.

Hospicefilosofiens formulering «the total pain» innebærer en tverrfaglig tilnærming til pasient og pårørende. «Total pain»-begrepet innbefatter hele bredden i smerteopplevelsen: fysiske og psykiske symptomer, sosiale, eksistensielle og åndelige problemer og personalets smerte, som igjen virker tilbake på pasientens problemer. Skal pasienten få adekvat hjelp, må ulike faggrupper samarbeide i behandlingen, pleien og omsorgen. Oppfølging av pårørende, også etter pasientens død, ses som en nødvendig forutsetning for god behandling, pleie og omsorg. Hospice er et begrep som internasjonalt både har et verdimessig innhold (behandlings- og omsorgsfilosofi) og som representerer et tjenestetilbud spesielt knyttet til sen palliativ fase.

På 1990-tallet ble begrepet «hospice» i økende grad erstattet med begreper som blant annet lindrende behandling og palliativ medisin. En hovedintensjon med begrepsendringen er å vektlegge moderne medisinske behandlingsprinsipper og vitenskapsbasert behandling i kombinasjon med de verdiene som ligger i hospicefilosofien (NOU 1999: 2).

Når liv, helse og livskvalitet i stor grad avhenger av helsepersonellets behandling, pleie og omsorg, pålegger det helsepersonellet et stort helsefaglig og etisk ansvar for både den alvorlig syke og for de pårørende. Et krav om faglig forsvarlighet og omsorgsfull hjelp følger av helsepersonelloven § 4. I tillegg forventes det at helsepersonell har en profesjonsetisk kompetanse som bevisstgjør hva som er deres rolle, ansvar og oppgaver som fagpersoner.

En tydelig etisk bevissthet hos helse- og omsorgspersonell er en forutsetning for pasienters og pårørendes tillit. For leger er forholdet mellom profesjonsetikk og tillit formulert slik: «Tilliten bygger på at leger har en levende profe- 
sjonsetikk og vilje til selvjustis, slik at befolkningen kan stole på at pasientens og samfunnets beste ligger til grunn for de råd som leger gir» (Legeforeningen, 2006). Dette utsagnet er overførbart til alt helsepersonell. Det er viktig å ha en profesjonsetikk som formulerer de faglige forutsetningene for at det etiske grunnlaget kan realiseres i praksis. Hver faggruppe og den enkelte helsearbeider har et selvstendig ansvar for å være oppdatert og bevisst på sin profesjonsetikk. I alle sammenhenger er det avgjørende at pasient og pårørende blir hørt, og at man lytter til og tar stilling til deres ønsker. Dette kan være spesielt viktig og vanskelig i de tilfeller der pasient, pårørende og helsepersonell har ulik oppfatning om hva som bør gjøres. I boks 4.1 vises verdier og prinsipper som er sentrale i vestlige lands arbeid på palliasjonsfeltet.

\section{Boks 4.1 European Association for Palliative Care (EAPC) Standards and norms for hospice and palliative care in Europe}

På bakgrunn av en systematisk gjennomgang av vestlige lands arbeid på palliasjonsfeltet, har European Association for Palliative Care (EAPC) samlet og oppsummert felles verdier og prinsipper som ligger til grunn for landenes arbeid på dette området (EAPC, 2009). Verdiene og prinsippene er sentrale i palliativt arbeid internasjonalt og i Norge. De omfatter også mange grunnleggende elementer som man finner i andre sentrale etiske tilnærminger på palliasjonsfeltet.

1. Autonomy. In palliative care, the intrinsic value of each person as an autonomous and unique individual is acknowledged and respected. Care is only provided when the patient and/or family are prepared to accept it. Ideally, the patient preserves his/her self-determination regarding the power of decision on place of care, treatment options and access to specialist.

2. Dignity. Palliative care is supposed to be performed in a respectful, open and sensitive way, sensitive to personal, cultural and religious values, beliefs and practices as well as the law of each country.

3. Relationship between patient-healthcare professionals. Palliative care staff should maintain a collaborative relationship with patients and families. Patients and families are important partners in planning their care and managing their illness.

4. Quality of life. A central goal of palliative care is to achieve, to support, to preserve and enhance the best possible quality of life.

5. Position towards life and death. Palliative care seeks neither to hasten death or to postpone it.

6. Communication. Good communication skills are an essential prerequisite for quality of pal- liative care. Communication refers to the interaction between patient and healthcare professionals, but also to the interaction between patients and their relatives as well as interaction between different healthcare professionals and services involved in the care.

7. Public education. It is essential to promote preventive healthcare that will leave future generations less afraid of the dying and bereavement that will confront all of us.

8. Multiprofessional and interdisiplinary approach. Palliative care is supposed to be provided within a multiprofessional and interdisciplinary framework. Although the palliative care approach can be put into practice by a single person from a distinct profession or discipline, the complexity of specialist palliative care can only be met by continous communication and collaboration between the different professions and disciplines in order to provide physical, pschyological, social and spiritual support».

9. Grief and bereavment. Palliative care offers support to family and other close carers during the patient's illness, helps them prepare for loss and continues to provide bereavment support, where required, after the patient's death. Bereavement services are recognised as a core component of palliative care service provision. Grief and bereavement risk assessment is routine, developmentally appropriate and ongoing for the patient and family throughout the illness trajectory, recognising issues of loss and grief in living with a life-threatening illness. Bereavement services and follow-up support are made available to the family after the death of the patient. 
Helse- og omsorgstjenestens samlede ressurser skal komme alle pasienter til gode, og prioriteringer handler både om økonomiske og verdimessige valg. Det er et ledelsesansvar å sørge for at tilgjengelige ressurser blir fordelt og brukt i overenstemmelse med sentrale føringer og verdier. Helse- og omsorgspersonellet skal også følge fastsatte retningslinjer for prioriteringer (Meld. St. 34 (2015-2016). "Riktig prioritering handler ikke bare om å la være å gjøre det som ikke virker, men også om å la være å gjøre det som kan skade, og heller bruke ressurser på å finne den rette tid for å avslutte aktiv, sykdomsrettet behandling. I mange tilfeller kan det være bedre å bruke ressurser på lindrende behandling og på gode prosesser med pasient og pårørende» (Meld. St. 34 (20152016).

Veilederen Beslutningsprosesser ved begrensning av livsforlengende behandling (Helsedirektoratet, 2017c) skal bidra til at man får gode prosesser forut for beslutningen som legen til syvende og sist må ta. Veilederen er også ment å være et bidrag til diskusjoner om vanskelige juridiske, etiske og medisinske spørsmål.

\subsection{Kommunikasjon og pasienters rett til medvirkning - hva er viktig for meg?}

Pasient- og brukermedvirkning er en grunnleggende forutsetning i alle pasientforløp. Fagpersonene er spesialister på sykdom, behandling, pleie, omsorg og annen faglig støtte. Pasientene er spesialister på sin sykdom og hvordan den oppleves og erfares i deres liv.

Pasient- og brukerrettighetsloven hjemler i § 3-1 den enkelte pasients rett til å medvirke ved gjennomføring av helse- og omsorgstjenester. Pasientens rett til å medvirke har betydning for helsepersonellets forståelse av pasientens og egen rolle. Helsepersonell skal aktivt legge til rette for medvirkning. Forventningen om at pasienten tar ansvar i egen behandling skal tydeliggjøres. Et mål ved medvirkning er også å bidra til bedre kvalitet i helse- og omsorgstjenesten.

Helse- og omsorgspersonell har et betydelig ansvar for å informere pasienten på en hensynsfull måte, tilpasset pasientens individuelle forutsetninger, slik at han eller hun blir i stand til å gjøre informerte valg. Det styrende prinsippet er at informasjonen skal gis til pasientens beste. Et flertall av pasienter med alvorlig sykdom gir uttrykk for at de ønsker å være informert om sin sykdom og prognose, og diskutere spørsmål knyttet til behandling og omsorg i livets sluttfase (Pasientog brukerombudet, 2016). I alle sammenhenger er det avgjørende at pasienter og pårørende blir hørt, og at man lytter og tar stilling til deres ønsker. Dette kan være spesielt viktig og vanskelig i de tilfeller der pasient, pårørende og helsepersonell har ulik oppfatning om hva som bør gjøres. Mange pasienter erfarer at ønsket om å være informert ikke blir ivaretatt. Pasient- og brukerombudet finner elementer av mangelfull eller dårlig informasjon $\mathrm{i}$ nesten alle henvendelser (Pasient- og brukerombudet, 2016).

Gode beslutninger forutsetter også at det gis rom og tid til pasientens ønsker, ut fra hva han eller hun tror vil gi best livskvalitet. Livskvalitet er subjektivt og kan best kartlegges i samhandling med pasienten. Informasjon fra pasienten bør innhentes på en systematisk måte, og innbefatte hele pasientens livssituasjon.

For at en pasient skal ha mulighet til å treffe gjennomtenkte avgjørelser og benytte medvirkningsretten, må han eller hun være i stand til å forstå sin helsetilstand og hvilke behandlingsmuligheter som finnes. Å ivareta pasientens evne og vilje til å være medvirkende kan være utfordrende når pasienten er alvorlig syk eller døende. Det kan skyldes allmenn svekkelse som følge av fremskreden sykdom, sterke smerter eller reduserte kognitive funksjoner. For pasienter med nedsatte kognitive funksjonsevner må deres interesser i større eller mindre grad ivaretas av pårørende, verger eller av helse- og omsorgspersonell, basert på gjeldende rett. For pasienter som har/ vil få nedsatte kognitive funksjoner bør dialogen mellom helsepersonell og pasienten om dennes ønsker og verdipreferanser derfor komme på et tidspunkt $\mathrm{i}$ sykdomsforløpet hvor det fortsatt er mulig for pasienten å tilkjennegi slike.

Begrepet samvalg (shared decisionmaking) er blitt vanlig i helse- og omsorgstjenesten de senere årene. Ved samvalg samarbeider pasienter og helse- og omsorgspersonell om å treffe beslutninger om utredning, behandling og oppfølging. Samvalg betyr at pasienten får hjelp av helsepersonell til å vurdere de ulike alternativene for å kunne ta et informert valg. Målet er å få frem alle fordelene og ulempene slik at pasienten og helsepersonellet sammen kommer frem til det alternativet som er mest i tråd med det som er viktig for pasienten (helsenorge.no/).

Rett til medvirkning handler ikke om retten til å kreve en bestemt behandling, men om pasientens rett til, på informert grunnlag, å akseptere eller avslå tilgjengelig behandling. Medvirkningsretten fritar ikke helsepersonell fra å treffe avgjø- 
relser som sikrer forsvarlig behandling av pasienten (helsepersonelloven 1999, § 4).

Selv om idealet er pasientautonomi, er det ikke alle pasienter som ønsker, eller føler seg i stand til å medvirke. Helse- og omsorgspersonell må være bevisst at retten til medvirkning også kan bety retten til ikke å medvirke (Helsedirektoratet, 2015a) . Pasienter som har tillit til sine behandlere, har trolig også tillit til at han eller hun vil anbefale det alternativet som er best for dem. En amerikansk undersøkelse der 27000 pasienter ved 51 sykehus deltok, fant at tiltro og tillit til behandlerne og det at de opplevde å bli mott med respekt og verdighet, var viktigere for pasientene enn autonomi i tradisjonell forstand (Joffe m.fl., 2003).

«Den gode samtalen» mellom helsepersonell og pasienten inngår i palliativ behandling. Det stiller krav til kommunikasjonsferdigheter hos helsepersonell. For at pasienten skal kunne få samtale om både fysiske, psykiske, sosiale og åndelige/ eksistensielle tema, er det viktig at pasienten så tidlig som mulig tilbys samtaler med aktuelle fagpersoner. Hva som er viktig for pasienten må være et styrende prinsipp for både hvilke faggrupper som skal tilbys og hva samtalene skal inneholde.

Kommunikasjonen må sees på som et sammenhengende forløp, hvor pasienten jevnlig får mulighet til å bli oppdatert på egen helsesituasjon og inviteres til å gi uttrykk for egne preferanser. Ikke sjelden endrer pasienters prioriteringer seg over tid. Når pasienten erkjenner at livet nærmer seg slutten, er det ekstra viktig at helsepersonellet er oppmerksomme på hva pasienten og pårørende ønsker å samtale om, enten det gjelder spesielle ønsker eller bekymringer knyttet til uro, smerter, sosiale situasjoner eller annet ubehag.

Møter mellom helsepersonell og pasienter og pårørende innebærer ikke sjelden møter mellom mennesker fra ulike kulturer. Våre holdninger utfordres i møte med det som kan oppleves som ukjent og fremmed. Når samtaler preges av til dels ukjente rolleforståelser og normer, kan det være utfordrende for helsepersonell som vil følge tradisjonelle definisjoner for god og respektfull kommunikasjon. Videre kan det oppleves som en stor faglig og etisk utfordring når pasienter velger andre behandlingsløsninger enn det faglige etiske retningslinjer tilsier. For eksempel er det viktig med tett oppfølging og god kommunikasjon når en pasient velger å ikke ta imot anbefalt smertelindring fordi det etter hans eller hennes livssyn er viktig å ta avskjed med sinnsro og med tankens klarhet i behold.

Å øve seg i kultursensitivitet hører med til helsepersonellets profesjonalitet. Kultursensitivet handler om likeverdig og anerkjennende kommunikasjon med mennesker med en annen referanseramme enn en selv, og innebærer vilje til å vise forståelse for å ville ivareta andres verdier og unikhet. (Eide, Rugkåsa, m.fl., 2009). Innen palliasjon er det viktig at helsepersonell søker å få innsikt i og forståelse for pasienters og pårørendes forhold til helse, sykdom og død. Helsepersonellets vilje til å vise empati, respekt og forståelse har avgjørende betydning for tillit $\mathrm{g}$ åpenhet, på tross av store kulturelle og verdimessige ulikheter.

Å kunne beholde en form for håp er viktig for mange pasienter og pårørende. Håpet kan ha betydning for opplevelsen av livskvalitet (Fremstedal, 2008). Håpet kan knyttes til det å bli helbredet. Det kan knyttes til det å få oppleve noe godt og meningsfullt, eller i det minste å få slippe plagsomme smerter eller annet ubehag, de dagene som er igjen av livet. Håpet kan også knyttes til det å kunne få lov til slippe fra et liv. Ikke sjelden har pasient og pårørende håp som helsepersonell ikke kan dele. Pasienten og pårørende kan holde på et håp om helbredelse selv om prognosen er svært dårlig, mens helsepersonell ser en sykdomsutvikling med et kort livsperspektiv. Jo mer tid helsepersonell investerer i samtaler med pasient og pårørende, jo større sjanser er det for at de får en felles forståelse av situasjonen og hva som er grunn til å håpe på. En god og støttende dialog med oppmerksomhet mot de muligheter som finnes motvirker gjerne opplevelsen av håpløshet. I dialogen mellom pasient, pårørende og helsepersonell er det nødvendig å få tydelig fram at palliativ behandling er aktiv behandling med formål om å oppnå best mulig livskvalitet. For pasient og pårørende endres også håpet underveis $i$ sykdomsperioden. Der håpet før var å bli frisk, er det nå kanskje knyttet til å få oppleve noe en siste gang, eller en god samtale med en bestemt person og få noen gode øyeblikk.

\subsection{Etiske utfordringer: pasientenes preferanser og rett behandlingsnivå}

Mange møter mellom pasient og helse- og omsorgspersonell handler om hva som er mulig og hva som er best å gjøre i en konkret situasjon. Mange av valgene som skal tas er også etiske dilemmaer ved at ulike verdier, faglige vurderinger, interesser, behov og ønsker - som hver for seg er viktige - til sammen ikke lar seg oppfylles.

Mange etiske utfordringer innen palliasjon finner vi igjen også innenfor andre fagfelt. Det kan 
være utfordringer knyttet til uenighet mellom pasientens ønsker om behandling og helsepersonellets vurderinger av hva som er den beste behandlingen. Det kan være uenighet knyttet til helsepersonellets behov for å sette av tid til å drøfte et behandlings- eller pleietiltak satt opp mot pasientens behov for å fortelle om egen situasjon. Det kan også være utfordringer knyttet til hvor mye tid og ressurser helsepersonellet skal bruke i møte med den ene pasienten, satt opp mot behovet pasientgruppen som helhet har.

\subsubsection{Rett behandlingsnivå og kvalitetsindikatorer}

En spesiell utfordring ved palliasjon er når målet for behandling, pleie og omsorg ikke lenger er at pasienten skal bli helbredet, men at pasienten skal få mulighet til å leve resten av livet så godt og aktivt som mulig. Det er helse- og omsorgspersonellets etiske plikt å lytte til pasienters og pårørendes behov og ønsker. Samtidig er det helsepersonellets ansvar å unngå overbehandling mot livets slutt. Det er ikke riktig å imøtekomme krav om sykdomsrettet behandling, når behandlingen med stor sannsynlighet ikke kan gi livsforlengelse eller god symptomlindring, men kun vil påføre pasienten komplikasjoner og ubehag. Det kan være vanskelig å finne riktig intensitet på medisinsk behandling av pasienter i livets sluttfase. Utfordringene ligger på mange plan, både medisinskfaglig, etisk og samfunnsmessig. Dette har blitt særlig aktuelt de siste tiårene fordi moderne medisin har gjort det mulig å forlenge livet for personer som ellers ville ha dødd (Kunnskapssenteret, 2014).

Overbehandling innebærer at man gir sykdoms- eller symptomrettet behandling som har liten eller ingen effekt, og/eller som påfører pasienten unødig plage og funksjonstap. Overbehandling kan føre til dårligere livskvalitet både for pasient og familie den siste tiden pasienten har igjen å leve, den kan også redusere forventet levetid, i tillegg til at det brukes ressurser som andre pasienter trolig kunne ha bedre nytte av. Et annet forhold helsetjenesten må ta hensyn til, er bruk av ressurser mot livets slutt.

Helsepersonell har den krevende oppgaven å hindre overbehandling når palliasjon er formålet. Behandling som vurderes som nytteløs kan ta oppmerksomheten bort fra det faktum at livet går mot slutten. Behandlers faglige og etiske utfordring er å finne ut når det er riktig å avslutte livsforlengende behandling og formidle denne vurderingen i en dialog med pasient og pårørende. Det er et lederansvar å påse at behandling som har liten eller ikke effekt, og/eller som påfører pasienten unødig plage og funksjonstap ikke gis.

Sentrale spørsmål om overbehandling blir reist av helse- og omsorgspersonell som arbeider med alvorlig syke og døende pasienter. Mange mener at overbehandling forekommer hyppig og er et alvorlig dilemma. I flere studier er det vist at pasienter blir overbehandlet mot livets slutt (National Institutes of Health, 2017). Det er problematisk både av hensyn til pasientenes lidelse, verdighet og integritet, men også fordi en synes ressursene kunne ha vært brukt på en annen måte. Når er behandling kun en utsettelse av en nært forestående død, og når er behandlingen en reell livsforlengelse? Når vil hjelpen ha en slik verdi for pasient og pårørende at den likevel skal ytes? Vil de ressursene som eventuelt brukes i en slik behandlingsfase (personale, sengekapasitet på intensivavdelingen, respirator, dialysemaskin osv.) begrense mulighetene til å behandle pasienter med bedre prognose?

I moderne medisinsk utdanning er død et tema som ikke behandles som en naturlig følge av å ha levd et liv, men som et onde som kan forsky-

\section{Boks 4.2 Pasienthistorie}

«Jeg fikk en pasient på vakt i går fra et sykehjem i kommunen, han var gammel, sterkt allment og kognitivt redusert, men sa fra at han ønsket å dø. Legevaktslegen som kom til sykehjemmet kunne ikke ta ansvar for pasienten som hadde en sannsynlig lungebetennelse. Derfor ble han lagt inn til overvåkning på medisinsk avdeling». «Hvorfor kom denne pasienten til oss, når han etter min vurdering var best tjent med hjerte-lungeredning minus (HLR minus) og å få behandling, pleie og omsorg på sykehjemmet?» «Dersom sykehjemmet (lege og sykepleier) sammen med pasienten og familien hadde snakket om situasjonen, brukt prinsippene om forhåndssamtale (advance care planning) og pasientsentret behandling hadde de konkludert med at pasienten ikke skal ha antibiotika ved infeksjon og heller ikke væskebehandling, så sant ikke det overordnede målet er ren symptomlindring. Da ville sannsynligvis denne pasienten ikke blitt flyttet til oss på medisinsk avdeling». 
ves med riktig behandling (Williams og Wilson mfl., 2005). Det er et paradoks at ny medisinsk teknologi bidrar til bedre intensiv behandling og bedre livsforlengende behandling av store sykdomsgrupper, slik som kreft, nyre-, hjerte- og lungesykdommer - samtidig som utviklingen bidrar til overbehandling og unødvendig lidelse og plage mot livets slutt.

I den offentlige diskusjonen blir medisinsk høyteknologisk behandling beskrevet som helbredende, når den er livsforlengende. Helsepersonell blir, i likhet med andre, påvirket av dette. Helsepersonell bør, med jevne mellomrom, være med i diskusjoner om livet og døden, prioriteringer og verdivalg, og drøfte sentrale etiske og faglige tema knyttet til spørsmål om overbehandling, beslutningsvalg og ivaretakelse av pasienter med særlige behov.

\subsubsection{Pasientenes preferanser - forhåndssamtaler}

Forhåndssamtaler (advance care planning) er samtaler med pasienter om framtidig behandling. Slike formaliserte samtaler vil kunne bidra til at pasientens ønsker er kjent ved krevende beslutninger mot livets slutt generelt, og spesielt hvis den kognitive evnen forventes å bli redusert.

Pasienter som trenger palliativ behandling har ofte sammensatte lidelser. Økt risiko for kritiske hendelser, sykehusinnleggelser og død peker nettopp på behovet for samtaler med pasienten om tiden fremover, hvordan man skal bli enige om gode beslutninger og hva som skal skje hvis helsetilstanden forverres.

Studier (Friis og Førde, 2015, EAPC, 2017) viser at et tilbud om forhåndssamtaler ble godt mottatt av geriatriske pasienter under et sykehusopphold og at forhåndssamtaler brukes i flere sykehjem. Tidligere studier har vist at et mindretall av sykehjemmene praktiserer slike samtaler. En spørreundersøkelse blant norske sykehjem i 2014 (Sandsdalen, 2016) viser at stadig flere sykehjem gjennomfører en form for forberedende samtaler, men at tidspunkt, innhold i samtalene og hvem som deltar, varierer. Undersøkelsen viste at pasientene sjelden deltok i samtalene. Dette har trolig sammenheng med at det er en relativt høy andel med kognitiv svikt i denne pasientgruppen. At praksis varierer, er ikke overraskende - sett i lys av at diskusjonen om viktigheten av forhåndsamtaler for bedre å ivareta pasientens ønsker og verdier er relativt ny i Norge. Funn bekreftes i andre nyere studier - sykehjemspasienter deltar bare unntaksvis i slike samtaler, selv når de er samtykkekompetente. Dette gir grunn til å stille spørsmål om hvordan pasientens rett til selvbestemmelse ivaretas og hva helsepersonellets beslutninger er basert på (Gjerberg og Lillemoen, 2017).

I dag finnes det ikke nasjonale retningslinjer for forhåndsamtaler, men Helsedirektoratet anbefaler at sykehjem inviterer pasient og pårørende til denne type samtaler (Helsedirektoratet, 2013). Utvalget mener at det bør være et mål at det utvikles retningslinjer for forhåndssamtaler og at ordningen med forhåndssamtaler implementeres $\mathrm{i}$ alle deler av helsetjenesten. Retningslinjene bør omhandle innholdet av forhåndssamtalene, hensikten med samtalene, når og hvordan man introduserer dem og i hvilken form de bør foregå.

Flere land har tatt i bruk forhåndssamtaler som et systematisk verktøy. Det pekes på at advance care planning gjerne består av flere samtaler, hvor pasienten sammen med helsepersonell får mulighet til å tenke og snakke gjennom, og planlegge fremtidig behandling og omsorg, inklusiv behandling og omsorg også når livet går mot slutten. Det styrende spørsmålet er også her «Hva er viktig for deg?» (advancecareplanning.org). Pasientens for-

\section{Boks 4.3 Definisjon av forhåndssamtale}

European Association for Palliative Care (EAPC) har laget denne definisjonen av «advance care planning»: «Advance care planning enables individuals who have decisional capacity to identify their values to reflect preferences for future medical treatment and care, and to discuss these with family and healthcare providers. ACP addressess individuals concerns across the physical, psychological, social, and spiritual domains. It encourages individual's to identify to a personal representative and to record an regularly review any preferences, so that their preferences can be taken into account should they, at some point, be unable to make their own decisions» (EAPC, 2017).

Kort definisjon: «Advance care planning enables individuals to define goals and preferences for future medical treatment and care, to discuss these goals and preferences with family and health-care providers, and to record and review these preferences if appropriate». 
hold til pårørende og hvilke roller pasienten ønsker de skal ha, er også viktige spørsmål. Forhåndssamtaler forutsetter tilstrekkelig kompetanse blant annet innen juss og etikk, samt gode kommunikasjonsferdigheter og skjer gjerne innen rammen av et tverrfaglig samarbeid.

Forhåndsdirektiv eller forhåndserklæring om å avstå fra medisinsk behandling i gitte situasjoner kan styrke pasientens autonomi i beslutninger om behandlingsbegrensning når pasienten selv er ute av stand til å delta i beslutningene (Nasjonalt kunnskapssenter for helsetjenesten, 2014).

Utvalget mener at en styrket selvbestemmelsesrett krever økt samtalefrekvens mellom den uhelbredelig syke pasienten og helsepersonell. Utvalget vil foreslå at man setter forhåndssamtaler i system ved at en person med relevant helsefaglig utdanning som pasienten har særlig tiltro til, har jevnlige forhåndssamtaler om behandlingsnivå og intensitet, samt tar opp spørsmål av eksistensiell karakter og hvor det er hensiktsmessig å informere om muligheten til å opprette et livstestament i kjernejournalen. Et slikt system krever at aktuelt helsepersonell trenes/utdannes til å gjennomføre forhåndssamtaler. Utvalget foreslår derfor som tiltak et kommunikasjonsforløp som inngår i en standard for god behandling, pleie og omsorg. Det utvikles en nasjonal metodikk for forhåndssamtaler og denne skal implementeres som en obligatorisk del av de palliative pasienttilpassede forløpene.

Utfordringer knyttet til overbehandling i palliativ fase bør møtes ved å avklare behandlingsmuligheter, pasientens ønsker etter en god dialog om forventet effekt og eventuelle bivirkninger av behandlingen, og det må gjøres et valg når det gjelder behandlingsintensitet. Dette krever en avklaring av behandlingsnytte, og en forberedelse på forestående død.

\subsubsection{Etiske vurderinger ved palliasjon til barn}

Etisk tenkning og vurdering er grunnleggende i all behandling av barn. Man kan argumentere for barns rett til palliativ behandling ut fra en rettighetsbasert tilnærming, der Verdens helseorganisasjons definisjon av palliasjon til barn er sentral, sammen med pasient- og brukerrettighetsloven.
Nasjonal faglig retningslinje for palliasjon til barn og unge uavhengig av diagnose (Helsedirektoratet, 2017) anbefaler at tiltak og/eller behandling vurderes ut fra de fire etiske grunnprinsippene: ikke gjøre skade, gjøre godt, respektere barnets og familiens autonomi og fordele begrensede goder på en rettferdig måte. Av retningslinjen framgår det videre at kontinuerlig åpenhet og dialog er grunnleggende i palliativ tenkning.

Palliativ involvering og behandling skal starte før kurativ behandling avsluttes. Helsepersonell bør tilstrebe enighet med pasient og pårørende om overgangen fra livsforlengende og symptomrettet behandling til lindrende behandling. Barn skal ha tilgang til likeverdige palliative tjenester, enten det er i hjemmet, i heldøgns omsorgsbolig eller på sykehuset.

Palliasjon stiller store krav til kommunikasjon, det gjelder barn i alle aldre, overfor foreldre med barn som lever med en uhelbredelig sykdom, barn i sorg og barn i møte med døden. Barn har rett til å delta i samtaler og avgjørelser knyttet til deres eget liv og helse, men involvering og ansvar må tilpasses barnets helsetilstand, modenhet og alder. Det er viktig å legge til rette for at barnet kan komme fram med sine tanker knyttet til sin livssituasjon og til døden.

Når et barn er alvorlig sykt, rammes hele familien. Det er svært viktig at det etableres rutiner som inkluderer foreldre og søsken i samtaler gjennom hele forløpet, fra diagnosen stilles, til ettervern når barnet har dødd. I samtalene bør oppmerksomheten rettes mot det syke barnets situasjon og foreldre og søskens egen situasjon og behov.

\subsection{Tiltak}

- Alle sykehus skal ha en plan for å forebygge overbehandling mot livets slutt. Planen må være en del av de pasienttilpassede forløpene.

- Det etableres nasjonale indikatorer for å fange opp overbehandling mot livets slutt.

- Det utvikles en nasjonal metodikk for forhåndssamtaler. Forhåndssamtalene skal være en obligatorisk del av de pasienttilpassede forløpene. 


\section{Kapittel 5 \\ Perspektiv}

\begin{abstract}
Hva om syke og eldre allerede ofres; hva om de er ofre for vår manglende evne til å se det uunngåelige faktum ved livet $i$ oynene - at det tar slutt en dag? Og hva om det finnes bedre tilncerminger rett foran oynene på oss?
\end{abstract}

A. Gawande

\subsection{Et tilbakeblikk}

\subsubsection{Tidligere utredninger og stortingsmeldinger}

NOU 1984: 30 Pleie og omsorg for alvorlig syke og døende mennesker anbefalte etableringen av palliative enheter med akademisk forankring ved norske universitetssykehus. Det skulle gå nesten ti år før en slik enhet ble opprettet i Norge. Seksjon lindrende behandling (SLB) ved Regionsykehuset i Trondheim ble opprettet i 1994. Enheten ble etablert som en del av Kreftavdelingen og var Norges første integrerte universitetsbaserte palliative tilbud. Den første professoren i palliativ medisin ble i 1993 ansatt ved Det medisinske fakultet ved NTNU i Trondheim. Selv om det tok mange år før noen av utvalgets tiltak ble realisert, har utredningen hatt stor betydning. (Strømskag, 2012).

NOU 1997: 20 Omsorg og kunnskap! Norsk kreftplan ble utarbeidet av en ekspertgruppe som skulle peke på de viktigste utfordringene innen kreftområdet $\mathrm{i}$ årene framover. Ekspertgruppen anbefalte en oppbygging av både kompetansen og kapasiteten i palliativ medisin, at palliativ medisin burde ha en akademisk forankring og at faget burde bygges opp som en integrert del av helsetilbudet. Ekspertgruppen pekte på behovet for en oppbygging av en sammenhengende kompetanseog tiltakskjede fra regionsykehusene via behandlende avdeling ved sentral- og fylkessykehusene til primærhelsetjenesten. Utredningen anbefalte en styrking av palliativ kreftbehandling og at kreftsyke i livets sluttfase må få tilbud om hjemmebasert behandling og pleie.

St.prp. nr. 61 (1997-98) Om nasjonal kreftplan og plan for utstyrsinvesteringer ved norske sykehus foreslo å bygge opp kompetansesentre for smertelindring ved alle landets regionsykehus. Forslaget ble fulgt opp i statsbudsjettet (St.prp. nr. 1 (199899)), der det ble bevilget midler til etablering av kompetansesenter for lindrende behandling ved alle landets regionsykehus. Se nærmere omtale av de regionale kompetansesentrene for lindrende behandling (kapittel 9).

I NOU 1999: 2 Livshjelp ble det fremmet konkrete forslag til hvordan palliasjon bør organiseres i Norge. Utvalget anbefalte etablering av kompetansesentre innen palliasjon ved regionsykehusene med ansvar for sin region, noe som senere er blitt fulgt opp med egne bevilgninger. Andre forslag fra Livshjelpsutvalget er egnede plasser i sykehjem for pasienter som har behov for palliasjon, opprettelse av enheter for lindrende behandling ved sentralsykehus, og egne konsulentteam og poliklinikker ved sentralsykehus og lokalsykehus. Dette er senere fulgt opp. Utvalget foreslo også krav til kompetanse innen palliasjon for helsepersonell, blant annet en egen spesialitet for leger innen palliativ medisin og videreutdanning $\mathrm{i}$ palliativ omsorg for sykepleiere.

I St.meld. nr. 47 (2008-2009) Samhandlingsreformen er det et mål at pasienter og brukere møter en helsetjeneste som er godt samordnet, preget av kontinuitet og med behandlingskjeder og pasientforløp som ivaretar god behandlingskvalitet, uansett hvem som har ansvaret for de enkelte deltjenestene. Særlig viktig er dette for pasienter med langvarige og sammensatte behov, som eldre personer med flere diagnoser, syke barn og unge, pasienter med kroniske lidelser, pasienter med psykiske helseproblemer, personer med rusmiddelproblemer og pasienter med kort forventet levetid. Samhandlingsreformen slår fast at kommunene skal sørge for en helhetlig tenkning med forebygging, tidlig intervensjon, tidlig diagnostikk, behandling og oppfølging, slik at helhetlige pasientforløp i størst mulig grad kan ivaretas innenfor beste effektive omsorgsnivå (BEON).

I Meld. St. 26 (2014-2015) Fremtidens primorhelsetjeneste - ncerhet og helhet fremgår det at for å 
gi et godt faglig palliativt tilbud er det behov for å styrke kompetansen om lindrende behandling og omsorg i den kommunale helse- og omsorgstjenesten. Stortingsmeldingen viser til at styrket kunnskap om fagfeltet, ansattes holdninger, flerfaglig samarbeid og etablering av gode styringsverktøy er grunnleggende for å gi et godt palliativt tilbud. Det er videre behov for å tydeliggjøre ansvarsforhold i tiltakskjeden og å etablere gode rutiner, blant annet ved inn- og utskriving til spesialisthelsetjenesten og for å involvere pasienter og pårørende.

I Meld. St. 34 (2015-2016) Verdier $i$ pasientens helsetjeneste - melding om prioritering legges tre kriterier til grunn for prioritering: Nyttekriteriet, ressurskriteriet og alvorlighetskriteriet. Det framgår at disse kriteriene må vurderes samlet, $o g$ at jo mer alvorlig en tilstand er og jo større nytte et tiltak har, jo høyere ressursbruk kan aksepteres. Det framgår at riktig prioritering ikke bare handler om å la være å gjøre det som ikke virker, men også om å la være å gjøre det som kan skade, og heller bruke ressurser på å finne rett tid for å avslutte aktiv, sykdomsrettet behandling. I mange tilfeller kan det være bedre å bruke ressurser på lindrende behandling og tid til gode prosesser med pasient og pårørende. Selv om slike prosesser kan være særlig krevende i møte med dødelig sykdom vil de samme mekanismene være til stede ved kroniske lidelser som ikke kan helbredes. I mange tilfeller vil det da være viktig at helsepersonellet drøfter mulige alternativer som kan bidra til at pasienten på best mulig måte kan leve med en sykdom eller skade.

Meld. St. 11 (2015-2016) Nasjonal helse- og sykehusplan omtaler arenafleksible helsetjenester, som er helsetjenester som kan ytes på ulike steder. Det tas utgangspunkt i hvilke tjenester pasientene trenger og deretter hvor det er best å få tjenestene: i sykehus, i distriktspsykiatrisk senter, ved poliklinikk, hos fastlegen, på sykehjem, hjemme hos pasienten eller via smarttelefonen. Ekonsultasjoner og ambulante og tverrfaglige tjenester vurderes som en spesielt nyttig arbeidsform overfor pasienter og brukere som helst bør være i egne og kjente omgivelser.

Helsedirektoratet har utarbeidet retningslinjer og dokumenter som gir føringer for utvikling av palliasjon: Nasjonalt handlingsprogram for palliasjon $i$ kreftomsorgen (Helsedirektoratet, 2015b), Nasjonal faglig retningslinje for palliasjon til barn og unge uavhengig av diagnose (Helsedirektoratet, 2017) og Rapport om tilbudet til personer med behov for lindrende behandling og omsorg ved livets slutt- å skape liv til dagene (Helsedirektoratet, 2015a).

Palliasjon er av stor betydning for pasienter innenfor de fleste fagområder, men er omtalt i få offentlige dokumenter. Det er derfor viktig å sette dette temaet på dagsorden nå.

\subsection{2 Økt medbestemmelse - fra paternalistisk tilnærming til "pasientens helsetjeneste» og pasientens behov som utgangspunkt}

En paternalistisk tilnærming var lenge rådende $\mathrm{i}$ helsetjenesten, både i Norge og i andre land. Profesjonene gikk på statens vegne inn i folks liv og fortalte dem hvordan de skulle leve. Ved gjennomføringen av pasientrettighetsloven av 1999 og lovfesting av autonomiprinsippet fikk paternalismen sitt grunnskudd når det gjelder medisinsk behandling. Rettsliggjøringen av helse- og sosialpolitikken kan oppfattes som forløperen for valgfrihet som politisk ideal. Den skiftende politiske tenkemåten og de historiske utviklingslinjene avspeiles blant annet i omtalen av målgruppene i helse- og sosialtjenesten. Først het det de fattige, så de nødstedte, de trengende, etter hvert klientene, de trygdede, tjenestemottakerne - og nå: pasientene, beboerne, brukerne og kundene (Heløe, 2012).

Pasient- og brukerrettighetsloven (1999) hjemler den enkelte pasients rett til å medvirke ved gjennomføring av helse- og omsorgstjenester med mål om at det skal bidra til bedre kvalitet $\mathrm{i}$ helse- og omsorgstjenesten. Innføring av loven utfordret helsepersonell i deres holdninger og forståelse både av pasientens og deres egen rolle. Rett til medvirkning handler ikke om retten til å kreve en bestemt behandling, men om pasientens rett til, på informert grunnlag, å akseptere eller avslå tilgjengelig og forsvarlig behandling. Medvirkningsretten fritar ikke helsepersonell fra å treffe avgjørelser som sikrer forsvarlig behandling av pasienten (helsepersonelloven $\S 4$ ).

Det ble tatt til orde for en mer aktiv pasient- og brukerrolle i Meld. St. 10 (2012-2013) God kvalitet - trygge tjenester. Kvalitet og pasientsikkerhet $i$ helse- og omsorgstjenesten. Det understrekes at pasienters og brukeres behov skal stå i sentrum, og at pasienter og brukere skal trekkes mer aktivt inn $\mathrm{i}$ beslutninger om eget behandlingsopplegg eller omsorgstilbud. Det ble foreslått en rekke tiltak i meldingen, blant annet å utvikle og implementere beslutningsstøtteverktøy for å hjelpe pasienter og brukere til aktiv medbestemmelse, videreutvikle og implementere tiltak for å bedre 
kommunikasjonen mellom pasienter og brukere og helse- og omsorgspersonell, samt videreutvikle brukererfaringsundersøkelsene, og å utvikle flere pasient- og brukerrapporterte effektmål.

Dagens regjering har pasientens helsetjeneste som et mål. Dette framgår i oppdragsdokumentet til de regionale helseforetakene i 2017 (Helse- og omsorgsdepartementet, 2016):

«Regjeringen vil skape pasientens helsetjeneste. I møtet med helsetjenesten skal hver enkelt pasient oppleve respekt og åpenhet, få delta $\mathrm{i}$ beslutningene om egen behandling og hvordan den skal gjennomføres. Pasientene skal oppleve helhetlige og sammenhengende tjenester også mellom spesialist- og kommunehelsetjenesten. Det skal legges til rette for god kommunikasjon mellom helsepersonell og pasient, dette innebærer bruk av tolketjenester når det er behov for det. Samiske pasienters rett til og behov for tilrettelagte tjenester må etterspørres og synliggjøres fra planleggingsfasen, gjennom utredningsfasen, $o g$ når beslutninger tas.»

\subsubsection{Den internasjonale utviklingen}

Utviklingen av palliasjon spenner fra de første hospicene som ble etablert i Lyon i 1842 og i Dublin i 1879, fram til etableringen av St. Christopher's Hospice i London i 1967 og den videre utviklingen de siste 20-25 årene. Etableringen av St. Christopher's Hospice markerte starten på en ny æra, både innen hospicefeltet generelt og som en begynnelse på fagfeltet palliativ medisin. Tidligere ble det lagt mest vekt på pleie og omsorg for den døende, og det var liten eller ingen medisinsk tilnærming. En av hovedmålsetningene med å etablere St. Christopher's hospice var å drive klinisk forskning. Drift av institusjonene ble i hovedsak basert på frivillighet og innsamlede gaver. De første 30 årene var driften av St. Christopher's Hospice også til en viss grad basert basert på disse prinsippene, men etter hvert er denne institusjonen i stadig større grad blitt integrert i den offentlige helsetjenesten. I tillegg var det å gi palliasjon et akademisk grunnlag en av de oppgavene som Cicely Saunders (1918-2005) la vekt på ved grunnleggingen av St. Christopher's Hospice. Hun sa allerede i 1965 at: «We want to plan and carry out research in the relief of distress, such as has not been done anywhere else, so far as I have been able to discover». I mange land, også i Norge, var legene lite synlige i palliasjon inntil slutten av 1980-årene. Det var mye oppmerksom- het rundt den døende pasienten, det var liten eller ingen akademisk forankring av faget, og utviklingen var i stor grad preget av enkeltpersoner med et betydelig personlig engasjement (Kaasa og Haugen, 2006).

Med etableringen av St. Christopher's Hospice ble tilnærmingen til pasientene satt i system. Både fysiske symptomer, psykiske plager, sosiale, åndelige og eksistensielle problemer regnes som utgangspunkt for den moderne hospicebevegelsen (Strømskag, 2012). Hospice er betegnelsen på ulike institusjoner som tilbyr lindrende behandling på ulike nivåer. Betegnelsen brukes forskjellig i ulike land. Hospice har i dag en dobbel betydning ved at det både handler om en tilnærmingsmåte til alvorlig syke og døende pasienter og ved at det er betegnelse på institusjoner med noe forskjellig innhold ulike steder i verden. Hospice er fundamentert på hospicefilosofien.

Medisinsk og teknologisk utvikling har redusert spedbarns- og barnedødeligheten og økt sjansene for overlevelse for barn med alvorlige, sjeldne og potensielt dødelige sykdommer. Det har vært en betydelig utvikling av palliasjon til barn. På 1970-tallet viste forskning at kreftrammede barn kunne få behandling hjemme som alternativ til sykehus. De første fagbøkene om barnepalliasjon ble utgitt mellom 1978 og 1994, og det første hospicet for barn ble åpnet i Virginia i 1978 (Goldman, 2016). Barn og ungdom med livstruende og livsbegrensende sykdom og deres familie bør tilbys palliativ oppfølging i henhold til Verdens helseorganisasjons definisjon og utdyping. Palliasjon til barn skal være i tråd med norsk lovgivning (Grunnloven § 104) og Norges internasjonale forpliktelser (Helsedirektoratet, 2017). I 2015 arrangerte Verdens helseorganisasjon en sesjon om barnepalliasjon på det 68 . World Health Assembly (Verdens helseorganisasjons høyeste besluttende organ). Dermed markerte organisasjonen et historisk sprang framover for en global støtte til barnepalliasjon. (Verdens helseorganisasjon, 2017).

Internasjonalt har det vært en bevegelse for utvikling av palliasjon til barn og unge siden tidlig på 2000-tallet, med engasjement over hele verden. International Childrens's Palliative Care Network ble stiftet i 2005.

Retningslinjer og handlingsplaner for palliasjon er ofte forankret i kreftplaner og har dermed $i$ hovedsak rettet seg mot kreftpasienter, og ikke så ofte andre pasientgrupper, eldre mennesker eller barn og unge. Behovet for palliasjon hos eldre mennesker, de som er i tidlige stadier av sykdom og hos pasienter som ikke har kreft, for eksempel 
personer med demens, nevrologiske progredierende lidelser, palliasjon til barn, luftveissykdommer, hjertesykdom eller hjerte- og karsykdommer, blir ofte ikke ivaretatt.

Det foreligger evidens og forskningsresultater som viser god effekt av å integrere palliasjon tidlig i forløpet, både ved kreft og andre, livsbegrensende sykdommer (Hui og Bruera, 2016).

\subsubsection{Utviklingen i Norge og Norden}

Palliasjon i Norge og Norden har i hovedsak fulgt den samme utviklingen som i Nord-Europa på 1980- og 1990-tallet. Felles for Sverige, Danmark og Norge er at palliative tjenester i dag er organisert som en integrert del av den offentlige helsetjenesten. Samtidig er det noen ulikheter mellom de nordiske landene.

I Sverige ble de første palliative virksomhetene etablert ut fra lokale initiativ på 1970-tallet. Sverige har hatt en betydelig satsing på integrert palliasjon i hjemmet. Denne utviklingen har vært sterkere enn i de andre nordiske landene, og har vært med på å prege den palliative utviklingen. Sverige fikk sitt første professorat i palliativ medisin i 2001, og palliativ medisin har siden 2015 vært godkjent som en påbyggingsspesialitet for leger.

I Danmark har hospicebevegelsen stått sterkt i utviklingen av palliasjon, båret frem av en folkebevegelse og preget av stor grad av frivillighet. Det første hospicet ble etablert i 1992. Danmark har i dag ett eller flere selveide hospice i hver helseregion. Hospicetilbudet inkluderer et barnehospice. Den første palliative enheten på sykehus ble etablert på Bispebjerg Hospital i 1997, og Danmark fikk sine to første professorater i palliativ medisin i 2012. I 2004 vedtok Folketinget en egen forskrift om hospice, og siden har hospicene vært en del av tilbudet $\mathrm{i}$ spesialisthelsetjenesten.

I Norge var det en økende interesse for alvorlig syke og døende og deres pårørende på slutten av 1960-tallet og på 1970-tallet. Enkelte fagpersoner ble inspirert av Cicely Saunders arbeid. Diakonien vokste også fram. I 1977 startet Fransiskushjelpen i Oslo sitt arbeid for alvorlig syke og døende i hjemmet.

Fra 1970-årene begynner arbeidet for de alvorlig syke og døende å bli mer koordinert og personuavhengig. Det ble etablert palliative tilbud som en del av kreftavdelingene i Bergen, Trondheim og Tromsø og også tverrfaglige rådgivningsgrupper for omsorg ved livets slutt. I 1984 ble disse organisert under det nasjonale Omsorgsrådet. Pionerene innen smertebehandling spilte en viktig rolle i å få palliasjon inn på sykehusene og uni- versitetene. I 1993 fikk Norge Nordens første professorat i palliativ medisin og året etter åpnet Seksjon lindrende behandling ved St Olavs hospital. Senere er det opprettet professorater i palliativ medisin både i Bergen og i Oslo. Sunniva hospice i Bergen etablerte et ambulerende tilbud til alvorlig syke og døende i hjemmet i 1993, og Hospice Lovisenberg åpnet sin dagpost i 1994. Med dette fikk man en formell tilknytning til palliasjon til den offentlige helsetjenesten i Norge. På 1990-tallet ble det en rask utvikling av palliasjon i Norge. Norsk forening for palliativ medisin ble stiftet $\mathrm{i}$ 2000, og ble i 2001 en del av Legeforeningen. Norsk Palliativ Forening ble stiftet samme år. Alle interesserte innenfor fagfeltet palliasjon kan bli medlem. Foreningens mål er å arbeide for å bedre behandling, pleie og omsorg for alvorlig syke og døende og deres pårørende (Norsk Palliativ Forening, 2017). Norsk forening for pallitiv medisin og Norsk Palliativ Forening arrangerer sammen med fagmiljøene hvert annet år en landskonferanse om palliasjon.

Foreningene, de kliniske palliative miljøene og de regionale kompetansesentrene i lindrende behandling har arbeidet systematisk for å få etablert palliasjon i alle helseregioner. Etableringen av en egen tilleggsfinansiering for palliasjon i 2003 bidro sterkt til etablering av palliativ virksomhet både ved lokalsykehus og ved universitetssykehusene i Norge. Gjennom de siste 15-20 årene er det bygget opp palliative tilbud på begge nivåer i helsetjenesten. Omsorg til familiemedlemmer er endret fra å være et anliggende for familien til å bli et offentlig, kommunalt ansvar.

I ulike deler av den kommunale helse- og omsorgstjenesten og spesialisthelsetjenesten har barnepalliasjon $\mathrm{i}$ hovedsak dreid seg om lindrende behandling til barn med kreft. Det har ikke vært god nok struktur og plan for andre sykdomsgrupper med palliative behov. Nasjonal faglig retningslinje for lindrende behandling til barn og unge uavhengig av diagnose (Helsedirektoratet, 2017) gir anbefalinger for videre utvikling av fagfeltet. Et videreutdanningstilbud i palliasjon til barn for sykepleiere startet i 2017 ved Høgskolen i Oslo og Akershus. Tilbudet skal evalueres.

Palliasjon er ikke lenger i en begynnende fase. Det er etablert som eget fagfelt.

\subsubsection{Paradigmeskifte - fra kreft til andre diagnoser og integrasjon i hele sykdomsforløpet}

Tradisjonelt var man i begynnelsen av palliasjonens historie mest opptatt av symptomkontroll og 
støtte for kreftpasienter. Dette hadde sitt utspring i den britiske hospicetradisjonen hvor Cicely Saunders hovedsakelig konsentrerte seg om pasienter som døde av kreftsykdom, selv om det aldri var hennes intensjon å begrense seg til en sykdomsgruppe. Senere håpet hun at erfaringene fra kreft kunne overføres også til andre sykdommer. Kreftsykdom var et naturlig utgangspunkt siden kreftsykdom ble oppfattet som mer forutsigbar med en definert «palliativ fase» hvor kreftbehandling var avsluttet. Palliasjon ble dessuten inkludert som et tema i undervisning i onkologi, mens den samme historiske satsingen ikke har funnet sted for de store indremedisinske sykdommene som lungesykdommer, hjertesykdommer, nevrologiske sykdommer og nyresykdommer.

Dette har fort til ulikheter mellom palliative tilbud for kreft og andre diagnoser. Selv om den pasientsentrerte tilnærmingen til døende $\mathrm{i}$ stor grad er overførbar til alle alvorlig syke pasienter med livsbegrensende sykdommer, er ikke nødvendigvis plagene som trenger behandling det, spesielt tidligere i forløpene. Forståelsen har derfor beveget seg mot en økende erkjennelse av at man trenger diagnoserelatert spesialkunnskap, spesielt tidlig i forløpet for å kunne gi den beste behandlingen samtidig med palliasjon. Mange diagnoser utenom kreftdiagnoser har mer uforutsigbare forløp, men også kreftsykdommer er, pga nye behandlingsmuligheter, i større grad uforutsigbare. Dette gjør at man kan ikke vente til man er døende før man skal motta palliativ behandling for alle diagnoser. Derfor må palliativ behandling integreres tidligere inn i forløpene og tilbys til alle diagnosegrupper som tradisjonelt ikke har vært omfattet av palliasjon (diagnoser utenom kreftdiagnoser).

Tidligere var det heller ikke en erkjennelse av at plager knyttet til andre sykdommer enn kreft kunne være like store som ved kreftsykdom, men dette er nå bekreftet gjennom mange studier. Denne utviklingen er en del av årsaken til at palliativ medisin ble et eget fagfelt og ikke bare en utvidet og integrert del av kreftbehandlingen og at palliasjon ble vurdert til å være en viktig del av all medisinsk behandling.

I 2014 vedtok Verdens helseorganisasjon å oppfordre sine medlemsstater til sterk satsing på lindrende behandling i hele sykdomsforløpet, og legge til rette for palliasjon som en integrert del av helse- og omsorgstjenesten (Helsedirektoratet, 2015a). Det ble også vedtatt å oppfordre til økt satsing på barnepalliasjon i samarbeid med UNICEF.

Verdens helseorganisasjon har utformet en generell definisjon av palliasjon, uten tilknytning til en særskilt sykdomsgruppe. Likevel har palliasjon i stor grad vært knyttet til kreftpasienter. Dette kan naturlig forklares ved to faktorer: (1) de palliative enhetene har i hovedsak vært organisert i en kreftklinikk/ kreftavdeling, (2) kreft har vært den største sykdomsgruppen i behov av palliasjon.

\subsubsection{Palliasjon til flere pasientgrupper}

Flere pasienter enn de som får lindrende behandling i dag har behov for det (Helsedirektoratet 2015a, Sintef, 2016). Livshjelpsutvalget pekte allerede i 1999 på at prinsippene i palliativ behandling også kan anvendes overfor pasienter med ulike sykdomsforløp. Dette innebærer at palliativ behandling også bør ytes innenfor blant annet kardiologi, nevrologi og lungemedisin og i større grad bli en del av disse spesialfeltene (NOU 1999: 2).

I det særskilt organiserte tilbudet i spesialisthelsetjenesten (palliative enheter og team) er det til en stor grad kreftpasienter som får lindrende behandling. Dette kan forklares med at palliative enheter de fleste steder er organisert under en kreftklinikk/kreftavdeling. Der hvor kreftklinikk/ avdeling organiserer palliasjon, kan det være faglige og organisasjonsmessige utfordringer $i$ å overføre erfaring og praksis til andre pasientgrupper (Sintef, 2016). Samtidig er det andre erfaringer der palliative tiltak er organisert som et samarbeid med alle avdelinger med palliative pasienter. Ved Haukeland universitetssykehus, der palliativt team er organisert under anestesiavdelingen, er under halvparten av pasientene innlagt ved kreftavdelingen, og teamene forholder seg til mange pasienter uten kreft (Helse Bergen, 2016). Personer med demens er en gruppe som tilsynelatende i liten grad mottar et særskilt organisert palliativt tilbud. Økningen i antall eldre gir nye utfordringer til det palliative feltet med flere pasienter som lever lenge med alvorlige, kroniske sykdommer, og flere pasienter med kognitiv svikt (Helsedirektoratet, 2015a). De palliative enhetene i sykehus gir i liten grad tilbud til barn. Barn med behov for palliasjon ivaretas hovedsakelig av barneavdelinger $\mathrm{i}$ spesialisthelsetjenesten som yter grunnleggende palliasjon, men kommunene kan få opplæring av sykehuset og følge opp barn hjemme (Sintef, 2016).

Andre pasientgrupper som kan ha nytte av og behov for økt tilgang til palliativ behandling er pasienter med kronisk hjerte-, lunge- og nyresykdom, inkludert kols, pasienter med nevrologiske sykdommer (ALS, MS, Parkinsons sykdom), 


\section{Boks 5.1 EU-erklæring om palliasjon (Palliative Care), 2014}

«Palliasjon er en tilnærmingsmåte som har til hensikt å forbedre livskvaliteten til pasienter og deres familier i møte med livstruende sykdom, gjennom forebygging og lindring, ved hjelp av tidlig identifisering, grundig vurdering og behandling av smerte og andre problemer av fysisk, psykososial og åndelig art» (Verdens helseorganisasjon, Helsedirektoratet, 2015).

Palliasjon bør anvendes tidlig $i$ sykdomsforløpet, sammen med potensielt kurativ behandling, men innebefatter også omsorg ved livets slutt.

For å sikre integrering av palliasjon i et alderdomsvennlig EU, anbefaler vi at myndigheter og beslutningstakere på regionalt, nasjonalt og internasjonalt nivå:

1. Erkjenner at utøvelse av og tilgang til lindrende behandling av høy kvalitet er en prioritert folkehelseoppgave som krever en folkehelsetilnoerming.

2. Utvikler og omdefinerer nasjonal og internasjonal helsepolitikk, som for eksempel retningslinjer for sunn aldring, institusjonsbasert pleie og omsorg samt demens, til å inkludere palliasjon som en viktig del.

3. Utvikler og omdefinerer retningslinjer for palliasjon slik at de omfatter henvisningskriterier som tillater pasienter og pårørende tilgang til palliativ behandling ut fra behov, uavhengig av diagnose, alder, prognose, forventet levealder eller bosituasjon.

4. Utvikler eller omdefinerer retningslinjer til å omfatte mekanismer for å sikre tilgang til spe- sialiserte, tverrfaglige palliative team eller tjenester i alle deler av helse- og omsorgstjenestene.

5. Fremmer et paradigmeskifte innen helse- og sosiale tjenester rettet mot grunnleggende kompetanse i palliasjon for alt helsepersonell, for å hjelpe dem til å levere pasientsentrert, familiefokusert behandling og pleie til alle mennesker med en livsbegrensende sykdom, basert på personlige tilpassede behandlings- og pleieplaner, som tar hensyn til alle behov hos pasienten og de pårørende.

6. Støtter tverrfaglig samarbeid som en hjørnestein i palliativ behandling og utdanning av høy kvalitet.

7. Investerer i å utvikle loereplaner og utdanning i palliasjon på både lavere og høyere nivå i alle fagfelt innen helse- og sosialfag, og etablerer spesialutdanninger $i$ palliasjon.

8. Fremmer offentlig bevissthet gjennom tiltak på samfunnsnivå: utdanning av allmennheten og opplæring av pårorende og frivillige.

9. Øker finansieringsmuligheter for nasjonal og internasjonal forskning innen palliasjon.

10. Etablerer varige systemer for å overvåke og forbedre kvaliteten på og tilgangen til palliasjon.

Kilde: Launched in Brussels, October 2014. Palliativ Care 2020, EU. http://palliativecare2020.eu/declaration/no.php funksjonshemmede/ryggmargskadede, personer med psykisk utviklingshemning, samt mennesker med rusmiddelproblemer og psykiske helseproblemer (Helsedirektoratet, 2015a, 2015b).

For å gi et godt palliativt tilbud til alle pasienter, uavhengig av alder og diagnose, må det ytes tjenester ved alle avdelinger, også utenom kreftavdelingene. Det vises til nærmere omtale i kapittel 9.

Studier og erfaringer viser at pasientgrupper med mer eller mindre jevn forverring av funksjon og symptomer ofte har behov for palliasjon ut over et grunnleggende nivå. De vil først og fremst ha behov for tilpasset symptomlindring, men også støtte til mestring av sykdom, ernæringsmessige utfordringer og mer avanserte pleietiltak. Dette gjelder pasienter med uhelbredelig kreftsykdom, og også andre pasientgrupper med langtkommen hjerte-, lunge- og nyresykdom, pasienter med nevrologiske sykdommer og pasienter med demens. Alle disse pasientene trenger palliasjon som en integrert del av helse- og omsorgstilbudet.

\section{Barn}

Palliasjon til barn med en dødelig sykdom er også fundert på WHOs generelle definisjon om palliasjon. Palliasjon er en aktiv og helhetlig støtte til barnets fysiske, psykiske, sosiale og åndelige/ eksistensielle behov, og til barnets familie. Støtten gis gjennom hele livsløpet fram til døden og omfatter også oppfølging av foreldre og søsken etter 


\section{Boks 5.2 WHO Definition of Palliative Care for Children}

Palliative care for children represents a special, albeit closely related field to adult palliative care. WHO's definition of palliative care appropriate for children and their families is as follows; the principles apply to other paediatric chronic disorders (WHO, 1998a):

Palliative care for children is the active total care of the child's body, mind and spirit, and also involves giving support to the family.

It begins when illness is diagnosed, and continues regardless of whether or not a child receives treatment directed at the disease.

Health providers must evaluate and alleviate a child's physical, psychological, and social distress.

Effective palliative care requires a broad multidisciplinary approach that includes the family and makes use of available community resources; it can be successfully implemented even if resources are limited.

It can be provided in tertiary care facilities, in community health centres and even in children's homes.

barnets død. Palliasjon til barn omfatter alle i alderen 0-18 år. Palliasjon skal tilbys barn og familier der barnet har en alvorlig misdannelse eller en medisinsk tilstand som krever livslang kontakt med helsetjenesten. Palliasjon starter så snart diagnosen er stilt. Palliasjon erstatter ikke medisinsk behandling av sykdommen, men tilbys sammen med sykdomsrettet behandling, avhengig av barnets og foreldrenes ønsker og behov.

Moderne medisinsk behandling gjør at mange barn med alvorlige eller uhelbredelige sykdommer kan leve i mange år med god livskvalitet. Dette er en av årsakene til at antall barn med behov for lindrende behandling og omsorg øker. Basert på tall fra Storbritannia er det beregnet at minst 3500-4000 barn i Norge årlig har behov for lindrende behandling og omsorg. Ca. 40 prosent har genetiske eller medfødte tilstander, ca. 40 prosent har nevromuskulære tilstander og ca. 20 prosent har kreftsykdommer. Anslagsvis 40-50 barn i disse gruppene dør årlig i Norge (Helsedirektoratet, 2015a).

\section{Eldre}

Andelen eldre over 67 år er økende, og særlig blir det flere av de eldste eldre. Det er en sterk økning $\mathrm{i}$ antall mennesker som lever med alvorlige, kroniske sykdommer og etter hvert dør av disse. Mange eldre er multisyke, og når flere sykdommer foreligger samtidig, vil de som regel forsterke hverandre og behandlingen blir mer komplisert. Siden mange eldre har flere sykdommer, bruker de ofte mange legemidler. De ulike legemidlene kan påvirke hverandres effekter og gi plagsomme bivirkninger. Eldre pasienter er dessuten forskjellige fra yngre, med henblikk på både medisinske og psykososiale forhold. De kjennetegnes av økt forekomst av organsvikt, både kognitivt, mentalt og fysisk. Disse aldersforandringene gir reduserte reserver og økt sårbarhet. I tillegg er mange eldre ensomme på grunn av lite eller manglende sosialt nettverk. Organsvikten hos eldre kan ha store individuelle variasjoner. Den kompliseres gjerne av sansesvikt (spesielt syns-, hørsels- og smaksans) og redusert yteevne og utholdenhet. Både symptomer og sykdomstegn framstår gjerne på en annen og mer diffus måte enn hos yngre, og bruk av mange ulike legemidler påvirker ofte sykdomsbildet. Døden kommer gjerne etter en periode med økende skrøpelighet, der både tiltakende kroniske og akutte helseproblemer kan føre til gjentatte sykehusinnleggelser. Tilgangen til generell palliativ behandling og omsorg for eldre er begrenset. Eldre pasienter har også dårligere tilgang til spesialiserte palliative tilbud, noe som fører til dårligere kartlegging av behov og ønsker, dårligere smerte- og symptomlindring samt færre muligheter for hjemmeomsorg og hjemmedød (Helsedirektoratet, 2015a). Mange eldre lever livets sluttfase med betydelig lidelse uten relevante tiltak. Norske studier påpeker at smertetilstander hos eldre pasienter er underbehandlet (Gran, og Grov m.fl., 2013).

\section{Pasienter med kronisk hjerte-, lunge- og nyre- sykdom}

Innen alvorlige lungesykdommer er pasienter med kols den største gruppen. Mellom 250000 og 300000 personer (helsenorge.no) lever med kols i Norge. Nærmere 20 prosent har sykdommen i alvorlig eller svært alvorlig stadium. Antall pasienter med kols forventes å øke betydelig i årene som kommer. Pasienter med kols har ofte et langt sykdomsforløp med gjentatte, forbigående infeksjoner og forverringer, gradvis dårligere lungefunksjon og etter hvert betydelige symptomer. 
Som med alle andre diagnosegrupper bør grunnleggende palliasjon integreres fra diagnosetidspunktet, ofte sammen med rehabilitering. Tverrfaglig samarbeid er viktig for god symptomlindring, opplæring av pasienter og pårørende og for tilrettelegging av behandling og omsorg i hjemmet.

I Norge har ca. 10 prosent av personer over 75 år kronisk hjertesvikt. Kronisk hjertesvikt er en alvorlig tilstand med høy dødelighet. Mange pasienter lever i flere år med langsom forverring av tilstanden. Pasientene med langtkommen hjertesvikt har flere symptomer som kan sammenliknes med symptomene til en pasient med langtkommen kreft.

Kronisk nyresykdom rammer cirka 10 prosent av befolkningen. Palliasjon skal være et tilbud også i sluttfasen, både til pasienter som får nyreerstattende behandling og pasienter som avstår fra slik behandling (Helsedirektoratet, 2011). Det er utarbeidet veiledende retningslinjer for når kols (Helsedirektoratet, 2014), hjertesvikt (Helsedirektoratet, 2015a) og nyresviktpasienter (Helsedirektoratet, 2015) sannsynligvis vil ha nytte av henvisning til et spesialisert palliativt tilbud.

\section{Pasienter med nevrologiske sykdommer}

I Norge er de mest aktuelle sykdommene i denne gruppen amyotrofisk lateral sklerose (ALS), multippel sklerose (MS) og Parkinsons sykdom. Totalt lever det ca. 300 pasienter med ALS, ca. 8000 med MS og 6000-8000 med Parkinsons sykdom. Disse sykdommene rammer også yngre pasienter (under 65 år). Sykdommen ALS gir tiltakende lammelser og pasientene har en gjennomsnittlig levetid på tre år etter symptomdebut. Pasientene trenger stor innsats fra hjelpeapparatet og en bred tverrfaglig tilnærming. Sykehusbaserte, tverrfaglige ALS-team har bedret livskvaliteten for pasientene og økt overlevelsen (Miller og Jackson m.fl., 2009). Brukermedvirkning står sentralt i omsorg og behandling, både ved kartlegging av symptomer og behov, ved fortløpende vurdering av endring i funksjonsnivå over tid, og ved evaluering og endring av behandlingsmål. Det er viktig å starte diskusjonen rundt behandlingsintensitet tidlig i forløpet og ta den opp igjen ved vendepunkter i sykdommen. Andre nevrologiske pasienter kan i noen grad ha samme utfordringer som ved ALS, men forløpet er mer varierende og ofte svingende. Gode hjelpemidler og ivaretakelse av familien er viktig for alle gruppene.

\section{Pasienter med demens}

Mange av de alvorlig syke og døende pasientene i kommunene både i sykehjem og hjemme, lider av kognitiv svikt i en eller annen form (Helsedirektoratet, 2015a). Demens er en fellesbetegnelse for en gruppe degenerative hjernesykdommer som fører til kognitiv svikt med gradvis tap av hjernefunksjoner i form av hukommelsessvikt, sviktende handlingsevne, sviktende språkfunksjon, personlighetsforandringer og atferdsendringer. I Norge lever vel 70000 personer med demens. Anslagsvis 80 prosent av de ca. 18000 som dør i sykehjem hvert år, har en eller annen form av kognitiv svikt (Helsedirektoratet, 2015). Det er et stort potensial for å utvide det palliative tjenestetilbudet til denne pasientgruppen. 50-70 prosent av pasienter med demens antas å ha smerter og kan ha utbytte av økt grad av palliativ behandling. (Sintef, 2016).

Utvalget viser til European Association for Palliative Care (EAPC) som i 2014 ga ut et «White Paper» om optimal palliasjon til eldre mennesker med demens. Her understrekes at god palliasjon forutsetter og krever gode kommunikasjons- og beslutningsprosesser over tid mellom pasient, pårørende og personalet. Forløpet må ta hensyn til endringer i sykdomsutviklingen, funksjonsnivå, symptomer og behov. Det vises videre til at en tilnærming basert på avklarte mål for behandling, pleie og omsorg kan gjøre beslutningsprosesser mindre kompliserte (EAPC, 2014).

\section{Pasienter med kreft}

I 2016 fikk nesten 33000 personer i Norge en kreftdiagnose og 260000 pasienter levde med en kreftdiagnose. I 2015 døde i overkant av 11000 nordmenn av kreft. Antall krefttilfeller antas å fortsette å øke i årene fremover, omkring 40 prosent flere vil få kreft i 2035 sammenlignet med i dag (Kreftregisteret, 2017). Bedre diagnostikk og behandling har medført at stadig flere overlever kreft eller lever lenge med sin sykdom. Pasientene behandles i stor grad poliklinisk, slik at mer tid tilbringes i hjemkommunen. Det er likevel vanlig med innleggelser for ulike komplikasjoner under sykdomsforløpet, og fortsatt er sykehus vanligste dødssted for kreftpasienter. Kreftbehandlingen er blitt mer kompleks, og den strekker seg ofte over en lang tidsperiode. Overgangen fra tumorrettet, livsforlengende behandling til symptomlindrende behandling skyves stadig nærmere sluttfasen av livet, og fasen som tradisjonelt har vært palliativ, har for mange blitt veldig kort. 
Dette har skapt et forsterket behov for å integrere palliasjon tidligere i sykdomsforløpet. Et palliativt behandlingstilbud tidlig i sykdomsforløpet har vist seg å redusere bruk av uhensiktsmessig behandling i livets sluttfase, og pasienten har dermed fått bedre livskvalitet.

\section{Mennesker med rusmiddelproblemer og psykiske helseproblemer}

Personer med rusmiddelproblemer, spesielt de som er avhengige av illegale rusmidler, eller personer som har alvorlige psykiske helseproblemer som schizofreni og visse stemningslidelser, har kortere forventet levealder enn normalbefolkningen. Dette skyldes i stor grad livsstilsrelaterte og andre somatiske skader og sykdommer, og ikke selve rusmiddelproblemet eller det psykiske helseproblemet. Disse personene rammes også av livstruende sykdommer. Livssituasjonen vil ha betydning for hvordan omsorgen mot livets slutt kan organiseres. Opioidavhengighet eller abstinens og uro vil utløse behov for kompetanse på rusmiddelproblemer og/eller psykiske helseproblemer, i tillegg til palliativ kompetanse. Smertelindring til disse pasientene er en spesialistoppgave (Helsedirektoratet, 2015a). Utvalget mener palliasjon må inn som en integrert del av pasientforløpet $\mathrm{og}$ foreslår at det foretas forhåndssamtaler for å finne ut hva pasienten ønsker av videre behandling. Forhåndssamtaler er nærmere omtalt i kapittel 4.

Rusmiddelmisbruk er ofte forbundet med dårlig somatiske helse. God somatisk helse kan være en av faktorene som kan bidra til bedring. Det er viktig å ha særlig oppmerksomhet rettet mot de sykdommene eller tilstandene personer med ulike typer rusmiddelproblemer er mest utsatt for å få (Helsedirektoratet, 2011b). Ofte er dette pasienter som mottar sykdomsrettet og lindrende behandling i somatiske avdelinger ved sykehuset, samtidig som de har behov for oppfølging fra tverrfaglig spesialisert behandling av rusmiddelproblemer (TSB) og/eller psykisk helsevern. Dette krever spesiell fleksibilitet og åpenhet for samarbeid, tverrfaglighet og smidige løsninger.

\section{Mennesker med utviklingshemning}

I takt med medisinske framskritt øker levealderen for personer med psykisk utviklingshemning, og dermed forekomsten av aldersrelaterte sykdommer. Det sees økt forekomst av både lungesykdommer og demens samt utvikling av livstruende sykdommer fem til ti år tidligere enn hos den øvrige befolkningen. For personer med psykisk utviklingshemning er tilrettelegging, kontinuitet, trygghet og forutsigbarhet særlig viktig. De trenger i størst mulig utstrekning å få tilbringe livets siste fase i eget hjem der det legges til rette for god lindring i tråd med deres egne ønsker og behov. Ivaretakelse av pårørende er spesielt viktig fordi det ofte er tette bånd mellom foreldre, eventuelle søsken og den som er syk. Tverrfaglig samarbeid er viktig for å avklare smertetilstander og kommunisere om alvorlig sykdom og død (Helsedirektoratet, 2015a).

\subsection{Framtidens utfordringer og behov}

\subsubsection{Kulturelle faktorer}

\section{Et flerkulturelt samfunn}

Norge er blitt et flerkulturelt samfunn med innbyggere fra over 200 land. Ca. 15 prosent av befolkningen er innvandrere eller har innvandrerbakgrunn. Arbeidsinnvandrere fra andre europeiske land utgjør de største gruppene. Den største gruppen kommer fra Polen, deretter Sverige og Litauen. Det er høy og økende innvandring fra land med krig og uroligheter som Syria, Eritrea, Somalia og Afghanistan. Innvandrerne bosetter seg i hele landet. Det er flest innvandrere i Oslo, der innvandrerne utgjør over 30 prosent av befolkningen. Nasjonal strategi for innvandreres helse (2013-2017) belyser utfordringer knyttet til innvandrerhelse. Høyere forekomst av livsstilssykdommer som diabetes og hjerte- og karsykdommer, høyere forekomst av brystkreft hos kvinner fra enkelte land og at færre oppsøker hjelp for psykiske helseutfordringer er noen eksempler som gir grunnlag for særskilt oppfølging (Meld. St. 11 (2015-2016)).

Med en økende andel innvandrere, etter hvert også mange eldre, øker behovet for å rette oppmerksomhet mot tilbud og tjenester til denne sammensatte brukergruppen. Demens rammer eldre personer fra alle etniske grupper. Helsedirektoratet har som en del av Demensplan 2015 gitt Nasjonal kompetanseenhet for minoritetshelse (NAKMI) i oppdrag å lede et treårig forskningsog fagutviklingsprogram, Demens og eldre innvandrere. Utviklingsprogrammet skal blant annet framskaffe kunnskap om eldre innvandrere med demens og deres pårørende, hvordan de opplever sin situasjon og hva slags erfaringer de har gjort $\mathrm{i}$ møte med helse- og omsorgstjenestene.

Det er et mål at hele befolkningen skal ha lik tilgang til helse- og omsorgstjenester av god kvali- 


\section{Boks 5.3 Demografisk utvikling}

Nasjonal helse- og sykehusplan peker på følgende utfordringer $\mathrm{i}$ spesialisthelsetjenesten (Meld. St. 11 (2015-2016):

- Vi blir flere eldre. Dette vil ha stor betydning for helsetjenestene, da eldre over 70 år bruker dobbelt så mye helsetjenester som 40åringer.

- Folketallet i de store byene øker. Unge mennesker og innvandrere bosetter seg i første rekke i byene. Presset på helsetjenester $\mathrm{i}$ byene skyldes flere eldre, flere innflyttere og flere innvandrere. Distriktenes utfordringer er i første rekke knyttet til økningen i antall eldre.

- Det er spesielt tilbudet til pasientene i de største sykdomsgruppene som vil være under press. Sykdom øker med alder, og disse sykdomsgruppene omfatter i stor grad eldre pasienter som ofte også har flere diagnoser.
- De demografiske endringene vil øke behovet for årsverk i spesialisthelsetjenesten med 27 prosent fram mot 2030, og med 40 prosent fram mot 2040 (Statistisk sentralbyrå, 2015).

- Ressursbehovet påvirkes ikke vesentlig av endringer i forutsetninger om innvandring, levealder og helsetilstanden til de eldre. Produktivitetsvekst og bedre standard på tjenestene er faktorer som særlig påvirker ressursbehovet. Det er nødvendig med både økte ressurser og høyere omstillingstakt i helsetjenesten for å møte utfordringen.

Vi vet at vi i årene fremover vil få et økende antall eldre med palliative behov, og at kreft også er i ferd med å passere hjerte - og karsykdommer som den hyppigste dødsårsak i Norge.

Kilde: Dødsårsaksregisteret, 2015. tet, tilpasset den enkeltes behov og forutsetninger. For å imøtekomme disse målene, må det blant annet tas hensyn til personer med språklig og kulturell minoritetsbakgrunn. Dette omfatter både innvandrerbefolkning og urbefolkning. Helse- og omsorgspersonell har ansvar for å vurdere behovet og skaffe kvalifisert tolk i møte med pasient/bruker/pårørende som har begrensede norskkunnskaper. Skriftlig informasjon må vurderes oversatt til aktuelle språk. Innen palliasjon er det mest brukte kartleggingsverktøyet ESAS (Edmonton Symptom Assessment System) som er tilgjengelig på 34 ulike språk. Kompetansesenter for lindrende behandling ved Universitetssykehuset i Nord-Norge har oversatt ESASr til samisk. Helse- og omsorgspersonell må være sensitive for den enkelte pasients og brukers forståelse av egen sykdom og behandling. Kultursensitivitet, kulturell bevissthet og kompetanse er nødvendig for å tilpasse omsorgen til personer med annen bakgrunn. Det må legges til rette for at den palliative omsorgen er i tråd med den enkelte persons tradisjon og kulturelle tilhørighet, så langt dette er mulig (Helsedirektoratet, 2015a).

\section{Den samiske befolkningen}

Samene er urbefolkningen i Norge, og deres rettigheter i møte med helse- og omsorgstjenesten reguleres av internasjonale konvensjoner og nasjonalt lovverk. Hva som skal til for å sikre samiske mottakere av helse- og omsorgstjenester et godt og likeverdig tilbud, er avhengig av hvem den enkelte samiske tjenestemottakeren er og hvor i landet den enkelte bor. Det er store individuelle og lokale språklige, kulturelle og næringsmessige variasjoner innenfor det samiske samfunnet. Helse- og omsorgspersonell må derfor ha kunnskap om sosiale, historiske og lokale, kulturelle faktorer som kan ha betydning for møter mellom samer og helse- og omsorgstjenesten.

Det er lite som tyder på at det er store forskjeller mellom den samiske befolkningen og majoritetsbefolkningen når det gjelder helsetilstand, forekomst av sykdom og bruk av helsetjenester. I en del litteratur framgår det at samer har en annen forståelse av helse, sykdom og behandling enn majoritetsbefolkningen, og at spesielt eldre samer snakker om sykdom og helse på indirekte måter og ved hjelp av metaforer. Dette er ikke nødvendigvis en sannhet som gjelder for alle samer. Oppfatningen av at samisktalende personer foretrekker å bruke samisk i samhandling med helseog omsorgstjenestene nyanseres $i$ nyere forskning, som viser at preferanser for bruk av språk er individ- og situasjonsavhengig. Betydning av slektskap og tradisjoner for selvhjelp vektlegges $\mathrm{i}$ deler av litteraturen. Samtidig viser forskning at samer etterlyser mer hjelp fra det offentlige (Blix, 2016). 
Litteraturen peker på betydningen av at helseog omsorgspersonell har kunnskap om samisk språk og kultur i møte med samiske personer med demens. Det foreligger lite forskning om situasjonen til samiske personer med demens, deres familier og samhandling med offentlige helse- og omsorgstjenester. Det er igangsatt nye forskningsprosjekter på disse områdene. I Norge finnes det i liten grad helse- og omsorgstjenester som er utviklet speselt for den samiske befolkningen. Målet har vært å gi et kulturelt tilrettelagt tilbud til den samiske befolkningen innenfor de etablerte tjenestene (B. H. Blix, 2016).

Både kommuner og spesialisthelsetjenesten bør tilrettelegge for kultursensitiv og språklig tilpasset behandling. Det er behov for å se på alternative måter å jobbe på for å nå ut med et tilbud til flest mulig som trenger helse- og omsorgstjenester, blant annet økt bruk av ambulante tjenester. Samiske pasienter har rett til et likeverdig behandlingstilbud som tar utgangspunkt i samisk språk og kultur. Et godt tilbud til samiske pasienter forutsetter kompetanse i samisk språk og forståelse for samisk samfunnsliv. Slik kompetanse bør etterspørres ved rekruttering av personell som skal arbeide med samiske pasienter (Meld. St. 30 (2011-2012)).

\section{Kultursensitivitet og kulturkompetanse}

Nyere litteratur understreker at kultursensitivitet og kulturkompetanse ikke utelukkende handler om å ha kjennskap til «den andres» kultur, men også å reflektere over eget ståsted og egen forståelse. Kultur må i tillegg forstås innenfor større sosiale, historiske og politiske rammer (Blix, 2016).

Utvalget mener kultursensitivitet og kulturkompetanse må ligge til grunn for å utvikle gode palliative tjenester til alle pasienter som trenger det, uavhengig av kulturell og etnisk bakgrunn.

\subsubsection{Demografi og sykdomsutvikling}

Meld. St. 29 (2016-2017) Perspektivmeldingen 2017 peker på at aldringen i befolkningen vil gi økt behov for helse- og omsorgstjenester i tiårene framover. En rikere befolkning vil samtidig etterspørre mer av og høyere kvalitet på mange av de tjenestene som i dag er et offentlig ansvar. Det kan gjelde for eksempel utdanning, kultur og ikke minst helse- og omsorgstjenester. Mange offentlige tjenester er også arbeidsintensive. Hvis produktivitetsveksten for disse tjenestene er lavere enn produktivitetsveksten i samfunnet ellers, og lønnsveksten skal holde tritt med den generelle lønnsveksten, vil tjenestene bli forholdsmessig dyrere enn andre varer og tjenester. Når tidsperspektivet forlenges, blir presset på offentlige finanser enda sterkere. De aller eldste blir flere. Mens de over 80 år i dag utgjør drøyt 4 prosent av befolkningen, ventes andelen å øke til nesten 10 prosent i 2060. Bedre helse blant eldre kan dempe, men ikke fjerne, det økte behovet for helse- og omsorgstjenester.

For å møte velferdsutfordringene Norge står overfor, viser meldingen til at dette vil kreve innsats på flere områder, blant annet ved at flere står lenger $\mathrm{i}$ jobb, at flere deltar $\mathrm{i}$ arbeidslivet, og at arbeidstiden økes gjennom mer heltid og mindre sykefravær. Høy sysselsetting i en verden som stadig gjør teknologiske framskritt, krever at det satses på utdanning, forskning og innovasjon. I tillegg til økt sysselsetting er det behov for mer effektive løsninger i offentlig sektor. Dette krever god organisering og tydelige prioriteringer. Meldingen peker på at Norge må ta i bruk de mulighetene som ligger i ny velferdsteknologi og digitalisering av forvaltningen, noe som også kan legge til rette for bedre tjenester.

Noe av det viktigste som kan gjøres for å sikre rasjonell bruk av medisinske ressurser, er å unngå å bruke ressurser der de ikke har effekt. Integrasjon av palliasjon tidlig i sykdomsforløpet vil kunne bidra til å redusere unødvendige sykehusopphold, samt unngå overflødig utredning/ behandling (Journal of Palliative Medicin: Cassel og Webb-Wright m.fl., 2010, Rabow og Kvale m.fl., 2013, May og Normand m.fl., 2014).

\section{Sykdomsutviklingen}

Hjerte- og karsykdommer er den sykdomsgruppen som forårsaker flest dødsfall i Norge, og innebærer ofte langvarige helseproblemer og funksjonsnedsettelse. Hjerte- og karsykdom utgjør 35 prosent av alle dødsfall. De siste 40-50 årene er dødeligheten av hjerteinfarkt falt med 80 prosent i aldersgruppen 40-70 år. En ytterligere nedgang er mulig. Etter hjerteinfarkt kan hjertesvikt utvikles. Behandling av risikofaktorer, kontinuerlig og koordinert oppfølging samt hjelp til egenomsorg og rehabilitering er avgjørende for livskvalitet og overlevelse.

Nye beregninger fra Kreftregisteret viser at antall krefttilfeller kommer til å øke med 40 prosent i løpet av de neste 15 årene. I år 2030 kommer 17900 kvinner og 25700 menn til å få en kreftdiagnose. Til sammen utgjør dette 43600 nye tilfeller mot 31651 tilfeller i 2014, en økning på 
nesten 12000 tilfeller, eller nærmere 40 prosent. Fordelt på alder vil antall nye tilfeller for personer mellom 50 og 69 år øke med 14 prosent (Kreftregisteret 2016). Utviklingen i aldersgruppen over 70 år er dramatisk. Antall nye krefttilfeller per år vil ha økt med bortimot 68 prosent. Disse pasientene vil også rammes av andre kroniske sykdommer. Forskning har vist at blant personer over 75 år har mer enn halvparten fire eller flere sykdommer som de trenger behandling for, og veldig få eldre kreftpasienter har bare kreft.

Hjerneslag er den tredje vanligste dødsårsaken i Norge og utgjør 12 prosent av alle dødsfall. 75 prosent av tilfellene oppstår etter 70 år. I Norge dør 5500 personer av hjerneslag årlig. Vi regner at det årlig er ca 12000 tilfeller av hjerneslag i Norge. Ca. to av tre tilfeller er førstegangsslag, mens de øvrige er slag hos personer som har hatt hjerneslag før. Forekomsten forventes å øke med et økende antall av de eldste eldre, siden det er denne gruppen som rammes hyppigst av hjerneslag. Det lever anslagsvis ca. 60000 personer i Norge med gjennomgått hjerneslag, og om lag to tredeler av disse har en funksjonssvikt som følge av slaget. I løpet av livet vil én av seks personer kunne rammes av hjerneslag. Hjerneslag er den sykdomsgruppen som krever flest pleiedøgn i den somatiske delen av helsetjenesten (Norsk helseinformatikk, 2017).

Rundt 250 000-300 000 mennesker i Norge har kols, og det tilkommer 30-40 000 nye tilfeller per år (helsenorge.no). Opptil 75 prosent av pasienter med kols er ifølge Hordalandsundersøkelsen udiagnostisert. Det dør rundt 2000 mennesker hvert år av kols i Norge. 18 prosent av befolkningen over 40 år har kols. Rundt 40000 mennesker har alvorlig kols som krever jevnlig kontakt med helse- og omsorgstjenesten (Helse- og omsorgsdepartementet, 2013).

Rundt 28000 personer i Norge har diabetes type 1-diabetes. Sykdommen kan ikke forebygges, men senkomplikasjoner og for tidlig død kan utsettes og eventuelt forhindres gjennom god behandling, oppfølging og egeninnsats. Type 2diabetes debuterer oftest $\mathrm{i}$ voksen alder og er forbundet med blant annet fysisk inaktivitet og overvekt. Forekomsten er økende (Helse- og omsorgsdepartementet, 2013).

Den demografiske utviklingen og økende forekomst av høyt blodtrykk, hjerte- og karsykdom og diabetes gjør at flere er i risiko for å utvikle kronisk nyresykdom. Økende forekomst av kronisk nyresykdom vil føre til økt risiko for hjerte- og karsykdom og okt behov for nyreerstattende behandling. Den demografiske utviklingen med flere eldre og flere med kroniske sykdommer, for eksempel diabetes og sykelig overvekt, tilsier at det vil bli en økning i antallet pasienter med kronisk nyresykdom. Tall fra Norge basert på Helseundersøkelsen i Nord-Trøndelag (HUNT) viser at forekomsten av kronisk nyresykdom er om lag 10 prosent. Samme undersøkelse viste at en prosent av den undersøkte befolkningen hadde alvorlig til svært alvorlig reduksjon i nyrefunksjon (Helsedirektoratet, 2011a).

Det er også et økende antall eldre som vil få demens. I Europa har man anslått at hver fjerde person over 85 år har betydelige demensproblemer (Kreftregisteret, 2016). Personer med demens har i liten grad selv mulighet for å ivareta sine pasientrettigheter på grunn av begrenset kognitiv kapasitet. Kommunikasjon og medvirkning kan være utfordrende, og må tilpasses brukernes funksjon. Studier viser at pasienter med demens ofte ikke er forberedt på sykdomsforløpet. De blir ikke spurt om preferanser, verdier og veivalg, noe som kan føre til uheldige avgjørelser og utilfredsstillende behandling ved livets slutt. Forskning viser at sykehjemspasienter med demens eller kognitiv svikt sjeldnere får smertestillende behandling enn kognitivt velfungerende pasienter. Smertevurdering og smertebehandling hos pasienter med demens er utfordrende, da de ved moderat og alvorlig grad av demens har redusert hukommelse, språk, refleksjonsevne og forventning knyttet til smerteopplevelsen (Helsedirektoratet, 2015).

Nevrologisk skade og sykdom kan være medfødte eller ervervet, og fører ofte til svekkelse av funksjoner på flere områder. Det anslås at mellom 110000 og 150000 personer har en nevrologisk skade eller sykdom isolert eller som del av annen sykdom. De hyppigst forekommende nevrologiske skader og sykdommer blant omsorgstjenestens brukere er multippel sklerose (MS), cerebral parese (CP), Parkinsons sykdom, hjerneslag, amyotrofisk lateralsklerose (ALS) og epilepsi. Undersøkelser viser at om lag 20 prosent av de yngre tjenestemottakerne i hjemmetjenesten har nevrologiske skader og sykdommer. Mange av disse brukerne mottar i dag omfattende og langvarige tjenester. Mens personer med nevrologiske sykdommer og skader utgjør om lag 20 prosent av de yngre hjemmetjenestemottakerne, mottar de samlet sett 35 prosent av alle timer som ytes i form av hjemmesykepleie og praktisk bistand til yngre personer (Helse- og omsorgsdepartementet, 2015b). 


\section{Boks 5.4 Sykdomsbyrde i Norge i 2015}

Byrden av en sykdom eller en skade i en befolkning bestemmes av dens alvorlighet i form av dødelig og ikke-dødelig helsetap (sykelighet), hvor mange den rammer, alderen på de som rammes, og hvor lenge den varer. Sykdomsbyrdeberegninger gir en helhetlig oversikt over helsetilstanden i befolkningen. Dette gir muligheter for å sammenlikne hvordan dødelige og ikkedødelige sykdommer, skader og risikofaktorer påvirker sykdomsbyrden i ulike befolkningsgrupper etter kjønn, alder, geografi og over tid. Resultatene for Norge viser:

- Forventet levealder ved fødsel i den norske befolkningen økte med 22 måneder, til 82,0 år, i tiåret fra 2005 til 2015. Forventede friske leveår økte i samme periode med 20 måneder, til 71,5 år.

- Mer enn halvparten (53 pst.) av den samlede sykdomsbyrden kan knyttes til ikke-dødelig helsetap (sykelighet).

- Kun ett av fire dødsfall (23 pst.) skjer før fylte 70 år.

- De tre viktigste store dødsårsaksgruppene er hjerte- og karsykdom, kreft og nevrologiske sykdommer (i hovedsak demens). Disse utgjør tilsammen 71 prosent av alle dødsfall.
- I befolkningen under 70 år er kreft den største dødsårsaken. Hjerte- og karsykdom er den viktigste dødsårsaken etter 70 år.

- Når man tar hensyn til befolkningsøkning og aldring, er dødelighet for både hjerte- og karsykdom og kreft redusert fra 2005 til 2015.

- Blant mer detaljerte dødsårsaker er de fem viktigste iskemisk hjertesykdom (i hovedsak hjerteinfarkt), demens, karsykdom i hjernen (hjerneslag), kols og lungekreft. De fire første rammer i høy alder, mens 45 prosent av lungekreftdødsfall skjer før fylte 70 år.

- Selvmord og overdoser er de viktigste årsakene til død blant unge og voksne i alderen 15 til 49 år.

- Muskel- og skjelettsykdommer og psykiske lidelser er viktige årsaker til ikke-dødelig helsetap i nesten alle aldersgrupper.

- Røyking, usunt kosthold, høyt blodtrykk og bruk av alkohol og illegale rusmidler (narkotika) er de viktigste risikofaktorene for død før fylte 70 år.

Kilde: Folkehelseinstituttet, 2016

\section{Utvikling i dødsårsak og dødssted}

Vi har god kunnskap om hva innbyggerne i Norge dør av og hvor de dør. Endringer i innbyggernes alder, kjønn og dødsårsak har fra 1987 og fram til i dag ført til store endringer i hvor folk dør i Norge (Kalseth and Theisen, 2017). I mange vestlige land, også i Norge, er det bygget opp helse- og omsorgstjenester i institusjoner. Slike tilbud har ført til en utvikling der flere dør i institusjon og færre dør hjemme. De siste 30 årene har det i tråd med en ønsket utvikling, vært en dreining fra at pasientene dør på sykehus til at flere dør i institusjon i den kommunale helse- og omsorgstjenesten.

Når man sammenlikner tall fra 1987 med tilsvarende fra 2011, ser en at andelen som døde i sykehus sank fra 46 prosent i 1987 til 31 prosent i 2015. Andelen som døde i pleie- og omsorgsinstitusjoner økte samtidig fra 30 prosent til 48 prosent, mens andelen som døde hjemme var relativt stabil (15 prosent i 1987 og 18 prosent i 2011). De viktigste forklaringer til denne endringen er en aldrende befolkning og stor nedgang i antall dødsfall som skyldes hjerte-karsykdom (reduksjon fra 48 prosent til 29 prosent). Samtidig har andelen dødsfall forårsaket av kreftsykdom økt fra 22 prosent til 27 prosent (Kalseth og Theisen, 2017). De fleste dør av kreft og hjerte- og karsykdommer, men også demenssykdommer er blant de hyppigste dødsårsakene i sykehjem. De aller fleste som døde i sykehjem var i aldersgruppen 80-94 år. Hovedårsakene til dødsfall i sykehjem er kreft (27,6 pst.), hjerte- og karsykdommer (26,6 pst.) og demens (15,2 pst.) (Folkehelseinstituttet, 2016).

Halvparten av de som dør av kreft i sykehjem er under 80 år. Årsaken til dette er mest sannsynlig at mange kreftpasienter dør på lindrende enheter som er tilknyttet sykehjem. Antallet registrerte dødsfall på grunn av demenssykdommer har økt kraftig de siste 50 årene. En årsak er at demenssykdommene særlig rammer eldre, og med en økende andel eldre, er det flere som utvikler demens. 89 prosent av de som dør av demenssykdommer, dør på sykehjem (Folkehel- 


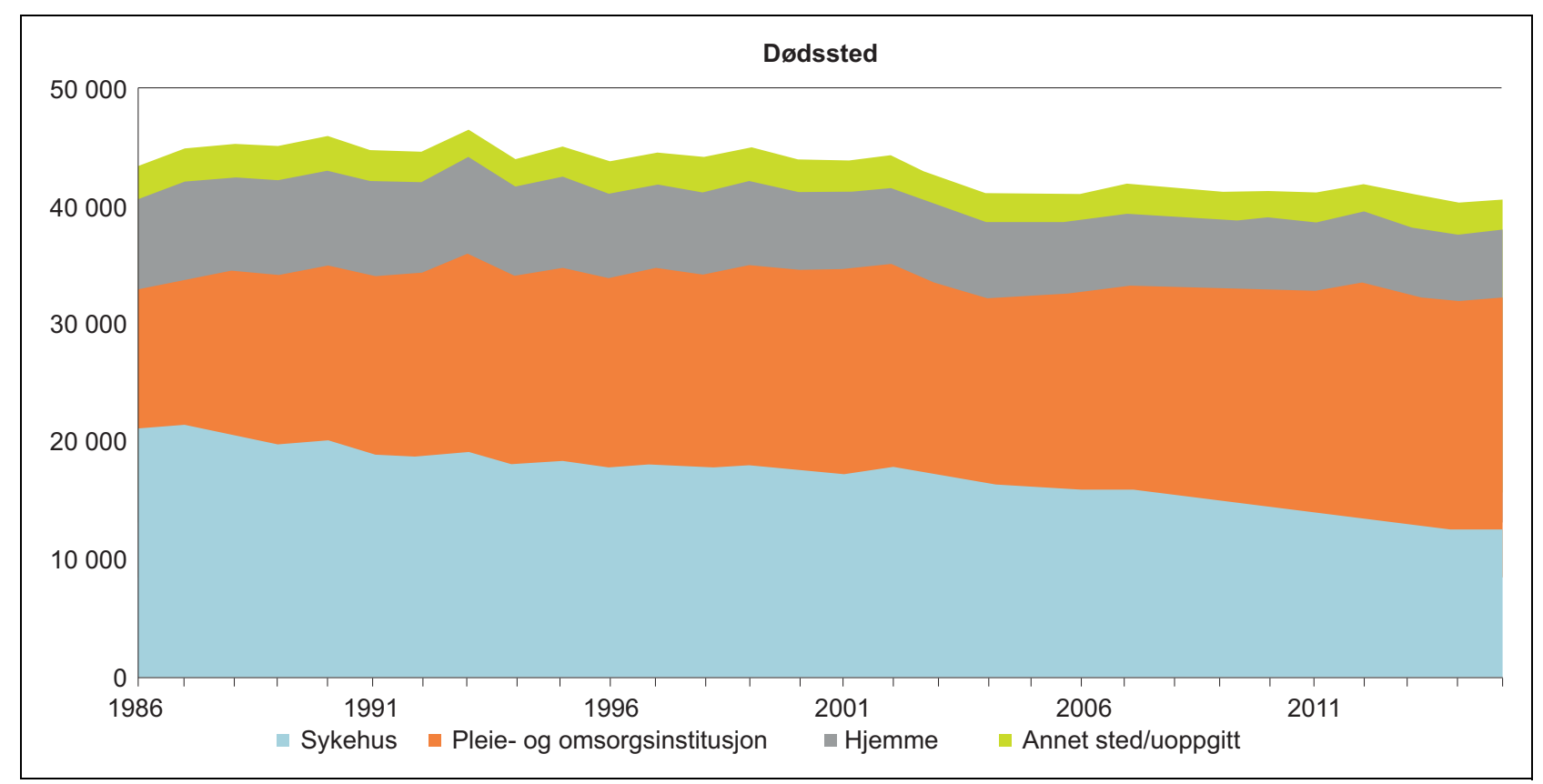

Figur 5.1 Dødssted

Kilde: Folkehelseinstituttet, 2016.

seinstituttet, 2016). Figur 5.1 viser utviklingen i dødssted i perioden 1986-2011 (Folkehelseinstituttet, 2016).

\section{Teknologisk utvikling}

Det er utarbeidet en Nasjonal e-helsestrategi og handlingsplan 2017-2022 som beskriver foreslått strategisk retning for målet om en digitalisert, samlet helse- og omsorgstjeneste som oppleves enklere, bedre og mer helhetlig for innbyggerne (Direktoratet for e-helse, 2017).

\section{Lyd og bilde løsninger}

Norges geografi gir utfordringer i form av potensiell lang reisevei, behov for å ha kompetansepersonell i området med lite innbyggere og reisekostnader for samfunnet og pasientene. For palliative pasienter som ønsker å være mest mulig hjemme, eller som som har et fysisk funksjonsnivå som gjør lang forflytning vanskelig, er ofte utreise med palliativt team eller lokalt palliativt kompetent personell eneste løsning. For å gjøre palliativ kartlegging og behandling mer tilgjengelig for pasienten, kan audiovisuelle hjelpemidler for direkte kommunikasjon med fagpersonell være et godt alternativ. Det finnes etablerte godkjente telemedisinske løsninger hvor palliasjon benyttes i noen grad, men dette krever at pasienten kommer til et telestudio. Eksempler på institusjoner som bruker andre skreddersydde løsninger for hjemmebruk er Sunnås sykehus og oppfølging av kols pasienter i Stavanger og Kristiansand med godkjent videokonferanseutstyr, men det er også utviklet bruk av trygge nettløsninger for nettbrett som blant annet brukes i studier rundt pasientsentrert helseteam i Tromsø, Balsfjord og Harstad.

Utfordringer som må avklares i forbindelse med implementering er medisinsk ansvar for behandlingen, samtykke og personvernutfordringer med sikkerhet for å sikre at opplysninger ikke kommer på avveie. På den annen side må ikke kravene bli så rigide at praktisk bruk ikke kan gjennomføres.

\section{Helseplattformen i Midt-Norge RHF}

Våren 2016 ble det utført vurdering av gjennomføringsstrategi og relevans av Helseplattformen i Midt-Norge for realisering av strategien Én innbygger - én journal. Regjeringen ga i juni 2016 sin tilslutning til hovedanbefalingen i strategien, en felles journalløsning for hele helse- og omsorgssektoren, og besluttet at programmet Helseplattformen i Midt-Norge skal være et regionalt utprøvingsprogram. Målet med Helseplattformen er å etablere en helhetlig, regional løsning i samarbeid med kommunene. Et felles arbeid mellom kommuner og spesialisthelsetjenesten er organisert i programmet og et stort flertall av kommunene i Midt-Norge har gitt sin fullmakt til arbei- 


\section{Boks 5.5 Avstandsoppfølgingsprosjektet}

Avstandsoppfølgingsprosjektet startet høsten 2016 og gjennomføres i Oslo, Trondheimsområdet, Stavanger og Sarpsborg. I Oslo deltar bydelene Grünerløkka, Gamle Oslo, St. Hanshaugen og Sagene. I Trondheimsområdet deltar kommunene Trondheim, Malvik, Melhus, Midtre Gauldal og Klæbu. Brukerne følges opp av helsepersonell ved hjelp av teknologiske løsninger. Foreløpige funn tyder på at slik oppfølging gir økt trygghet og mestring.

Brukerne utfører målinger selv og svarer på enkle spørsmål knyttet til sin helse. Målingene overføres til en responstjeneste, der helsepersonell følger med på informasjonen som sendes inn. Målgruppen er brukere med kols, diabetes og hjertesvikt, det vil si kroniske sykdommer, ofte med langt forløp. Mange av brukerne har flere diagnoser i tillegg til hoveddiagnosen. Bruk av fastlege, lokale sykehustjenester og kommunale tjenester er også registrert. Det er for tidlig å konkludere etter bare et år med denne tjenesten, men det ser ut til at trenden med økt forbruk av helsetjenester i perioden før oppstart har snudd, og at pasientene føler økt trygghet og mestring.

Avstandsoppfølgingsprosjektet er en del av Nasjonalt program for utvikling og implementering av velferdsteknologi 2014-2020. Designit A.S. ved Arkitektur- og designhøgskolen i Oslo leder prosjektet, og Helsedirektoratet er oppdragsgiver.

Les mer: https://helsedirektoratet.no/ det. Helseplattformen kunngjorde anskaffelse i 2016, det skal inngås kontrakt i slutten av 2018, og de skal levere første del av innføringen i 2021. Direktoratet for e-helse skal planlegge en nasjonal løsning for den kommunale helse- og omsorgstjenesten (Direktoratet for e-helse, 2017).

\section{Velferdsteknologi}

Målet med velferdsteknologi er å skape en tryggere og enklere hverdag både for brukere, pårørende og omsorgspersonell. Velferdsteknologi er en fellesbetegnelse på tekniske installasjoner og løsninger som kan bedre den enkeltes evne til å klare seg selv i egen bolig, og bidra til å sikre livskvalitet og verdighet for brukeren. Velferdsteknologi kan gi bedre tjenester for hjemmeboende eldre og bidra til at de kan være lengst mulig hjemme. Velferdsteknologi kan også gi bedre tjenester for pasienter i sykehjem, innen rus og psykisk helse og for personer med nedsatt funksjonsevne. Erfaringer viser også at velferdsteknologi kan gi mer effektiv bruk av ressurser i helse- og omsorgstjenestene i kommunene. Teknologi vil aldri kunne erstatte menneskelig omsorg og fysisk nærhet, men den kan bidra til å forsterke sosiale nettverk og mobilisere til økt samspill med tjenestene, nærmiljøet og frivillige. Dermed kan den også frigjøre ressurser i omsorgstjenesten som i større grad kan brukes i direkte brukerrettet arbeid (St. meld. nr. 29 (2012-2013)). Nasjo- nalt velferdsteknologiprogram er et samarbeid mellom KS, Direktoratet for e-helse og Helsedirektoratet som skal bidra til at flere kommuner tar i bruk velferdsteknologi (Direktoratet for e-helse, 2017).

For pasienter med demens kan velferdsteknologiske løsninger trolig bidra til økt mestring, trygghet og sosial deltakelse. Kunnskapsgrunnlaget om effekten av teknologisk assistanse for denne gruppen er begrenset, men flere studier synes likevel å peke på positive effekter ved bruk av velferdsteknologi, selv om bruk av slik teknologi også kan skape nye utfordringer for pårørende og personer med demens. Ulike typer velferdsteknologiske løsninger tilpasset denne gruppen, synes å stimulere sosial kontakt og kommunikasjon. Velferdsteknologiske løsninger ser også ut til å bidra til å støtte opp under sviktende hukommelse (Helsedirektoratet, 2012a). I boks 5.5 presenteres foreløpige resultater fra Avstandsoppfølgingsprosjektet av personer med kroniske sykdommer, som vil kunne være aktuelt for pasienter med palliative behov. Erfaringene fra Avstandsoppfølgingsprosjektet er at teknologien medførte (1) økt trygghet og egenmestring, og (2) en sannsynlig nedgang i forbruk av helsetjenester. Prosjektet Velferdsteknologi i Sentrum (se boks 5.6) medførte (1) reduksjon i antall innleggelser, liggedøgn og poliklinikkavtaler, og (2) nedgang i bruk av hjemmesykepleietjenester. 


\section{Boks 5.6 Innføring av velferdsteknologi i sentrumsbydelene i Oslo}

Bydelene St. Hanshaugen, Gamle Oslo, Sagene og Grünerløkka satte i gang prosjektet Velferdsteknologi i Sentrum i 2014. Hensikten var å se om velferdsteknologi bidrar til å redusere behovet for tjenester, målt ved legevaktbesøk, innleggelser og liggedager i institusjon.

Det ble samlet inn data før og etter at velferdsteknologi ble tatt i bruk. Etter at teknologien ble innfort er antall innleggelser redusert med 18,6 prosent og antall liggedøgn i sykehus med 33 prosent. Også bruke av hjemmesykepleie har gått ned med 34 prosent seks måneder eller mer etter at teknologien ble tatt i bruk. Pleierne bruker nesten 60 prosent kortere tid til pleie hos brukerne et halvt år etter at teknologien ble tatt i bruk.

Bydelene, sykehuset og brukerne har spart betydelig summer etter innføring av velferdsteknologi, og særlig etter at den har fătt virke en stund hos brukerne. Besparelsen er på 73000 $\mathrm{kr}$ i gjennomsnitt per bruker over ett år. Dette er en reduksjon på 32 prosent.

Intro International og Arkitektur og Arkitektur- og designhøgskolen i Oslo (AHO) ble valgt som partnere til å forske på effektene av prosjektet underveis. Helsedirektoratet er oppdragsgiver.

Les mer: https://helsedirektoratet.no/ 


\section{Kapittel 6 \\ Pasienttilpassede forløp}

\begin{abstract}
Døden er ikke så skremmende som før. Folk jeg var glad $i$ har gått foran og kvistet loype. De var skogskarer og fjellvante. Jeg finner nok frem.
\end{abstract}

Kolbein Falkeid

\subsection{Innledning}

En av hovedutfordringene i helsetjenesten i dag er at mange pasienter opplever en helsetjeneste som er fragmentert og med mangelfullt samarbeid mellom nivåene (spesialisthelsetjenesten og den kommunale helse- og omsorgstjenesten) og også innen nivåene. Dette medfører forsinket og dårlig planlagt utredning og behandling. Når kompleksiteten øker i behandlingsforløpene og når behovet for helsetjenester varierer over tid, slik det ofte er i palliasjon, er det nødvendig med gode forutsigbare planer, tilpasset pasientens behov. Metoden pasientforløp bør brukes og tilpasses den enkelte pasients behov, slik at hver enkelt pasient får en plan - et pasienttilpasset forløp. Denne planen skal revideres etter behov. På denne måten vil det hele tiden være et pasientsentrert og pasienttilpasset forløp som danner grunnlaget for den palliative behandlingen, pleien og omsorgen.

Kjennetegn ved pasienter med store og sammensatte behov er at symptomer og faktorer er vevd sammen. Tilstanden kan ikke forstås ut fra enkeltfaktorer som diagnose eller avgrenset funksjonsproblem, men ut fra pasientens helhetlige situasjon. Utfordringene for tjenestene er å akseptere kompleksiteten og forstå de ulike faktorenes gjensidige påvirkning (Helsedirektoratet 2017b).

Pasienter med behov for palliasjon får helsehjelp og omsorg i alle deler av helse- og omsorgstjenesten, ofte fra flere aktører samtidig. I dag møter mange pasienter et utrednings- og behandlingstilbud som er preget av for store uønskede variasjoner og som er fragmentert (St. meld. nr. 47 (2008-2009)). Gode planer, forutsigbarhet og pasientinvolvering er sentrale elementer som er etterspurt i dagens helsetjeneste. Det forventes at pasientene får et likeverdig tilbud uavhengig av hvor de bor. Nasjonale faglige retningslinjer skal bidra til dette. Innholdet i de faglige retningslinjene skal være basert på den beste forskningen internasjonalt. Derfor bidrar retningslinjene også til at behandlingen og omsorgen norske pasienter får, holder høyt nivå internasjonalt og har god kvalitet.

Det er behov for systemer som understøtter pasientens behov for helhet i de palliative pasientforløpene. Dette er spesielt viktig for pasienter med komplekse palliative behov, fordi de ofte trenger tjenester både fra sykehus og kommunene. Dessuten kan flere sykehus være involvert, i tillegg til både fastlege, sykehjem og hjemmesykepleien.

Godt organiserte pasientforløp vil kunne bedre logistikk og samhandling, redusere risikonivået for uønskede hendelser og derved øke pasientsikkerheten.

Standardiserte pasientforløp er en metode som brukes for å planlegge pasientenes reise $\mathrm{i}$ helsetjenesten. Standardiserte forløp som grunnelement i planleggingen vil kunne bedre logistikk og samhandling, redusere risikonivå og øke pasientsikkerhet. Slike pasientforløp kan i tillegg gi pasienter og pårørende bedre oversikt, forutsigbarhet $o g$ forståelse for de ulike trinn i behandlingen og dermed økt trygghet. Det er et godt og anerkjent virkemiddel nasjonalt og internasjonalt. Standardiserte pasientforløp kan også brukes for å implementere nasjonale retningslinjer presist og effektivt inn i klinisk praksis, og den kan fungere som en plan for den enkelte pasient.

Pasientforløpene må tilpasses den enkelte. Derfor bruker utvalget gjennomgående begrepet «pasienttilpassede forløp».

\subsection{Dagens situasjon}

\subsubsection{Hva er standardiserte pasientforløp?}

Ifølge St.meld. nr. 47 (2008-2009) Samhandlingsreformen er det et mål at pasienter og brukere møter en helsetjeneste som er godt samordnet, 
preget av kontinuitet og med behandlingskjeder og pasientforløp som ivaretar god behandlingskvalitet, uansett hvem som har ansvaret for de enkelte deltjenestene. Særlig viktig er dette for pasienter med langvarige og sammensatte behov, som for eksempel eldre personer med flere sykdommer, syke barn og unge, pasienter med kroniske lidelser, pasienter med psykiske helseproblemer, personer med rusmiddelproblemer og pasienter med kort forventet levetid.

Definisjonen av et standardisert pasientforløp bygger på European Pathway Association (EPA) sin definisjon av «care pathway» og fremhever følgende kriterier for et pasientforløp (European Pathway Association, 2017):

- en koordinert tverrfaglig prosess for en definert pasientgruppe, som kan omfatte utredning, behandling, oppfølging og omsorg

- diagnostikk, behandling og oppfølging skal være evidensbasert og føre til kunnskapsbasert praksis

Det pasienttilpassede forløpet må legges til grunn for behandling, pleie og omsorg for å synliggjøre de ulike tjenestenes ansvar. Samtidig må pasientforløpet ivareta pasientens perspektiv ved at den enkelte pasients behov ivaretas gjennom hele forløpet - fra diagnosen blir satt og fram til død. Forløpet må samtidig være dynamisk i den forstand at det underveis i den palliative behandling, pleie og omsorg må gjøres justeringer med utgangspunkt $\mathrm{i}$ den enkelte pasients behov og ønsker i de ulike fasene i pasientforløpet. For å få til dette må det være god kommunikasjon mellom helsepersonell og pasient og pårørende. Pasientens behov for palliativ behandling, pleie og omsorg kan endre seg underveis i forløpet, og helsepersonell må hele tiden være sensitive overfor pasientens situasjon og behov. For å ivareta pasientens stemme, må helsepersonell i hele forløpet stille spørsmålet: Hva er viktig for deg nå?

Oppfølging av pårørende etter pasientens død, og av helsepersonellet, ses også som en nødvendig forutsetning for god behandling, pleie og omsorg, og må inngå som en del av pasientforløpet. Det vises til nærmere omtale i kapittel 10.

For å vite hvilket fagspesifikt forløp pasientene skal gå inn i, må pasientene grundig diagnostieres og grupperes (pasienttilpasset behandling). Dette gjøres ved å klassifisere pasientens tilstand, basert på den beste kunnskap. Pasientens tilstand er bestemmende for behandlingen, basert på det til enhver tid beste alternativet for akkurat denne tilstanden. For norske forhold er det Helsedirektoratets nasjonale faglige retningslinjer som skal danne grunnlaget for de pasienttilpassede forløpene. Dette betyr at utredning og behandling i de pasienttilpassede forløpene må tilpasses de nasjonale faglige retningslinjene. I denne sammenheng blir de pasienttilpassede forløpene implementeringsmetoden av de nasjonale retningslinjene.

Det er to sentrale spørsmål som bør stilles i forbindelse med utvikling av pasienttilpassede forløp: Hva er viktig for pasienten? Hva er forskningsgrunnlaget som kan bidra til de nasjonale retningslinjene og innholdet/planene av dette pasienttilpassede forløpet? Spørsmålene er aktuelle uavhengig av hvor pasienten befinner seg i forløpet. I utarbeidelse av et palliativt pasientforløp er det viktig å finne ressurser hos pasienten som kan brukes og styrkes i forløpet som venter. Sett fra pasientens ståsted bør det være en del av behandlingsforløpet at helsepersonell gjør seg kjent med den enkelte pasients individuelle historie, og kartlegger pasientens og de pårørendes ressurser. De ulike pasientforløpene kan inneholde forskjellige elementer som det må tas hensyn til for den enkelte sykdomsgruppe og for den enkelte pasient. Se også omtale av medvirkning og kommunikasjon i kapittel 4.

Pasientforløp kan utarbeides ut fra en metodikk med grunnleggende mål om å bidra til en plan som gjør at både pasient og helsepersonell vet hva som skjer og i hvilken rekkefølge. Pasientforløp er med andre ord en plan for pasientens «reiser» i helsetjenesten, som skal møte pasientens fysiske, psykiske, sosiale, åndelige og eksistensielle behov. Innholdet i planen - pasientforløpet - skal være basert på den beste kunnskapen som finnes for å nå målet om kunnskapsbasert praksis.

Veien frem til pasientforløp - «rammeforløpet» - er det grunnleggende arbeidet som gjøres. Dette forløpsarbeidet er basert på en generell metodikk som kan kalles prosessanalyse. Denne arbeidsprosessen kan benyttes generelt i helseog omsorgstjenestene og skal også benyttes for å planlegge hvordan palliative pasienter skal håndteres.

Denne overordnede analysen og den påfølgende planen skal tilpasses den enkelte pasient, se figur 6.1. Trinn 1 innebærer at nasjonale retningslinjer er utarbeidet og rammene om et pasientforløp er skissert. Når trinn I er gjennomført, må man vurdere hva som er tilgjengelig av struktur/organisering og kompetanse innen sykehus, den kommunale helse- og omsorgstjenesten og hvordan de to nivåene skal samarbeide. Den andre delen av trinn II skal bestå av en individuell 


\section{Boks 6.1 Hva kan pasienttilpassede forløp bidra med?}

- Pasientene opplever helse- og omsorgstjenesten som sammenhengende

- Pasientene får en plan basert på høyt kunnskapsnivå tilpasset sin egen situasjon og behov

- Kvaliteten på behandlingen øker

- Helsepersonellets kompetanse og ressurser blir utnyttet bedre - «mer og bedre helse for hver krone»

- Nasjonale retningslinjer blir implementert (gjennom de pasienttilpassede forløpene) $\mathrm{i}$ klinisk praksis

- Likeverdig palliasjon i hele landet

vurdering av hver pasient, både med et sykdomsfokus og et pasientsentrert fokus. Under disse vurderingene blir den pasienttilpassede dimensjonen lagt til de standardiserte «rammeforløpene». Dette blir samlet, det pasienttilpassede forløpet (trinn III). Når man har kommet til trinn III må det påses at det pasienttilpassede forløpet blir fulgt i praksis, med andre ord implementert. Deretter må det påsees at det pasienten, sammen med legen og andre i det tverrfaglige teamet er enige om innholdet og at blir brukt i klinisk praksis.

Figur 6.1 illustrerer på et overordnet nivå noen av de elementene som vil påvirke mulighetene for å komme frem til et skreddersydd forløp for den enkelte pasienten. Pakkeforløp, slik det er definert i helsetjenesten, er basert på den samme metodikken som standardiserte pasientforløp, men de er en mer overordnet plan enn de palliative pasienttilpassede forløpene.

I boks 6.2 fremgår grunnleggende elementer i pasienttilpassede forløp.

\section{Boks 6.2 Pasienttilpassede forløp - grunnleggende elementer}

- Analyse av «pasienten på veien» i forløpet (prosessanalyse)

- Vurdere det forskningsbaserte grunnlaget for innholdet $\mathrm{i}$ forløpene

- Kombinere veien i pasientforløpet med innholdet (nasjonale retningslinjer)

- Utvikle forløpet for den aktuelle diagnose/ pasientgruppen

- Tilpasse forløpet til den enkelte pasient

Noen pasientforløp er enkle å planlegge, mens andre er mer kompliserte. Kompleksiteten øker med antall aktører involvert, pasientenes sammensatte sykdomsbilde, familieinvolvering og alvorlighetsgraden av sykdommen. Tabell 6.1 illustrerer graden av kompleksitet, fra $0-3$, der 3 er den høyeste graden av kompleksitet. Pasienter med uhelbredelig sykdom, og spesielt pasienter med kort forventet levetid, har i mange tilfeller de mest kompliserte pasientforløpene. Dette er noen av kjernepasientene i palliasjon og de vil kreve gode og forutsigbare pasienttilpassede forløp.

Pasienter med behov for palliative tjenester vil ofte trenge hjelp fra spesialisthelsetjenesten, fastlegen og den kommunale helse- og omsorgstjenesten samtidig. En forløpstilnærming må synliggjøre hvilke aktører og ressurser som skal bidra gjennom hele forløpet. Det vil være behov for ulike typer personell i de ulike fasene i et forløp, og det vil være behov for tverrfaglig samarbeid. I enkelte tilfeller vil familien bidra til å pleie pasienten sammen med hjemmesykepleien og palliativt team. Det palliative teamet kan enten være et kommunalt palliativt team eller et palliativt team fra spesialisthelsetjenesten, avhengig av sykdommens kompleksitet og behovene til pasienten og

Tabell 6.1 Palliative forløp - faktorer som virker inn på kompleksiteten i forløpene

\begin{tabular}{lrrrr}
\hline & $\begin{array}{r}\text { Sammensatt } \\
\text { sykdomsbilde }\end{array}$ & $\begin{array}{r}\text { Familie- } \\
\text { involvering }\end{array}$ & $\begin{array}{r}\text { Alvorlighets- } \\
\text { grad av } \\
\text { sykdommen }\end{array}$ & $\begin{array}{r}\text { Antall aktører i } \\
\text { heljenesten } \\
\text { involvert }\end{array}$ \\
\hline «Kort» (under 12 mnd.) forventet levetid & 3 & 3 & 3 & 3 \\
Døende pasienter & 2 & 3 & 3 & 1 \\
Uhelbredelig - lang forventet levetid & 2 & 1 & $3(2)$ & 2 \\
\hline
\end{tabular}

0 = Ingen, 1 = Lett, 2 = Mye, 3 = Svært mye 


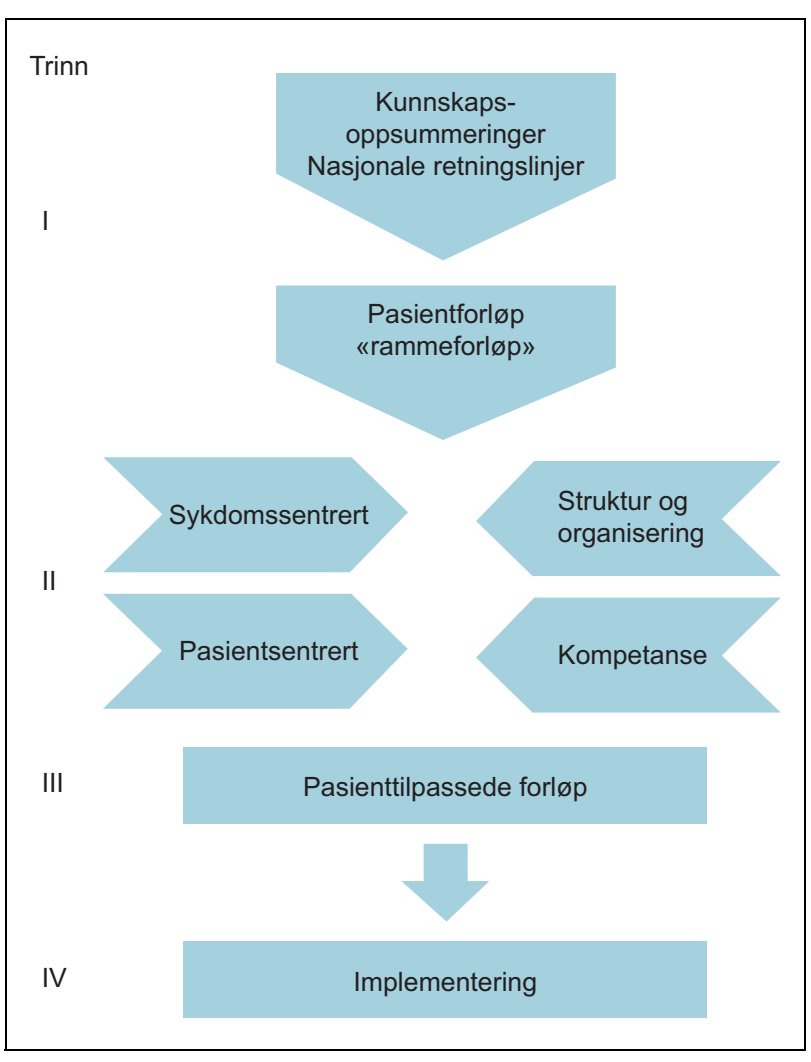

Figur 6.1 Utvikling av palliative pasientforløp

familien. God planlegging er en forutsetning for å utnytte den faglige kompetansen optimalt.

\subsubsection{Retningslinjer, planer og verktøy for palliative forløp}

Nasjonale utredninger, planer og retningslinjer om pasientforløp

I en rekke nasjonale utredninger og anbefalinger helt tilbake til 1984 er det pekt på kompleksiteten i de palliative pasientforløpene og behovet for å integrere kompetanse og ferdigheter om lindrende behandling i palliativ behandling, pleie og omsorg. Dette gjelder både tidlig når pasienten får en livstruende diagnose, under livsforlengende behandling og mot livets slutt. Samarbeid mellom tjenestenivåene er et tema som går igjen $\mathrm{i}$ alle disse dokumentene, fra NOU 1984: 30 Pleie og omsorg for alvorlig syke og døende mennesker, via NOU 1999: Livshjelp, og til St.meld. nr. 47 (20082009) Samhandlingsreformen.

Utvikling av helhetlige pasientforløp er et av samhandlingsreformens viktigste mål (St.meld. nr. 47 (2008-2009)). Den tradisjonelle organiseringen av helsetjenesten $\mathrm{i}$ «siloer» innad og mellom nivåer er en utfordring for gode pasientforløp og en lite hensiktsmessig måte å forvalte totalres- sursene på. Med siloer menes her egne organisatoriske enheter i den kommunale helse- og omsorgstjenesten og i spesialisthelsetjenesten. Samhandlingsreformen viste til at helsetjenesten har mange systemer som er rettet mot deltjenestene, og i liten grad systemer som støtter pasientens behov for helhet i pasientforløpet. Det er også en stor utfordring at helsepersonell er organisert i hver sin silo, med egne budsjetter, mens pasientforløpene går på tvers av siloene, se figur 6.2. Pasientforløp med klart ansvar for hvert delforløp og nødvendig ressurssetting er den metoden som best kan bygge broer mellom siloene. I figur 6.2 har pilen «Pasienttilpassede forløp» to spisser for å illustrere at de palliative pasientforløpene går mellom «siloene» $\mathrm{i}$ begge retninger, basert på pasientens og familiens behov.

Disse utfordringene er fulgt opp i en rekke dokumenter, blant annet i Meld. St. 26 (20142015) Fremtidens primcerhelsetjeneste - noerhet og helhet. Denne meldingen peker på at gode pasientforløp kjennetegnes ved at tjenestene tar utgangspunkt i pasientens ønsker og mål, oppsummert kunnskap om hvilke tiltak som har god effekt, og ved at tjenestene gis koordinert i en planlagt og mest mulig uavbrutt kjede. I meldingen vises det til at ulike tiltak som veiledere, retningslinjer og læringsnettverk er verktøy for å bedre pasientforløpene.

I «Sammen - mot kreft» Nasjonal kreftstrategi 2013-2017 anbefales det å etablere standardiserte forløp i alle handlingsplanene for kreft som skal bidra til å heve kvaliteten på norsk kreftomsorg, og legge grunnlaget for bedre samhandling i pasientforløpet. Forslagene i strategien er senere fulgt opp gjennom utarbeidelse av 28 pakkeforløp for kreft. Godt organiserte pasientforløp med anbefalte forløpstider skal sikre pasienten et raskt, forutsigbart og helhetlig forløp gjennom diagnostikk, utredning, behandling og oppfølging. Samtidig skal pakkeforløpene redusere risikofaktorer og unødvendig ventetid for pasientene. Styrken med pakkeforløpene er at helsemyndighetene har satt krav til helsetjenesten om planer for å utrede, diagnostisere og behandle pasienter innen en gitt tidsfrist. Pakkeforløpene kan betraktes som myndighetspålagte krav om en tidsangivelse som forventes å bli oppnådd.

Pasientforløp for barn og unge er beskrevet $\mathrm{i}$ Nasjonal faglig retningslinje om palliasjon til barn og unge uavhengig av diagnose (Helsedirektoratet, 2017). Helsedirektoratet anbefaler at pasientforløpsmodellen bør bli en nasjonal standard for barn med livstruende og livsbegrensende sykdom og 


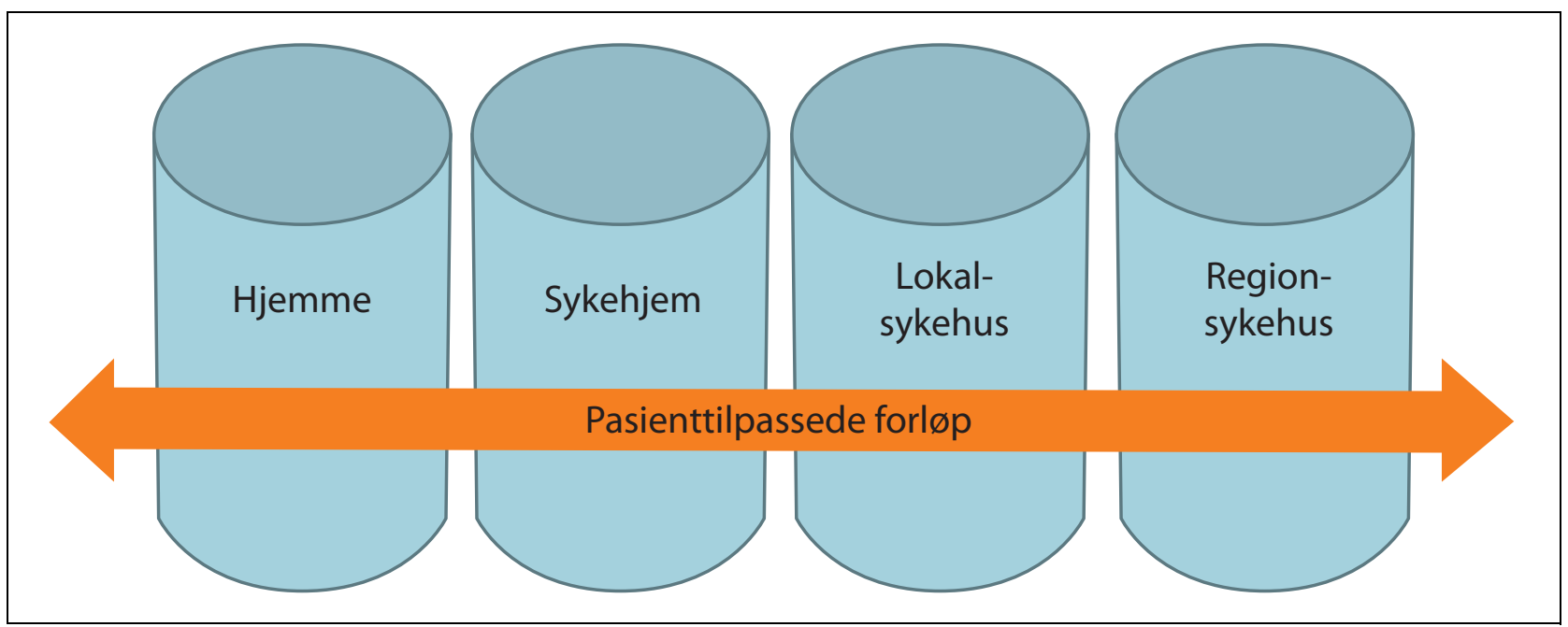

Figur 6.2 Pasientforløp på tvers av siloer

deres familier. Forløpsmodellen for palliasjon til barn og unge er delt i fire faser:

1. pre- og perinatal palliasjon

2. diagnose eller erkjennelse av en livstruende eller livsbegrensende tilstand

3 . å leve med en livstruende eller livsbegrensende tilstand

4. erkjennelse av at barnets død nærmer seg, terminalfase og død

\section{Symptom- og funksjonskartlegging}

I dag brukes et eget begrep for pasienters egenrapporterte funksjonsnivå og symptomer, «pasientrapporterte endepunkter», på engelsk PROMs (patient reported outcome measures). PROMs er i dag i ferd med å bli en benevnelse som også brukes på norsk. Kartleggingsverktøyet Edmonton Symptom Assessement System (ESAS) er anbefalt brukt som standard kartleggingsverktøy i all palliativ virksomhet. ESAS er et selvrapporteringsskjema for noen av de vanligste symptomene som palliative kreftpasienter kan oppleve. Formålet med skjemaet er bedre kartlegging av pasientens symptomer, noe som igjen skal bidra til økt kvalitet på behandling og pleie. ESAS er utviklet for bruk hos kreftpasienter i palliativ fase, men forskning har vist at det også egner seg for bruk tidligere i sykdomsforløpet og hos pasienter med andre diagnoser. Det er anbefalt at ESAS skal inngå som en del av arbeidet med å kvalitetssikre og evaluere palliativ behandling samt at det skal kunne anvendes i forskning (helsebiblioteket.no).

I noen elektroniske pasientjournaler (EPJ) kan ESAS integreres eller lastes inn manuelt og bli en del av pasientdokumentasjonen. Dette gjøres i dag ved henholdsvis Universitetssykehuset NordNorge, Haukeland universitetssykehus og Oslo universitetssykehus. Nyere studier viser at systematisk bruk av PROMs både under helbredende, livsforlengende og palliativ behandling bedrer symptomkontroll og gir bedre livskvalitet. Noen studier har vist at det også kan forlenge levetiden til pasientene (Basch m.fl. 2017). Med ny teknologi basert på nettbrett og åpne nettløsninger er det mulig å overføre PROMS fra pasientens hjem, fra sykehjem, fra poliklinikk eller hvor enn pasienten måtte være inn i den elektroniske databasen (EPJ).

\section{Individuell plan i palliasjon}

Pasient og bruker med behov for langvarige og koordinerte helse- og omsorgstjenester har rett til å få utarbeidet individuell plan, jf. pasient- og brukerrettighetsloven $\S 2$-5.Tilsvarende har kommunens helse- og omsorgstjeneste og helseforetaket plikt til å sørge for at individuell plan etter pasientog brukerrettighetsloven $\S 2-5$ utarbeides for pasienter og brukere med behov for langvarige og koordinerte tjenester, jf. helse- og omsorgstjenesteloven $\S 7-1$, spesialisthelsetjenesteloven $\S 2-5$ og psykisk helsevernloven $\S 4$-1. Ifølge Veileder om rehabilitering, habilitering, individuell plan og koordinator (Helsedirektoratet, 2017a) er formålet med individuell plan blant annet å styrke samhandlingen mellom tjenesteyter og pasient, bruker og eventuelt pårørende, og mellom tjenesteytere og etater innen et forvaltningsnivå eller på tvers av forvaltningsnivåene. Dersom pasienten ikke ønsker individuell plan, skal det likevel oppnevnes en koordinator. 


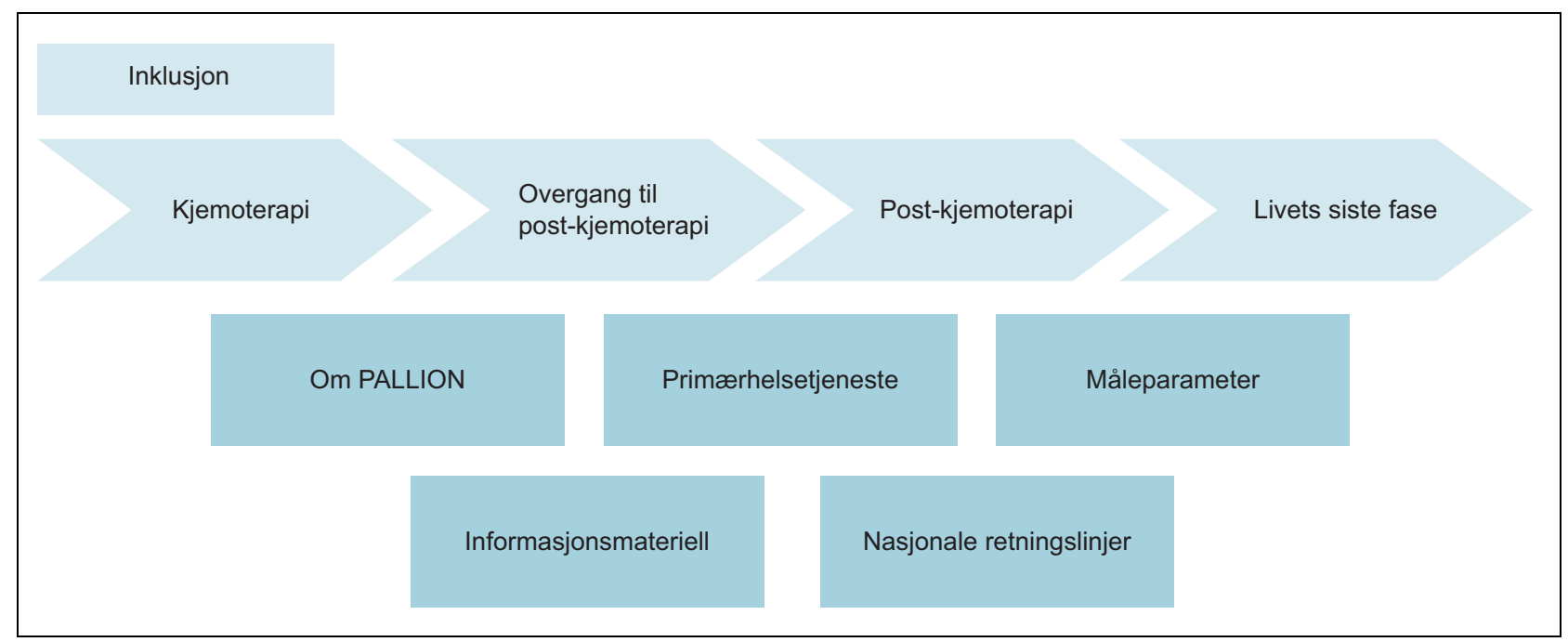

Figur 6.3 Pasienttilpasset forløp (Pallion)

Det er foreslått en endring i forskrift om habilitering, rehabilitering, individuell plan og koordinator $\S 3$. Formålet med forslaget er å forsterke brukerperspektivet i tråd med målet om pasientens helsetjeneste, ved å tydeliggjøre i definisjonen at det er pasienten og brukerens mål for eget liv som skal legges til grunn ved utformingen av habilitering- og rehabiliteringstilbudet. I tillegg skal definisjonen fange opp at habilitering og rehabilitering er prosesser som både kan være tidsavgrenset og av livslang varighet og at behovet for tverrfaglig samarbeid og koordinering kan variere over tid i et forløp. Det tas sikte på at endringene trer i kraft våren 2018, forutsatt at endringen i definisjonen blir vedtatt.

I Nasjonalt handlingsprogram for palliasjon $i$ kreftomsorgen (Helsedirektoratet, 2015b) anbefales det at utformingen og omfanget av den individuelle planen i palliasjon tilpasses pasientens spesielle situasjon med stadig endring i tilstanden og vekslende behov for oppfølging og tiltak. Ifølge handlingsprogrammet har både kommunen og helseforetaket ansvar for å utarbeide individuell plan til pasienter som har behov for det. Kommunen har ansvar for å koordinere arbeidet dersom begge nivåer er involvert (spesialisthelsetjenesteloven $\S 2-1$, helse- og omsorgstjenesteloven $\S 7-1$, forskrift om habilitering, rehabilitering, individuell plan og koordinator). Hovedmålet for planen må være at den bidrar til en helhetlig og forutsigbar tjeneste med tydelig oppgavefordeling og tydelige avtaler om tilgjengelighet og oppfølging. I Nasjonalt handlingsprogram for palliasjon $i$ kreftomsorgen går det fram at erfaringen tilsier at en slik plan kan være svært nyttig og burde tilbys flere pasienter med behov for palliasjon (Helsedirektoratet, 2015b).

Det anbefales i handlingsprogrammet at individuell plan skal inneholde:

- pasientens skriftlige samtykke

- en koordinator, f.eks. hjemmesykepleier

- pasientens mål

- en ansvarlig tjenesteyter for hvert tjenesteområde

- kontaktoversikt og ansvarsfordeling, inkludert kveld, natt og helg

- avtalt oppfølging

- klare retningslinjer for hvor og hvordan eventuell innleggelse skal ordnes. Dersom åpen returbegrepet brukes, skal dette være klart definert

\subsubsection{Bruk av pasientforløp innen palliasjon}

I denne delen er det gitt noen eksempler på pasienttilpassede forløp. Disse illustrerer hvordan pasientforløpene planlegges, og hvordan man tar hensyn til den enkelte pasienten. Det er illustrert med forløp som starter tidlig (tidlig integrasjon) og forløp mot livets slutt.

Pallion er et pågående nasjonalt forskningsprosjekt (www.pallion.no). Prosjektet skal teste effekten av en tredelt intervensjon som integrerer onkologi og palliasjon for kreftpasienter som behandles med antatt siste mulighet til å få medikamentell behandling av sykdommen. Intervensjonen sikter mot å øke legenes kompetanse, gi oversiktlige og forutsigbare pasientforløp, og fremme felles beslutningstaking mellom pasient og behandlere. 
Hovedelementene i prosjektet er systematisk elektronisk symptomkartlegging, pasientforløp, retningslinjer for hvordan konsultasjonene skal gjennomføres og når det skal skje $\mathrm{i}$ henhold til en plan. Dette er illustrert i figur 6.4 som er åpningsbilde i Pallion's pasienttilpassede forløp. Dette bildet illustrer også at det er underforløp. Innen hvert av disse underforløpene er det gitt detaljerte råd/prosedyrer som skal følges som en del av det pasienttilpassede forløpet.

I pallion er det formalisert et samarbeid mellom onkologisk poliklinikk og palliativ poliklinikk basert på Pallionforløpene. Et annet element i Pallion er integrering av palliasjon inn i forløpet mens pasientene får livsforlengende kjemoterapi (se figur 6.3).

\section{Tiltaksplan for ivaretakelse av den døende pasienten}

I Nasjonalt handlingsprogram for palliasjon i kreftomsorgen beskrives hvilke elementer som bør inngå i en tiltaksplan for ivaretakelse av den døende pasienten (Helsedirektoratet, 2015b). Den mest brukte planen for pasientforløp i livets siste fase er Livets siste dager - plan for lindring i livets sluttfase. Livets siste dager er en videreutvikling av Liverpool Care Pathway (LCP), tilpasset for bruk i Norge. LCP er et strukturert pasientforløp for god ivaretakelse av døende pasienter de aller siste levedager og -timer og for deres pårørende, uavhengig av oppholdssted. Livets siste dager er et pasienttilpasset forløp som er basert på den beste kunnskapen nasjonalt og internasjonalt innen dette området av palliasjon. Livets siste dager er et eksempel på en tiltaksplan for hovedforløpet som kan kalles livets slutt. I anbefalingen av hvordan Livets siste dager skal benyttes, er det krav om helsefaglig kompetanse, involvering av pasient og pårørende, og hvordan pasientens behov systematisk skal følges i forløpet.

Livets siste dager brukes mange steder i Norge i dag. Pr. 03.11.17 var det 445 brukersteder i Norge - 23 sykehus med 46 avdelinger, 326 sykehjemsavdelinger og 96 hjemmesykepleietjenester (Kompetansesenter i lindrande behandling Helseregion Vest, 2017). Kompetansesenteret i lindrande behandling Helseregion Vest har en landsdekkende funksjon som koordinerende senter og har laget en omfattende prosedyre for implemen-

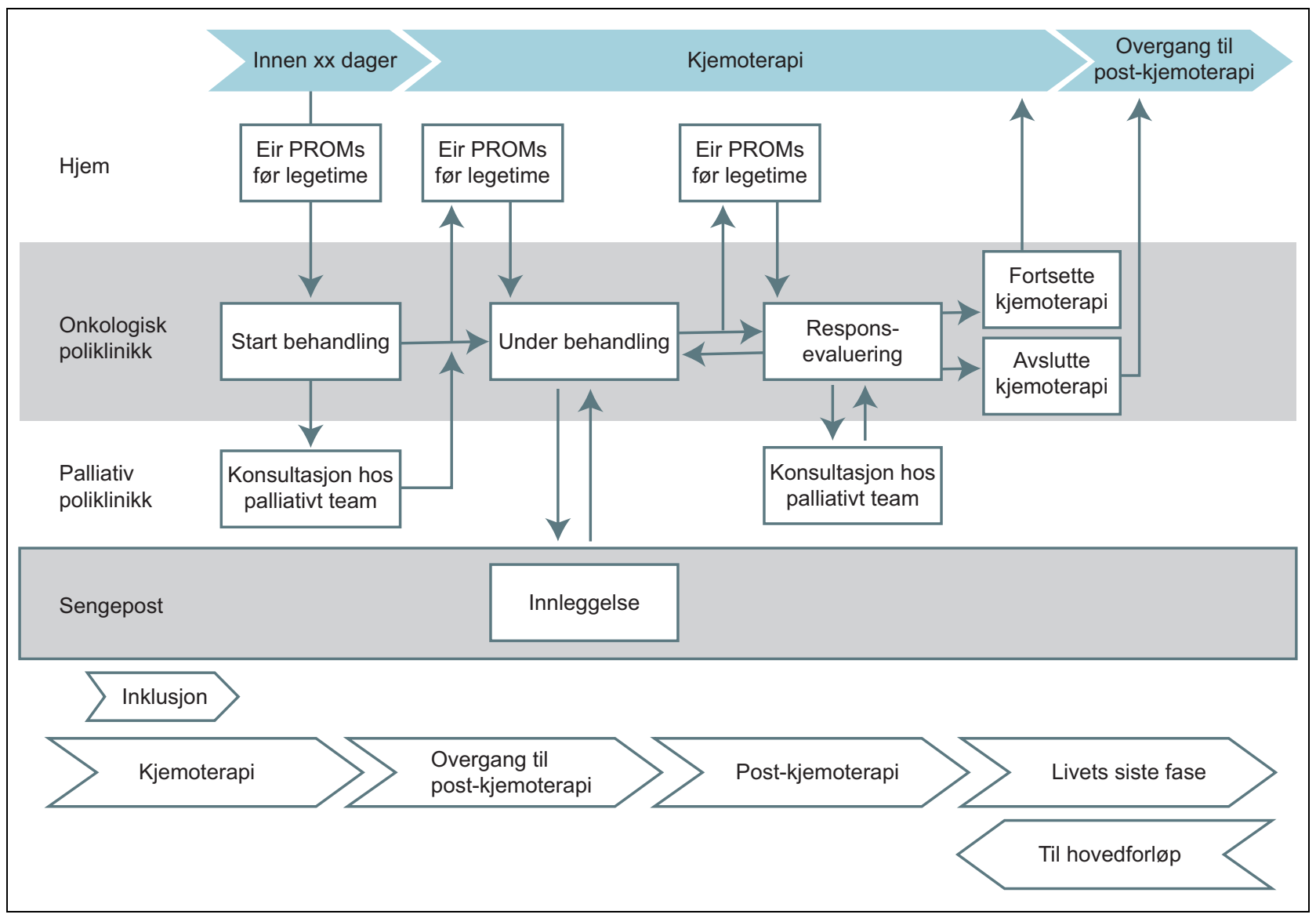

Figur 6.4 Samarbeid mellom onkologisk poliklinikk og palliativ poliklinikk.

Kilde: www.stolav.no 


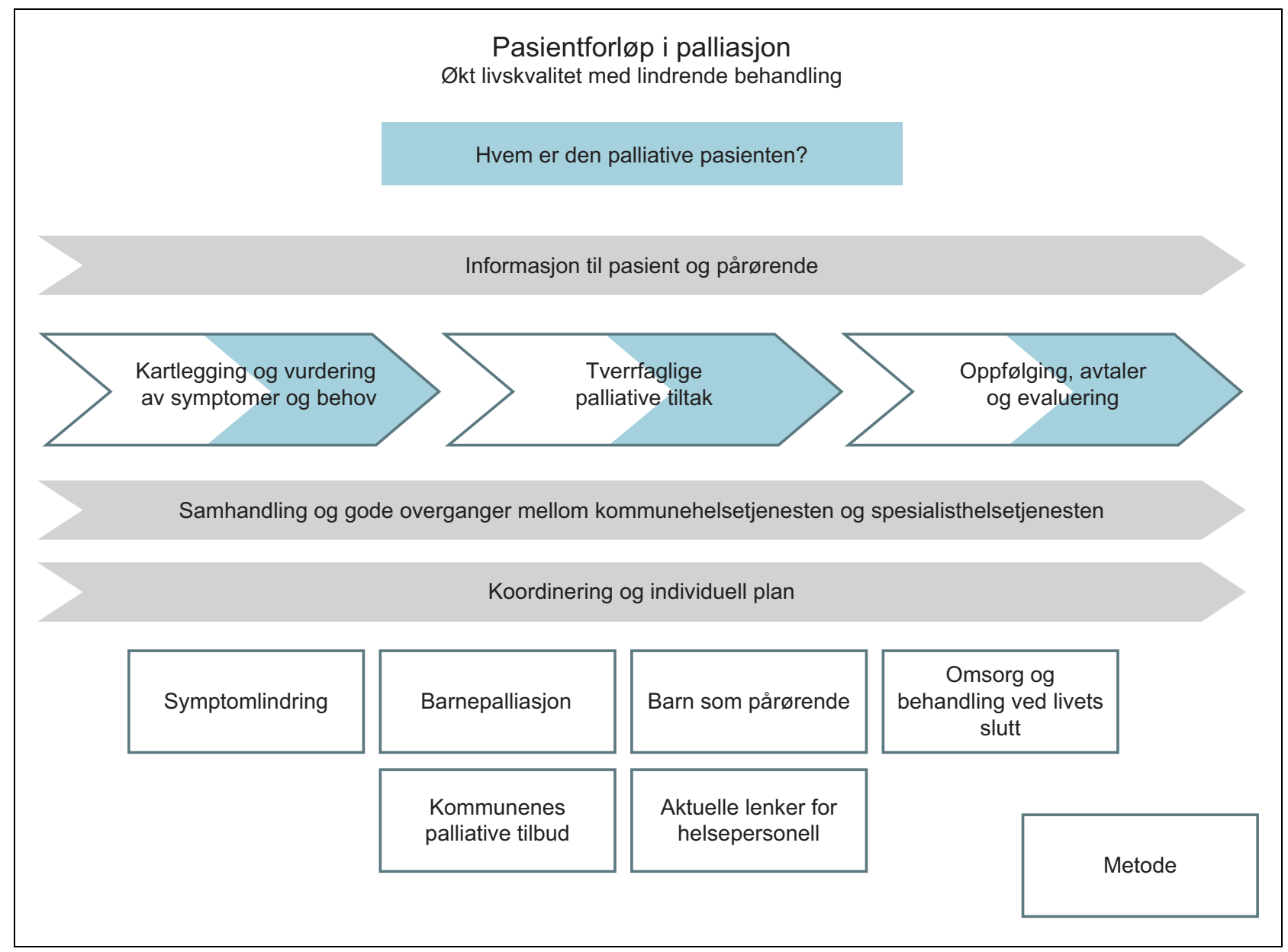

Figur 6.5 Pilot - Pasientforløp i palliasjon i Helse Stavanger HF

Kilde: Helse Stavanger, 2017. https://helse-stavanger.no/avdelinger/medisinsk-klinikk/avdeling-for-blod-og-kreftsykdommer/ palliativt-senter\#pasientforløp

tering og bruk (helsebiblioteket.no). Bruk av dette verktøyet krever registrering av brukerne.

Liverpool Care Pathway (LCP) er tatt i bruk som modell i over 20 land. I Storbritannia, der LCP ble utviklet, er det stilt spørsmål ved bruken av denne planen, og mange institusjoner har sluttet å bruke LCP. National Institute for for Health and Care Excellence (NICE) har utviklet nye retningslinjer basert på LCP. Det har også vært ulike oppfatninger i det norske fagmiljøet om bruken av LCP. Den sterkeste kritikken har gått ut på at LCP ikke må brukes hvis kompetansen til helsepersonell ikke er tilstrekkelig. Det har også vært påpekt at bruk av LCP ikke er egnet for personer med demens eller annen kognitiv svikt. Helsedirektoratet har anbefalt at bruken av verktøyet LCP i Norge bør evalueres for å få fram erfaringer og vurdere videre bruk (Helsedirektoratet, 2015a).

\section{Forpliktende samarbeidsavtaler}

En løsning for å få til helhetlige palliative pasientforløp kan være inngåelse av forpliktende avtaler om palliative forløp mellom spesialisthelsetjenesten og den kommunale helse- og omsorgstjenesten, som en delavtale knyttet til den lovpålagte samarbeidsavtalen. Et eksempel er Helse Stavanger HF og kommunene i helseforetaksområdet som i samarbeid har utarbeidet en avtale om pasientforløp for palliasjon som en delavtale til overordnet samarbeidsavtale. Formålet med avtalen er å bidra til samhandling mellom Helse Stavanger HF og kommunene i opptaksområdet om palliative pasienter, slik at behandlingen blir tilpasset pasientens behov, ansvar for oppfølging av pasienter med behov for «samtidige tjenester» avklares og nødvendig kontinuitet sikres, se figur 6.5.

Palliativt pasientforløp skal gi en helhetlig beskrivelse av pasientens kontakter med de ulike delene av helse- og omsorgstjenestene i løpet av 


\section{Boks 6.3 Samarbeidsavtale om behandlingsforløp for palliasjon}

Det er utarbeidet en samarbeidsavtale om behandlingsforløp for palliasjon mellom Helse Stavanger HF og kommunene i helseforetaksområdet. Avtalen er inngått som en delavtale til en overordnet samarbeidsavtale og bygger på bestemmelsene i helse- og omsorgstjenesteloven $\S 6-2$ om helhetlige og sammenhengende helse- og omsorgstjenester til pasienter med behov for koordinerte tjenester.

Avtalen skal:

- Bidra til at den enkelte pasient får et forsvarlig og verdig tjenestetilbud

- Sikre at pasientforløpet er i overensstemmelse med pasient- og brukerrettighetsloven, samt basert på nasjonalt handlingsprogram og relevante palliative kartleggingsverktøy

- Sikre at palliative pasientforløp kan integreres i eksisterende og framtidige pasientforløp, basert på kriterier knyttet til pasientens tilstand, behov for kompetanse og krav til teknologi/hjelpemidler, og sikre krav til nødvendig kompetanse på alle nivåer, jf. Nasjonalt handlingsprogram med retningslinjer for palliasjon i kreftomsorgen

- Sikre Helse Stavanger HFs veiledningsansvar overfor kommunene, samt partenes gjensidige opplæringsansvar
- Gi anbefalinger til videreutvikling av palliative tjenester

I avtalen er det synliggjort hva som er felles ansvar og hovedoppgaver for de to nivåne, og hvilke særskilte oppgaver kommunen og helseforetaket har. Ved samhandling om palliative pasientforløp har begge parter ansvar for:

- Å bidra til å initiere og delta i nettverksmøter/felleskonsultasjoner

- Dokumentasjon fra begge parter skal gi opplysninger om hvor i sykdomsløpet pasienten befinner seg (stabil, progresjon, akselererende sykdom, kort forventet levetid, døende), vurdere videre behandlingsintensitet, vurdere hensiktsmessige tiltak- ønsker og reservasjoner, hva som bør gjøres dersom det oppstår nye situasjoner/komplikasjoner, og opplysninger om hvilken informasjon som er formidlet til pasient og pårørende

- Vurdere behov for individuell plan

- Sørge for at epikrise og utskrivningsrapport skal følge pasienten ved utskrivelse

Kilde: https://helse-stavanger.no/seksjon/Samhandling/ Documents/Avtaler/Stavanger/F\%20-\%

20Stavanger\%20LSA\%20-\%20Delavtale\%202d.PDF den palliative fasen av sykdomsforløpet. Målsettingen er å sikre forutsigbare og likeverdige tjenester og behandlingsforløp for den palliative pasienten $o g$ de pårørende. Pasientforløp i palliasjon testes gjennom en pilot i Stavanger kommune ved bruk av oppfølgingsteam høsten 2017. Testen foretas via prosjektet Kompetanseøkning i palliasjon i primærhelsetjenesten. Pasientforløpet ferdigstilles endelig i januar 2018.

Samhandlingsreformen har ikke gitt merkbar uttelling med hensyn til helhetlige pasientforløp. Evaluering av samhandlingsreformen (Norges forskningsråd, 2016) viser blant annet at:

- Diagnosebaserte pasientforløp oppleves som lite tilpasset den kommunale virkeligheten og for spesialisert for det lokale pasientgrunnlaget

- Diagnoseuavhengige pasientforløp synes å passe bedre, særlig for pasienter med flere sykdommer
- Brukerne har i begrenset utstrekning medvirket i utformingen av avtalene mellom kommuner og helseforetak

- Nesten alle kommuner hadde ved utgangen av 2015 tatt i bruk digitale pleie- og omsorgsmeldinger, noe som har bidratt til bedre oversikt over pasientstrømmer

I tillegg til å gjennomføre pakkeforløp for kreft, har det vært stilt krav til de regionale helseforetakene om å etablere flere pasienttilpassede forløp i henhold til nasjonale retningslinjer (Helse- og omsorgsdepartementet, 2015). På den enkelte institusjon og/eller mellom institusjoner bør dette arbeidet samordnes slik at beskrivelsen av de enkelte forløp blir ensartet. Utvikling av en felles mal for alle forløpene bør skje på en slik måte at det er mulig å legge inn tilpasninger som tar hensyn til spesielle diagnoser, typer av aktuelle intervensjoner og nødvendig antall delforløp. Denne 
Fastlege

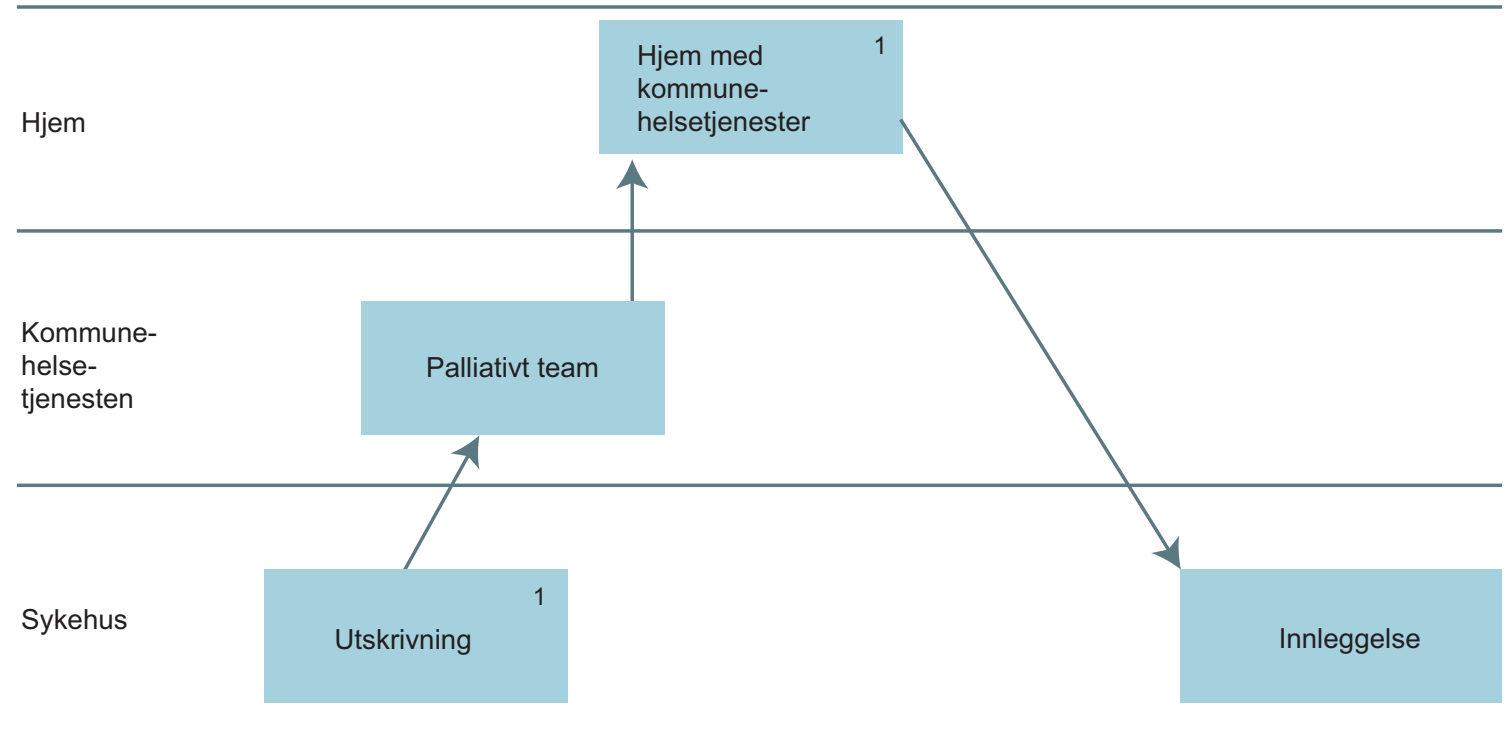

${ }^{1}$ Før utskrivelsen skal en planlegge god overføring fra sykehus til hjemmet - kommunehelsetjenesten. Palliativt team i kommunen kan bidra (ny organisasjon) mot hjemmet sammen med hjemmesykepleie og fastlege. Det skal som illustrert i figuren legges en plan for tiltak fra kommunehelsetjenesten ved utskrivelsen og dette må skje etter en fast avtaleplan. Pasientene får et forløp tilpasset hans/hennes situasjon som kan endres etter behov.

Figur 6.6 Pasientforløp fra sykehus til hjemmet

malen bør være digital, slik at den blir en del av elektronisk pasientjournal. Malen skal brukes til å implementere nasjonale retningslinjer og veiledere.

Helse- og omsorgstjenesteloven kapittel 6 forplikter kommuner og helseforetak til å inngå samarbeidsavtaler for å bidra til at pasienter og brukere mottar et helhetlig tilbud om helse- og omsorgstjenester. Minimumskravene til innholdet i avtalene er med på å sikre nødvendig samhandling mellom kommuner og sykehus. Partene kan inngå avtaler om spleiselag (ambulante tverrfaglige team, lokalmedisinske sentre, tjenester $\mathrm{i}$ hjemmet o.1.) når det gir en bedre løsning for pasientene. Et eksempel er palliativt team ved Sykehuset Telemark, der kommunene i Telemark bidrar med en prosentandel av kostnadene til legestillingen i det ambulante teamet. Figur 6.6 viser pasientforløp fra sykehus til pasientens hjem.

\section{Fastlegen i det palliative pasientforløpet}

Det er iverksatt flere tiltak med mål om å involvere fastlegene mer i oppfølgingen av de palliative pasientene slik at de kan være en aktiv deltaker i det palliative pasientforløpet. Dette omfatter både prosjekter og kurs. Et eksempel er et prosjekt i regi av Sykehuset i Telemark, der palliativt team fra sykehuset reiser hjem til pasienten sammen med fastlegen og hjemmetjenesten, inkludert ressurssykepleier. Målet er å etablere kontakten mellom fastlegen og pasienten. Prosjektet beskrives som vellykket, og generelt er erfaringen at fastlegene er positive til prosjektet. Erfaringer fra prosjektet viser at flere fastleger har hyppigere hjemmebesøk etter kurset, og parallelt har de gjort hjemmebesøk sammen med kreftkoordinator. På grunn av pasientforløpet har det blitt skapt bedre rammer for kommunikasjon mellom nivåene, noe som igjen har gjort det lettere for legene å ta en telefon til palliativt team på sykehuset. Som et resultat kan legene gi bedre oppfølging i hjemmet, for eksempel ved å iverksette smertelindring. Flere av kompetansesentrene holder kurs innen palliasjon som er relevante for fastlegene, men det er varierende deltakelse (Sintef, 2016). 


\section{Boks 6.4 Momenter som er viktig for pasienten og for helsetjenesten}

Hva er viktig for pasienten:

- Forutsigbarhet (gode planer)

- At behandlingen ligger på et høyt internasjonalt nivå (finnes i de nasjonale retningslinjene til Helsedirektoratet)

- At de selv er aktive deltagere i planlegging av behandling, pleie og omsorg (advance care planning and shared decision making)

- At symptomer og funksjoner blir kartlagt med et pasientperspektiv (PROMs)

- At det er mulig å være hjemme

- At pasienten (og familien) får den hjelpen de trenger til enhver tid
- At alle aktørene er godt samkjørt

- At pasientene vet hvem som er kontaktpunktet $\mathrm{i}$ helsetjenesten til enhver tid

Tilleggsmomenter som er sentrale for helsetjenesten:

- At helsepersonell blir benyttet optimalt og at det er rett kompetanse på rett sted til rett tid

- At planene finnes i elektronisk pasientjournal

- At man i fremtiden får et fleksibelt journalsystem som dokumenterer de pasienttilpassede forløpene med fortløpende endringer

\subsection{Vurdering og drøfting av dagens praksis}

\subsubsection{Manglende samhandling og fragmenterte tjenester}

Bruk av pasientforløp har vært anbefalt i flere utredninger, stortingsmeldinger og nasjonale faglige retningslinjer, helt tilbake til 1984 innen palliasjon og 1997 innen kreftområdet. Til tross for dette, opplever fortsatt mange pasienter at «reisen» i helsetjenesten er uoversiktlig, lite forutsigbar, tilfeldig, og at rett kompetanse ofte ikke er til stede eller er vanskelig å nå. Dette synes å være mest uttalt når forløpene øker i kompleksitet og når de foregår i store og sammensatte organisasjoner (store sykehus og store bykommuner). Dette kan dreie seg om større kommuner eller større sykehus med lokalisering flere steder.

Pakkeforløp for kreftpasienter har vært suksess målt i forløpstid. For pasienten er det viktig å få en plan der aktuelle tidspunkt er forhåndsbestemt fra første møte hos fastlegen med mistanke om kreft. Pakkeforløpene blir ikke målt på kvalitet av utredning og behandling.

For å få til tiltakskjeder, foreslo NOU 1999: 2 Livshelpsutvalget at utvikling og bruk av pasienttilpassede forløp for palliasjon kan bidra til et nært samarbeid mellom nivåene i helsetjenesten, slik det er i inngangen til pakkeforløp fra fastlege til sykehus. Dette kan bidra til å skape et helhetlig og sømløst forløp for pasienten.

I Nasjonalt handlingsprogram for palliasjon $i$ kreftomsorgen (Helsedirektoratet, 2015b) er det ikke utarbeidet en mal for pasienttilpassede pallia- tive forløp som omfatter både spesialisthelsetjenesten og den kommunale helse- og omsorgstjenesten. Utvalget mener dette bør utarbeides og implementeres i handlingsprogrammet.

Mangler i informasjonsutveksling og kommunikasjon mellom sykehus og kommune er alvorlig da dette kan føre til at pasientene ikke får den behandling og pleie de har behov for. For å sikre at tilstrekkelig og relevant informasjon overføres ved pasientoverganger mellom sykehus og kommune, er pleie- og omsorgsmeldinger (PLO-meldinger) innført som et redskap for å bedre denne samhandlingen. Meldingene omfatter et sett av flere standardiserte meldingstyper som understøtter fasene innleggelse, utredning/behandling og utskrivning ved et sykehusopphold. I tillegg finnes det dialogmeldinger for mer løpende, interaktiv samhandling. Pr. 1. januar 2015 hadde 98,6 prosent av alle kommuner (422/428) tatt i bruk PLOmeldinger i samhandling med sykehus. Dette er en sterk økning fra fire kommuner i mai 2012 (Brattheim, Hellesø m.fl., 2017).

I Nasjonal faglig retningslinje for palliasjon til barn og unge uavhengig av diagnose (Helsedirektoratet, 2017), anbefales det at pasientforløpsmodellen bør bli en nasjonal standard for barn med livstruende og livsbegrensende sykdom og deres familier. Utvalget mener det må komme klarere fram i denne retningslinjen at det må tas hensyn til pasienten og pårørendes ønsker for hvor og hvordan barnet skal motta behandling og omsorg, og hvor de ønsker at barnet skal få dø. Pasienten og de pårørendes stemme må komme tydeligere fram i beskrivelsen av pasientforløpene i retningslinjen. Det er videre behov for at overgangen fra 
barn til voksen og ettervern og omsorg ved livets slutt tydeliggjøres som en del av pasientforløpet i retningslinjen.

Det må sikres gode samarbeidsrutiner mellom helseforetak og kommune ved at det inngås samarbeidsavtaler om palliasjon. Samarbeidsavtaler skal inngås for at helsetjenesten skal kunne utløse refusjon for palliative tiltak. Avtalen må blant annet omfatte at epikrise er tilgjengelig ved utskrivelse fra sykehuset, men det må også beskrives hva som er viktig når pasienter legges inn på sykehus.

Ved utskrivning fra sykehus bør aktuelt helsepersonell i kommunen ved behov inviteres til et avklaringsmøte sammen med pasient og pårørende. Der bør det klargjøres hvilke tjenester og ressurser helseforetaket skal bidra med, og det skal oppgis hvem som er pasientens kontaktlege.

Pasientens kontaktlege må delta i avklaringsmøtet. Dette bør legges inn i de obligatoriske samarbeidsavtalene. Utvalget foreslår at det etableres ambulerende tjenester/team i den kommunale helse- og omsorgstjenesten og i spesialisthelsetjenesten. Tjenesten/teamene bør ha tilpasset kompetanse avhengig av pasientens behov, og komme dit pasienten er, enten de er hjemme, på sykehus, i sykehjem eller andre aktuelle institusjoner.

\subsubsection{Manglende integrasjon av palliasjon i behandlingen}

Pasienter bør ha tilgang til god palliasjon fra primærdiagnosen stilles til livets slutt. Tidlig integrasjon av palliasjon i behandlingen er av stor betydning for pasienttilfredshet, livskvalitet og overlevelse (Hui og Bruera, 2016). Tidlig integrasjon er ikke gjennomført i de fleste land, heller ikke i Norge. Integrasjon av palliasjon i pasientforløpet bør skje ved at alle fagområder innen helse- og omsorgstjenestene, som kan bidra til best mulig behandling og oppfølging, blir en del av forløpene. Dette gjelder for de fleste diagnosegrupper som kreft, kronisk hjertesykdom, kronisk lungesykdom, kronisk nyresykdom, kroniske progressive nevrologiske lidelser, demens og barn med alvorlige sykdommer.

Tallet på personer med demens vil sannsynligvis dobles de nærmeste 30-40 årene som følge av økt levealder og endret alderssammensetning. De fleste personer med demens vil ha behov for ulike tjenester i eget hjem eller i sykehjem i løpet av sykdomsperioden, og deres nærmeste vil ha behov for avlastning og støtte. Dagens kommunale helse- og omsorgstjeneste er ikke i tilstrekkelig grad organisert og tilrettelagt for personer med demens og deres pårørende. Det er nødven- dig med endringer både når det gjelder kompetanse, organisering og fysisk utforming av tjenestene. Dette bør planlegges i detalj slik det er skissert i metodikk for pasienttilpassede forløp. Det skal utvikles overordnede nasjonale rammer for demensforløp. Disse kan brukes for å utvikle pasienttilpassede forløp for den enkelte pasient. Det vises til Demensplan 2020. Et mer demensvennlig samfunn, der et av de strategiske hovedgrepene er å utarbeide pasientforløp med systematisk oppfølging og tilpassede tjenestetilbud til demente (Helse- og omsorgsdepartementet, 2015a).

Integrasjon av palliasjon innenfor alle fagområder er et nødvendig grep for å oppnå gode og helhetlige pasientforløp. Etter at forløpene er utviklet, basert på en god metodikk, må de implementeres i klinisk praksis. Slik metodikk er utviklet ved Oslo universitetssykehus, Avdeling for kreftbehandling.

\subsubsection{Pasientmedvirkning i de palliative pasientforløpene}

Studier viser at det er behov for å legge vekt på samtaler mellom pasient, pårørende og helsepersonell om spørsmål knyttet til livets sluttfase og planlegging av denne fasen ved alvorlig, livsbegrensende sykdom, dersom det er mulig. Forskning viser at de fleste, men ikke alle, ønsker å være informert om sin sykdom og prognose, og de ønsker i større eller mindre grad å delta i beslutninger rundt egen sykdom. Dette synes å være uavhengig av diagnose og etnisitet. Det er ikke funnet noen dokumentasjon av negative konsekvenser for pasienten ved å ta opp problemstillinger knyttet til livets sluttfase. Forskning viser også at det å kjenne til pasientens egne ønsker og preferanser om livsforlengende behandling gjør beslutningsprosessen rundt behandlingsbegrensning i livets sluttfase lettere for pårørende og helsepersonell (Kunnskapssenteret, 2014). Se også omtale i kapittel 4.

Hva er viktig for deg nå? Pasientens stemme i pasientforløpene

Hva har verdi for pasienten i prosessen før, under og etter et eventuelt sykehusopphold, møtet hos fastlegen, besøk i pasientens hjem eller på sykehjem? Spørsmålet gjelder uavhengig av hvor pasienten befinner seg i forløpet, og er rettet like mye mot faglig kvalitet som mot pasienttilfredshet og ressursbruk. Se omtale av verdier kapittel 4.

For å gi pasientene en reell og forutsigbar mulighet til selv å bli en aktiv del av gjennomførin- 
gen av forløpene, må de medvirke i planlegging av egen behandling og omsorg. Det bør utvikles en beskrivelse av pasientforløpene tilpasset hver enkelt pasient, som skal være lett tilgjengelig for pasienten. Forløpene skal beskrives langs en forventet tidslinje som vil gi en overordnet og lett forståelig oversikt, og som i tillegg gjør det mulig å følge den enkelte pasient gjennom forløpet.

Beskrivelsen av forløpene skal være så detaljert at innholdet i hver enkelt fase blir tydelig, og slik at det fremgår hvilken fagkompetanse og hvilke ressurser som er nødvendig til enhver tid. Det er derfor nødvendig med en detaljert spesifisering av utredning, behandling, pleie og omsorg for å sikre at disse faktisk blir utført etter planen, og for å unngå unødvendige forsinkelser for pasientene. Forløpene bør også illustrere behovet for et tett samarbeid på tvers av avdelingene i sykehuset, mellom sykehus og primærhelsetjeneste/ sosiale tjenester om hvordan et optimalt samarbeid bør planlegges og organiseres. Gode pasientforløp bidrar til at pasienten og de pårørende opplever at overgangene innad og mellom nivåer, for eksempel mellom hjemmesykepleien og sykehjem, utskriving fra sykehus til kommunen eller mellom fastlege og sykehus, fungerer på en hensiktsmessig måte, og at informasjonsbehovet ivaretas.

Hvordan informasjonen gis, må være tilpasset den enkelte pasient og hvor han eller hun er i forløpet. Slik kan pasientene få et godt og forutsigbart inntrykk av hva som venter dem i sykehuset, og når de kommer hjem fra sykehuset eller i andre deler av helsetjenesten. Hensikten er å trygge pasienten og øke hans eller hennes kunnskap om tilbudet som finnes, og om utredning, behandling og oppfølging av rettigheter. Advance Care Planning (ACP) eller forhåndssamtale, er en plan for å bedre omsorgen i livets sluttfase. Målet er å involvere pasienten tidlig $\mathrm{i}$ forløpet slik at viktige beslutninger den siste tiden kan tas før det er for sent, se nærmere omtale i kapittel 4. Utvalget mener at forhåndssamtaler skal være en obligatorisk del av planleggingen av pasienttilpassede forløp for pasienter med uhelbredelig sykdom og kort forventet levetid. Se omtale i kapittel 4.

\section{Det pasienttilpassede forløpet må omfatte alle tjenestenivåene}

Tett samarbeid mellom spesialisthelsetjenesten og den kommunale helse- og omsorgstjenesten er nødvendig for at pasienten skal få de palliative tjenestene han eller hun har behov for. Det er behov for en mal for et palliativt pasientforløp som omfat-

\section{Boks 6.5 Å tilrettelegge for livskvalitet}

«Vi har misforstått vårt ansvar som leger. Vi tror at jobben vår er å sikre helse og overlevelse. Men i virkeligheten handler den om mye mer. Den handler om å tilrettelegge for velvære. $\mathrm{Og}$ velvære handler om hvorfor man vil være i live. De grunnene er ikke bare viktige på slutten av livet, eller når uførhet rammer, men langs hele livsveien. Når alvorlig sykdom inntreffer og kroppen eller sinnet ditt bryter sammen, gjelder de samme livsviktige spørsmålene: Hva er din forståelse av situasjonen og dens potensielle utfall? Hvilke utfall er du redd for, og hva håper du på? Hvilke byttehandler er du villig til å gjøre, hvilke er du ikke villig til å gjøre? Og hvordan skal denne forståelsen best følges opp?

Noen ganger kan vi tilby en kur, noen ganger kun en lindrende salve, noen ganger ikke engang det. Men uansett hva vi kan tilby, kan vi kun rettferdiggjøre intensjonene våre, og risikoen og byrden det innebærer, når de tjener de større målene i en persons liv. Når vi glemmer det, kan lidelsen vi påfører være barbarisk. Når vi husker det, er det gode vi kan gjøre fantastisk.»

Kilde: Atul Gawande: Å være dødelig. Om legekunst og livskvalitet, 2016

ter både spesialisthelsetjenesten og den kommunale helse- og omsorgstjenesten.

Utvalget foreslår at det utarbeides og implementeres en slik mal for palliativt pasientforløp i Nasjonalt handlingsprogram for palliasjon $i$ kreftomsorgen. Det bør implementeres tilsvarende mal i de øvrige nasjonale faglige retningslinjene for ulike diagnoser der dette er relevant. Utvalget foreslår videre at det igangsettes en nasjonal evaluering av pasientforløpet Livets siste dager for å vurdere videre bruk.

I dag framkommer den kommunale helse- og omsorgtjenestens plikt til å tilby palliativ behanding dels av helse- og omsorgstjenesteloven § 3-2 første ledd punkt 4 (utredning, diagnostisering og behandling, herunder fastlegeordning), punkt 5 (sosial, psykososial og medisinsk habilitering og rehabilitering), og punkt 6 bokstav a (helsetjenester i hjemmet), avhengig av hvor pasienten befinner seg i sykdomsforløpet. Det gjør kommu- 
nenes sørge-for ansvar for palliativ behandling fragmentert. Utvalget mener derfor at kommunenes plikt til å sørge for at pasienter som trenger det får palliativ behandling og at det bør fremgå direkte av lovteksten og vil foreslå at begrepet «palliativ behandling» tas inn i helse- og omsorgstjenesteloven $\S 3-2$ nr. 5.

Pasienttilpassede forløp må kunne legges inn i elektronisk pasientjournal og følge pasienten uavhengig av hvor han eller hun befinner seg i pasientforløpet. Det bør derfor utarbeides en egen palliativ plan for pasienten som i tillegg til å inngå i pasientens elektroniske journal også framgår av pasientens individuelle plan når en slik plan er utarbeidet, jfr. pasient- og brukerrettighetsloven $\S$ 2-5. Pasienten skal loses gjennom forløpet og nødvendige endringer i den palliative planen må gjøres fortløpende ved behov. Når pasienten har fătt oppnevnt en koordinator bør denne påse at den palliative planen er oppdatert i forhold til pasientens ønsker og behov.

Det er særlig viktig at tjenester til pasienter $\mathrm{i}$ sykehjem og pasienter som bor hjemme samordnes. Koordinator i kommunen må samarbeide med fastlegen, mens koordinator i sykehuset må samarbeide med pasientens kontaktlege i sykehuset. I kommunen er det ikke krav til hvem som kan være koordinater, mens det i spesialisthelsetjenesten er krav om at koordinator skal være helsepersonell (forskrift om habilitering, rehabilitering, individuell plan og koordinator, 2011).

\section{Tydeliggjøre kommunenes sørge for-ansvar}

Utvalget vil framheve at palliativ behandling til pasienter som har behov for det følger av kommunenes «sørge for-ansvar». I dag framkommer kommunenes plikt til å tilby palliativ behandling dels av helse- og omsorgstjenesteloven $\S 3-2$ første ledd punkt 4 (utredning, diagnostisering og behandling, herunder fastlegeordning), punkt 5 (sosial, psykosial og medisinsk habilitering og rehabilitering), og punkt 6 bokstav a (helsetjenester i hjemmet), avhengig av hvor pasienten befinner seg i sykdomsforløpet. Det gjør kommunenes sørge for-ansvar for palliativ behandling uklart. Utvalget mener derfor at kommunenes plikt til å sørge for at pasienter som trenger det får palliativ behandling bør tydeliggjøres ved å framgå direkte av lovteksten og vil foreslå at begrepet «palliativ behandling» tas inn i helse- og omsorgstjenesteloven $\S 3-2$ nr. 5. Dette kan gjøres slik: For å oppfylle ansvaret etter § 3-1 skal kommunen blant annet tilby følgende: hol $\S 3-5 \mathrm{nr}$. 5: Sosial, psykososial og medisinsk rehabilitering og palliasjon.

\subsection{Tiltak}

- Det skal være samarbeidsavtaler mellom kommuner og sykehus om felles utvikling og bruk av pasienttilpassede forløp innen palliasjon.

- For å få utløst palliativ refusjon i spesialisthelsetjenesten stilles det krav om at palliativt team skal veilede den kommunale helse- og omsorgstjenesten om felles pasienter.

- Det utarbeides en nasjonal mal for palliativt pasientforløp som omfatter både spesialisthelsetjenesten og den kommunale helse- og omsorgstjenesten.

- For å tydeliggjøre kommunenes «sørge-for»ansvar for palliativ behandling bør denne forpliktelsen framgå av helse- og omsorgstjenesteloven (hol) $\S 3$-2 første ledd nr. 5 ved at begrepet palliasjon inntas i lovteksten.

- Pasienter skal delta i utarbeidelse av pasienttilpassede forløp, blant annet gjennom bruk av forhåndssamtaler.

- Det skal igangsettes en nasjonal evaluering av pasientforløpet Livets siste dager. 


\section{Kapittel 7 \\ Palliasjon i utdanningene}

At vi sammen kan se det vi tidligere ikke så, og
sammen forstå det vi ikke tidligere forstod.

Ukjent

\subsection{Innledning}

For å møte pasientenes behov, trenger helse- og omsorgspersonell både kompetanse om grunnsykdommen og om palliasjon. I tillegg er det nødvendig å ha kompetanse til å gjenkjenne når det er behov for andre faggrupper og annen kompetanse enn den man selv har. Å møte en pasient med livstruende sykdom fordrer kompetanse i å kommunisere med pasienter og pårørende som er i en sårbar situasjon (se omtale i kap 4). For å sikre rett kompetanse på rett sted til rett tid, må det være systemer for kunnskapsbygging, kunnskapsdeling og samhandling, når pasienten beveger seg mellom ulike enheter i den kommunale helse- og omsorgstjenesten, spesialisthelsetjenesten eller i hjemmet.

De palliative pasientforløpene er ofte sammensatte og krever kompetanse fra helse- og omsorgspersonell med ulik fagbakgrunn samtidig, eller i en gitt rekkefølge. Av WHOs definisjon av palliasjon (se kap 5) fremgår det at palliasjon skal være en del av helsetjenesten også når behandling gis med en helbredende og livsforlengende intensjon. Definisjonen tydeliggjør dermed at palliasjon ikke «kun» omfatter behandling og lindring ved livets slutt, slik begrepet palliasjon tradisjonelt er omtalt. Kompetanse i palliasjon må derfor være tilstede også når pasientene får behandling med kurativ og livsforlengende målsetting, i tillegg til lindrende behandling ved livets slutt. Med en slik utvikling blir det en utfordring å identifisere når det palliative pasientsentrerte tilbudet skal integreres i pasientforløpene for pasienter som får behandling med kurativ, livsforlengende og symptomlindrende målsetting.

Figur 7.1 illustrerer at behovet for palliativ kompetanse øker innen og mellom de fem ulike forløpene. Figuren illustrerer også at alt helse- og omsorgspersonell har behov for en generell kompetanse innen palliasjon. Denne generelle kompetansen bør helsepersonell få gjennom sin grunnutdanning. Helsepersonell som arbeider ved enheter med behandling og oppfølging av pasienter som trenger palliativ behandling, både i kommunen og i spesialisthelsetjenesten, bør ha spesialisert kompetanse i palliasjon. Dette gjelder helsepersonell som arbeider ved palliative enheter eller i palliative team, der pasienter med komplekse palliative behov er.

Kompetansenivåene i palliasjon går på tvers av nivåene og diagnosegruppene $\mathrm{i}$ helse- og omsorgstjenesten. Dette innebærer f. eks. at kompetanse på spesialisert nivå må være til stede i palliative enheter både i den kommunale helse- og

Pasienttilpassede forløp - de fem hovedforløpene

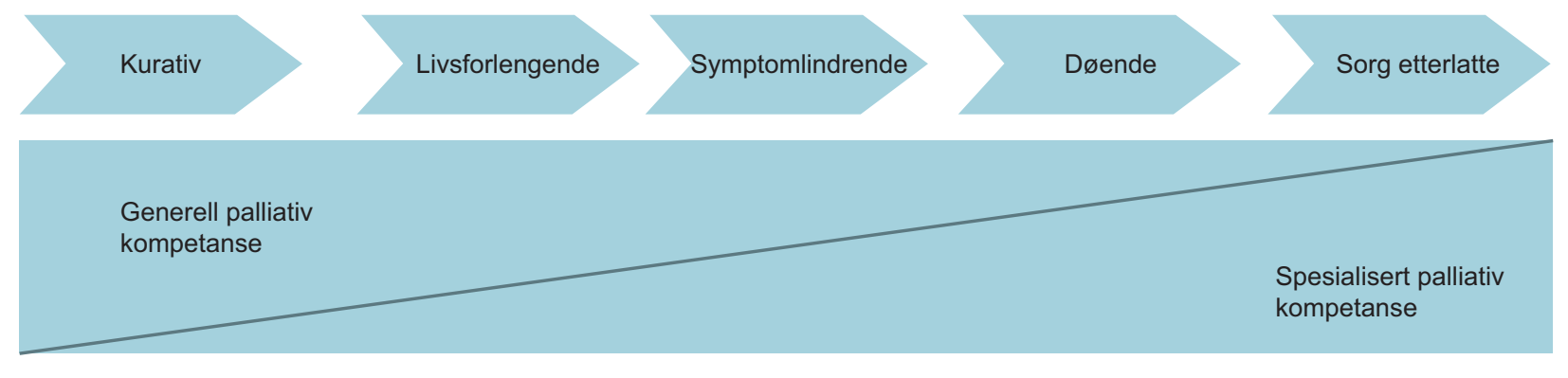

Figur 7.1 Pasienttilpassede forløp - de fem hovedforløpene 
omsorgstjenesten og i spesialisthelsetjenesten. Hvordan arbeidsgiver i helse- og omsorgssektoren velger å sette sammen personalressursene, vil avhenge av flere faktorer, som pasientsammensetningen, forekomsten av pasienter med palliativt behov og tilgang på kompetent personell.

Omfanget av undervisning i palliasjon varierer både innad og mellom de ulike utdanningene og utdanningsstedene. Det er viktig at de pågående endringene $i$ alle helse- og sosialfaglige utdanninger og endringene $i$ spesialiststrukturen for leger (se nærmere omtale i 7.3) bidrar til at undervisningen i palliasjon styrkes, både teoretisk og praktisk. Innholdet i undervisningen i palliasjon bør omfatte palliasjon til alle som har behov, uavhengig av diagnose og alder, ha oppmerksomhet på tidlig integrasjon av palliasjon og ha et tverrfaglig perspektiv.

En sentral utfordring er implementering av kunnskap. For å bruke kompetansemiljøenes ressurser på en best mulig måte, beskrives disse $\mathrm{i}$ modeller for organisering i kapittel 9 .

Kompetansen i palliasjon er styrket de siste 15 årene. Vi har i Norge mange gode utdanninger og en god struktur for å bygge opp kompetansegrunnlaget i palliasjon. Det er nødvendig for å imøtekomme økte behov hos befolkningen og styrke kvaliteten for alle pasienter som trenger palliative tjenester. Det er viktig å ha modeller for palliasjon som er tilpasset geografiske forhold og pasientgrunnlag. En modell som passer for en stor kommune som Bergen, kan være lite hensiktsmessig $\mathrm{i}$ en mindre kommune, hvor det vil være få (eller ingen) med spesialisert kompetanse i palliasjon. Det er sentralt å finne gode samarbeidsmodeller mellom nivåene $\mathrm{i}$ helsetjenesten (se kapittel 9).

\subsection{Dagens situasjon}

\subsubsection{Sentrale dokumenter}

Palliasjonsutvalget har i sin vurdering av behovet for utdanning lagt vekt på følgende dokumenter: NOU 1999: 2 Livshjelp: Behandling, pleie og omsorg for uhelbredelig syke og døende pekte på behovet for at helse- og omsorgspersonell, gjennom sin grunnutdanning, bør ha fått kunnskap som danner et grunnlag for å yte god palliativ hjelp. Utvalget anbefalte at lærestedene bør utvikle studieplaner som spesielt er rettet mot diagnostiske, behandlingsmessige og tverrfaglige aspekter innen fagfeltet palliativ medisin. Videre vurderte utvalget at legespesialitetene bør omfatte kunnskap om uhelbredelige sykdommer. Det ble

\section{Boks 7.1 Sentrale dokumenter:}

- NOU 1999: 2 Livshjelp: Utvalget anbefalte opprettelsen av en egen spesialitet for leger $\mathrm{i}$ palliativ medisin, videreutdanninger $\mathrm{i}$ onkologisk sykepleie $\mathrm{i}$ alle regioner og videreutdanning i palliativ omsorg

- Nasjonalt handlingsprogram for palliasjon i kreftomsorgen, Sammen - mot kreft: Nasjonal kreftstrategi: Strategien anbefaler å øke tilgangen av sykepleiere med videreutdanning i kreftsykepleie og palliasjon, både $\mathrm{i}$ spesialisthelsetjenesten $\mathrm{og} \mathrm{i}$ den kommunale helse- og omsorgstjenesten

- Nasjonale retningslinjer for barn og unge uavhengig av diagnose: Det overordnede målet for retningslinjen er å sikre god total omsorg til barn og unge med livsbegrensende eller livstruende sykdommer

- EAPC White Paper: gir anbefalinger om kjernekompetanse i palliasjon for voksne og barn.

påpekt at spesialistene som tradisjonelt har tatt seg av disse pasientene, har liten obligatorisk utdanning i palliativ medisin og at det er liten oppmerksomhet på dette fagfeltet. Utvalget skriver at «mange spesialiteter er organrelaterte». Utvalget anbefalte opprettelsen av en egen spesialitet for leger i palliativ medisin, videreutdanninger i onkologisk sykepleie $\mathrm{i}$ alle regioner og videreutdanning i palliativ omsorg.

Sammen - mot kreft. Nasjonal kreftstrategi 2013-2017 (Helse- og omsorgsdepartementet, 2013b) er en strategi som skal bidra til å styrke tilbudet til personer som har en kreftdiagnose. Brukerorienterte tjenester og gode pasientforløp er sentrale mål i strategien. Strategien anbefaler å øke tilgangen av sykepleiere med videreutdanning i kreftsykepleie og palliasjon, både i spesialisthelsetjenesten og i den kommunale helse- og omsorgstjenesten.

The European Association for Palliative Care (EAPC) har utviklet «White paper» som angir pensum for kjernekompetansen i palliasjon for helseog sosialfaglige utdanninger, rettet mot både voksne og barn (EAPC, 2013).

Nasjonalt handlingsprogram for palliasion $i$ kreftomsorgen (Helsedirektoratet, 2015b) anbefaler hvilken utdanning sentrale yrkesgrupper bør ha i palliasjon. 


\subsubsection{Palliasjon $\mathrm{i}$ utdanningene}

Det er utarbeidet en «Forskrift om felles rammeplan for helse- og sosialfagutdanninger». Forskriftens formål er å sikre at utdanningsinstitusjonene tilbyr praksisnære og forskningsbaserte helse- og sosialfagutdanninger med høy faglig kvalitet og relevans. Den skal sammen med retningslinjene sikre at utdanningene forholder seg til de standardene og kriteriene som gjelder for helse- og sosialfagutdanninger og imøtekommer samfunnets nåværende $\mathrm{og}$ framtidige behov for kompetanse. Forskriften er planlagt å gjelde fra og med opptak til studieåret 2019/2020.

Utdanningene i helse- og sosialfagene er i endring både organisatorisk og innholdsmessig. Flere utdanningsinstitusjoner slås sammen til større enheter, utdanningstilbud endres og studieplaner revideres. For sykepleie er det nye studieplaner i bachelorutdanningen, og flere videreutdanninger i sykepleie og tverrfaglige videreutdanninger innpasses/utvidet til masternivå. Dette åpner for nye utdanningsløp der palliasjon kan være/er en del av utdanningen.

Mange ansatte i helse- og omsorgstjenestene har god kompetanse i palliasjon. Nasjonal kartlegging av palliative tiltak i 2014 viste at 62,8 prosent av sykepleierne ved palliative sentre i spesialisthelsetjenesten og 44,5 prosent ved lindrende enheter i sykehjem hadde en videreutdanning. (Lekven B.E.L., 2016). De vanligste videreutdanningene for sykepleiere er i kreftsykepleie, palliativ omsorg/sykepleie eller i aldring og eldreomsorg.

For å få oversikt over omfanget av palliasjon i utdanningene, har utvalget gitt de regionale kompetansesentrene i lindrende behandling i oppdrag å kartlegge undervisningen av palliasjon i sentrale helse- og sosialfaglige utdanninger. Helse- og omsorgspersonell fra disse utdanningene møter palliative pasienter og deres pårørende i yrkesutøvelsen. Av tabell 7.1 fremgår det hvilke utdanninger som er kartlagt. Tabellene er inndelt ut fra nivå på grunnutdanningen. 


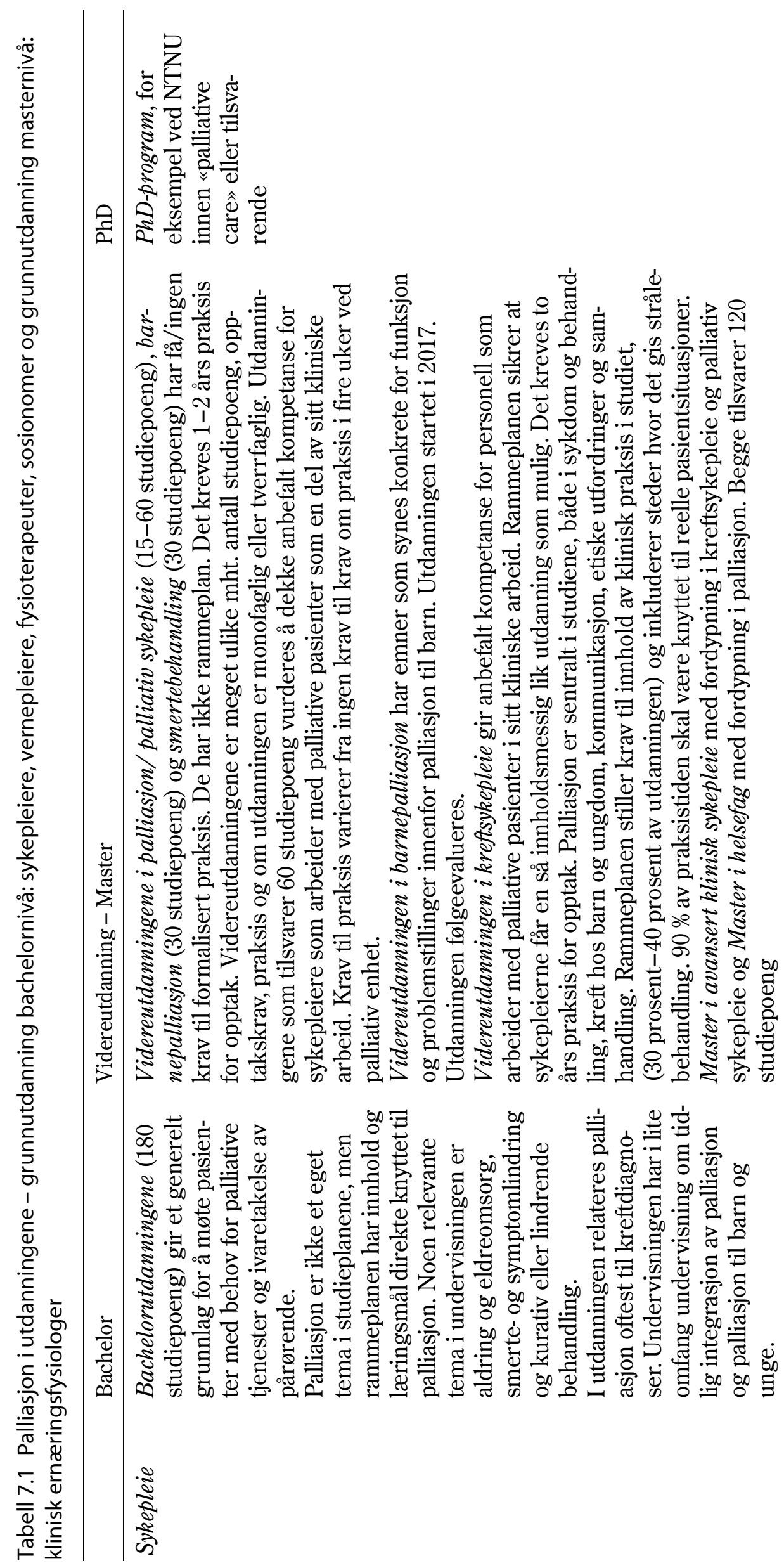


NOU 2017: 16

På liv og død

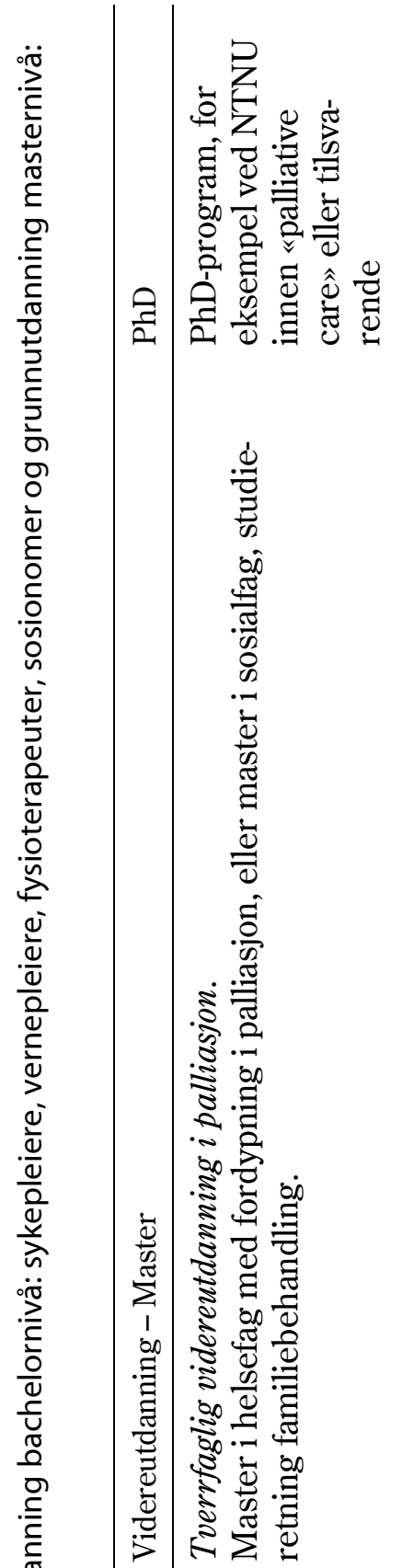

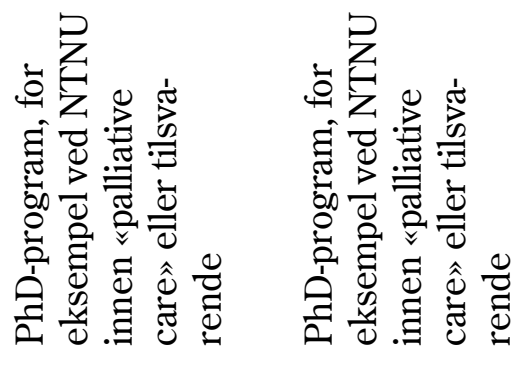

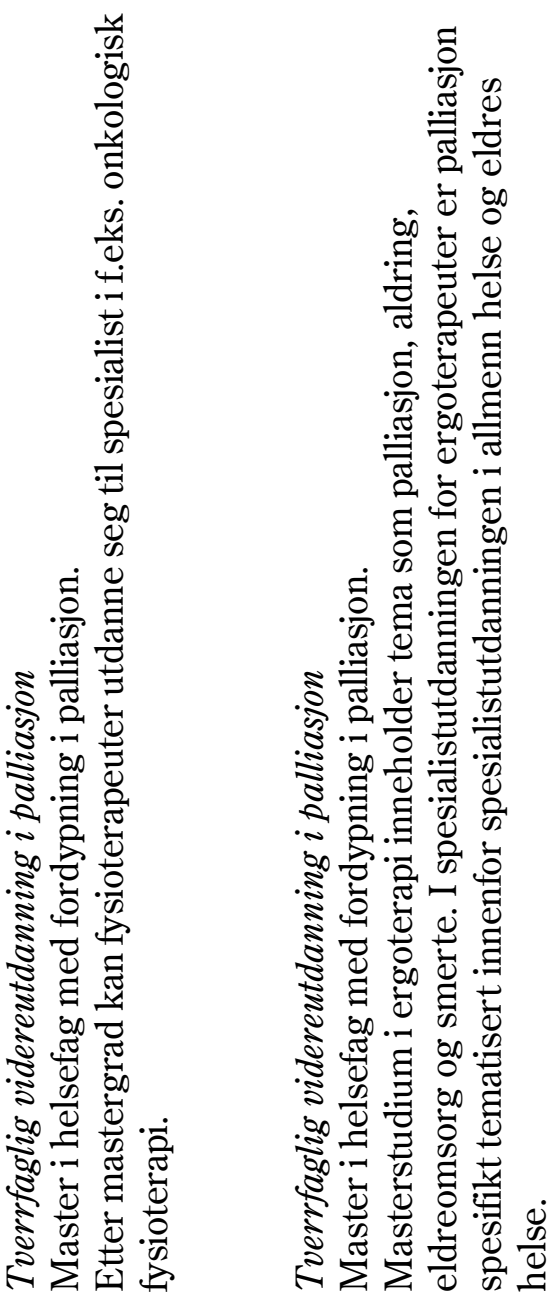

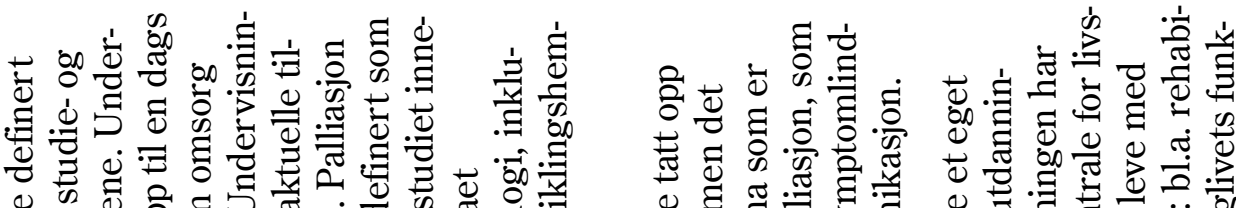
क क

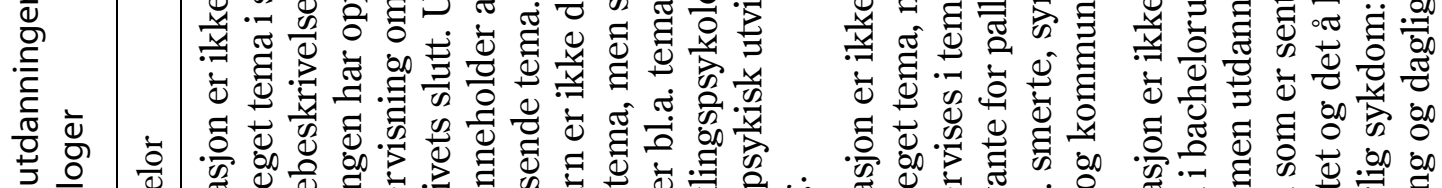

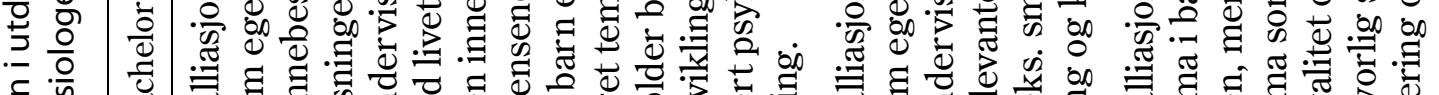

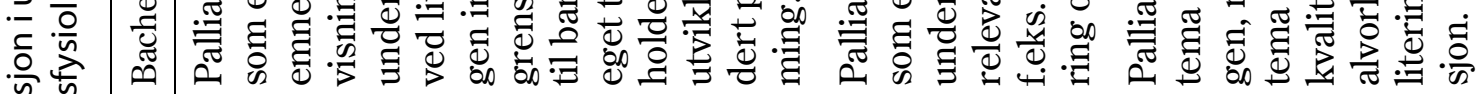

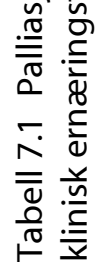

$\frac{\sqrt{2}}{\stackrel{5}{2}}$

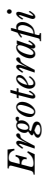


NOU 2017: 16

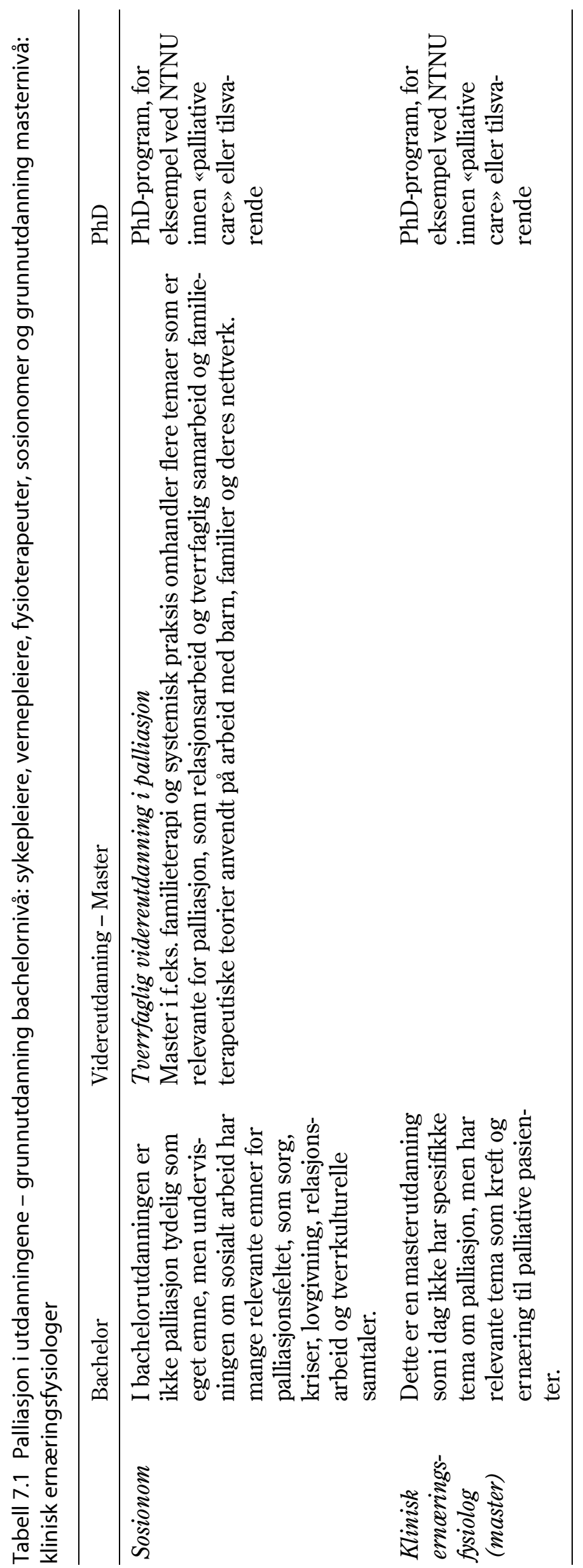


Formell utdanning innen det palliative feltet foregår på universiteter og høgskoler flere steder $\mathrm{i}$ Norge. Etter bachelorgrad innen helse- og sosialfaglige områder som bachelor i sykepleie, ergoterapi, sosialt arbeid etc., tilbys det videre utdanningsløp (postgraduate) innen palliasjon ulike steder i Norge. I dag er disse utdanningstilbudene av ulik lengde, dybde og innhold (varierer fra 15-60 studiepoeng). Noen av utdanningstilbudene er innpasset $\mathrm{i}$ et mastergradsløp. Det finnes både utdanninger for enkeltprofesjoner, som Videreutdanning i palliativ sykepleie ved VID (Vitenskapelig høgskole 60 studiepoeng), Haraldsplass i Bergen (60 studiepoeng) og tverrfaglige utdanningstilbud innen Palliativ omsorg som Lovisenberg Diakonale Høgskole i Oslo (30 studiepoeng) og NTNU i Gjøvik (60 studiepoeng). De ulike utdanningstilbudene har ulik grad av praksis tilknyttet utdanningsløpet fra hospiteringspraksis på noen dager til flere ukers praksis pr. studieår. Mastertilbudet ved NTNU i Trondheim innen smerte og palliasjon har ingen krav til praksis.

Grunnutdanningene det refereres til i tabellen over har ikke palliasjon som eget tema, men det undervises i tema som er svært sentrale for palliasjon. Det kan synes som det er tilfeldig om studentene møter pasienter med palliative behov i praksis. Palliasjon relateres oftest til kreftdiagnoser. Utdanningene har i lite omfang undervisning om tidlig integrasjon av palliasjon og palliasjon til barn og unge. Noen skoler har praksisplasser ved kreftavdelinger eller palliative enheter.

Videreutdanningene i kreftsykepleie har palliasjon som et sentralt tema i undervisningen av sykdom og behandling. Videre gis det undervisning i kreft hos barn og ungdom, i tillegg til at temaer knyttet til kommunikasjon, etiske utfor- dringer, pårørende, tverrfaglig samarbeid, nettverksarbeid og samhandling tas opp. For de øvrige videreutdanningene som er presentert i tabellen er palliasjon et sentralt tema, men palliasjon omtales oftest i forbindelse med kreftdiagnoser og som omsorg ved livets slutt. Andre diagnosegrupper enn kreft er ikke systematisk tatt inn i palliasjonsemnet i alle utdanningene, men er ofte tematisert knyttet til undervisning om ulike diagnoser. Tidlig integrasjon av palliasjon og palliasjon til barn og unge er lite omtalt, med unntak av viderutdanningen i kreftsykepleie.

Utdanning er avgjørende i utviklingen av barnepalliasjon som fag og for kvaliteten i helse- og omsorgstjenesten. Helse- og omsorgspersonell og andre fagpersoner bør få den opplæringen de trenger for å kunne tilby barn og unge god palliativ behandling, pleie og omsorg. Det er behov for helsepersonell med ulik medisinsk fagkompetanse, i tillegg til kompetanse i palliasjon. Det er også behov for kunnskap knyttet til det å leve med funksjonsnedsettelse for barnet og utfordringer for familien. Pediatrien har et stort spekter av ulike sykdommer og er på mange måter i en særstilling hvor det må bygges opp en palliativ kompetanse. Palliasjon til barn og ungdom og til pasienter med andre sykdommer enn kreft, er kommet inn i flere av videreutdanningene de siste årene, men ved en del steder har palliasjon fremdeles liten plass i undervisningstimer og pensum.

Helsefagarbeidere gir grunnleggende sykepleie til pasienter med behov for pleie i den kommunale helse- og omsorgstjenesten ved sykehjem og også ved palliative enheter og i hjemmetjenesten. Helsefagarbeidere arbeider også ved ulike avdelinger i spesialisthelsetjenesten.

Tabell 7.2 Palliasjon i utdanningen: helsefagarbeider

\begin{tabular}{lll}
\hline & Videregående skole & Videreutdanning \\
\hline Helsefagarbeider & Utdanningen har i liten grad undervis- & Videreutdanningen i kreftomsorg og \\
& ning i palliasjon. I praksis er det tilfeldig & lindrende pleie synes å gi relevant \\
& om elevene får undervisning i eller & kunnskap i palliasjon på fagskolenivå, \\
& møter palliative problemstillinger & med vekt på kreftsykdommer. \\
& i studietiden og i praksis. & Videreutdanningen har felles ramme- \\
& & plan, som gjør at utdanningene er svært \\
& like i oppbygging og innhold. \\
\hline
\end{tabular}


宽 尝

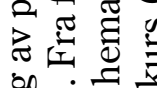

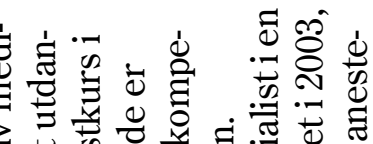

这

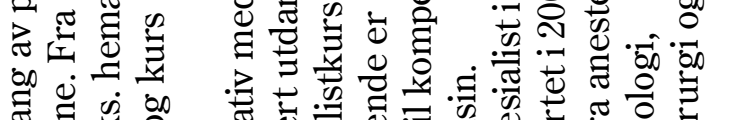

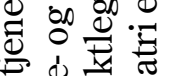

过娄

Ð 窟

घ워

Q

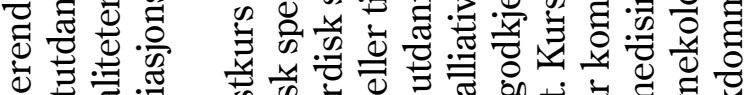

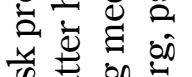

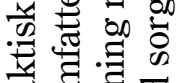

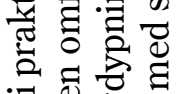

.

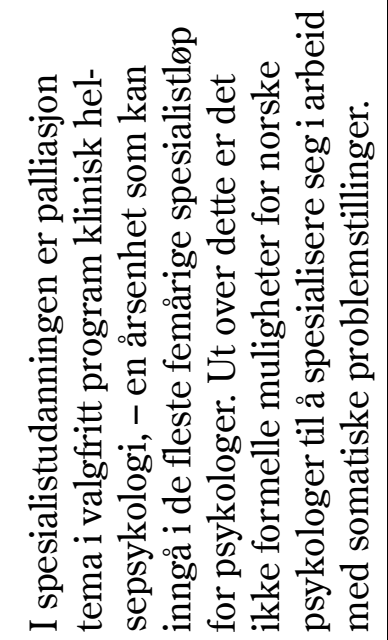

.

. :

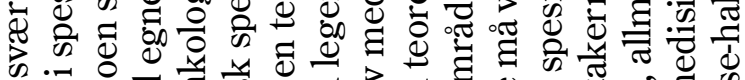

可 क

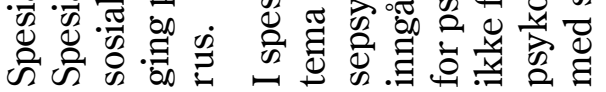

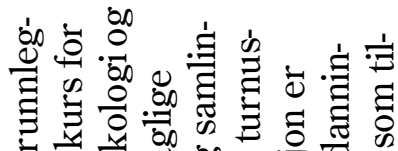

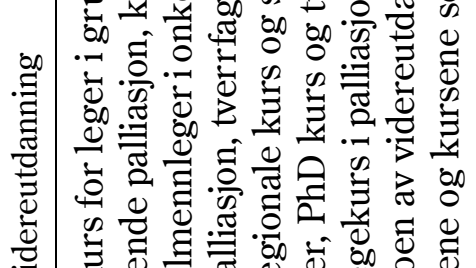

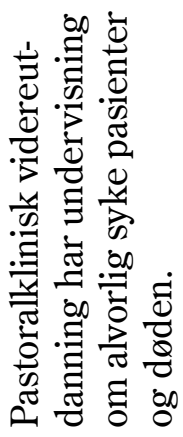

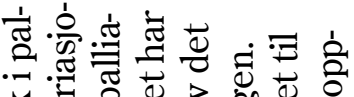

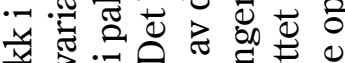

密它的.

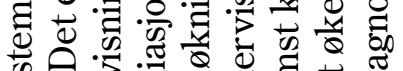

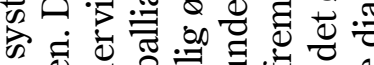

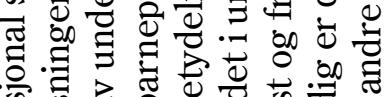

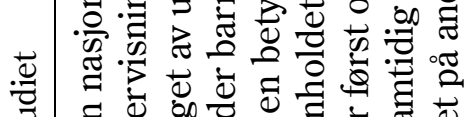

$-1$

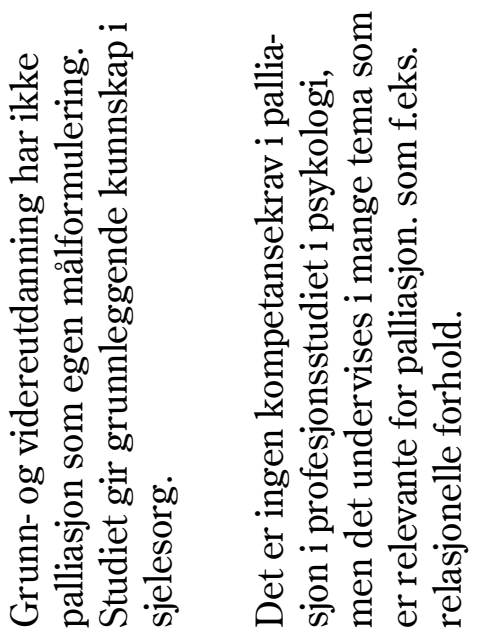

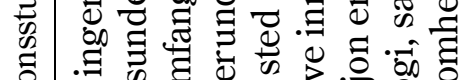

赵

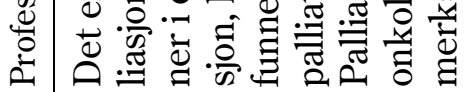

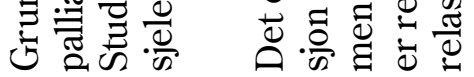

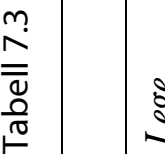

$\frac{\sqrt{2}}{8}$

$\frac{\sqrt{3}}{\sqrt[3]{2}}$ 
Følgende spesialistutdanninger i medisin er kartlagt: gynekologi, indremedisinske spesialiteter, kirurgiske spesialiteter, anestesi, geriatri, onkologi, allmennmedisin og kompetanseområdene for alders- og sykehjemsmedisin og palliativ medisin.

Legeforeningen har etablert en ordning med kompetanseområder innen fire områder: palliativ medisin, alders- og sykehjemsmedisin, allergologi og smertemedisin. Hensikten med ordningen er å sikre et godt og enhetlig tilbud nasjonalt, samt bedre rekrutteringen til fagfeltet. Det har samtidig vært et mål å formalisere kompetansen til leger som arbeider i de aktuelle virksomhetene. Et kompetanseområde er karakterisert ved at leger med særlig interesse og kompetanse arbeider innenfor et område som griper inn i tre eller flere spesialiteter. Det er særlig to kompetanseområder som er relevante for palliasjon:

I kompetanseområde palliativ medisin er målet å sikre et godt og enhetlig palliativt tilbud nasjonalt ved å formalisere kompetansen til leger som arbeider i palliativ virksomhet (Helsedirektoratet, 2016b). I tillegg til teoridelen på det nordiske kurset er det krav om to års tjeneste ved et av de 17 godkjente utdanningsstedene i Norge. Det er ingen utdanningssteder nord for Nordlandssykehuset i Bodø. I 2017 er det 62 godkjente kandidater som har tatt påbygningsspesialiteten i palliativ medisin. En evaluering av ordningen i 2015 anbefalte at palliativ medisin bør bli et formelt kompetanseområde med nasjonal godkjenning, sekundært en egen spesialitet, med derav følgende godkjenningsordning (Helsedirektoratet 2015d). Forutsetningen for denne konklusjonen var at påbyggingsspesialitet som $\mathrm{f}$. eks. Sverige har valgt, ikke var aktuelt på grunn av datidens spesialiststruktur. Kompetanseområdet er til videre vurdering $\mathrm{i}$ Helsedirektoratet og Helse- og omsorgsdepartementet.

I kompetanseområde alders- og sykehjemsmedisin er det krav om to års tjeneste ved sykehjem eller tilsvarende boform. Det er ikke krav om tjeneste i palliasjon. Spesialitetene som må ligge i bunn er allmennmedisin, indremedisin, geriatri, nevrologi eller fysikalsk medisin. De tre førstnevnte har i noen grad integrert palliasjon i utdanningen. Innholdet i utdanningen omfatter undervisning i sansesvikt og rehabilitering, alderspsykiatri og somatisk geriatri. Palliasjon eller lindring er ikke omtalt i kurset på 80 timer som inngår for godkjenning i kompetanseområdet.

For fastleger finnes det mulighet for å øke sin palliativ kompetanse gjennom kurs i palliasjon og hospiteringsopphold ved lindrende enheter i kom- munen eller i spesialisthelsetjenesten, f.eks. i sykehusets palliative team.

\subsection{Vurdering av omfang og innhold av palliasjon i utdanningene}

Et hovedgrep for å styrke kompetansen er å sikre at palliasjon anerkjennes som eget fagfelt og egen spesialitet. I alle helse- og sosialfaglige utdanninger, der fagpersonellet møter pasienter som har behov for palliative tjenester og deres pårørende, må det framgå av rammeplaner, studieplaner og læringsutbytte at palliasjon er et fagfelt. Dette krever at det må undervises systematisk i palliasjon $\mathrm{i}$ grunn-, videre- og etterutdanninger i helse- og sosialfagene. Palliasjon skal ikke framstå som kun knyttet til døden, eller som en del av andre tema.

Denne endringen - å anerkjenne palliasjon som et eget fagfelt og en egen spesialitet, bør inn $\mathrm{i}$ nasjonale retningslinjer for utdanningene. Undervisningen må tydeliggjøre at palliasjon skal gis til alle pasienter som har behov for det, uavhengig av hvor de får helsehjelp, diagnose, alder eller andre forhold, gjennom hele sykdomsforløpet. Et eksempel er psykologi. Mange komponenter av psykologers grunnkompetanse er viktig i palliasjon (f.eks. ferdigheter og kunnskaper i kommunikasjon, relasjon, familieterapi, sorg, kriser og nettverk). Profesjonsutdanningen har imidlertid etter utvalgets oppfatning for lite om palliative tema til å kunne gi tilfredsstillende kompetanse. Det er ingen egen spesialitet for psykologer som arbeider med somatiske problemstillinger i dag, selv om det finnes et «valgfritt program» som en årsenhet (kurs, veiledning, praksis) der palliasjon inngår som ett element/tema. Valgfritt program går inn som ett av fem år i psykologers spesialisering, og er åpen for alle psykologer som ønsker en tilleggskompetanse. Det vil si at det er opp til den enkelte psykolog å tilegne seg nødvendig kompetanse for å jobbe med palliative problemstillinger.

\section{Boks 7.2 Kompetanse i palliasjon - hovedutfordringer}

- Overordnet: Palliasjon er ikke anerkjent som et eget fagfelt og en egen spesialitet

- Undervisningen er oftest relatert til kreftpasienter og omsorg ved livets slutt

- Manglende inkludering av klinisk praksis i utdanningene 
Utvalget vil derfor anbefale at det etableres en egen spesialitet i klinisk helsepsykologi, og at palliasjon inngår som ett viktig tema. Fra 2020 innføres det en lovplikt for kommunune til å ha psykologkompetanse. Dette er psykologer som bør kunne involveres i palliativ virksomhet i den kommunale helse- og omsorgstjenesten, både som medlemmer av kommunale palliative team, og som støtte til pasienter og pårørende, under og etter sykdomsforløpet.

En annen utfordring er at undervisningen i palliasjon oftest er relatert til pasienter med kreft og til omsorg ved livets slutt. Undervisning om palliasjon tidlig i sykdomsforløpet og til pasienter med andre diagnoser enn kreft gis i varierende og lite omfang. Dette gjelder også palliasjon til barn og unge. Palliasjon bør være obligatorisk i alle aktuelle spesialistutdanninger i medisin, herunder også pediatri. De samme prinsippene skal gjelde for alle relevante helseutdanninger. Sentralt i palliasjon er det pasientsentrerte fokuset, også for pasienter i kurative og livsforlengende forløp.

Flere av utdanningene stiller ikke krav til innholdet i den praktiske utdanningen, og heller ikke til hvilke typer palliative enheter eller sentre praksisen skal gjennomføres på. Palliasjon er både et teoretisk og praktisk fagfelt, og utdanningene bør derfor ha krav om relevant praksis, der studentene møter pasienter som har behov for lindrende behandling.

Generelt vil en utvidelse til masterløp for de mest aktuelle videreutdanningene kunne bidra til sterkere fagutvikling i fagfeltet for flere yrkesgrupper. En utvikling mot masterløp hvor palliasjon inngår gir mulighet for fagutvikling i palliasjonsfeltet for flere yrkesgrupper, og åpner for PhD-studier og forskning. For å tilpasse seg praksisfeltets behov og den enkelte student, bør det fortsatt være mulig å avlegge eksamen etter gjen-

\section{Boks 7.3 Videreutdanninger på masternivå}

- Utdanningene i palliasjon på masternivå bør tilsvare 60 studiepoeng, ha minimum 6 ukers veiledet praksis og harmoniseres med hensyn til innhold

- Innholdet bør følge internasjonale anbefalinger (f.eks. EAPCs White Paper 2013)

- Utdanningene i det palliative området kan være både monofaglige og tverrfaglige

- Videreutdanningene bør være på masternivå nomført videreutdanning på masternivå uten å måtte fortsette på en masterutdanning. Utvalget mener også at videreutdanningen i barnepalliasjon for sykepleiere bør være tverrfaglig.

Det ulike omfanget av og innholdet i videreutdanningene på masternivå gjør det vanskelig for arbeidsgivere å vurdere hvilken teoretisk og praktisk kompetanse den enkelte arbeidstaker har.

En nærmere vurdering av omfanget av palliasjon i profesjonsutdanningen i medisin og i videre- og etterutdanning for leger

\section{Spesialistutdanning for leger}

Med et økende behov for palliativ kompetanse i pasientforløpene, også under kurativ og livsforlengende behandling, vil mange spesialister ha behov for grunnleggende spesialistkompetanse i palliativ medisin. Det samme gjelder for fastleger som vil få ansvar for flere pasienter når de er hjemme og mottar livsforlengende behandling, men ikke minst når pasientene er i en symptomlindrende og døende fase.

For å imøtekomme pasientens behov og for å være aktive deltakere i planlegging og gjennomføring av de pasienttilpassede forløpene er rett kompetanse nødvendig.

På palliative spesialenheter i den kommunale helse- og omsorgstjenesten, helsehus eller sykehjem, skal det være ansatt leger som er spesialister i palliativ medisin. Det samme gjelder for leger som arbeider på palliative enheter i sykehus og de som arbeider ved de regionale palliative sentrene (se kapittel 9). Det er derfor behov for et formali-

\section{Boks 7.4 Utdanning i palliasjon for leger. Rett legekompetanse på rett sted i de pasienttilpassede forløpene}

- Normering og harmonisering av palliasjon mellom de medisinske utdanningsteder

- Teoretisk (kurs) og praktisk (klinisk tjeneste) i alle relevante kliniske spesialiteter

- Palliasjon må formaliseres som et eget medisinsk fagfelt

- De regionale kompetansesentrene i linderende behandling må samarbeide om den teoretiske utdanningen

- Norge må innhente etterslepet når det gjelder antall utdannede legespesialister i palliativ medisin 
sert kompetanseløft innen palliativ medisin. Dette bør skje som en del av læringsmål og obligatorisk tjeneste i relevante spesialistutdanninger og ved at palliativ medisin blir godkjent som en egen påbygningsspesialitet.

Palliativ medisin sin plass i utdanningen av legespesialister bør klargjøres og formaliseres. I forslagene til de nye læringsmålene for spesialistutdanningene har flere tatt inn palliasjonskompetanse som et delmål. Omfanget varier imidlertid og vurdert opp mot det kliniske behovet synes utdanningsvolumet å være lavt. I enkelte spesialiteter er det helt fraværende. Geriatri, onkologi og gynekologi er eksempler på spesialiteter som har tatt inn palliasjon som mål, obligatoriske kurs og tellende tjeneste. I sentrale spesialiteter hvor det er mange pasienter med store palliative behov som kirurgi, indremedisin, hematologi, hjertemedisin, lungemedisin, pediatri, nevrologi og allmennmedisin er det ut fra utvalgets vurdering behov for å se på utdanningene og gi palliativ medisin en mer sentral plass.

For å sikre omfanget og tilnærmet likhet mellom de forskjellige spesialistutdanningene, støtter utvalget ambisjonene i Sammen - mot kreft. Nasjonal kreftstrategi 2013-2017 (Helse- og omsorgsdepartementet, 2013). Her er et av målene å sikre at palliativ medisin er dekket innenfor obligatoriske kurs i spesialistutdanningen, blant annet for leger i allmennmedisin. De regionale kompetansesentrene for lindrende behandling bør samarbeide for å sikre et kurstilbud for spesialistkandidater innen flest mulig spesialiteter, herunder allmennmedisin.

\section{Palliativ medisin som en påbyggingsspesialitet}

Etableringen av kompetanseområdet $\mathrm{i}$ palliativ medisin har bidratt til en viktig kvalitetsheving $\mathrm{i}$ pasientbehandling og en fagliggjøring for legene. Kompetanseordningen oppfattes samtidig av fagmiljøet som svak i forhold til en eventuell påbygningsspesialitet.

Utvalget mener at palliativ medisin bør bli en egen spesialitet - påbyggingsspesialitet. Dette er nødvendig for å erkjenne pasientenes og samfunnets behov. Spesialiststrukturen er den mest anerkjente strukturen for videreutdanning for leger. Hva et kompetanseområde er og hvilke kvalifikasjoner det gir, er i varierende grad kjent utenfor miljøene der dette er innført. For pasienter, pårørende, annet helsepersonell, helseledere og arbeidsgivere, vil en spesialitet tydeliggjøre den kompetansen legen besitter. En påbyggingsspesi- alitet vil sikre at kandidatene har en spesialitet fra før og derved har et klinisk ståsted før de utdanner seg i palliasjon.

En spesialitet i palliativ medisin vil være $\mathrm{i}$ tråd med spesialitetutdanning i mange EU land. Den britiske utdanningsmodellen er basert på at man starter direkte med spesialistutdanning i palliativ medsin fra medisinstudiet. Denne modellen er implementert i Irland, Malta, UK, Australia og Polen. Andre steder, som Canada, Tyskland, Israel, Ungarn, Frankrike, Sverige, Romania og USA, har man valgt en annen modell med subspesialitet eller påbyggingsspesialitet. Andre steder har man en løsere modell med et kompetanseområder slik som i Danmark, Finland, Italia, Latvia, Portugal og Slovakia.

\section{Utdanningsstillinger}

For å nå de to sentrale målene om mer og bedre palliativ medisinutdanning innen relevante spesialiteter og at palliativ medisin blir en egen påbyggingsspesialitet, kreves det teoretisk og praktiskklinisk utdanningsmulighet.

For å nå mål en om mer palliativ medisinsk utdanning i relevante spesialiteter, mener utvalget at de regionale kompetansesentrene, sammen med Helsedirektoratet, helseforetak og eventuelt andre bør utvikle et nasjonalt kurstilbud som en del av spesialistutdanningen. Det bør også settes av stillinger for LIS (leger i spesialisering) under utdanning ved palliative sentre på sykehus og ved de regionale palliative sentrene.

For å nå mål to palliativ medisin som en egen påbyggingsspesialitet, må den teoretiske delen utvides ved at man oppretter en egen norsk teoretisk utdanning. Denne kan tilsvare den nordiske utdanningen som finnes i dag for kompetanseområdet. Da kan utdanningskandidatene velge mellom en norsk utdanning eller den nordiske. Denne ordningen tilsvarer den man nylig har innført i Sverige.

I tillegg må det opprettes egne utdanningsstillinger ved de regionale palliative sentrene og ved palliative sentre på sykehus som kan ta i mot leger som har startet påbyggingsspesialiteten, men som allerede har en annen spesialitet $\mathrm{i}$ bunn.

\subsection{Tiltak}

- Palliativ medisin etableres som en egen påbyggingsspesialitet.

- Det opprettes kliniske utdanningsstillinger for påbyggingsspesialiteten i palliativ medisin. 
- Det opprettes LIS-stillinger for utdanning innen palliativ medisin for relevante spesialiteter.

- Videreutdanning i palliasjon på masternivå for relevante helsefagprofesjoner utvides og formaliseres.

- Bør tilsvare 60 studiepoeng, ha minimum 6 ukers veiledet praksis og harmoniseres $\mathrm{i}$ innhold
- Innholdet bør følge intenasjonale anbefalinger (f.eks. EAPCs White Paper, 2013)

- Utdanningene kan være monofaglige og/ eller tverrfaglige

- Videreutdanningene bør være på masternivå

- Det anbefales masterprogram som kvalifiserer for videre $\mathrm{PhD}$ program. 


\section{Kapittel 8 \\ Forskning}

\begin{abstract}
Alt for å finne det sannes mysterium - det er den ekte forskers kriterium.
\end{abstract}

Henrik Ibsen

\subsection{Innledning}

Palliasjon er forankret i et personsentrert perspektiv, i utredningen presentert som pasientsentrert tilnærming. Dette innebærer at pasientens og pårørendes perspektiv er viktig for fagforståelse og utvikling av kunnskapsgrunnlaget i palliasjon.

Mange pasienter har sammensatte problemer og de har behov for kompetanse fra en rekke helseprofesjoner. Derfor er kunnskapsgrunnlaget for praksis forankret i flere fag, med forskjellige kunnskaps- og forskningstradisjoner.
For å styrke kompetansen og kvaliteten i helse- og omsorgstjenesten er det et stort behov for forskning innen palliasjon på mange områder. Utvalget vil særlig rette oppmerksomheten mot tre viktige forskningsområder:

- Klinisk forskning for å utvikle og forbedre pasientbehandling, pleie og omsorg, og få kunnskap om sykdommers påvirkning på pasienten

- Helsetjenesteforskning for å evaluere og prøve ut ulike modeller for organisering av de de palliative tjenestene, for eksempel gjennom pasientforløpsmodeller

- Få bedre kunnskap om hvilken behandling og omsorg som er best for den enkelte pasient, blant annet gjennom forskning på pasienters og pårørendes preferanser

\section{Boks 8.1 Et system for å gradere evidens: Strength and consistence of evidence supporting grades for each recommendation (as used by the Agency for Healthcare Policy and Research, USA)}

A Requires at least one randomised controlled trial as part of a body of literature of overall good quality and consistency addressing the specific recommendation (evidence levels la and $\mathrm{lb}$ ).

B Requires the availability of well-conducted clinical studies but no randomised clinical trials on the topic of recommendation (evidence levels lla, llb and 1ll).

C Requires evidence obtained from expert committee reports or opinions and/or clinical experiences of respected authorities. Indicates an absence of directly applicable clinical studies of good quality (evidence level IV).
Category of evidence:

Ia evidence from meta-analysis of randomised controlled trials.

Ib evidence from at least one randomised controlled trial.

IIa evidence from at least one controlled study without randomisation.

IIb evidence from at least one other type of quasi-experimental study.

III evidence from non-experimental descriptive studies, such as comparative studies, correlation studies and case-control studies.

IV evidence from expert committee reports or opinions or clinical experience of respected authorities, or both.

Kilde: Hadorn m.fl., 1996, US Department of Health and Human Services, 1993 


\subsubsection{Kvaliteten på forskning i palliasjonsfeltet}

Forskning bør danne grunnlaget for klinisk praksis. Dette gjelder også for det palliative fagfeltet. I Norge finnes normer for pasientbehandling i nasjonale faglige retningslinjer som utarbeides av Helsedirektoratet i samarbeid med fagmiljøene. Kvaliteten på og omfanget av den kliniske forskningen i palliasjonsfeltet, som skal danne grunnlaget for de nasjonale retningslinjene, er svakt. De fleste anbefalingene er basert på laveste evidensnivå (nivå IV), dvs. ekspertgruppeuttalelser, og kvaliteten er ofte på laveste nivå (nivå C), se boks 8.1. Dette gjelder også et av de mest utforskede områdene innen palliasjon, som er smertebehandling hos kreftpasienter.

\subsection{2 Økende behov for palliativ forskning}

Kvaliteten på og omfanget av den palliative forskningen står i sterk kontrast til det raskt økende behovet. Befolkningen blir eldre, det palliative behovet øker og samtidig øker kompleksiteten i behandling, pleie og omsorg. Eldre mennesker har ofte mer sammensatte sykdomsbilder enn yngre, og hjelpen som kreves fra helse- og omsorgstjenesten blir derfor mer krevende og sammensatt. Store ressurser benyttes på pasientene det siste leveåret $\mathrm{og}$ spesielt de tre siste månedene. Denne utviklingen forventes å bli forsterket.

Vi har i dag lite kunnskap i helsetjenesten om grad av over- eller underbehandling for ulike grupper. I forhold til ressursbruken er forskningsaktiviteten på god behandling i livets sluttfase lav, og innenfor enkelte områder fraværende. Den manglende dokumentasjonen som finnes på medikamentell behandling i livets sluttfase er et eksempel på dette (Jansen, Haugen m.fl., 2017).

Det meste av forskningen er rettet mot yngre personer. Vi vet for lite om hvordan sykdommen virker på eldre mennesker som lever med en dødelig sykdom. Vi vet også lite om hvordan pasienten og familien håndterer alvorlig og livstruende sykdom. Det er også mangelfull kunnskap om hvordan helse- og omsorgstjenesten bør organiseres på best mulig måte til personer med sammensatte palliative behov.

Et av områdene som det er forsket mest på er smertelindring av kreftpasienter. Til tross for at man har styrket kvaliteten på smertebehandling, er det fortsatt nærmere 50 prosent av kreftpasientene som ikke får god nok smertebehandling (Holtan, Aass m.fl., 2007, Kongsgaard, Kaasa m.fl,
2005). Den viktigste grunnen til dette er antakelig at standard utredning og behandling ikke er godt nok implementert i klinisk praksis.

Det er fortsatt behov for å utvikle bedre behandlingsmuligheter generelt i palliasjon. Det er for eksempel behov for bedre kunnskap om hvordan man best skal håndtere en rekke andre plagsomme symptomer, og hvordan man kan motvirke vekttap og underernæring hos palliative pasienter (Fearon, Strasser m.fl., 2011, Teunissen, Wesker m.fl., 2007).

Nasjonalt handlingsprogram for palliasjon $i$ kreftomsorgen (Helsedirektoratet, 2015b) gir retningslinjer for behandling, kompetanse og organisering av palliative tjenester i Norge. Imidlertid er det få studier som har evaluert effekten av disse anbefalingene.

I Norge i dag dør rundt 48 prosent av befolkningen på sykehjem, det vil si 18-19 000 dødsfall i året. Vi vet lite om kvaliteten ved de ulike lindrende enhetene på sykehjem i Norge.

Pasientmedvirkning i utvikling av tjenestene er tema i ulike nasjonale strategier. Det er likevel få studier som ser på pasienter og pårørendes ønsker for hvordan de vil bli ivaretatt i den palliative fasen. Ved en litteraturgjennomgang om pasienters preferanser for behandling og omsorg $\mathrm{i}$ livets sluttfase fant man ingen norske studier. Det finnes likevel enkelte studier som peker på områder pasienter mener er av betydning for omsorgen i den siste tiden (Sintef, 2016).

I figur 8.1 er de forskjellige behandlingsintensjonene/omsorgsintensjonene illustrert, fra kurativ behandling til døende pasienter, og pårørende $\mathrm{i}$ sorg etter pasientens død. Forskning på den palliative fasen, på døende og den etterfølgende tiden, skal ha en pasientsentrert tilnærming. Forskning på tidligere faser i pasientforløpet, det vil si både kurativ og livsforlengende behandling, må ha oppmerksomhet, både på behandlingens effekt og på pasienten.

Det som kjennetegner den palliative forskningen kan beskrives ut fra flere forhold. Dette er skissert i boks 8.2 .

Det grunnleggende og delvis unike med palliativ forskning er fokus på «pasienten med sykdommen». Med andre ord: hvordan er det å leve med en livstruende sykdom? Å leve med en pågående behandling? Å være døende eller forvente at man vil dø i løpet av kort tid? Denne tilnærmingen står ikke i motsetning til, men kommer i tillegg til sykdomsrettet forskning, der hovedformålet er å gjøre noe med årsaken til sykdommen og behandlingen av den. 


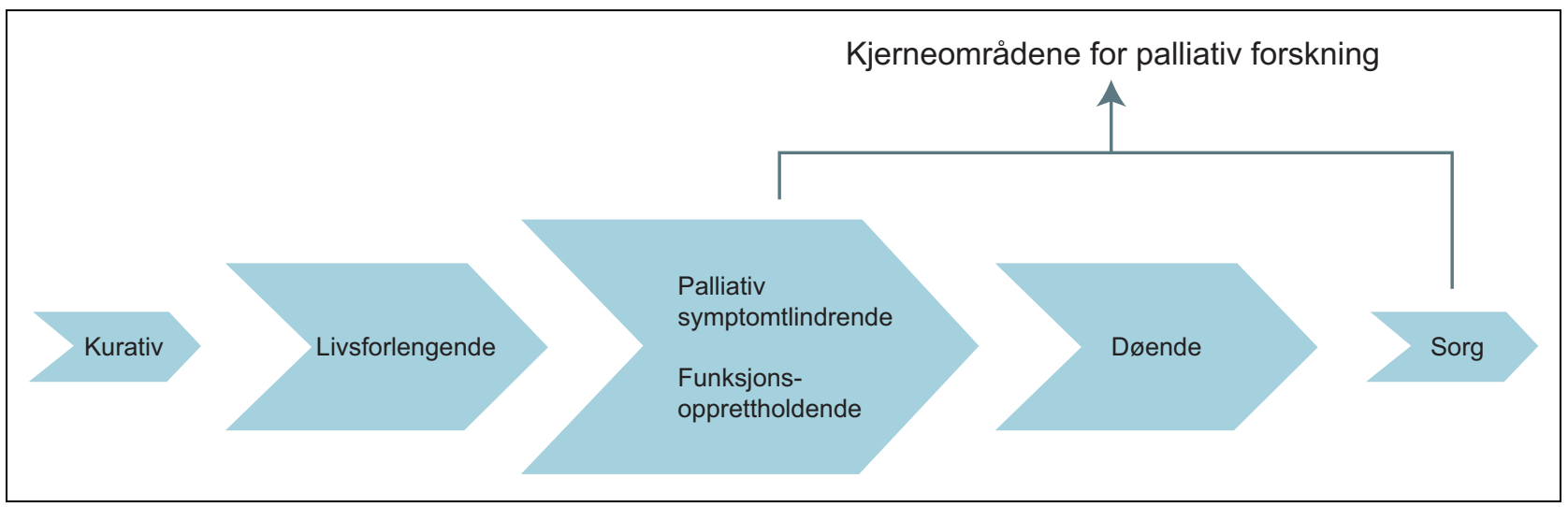

Figur 8.1 Behandlings- og omsorgsintensjoner i et palliativt pasientforløp

Det vil i en del tilfeller være hensiktsmessig at det er et samarbeid mellom forskere på palliasjon og de som arbeider med forskning med et kurativt eller livsforlengende siktemål. Det vil også være hensiktsmessig å samarbeide med forskere som arbeider med grunnleggende forskning innen biologi, psykologi, kommunikasjon, sosiologi og etikk. Hvordan man samarbeider, er sentralt for å utvikle en tverrfaglig, god forskningsgruppe for å dekke områder over tid. En tverrfaglig sammensatt forskningsgruppe kan besvare felles forskningsspørsmål eller besvare flere ulike problemstillinger, og er vesentlig med tanke på kunnskapsutvikling innen det palliative området. For å beholde den pasientsentrerte tilnærmingen må forskningsspørsmålet konkretiseres rundt dette temaet, og tematikken må bli anerkjent som et eget forskningsområde. Det er i liten grad etablert forskningsgrupper som favner forskere på tvers av palliasjonsfeltet i Norge. Noen enkeltprosjekter, slik som Orkdalprosjektet, involverer både den kommunale helse- og omsorgstjenesten og spesialisthelsetjenesten.

Forskning på palliative problemstillinger krever ikke egne metodologiske tilnærminger eller særskilte forskningsetiske vurderinger. Eksisterende forskningsmetodikk fra biomedisin, psykologi og samfunnsmedisin kan brukes i palliativ forskning, men innretningen av metodikken vil ofte være annerledes.

\section{Effektmål}

Det er store utfordringer knyttet til å måle effekt av tiltak. En pasientsentrert tilnærming er sentral for palliativ forskning, og det er derfor nødvendig

\section{Boks 8.2 Forskningsområder i palliasjon}

- Pasientpopulasjonen

- Kort forventet levetid (uhelbredelig sykdom)

- Palliativt behov under livsforlengende behandling (tidlig integrasjon)

- Den døende pasienten

- Ulik type forskning/intervensjoner

- Pasientopplevelse av tilstanden

- Symptom- og funksjonsfokus

- Helsetjenesteutvikling/forskning

- Kommunalt- og spesialisthelsetjenestenivå

- Sosiale forhold og levekår

- Diagnose- og pasientgrupper

- Kreft

- Andre diagnosegrupper
- Ulike pasientgrupper; barn, eldre, personer med utviklingshemming, personer med ruslidelser $\mathrm{mm}$.

- Pasient- og pårørendeinvolvering

- Informasjon

- Kommunikasjon

- Shared decision making (samvalg)

- Advance care planning (for eksempel forhåndssamtaler)

- Effektmål (outcomes)

- Livskvalitet

- Symptomendring og funksjon

- Overlevelse

- Bivirkninger

- Kostnader 
å samle data fra pasienten og pasientens pårørende. I palliativ forskning vil det som regel være avgjørende å få pasientens egen vurdering av behandling, pleie og omsorg. Pasientrapporterte effekter (patient reported outcome measures, PROMs) og pasientens rapporterte erfaringer (patient reported experience measures, PREMs) er vesentlig i palliasjon. Et eksempel på effektmål kan være pasienters bedømming av smerte og mulige endringer knyttet til ulike intervensjoner, effekten av diagnostikk, behandling og oppfølgning (PROMs). Når det gjelder pasienters erfaringer (PREMs) er dette helt sentralt ved studier som eksempelvis undersøker pasienter og pårørendes bedømming av kvalitet eller beslutningsadferd.

Det er problemstillingene eller forskningsspørsmålene som skal bestemme hvilke effektmål man bruker i en studie. De primære effektmålene i palliative studier vil ofte være pasientrettede. I enkelte tilfeller hos kognitivt reduserte pasienter er det nødvendig å observere pasienten eller innhente data via pårørende eller andre som observerer (såkalte proxy outcome). I enkelte tilfeller kan det være hensiktsmessig å bruke sekundære eller tertiære effektmål slik som levetid, kostnader, biologiske parametere etc.

Dersom det forskes på organisering av helsetjenesten, vil det benyttes andre typer effektmål. Dersom man undersøker hvordan kvaliteten på helsetjenesten er den siste delen av livet vil hjemmetid, hvor pasientene dør, symptomkontroll og pårørendes livskvalitet være gode effektmål. For samfunnet er det også viktig å finne den mest kostnadseffektive behandlingen.

\section{Implementering av forskning, retningslinjer og} faglige råd

Resultater fra internasjonal og nasjonal klinisk forskning skal danne grunnlaget for utvikling av nasjonale faglige retningslinjer, som igjen er utgangspunkt for klinisk praksis. Det er nødvendig å monitorere klinisk praksis, for å sikre at den er i tråd med gjeldende kunnskap. Retningslinjene danner videre grunnlag for prosedyrer som er med på å sikre at den enkelte pasient får god behandling.

Alle ledd i helsetjenesten bør dele ansvaret for å sikre at nasjonale retningslinjer blir kjent og etterlevd, samt å sikre god kvalitet i tjenesten. Utdanningssystemet (universiteter, høyskoler og fagskoler), er sentrale i formidling av hvordan nasjonale retningslinjer kan implementeres.
Nasjonalt handlingsprogram for palliasjon $i$ kreftomsorgen setter krav til videreformidling av kompetanse. Dette kommer i tillegg til den formelle utdannelsen som skjer på universiteter og høyskoler. Dette gjøres for å fordele ansvaret ut i tjenesten - nær pasientene. Det daglige implementeringsansvaret legges til helsepersonell som arbeider innenfor det spesialiserte palliative tilbudet og som leder eller arbeider ved palliative enheter og team (Helsedirektoratet, 2015b).

\subsection{Dagens status nasjonalt og internasjonalt}

\subsubsection{Historikk}

Palliasjon er et ungt akademisk fag. I internasjonal sammenheng begynte utviklingen av palliasjon som fagfelt med forskningen og registreringen til Cicely Saunders på 1950-tallet og Robert Twycross sin forskning ved St. Christophers Hospice på 1970-tallet. Det første professoratet i palliativ medisin ble opprettet i Storbritannina 1991, der Geoffrey W. Hanks ble ansatt i stillingen.

I Norge begynte forskning på palliasjonsfeltet på 1970- tallet, med spredt forskning og registreringsarbeid. Dette arbeidet fikk ikke gjennomslag i det bredere forskningsmiljøet på landsbasis, det var heller et uttrykk for enkeltpersoners iver og engasjement. I praksis var det ingen konkret forskningsaktivitet eller videre akademisering $\mathrm{i}$ faget og fagområdet før på 1990-tallet.

NOU 1984: 30 Pleie og omsorg for alvorlig syke og døende anbefalte å opprette egne avdelinger for lindrende behandling. Den første seksjon for lindrende behandling ble opprettet i Trondheim i 1993/94, med klinisk og akademisk ledelse. Det første professoratet i palliativ medisin ble etablert i 1993. Seksjon lindrende behandling i Trondheim ble etablert på tre fundamenter: klinisk virksomhet, forskning og undervisning.

Til å begynne med var det meste av forskningen rettet mot to hovedområder: helsetjenesteforskning og symptomlindring. Forskningen på symptomlindring med spesielt fokus på smerte, ble utført i samarbeid mellom Seksjon Lindrende behandling ved St. Olavs hospital og smerteklinikken i Trondheim. Forskningen var tverrfaglig, med bidrag fra leger, sykepleiere, klinisk ernæringsfysiolog, fysioterapeut, molekylær biologer, samfunnsvitere, psykologer med flere. Så tidlig som på 1970-tallet ble det forsket på omsorg mot livets slutt ved Gruppe helsetjenesteforskning, Institutt for allmennmedisin ved Universitet i Oslo (Strømskag, 2012). 
De regionale kompetansesentrene ble etablert omkring 2000. Forskning var et av områdene kompetansesentrene skulle ivareta.

Medisinsk forskning har lengre tradisjon i spesialisthelsetjenesten enn i den kommunale helseog omsorgstjenesten. Det meste av forskningen i Norge innen palliasjon har universitetssykehusene stått for, spesielt de regionale kompetansesentrene for lindrende behandling. Høgskoler har gjennomført evalueringer og forskningsprosjekter på palliasjonsfeltet. Fra 2002 har det vært en tilskuddsordning til prosjekter i kommunene, Kompetansehevende tiltak for lindrende behandling og omsorg ved livets slutt (Prop 1S (2016-2017), kap.761 post 67). Tilskuddsrammen har de siste årene vært ca. 16 mill. kroner per år.

\subsubsection{Forskning internasjonalt og i Norge}

Publikasjon av vitenskapelige artikler

Forskning på palliasjon har ulik metodisk tilnærming, fra randomiserte studier til beskrivende studier. Både kvantitativ og kvalitativ metode er benyttet. Forskningen spenner fra noen få store multisenterstudier til lokale kvalitetsforbedringsprosjekter med nasjonal overføringsverdi.

Palliativ forskning og fagutvikling har hatt en betydelig vekst fra 1980-tallet. Dette gjenspeiles i en stor økning av antall forskningsartikler innen palliasjon. I internasjonale medisinske databaser ble det registrert 1594 publiserte artikler i år 2000, mens det i 2016 ble publisert 4821 artikler (PubMed, 2017).

Forskningsaktivitet på palliasjon i Norge finner vi ved flere sykehus, på høgskoler og ved universitetene. I forbindelse med denne utredningen har Kompetansesenter for lindrende behandling Sør-Øst gjennomført et grundig litteratursøk for å kartlegge den nasjonale forskningsaktiviteten innen palliasjon. Kompetansesenteret identifiserte publikasjoner i norske og internasjonale tidsskrift av forskere med tilknytning til norske institusjoner de siste fem år (januar 2012 - oktober 2017). Det var ingen begrensninger mht. studiedesign, metode, diagnosegruppe, eller alder på studiepopulasjonen. Søket ble foretatt i referansedatabaser innen medisin og helsefag. PubMed/Medline, Cochrane og Svemed+. Svemed+ -søket var begrenset til forskningsbaserte tidsskrift. Kommentarartikler, brev, case-studier og anekdotiske publikasjoner ble utelatt. Spesifikke søk på norske medarbeidere i internasjonale forskningskonsortier, der ikke «Norway» er spesifisert er ikke fore- tatt. Det er derfor rimelig å tro at antall publikasjoner er noe høyere.

Søket ga 414 treff, hvorav 265 var relevante. Av disse var det kun ni (3 pst.) randomiserte studier, 39 (15 pst.) reviewartikler, hvorav to Cochrane reviews og 61 kvalitative studier (23 pst.). Resten var hovedsakelig observasjonsstudier, surveys, etikkdrøftinger og terapianbefalinger. 143 studier (54 pst.) fokuserte utelukkende på kreft; kreftpopulasjoner, pårørende til kreftpasienter, onkologisk helsepersonell $\mathrm{mm}$. Ti studier var fra diagnosegrupper som kols (3), intensivmedisin (5) og nevrologi (2). Disse publikasjonene var rettet mot kostnader, helsetjenester til pasienter med langtkommen sykdom, etiske betraktninger, palliativ behandling i sykehjem og behandling, pleie og omsorg ved livets slutt (end-of-life care).

Med bakgrunn i litteratursøket kan vi konkludere med at det kun har vært en liten økning i antall publikasjoner de siste 5 år; 49 i 2012 til rundt 60 de siste 4 år. De fleste studiene omhandler kreft, noe som kan tyde på at andre miljøer bruker andre emneord/terminologi. Heterogeniteten i metode, design og studiestørrelse gjør det ikke mulig å få et entydig svar på effekt, kvalitet eller innhold av spesialisert palliativ behandling. Et sentralt punkt er hvorvidt tiltak som har positiv effekt i studiesammenheng, kan implementeres i praksis, og således ha effekt på sikt.

Det finnes ingen samlet oversikt over palliativ forskning i Norge. Søkning i norske databaser over norske forskningsprosjekter kan søkes opp i Forskningsrådets prosjektbank (https:// www.forskningsradet.no/prosjektbanken/), Cristin (https://www.cristin.no/), det nasjonale systemet for forskningsdokumentasjon og eRapport (https://forskningsprosjekter.ihelse.net/) som blant annet inneholder forskningsprosjekter finansiert av de regionale helseforetakene. De gir en viss oversikt, med en omtrentlig forekomst av 1530 prosjekter i hver database som har relevans for palliasjon.

En europeisk studie viser at de fleste forskningsgruppene innen behandling, pleie og omsorg ved livets slutt er små og at de større forskningsmiljøene har forholdsvis større aktivitet målt i publiserte artikler og antall doktorgrader (Sigurdardottir, Haugen m.fl., 2012). I Norge er også forskningsmiljøene små i palliasjonsfeltet.

Den palliative forskningen i Norge og internasjonalt tar i stor grad utgangspunkt i pasienter med en kreftdiagnose. Omtrent 50 prosent av publikasjonene de siste 5 årene omhandler kreftpasienter, mens de resterende 50 prosent er fordelt på andre diagnosegrupper (Søk i PubMed, 
2017). I de siste årene har det vært økende oppmerksomhet på palliativ forskning innen andre diagnoser. Det er lite palliativ forskning på barn.

\section{Kompetansesentre for lindrende behandling}

Kompetansesenter $i$ lindrende behandling MidtNorge ved St. Olavs hospital utviklet et forskningsmiljø på feltet på 1990-tallet, i forbindelse med etablering av professoratet. European Palliative Care Research Center (PRC) forvalter kompetansesenterets forskningsaktivitet. PRC ble opprettet i 2009 som en oppfølgning av et fireårig prosjekt finansiert av EU. Kreftforeningen bidro med 15 millioner over fem år til senteret. Denne finansieringen var avgjørende for at PRC sin forskning ble startet opp og fikk et nasjonalt og internasjonalt preg. PRC er et internasjonalt forskningssenter med bakgrunn i The European Association for Palliative Care (EAPC). EAPC er en organisasjon som favner helsepersonell tverrfaglig og har etablert et europeisk forskingsnettverk. I tillegg er det bygget opp et nasjonalt forskningsnettverk. Senteret har arbeidet mye med forskning på organisering av palliasjon, og på flere symptom/funksjonsområder som smerte, depresjon og kakeksi (avmagring, kraftløshet) - både med tanke på kartleggingsverktøy, diagnostikk og intervensjonsstudier.

Senteret har et omfattende forskningssamarbeid med landets øvrige kompetansesentre. PRC har to professorater og ett æresprofessorat $(0,8$ stillinger) og 5 ansatte i akademiske stillinger (2,9 stillinger) og 11 stipendiater.

Regionalt kompetansesenter for lindrende behandling, Sør-Øst ved Oslo universitetssykehus har de siste årene intensivert forskningsarbeidet. Forskningen har blant annet vært knyttet til kartleggingsverktøy for palliative pasienter og pårørende. Den største satsningen de senere årene har vært knyttet til Pallionstudien, en multisenterstudie med temaet integrasjon av onkologi og palliasjon. Prosjektet er flerregionalt og er finansiert med midler fra Norges forskningsråd. Senteret har to professorater, to professorater ved annen institusjon og fem ansatte $\mathrm{i}$ akademiske stillinger (4.0 stillinger).

Kompetansesenter i lindrende behandling Midt-Norge og Kompetansetjeneste for lindrende behandling, Helse Sør-Øst har samarbeidet om flere studier nasjonalt og internasjonalt i regi av PRC. De største studiene er: The Multimodal Exercise/Nutrition/Anti-inflammatory treatment for Cachexia trial (MENAC) en randomisert internasjonalt multisenter studie. Målet med dette forskningsprosjektet er å undersøke om kreftpasienter som får en kombinasjonsbehandling bestående av trening, næringsdrikker og betennelsesdempende medisin i tillegg til kreftbehandling, utvikler mindre kakeksi (avmagring, kraftløshet) enn pasienter som får kreftbehandling alene. 450 pasienter deltar i studien. The Palliative Radiotherapy and Inflammation Study (PRAIS) er en åpen internasjonal kohortstudie som ser på sammenhengen mellom strålebehandling av skjelettmetastaser og smertelindrende effekt og biologiske forklaringer til dette.

Kompetansesenter i lindrende behandling region Vest ved Haukeland universitetssykehus har arbeidet med forskning tilknyttet PRC og andre internasjonale miljøer. Kompetansesenteret leder et stort EU finansiert prosjekt som forsker på pasienter i livets sluttfase. Prosjektet er et samarbeidsprosjekt mellom sju ulike forskningssentre i Europa og i Sør-Amerika. Kompetansesenteret har i tillegg flere lokale prosjekter om den døende pasienten. Senteret arbeider også innen forskning, systematisk fagutvikling og implementering av forskning mot det kliniske feltet. Sentret har 2 professorater, to ansatte i akademiske stillinger (1,2 stillinger) og en stipendiat (0,5 stillinger).

Kompetansesenter i lindrende behandling region Nord - Lindring i Nord, ved Universitetssykehuset i Nord-Norge har gjennom mange år arbeidet med «Håndbok i lindrende behandling» som har hatt stor betydning i klinisk utøvelse av palliasjon både $\mathrm{i}$ den kommunale helse- og omsorgstjenesten og i spesialisthelsetjenesten. Sentret har ikke professorater eller akademiske stillinger. Tre ansatte har forskningskompetanse. Kompetansesenteret har ikke forskningsmidler.

\section{Forskning i den kommunale helse- og omsorgs- tjenesten}

HelseOmsorg21-strategien legger opp til et kunnskapsløft, inkludert forskning, for kommunesektoren som en av fem hovedprioriteringer. Kunnskapsløftet er viktig for arbeidet med å videreutvikle den kommunale helse- og omsorgssektoren for bedre å kunne møte dagens utfordringer. (Helse- og omsorgsdepartementet, 2014). Den samlede FoU-innsatsen i 2015, som var knyttet til kommunale helse- og omsorgstjenester, anslås til vel 840 millioner kroner. Dette utgjør anslagsvis 10 prosent av den samlede ressursinnsatsen innenfor medisinsk- og helsefaglig forskning dette året (Wiig, Rørstad m.fl., 2016). Ser man på de samlede kostnadene i spesialisthelsetjenesten og den kommunale helse- og omsorgstjenesten 


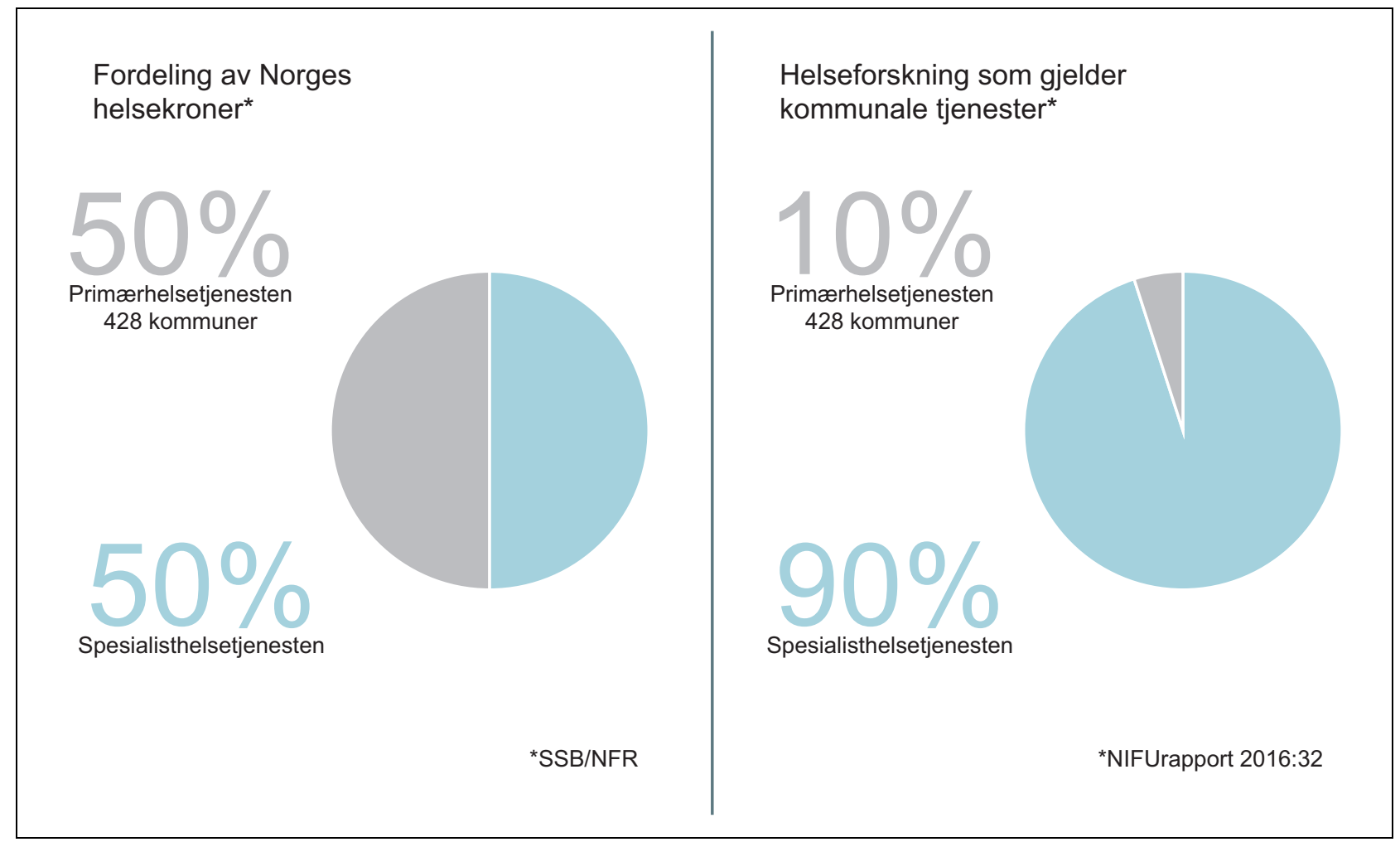

Figur 8.2 Fordeling av midler til helse og forskning på helse i Norge

Illustrasjon: Nina Mevold.

Kilde: http://www.ks.no/fagomrader/helse-og-velferd/helse-og-omsorg/kommunale-helsetjenester/

kunnskapsloft-for-kommunene/

(inklusiv helserefusjoner og legemidler) er det omtrent lik fordeling mellom sektorene (Statistisk sentralbyrå, 2015a og b, Helsedirektoratet, 2016) Figur 8.2 illustrerer dette forholdet (Kommunenes sentralforbund, 2017).

Kommunenes strategiske forskningsorgan (KSF) ble opprettet i 2017, for å styrke forskningen innen den kommunale helse- og omsorgstjenesten. KSF skal være pådriver og bidra til å videreutvikle og ivareta behov for forskning, innovasjon og utdanning for og med kommunene/kommunehelsetjenesten (KS, 2017).

Senter for omsorgsforskning ble opprettet av Helse- og omsorgsdepartementet på bakgrunn av St.meld.nr. 25 (2005-2006) Mestring, muligheter og meninger og er etablert ved Universitetet $\mathrm{i}$ Tromsø, Høgskolen i Nord-Trøndelag, Høgskolen i Bergen, Universitetet i Agder/Høgskolen i Sørøst-Norge og NTNU i Gjøvik. Senter for omsorgsforskning har gjort helsetjenesteforskning i palliasjon på oppdrag fra blant annet Helsedirektoratet.

En stor del av pasientene i den kommunale helse- og omsorgstjenesten har palliative behov og palliasjon bør integreres i denne tjenesten, se kapittel 9. De pasienttilpassede forløpene skal også inkludere palliasjon samt samarbeid mellom spesialisthelsetjenesten og den kommunale helseog omsorgstjenesten.

Kompetansehevende tiltak for lindrende behandling og omsorg ved livets slutt er en tilskuddsordning til prosjekter i kommunene, som har eksistert siden 2002 (Prop. 1S, kap.761 post 67). Tilskuddsrammen har de siste årene vært 16 mill. kroner per år, fordelt på 70-80 prosjekter årlig. Målet med ordningen er å styrke kvaliteten i tilbudet til pasienter med behov for lindrende behandling og omsorg, samt bidra til kompetanseoppbygging i kommunene. Målgruppen er pasienter som har behov for lindrende behandling og omsorg ved livets slutt og deres pårørende. Tilskuddsmidlene er blant annet benyttet til å utarbeide undervisningsmateriell, tiltak som omhandler samarbeid med frivillige organisasjoner, samarbeidstiltak mellom nivåene i helsetjenesten og prosjekter rettet mot pårørende. Utviklingssentrene for sykehjem og hjemmetjenester har vært en viktig aktør i mange av prosjektene. Oversikt over prosjektene publiseres på hjemmesidene til de regionale kompetansesentrene for lindrende behandling (www.pallreg.no). Ordningen ble evaluert i 2012. Evalueringen viser at mange prosjekter har bidratt til god fagutvikling i kommunene. Til- 
skuddsordningen har vært viktig for å igangsette arbeidet med kompetansehevning i palliasjon $\mathrm{i}$ kommunene. En del av prosjektene vurderes å ha hatt nasjonal overføringsverdi. Prosjektene har bidratt til å gi fagfeltet oppmerksomhet og bidratt til å styrke kompetanse. Det å få på plass en dedikert ressurs i kommunen fremheves av kompetansesentrene å ha stor betydning for den langsiktige effekten av prosjektene. Av evalueringen fremgår det også at en videre satsning bør vurdere alternative måter å stimulere til fagutvikling på (Tingvold, Sogstad, 2012).

\section{Frivillige og ideelle aktørers bidrag til forskning}

Frivillige-/ideelle organisasjoner (som benevnes Non-Governmental Organization, NGO) støtter forskning som passer inn i organisasjonenes målsetting. Organisasjonene kan løfte fram perspektiver de ønsker forskning på. Forskningsmiljøer kan også samarbeide med pasient- og brukerorganisasjonene. De vil kunne være et viktig supplement i den palliative forskningen, både finansielt og ved for eksempel å løfte fram pasient- og brukerperspektivet. Organisasjonene har behov for å samhandle med robuste forskningsmiljøer av høy kvalitet.

Kreftforeningen, Extrastiftelsen og Nasjonalforeningen for hjerte- og lungesykdommer er noen av organisasjonene som støtter klinisk forskning. Det er en svært begrenset andel av forskningsmidlene fra organisasjonene som brukes til palliativ forskning.

\section{Forskningsmidler til palliasjon}

Forskning er en av fire lovfestede hovedoppgaver i sykehusene, sidestilt med pasientbehandling (diagnostikk, behandling og rehabilitering), utdanning av helsepersonell og opplæring av pasienter og pårørende.

Over statsbudsjettet øremerkes midler til forskning i helseforetakene. Tilskudd til forskning i helseregionene utgjør 680,2 mill. kroner i 2017. Dette inkluderer 133,2 mill. kroner til program for klinisk behandlingsforskning. Prosjektene er tett knyttet opp mot pasientbehandling og spesialisthelsetjenestens behov. Helseregionenes forskningsmidler skal medvirke til å sikre forskningsaktivitet i helseforetakene, og øke produktiviteten og kvaliteten på forskningen (Prop. 1S (20162017), s. 92).

Kommunene skal tilrettelegge for og medvirke til forskning for helse- og omsorgstjenester, men er ikke pålagt å finansiere den. Kommune- sektoren finansierer i liten grad FoU-aktivitet rettet mot kommunale helse- og omsorgstjenester. Den største finansieringskilden er Helse- og omsorgsdepartementet med underliggende etater, f.eks. Helsedirektoratet. Forskningsmidler kan også søkes gjennom Forskningsrådet, ideelle organisasjonen og EU (Wiig, Rørstad m.fl., 2016).

Det har i liten grad vært muligheter til å skaffe midler til større forskningsprogrammer i palliasjon. Enkelte palliative prosjekter finansieres gjennom programmer i Forskningsrådet. Forskningsrådet har etablert flere programmer som kan være aktuelle for palliativ forskning: Program for God og treffsikker diagnostikk, behandling og rehabilitering (Behandling), Bedre helse og livskvalitet (Bedrehelse) og Gode og effektive helse-, omsorgs-, og velferdstjenester (Helsevel).

Tjenestene som inngår i Helsevel er helse- og omsorgstjenester, arbeids- og velferdstjenester og barnevern. Hovedmålet for forskningen i Helsevel er: Gode og effektive tjenester skal gjennom forskning og innovasjon bidra til god kvalitet og kompetanse. Gjennom denne satsningen har palliasjon i noen grad blitt berørt.

\subsection{Vurdering og drøfting av dagens forskning}

\subsubsection{Behov for forskning i palliasjon}

Forskning skaper ny kunnskap og legger dermed også et grunnlag for gode og riktige prioriteringer (NOU 2014: 12 Apent og rettferdig - prioriteringer $i$ helsetjenesten).

Det bevilges i lite omfang midler til palliativ forskning, til tross for at det er et dokumentert behov: Det palliative feltet favner om et stort pasientvolum, det brukes betydelige ressurser til pasienter i en palliativ fase, og det er stor kompleksitet i pasientpopulasjonen. Dette er forhold som tilsier at vi har et stort behov for forskningsbasert kunnskap. Det er behov for gode konkluderende studier som kan bidra til god klinisk praksis, og det er behov for forskning som kan gi bedre kunnskap om hvilke utfordringer palliative pasienter og deres pårørende møter.

Størrelsesordenen på nasjonale midler som faktisk går til palliativ forskning i dag er vanskelig å anslå. Palliasjon er ikke søkbart som et eget område. Og det er heller ingen egne forskningsprogram for palliasjon i Norge. De senere årene har det vært noen utlysninger i EU regi som er spesifikke for palliativ forskning.

Ved PRC og kompetansesentrene for lindrende behandling er det samarbeid mellom nor- 


\section{Boks 8.3 Forhold som kan forklare lite omfang og kvalitet på palliativ forskning i Norge}

- Ungt akademisk fagfelt (under 25 år)

- Få forskere på høyt internasjonalt nivå

- Mange forskere må kombinere klinikk med forskning

- Ikke nok til internasjonalt samarbeid

- Fravær av egne palliative forskningsprogram

- Palliative forskningssøknader synes ikke å bli prioritert

- Fagfeltet er stort og sammensatt med hensyn på pasientpopulasjon og helsetjenester

ske og internasjonale forskere på palliasjonsfeltet. Et internasjonalt forskningssamarbeid i palliasjon både i helsetjenesteforskning, omsorgsforskning og i medisin, vil styrke forskningen. Det er behov for ulik type forskning for å få kunnskap om utfordringene palliative pasienter og deres pårørende møter. I internasjonal sammenheng mangler det også forskning av god kvalitet på fagfeltet, god evidensbase for retningslinjer, samt at retningslinjer mange steder er fraværende. Det er behov for koordinering av forskning i Europa på det palliative feltet (Sigurdardottir, Haugen m.fl., 2010).

\subsubsection{Hva og hvem bør det forskes på?}

Utvalget ønsker å fremheve noen hovedområder det bør fokuseres på innen forskning, se faktaboks 8.4.

Tidlig integrasjon av palliasjon: Palliasjonsbegrepet er utvidet til pasienter med lengre levetid (WHO 2002). Forskning viser at kreftpasienter

\section{Boks 8.4 Tema det bør forskes på i palliasjon}

- Symptombehandling (smerte, kvalme, emosjonell funksjon etc.)

- Funksjonsforbedring/opprettholdelse

- Pasient- og pårørendemedvirkning i beslutninger

- Organisering av palliasjon

- Forståelse av dødsprosessen

- Biologisk, psykologisk og eksistensielt som tilbys palliasjon tidlig i forløpet, ser ut til å unngå overbehandling, få bedre symptomlindring og kanskje leve lenger (Jordhøy, 2000, Temel, 2010, Zimmermann, 2004, Kavalieratos, 2016, Gaertner, 2017). Tilsvarende forskning bør gjøres på andre pasientgrupper.

Palliasjon skal integreres tidlig i pasientforløpene også når pasientene får behandling med et kurativt eller en livsforlengende målsetning. Et eksempel på en slik pasientgruppe er pasienter med lungekreft som blir operert med et kurativt siktemål, og hvor ca. en fjerdedel av pasientene er $\mathrm{i}$ live etter fem år. Denne pasientgruppen bør både klinisk og forskningsmessig ha en integrasjon av palliasjon allerede fra diagnosetidspunkt, under og etter primær operativ behandling hvor kurasjon er målet. Å introdusere palliasjon tidligere i forløpet gir også behov for forskning som inkluderer denne fasen i pasientforløpene.

Klinikknœer forskning: Satsning på klinikknær forskning med bred metodologisk tilnærming er viktig. Forskning knyttet til palliasjon bør ha fokus på kliniske palliative problemstillinger og en tydelig forankring både i den kommunale helse- og omsorgstjenesten og i spesialisthelsetjenesten. Selv om det de siste årene er utviklet kunnskap om god behandling, for eksempel på smerter, viser forskningen at mange kreftpasienter har ubehandlet smerte. Det er behov for forskning på gode modeller for implementering av kunnskap i spesialisthelsetjenesten og $\mathrm{i}$ den kommunale helse- og omsorgstjenesten.

Forskning på behandling, oppfølging, levekår og familieperspektivet er viktige for å få økt kunnskap på pasientens og pårørendes helhetlige situasjon. Den palliative forskningen må ha oppmerksomhet rettet mot pasienter med ulike diagnoser $\mathrm{i}$ de siste leveår hvor pasienten med livstruende sykdom mottar palliativ behandling og omsorg.

Pasientsentrerte, kliniske og samfunnsmessige problemstillinger: Forskningsspørsmålene eller de overordnede målsetningene innen palliativ forskning skal være pasientrettet. Utvalget ønsker å presisere at et løft innen palliativ forskning må være rettet mot pasientsentrerte, kliniske og samfunnsmessige problemstillinger. Det bør skje en politisk styrt dreining mot pasientsentrert forskning som kan bedre behandling, pleie og omsorg for palliative pasienter, samt ivareta pårørende i en krevende situasjon. Forskning om pasienters og pårørendes preferanser, barrierer og utfordringer ved å motta behandling og omsorg $\mathrm{i}$ eget hjem, er områder som bør vies større oppmerksomhet. Utvalget mener det er behov for en tydeligere pasient- og pårørendestemme inn $\mathrm{i}$ 
forskningsfeltet som vil styrke utviklingen av tjenesten.

Helsetjenesteforskning: Helsetjenesteforskning og forskning på samhandling i palliasjon er nødvendig da pasientene har behov for helse- og omsorgstjenester på ulike nivå og fra ulike aktører. Forskingssamarbeid mellom forskningsmiljøer fra de to nivåene vil kunne generere viktig kunnskap. Utvalget mener det bør etableres palliative forskningsprogram med øremerkede midler på tvers av nivåene i helse- og omsorgstjenesten. Overgangene i helsetjenesten kan være utfordrende for pasienten. Pasienter og pårørendes opplevelse av samhandling mellom ulike tjenesteytere er et viktig område for forskning.

Prospektive studier: Gode prospektive studier, hvor man følger en gruppe pasienter framover i tid med kontrollgruppe, er en mangelvare både nasjonalt og internasjonalt. Dette gjelder både innen symptomlindring, helsetjenesteforskning og spesielt pasienter med kort forventet levetid. Det er behov for å dokumentere effekt og konsekvenser av alle typer tiltak, både for pasienter, pårørende $o g$ helsepersonell. Spesielt når det gjelder organisatoriske tiltak er det behov for godt koordinerte forskningsinitiativ som følger pasientgrupper over lengre perioder og helst på tvers av helsetjenestene. Dette vil gi kunnskap om hvordan behandling og omsorg for pasienter med alvorlig og livsbegrensende sykdom kan utvikles best mulig. Det er behov for pålitelig forskning med både kvalitative og kvantitative metoder (Kunnskapssenteret, 2014).

Systematisering/registrering av epidemiologiske data - kvalitetsregistre: Norge bør samle epidemiologiske data om forekomst av tilstander som krever palliativ omsorg og behandling. Diagnosespesifikke kliniske kvalitetsregistre vil kunne bidra til å utvikle forsvarlig og effektiv helsehjelp. Pasientsikkerhet, effektiv behandling og ressursbruk kan dermed sies å være helseregistrenes overordnede formål. Utvalget mener det bør opprettes et eget register som kan brukes for å monitorere og kvalitetssikre pasienters (menneskers) siste levemåneder. Det bør også vurderes om variabler knyttet til palliasjon bør legges inn i eksisterende registre.

Det finnes per i dag ikke fullstendig oversikt over forekomst av sykdommer som er livstruende eller som medfører begrenset livslengde hos barn i Norge. Dødsstatistikken over barn og unge alene gir ikke et riktig bilde av forekomsten. Informasjon og data om tall, diagnose, aldersspenn og plassering av barn med livsbegrensende eller livstruende forhold er grunnleggende for planlegging og organisering av tjenester innen barnepalliasjon.

\subsubsection{Utvikling og styrking av palliativ forskning}

\section{Grunnlag for palliativ forskning}

Målene om høyt nasjonalt og internasjonalt nivå innen palliasjon bør være realistiske å nå. Det er flere gode grunnleggende forutsetninger i norsk helse- og omsorgstjeneste som gjør at Norge kan bidra i betydelig grad internasjonalt. Noen av de viktigste er oppsummert i boks 8.5.

Palliativ forskning innen palliasjon trenger gode og robuste miljøer som kan arbeide med konkrete palliative problemstillinger over tid. For å utvikle fagområdet bør man kombinere kompetanse fra flere fagretninger i samme gruppe. Da vil man raskere og mer effektivt kunne besvare sammensatte forskningsspørsmål.

Studier bør ha god forankring i palliative forskningsmiljø. Samarbeid mellom forskningsmiljøer og en større satsning på miljøer med forskningskompetanse på høyt nivå bør prioriteres. Forskningsmiljøene utenfor spesialisthelsetjenesten og universitetene er små, og det bør satses på samarbeid nasjonalt, nordisk og internasjonalt. Man kan gi vekstmuligheter for de sterke miljøene, men med forutsetning om at de samtidig skal bidra til å løfte og inkludere svakere miljøer. På denne måten kan man sammen bidra til mer og bedre forskning innen palliasjon nasjonalt, regionalt og ved universiteter og høyskoler. Fastleger og andre helseprofesjoner i den kommunale helse- og omsorgtjenesten bør involveres i planlegging og gjennomføringen av forskning. Internasjonalt samarbeid stimulerer til nettverksbygging og vil også være gunstig for stipendiater og andre forskere som får et bredere forskningssam-

\section{Boks 8.5 Grunnleggende norske fortrinn}

- Offentlig finansiering av helse- og omsorgstjenestene

- Samarbeid mellom universitetssykehus, lokalsykehus og den kommunale helse- og omsorgstjenesten

- Oversiktlig befolkning

- Likeverdig tilbud som en grunnleggende verdi i norsk helse- og omsorgstjeneste

- Politiske og sosiale forventninger om pasientsentrert behandling 
arbeid for utdanningsinstitusjonene på palliasjonsfeltet.

Bedre organisering og samarbeid i palliativ forskning er nødvendig. For å heve kvaliteten og omfanget på den palliative forskningen nasjonalt og for å bidra internasjonalt må forskere på høyt nasjonalt og internasjonalt nivå arbeide sammen over flere år. Siden det publiseres få studier fra de palliative norske miljøene på høyt internasjonalt nivå, må kompetansen samles rundt sentrale problemstillinger og med forskere som i dag holder et høyt internasjonalt nivå. Med noen få unntak, som PRC, er det lite internasjonalt samarbeid.

Kombinasjonen av forhold som er skissert i boks 8.5 (Grunnleggende norske fortrinn) tilsier at ved å samle forskningen vil Norge kunne bidra på et høyt internasjonalt nivå. For å lykkes med dette bør det legges opp til samme struktur som innen grunnforskning basert på forskning med fremragende sentre, såkalte Sentre for fremragende forskning (SFF). Dette bør komme i tillegg til de generelle forskningsmidlene som det konkurreres om nasjonalt og regionalt. Utvalget mener at det bør etableres en betydelig langsiktig finansiering av flere palliative forskningsområder i Norge på lik linje med SFF-modellen for grunnleggende forskning.

Samtidig med at det satses på større sentre som skal bidra nasjonalt og internasjonalt, er det viktig å styrke den generelle forskningen i regionene. Dette skal koordineres og integreres av de regionale kompetansesentrene (se kapittel 9) gjennom regional heving av forskningskompetansen på master, $\mathrm{PhD}$ og postdoc-nivå. I de regioner som eventuelt får et palliativt senter for fremragende forskning bør dette også bidra inn mot den øvrige regionale og nasjonale forskningen. Utvalget mener at det er viktig å samordne kliniske studier regionalt og nasjonalt for å fremme planlegging og gjennomføring av større konklusive kliniske studier fremfor mange små studier som i liten grad kan bidra til å bedre klinisk praksis. Større studier med relevante endepunkt, fortrinnsvis multisenterstudier, kan bidra til kunnskapsbasert endring og omorganisering av praksis, og bør være et viktig satsingsområde for palliative forskning fremover.

Ved Kompetansesenter i lindrende behandling region Nord er det ingen ansatte $\mathrm{i}$ akademiske stillinger knyttet til palliasjon. Utvalget mener at det bør være forskningsaktivitet ved alle de regionale kompetansesentrene i lindrende behandling og det bør derfor opprettes et professorat ved Kompetansesenter i lindrende behandling region
Nord på lik linje med de andre kompetansesentrene.

I den regionale satsingen vil utvalget presisere at forskning i kommunene på palliative problemstillinger, spesielt på pasienter med kort forventet levetid og den døende pasient må være sentralt. Det regionale kompetansesenteret skal også bidra til å fremme denne forskningen i de sine regioner.

Tverrfaglighet er et viktig aspekt i palliasjon. Pasienten har behov for kunnskapsbasert tilnærming fra alle de involverte yrkesgrupper. Det er utvalgets inntrykk at det er lite aktivitet i tverrfaglig forskning og at dette må prioriteres.

Frivillige og ideelle aktører vil kunne være et viktig supplement i den palliative forskningen ved å løfte fram pasient- og brukerperspektivet.

Det er behov for styrket kunnskap gjennom forskning og innovasjon på det kommunale feltet. Kommunene har et ansvar for å bygge opp forskningskompetansen. Satsning på forskning i den kommunale helse- og omsorgstjenesten vil blant annet kunne bidra til en større mulighet for at pasienter skal få være mest mulig hjemme den siste tiden av livet og kunne få dø hjemme om en ønsker det.

Kommunene må selv være med på å bestemme hva som skal være målet og innholdet $\mathrm{i}$ forskningen. Forskning knyttet til det kommunale helsetjenestetilbudet må utvikles for å sikre bedret kunnskap innen palliasjon. Problemstillinger knyttet til pasienten og familienes utfordringer i møte med helsetjenesten og utviklingsbehov som kommunehelsetjenesten definerer, vil være utgangspunkt for forskningsaktiviteten.

Senter for omsorgsforskning kan, sammen med utviklingssentrene for sykehjem og hjemmetjenester, bidra med forskning, formidling og implementering av kunnskap i kommunen og samhandling mellom nivåene.

I dag bidrar kommunene i svært liten grad med egne forskningsmidler. Sett i lys av de store ressursene som brukes i palliasjon i den kommunale helse- og omsorgstjenesten bør det settes av betydelig ressurser til forskning på denne pasientpopulasjonen for å sikre god behandling basert på kunnskap. I dag gis dette basert på et meget lavt kunnskapsgrunnlag.

Utvalget mener at rapporter fra prosjekter som får midler fra tilskuddsordningen Kompetansehevende tiltak for lindrende behandling og omsorg ved livets slutt (Prop 1S (2016-2017), kap.761 post 67) bør gjøres tilgjengelige slik at kunnskap og erfaringer fra prosjektene kan komme fagmiljøet til gode. 


\subsubsection{Finansiering}

Hvis det skulle ha vært gitt forskningsmidler basert på ressurser som blir brukt i helse- og omsorgstjenestene i Norge, burde opp mot 50 prosent av ressursene av forskningen i spesialisthelsetjenesten gått til palliative prosjekter. Det meste av midlene går til forskningsprosjekter primært rettet mot selve sykdommen, og ikke mot pasienten (pasientsentrert). Det er et gap mellom behovet for palliativ forskning, pasientpopulasjonens størrelse, samfunnets behov og forskningsinnsatsen på området.

Program for palliativ forskning bør derfor etableres på flere nivåer. Dette bør skje både innen allokering av forskningsmidler på RHF- og HFnivå, på kommunalt nivå og i frivillige organisasjoner (NGO).

De frivillige organisasjonene gir betydelige midler til forskning hvert år. Med de store utfordringene helse- og omsorgstjenestene har i dag og hvor mye dreier seg om palliasjon, er det ønskelig at NGOene bruker mer midler til palliativ forskning. Utvalget mener at alle NGOene (og legater) som gir midler til klinisk forskning bør opprette egne program for palliativ forskning. NGOene vil kunne bidra til en betydelig kvalitetsog volumøkning av den palliative forskningen.

Ved en langsiktig finansiering av et (eller flere) sentre, som Sentre for fremragende forsking (SFF), er det i dag et faglig fundament som kan bidra med forskning på et høyt internasjonalt nivå. Dette vil også gi muligheter for at klinikere kan drive med forskning parallelt med klinikk ved at de kjøpes fri.

Forskningsrådet gir midler knyttet til prioriterte områder i samfunnet hvor det er behov for kunnskap. En pasientsentrert helsetjeneste og palliasjon bør være et slikt område. Palliative problemstillinger bør være en tydelig integrert del i de etablerte forskningsprogrammene i Forskingsrådet: Program for God og treffsikker diagnostikk, behandling og rehabilitering (Behandling), Bedre helse og livskvalitet (Bedrehelse) og Gode og effektive helse-, omsorgs-, og velferdstjenester (Helsevel).

Utvalget anbefaler at det etableres et eget forskningsprogram i palliasjon i Nasjonalt forskningsråd. Programmet må omhandle både den kommunale helse- og omsorgstjenesten og spesialisthelsetjenesten. Gjennom forskningsprogrammet kan at man få til en god dynamikk og stimulere nye tverrfaglige miljøer samt kunne etablere nasjonale og internasjonale forskningsgrupper. Forskning rettet mot frivillighet vil også kunne inngå i dette programmet.

\subsection{Konkrete forslag til tiltak - forskning}

- Det opprettes et eget forskningsprogram i Forskningsrådet for palliativ forskning for å støtte store, gode kliniske studier innen palliasjon.

- De regionale helseforetakene skal styrke den regionale palliative forskningen ved å bygge opp og støtte lokale og regionale palliative forskningsgrupper som skal ha nasjonale og internasjonale samarbeidspartnere.

- Det etableres en nasjonal finansiering for palliative sentere for fremragende forskning.

- De regionale palliative sentrene får likelydende oppdrag om forskningsoppgaver fra Helse- og omsorgsdepartementet via de regionale helseforetakene, og det rapporteres årlig.

- Det opprettes egne diagnosespesifikke kliniske kvalitetsregistre innen palliasjon, herunder et eget register for barn. 


\section{Kapittel 9 \\ Organisering, struktur og kompetanse}

\author{
Hvis du ikke forandrer noe, vil ikke noe forandre \\ seg.
}

Ukjent

\subsection{Innledning}

Pasienter med behov for palliasjon finnes $\mathrm{i}$ alle deler av helsetjenesten. De vil vekselvis ha behov for tilbud fra fastlege, den kommunale helse- og omsorgstjenesten og spesialisthelsetjenesten. Ingen palliative forløp utvikler seg likt.

Pasienter med mindre komplekse palliative behov vil få hjelp i den kommunale helse- og omsorgstjenesten. Mange pasienter vil også ha behov for det spesialiserte palliative tilbudet, enten ved poliklinisk behandling eller ved konsultasjon fra palliativt team i hjemmet. Pasienter vil også ha komplekse palliative behov slik at de trenger innleggelse i en palliativ enhet i kortere eller lengre tid.

Pasienter med behov for palliasjon bør få hjelp i den ordinære helse- og omsorgstjenesten for å sikre helhetlige og koordinerte forløp og et likeverdig palliativt tilbud uavhengig av diagnose. Utvalgets flertall anbefaler at de palliative tjenestene, herunder palliasjon i livets aller siste fase, ikke organiseres som en særomsorg på siden av den ordinære helse- og omsorgstjenesten. Internasjonalt og nasjonalt anbefaler fagmiljøene at palliasjon må komme inn i pasientforløpet så snart pasienten har fătt en alvorlig diagnose, og at palliasjon integreres i den øvrige kliniske aktiviteten, både $\mathrm{i}$ spesialisthelsetjenesten, hos fastlegen og $\mathrm{i}$ den kommunale helse- og omsorgstjenesten (Helsedirektoratet, 2015a, Hui og Bruera, 2016).

For å innfri pasientenes behov og målsettingene i helse- og omsorgstjenesten må det stilles krav til hvordan de palliative tjenestene organiseres. Innholdet i og organiseringen av de palliative tjenestene påvirker hvordan pasientens behov blir ivaretatt. Kvaliteten i tilbudet til pasientene kan kun i begrenset grad måles gjennom resultater på enhetsnivå. Forskning og utvikling, undersøkel- ser og analyser av hva som samlet gir de beste tjenestene for pasientene bør danne grunnlag for tjenesteutvikling hvor hele bredden av tjenester inngår.

Intensjonene i samhandlingsreformen er å sikre bærekraftig, helhetlig og sammenhengende tjenestetilbud av god kvalitet, med høy pasientsikkerhet og tilpasset den enkelte pasient. Kommunene og fastlegene har fått større ansvar for behandling og oppfølging av pasienter. De organisatoriske strukturene må tilpasses volumet av pasienter, ansvarfordeling, variasjoner i befolkningstetthet og geografiske avstander.

Det er for eksempel store forskjeller mellom organiseringen av de palliative tjenestene i en stor kommune som Oslo og i en mindre kommune, for eksempel i Nord-Norge. Det vil også være forskjeller i organiseringen innad i spesialisthelsetjenesten, fra de største universitetssykehusene til mindre lokalsykehus. Et viktig politisk prinsipp er at helse- og omsorgstjenesten skal tilbys nærmest mulig der pasienten bor, og at det nasjonalt skal være et likeverdig tilbud til alle pasienter.

Selv om det er store geografiske og volummessige forskjeller innad og mellom de enkelte kommuner og sykehus, er det fortsatt de samme prinsippene som skal legges til grunn for organiseringen av de palliative tjenestene. Det er en målsetting å få sammenhengende pasientforløp og tidlig integrasjon av de palliative tjenestene sammen med den øvrige helse- og omsorgstjenesten. For å nå disse målsettingene er det nødvendig at helsepersonell har høy kompetanse i palliasjon.

Forskningsrapporter og kunnskapsoppsummeringer viser at kvalitet ofte påvirkes av antall behandlinger utfort av behandleren eller behandlingsenheten. Sykehus som behandler mange pasienter med en bestemt problemstilling har ofte bedre resultater enn sykehus som behandler få pasienter. Det gjelder særlig ved kompliserte prosedyrer og behandling av alvorlig syke pasienter (Kunnskapssenteret, 2014). Det er med andre ord en sammenheng mellom pasientvolum og kvalitet. Derfor bør helsetjenesten utformes og organise- 
res slik at behandlere og behandlingsinstitusjoner har det nødvendige volum for å sikre god kvalitet (Nasjonalt råd for prioritering $\mathrm{i}$ helsetjenesten, 2009). Lavt volum gir spesielle utfordringer, og på palliasjonsfeltet gjelder dette særlig for palliasjon til barn. Det kan derfor være behov for å samle noen behandlinger og prosedyrer på regionalt nivå. Barneavdelingene bør ha en sentral og tydelig rolle i gjennomføring av de palliative pasientforløpene, både i spesialisthelsetjenesten og i den kommunale helse- og omsorgstjenesten. Samtidig ser utvalget det som sannsynlig at de fleste familier som har barn med behov for palliative tjenester vil ønske å bo hjemme så lenge som mulig. Dette bør imøtekommes så langt det er mulig gjennom et grunnleggende og et spesialisert palliativt behandlingstilbud i familiens hjem. Dette vil ofte kreve et tett og formalisert samarbeid mellom spesialisthelsetjenesten, fastlegen, den kommunale helse- og omsorgstjenesten og barnets familie. Prinsipielt bør forløpet og samarbeidet skje på samme måte som for voksne pasienter.

Palliasjon omfatter ivaretakelse av pasientenes fysiske, psykiske, sosiale og åndelige/eksistensielle behov. Dette krever en tverrfaglig tilnærming. Utvalget vil understreke betydningen av at det tverrfaglige perspektivet er til stede fra starten av når en pasient med palliative behov skal vurderes og behandles.

Det er en grunnleggende verdi å legge til rette for at pasienter som vil og kan være hjemme, og de som ønsker å dø hjemme, skal få mulighet til det.

Tidlig integrasjon av palliasjon i pasientforløpet $o g$ integrasjon av den palliative tilnærmingen inn i de kliniske avdelingene på sykehusene, vil kunne bidra til å redusere overbehandling. En slik integrering finnes i liten grad i sykehusene i dag. Det er derfor et mål at sykehusene skal ha spesialister som også har formell kompetanse i palliasjon. Det vises til nærmere omtale av overbehandling i kapittel 4.

Palliasjon foregår innenfor de fleste fagområder og på alle nivåer i helsetjenesten. Det vil i framtiden være et økende behov for palliasjon, og det blir viktig å forvalte ressursene best mulig og mest mulig effektivt. Vi må tenke nytt om organisering og hvordan kompleksiteten både i sykdomsbildet og i helse- og omsorgstjenesten best kan håndteres. Det blir også viktig å tydeliggjøre innhold i og samarbeid mellom grunnleggende og spesialisert palliasjon.

\subsection{Dagens situasjon}

St.meld. nr. 47 (2008-2009) Samhandlingsreformen gir anbefalinger om organiseringen av helseog omsorgstjenestene og Nasjonalt handlingsprogram for palliasjon $i$ kreftomsorgen (Helsedirektoratet, 2015b) gir anbefalinger om organisering av palliative tjenester. Nasjonal faglig retningslinje for palliasjon til barn og unge uavhengig av diagnose (Helsedirektoratet, 2017) gir anbefalinger om organisering, forløp og kompetanse for palliasjon til barn. I kapittel 9.2.1 og 9.2.2 beskrives dagens organisering av palliative tjenester. I boks 9.1. vises noen sentrale elementer som bør være grunnleggende for organiseringen av palliative tjenester.

\subsubsection{Dagens organisering, struktur og kompetanse i palliasjon i spesialisthelsetjenesten}

Regionalt palliativt senter

Hver helseregion skal ha et regionalt palliativt senter på regionsykehuset med en klinisk del og en forsknings- og utviklingsdel.

\section{Boks 9.1 Formålet for organiseringen av palliasjon}

- Pasienten, de pårørende og aktuell behandler har til enhver tid tilgang til nødvendig hjelp ut fra sine behov

- Behandling, pleie og omsorg gis innenfor rammene av fleksible og individuelt tilpassede systemer på tvers av nivåene, med klar plassering av ansvar

- Tilbudene baseres på en helhetlig og tverrfaglig tilnærming

- Pasienten og de pårørende opplever at de får hjelp i en «sømløs» tiltakskjede med god kommunikasjon og samhandling

- Det legges til rette for at behandling, pleie og omsorg kan skje i hjemmet eller så nær hjemmet som mulig

- Organiseringen fremmer den videre utviklingen av fagområdet palliasjon, både klinisk praksis og forskning

- Anbefalingene understreker også at man bør tilstrebe at pasientene kan dø på stedet der de selv ønsker

Kilde: Kaasa og Loge, 2016 


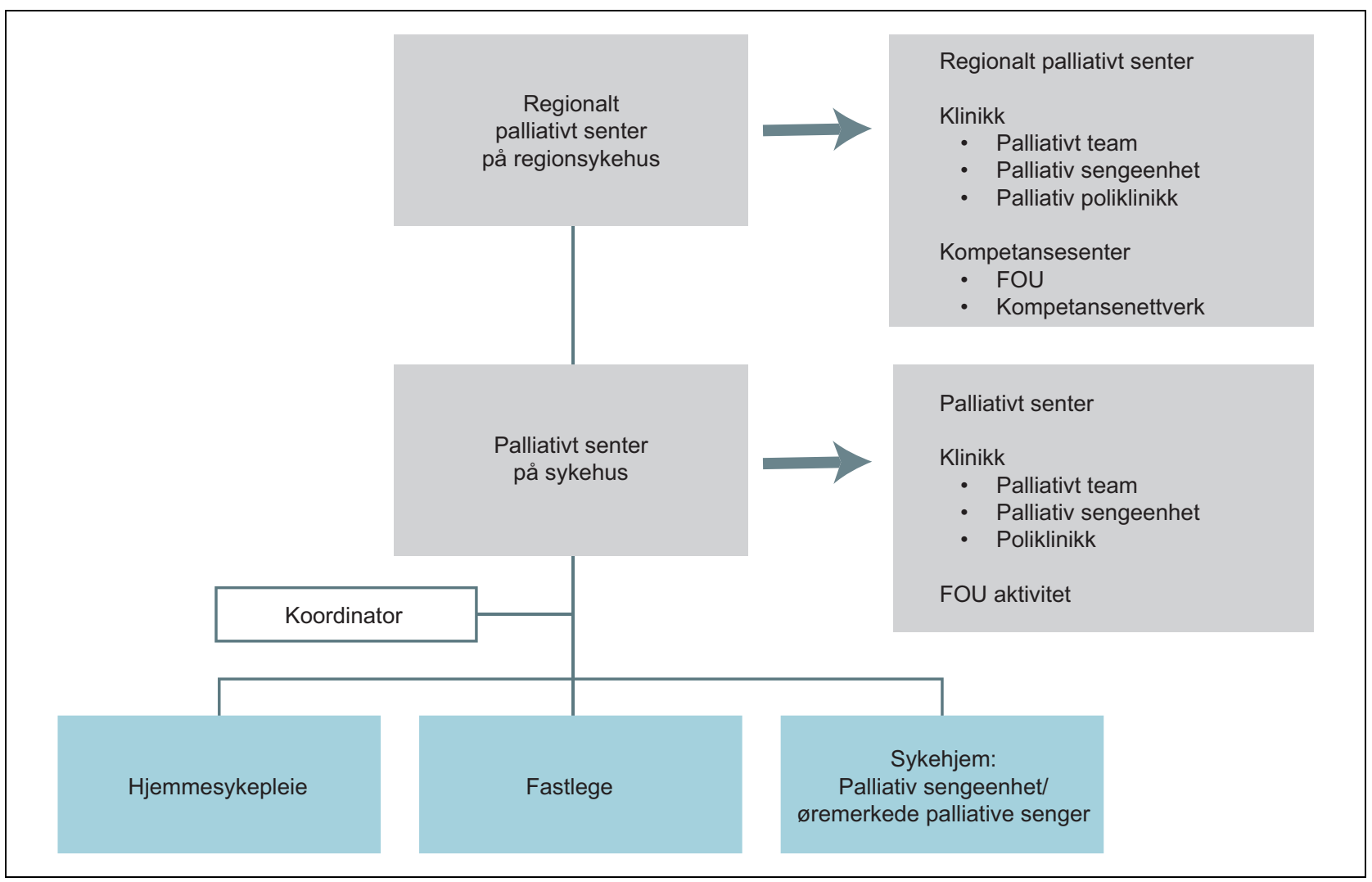

Figur 9.1 Det særskilt organiserte palliative tilbudet til voksne

\section{Klinisk del}

Ved den kliniske delen behandles pasienter i sykehuset, i all hovedsak fra sykehusets nedslagsfelt, men den er også en referanseavdeling for palliative sentre på sykehus i egen region. Det regionale palliative senteret kan bidra med råd og veiledning, behandling av pasienter med spesielt komplekse plager og symptomer, hospiteringstilbud og praksissted, og være base for kliniske studier og annen forskning. Senteret har en samordnende funksjon for de palliative sentrene ved andre sykehus i sin region. Det regionale palliative senteret skal bidra til formidling av ny kunnskap og til at det arbeides med satsings- og utfordringsområder som trenger å styrkes i regionen. Regionalt palliativt senter skal være tverrfaglig bemannet.

\section{Forsknings- og utviklingsdel}

Det regionale kompetansesenteret for lindrende behandling utgjør forsknings- og utviklingsdelen av det regionale palliative sentret.

Nasjonalt handlingsprogram for palliasjon $i$ kreftomsorgen gir anbefalinger om hvilke funksjoner de regionale kompetansesentrene for lin- drende behandling skal ha. De regionale kompetansesentrene for lindrende behandling er tillagt et spesielt ansvar for undervisning og opplæring $\mathrm{i}$ regionen, forskning og kompetansenettverk (Helsedirektoratet, 2015b).

Helse Sør-Øst RHF har utarbeidet en generell retningslinje for etablering, organisering og finansiering av regionale kompetansetjenester. Kompetansesenteret for lindrende behandling har endret navn til Regional kompetansetjeneste for lindrende behandling, i tråd med Helse Sør-Øst sin retningslinje, og i tråd med at tidligere nasjonale medisinske kompetansesenterfunksjon er endret til nasjonal kompetansetjeneste (Helse- og omsorgsdepartementet, 2010). Det framgår av retningslinjen til Helse Sør-Øst RHF at begrepet kompetansetjeneste også omfatter forskningsaktivitet. Oppgaver for regionale kompetansetjenester i Helse Sør-Øst RHF er beskrevet i boks 9.4 (Helse Sør-Øst RHF, 2012).

I Helse Sør-Øst er kompetansesenter for lindrende behandling en enhet i Seksjon lindrende behandling ved avdeling for kreftbehandling, Kreftklinikken ved Oslo universitetssykehus HF. Kompetansesenteret hadde ved utgangen av 2016 8,9 årsverk (Kompetansesenter for lindrende behandling Helseregion Sør-Øst, 2016). 


\section{Boks 9.2 Grunnleggende og spesialisert palliasjon}

Grunnleggende palliasjon innebærer god behandling, symptomlindring og omsorg mot livets slutt, eventuelt gjennom livsløpet, for personer med uhelbredelige lidelser eller funksjonshemninger. Palliasjon omfatter også oppfølging av pårørende og etterlatte.

Grunnleggende palliasjon skal utøves i alle deler av helse- og omsorgstjenesten som har ansvar for alvorlig syke og døende. Grunnleggende palliasjon gis ved vanlige sykehusavdelinger, på sykehjem og i hjemmesykepleien, samt $\mathrm{i}$ allmennpraksis (fastleger). Alle virksomheter der det er alvorlig syke pasienter og/eller døende skal utøve grunnleggende palliasjon.

Spesialisert palliasjon utøves i de deler av sektoren som har palliasjon som sin primære oppgave. Dette omfatter palliative team, palliative enheter, poliklinikker og dagenheter i sykehus. Spesialisert palliasjon utøves i tverrfaglige team, som skal bestå av lege og sykepleier, og i tillegg skal minst to andre yrkesgrupper være fast tilknyttet (prest, sosionom og/eller fysioterapeut). Ansatte i det spesialiserte tilbudet skal sørge for kompetanseheving gjennom å gi råd, veiledning og undervisning til dem som utøver grunnleggende palliasjon. Hoveddelen av arbeidet som gjøres innenfor spesialisert palliasjon er for kreftpasienter. Det kan tyde på at det er nødvendig med en styrking av det spesialiserte palliative tilbudet for andre pasientgrupper.

Kilde: (Helsedirektoratet, 2015 a)
I Helse Vest RHF er det utarbeidet generelle kriterier for alle regionale kompetansesentre (dvs. på en rekke ulike fagområder i helseregionen). Generelle kriterier for regionale kompetansesentre i Helse Vest RHF fremgår av boks 9.3.

I Helse Vest fungerer Kompetansesenter i lindrande behandling Helseregion Vest som en selvstendig enhet. Senteret er organisert som en seksjon i Avdeling for kreftbehandling og medisinsk fysikk ved Haukeland universitetssjukehus, Helse Bergen HF. Kompetansesenteret er organisert med en sentral enhet ved Haukeland universitetssjukehus, tilknyttet et tverrfaglig nettverk av regionale medarbeidere i deltidsstilling i sykehus og kommuner i regionen. I 2016 utgjorde dette 6,7 årsverk fordelt på 23 ansatte. Sju ansatte arbeidet $\mathrm{i}$ den sentrale delen av senteret ved Haukeland universitetssjukehus, de øvrige var deltidsansatte medarbeidere i regionen (Kompetansesenter i lindrande behandling Helseregion Vest, 2016). Det er utarbeidet en egen strategi for palliasjon i Helse Bergen HF, der kompetansesenteret har en viktig rolle. Kompetansesenteret har en regionalt sammensatt styringsgruppe som vedtar strategi for kompetansesenteret hvor en årlig fremdriftsplan for senteret vedtas.

I Helse Midt-Norge er det regionale kompetansesenteret organisert som en enhet under Avdeling for palliasjon ved Kreftklinikken, St. Olavs hospital HF. 6 personer var tilknyttet senteret i 2016 (Regionalt kompetansesenter for lindrende behandling Midt-Norge, 2016).
I Helse Nord er det regionale senteret for lindrende behandling organisert som en enhet $\mathrm{i}$ Kreftavdelingen, Universitetssykehuset NordNorge HF. Kompetansesenteret har 4,8 årsverk (Lindring i nord, 2016).

\section{Kompetansenettverk}

De regionale kompetansesentrene har et overordnet ansvar for etablering, drift og utvikling av ulike palliative kompetansenettverk i sitt nedslagsområde. Kompetansenettverkene er bygget opp i samarbeid mellom kommuner og helseforetak. Nettverkene er formalisert gjennom forpliktende avtaler mellom foretak og kommuner og de fleste steder integrert i gjeldende avtaleverk. Flere steder er også høyskoler, utviklingssentre og frivillige organisasjoner med i samarbeidet. Nettverkene er generelt best utbygd for sykepleiere og dekker både kreftomsorg og lindrende behandling. Fagnettverk av ressurssykepleiere i kreft og lindrende behandling er en viktig arena for kompetanseheving, informasjonsarbeid og samhandling (Regionalt kompetansesenter for lindrende behandling i Helse Nord, 2016).

Det finnes i dag kompetansenettverk av om lag 2000 ressurssykepleiere i kreftomsorg og lindrende behandling i de aller fleste fylker i Norge. Flere steder er det også tilsvarende nettverk for fysioterapeuter, ergoterapeuter, sosionomer og ernæringsfysiologer og for helsepersonell som arbeider med smerteproblematikk. Det finnes 
Tabell 9.1 Oversikt over regionale palliative sentre (kompetansesenter og klinisk virksomhet) og palliative sentre (team og enheter) i spesialisthelsetjenesten og lindrende enheter og enkeltsenger i sykehjem i Norge, 2017.

\begin{tabular}{|c|c|c|c|c|c|}
\hline Helseregion & Sør-Øst & Vest & Midt-Norge & Nord & Sum \\
\hline $\begin{array}{l}\text { Befolkning } \\
\text { (avrundet, per } \\
\text { 01.01.2017) }\end{array}$ & 2950000 & 1100000 & 700000 & 500000 & 5250000 \\
\hline $\begin{array}{l}\text { Regionalt pallia- } \\
\text { tivt senter }^{1}\end{array}$ & $\begin{array}{l}\text { Oslo universi- } \\
\text { tetssykehus: } \\
\text { Kompetanse- } \\
\text { senter og kli- } \\
\text { nisk virksom- } \\
\text { het med pallia- } \\
\text { tivt team og } 12 \\
\text { senger på Ulle- } \\
\text { vål og palliativt } \\
\text { team og } 2 \text { sen- } \\
\text { ger på Radium- } \\
\text { hospitalet }\end{array}$ & $\begin{array}{l}\text { Kompetanse- } \\
\text { senter ved Hau- } \\
\text { keland universi- } \\
\text { tetssjukehus: } \\
\text { Klinisk virksom- } \\
\text { het ved Haralds- } \\
\text { plass Diakonale } \\
\text { sykehus med } \\
\text { palliativt team } \\
\text { og palliativ } \\
\text { enhet med } 8 \\
\text { senger }\end{array}$ & $\begin{array}{l}\text { St. Olavs hospi- } \\
\text { tal: Kompetan- } \\
\text { sesenter og kli- } \\
\text { nisk virksom- } \\
\text { het (Seksjon lin- } \\
\text { drende behand- } \\
\text { ling) med } \\
\text { palliativt team } \\
\text { og enhet med } \\
12 \text { senger }\end{array}$ & $\begin{array}{l}\text { Universitets- } \\
\text { sykehuset } \\
\text { Nord-Norge: } \\
\text { Kompetanse- } \\
\text { senter og kli- } \\
\text { nisk virksom- } \\
\text { het med pallia- } \\
\text { tivt team }\end{array}$ & $\begin{array}{l}4 \text { kompetanse- } \\
\text { sentre } \\
5 \text { team } \\
\text { ( } 2 \text { ved OUS) } \\
4 \text { enheter } \\
\text { ( } 2 \text { ved OUS) } \\
34 \text { senger }\end{array}$ \\
\hline $\begin{array}{l}\text { Palliative sentre } \\
\text { i sykehus }^{1}\end{array}$ & $\begin{array}{l}18 \text { team } \\
11 \text { enheter } \\
\text { (56 senger) }\end{array}$ & $\begin{array}{l}4 \text { team } \\
2 \text { enheter } \\
\text { ( } 7 \text { senger) }\end{array}$ & $\begin{array}{l}6 \text { team } \\
2 \text { enheter } \\
\text { ( } 7 \text { senger) }\end{array}$ & $\begin{array}{l}7 \text { team } \\
2 \text { enheter } \\
\text { ( } 6 \text { senger) }\end{array}$ & $\begin{array}{l}35 \text { team } \\
17 \text { enheter } \\
\text { ( } 76 \text { senger) }\end{array}$ \\
\hline $\begin{array}{l}\text { Lindrende } \\
\text { enheter og } \\
\text { senger i syke- } \\
\text { hjem² }^{2}\end{array}$ & $\begin{array}{l}32 \text { enheter } \\
\text { ( } 209 \text { senger) } \\
21 \text { enkeltsenger }\end{array}$ & $\begin{array}{l}7 \text { enheter } \\
\text { (44 senger) } \\
56 \text { enkeltsenger }\end{array}$ & $\begin{array}{l}5 \text { enheter } \\
\text { (19 senger) } \\
32 \text { enkeltsenger }\end{array}$ & $\begin{array}{l}4 \text { enheter } \\
\text { (22 senger) } \\
38 \text { enkeltsenger }\end{array}$ & $\begin{array}{l}48 \text { enheter } \\
\text { ( } 294 \text { senger) } \\
147 \text { enkelt- } \\
\text { senger }\end{array}$ \\
\hline
\end{tabular}

Kommunale 1' (Fransiskus-

palliative team hjelpen i Oslo)

Sum palliative

senger totalt

300

115

70

66

551

118 palliative sentre er godkjent som utdanningssted for Kompetanseområde palliativ medisin per oktober 2017: 11 i Helse SørØst, 4 i Helse Vest, 2 i Helse Midt-Norge og 1 i Helse Nord. (Kilde: Helsedirektoratet.)`Fransiskushjelpen i Oslo

2 Palliativ sengeenhet i sykehjem er organisatorisk tilrettelagt og har faglig kompetent personale for å kunne gi mer avansert palliasjon enn det som kan tilbys i en vanlig sykehjemsavdeling. Palliative senger i sykehjem er senger øremerket for palliasjon som krever skjerming, mulighet for overnatting for pårørende og tilstrekkelig kompetanse hos personalet for å gi god grunnleggende palliasjon. Minst en sykepleier bør ha videreutdanning i kreftsykepleie eller palliasjon.

3 Lindrende enhet i spesialisthelsetjenesten har akuttsenger og tilstreber en liggetid på 5-7 dager, har aktiv diagnostikk og behandling og muligheter for opphold i pasientens siste levetid (terminalfase).

Kilde: PallReg.no

også et nasjonalt nettverk for åndelig/eksistensiell omsorg i palliasjon.

Målene med nettverkene er å være en lokal ressurs innen palliativ behandling, spre kompetanse og bidra til samhandling på tvers av tjenestene. Kompetansenettverkene er viktige for å sikre samarbeid og kontinuitet og en felles tilnærming mellom kompetansesentrene og palliative enheter i spesialisthelsetjenesten, og med den kommunale helse- og omsorgstjenesten. Minst en sykepleier i hver kommune bør være med i nettverket av ressurssykepleiere $\mathrm{i}$ foretaksområdet.
Dersom kreftsykepleier er ansatt i kommunen, vil det være naturlig at kreftsykepleier har denne funksjonen. Ressurssykepleier skal bistå det øvrige personalet $\mathrm{i}$ hjemmesykepleien med råd og veiledning, og kan om nødvendig også delta i pleien. Ressurssykepleier er kontaktperson for palliativt senter i foretaket. 


\section{Boks 9.3 Kriterier for regionale kompetansesentre i Helse Vest}

Regionale kompetansesentre må oppfylle følgende kriterier:

- Inneha faglig høy kompetanse og en tilstrekkelig nødvendig støttestruktur

- Adekvat pasientvolum - hvis klinisk virksomhet

- Evne til samarbeid og innen sitt felt bygge opp et nødvendig fagnett regionalt, nasjonalt $o g$ internasjonalt

- Utarbeide retningslinjer for pasientlogistikk og pasientinformasjon

- Drive forskning, utvikling og undervisning med spredning av kunnskap til hele regionen

- Arbeide for «evidence based medicine» (EBM)

- Lede og utvikle retningslinjer for etablering av nye teknikker og metodeutvikling (guidelines)

- Kontinuerlig kunne redegjøre for behandlingsresultat

- Opprette registerfunksjon

Av kriteriene fremgår det også at det regionale kompetansesenteret bør gjennomgå en omfattende evaluering hvert 3-5. år.

Kilde: Helse Vest, Regionale kompetansesentre i Helse Vest. Arbeidsgrupperapport 2003

\section{Palliativt senter på sykehus}

Palliativt senter på sykehus består av et tverrfaglig behandlingsteam (palliativt team) og det kan også inneholde en palliativ enhet, dvs. senger.

Totalt finnes det 40 palliative sentre i Norge, alle har et palliativt team. Ved 21 av sentrene er det også palliativ sengeenhet med til sammen 110 senger (PallReg, 2017). Noen av sentrene har egen dagenhet. To av de palliative sentrene bruker benevnelsen hospice, Hospice Lovisenberg og Hospice Sangen, begge organisatorisk en del av Lovisenberg Diakonale Sykehus.

\section{Palliativt team}

Det palliative teamet skal ha bred kompetanse innen palliasjon. Teamet er helseforetakets utadrettede tilbud i spesialisert palliasjon. Teamet

\section{Boks 9.4 Oppgaver for regionale kompetansetjenester Helse Sør-Øst}

Hovedfokus for kompetansetjenestene skal være å formidle og bygge opp kompetanse, samt bidra til at det utarbeides handlingsplan for kompetansespredning og implementering av nasjonale retningslinjer og kunnskapsbasert praksis. Oppgaver og ansvarsforhold mellom kompetansetjenestene og aktuelle fagråd må avklares i hvert enkelt tilfelle.

I tillegg skal kompetansetjenestene:

- Sørge for veiledning, kunnskaps- og kompetansespredning til helsetjenesten og der det er aktuelt også til kommunehelsetjenesten

- Bidra i relevant undervisning

- Bidra til forskning og etablering av forskernettverk

- Initiering og drift av fagnettverk

- Samarbeid med universitetene og høgskolene i regionen for å tilrettelegge for utdanningsløp innen kompetanseområdet ved behov

- Utarbeide behandlingsforløp som omfatter hele regionen og bidra med evidensbasert kunnskap inn i relevante behandlingslinjer rundt flerområde- $o g$ regionale funksjoner

- Bistå Helse Sør-Øst RHF med å utvikle styringsindikatorer, med hensyn til aktivitet, kvalitet og resultat/effekt av medisinsk behandling, rehabilitering og habilitering

Kilde: Helse Sør-Øst, 2012. Retningslinje for etablering, organisering og finansiering av regionale kompetansetjenester i Helse Sør-Øst

bistår sykehusets avdelinger med kliniske konsultasjoner, råd og veiledning om palliative problemstillinger. Flere av teamene har også ambulant virksomhet til pasientens hjem eller til sykehjem, $i$ samhandling med den kommunale helse- og omsorgstjenesten. Palliativt team vil da i hovedsak ha en konsulentfunksjon. De palliative teamene er mange steder sentrale for å bidra til gode forløp og styrke samhandlingen innad i spesialisthelsetjenesten og mellom spesialisthelsetjenesten og den kommunale helse- og omsorgstjenesten. Erfaring og studier viser at støtte fra et palliativt team til fastlegen og hjemmesykepleien skaper trygghet og ofte er avgjørende for å få til et godt palliativt tilbud i hjemmet (Meld. St. 26 (2014-2015)). 
De fleste teamene har hoveddelen av sin aktivitet innad i sykehuset, og omfanget av den polikliniske aktiviteten og øvrig aktivitet (de ambulante funksjonene) til den kommunale helse- og omsorgstjenesten er varierende. En nasjonal kartlegging i 2014 av de palliative teamene i spesialisthelsetjenesten, viste at 66 prosent av tilsyn var til inneliggende pasienter, 19 prosent polikliniske konsultasjoner, 12 prosent hjemmebesøk og 3 prosent konsultasjoner i sykehjem og lignende institusjoner (Kompetansesenter i lindrande behandling Helseregion Vest, 2014).

Opplysninger fra de palliative teamene viser at det palliative tilbudet gis til alle avdelinger og pasientgrupper, men at det fortsatt er hovedsakelig kreftpasienter som henvises til teamene (Hestnes 2014, Lekven B.E L., 2016). Ved nasjonal kartlegging i 2012 og 2014 ble det funnet at hhv. $98 \mathrm{og}$ 97 prosent av pasientene hadde kreft og at spesialisert palliasjon ser ut til å være et tilbud som først og fremst kommer kreftpasienter tilgode. I spesialisthelsetjenesten kan dette ha sammenheng med at flere av enhetene er samlokalisert med onkologisk avdeling (Kompetansesenter i lindrande behandling Helseregion Vest, 2014).

\section{Palliativ enhet i spesialisthelsetjenesten}

I Norge brukes betegnelsen lindrende/palliativ enhet om et særlig organisert tilbud i institusjon rettet mot personer som trenger palliativ behandling. De palliative enhetene i sykehus har et avansert tilbud. De sentrale oppgavene er utredning av sammensatte symptomer inkludert psykososiale utfordringer.

En palliativ enhet skal være en definert enhet eller definerte senger der pasientene kan være inneliggende for palliativ behandling (Helsedirektoratet, 2015b). En palliativ enhet anbefales å ha akuttsenger med vekt på problemløsning og kort liggetid på 5-7 dager, drive aktiv diagnostikk og behandling når det gjelder symptomlindring og optimalisering av funksjon, planlegge pasientens videre oppfølgning og ha mulighet for opphold i pasientens terminalfase (Helsedirektoratet, 2015b).

\section{Forskning og utvikling (FOU)}

Det palliative senteret skal ha forskning og utvikling som en del av sin virksomhet. I samarbeid med regionalt palliativt senter skal virksomheten blant annet omfatte utarbeidelse av prosedyrer og retningslinjer for eget helseforetak, inkludert nettverket av ressurssykepleiere, undervisning og hospitering, samt deltakelse i forsknings- og fagutviklingsprosjekter (Helsedirektoratet, 2015b).

\section{Dagbehandling}

Dagbehandling er palliativ behandling, pleie og omsorg gitt som behandling til polikliniske pasienter. Innholdet skal i henhold til retningslinjene (Helsedirektoratet, 2015b) ha en sammensetning og varighet som klart skiller tilbudet fra en poliklinisk konsultasjon. Dagbehandling kan gis på poliklinikken på palliativt senter, på palliativ enhet eller på egen dagavdeling. Dagbehandling skal være et medisinsk tilbud med lege- og sykepleiertjenester og tilgang til konsultasjoner hos alle medlemmer av det palliative teamet. Det er i dag tre palliative dagavdelinger $\mathrm{i}$ spesialisthelsetjenesten. Noen kommuner har også dagtilbud for palliative pasienter.

\section{Smerteklinikker}

I Norge var det registrert 16 tverrfaglige smerteklinikker i 2013 (Helsedirektoratet, 2015c). Smerteklinikken har ansvar for å bidra til smertebehandling av pasienter med akutte og/eller langvarige smertetilstander og palliative pasienter. Tilbudet omfatter tverrfaglige smertesentre ved Oslo universitetssykehus, Haukeland universitetssykehus, St. Olavs hospital og Universitetssykehuset i Nord-Norge og smertepoliklinikker ved flere av de øvrige sykehusene. Alle de fire største klinikkene er tverrfaglig bemannet, dvs. med minimum lege, fysioterapeut, psykolog og sykepleier, som skal være til stede i klinikken samtidig. Sentrene har både poliklinikk og konsulentfunksjon for inneliggende pasienter. I 2013 var det totalt 6 klinikker med tverrfaglig drift, og 10 uten alle faggrupper representert. Det er i dag (2017) flere smerteklinikker, og antallet med tverrfaglig bemanning har økt.

Alle enhetene skal gi et tilbud for alle typer vanskelige smertetilstander. I følge Helsedirektoratets veileder for organisering og drift av tverrfaglige smerteklinikker, skal smertesentrene/klinikkene ha organisert samarbeid med palliativt senter og enhetene kan med fordel være samlokalisert. Ved enkelte sykehus har smerteklinikkene hatt ansvar for oppfølging av palliative pasienter som ikke er innlagt på kreftavdelinger. Det er vanlig med et samarbeid mellom palliative team og smerteklinikkene om pasienter med vanskelige smertetilstander. Ved Haukeland universitetssykehus er palliativt team en del av smertesenteret og de er organisert i samme seksjon, Seksjon 
Tabell 9.2 Kartlegging av smerteenheter 2013

\begin{tabular}{lrrrr}
\hline & Sør-Øst & Vest & Midt & Nord \\
\hline Tverrfaglige smertesentre & 1 & 1 & 1 & 1 \\
Smerteklinikker med tverrfaglig drift & & 1 & & 1 \\
Smerteklinikker uten tverrfaglig drift & 6 & 2 & 2 & \\
\hline
\end{tabular}

smertebehandling og palliasjon. (Helsedirektoratet, 2015b).

\subsubsection{Dagens organisering av det palliative tilbudet i den kommunale helse- og omsorgstjenesten}

I den kommunale helse- og omsorgstjenesten skal grunnleggende palliasjon gis i hjemmesykepleien, i omsorgsboliger, i sykehjem eller tilsvarende bolig særskilt tilrettelagt for heldøgnstjenester og i allmennpraksis. I tillegg til lege og sykepleier bidrar også andre grupper helsepersonell som fysioterapeuter og ergoterapeuter til å gi grunnleggende palliasjon. Spesialisert palliasjon skal gis i lindrende/palliative enheter ved heldøgns omsorgsboliger.

\section{Institusjonsbaserte palliative tjenester i kommunen}

Totalt finnes det 44 palliative enheter i den kommunale helse- og omsorgstjenesten. Tre av disse enhetene bruker benevnelsen hospice; Hospice Austjord, Hospice/lindrende enhet Solvang Helsehus og Hospice Stabekk. Noen lindrende enheter er definert som halvannenlinjetjeneste og mottar finansiering fra det lokale helseforetaket $\mathrm{og}$ fra kommunen, f.eks. Øya Helsehus i Trondheim.

Spesialisert palliasjon i kommunen er organisert gjennom palliative enheter og «palliative/lindrende senger» i sykehjem. En kommunal palliativ enhet i boformer med heldøgns pleie, oftest i sykehjemmet, sykestue, helsehus eller distriktsmedisinsk senter, er organisatorisk tilrettelagt og har faglig kompetent personale for å kunne gi mer avansert palliativ behandling og pleie enn det som kan tilbys i en vanlig sykehjemsavdeling. En palliativ enhet i kommunen er et tilbud til pasienter som ikke har mulighet til å få omsorg i eget hjem, har behov for avlastning, eller trenger hjelp til bedret symptomkontroll. Nasjonalt handlingsprogram for palliasjon $i$ kreftomsorgen (Helsedirektoratet, 2015b), stiller krav til organisering av palliative enheter i kommunene. Disse enhetene skal ha eget pleiepersonell (sykepleiere og hjelpepleiere) og økt bemanning i forhold til bemanningen ved vanlige sykehjemsavdelinger. En lege med fast tilknytning skal være ved enheten, og legen skal ha kompetanse i palliasjon. Enheten skal videre ha økt legebemanning i forhold til vanlige sykehjemsavdelinger. En palliativ enhet bør organiseres i sykehjem, helsehus el. lign. og ha minst fire senger. Tilsvarende vil gjelde for organisering i en sykestue eller på et distriktsmedisinsk senter.

Enheten skal ha tilbud om kort- eller langtidsopphold, og pleie og omsorg inntil døden. Jo færre senger den lindrende enheten har, jo mer aktualiseres utfordringen med å opparbeide seg og vedlikeholde palliativ kompetanse. Også i større kommuner kan det være utfordrende med riktig kompetanse blant de ansatte (Sintef, 2016).

En palliativ sykehjemsenhet vil være realistisk i kommuner med flere enn 10-15 000 innbyggere. Et alternativ i mindre kommuner kan være øremerkede palliative senger som benyttes etter behov, eller etablering av interkommunale løsninger. Fortsatt mangler en del kommuner en palliativ/lindrende enhet, alene eller i interkommunale ordninger (Helsedirektoratet, 2015a). I Finnmark er det kun etablert palliative senger, mens det $\mathrm{i}$ Troms i de siste årene er etablert en lindrende enhet i Tromsø og 4 senger i Harstad.

Av landets 426 kommuner har 46 heldøgns omsorgsboliger eller sykehjem med en lindrende enhet. Totalt har de lindrende enhetene til sammen 285 senger. I tillegg er det to interkommunale enheter med til sammen 9 senger, og en seng på et distriktsmedisinsk senter. Det finnes 146 enkeltsenger tilrettelagt for pasienter som trenger palliativ behandling, ofte omtalt som lindrende senger, fordelt på 97 sykehjem. Totalt er det etablert 441 lindrende senger fordelt på sykehjem eller andre institusjoner i den kommunale helse- og omsorgstjenesten (PallReg, 2017).

Det er ikke palliative team i den kommunale helse- og omsorgstjenesten (PallReg, 2017), med ett unntak: Stiftelsen Fransiskushjelpen, Pleietjenesten, Oslo kommune (PallReg, 2017). Pleietjenesten i Fransiskushjelpen er et ambulerende hospiceteam i Oslo, med døgntjeneste til kreftpasienter. Fransiskushjelpens lege er tilsynslege i 20 prosent stilling (www.fransiskushjelpen.no). 
Det finnes ingen fullstendig oversikt i dag over hvordan det palliative tilbudet i kommunene er organisert. De største byene synes å ha et fragmentert tilbud. For å illustrere dette har utvalget innhentet informasjon om hvordan det palliative tilbudet er organisert $\mathrm{i}$ fire av de største byene $\mathrm{i}$ Norge. I Oslo kommune er det kun ett sykehjem som har øremerkede palliative funksjoner, Solvang helsehus, der hospice/lindrende enhet har 16 palliative senger. Det er ikke noe palliativt team knyttet til enheten. Enheten drives som et samvirke mellom bydelene i Oslo.

I Bergen er det 8 palliative senger ved et sykehjem (Bergen Røde Kors sykehjem), og det finnes ikke noe palliativt team i kommunen. I Trondheim er det en palliativ enhet på Øya Helsehus med 8 senger, men ikke noe kommunalt palliativt team knyttet til enheten (PallReg, 2017). Den palliative enheten er tett knyttet opp til teamet på Seksjon Lindrende behandling på St. Olavs hospital. I Tromsø åpnet en lindrende avdeling med 9 plasser på det nye helsehuset i 2017 (www.tromso.kommune.no).

Det er et ubesvart spørsmål om sykehjem uten palliativ enhet eller palliative senger klarer å legge til rette for og gi god symptomlindring og god terminal pleie og omsorg for alle pasientene i sykehjemmet.

\section{Legedekning i sykehjem}

Norge har ca. 1000 sykehjem med til sammen over 40000 beboere. Mer enn 45 prosent av alle dødsfall skjer i sykehjem. Fra 2005 til 2015 økte antall legeårsverk i sykehjem fra 274 til 569. (Helsedirektoratet, 2015). I 2016 var antall legeårsverk økt til 590 (SSB, 2017). Dette er en positiv utvikling, men det er fortsatt for dårlig legedekning mange steder (Sintef, 2016). Det er ingen fast norm for legetimer i sykehjem, og ingen spesifikke krav til spesialisering.

I forbindelse med innføring av lokal normering av legetjenester i sykehjem, ble legeårsverk innført som kvalitetsindikator i KOSTRA (KOmmuneSTat-RApportering) for sammenligning mellom kommuner. Det har vært en utvikling med mer behandlingstrengende sykehjemspasienter, både som følge av tidligere utskrivninger fra spesialisthelsetjenesten, og øyeblikkelig hjelp innleggelser i et kommunalt døgnopphold i sykehjem.

Nyere norske studier om livets siste tid i sykehjem dokumenterer utfordringer både vedrørende holdninger og fagkunnskap blant helsepersonell og manglende rutiner for å involvere pårørende. Pårørende etterspør faglært personell, gode norskkunnskaper og økt kompetanse blant de ansatte (Helsedirektoratet, 2015a). Den nasjonale kartleggingen av palliative tiltak i 2012 viste stor variasjon også blant palliative enheter i sykehjem. Flere palliative enheter fulgte ikke anbefalingene om 2-3 legetimer per pasient per uke, og viktige yrkesgrupper i teamet var ikke på plass (Hestnes K, 2014, Helsedirektoratet, 2015a). Ansatte i sykehjem ønsker økt tilgjengelighet til sykehjemsleger (Sintef, 2016).

\section{Hjemmebasert omsorg}

Hjemmebasert omsorg for pasienter med behov for palliasjon utføres av hjemmesykepleien i samarbeid med fastlegen og annet helsepersonell $\mathrm{i}$ kommunen. Hjemmesykepleie er et tilbud til pasienter som har et særlig hjelpebehov på grunn av sykdom eller funksjonshemning, hvor hjelpebehovet kan ivaretas i hjemmet. Helsehjelp til pasienter i hjemmesykepleien er hjemlet i helse- og omsorgstjenesteloven, og forskrift om kvalitet i pleie- og omsorgstjenestene.

Det overordnede målet for hjemmesykepleien er at pasienten skal mestre hverdagen i sitt eget hjem så lenge det er forsvarlig og ønskelig. Pasientene skal møtes med en helhetlig tilnærming, der det legges vekt på alle faktorer som påvirker helsetilstanden. Det krever kunnskap om hvordan ulike symptomer påvirker pasienten, og hvilke tiltak som skal iverksettes for at pasientene skal leve et så godt liv som mulig og unngå at situasjonen forverres.

Hjemmesykepleie er et felles begrep for all sykepleie som utføres i pasientens hjem. De ansatte i hjemmesykepleien har ansvar for alle typer pasienter, i alle livsfaser og livssituasjoner, fra barn til de aller eldste. Anmodning om hjemmesykepleie kan komme fra pasienten selv eller fra andre som kjenner pasientens forhold, for eksempel pårørende eller fastlege. Alle som mener å ha et behov for hjemmesykepleie kan ta kontakt med den kommunen man bor eller oppholder seg i for å søke om hjemmesykepleie. Hjemmesykepleie er gratis.

En følge av samhandlingsreformen er at kommunene har fått et større ansvar for pasienter med betydelige og sammensatte behov for behandling, pleie og omsorg og som ofte har behov for avansert medisinsk behandling. Det kan være pasienter som er i behov av avansert medisinsk utstyr, pasienter med behov for palliasjon og pasienter hvor hjemmesykepleien må følge opp og koordinere behandling og oppfølging fordi pasientene 
har behov for hjelp både fra fastlege og helsepersonell i spesialisthelsetjenesten.

Det er rettet oppmerksomhet mot hvordan helsetjenesten skal fungere $\mathrm{i}$ årene framover, inkludert hva som skal være hjemmesykepleiens framtidige rolle. Meld. St. 26 (2014-2015) Fremtidens primorhelsetjeneste - noerhet og helhet beskriver behovet for en helhetlig helse- og omsorgstjeneste i kommunene, med fokus på tre satsningsområder: Økt kompetanse, bedre ledelse og teamorganisering.

\section{Hjemmedød}

I Norge er det få som dør hjemme (under 14-15 pst. på landsbasis, 7 pst. i Oslo). Andelen som dør i sykehus har gått kraftig ned, fra rundt 48 prosent i 1986 til vel 31 prosent i 2015. I den samme perioden har andelen som dør på sykehjem økt fra omtrent 27 prosent til over 48 prosent. Mange har kroniske sykdommer som gjør at de har behov for omsorg på sykehjem de siste årene i livet. Tidligere skjedde mange av dødsfallene på grunn av kreft i sykehus, mens de nå ofte skjer på lindrende enheter ved sykehjem (Folkehelseinstituttet, 2016). Dette er en ønsket dreining og sannsynligvis også en konsekvens av samhandlingsreformen.

\section{Flere enslige}

Flere enn 900000 nordmenn bor alene og andelen øker. 55 prosent av pasientene i hjemmesykepleien bor alene (SSB, 2017).

Mange aleneboende pasienter har levd et liv uavhengige av andre og det kan være en utfordring for disse personene å ta i mot hjelp fra hjemmesykepleien (Høvik, Kienlin m.fl. 2017). Når pasienten ikke har pårørende eller venner rundt seg i hjemmet stilles det ekstra krav til fastlege og hjemmesykepleie om å inngi tilstrekkelig trygghet gjennom kompetanse og tilgjengelighet. I Helsedirektoratets Rapport om tilbudet til personer med behov for lindrende behandling og omsorg mot livets slutt (2015a) foreslås det et våkekoneprosjekt i Norge, tilsvarende det som er etablert av Røde Kors i Danmark, som et supplement til den offentlige helsetjenesten. Frivillige oppholder seg sammen med personen som skal dø den siste tiden. Tiltaket retter seg særlig mot de aleneboende uten pårørende, men også de som har pårørende.

\section{Fastlegens rolle i palliasjon}

Det er av stor betydning å koble fastlegene på de palliative pasienttilpassede forløpene - både fordi de etter loven har det medisinske ansvaret for hjemmeboende pasienter, og fordi mange av dem har fulgt pasienter og familier over lang tid og har en relasjon og en bakgrunnskunnskap om familien som annet helsepersonell ikke har. Innrapporteringer av aktivitet fra fastlegene, registrert ved hjelp av innsendte refusjonskrav til Helfo (takster for sykebesøk), viser at om lag 57 prosent av fastlegene foretok 5 eller flere hjemmebes $ø \mathrm{k}$ i avtaleåret 2016-2017. Rapporteringen viser at mange fastleger ikke gjennomførte hjemmebesøk i det aktuelle kalenderåret, selv om det er et tilbud fastlegen er pålagt å gi i henhold til fastlegeforskriften når det er nødvendig for å sikre pasienten forsvarlig helsehjelp, eller når pasienten på grunn av sin helsetilstand eller funksjonsevne ikke er i stand til å møte til konsultasjon på legekontoret (fastlegeforskriften $\S 23$ ). I aktivitetsdataene registreres det ikke årsaken til at legen har vært på hjemmebesøk hos den aktuelle pasienten, hvor ofte hjemmebesøk har vært vurdert og ikke gjennomført, eller om pasienten har avslått et tilbud om hjemmebesøk. De fleste fastleger har pasienter som vil ha behov for besøk av fastlegen sin noen ganger i året. Utvalget mener rapporteringen kan tyde på at fastlegene i for liten grad tar seg av hjemmeboende palliative pasienter. Fastlegen kan bidra med effektiv behandling av mindre alvorlige lidelser og har en portvokterrolle inn i sykehusene ved å foreta en prioritering av hvilke pasienter som skal henvises til spesialisthelsetjenesten. Fastlegen bør delta i utformingen av de pasienttilpassede palliative forløpene. En del av denne planleggingen kan bestå $\mathrm{i} a ̊$ innhente kompetanse fra spesialisthelsetjenesten etter behov.

Fastlegene deltar i varierende omfang i palliative forløp i dag. Noen av årsakene til dette kan være at fastlegen kan ha mangelfull kunnskap om palliativ behandling, at det kan ta tid før fastlegen foretar hjemmebesøk, og manglende samhandling mellom spesialisthelsetjenesten og fastlegen og mellom sykehjemmene og fastlegen. Fastleger møter i gjennomsnitt bare et fåtall palliative pasienter med langtkommen sykdom i sin praksis pr. år. Pasientene har ofte et langt forløp i spesialisthelsetjenesten og fastlegen er ikke alltid informert og involvert (Helsedirektoratet, $2015 \mathrm{a}$ ).

Det er igangsatt flere tiltak for å integrere fastlegene tettere $\mathrm{i}$ den palliative behandlingen, for eksempel gjennom prosjekter der palliative team gjør hjemmebesøk hos pasienter sammen med 


\section{Boks 9.5 Orkdalsmodellen}

Forskningsprosjektet Orkdalsmodellen jobber for bedre kreftomsorg i Orkdalsregionen. Prosjektet er et samarbeid mellom NTNU, St. Olavs hospital, Samhandlingsenheten i Orkdalsregionen ( $\mathrm{SiO})$ og Oppdal kommune. Det overordnede målet er å gi kreftpasienter rett behandling av høy kvalitet til rett tid på rett sted. Dette skal oppnås gjennom å:

- Bedre samarbeidet mellom sykehuset og kommunen når det gjelder kreftomsorg

- Øke kunnskapen om kreft og lindrende behandling hos pasienter, pårørende og befolkningen i regionen

- Gi helsepersonell tilbud om videreutdanning innen kreft og palliasjon

- Innføre pasienttilpassede forløp som skal gjøre det forutsigbart å være kreftpasient, uavhengig av hvor behandling og oppfølging gis, samt å utvikle en kreftomsorg hvor pasienten selv er med på å bestemme innholdet $\mathrm{i}$ de pasienttilpassede forløpene

Orkdalsmodellen er en nettverksmodell med palliativ enhet i sykehus som sentral og koordinerende part. Modellen er tilpasset flere små kommuner rundt lokalsykehuset. Prosjektperiode: 2013-2015.

Modellen har sørget for kompetanseoppbygging for leger og sykepleiere, og kreftkoordina- tor har en sentral rolle. I Orkdalsmodellen er kompetanseheving satt i system for leger, sykepleiere og helsefagarbeidere gjennom blant annet kurs, fagdager, hospitering, masterprogram og undervisning lokalt. Det gis ukentlig undervisning i regi av Kompetansesenter i lindrende behandling Midt-Norge.

Det er utarbeidet pasienttilpassede forløp for den palliative kreftpasienten i Orkdalsregionen som omfatter både spesialisthelsetjenesten og den kommunale helse- og omsorgstjenesten. Prosjektet viser blant annet at helsepersonell som bruker pasientforløpet, har erfaringer med at implementeringen av de pasienttilpassede forløpene fører til at man i større grad når sentrale mål i palliasjon. De erfarer også at pasienter med sammensatte problemstillinger får mer helhetlige og koordinerte tjenester. Helsepersonell opplever at pasientene får bedre symptomlindring, og at de i større grad kan være hjemme eller nærmest mulig hjemmet. De erfarer også at der hvor pasientforløp er tatt i bruk, får pasienter med sammensatte problemstillinger mer helhetlige og koordinerte tjenester enn tidligere (Johnsen, 2016).

Kilde: Informasjonsbrosjyre om kreftomsorg i Orkdalsregionen. https://stolav.no/seksjon-avdeling/Documents/I nfobrosj_Orkdal_v2_FINAL\%20(2).pdf fastlegen. Det palliative teamet opplever ofte at fastlegen er vanskelig å få tak i (Sintef, 2016). Utvikling og implementering av pasientforløp for palliative pasienter og gjennomføring av emnekurs innen palliasjon for fastleger er sentrale elementer i Orkdalsmodellen. Se nærmere beskrivelse i boks 9.5. I Orkdalsmodellen har man erfart at flere fastleger har begynt å ha hyppigere hjemmebesøk etter at de har gått på kurs og blitt en aktiv del i planlegging av de pasienttilpassede forløpene. Man har sett at hjemmebesøk ofte foretas sammen med kreftkoordinator. På grunn av pasientforløpet har det blitt skapt bedre rammer for kommunikasjon mellom nivåene, noe som igjen har gjort det lettere for legene å ta en telefon til palliativt team på sykehuset. Resultatet har blitt at legene kan gi bedre oppfølging i hjemmet, for eksempel iverksette smertelindring. Flere av kompetansesentrene holder kurs innen palliasjon som fastlegene kan delta på, men det er varierende deltakelse fra fastlegene (Sintef, 2016).

Etter fastlegereformen i 2001 har fastlegene fått et tydeligere ansvar for pasientene på egen liste og overfor kommunene. Det er likevel svært varierende i hvor stor grad de ser på seg selv som ytere av kommunale tjenester. Det er også varierende i hvor stor grad kommunene betrakter fastlegene som viktige innsatsfaktorer i den kommunale tjenesteytelsen (Meld. St. 26 (2014-2015)). I St.meld. nr. 47 (2008-2009) Samhandlingsreformen ble det påpekt at fastlegene spiller en nøkkelrolle for å nå reformens målsettinger, men at de er for dårlig integrert $\mathrm{i}$ den øvrige helse- og omsorgstjenesten, og at kommunene mangler styringsmuligheter. For å møte disse og andre utfordringer ble fastlegeforskriften revidert i 2012 (lovdata.no). I revidert forskrift, som trådte i kraft 1. januar 2013, stilles tydeligere krav både til fastlegene og kommunene. Blant annet stilles det 


\section{Boks 9.6 Erfaringer - hovedpunkter for god palliasjon}

Utvalget har besøkt samtlige helseregioner og mott en rekke kommuner og fått presentert ulike modeller for palliativ behandling, omsorg og pleie. I denne boksen gjengis faktorer som ble fremmet som viktige for å få til god palliasjon. Dette er ikke en uttømmende liste, men kriterier som ofte ble fremsagt.

\section{Samhandling:}

- Tett samarbeid mellom 1.og 2. linjetjenesten

- Systematisk dialog mellom sykehus og fastlege i hele pasientforløpet

- Primærkontakt i hjemmesykepleien

- Planlagt og forpliktende involvering av fastlege

- Felles persontilpassede forløp for inneliggende og polikliniske pasienter

- Vurderingsutvalg som består av representanter fra aktuelle kommuner, sykehjem og palliativt team vurderer alle søknader for å gi pasienten et tilbud på rett sted og nivå til rett tid

Kompetanse:

- Systematisk fagutvikling og kompetansebygging ved blant annet kompetansenettverk/ ressursnettverk, kurs, fagdager, hospitering, masterprogram og undervisning lokalt

- Regionale medarbeidere i hele regionen. Stikkord: Kompetanseutvikling med lokal tilhørighet

- Vellykket integrasjon onkologi og palliasjon

- Lindrende enhet gir kompetanse til alle avdelinger på sykehjemmet; kompetansen ut til pasienten

- Kreftkoordinator, kompetanseheving etter læringsnettverksmodellen

- Tverrfaglighet: Tverrfaglige ressursgrupper i palliasjon på samtlige sykehjem

\section{Tilgjengelighet:}

- Palliativt team på sykehuset er tilgjengelig for konsultasjon og kan reise ut til pasienter i hele fylket og følge opp pasienter som ønsker å være hjemme lengst mulig. Inkluderer fastlegen og hjemmetjenesten

- Ambulerende team fra spesialisthelsetjenesten til alle kommuner i fylket

- Bruk av frivillige, f. eks. til våketjeneste nasjonale funksjons- og kvalitetskrav til fastlegenes virksomhet. Fastlegene synes ikke å medvirke mer i pasientforløpet etter samhandlingsreformen. Sykehuslegene og hjemmetjenesten legger mye av premissene for samhandlingen rundt utskrivningsklare pasienter, ved at kommunikasjonen går fra sykehus direkte til hjemmetjenesten (Nasjonalt senter for distriktsmedisin, 2017).

På grunn av manglende kommunikasjon mellom journalføringssystemer i spesialisthelsetjenesten og i den kommunale helse- og omsorgstjenesten, har helsepersonell (fastleger, sykehjemsleger) problemer med å få tilgang til oppdatert informasjon. Dette hemmer kommunikasjonen mellom tjenestenivåene og vanskeliggjør samtidige tjenester, og vil være et økende behov ettersom det etableres flere team som oppfølgingsteam og primærhelseteam.

\section{Koordinatorer kreft/lindrende behandling}

I 2012 ble det etablert et tilbud med kreftkoordinatorer i kommunene i samarbeid med Kreftforeningen. 215 av landets kommuner har kreftkoordinator. Oppgavene til en kreftkoordinator omfatter koordinering og tilrettelegging av hverdagen for pasienter og pårørende, ansvar for å samordne tilbud og tjenester til kreftpasientene i kommunen, og bidra til gode rutiner og systemer for kreftomsorg i kommunene. Gjennom denne innsatsen er formålet å bedre livskvalitet og levekår hos kreftpasienter og deres pårørende, og styrke kreftomsorgen i kommunene. En del av stillingene er interkommunale. I tillegg er 23 sykepleiere koordinatorer i kreft og palliasjon i kommunene utenfor denne ordningen (Helsedirektoratet, 2015a). Registreringen er imidlertid ikke fullstendig, og anslaget er trolig for lavt (Sintef, 2016, Kunnskapssenteret, 2014). Kreftkoordinatorene 
har samarbeid med onkologiske poliklinikker, kreftsykepleiere i kommunen, palliativt team, og tidvis fastlege og personell på sykehjem og annet personell som arbeider på palliasjonsfeltet (Syse og Moshina, 2015). Det skal være en definert ansvars- og funksjonsfordeling og faste samarbeidsrutiner mellom kreftkoordinator og ressurssykepleier. I mindre kommuner kan det være naturlig at samme person (kreftsykepleier) har begge funksjoner.

\section{Oppfølgingsteam og primærhelseteam}

I Meld. St. 26 (2014-2015) Primoerhelsemeldingen ønsker Regjeringen å legge til rette for primærhelseteam og oppfølgingsteam. Dette er en ny arbeidsform for kommunene innenfor dagens lovpålagte tjenestetilbud for brukere med store og sammensatte behov. Formålet er blant annet å redusere risikoen for framtidig sykehusinnleggelse. Teamene skal bidra til helhetlige, koordinerte og individuelt tilpassede tjenester. Primærhelseteam er team med ansvar for grunnleggende helsetjenester til hele befolkningen, og er foreslått som en utvidet allmennpraksis. Flerfaglige team etableres i mange land, og har som formål å yte, koordinere og tilrettelegge tjenester for en selektert og tydelig definert gruppe. Det kan være brukere med sammensatte og komplekse behov som har behov for et bredt sett med helse- og omsorgstjenester, og gjerne også andre tjenester f.eks. skrøpelige eldre og personer med alvorlig psykisk lidelse. Formålet med teamene er både koordinering og å yte tilrettelagte, flerfaglige tjenester. En slik teambasert tilnærming kan bidra til at pasientene kan behandles i eget hjem i stedet for på sykehus eller annen institusjon. Flerfaglige team ledes ofte av sykepleiere, evt. med tilleggsutdanning. I tillegg inngår ofte sosialfaglig personell, fysioterapeut og ergoterapeut. Sammensetningen varierer avhengig av brukergruppen (Meld. St. 26 (2014-2015) Fremtidens primorhelsetjeneste - noerhet og helhet). For noen av brukerne av hjemmetjenester vil et strukturert opplegg for oppfølging være tilstrekkelig for å sikre kvalitet. For andre kan det være faglig riktig i tillegg å etablere et formelt team med ansvar for oppfølgingen (oppfølgingsteam). Slike team består oftest av sykepleier (som er koordineringsansvarlig), fysio/ergoterapeut og ev. sosialfaglig personell. Teamet samarbeider på en systematisk måte med pasientenes fastlege/ primærhelseteam og andre. For mange brukere vil også personell fra spesialisthelsetjenesten være viktige støttespillere. Det gjelder f.eks. brukere med behov for palliasjon.

\subsubsection{Barn og unge}

Antall barn med palliative behov er ikke kartlagt i Norge. Basert på internasjonale beregninger er det anslått at det til enhver tid er omkring 3500 barn årlig med behov for palliasjon i Norge. Omkring 140 barn dør i løpet av første leveår, mens mange lever i flere år, og flere vil nå voksen alder på grunn av medisinsk behandling (Helsedirektoratet, 2017). Disse barna kan være alvorlig syke med komplekse tilstander og med store og ofte langvarige behov for godt organisert helsehjelp. Pediatrien, den medisinske spesialiteten om barns vekst og utvikling og sykdommer, er en tverrfaglig spesialitet, og fagområdet omfatter både forebyggende, helbredende og habiliterende tjenester. Det har manglet kompetanse og struktur for å gi et helhetlig tilbud til barn med en livsbegrensende tilstand og deres familier. Flere familier har følt seg alene med totalansvaret for barnet (Helsedirektoratet, 2017).

I Norge er det 19 barneavdelinger; 8 i Helse Sør-Øst, 4 i Helse Vest, 4 i Helse Midt og 3 i Helse Nord. Palliative tjenester til barn er ikke systematisert, og det gis i varierende grad støttetiltak til barn og foreldre med alvorlig sykdom, særlig ved tidspunktet for diagnose.

Mange barn med nevrologiske sykdommer ivaretas i habiliteringstjenesten som er knyttet til barneavdelingene. For å oppfylle krav om kvalitet og forsvarlighet i tjenesten, bør habiliteringstjenestene i spesialisthelsetjenesten være bredt tverrfaglig sammensatt med medisinsk, psykologisk, sosialfaglig, spesialpedagogisk og miljøterapeutisk kompetanse (Helsedirektoratet, 2017).

Barn med behov for palliasjon behandles ved alle landets barneavdelinger og i kommunene barna bor i. Noen av barna vil være tilknyttet barne- og ungdomsavdelingene på universitetssykehusene, men samtidig beholde en tilknytning til den lokale barne- og ungdomsavdelingen. Andre vil ha sin primære oppfølging fra den lokale barne- og ungdomsavdelingen inkludert habiliteringstjenesten lokalt. Det utføres et stort arbeid i den enkelte kommune og i barne- og ungdomsavdelingene overfor barn og familier med komplekse sykdommer. Dette gjelder både habiliteringsenheter og andre barnefagspesifikke seksjoner som hjerte, lunge, mage-tarm, kreft, nyfødt, nevrologi m.m.

Unge som blir alvorlig syke møter mange utfordringer. Sykdommen kan føre til en opplevelse av sorg eller tap over hva de ikke vil få oppleve i framtiden. Palliativ behandling kan også utfordre det å opprettholde en hverdag som ung, 


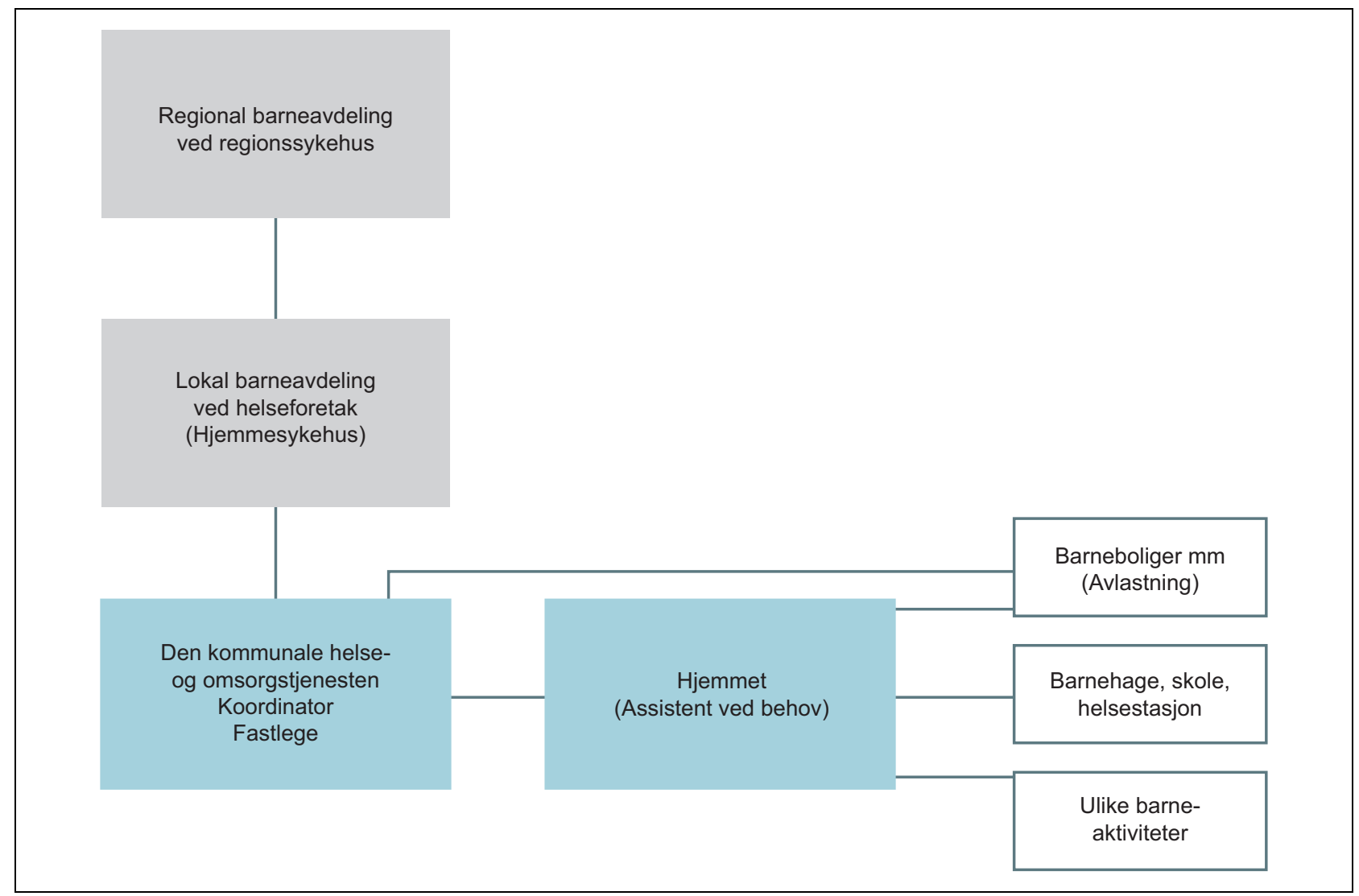

Figur 9.2 Dagens organisering av barnepalliasjon

med samvær med friske venner. Sykdom øker ungdommers følelse av avhengighet, samtidig som de fleste søker uavhengighet. Det er vist at ungdom med livstruende sykdommer har større forekomst av depresjon enn friske. Tjenester for voksne er ofte ikke tilpasset barn og unges behov for oppfølging, aktivitetstilbud og samvær med andre. Bevegelseshemning, svekket selvhjulpenhet og liknende funksjonsbegrensninger ledsages ofte av dårligere livskvalitet. Flere barn og unge $\mathrm{i}$ denne gruppen uttrykker at de er ensomme og har depressive plager enn blant funksjonsfriske (Departementene, 2016).

Overgangen fra pediatri til helsetjenester for voksne er en utfordring for unge og deres familier. Flere barn med alvorlig sykdom lever lenger enn tidligere. Fremskritt innen behandling av tilstander som for eksempel cystisk fibrose, innebærer at barn i dag når voksen alder, med livsbegrensende tilstander som er sjeldne i den voksne sektoren (Goldman og Hain m.fl. 2016).

I Nasjonal faglig retningslinje for pallisjon til barn og unge uavhengig av diagnose (Helsedirektoratet, 2017) anbefales det at hver helseregion oppretter et tverrfaglig barnepalliativt team lokalisert til den regionale barne- og ungdomsavdelingen.
Teamet bør ha hovedansvaret for fag- og kompetanseutvikling i sin region og være rådgivende for de lokale barnepalliative teamene. Teamet bør som et minimum ha lege, sykepleier, psykolog og sosionom, samt tilknyttet fysioterapeut, klinisk ernæringsfysiolog, prest og andre relevante yrkesgrupper. Teamet bør ha kontakt med avdelinger for lindrende behandling for voksne for å dele kompetanse og erfaring. Helsedirektoratet anbefaler at det på sikt bør opprettes et kompetansenettverk for palliasjon av barn og at det bør etableres en tverrfaglig koordineringsgruppe i kommunen for barn med livsbegrensende tilstand (Helsedirektoratet, 2017).

Den nasjonale retningslinjen anbefaler videre at det etableres et tverrfaglig barnepalliativt team på alle barne- og ungdomsavdelinger, et team som trer i funksjon når et barn med livstruende/ livsbegrensende tilstand blir kjent for avdelingen. Disse lokale teamene bør ha tilsvarende bemanning som de regionale tverrfaglige teamene. Det barnepalliative teamet bør ha et nært samarbeid med alle relevante enheter i barne- og ungdomsavdelingen /-klinikken, inkludert barnehabilitering og Avansert hjemmesykehus for barn, der dette finnes. Teamet har ansvar for nødvendig kompetanseover- 
føring innad i barne- og ungdomsavdelingen og til kommunal helse- og omsorgstjeneste.

Når et barn får en diagnose med en livstruende eller livsbegrensende tilstand, starter en sorgprosess. Sorg er personlig, med et stort spenn i hva som er normalt og naturlig for den enkelte når det gjelder reaksjoner, uttrykk og behov. Barnet og familien kan ha behov for psykososial støtte i hele eller deler av sykdomsforløpet, og de har behov for å møtes av personer med innsikt og forståelse, som anerkjenner og normaliserer deres sorg og sorgreaksjoner.

\subsubsection{Utskrivningsklare pasienter}

Utskrivningsklare pasienter kjennetegnes ofte ved at de har et komplekst og sammensatt sykdomsbilde og ikke kan skrives ut til det omsorgsnivået de ble lagt inn fra fordi funksjonsnivået er redusert, både kognitivt og fysisk (Birkestrand og Otterstad, 2010). Det har vært en sterk økning i antall pasienter som registreres som utskrivningsklare i perioden fra 2010 til 2014, fra om lag 24000 pasienter i 2010, til drøyt 87000 pasienter i 2014. Det er også færre pasienter som ligger ferdigbehandlet $\mathrm{i}$ sykehus i påvente av et kommunalt tilbud, og liggetiden for de som venter på et slikt tilbud har gått ned (Riksrevisjonen, 2016).

\subsection{Vurdering og drøfting av dagens praksis}

\subsubsection{6 sentrale målsettinger for palliasjon}

I denne delen av kapittelet vil utvalget anbefale seks sentrale målsettinger for palliasjon. Forslagene er basert på en drøfting av dagens struktur, med utgangspunkt i de seks målsettingene:

1. Tidlig integrasjon av palliasjon i de pasienttilpassede forløpene

2. Pasienttilpassede forløp utvikles mellom helsetjenesten og pasienten

3. Palliasjon til alle relevante pasientgrupper

4. Mye hjemmetid - hjemmedød til de som ønsker det

5. Et tilbud basert på tverrfaglig kompetanse

6. Forskning, utvikling (FOU) og kompetanse

1. Tidlig integrasjon av palliasjon i de pasienttilpassede forløpene

Det er publisert en rekke studier som underbygger prinsippet om å integrere palliasjon tidlig i de pasienttilpassede forløpene (se blant annet Kavalieratos m.fl. (2016) og Gaertner m.fl. (2017)). Noen av effektene som er dokumentert finnes $\mathrm{i}$ boks 9.10 .

Selv om de fleste studiene er utført på kreftpasienter, er det mye som taler for at de samme fun-

\section{Boks 9.7 Når er en pasient utskrivningsklar?}

En pasient vurderes som utskrivningsklar når lege ved helseinstitusjon omfattet av spesialisthelsetjenesteloven vurderer at det ikke er behov for ytterligere behandling ved døgnopphold i helseinstitusjonen. Vurderingen skal være basert på en individuell helsefaglig og psykososial vurdering, og følgende punkter skal være vurdert og dokumentert i pasientjournalen:

- Problemstillingen(e) ved innleggelsen slik disse var formulert av innleggende lege skal være avklart

- Øvrige problemstillinger som har framkommet skal være avklart

- Dersom enkelte spørsmål ikke avklares skal dette redegjøres for

- Det skal foreligge et klart standpunkt til diagnose(r) og videre plan for oppfølging av pasienten
- Pasientens samlede funksjonsnivå, endring fra forut for innleggelsen og forventet framtidig utvikling skal være vurdert

- Dersom pasienten har behov for spesialisthelsetjenester som er utenfor den aktuelle avdelingens ansvarsområde, skal det sørges for at relevant kontakt etableres, og plan for denne oppfølgingen beskrives

- Epikrise eller tilsvarende informasjon inkludert medikamentliste skal følge pasienten ved utskrivelse

Kilde: Forskrift om kommunal betaling for utskrivningsklare pasienter, 2012 


\section{Boks 9.8 Pasientsentrert behandling}

Rett kompetanse på rett sted til rett tid.

- Helsetjenesten er «silo» organisert

- Pasientene opplever «reisen» mellom siloene som ukoordinert

- Pasienttilpassede forløp kan bedre kvaliteten på sammensatte behandlingsforløp

- Samspill og samarbeid av kompetent personell mellom siloene

nene er gyldige for alle relevante diagnosegrupper innen palliasjon, som kols, kronisk hjertesvikt, ALS, m.fl. I pasientforløpet må det sikres at alle relevante diagnosegrupper får adekvat oppfølging. I spesialisthelsetjenesten bør palliasjon bli en integrert del av organiseringen av de ulike fagområdene, som for eksempel hjerte, lunge, kreft, pediatri og nevrologi.

Utvalget mener at Nasjonalt handlingsprogram med retningslinjer for palliasjon $i$ kreftomsorgen (Helsedirektoratet, 2015b) bør videreutvikles og at det blant annet tydeliggjøres hvordan det palliative tilbudet skal innarbeides i alle diagnosespesifikke retningslinjer. For å sikre tidlig integrasjon av palliasjon for andre diagnoser enn kreft, foreslår utvalget at det utarbeides en ny nasjonal retningslinje for alle relevante diagnosegrupper. Palliasjon $\mathrm{i}$ en tidlig fase av sykdommen vil være generell og gjelde for alle diagnoser, det samme vil være tilfelle for palliasjon i den siste levetiden. Den generelle retningslinjen skal omfatte både den kommunale helse- og omsorgstjenesten og spesialisthelsetjenesten. Palliasjon i en fase av sykdom hvor det gis helbredende eller livsforlengende behandling vil i større grad være sykdomsspesifikk enn palliasjon i en senere fase. Utvalget anbefaler derfor at palliasjon innarbeides i de diagnosespesifikke, nasjonale faglige retningslinjene for andre sykdommer, som hjertesykdom, kronisk lungesykdom, ALS, osv. For de ulike kreftsykdommene innarbeides palliasjon som en integrert del av disse retningslinjene. Retningslinjene må beskrive det sykdomsspesifikke knyttet til palliasjon for de ulike sykdomsgruppene.

\section{Pasienttilpassede forløp utvikles mellom helsetje- nesten og pasienten}

Den organisatoriske strukturen skal ta utgangspunkt i de pasienttilpassede forløpene og må tilpasses målet om god pasientflyt på tvers av siloer. Pasientene skal oppleve spesialisthelsetjenesten og den kommunale helse- og omsorgstjenesten som et samlet helsetilbud.

Det må utvikles detaljerte diagnosespesifikke pasienttilpassede forløp som inneholder både den sykdomsrettede og den pasientrettede palliative behandlingen. Det er sentralt at de palliative tjenestene innarbeides $\mathrm{i}$ forløpene og at det er tydelig hvilke aktører som bidrar, slik at vi får rett kompetanse på rett sted til rett tid.

For å bedre «pasientflyten» internt $\mathrm{i}$ «siloene» og mellom «siloene» er det også nødvendig med organisasjonstilpasninger og forbedringer (se figur 9.3). På noen områder der volumet av pasientene er lavt og kompleksiteten høy (for eksempel barn med en dødelig sykdom) kan det være hensiktsmessig at spesialisthelsetjenesten med sitt palliative team har hovedansvar for pasientene $\mathrm{i}$ hjemmet. Dette skal avtales og planlegges

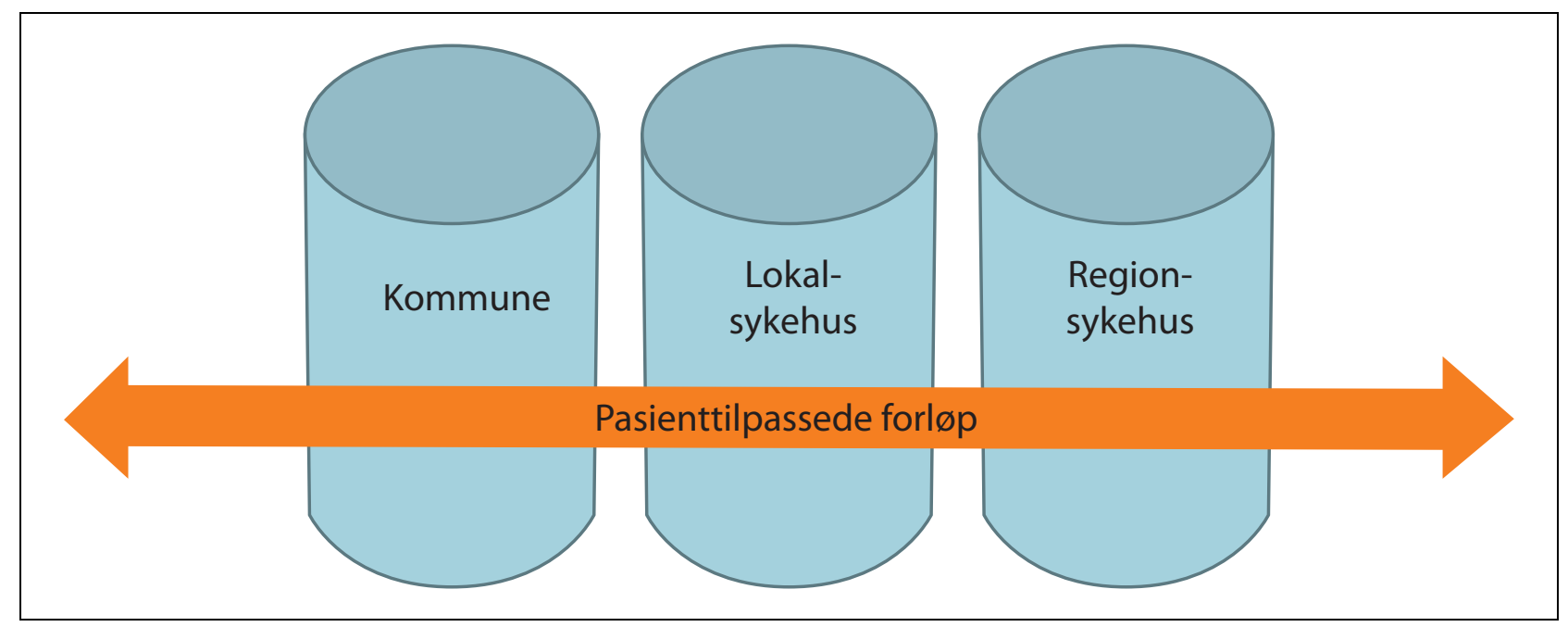

Figur 9.3 Pasienttilpassede forløp 
sammen med den kommunale helse- og omsorgstjenesten. Mindre kommuner bør vurdere interkommunalt samarbeid både med palliative sengeenheter på sykehjem og kommunale palliative team som kan operere mellom samarbeidskommuner.

Det er viktig at oppgavefordelingen, det vil si hvem som har hovedansvar for pasienten til enhver tid, er avklart både for pasient og helsepersonell. Dette gir forutsigbarhet for pasientene og for helsepersonell. Dette er illustrert i figur 9.4 ved at samspill mot pasientens hjem fra fastlege, hjemmesykepleie, sykehus og sykehjem/helsehus koordineres. For detaljer om pasienttilpassede forløp, se kapittel 6 .

\section{Boks 9.9 Mangelfull informasjonsutveksling mellom nivåene i helse- og omsorgstjenesten}

Behovet for god informasjonsutveksling har økt etter innføringen av samhandlingsreformen, blant annet som følge av at flere og sykere pasienter skrives ut fra sykehusene til behandling, pleie og omsorg i kommunene. Riksrevisjonen viser at mange helseforetak får mangelfull informasjon om pasientens funksjonsnivå fra kommunene $\mathrm{i}$ forbindelse med at pasienter legges inn på sykehus. Medikamentlistene er også ofte ufullstendige. Flere enn halvparten av kommunene opplever at de ikke får tilstrekkelig informasjon om pasientenes forventede framtidige utvikling når de skrives ut fra sykehus til videre behandling og oppfølging i den kommunale helse- og omsorgstjenesten.

Helsetilsynet avdekket at pasienter fikk for lite informasjon om behandlingen på sykehuset og hva som skulle skje når de kom hjem. Fylkesmennene fant flest lovbrudd og forbedringsområder i forbindelse med overføring av informasjon mellom sykehus og kommune. Dette handlet dels om måten informasjon ble oversendt på, men også om mangler ved innholdet, eksempelvis om pasientens helsetilstand, funksjonsvurdering og legemiddelinformasjon. Når vesentlig pasientinformasjon mangler eller er ufullstendig, kan det få alvorlige konsekvenser for den pasientbehandlingen kommunen skal yte.

Kilde: Riksrevisjonen, Dokument 3:5 (2015-2016) (avsnitt øverst). Helsetilsynet, Rapport 1/2016 (avsnitt nederst)

\section{Boks 9.10 Integrasjon av palliasjon og onkologi}

Nyere forskning viser at integrasjon av palliasjon tidlig i sykdomsforløpet kan bedre:

- Pasientenes livskvalitet og symptomkontroll

- Pasienttilfredshet og ivaretakelse av pårørende

- Sykdomsforståelse

- Kvalitet på behandling, pleie og omsorg ved livets slutt

- Overlevelse

- Kostnader knyttet til behandling, pleie og omsorg

Kilde: David Hui and Eduardo Bruera, 2016, Kaasa og Loge, 2016

Det er nødvendig å forbedre struktur/organisering innen hver av siloene. Det blir derfor foreslått organisatoriske endringer på hvert nivå tilpasset størrelse på enheten (befolkningstetthet) og geografiske utfordringer (reiseavstander) og mellom siloene for å bedre pasientflyt.

\section{Utskrivningsklare pasienter}

I følge mandatet skal utvalget innenfor rammen av palliative tjenester drøfte når palliative pasienter bør regnes for utskrivningsklare eller ikke, slik at man unngår uverdige utskrivninger motivert i en kommunal betalingsplikt. En pasient er utskrivningsklar når lege på sykehus vurderer at det ikke er behov for ytterligere behandling i spesialisthelsetjenesten. At en pasient er utskrivningsklar innebærer $i k k e$ at pasienten er ferdigbehandlet. I mange tilfeller er det kommunens helsepersonell som fullfører behandlingen. Pasienten kan fortsatt være i behov av hjelp fra spesialisthelsetjeneste, som gis ambulant eller poliklinisk. Dersom det er sannsynlig at pasienten vil dø under eller umiddelbart etter overflytting fra sykehuset, mener utvalget at overflytting skal unngås. En slik utskrivning oppfattes som uverdig, og selv om det ikke er behov for ytterligere behandling i spesialisthelsetjenesten skal man i slike tilfeller prioritere å skape en verdig død på sykehuset.

Når en pasient med behov for palliative tjenester skal skrives ut fra sykehuset er det viktig å ha en tydelig rolle- og ansvarsfordeling, gode kommunikasjonslinjer og kompetanseoverføring innen de 


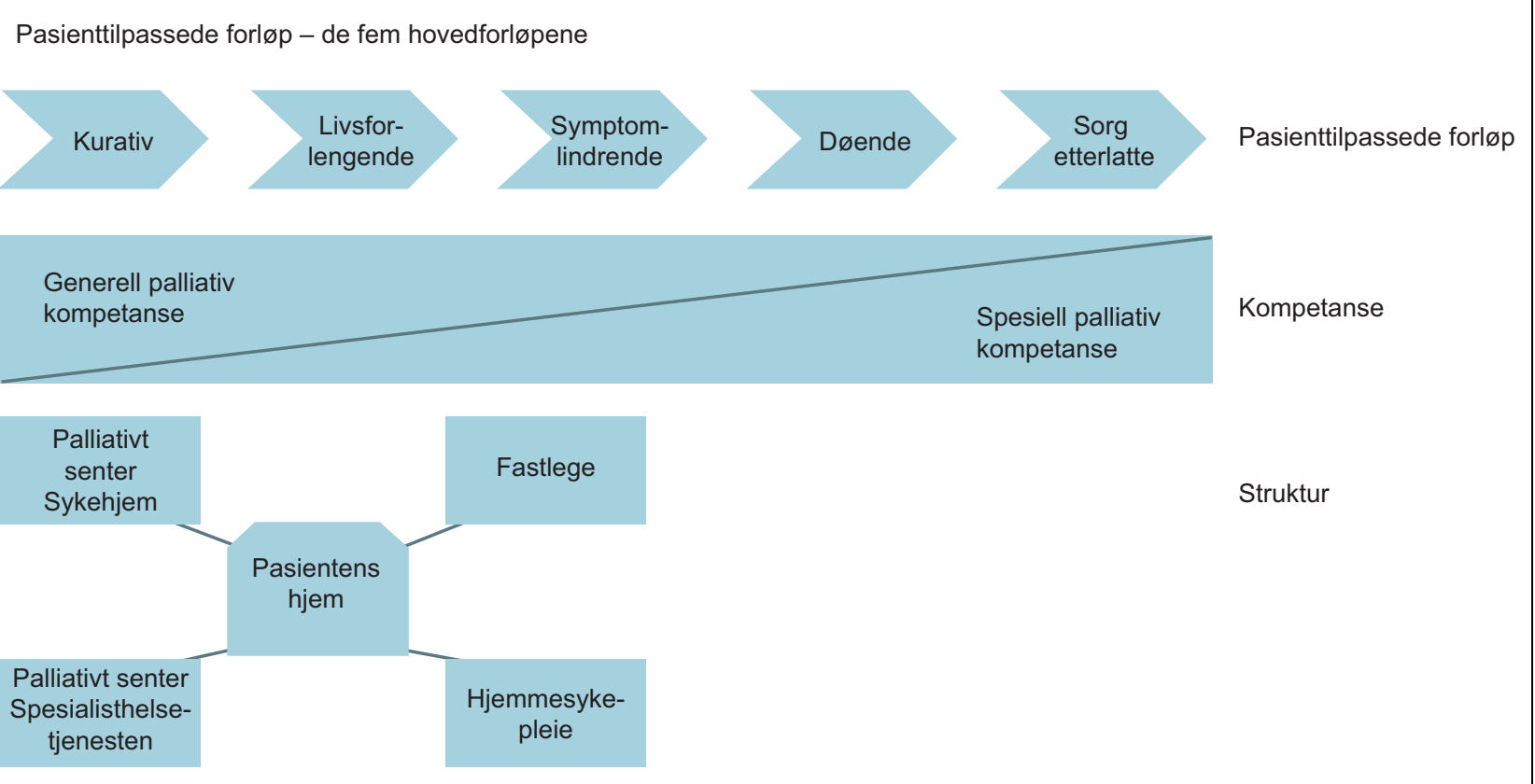

Figur 9.4 Pasienttilpassede forløp

ulike profesjonene og mellom nivåene. Dette krever god samhandling mellom sykehuset og den kommunale helse- og omsorgstjenesten. Utvalget mener det må etableres kontakt mellom pasientens kontaktlege i sykehuset og pasientens fastlege, eventuelt sykehjemslege, slik at pasienten sikres god overgang ved utskrivelse fra sykehus til sykehjem eller hjem.

Utvalget mener at spesialisthelsetjenesten ved utskrivelse må beskrive hvorfor pasienten ikke lenger har behov for spesialisthelsetjeneste og videreformidle den informasjonen helse- og omsorgspersonell i kommunene trenger, knyttet til diagnose og behandling. Spesialisthelsetjenesten må også beskrive den totale situasjonen til pasienten knyttet til funksjonsnivå og pasientens og pårørendes ønsker og behov. Spesialisthelsetjenesten må dokumentere at de har hatt samtale med pasient og pårørende, og hvilken informasjon som er gitt om videre forløp. Dette er elementer som bør tas inn i samarbeidsavtalene om palliasjon som utvalget anbefaler, se kap. 6. Utvalgets tiltak om forhåndssamtaler er også et tiltak for å bedre kommunikasjonen mellom sykehus, kommune og pasient og pårørende. Forhåndssamtaler er beskrevet i kapittel 4.

Det må sikres gode samarbeidsrutiner mellom helseforetak og kommune. Dette innebærer blant annet at dekkende/informative epikriser er tilgjengelige ved utskrivelse fra sykehuset, men det må også beskrives hva som er viktig når pasienter legges inn på sykehus. Helse Stavanger HF og kommuner i helseforetaksområdet har utarbeidet en samarbeidsavtale, der kommunen også forplikter seg til å sende et innleggelsesskriv som følger pasienten når han/hun innlegges $\mathrm{i}$ sykehus, jf. kapittel 6.

\section{Palliasjon til alle relevante pasientgrupper}

Innholdet $\mathrm{i}$ og organiseringen av det palliative tilbudet innen kreftområdet må utvikles. Samtidig må det igangsettes et betydelig løft innen mange andre sykdomsgrupper og kreftområder som har hatt lite palliativ oppmerksomhet.

Pasientgruppene som er nevnt i faktaboks 9.11 er de mest relevante og de som bør prioriteres etter utvalgets vurderinger. Det kan være flere andre, mindre diagnosegrupper som også bør ha et palliativt behandlingstilbud. I tillegg mener utvalget at pasienter med rusmiddelproblemer, psykiske helseproblemer og psykisk utviklingshemning bør få spesiell oppmerksomhet. Dette er pasienter som har særegne behov og spesielle behandlingsmessige utfordringer som krever annen kompetanse enn det som er vanlig innen palliasjon i Norge i dag. Palliasjon til alle relevante diagnosegrupper fordrer ny kompetanse og tett samarbeid mellom helsepersonell som jobber med palliasjon og spesialistene på pasientens grunnsykdom.

Figur 9.5 viser en modell som utvalget anbefaler for de største sykehusene i Norge. Palliativt team og palliativ enhet vil ha samme funksjon som 


\section{Boks 9.11 Noen av de vanligste pasientgrupper utenom kreft hvor palliasjon bør integreres i behandling, pleie og omsorg}

Palliasjon er mest integrert innen kreftområdet, men må også utvikles og integreres for følgende pasientgrupper.

- Pasienter med kroniske hjerte-, lunge- og nyresykdommer

- Pasienter med kroniske nevrologiske sykdommer, multippel sklerose (MS), amyotrofisk lateralsklerose (ALS) og Parkinsons sykdom

- Pasienter med demens

- Barn og unge med livstruende eller livsbegrensende tilstander

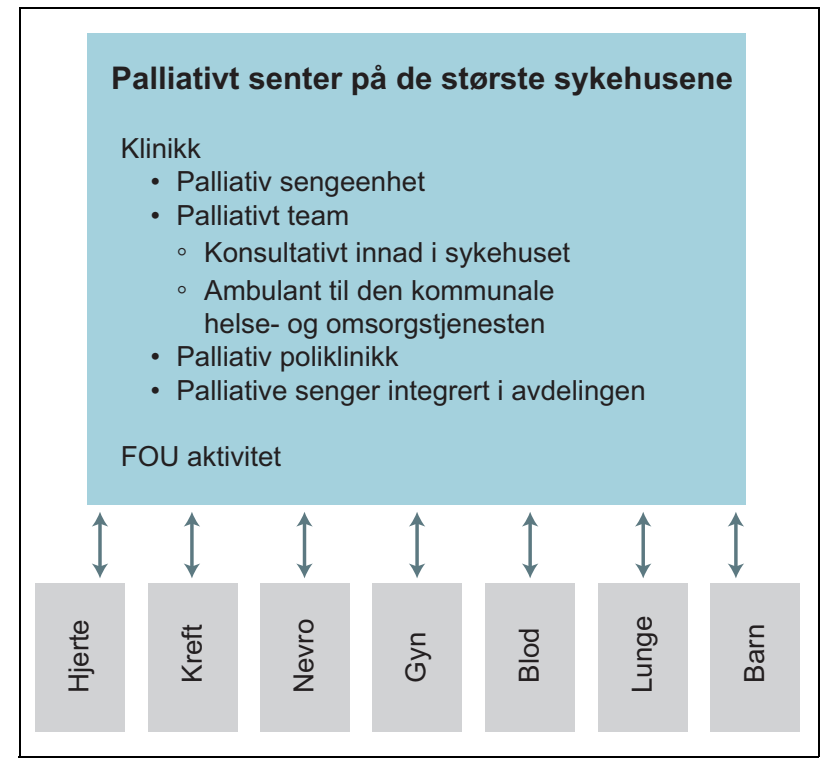

Figur 9.5 Organisering av palliasjon på sykehus (alternativ 1)

i dag. I tillegg legger modellen opp til at palliative senger integreres $\mathrm{i}$ aktuelle avdelinger $\mathrm{i}$ sykehuset. Modellen er basert på at palliasjon skal integreres i mange nye diagnosegrupper, og at det er nødvendig med palliativ kompetanse til stede i disse miljøene.

Modellen underbygger også at den organiserte palliative fagutviklingen og forskning (FOU) skal ligge ett sted på de største sykehusene, mens pasientbehandlingen må utøves i klinikken (på avdelings- og seksjonsnivå). Derfor mener utvalget at de regionale palliative sentrene bør organiseres som en samlet enhet med både klinikk og

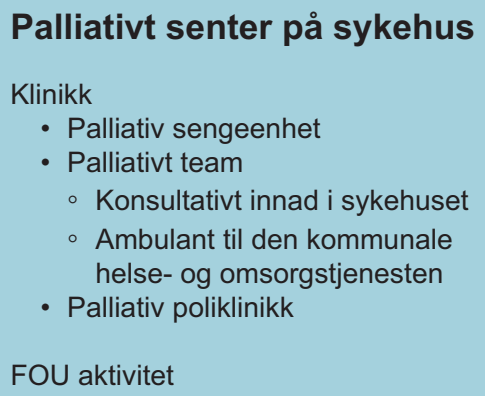

Figur 9.6 Organisering av palliasjon på sykehus (alternativ 2)

forskning. For å tydeliggjøre forsknings- og utviklingsvirksomheten og sikre de regionale, nasjonale og eventuelt internasjonale oppgavene, bør organisasjonsstrukturen ivareta disse behovene. Palliative sentre på sykehus og i kommunene bør ha tilsvarende organisering. Denne modellen kan utvikles videre ut fra pasientens behov, modenhet $\mathrm{i}$ organisasjonen og muligheter innenfor helsetjenesten lokalt på avdelingsnivå, sykehusnivå og regionalt. Imidlertid vil man på de fleste sykehus også ha behov for en spesialisert enhet for spesielt krevende palliasjon. Det er avgjørende at utviklingen av fagområdet tilpasses lokale forhold, som størrelsen på sykehuset, sammensetningen og organisering av de største diagnosegruppene og reiseavstander i lokalsykehusområdet. I en oppbyggingsfase er det viktig at den palliative kompetansen blir samlet.

Figur 9.6 viser en modell for de mindre sykehusene. Prinsippet for palliativt senter er det samme som i figur 9.5, men på mindre sykehus vil de palliative sengene være samlet på palliativ sengeenhet og det palliative teamet vil bistå sykehusets avdelinger med kliniske konsultasjoner, råd $\mathrm{og}$ veiledning om palliative problemstillinger. I begge figurer, 9.5 og 9.6, vil det palliative teamet også ha ambulant funksjon til pasientens hjem og sykehjem i samhandling med den kommunale helse- og omsorgstjenesten.

\section{Mye hjemmetid - hjemmedød for de som ønsker det}

En av utvalgets viktigste prioriteringer er å gi pasienter muligheten til å være hjemme så lenge som mulig og om mulig dø hjemme. Dette krever at helsepersonell i den kommunale helse- og omsorgstjenesten har nødvendig kompetanse, (se forslag om kommunale palliative sentre og team, pkt. 9.3.2) at spesialisthelsetjenesten bistår ved 
behov og at det utvikles pasienttilpassede forløp på tvers av tjenestene (se kap 6).

Hvor pasientene ønsker å tilbringe den siste tiden bør ha betydning for hvordan det palliative tilbudet organiseres. Det er behov for å tenke nytt om organiseringen av de palliative tjenestene, slik at flere får mulighet til selv å velge hvor de vil være i den delen av livet hvor de trenger palliative tjenester. Utvalget mener at det er viktig å differensiere mellom hjemmetid og hjemmedød. Begge målene bør være kvalitetsindikatorer i helsetjenesten.

Organiseringen av det palliative tjenestetilbudet må ta hensyn til at flere pasienter enn dem som får tilbud om det, ønsker å tilbringe mest mulig tid hjemme.

For noen pasienter er det verken ønskelig eller praktisk mulig å dø hjemme, men det kan være et ønske og et mål å få mest mulig hjemmetid. For å kunne velge å være hjemme til man dør, er det avgjørende å ha trygghet for at tjenestene som ytes er tilstrekkelige og gode nok. I debatten om tilrettelegging for hjemmedød er det videre viktig å reflektere over hvordan vi definerer begrepet «hjemme». For langtidsboere på institusjon vil dette være deres hjem.

Utvalget mener at økt hjemmetid kan være en riktigere målsetting enn økt hjemmedød, fordi hjemmedød kun sier noe om sted for selve dødstidspunktet, men hjemmetid sier noe om i hvilken grad pasientens ønske om å få leve den siste tiden i hjemmet oppfylles. Det er et mål at flest mulig pasienter får leve sin siste tid i kjente omgivelser i sitt private hjem eller på sykehjem og at de ikke legges inn på sykehus de siste timer/dager på grunn av komplikasjoner, lav kompetanse, økonomiske hensyn eller manglende kunnskap om pasientens og pårørendes preferanser. Det er behov for fleksible løsninger tilpasset den enkelte pasients ønsker og behov. Det stiller krav til helse- og omsorgspersonellet, til deres kompetanse og til hvordan tjenestene er organisert. Personer som har behov for palliativ behandling, skal kunne få disse tjenestene enten $\mathrm{i}$ palliative sengeenheter eller øremerkede palliative senger i kommunen eller i sykehuset, og i hjemmet.

Om pasienten skal få være mest mulig hjemme den siste tiden, innebærer dette at kompetansen må kunne komme til pasienten, ikke at pasienten må flytte dit kompetansen befinner seg. Å være alvorlig syk hjemme kan også innebære store endringer og forventning om stor innsats fra de pårørende, se omtale av pårørende i kapittel 10.

Det er viktig å se på ønsket om mest mulig hjemmetid i sammenheng med resten av tjeneste- tilbudet. Det vil være et politisk og økonomisk spørsmål i hvilken grad man ønsker å bygge ut hjemmebaserte tjenester eller særskilt organiserte institusjonsplasser, det vil si palliative enheter i sykehjem eller sykehus, eventuelt begge deler.

For flertallet av hjemmeboende pasienter som har behov for palliative tjenester, vil hjemmebasert omsorg alene være urealistisk. De fleste vil ha behov for et eller flere opphold på institusjon i løpet av sykdomsperioden, enten av medisinske grunner (akutt symptomforverring og/eller sykdom som kommer i tillegg til en opprinnelig sykdom), eller for avlastning (Helsedirektoratet, 2015b). Det er symptombildet, problemstilling og situasjonens kompleksitet som må avgjøre hvor pasienten kan få best behandling.

Pasienter med komplekse, palliative problemstillinger innlagt på sykehus vil best bli ivaretatt på egne palliative enheter med spesialistkompetanse. Slike enheter disponerer egne senger som skal fungere som akuttsenger for å ivareta problemløsning, diagnostikk og behandling av symptomer/tilstander. Noen pasienter vil også ha behov for behandling på en høyspesialisert enhet for palliativ medisin på 3 . linjenivå (Helsedirektoratet, 2015b)

Det kan også være aktuelt å tilrettelegge noen enheter/senger som er tilpasset pasienter mellom 18 og 67 år og deres pårørende. Disse enhetene bør integreres sammen med den generelle palliative sengeenheten i kommunen, men må kunne skjermes fra enheter hvor det er urolige pasienter når dette viser seg å være nødvendig. Omgivelsene bør ha minst mulig sykehuspreg. Et eksempel er Øya helsehus i Trondheim som kan ha yngre pasienter.

Mange pasienter får behandling som gjør at de beholder en forholdsvis god allmenntilstand til langt ut i forløpet, og så blir helsetilstanden raskt dårligere. For enkelte kan det ta noen uker fra livsforlengende aktiv behandling avsluttes til pasienten dør. Det kan da være krevende å planlegge for hjemmetid og eventuell hjemmedød. Det blir viktig å planlegge sammen med pasient og pårørende tidlig om hvordan den siste tiden skal være for å imøtekomme og legge rammene for en så god siste tid som mulig. Se omtale i kap 4.

Erfaring og studier viser at støtte fra et palliativt team til fastlegen og hjemmesykepleien skaper trygghet og er ofte avgjørende for å få til et godt palliativt tilbud i hjemmet (Meld. St. 26 (2014-2015)).

Pasienter med sammensatte palliative behov vil ofte ha behov for koordinerte tjenester fra pri- 
mærhelsetjenesten. Dersom pasienten bor hjemme, kan det være behov for at den kommunale helse- og omsorgstjenesten kommer hjem til pasienten. For å kunne gi hjemmeboende pasienter med behov for palliasjon de tjenestene de trenger, anbefaler utvalget etablering av ambulante palliative team i kommunen til pasientens hjem og til sykehjem. De kommunale palliative teamene må ha en fast organisering, der det er avklart hvem som er med i teamene. I større kommuner kan dette være faste team, mens i mindre og små kommuner kan teamene tre $\mathrm{i}$ kraft når det er behov for det. Teamet skal ha bred tverrfaglig kompetanse som kan bemannes med personer i allerede etablerte tjenester i kommunen. Det er pasientens behov som avgjør hvordan teamet settes sammen.

I Norhet og helhet - fremtidens primorhelsetjeneste (Meld. St. nr. 26 (2013-2014) foreslås det opprettet primærhelseteam og oppfølgingsteam i kommunen. Det vises til nærmere omtale av disse teamene i punkt 9.2.2. Det gjøres i dag flere forsøk med pasientsentrerte team hvor både sykehusene og den kommunale helse- og omsorgstjenesten samarbeider og samfinansierer for å å gi pasienten koordinerte tjenester fra kommunalt- og spesialisthelsetjenestenivå. Dette kan være en løsning for å bryte «silotenkningen» som kan være en konsekvens av dagens organisering ut fra de to helsenivåene.

Selv om pasientsentrerte team er under etablering, mener utvalget det er behov for kommunale palliative team som blant annet kan avlaste fastlegen i oppfølging av pasienter med behov for palliative tjenester.

I boks 9.12 er noen av forholdene for en god avslutning på livet i hjemmet skissert. Utvalget ønsker å understreke at det er pasientens og familiens ønsker og muligheter som vil avgjøre hvor pasienten til enhver tid befinner seg i helsetjenesten. Helsetilbudet må være fleksibelt og dynamisk, tilgang på rett kompetanse og institusjonsplass må være tilstede. Det er grunnleggende at pasientene ikke flyttes mellom steder mot livets slutt så sant det ikke er helt påkrevet. For barn mot livets sluttfase er det behov for i enda større grad å ha et slikt detaljert godt planlagt tilbud.

\section{Tilbud $\mathrm{i}$ i livets siste fase (End of life care)}

Utvalget mener at tilbud og kompetanse i livets sluttfase må styrkes, og at det er behov for enheter både i sykehus og i sykehjem, helsehus e.l. som har en særskilt oppmerksomhet og kompetanse på palliasjon i livets sluttfase. I tillegg skal de ha et ansvar for å overføre denne kompetansen til andre enheter i spesialisthelsetjenesten og i den kommunale helse- og omsorgstjenesten. På denne måten vil disse enhetene fungere som en kompetansebase for palliasjon i livets sluttfase. I lokalsykehus vil det være behov for en direkte linje til det regionale kompetansesenteret for lindrende behandling som må ha en særskilt kompetanse på dette området. I større byer vil det kunne være behov for en egen enhet for pasienter i livets siste fase. Utvalgets flertall mener disse enhetene må være en integrert del av den ordinære helseog omsorgstjenesten og ikke organiseres som en særomsorg.

Utvalget mener de palliative enhetene i kommunen i større grad enn i dag må ivareta palliativ behandling, omsorg og pleie i livets siste fase.

En egen enhet for pasienter i livets sluttfase vil bidra til at kompetansen på dette området vil øke. Hvis pasienten er døende, mener utvalget primært at pasienten skal få tilbringe den siste levetiden så nær hjemmet som mulig, eller hjemme, med støtte fra den kommunale helse- og omsorgstjenesten, så sant det er mulig ut fra pasientens tilstand. Det er et mål at pasientene skal ha mest mulig hjemmetid og dø hjemme dersom pasienten og de pårørende ønsker det. På samme måte som

\section{Boks 9.12 Mye hjemmetid - hjemmedød for de som ønsker det}

- Pasient og pårørende må ønske å være hjemme

- Alle aktuelle tjenester må involveres; Fastlege, kreftkoordinator, hjemmesykepleie, palliativt team, sosionom, fysioterapeut, ergoterapeut, psykolog, prest og/eller andre ressurser som kan bistå pasient og pårørende

- Det må utarbeides en plan som bygger på god planlegging og tilrettelegging av hjemmesituasjonen og som beskriver tiltak ved mulige scenarier. Fleksible og individuelle løsninger

- Det må være tilgang på helsehjelp 24/7. Viktige kontakter og telefonnummer, både på dagtid og om natten, må beskrives i en oversikt

- Både grunnleggende og spesialisert kompetanse må være tilgjengelig

- Hjelpemidler og teknisk utstyr må være på plass 
den palliative enheten i sykehuset vil være en kompetansebase for de ovrige kliniske avdelingene i sykehuset, vil den palliative sengeenheten på sykehjemmet, helsehus e.l. være en kompetansebase for palliasjon i livets sluttfase for den øvrige virksomheten på institusjonen og i hjemmetjenesten.

\section{Et tilbud basert på tverrfaglig kompetanse}

Det er et grunnleggende prinsipp i palliasjon at det skal være en bred, tverrfaglig tilnærming til pasienten. Pasienten og pårørendes fysiske, psykiske, sosiale og åndelige/eksistensielle behov skal dekkes. Behovet for tjenester vil variere over tid for den enkelte pasient. Pasientens pårørende skal ivaretas både under sykdom og i sorgen etter pasientens død. Dette fordrer en tverrfaglig tilnærming. Prinsippene om rett kompetanse på rett sted til rett tid er sentralt. I vurdering av pasienten skal de fire dimensjonene (fysiske, psykiske, sosiale og åndelige/eksistensielle) kartlegges rutinemessig.

Tverrfaglige team er en av hjørnesteinene i det palliative tilbudet. Teamene må ha en sammensetning som svarer til pasientenes behov. I utviklingen av palliative tjenester i Norge, er det gjennom systemet med innsatsstyrt finansiering et krav at palliativt team skal være tverrfaglig, og bestå av minimum lege og sykepleier, og minimum ha en annen yrkesgruppe representert. Det er utvalgets vurdering at det for å forstå, møte og gi god behandling til den enkelte er behov for noen få kjernegrupper: leger, sykepleiere og i tillegg fysioterapeut, prest, og tilgjengelig psykolog, ergoterapeut og sosionom. Utvalget mener flere faggrupper bør være med i teamet, og viser til Nasjonal faglig retningslinje for palliasjon til barn og unge uavhengig av diagnose (Helsedirektoratet, 2017) der det anbefales at det palliative teamet som et minimum bør ha lege, sykepleier, psykolog og sosionom, samt ha tilknyttet fysioterapeut, klinisk ernæringsfysiolog, prest, ergoterapeut og eventuelt andre relevante yrkesgrupper.

Hvordan disse teamene bør samarbeide er omtalt i kapittel 9.3.2. Der finnes også argumentasjon og redegjørelse for sammensetning av teamene. I boks 9.13 er de mest sentrale yrkesgruppene for det tverrfaglige teamet listet opp.

Det er behov for å skille mellom hvilke yrkesgrupper som skal være en del av et tverrfaglig team (se boks 9.13), og hvilke typer personell som kan være tilleggspersonell på en palliativ sengeen-

\section{Boks 9.13 Sammensetting av tverrfaglig palliativt team}

- Lege

- Sykepleier

- Fysioterapeut

- Psykolog/psykiater

- Prest

- Sosionom

- Klinisk ernæringsfysiolog

- Ergoterapeut

het. Aktuelt tilleggspersonell som utøver alternative, ikke-medikamentelle behandlingsmetoder kan være tilgjengelig $i$ et helhetlig behandlingsopplegg dersom pasienten ønsker dette, som for eksempel akupunktur, musikkterapi, terapeutisk berøring/massasje osv. Det bør også legges til rette for å kunne imøtekomme at også pasienter fra ulike religiøse grupper kan få ivaretatt sine behov.

Teamets kompetanse og i hvilken form de ulike yrkesgruppene deltar, vil variere mellom de tre nivåene og innen nivåene avhengig blant annet av størrelse på og hvilke type enhet man arbeider ved.

\section{Informasjon om velferdstjenestene}

Mange pasienter og pårørende vil ha behov for velferdstjenester i tillegg til de ordinære helsetjenestene. Dette kan være særlig viktig for å tilrettelegge for at pasienten kan være hjemme. Familien trenger og har krav på god informasjon om aktuelle velferdsytelser som for eksempel pleiepenger, omsorgslønn og avlastningstiltak (Kreftforeningen, 2016). Denne informasjonen kan gis av sosionom ved sykehuset eller NAV. Utvalget vurderer at det er behov for å gi pasienter i en palliativ fase og deres pårørende bedre tilgang til informasjon om velferdstjenestene. Utvalget mener derfor at det bør være sosionomer i kommunenes helse- og omsorgstjeneste, og at de bør være en del av et kommunalt palliativt team, slik at pasienten og de pårørende kan få tilgang på denne tjenesten når de trenger det. Mange av disse ytelsene er fra Folketrygden og forvaltes av NAV, mens andre forvaltes av kommunen og private aktører. Det vises til nærmere omtale av disse ytelsene i kapittelet 10. 


\section{Forskning, utvikling (FOU) og kompetanse}

Nyere studier har vist at palliasjon introdusert tidlig i forløpet av kreftsykdommen kan skape bedre forløp for pasientene, redusere bruk av «unødvendige» helsetjenester og redusere kostnader ( Jackman og Zhang m.fl., 2017).

I dag finnes det ingen finansiering for kompetanseoverføring fra spesialisthelsetjenesten til den kommunale helse- og omsorgstjenesten, tjenesten ytes uten økonomisk uttelling. Skal spesialisthelsetjenesten oppfylle plikten som ligger i samhandlingsreformen om å sikre veiledning og kompetanseoverføring mellom tjenestenivåene, må det være lønnsomt å prioritere kompetansebygging. Derfor bør kompetanseoverføring i ulike former tas inn i kodeverk og gi økonomisk uttelling.

Det er et mål at all palliativ virksomhet, på lik linje med all helsehjelp, skal være forskningsbasert. Kunnskapsfronten oppsummeres i nasjonale retningslinjer og implementeres ved bruk av de pasienttilpassede forløpene. Ansvaret for denne prosessen er lagt til helseforetakene (HF) og kommune. Det forventes at implementeringen skjer via pasienttilpassede forløp. De regionale kompetansesentrene har ansvar for:

- Utarbeidelse av prosedyrer og retningslinjer for eget helseforetak og egen region, inkludert kompetansenettverk av ressurssykepleiere, jf. palliativt senter på sykehus. Nasjonalt samarbeid om nasjonale retningslinjer

- Bistand til plan- og utredningsarbeid for organisering og utbygging av palliasjon i regionen og nasjonalt

- Oppfølging av palliative tiltak og prosjekter i regionen (Helsedirektoratet, 2015b)

Utvalget mener at de regionale kompetansesentrene skal ha det overordnede oppfølgingsansvaret og skal bidra innad i helseregionen, både mot spesialisthelsetjenesten og den kommunale helseog omsorgstjenesten, for å sikre at man driver en forskningsbasert praksis.

Det palliative feltet er forskningssvakt (se kapittel 8). Utvalget ønsker å styrke kvaliteten og omfanget av forskningen ved at forskningsoppgaver blir tillagt de regionale kompetansesentrene $\mathrm{i}$ lindrende behandling og de lokale FOU-enhetene. Dette gjelder ikke bare på lokalsykehus, men også ved at det i en framtidig organisering i den kommunale helse- og omsorgstjenesten blir utviklet lokale, regionale forskningsnettverk. Dette regionale forskningsnettverket bør ledes av regionalt kompetansesenter i lindrende behandling.
For å bedre «pasientflyten» internt $\mathrm{i}$ «siloene» og mellom «siloene» er det også nødvendig med organisasjonstilpasninger og forbedringer. På noen områder der volumet av pasientene er lavt og kompleksiteten høy (for eksempel barn med en dødelig sykdom) kan det være hensiktsmessig at spesialisthelsetjenesten med sitt palliative team har hovedansvar for pasientene i hjemmet. Dette skal avtales og planlegges sammen med den kommunale helse- og omsorgstjenesten. Mindre kommuner bør vurdere interkommunalt samarbeid både med palliative sengeenheter på sykehjem og kommunale palliative team som kan operere mellom samarbeidskommuner.

\subsubsection{Framtidens modell: en integrert palliativ modell}

Det er seks sentrale målsettinger for palliasjon: 1) tidlig integrasjon av palliasjon i de pasienttilpassede forløpene, 2) pasienttilpassede forløp mellom helsetjenesten og pasienten, 3) palliasjon til alle relevante pasientgrupper, 4) mye hjemmetid hjemmedød, 5) et tilbud basert på tverrfaglig kompetanse og 6) forskning, utvikling og kompetanse.

Utvalget anbefaler at det utvikles en integrert palliativ modell for å nå disse målsettingene. I en integrert palliativ modell opplever pasienten et pasienttilpasset pallitivt forløp preget av helhet og sammenheng, og hvor det er god dialog innad og mellom nivåene $\mathrm{i}$ helsetjenesten. I en integrert palliativ modell er det tydelig hvem som til enhver tid har ansvar for pasienten og hvordan man kan opprettholde åpne kommunikasjonslinjer. Utvalget mener at opprettelse av en felles pasientjournal mellom kommune og spesialisthelsetjenesten og internt $i$ den kommunale helse- og omsorgstjenesten vil gjøre de palliative forløpene enklere å planlegge og gjennomføre. Utvalget viser også til forslaget om å innføre forhåndssamtaler (se kap. 4), som vil kunne bidra til god kommunikasjon mellom helsepersonell, pasient og pårørende.

Organisering av palliasjon i den kommunale helseog omsorgstjenesten

Hovedelementene $\mathrm{i}$ organiseringen av de palliative tilbudene i kommunene er hjemmetjeneste (hjemmesykepleie), boliger med heldøgnsomsorgstjenester og fastlege. Størrelsen og avstanden i norske kommuner varierer betydelig. Dette må det tas hensyn til når ny palliativ struktur utvikles.

I retningslinjen Nasjonalt handlingsprogram for palliasjon $i$ kreftomsorgen anbefaler Helsedirek- 
toratet (Helsedirektoratet, 2015) at sykehjem med nedslagsfelt /ansvarsområde for over 15000 innbyggere bør ha en egen palliativ sengeenhet. For mindre kommuner bør det etableres palliative senger, eventuelt i samarbeid med andre kommuner.

\section{Etablering av kommunale palliative sentre og team}

For større byer er det i dag ikke gitt noen klare anbefalinger om struktur og volum. I større kommuner og bydeler i de største bykommunene med anslagsvis nedslagsfelt på over 50000 innbyggere, anbefaler utvalget at det etableres kommunale palliative sentre, fortrinnsvis på sykehjem. Selv om pasientpopulasjonen ved kommunale palliative sentre vil være annerledes enn palliative sentre på sykehus, mener utvalget at grunnstrukturen kan være den samme, med en palliativ sengeenhet og et tverrfaglig kommunalt palliativt team. Det palliative teamet bør ha konsultativ funksjon internt $\mathrm{i}$ sykehjemmet, mot andre sykehjem i kommunen/ bydelen og mot hjemmeboende pasienter. Det palliative senteret $\mathrm{i}$ kommunen må tilpasses kommunens størrelse og geografi. Teamene må være tverrfaglig sammensatt, slik som de palliative teamene i spesialisthelsetjenesten (se boks 9.13). En lege (fortrinnsvis en spesialist i palliativ medisin) bør være ansatt på fulltid. Ved større sykehjem bør legen ha palliasjon som sin hovedaktivitet. Kompetansen ved det palliative senteret $\mathrm{i}$ kommunen bør være tilgjengelig for den øvrige omsorgstjenesten i kommunen. Dersom en palliativ enhet $\mathrm{i}$ kommunen trenger bistand, kan dette ordnes innad i kommunen ved at kompetanseenheten $\mathrm{i}$ kommunen bistår med råd og faglig veiledning. Sentrene bør være en kompetansebase for palliasjon og ha en forbindelse til palliativt senter på sykehus. De palliative sengene bør organiseres som en enhet, størrelsen vil variere ut fra behovene (se figur 9.9). Sentrene kan eventuelt organiseres som interkommunale enheter.

Når kommunen har pasienter med behov for palliasjon som krever mer enn grunnleggende palliativ kompetanse, foreslår utvalget at det etableres kommunale palliative team. Teamene kan alternativt opprettes som et interkommunalt samarbeid. Opprettelse av palliative team i kommunene utgående fra kommunal palliativ sengeenhet eller kommunalt palliativt senter, eventuelt flere sentre i større byer, blir sentralt. De palliative teamene bør settes sammen ut fra den enkelte pasientens behov for palliative tjenester. Teamet bør samarbeide med øvrige kommunale team som er foreslått etablert, som oppfølgingsteam og primærhelseteam. Det kan i framtiden være aktuelt å se på en samordning mellom palliative team, primærhelseteam og oppfølgingsteam. Utvalget mener at man på denne måten legger til rette for en fleksibel bruk av kommunens ressurser, samtidig som pasienten får de tjenestene han eller hun har behov for. Teamet bør ha sin faste base knyttet til palliativ enhet/sengepost i kommunen, og ved behov også behandle pasienter med behov for palliative tjenester i sykehjemmet.

Det bør stilles krav om at en sykepleier med palliativ kompetanse skal være en fast deltaker i et kommunalt palliativt team, sammen med fastlegen eller sykehjemslegen som er spesialist i palliativ medisin. Palliativ lege i teamet bør være en støtte til fastlegen, eller delta i stedet for fastlegen. Det må avklares hvem som har det medisinske ansvaret for pasienten. Det må i tillegg stilles krav om at fysioterapeut, psykolog/psykiater, prest, sosionom, klinisk ernæringsfysiolog og ergoterapeut har fast tilknytning til teamet. Det bør legges til

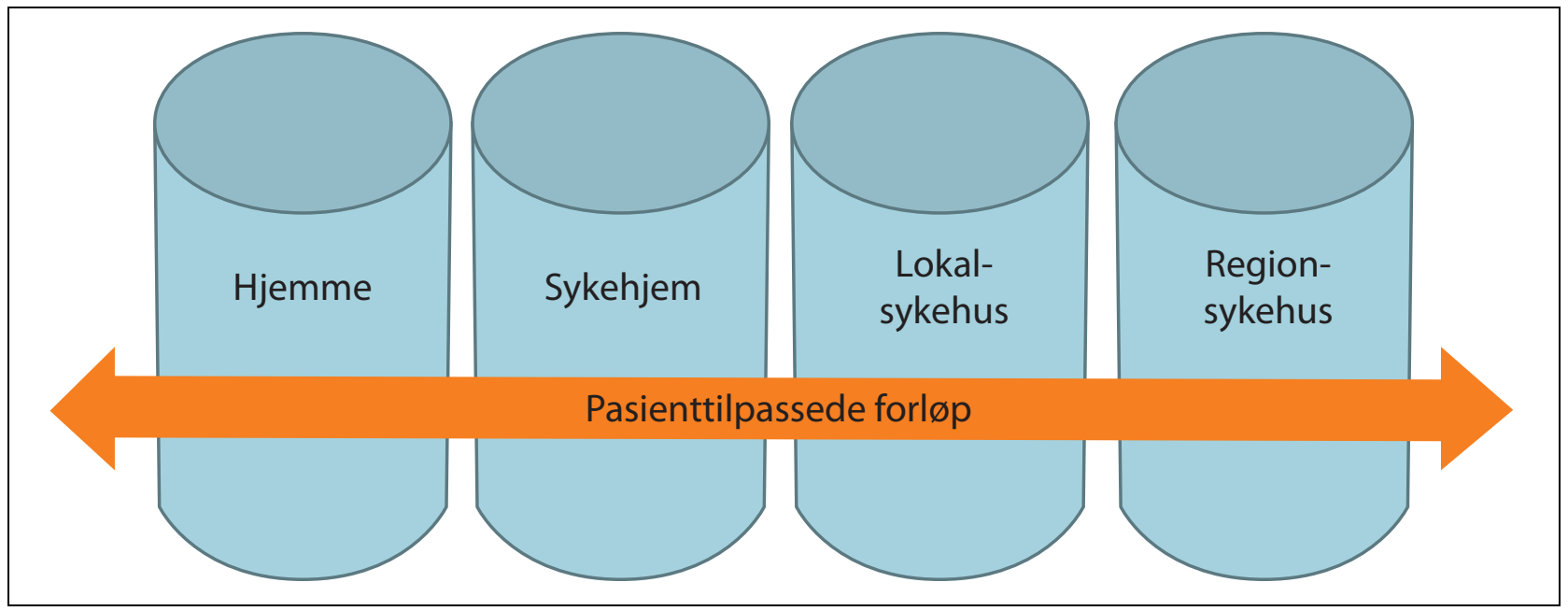

Figur 9.7 Pasienttilpassede forløp 


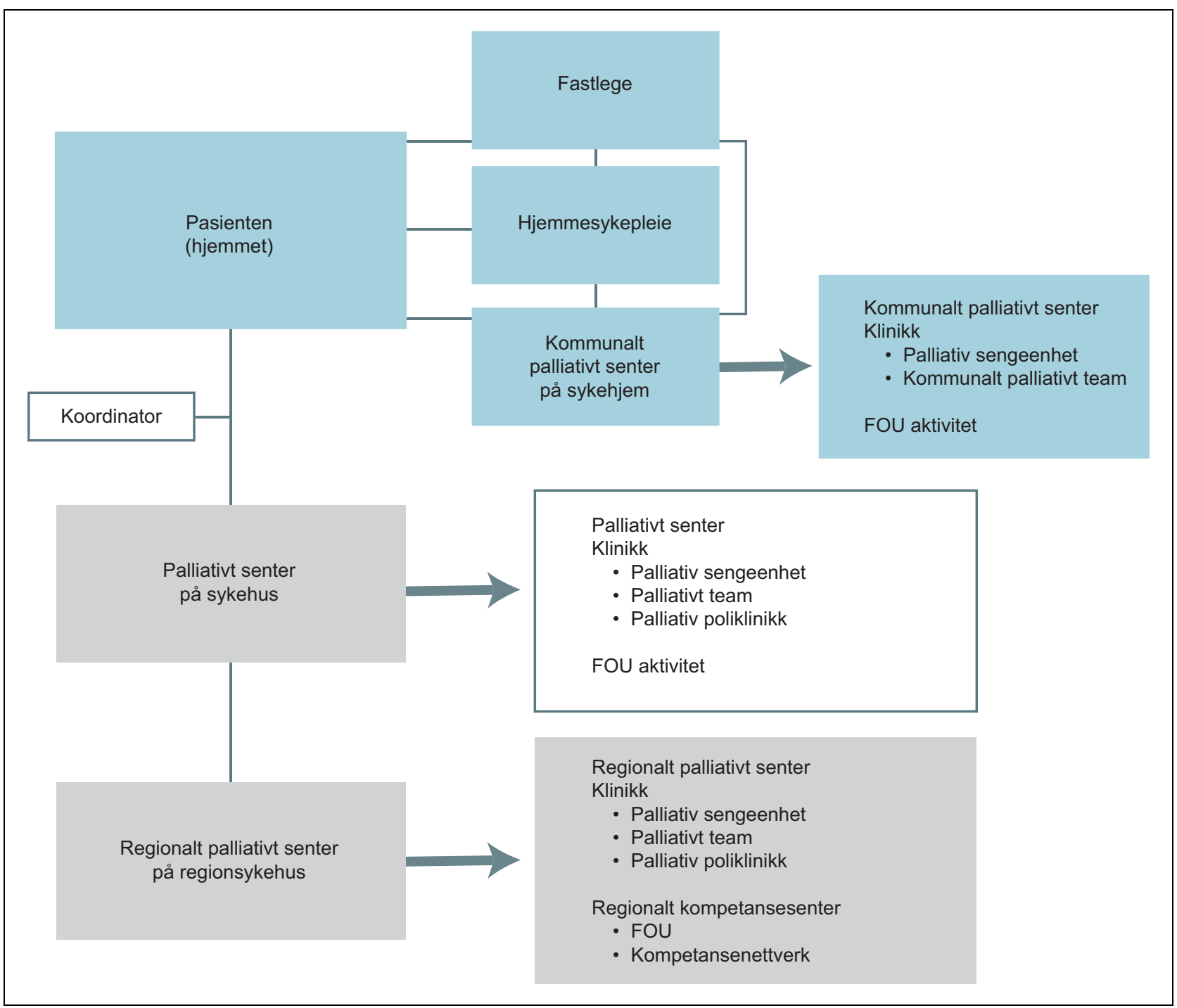

Figur 9.8 Modell for organisering av pallisjon til voksne i fremtiden

Figur 7 viser fremtidens organisering av palliasjon til voksne, der tjenestene til pasienten tilpasses pasientens behov til enhver tid.

rette for at det kommunale palliative teamet samarbeider om bruk av ressurser fra andre team i kommunen eller i spesialisthelsetjenesten når dette er aktuelt ut fra pasientens behov. For å få til dette, foreslås det at kommunens ansvar for palliasjon tydeliggjøres i helse- og omsorgstjenesteloven, se kapittel 6 . Utvalget mener at forslaget om opprettelse av kommunale palliative team med base i sykehjemmet, helsehus e.l., vil kunne bidra til at sykehjemslegen $\mathrm{i}$ større grad kan delta $\mathrm{i}$ behandling og oppfølging av pasienter med palliative behov. Et grunnleggende prinsipp bør være at kompetansen i det palliative teamet er tilgjengelig også når pasienten er hjemme.

Hovedelementene i modellen må tilpasses både med hensyn til pasientvolum, befolkningssammensetning og ut fra avstander og geografi. IKT må utvikles og tilpasses, slik at man får hjel- pemidler som kan bidra til god kommunikasjon mellom nivåene, og at informasjon om pasienten er tilstede til enhver tid.

I kommuner med befolkningsgrunnlag på over 100000 innbyggere, mener utvalget det bør etableres fullverdige kommunale palliative sentre, slik det er skissert i figur 9.9. I mindre kommuner eller gjennom interkommunalt samarbeid, bør det etableres en fullverdig modell og med den kliniske delen som et minimum. I Oslo og andre større byer betyr dette at antall palliative sentre i kommunen tilpasses befolkningsgrunnlaget med et senter på 12-18 senger per 100000 innbyggere.

For å legge til rette for hjemmetid og om ønskelig hjemmedød er det nødvendig med en klar struktur på helsetilbudene mot pasientens hjem basert på behovene som blir identifisert $\mathrm{i}$ utvikling av de pasienttilpassede forløpene. 
De sentrale aktørene mot pasientens hjem er fastlege, hjemmesykepleie, palliativ/kreftkoordinator og kommunalt palliativt team. I denne strukturen skal også spesialisthelsetjenesten bidra med palliativt team etter behov, avtalt med og koordinert av kommunen. Strukturen må også være fleksibel slik at pasientene kan legges inn på palliativt senter på sykehjem eller sykehus etter behov og etter avtale. Fastlegens bidrag mot hjemmet er sentralt.

Selv med økt oppmerksomhet på mer hjemmetid, vil mange pasienter ha behov for innleggelse i sykehjem. Sykehjemslegen på den kommunale palliative sengeenheten må derfor ha spesialkompetanse i palliativ medisin. Sammen med det kommunale palliative teamet og øvrig pleiepersonell vil den palliative kompetansen bli god når dette samles i mindre palliative enheter. For enkelte pasienter vil det være nødvendig med bidrag fra sykehuset. I slike tilfeller må det være tydelig hvem som har primæransvaret for pasienten. De kommunale palliative teamene må ha en fast organisering, der det er avklart hvem som er med i teamene. I større kommuner kan dette være faste team, mens i mindre og små kommuner kan teamene tre $\mathrm{i}$ kraft når det er behov for det, etter modell av kommunale kriseteam. Det er pasientens behov som avgjør hvordan teamene skal settes sammen.

Pårørende er en viktig ressurs for at pasientene skal kunne være hjemme mot livets slutt og om ønskelig dø hjemme. I kortere eller lengre perioder vil det være behov for mye hjelp i hjemmet. Da bør bl.a. avlastning for pårørende, som for eksempel i form av våketjeneste og bidrag fra frivillige, innlemmes i den enkelte pasients tilpassede forløp. Disse tilbudene bør være kjent og forutsigbare som en del av det kommunale palliative tilbudet.

\section{Forsknings- og utviklingsaktivitet}

For å ivareta utvikling og implementering av pasienttilpassede forløp i den kommunale helse- og omsorgstjenesten foreslår utvalget at det bør være palliative sentre i kommunene som kan ha forsknings- og utviklingsaktivitet, blant annet gjennom undervisning og forskning.

Utvalgets anbefalte modell for palliasjon i den kommunale helse- og omsorgstjenesten

Kommunalt palliativt senter

- Organisering

\section{Kommunalt palliativt senter på sykehjem}

Klinikk

- Palliativ sengeenhet

- Kommunalt palliativt team

Konsultativt innad i sykehuset

Ambulant til hjemmet/andre sykehjem

FOU aktivitet

Figur 9.9 Kommunalt palliativt senter på sykehjem

- Palliativ sengeenhet, palliativt team, FOUaktivitet

- Kompetansekrav:

- Fast lege på full tid som er spesialist i palliativ medisin

- Sykepleier med relevant videreutdanning

- I tillegg til sykehjemslege og sykepleier, skal fysioterapeut, prest, sosionom, klinisk ernæringsfysiolog, ergoterapeut og psykolog være fast tilknyttet det palliative teamet

\section{Pleie og omsorgstjenesten:}

- Organisering

- Skal ha samarbeid med et kommunalt palliativt senter

- Kompetansekrav

- Palliativ sengeenhet $i$ sykehjem: Fast tilknyttet lege som er spesialist i palliativ medisin og sykepleiere med relevant videreutdanning.

- Sykehjem uten palliativ enhet: Ansatte skal beherske grunnleggende palliasjon, ha kvalitetssikrede prosedyrer for smerte- og symptomlindring og pleie ved livets slutt.

- Hjemmesykepleien: Ansatte skal beherske grunnleggende palliasjon. Minst en sykepleier i sykehjem og i hjemmesykepleien i hver kommune/sone bør delta i nettverket av ressurssykepleiere.

Organisering av palliasjon i spesialisthelsetjenesten Palliative sentre på sykehus

Alle lokalsykehus i Norge skal ha et fullverdig palliativt senter, eller deler av et palliativt senter, tilpasset lokale forhold. Den kliniske delen bør i enda større grad enn på regionsykehusene tilpasses volum og avstander fordi variasjonen mellom sykehusene er betydelig. 


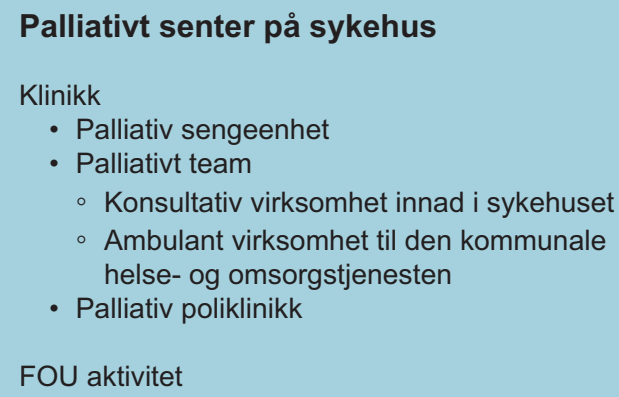

Figur 9.10 Fullverdig palliativt senter på sykehus

Større lokalsykehus med et anslagsvis nedslagsfelt på 30-50 000 innbyggere skal ha et fullverdig palliativt tilbud med et palliativt senter (både sengeenhet og team).

Den palliative enheten skal ha et palliativt team som må tilpasses sykehusets øvrige struktur og ha en tverrfaglig bemanning som skissert tidligere i kapittelet med en bemanning som tilsvarer kravet for palliativ tilleggsrefusjon. Et fullverdig palliativt senter på sykehus skal også ha en formalisert forsknings- og utviklingsaktivitet som skal foregå $\mathrm{i}$ tett samarbeid med det regionale palliative senteret.

I hovedtrekk er det anbefalt at et palliativt senter ved sykehus skal ha de samme organisatoriske elementene både på regionsykehusnivå og lokalsykehusnivå - klinikk og FOU. Dette er en overordnet ambisjon, men det må tilpasses sykehusenes størrelse og tilgjengelig lokal kompetanse.

Utvalget mener at de største sykehusene i Norge bør ha en struktur som tilsvarer et «fullverdig» palliativt senter. Strukturen må tilpasses størrelsen på pasientpopulasjonen, geografiske avstander og hvordan øvrige spesialistområder er organisert på sykehus. På mindre lokalsykehus tilpasses organisasjonsstrukturen den totale pasientpopulasjonen med henholdsvis palliativt team og palliativ sengeenhet/senger. Utvalget mener at det bør opprettes palliative team, før det etableres palliative senger. Har et sykehus enten et palliativt team eller en palliativ enhet, benevnes dette henholdsvis team eller enhet, ikke senter.

Utvalget mener det er viktig å sikre pasientene tilgang til medisinsk faglig kompetanse på kveld og helg. Dette kan organiseres ved egne vaktordninger for sykehjemmene, eller $\mathrm{i}$ et samarbeid mellom legevakten og sykehjemmene.

\section{Regionalt palliativt senter}

Det regionale palliative senteret består i dag av to hoveddeler, en klinisk del og en FOU/kompetanse del. Senteret skal ha et regionalt ansvar for å bygge opp og spre kompetanse. Det er ikke klart formulert hvilket ansvar det regionale senteret har for å utføre og koordinere klinisk forskning i regionen eller nasjonalt. Det er heller ikke gitt føringer om internasjonalt forskningssamarbeid.

Regionalt palliativt senter skal ha tre kliniske hovedaktiviteter: Palliativ sengeenhet, palliativt team og pallitiv poliklinikk. I tillegg skal det ha en kompetansedel, tilsvarende dagens kompetansesentre.

Det palliative teamet skal bestå av lege og sykepleier og andre fagdisipliner slik det er beskrevet tidligere i dette kapittelet. Det palliative teamet skal primært være konsultativt, men kan i særskilte tilfeller også ha direkte behandlingsansvar avklart med pasientens avdeling.

Det regionale palliative senteret skal ha regionalt ansvar for undervisning, pasienttilpassede forløp kompetansenettverk og forskning. Klinikken vil i all hovedsak omfatte lokalsykehus pasienter, men for særskilte vanskelige kliniske tilfeller skal senteret ha et regionansvar, og enhetsstørrelsen må gjenspeile dette. Det betyr at de må ha senger der de kan følge opp eller utrede pasienter med kompliserte palliative behov og ha døgnvakt med telefontilgjenglighet for regionen.

Kompetansesenteret skal ha fire hovedoppgaver: Undervisning, utarbeidelse og implementering av de pasienttilpassede forløpene, drift av kompetansenettverk og forskning - for hele regionen. Kompetansesentrene må dekke andre diagnosegrupper enn kreft slik som kronisk lungesykdom, kronisk hjertesykdom, progredierende

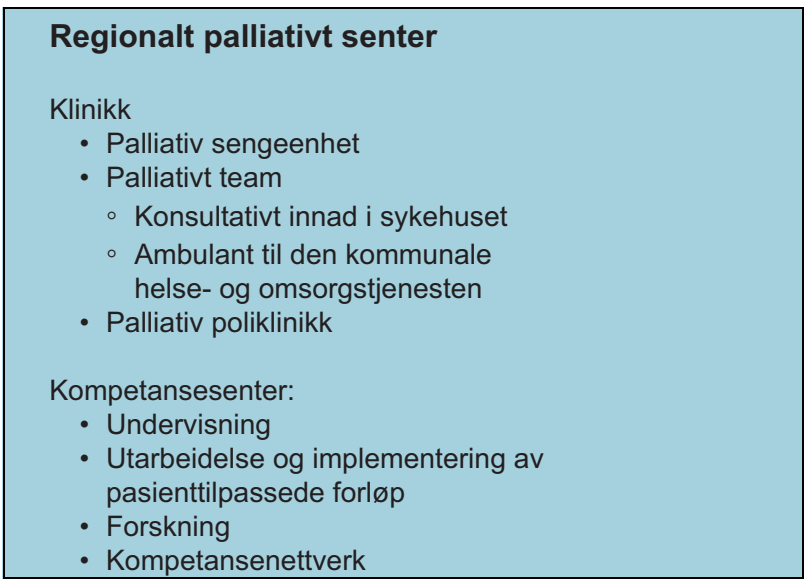

Figur 9.11 Organisering på et regionalt palliativt senter 
nevrologiske lidelser samt andre aktuelle diagnoser. Kompetansenettverkene er en betydelig ressurs i dagens palliative struktur, og det bør legges til rette for fortsatt drift og utvikling av disse nettverkene. Kompetansesenteret bør være en egen enhet i senteret, klart adskilt fra den kliniske virksomheten, men med tett samarbeid med klinikken.

De fire regionale palliative sentrene skal samarbeide om kompetanseoppgavene på et nasjonalt nivå. Utvalget foreslår at det nasjonale nettverk av kompetansesentrene skal fordele oppgavene seg imellom. Kompetansesentrene rapporterer i linjen til RHF-ene og samlet rapportering årlig vurderes av de regionale fagdirektørene.

Utvalget anbefaler å opprette nasjonale spisskompetanseområder ved de regionale kompetansesentrene for lindrende behandling. Kompetansesentrene får et differensiert ansvar for å koordinere spesielle områder nasjonalt. Utvalget foreslår at følgende områder kan få en nasjonal spisskompetansefunksjon:

- Klinisk palliativ forskning

- Fagutvikling, utdanning, kompetanse (prosedyrer, opplæringspakker, e-læringsprogram)

- Organisering

- Behandling, pleie og omsorg av døende (end of life care)

- Palliasjon til barn og unge

- Demens

- Andre ikke-maligne sykdommer (hjerte-, lunge- og nyresykdommer)

- Progredierende nevrologiske lidelser

Det må forventes og tas høyde for at det kan komme andre fagområder som det også kan være hensiktsmessig å organisere som nasjonale spisskompetanseområder.

For at flere personer som trenger palliative tjenester skal få tilbud om det, foreslår utvalget at palliasjon innarbeides $\mathrm{i}$ alle relevante nasjonale faglige retningslinjer.

\section{Kvalitet i palliasjon}

Helse- og omsorgstjenestene blir målt på blant annet bruk av ressurser (økonomi), ventetider og epikrisetid. Få, om noen, av de generelle målene (indikatorene) spør etter kvalitet på helse- og omsorgstjenestene mot livets slutt. Hvordan er smerten behandlet? Er pasienten alltid involvert i beslutninger om behandling? Fikk pasienten være hjemme den siste tiden, etter eget ønske? Hvordan var kvaliteten på sykehjemmet? Det er behov for å utvikle nye, flere og bedre kvalitetsindikato- rer for palliasjon. Palliasjon innebærer å møte pasientens fysiske, psykiske, sosiale og åndelige/ eksistensielle behov. God kvalitet fordrer at alle disse dimensjonene er dekket ved at nødvendig kompetanse er tilgjengelig når pasienten $\mathrm{og} \mathrm{de}$ pårørende trenger det.

Utvalget anbefaler at det utarbeides følgende kvalitetsindikatorer innen palliasjon:

- Hjemmetid de siste 30 eller 50 dager.

- Hvor pasienten er de siste 30 dager. Pasientforløp de siste 30 dager.

- Hjemmedød.

- Forhåndssamtaler (Advance Care Planning) hvorvidt dette er gjennomført. Tverrfaglig vurdering må være en del av dette.

- Symptomkartlegging - systematisk spørre pasienten om plager og symptomer.

- Indikator for pårørende - systematisk kartlegging av pårørendes behov (se kapittel 10).

\section{Finansiering}

En egen ICD-10 kode (Z51.50) brukes i spesialisthelsetjenesten for å gi en tilleggsfinansiering per pasientopphold gjennom en egen kode «Behandling i palliativt senter». Betingelsene for å bruke denne koden er at sykehuset har opprettet et eget, organisert palliativt tilbud $\mathrm{i}$ form av et palliativt senter med et palliativt team, eventuelt en palliativ enhet, og at senteret fyller gitte kriterier i oppfølgingen av pasientene. Behandlingen skal gjelde innleggelse eller dagbehandling. Det palliative teamet skal tilby ambulant behandling i pasientens hjem og sykehusets avdelinger som også skal kunne konsultere teamet (Helsedirektoratet, 2017).

Den palliative koden kan i dag benyttes dersom det palliative teamet tilbyr ambulant behandling i pasienten hjem. Utvalget ønsker å styrke de palliative teamenes rådgivende funksjon overfor den kommunale helse- og omsorgstjenesten. Denne virksomheten dekkes ikke av den palliative koden i dag. Utvalget er kjent med at det er foreslått en endring i finansiering av pallasjon i spesialisthelsetjenesten fra 2018.

\section{Palliasjon til barn og unge}

Palliasjon til barn innebærer spesielle utfordringer og vil kreve en noe annen tilretteleggelse av de pasienttilpassede forløpene enn forløp for voksne. Både underveis i forløpet og når døden nærmer seg vil familien bli rammet på en annen måte enn når voksne dør. Samtidig som det er noen særlige karakteristika for palliasjon til barn, 
legger utvalget til grunn at de samme generelle prinsippene som gjelder for palliasjon til voksne også vil gjelde for barn. I spesialisthelsetjenesten for voksne er de ulike sykdommene organisert på en annen måte, ut fra organspesifikke sykdommer eller sykdomskategorier. En slik tilnærming er en utvikling vi også ser innen pediatrien. Karakteristisk for pediatrien er likevel at alle sykdommmer er samlet i en spesialitet og en organisatorisk struktur.

Utvalget anbefaler at spesialisthelsetjenesten og den kommunale helse- og omsorgstjenesten må legge til rette for at barnet kan være mest mulig hjemme og leve et så normalt liv som mulig. Opphold på sykehus eller en annen institusjon bør reduseres til et nødvendig minimum, både av hensyn til barnet, søsken og familien som helhet. Det er behov for at skole/barnehage og behandlingssted koordinerer aktuelle tiltak for å sikre best mulig sammenheng og kontinuitet i barnets hverdag. Familier med behov for avlastning bør tilbys dette, enten i eget hjem, dersom de ønsker det, alternativt ved at barnet får et tidsbegrenset opphold i en barnebolig eller avlastningsbolig. Noen steder er det organisert et tilbud med ambulante spesialisthelsetjenestetilbud (hjemmesykehus for barn).

Utvalget mener barneboliger og avlastningsboliger kan være et alternativ til de aller sykeste barna som ikke kan bo hjemme. Helsetilsynet gjennomførte i 2009 et landsomfattende tilsyn med kommunale sosial- og helsetjenester til barn i barne- og avlastningsboliger. Tilsynet omfattet 75 kommuner og bydeler. I en oppsummering kom det fram at mange kommuner har for dårlig oversikt over tjenesten. Tilsynet avdekket brudd på helse- og omsorgslovgivningen i tre av fire tilfeller. Helsetilsynet fant at kommunene hadde mangelfull styring av tilbudet i avlastnings- og barneboligene. Det er mange deltidsansatte i boligene, stort innslag av ufaglærte og mangelfull opplæring av de ansatte. I ca. halvparten av sakene ble det avdekket brudd på reglene for legemiddelhåndtering. I tilsynsrapporten anbefales det at kommunene må ta et sterkere grep om styringen for å redusere risikoen for mangelfulle tjenester og etterspørre og følge opp kvaliteten på tjenestene i hver enkelt barne- og avlastningsbolig. Rapporten pekte videre på at regelverket ikke er godt tilrettelagt for drift av barne- og avlastningsboliger ved at det dels er mangelfullt og dels komplekst og vanskelig tilgjengelig, og at regelverket bør gjennomgås spesielt med tanke på disse barnas særskilte situasjon og behov (Helsetilsynet, 2010). Utvalget støtter Helsetilsynets anbefaling om å styrke kvaliteten på tjenestene i barneboliger og avlastningsboliger.

Fylkesmannsembetene har siden 2009 gjennomført ytterligere tilsyn med avlastnings- og barneboliger. Fylkesmennene har konstatert ett eller flere avvik i 13 av sakene. Avvikene er særlig knyttet til legemiddelhåndtering, kompetanse hos og opplæring av de ansatte mangel på fritidsaktiviteter og fysiske forhold i boligen (NOU 2016: 17 På lik linje). I forbindelse med iverksettelsen av ny kommunal helse- og omsorgstjenestelov ble barneboliger definert som helse- og omsorgsinstitusjon gjennom forskrift om kommunal helse- og omsorgsinstitusjon (Helse- og omsorgsdepartementet, 2011). Dette for å sikre et klart regelverk for kommunens ansvar for denne tjenesten.

Noen organisatoriske strukturer bør være tilgjengelige som en integrert del av de palliative pasienttilpassede forløpene for barn. Dette er barneboliger og avlastningsboliger. I boks 9.15 er det oppsummert noen av de spesielle forholdene som gjelder barn.

Forholdene som er omtalt i boks 9.14 , spesielt hjemmetid, er enda viktigere for barn og unge enn for voksne. De fleste steder er det få barn som trenger palliasjon. Et lavt volum kan gjøre det krevende å ha/opprettholde kompetanse. Dette forklarer hvorfor man ved noen større sykehus som Oslo universitetssykehus, Akershus universitetssykehus og Stavanger universitetssjukehus har utviklet en modell med «hjemmesykehus». I denne modellen tar det palliative teamet i spesialisthelsetjenesten helt eller delvis ansvar for alvorlig syke pasienter hjemme. Denne modellen har vært utprøvd også for voksne i noen deler av Sverige. Utvalget har ikke tatt stilling til om hjemmesykehus er en ønsket modell. Denne type tilbud bør imidlertid organiseres innenfor samme organisasjonsstruktur som de øvrige palliative tjenestene, basert på tidlig integrasjon av palliasjon, palliative team/kompetanse på barneavdelinger regionalt og lokalt og palliative team i kommunene. De palliative teamene på sykehusene, både regionalt og lokalt må sannsynligvis ta større ansvar for

\section{Boks 9.14 Palliasjon til barn og unge - spesielle forhold}

- Pediatri

- Alle sykdommer for barn i en spesialitet

- Lavt volum for hver enkelt tilstand

- Familien som helhet blir rammet

- Hjemmetid - høyt prioritert 


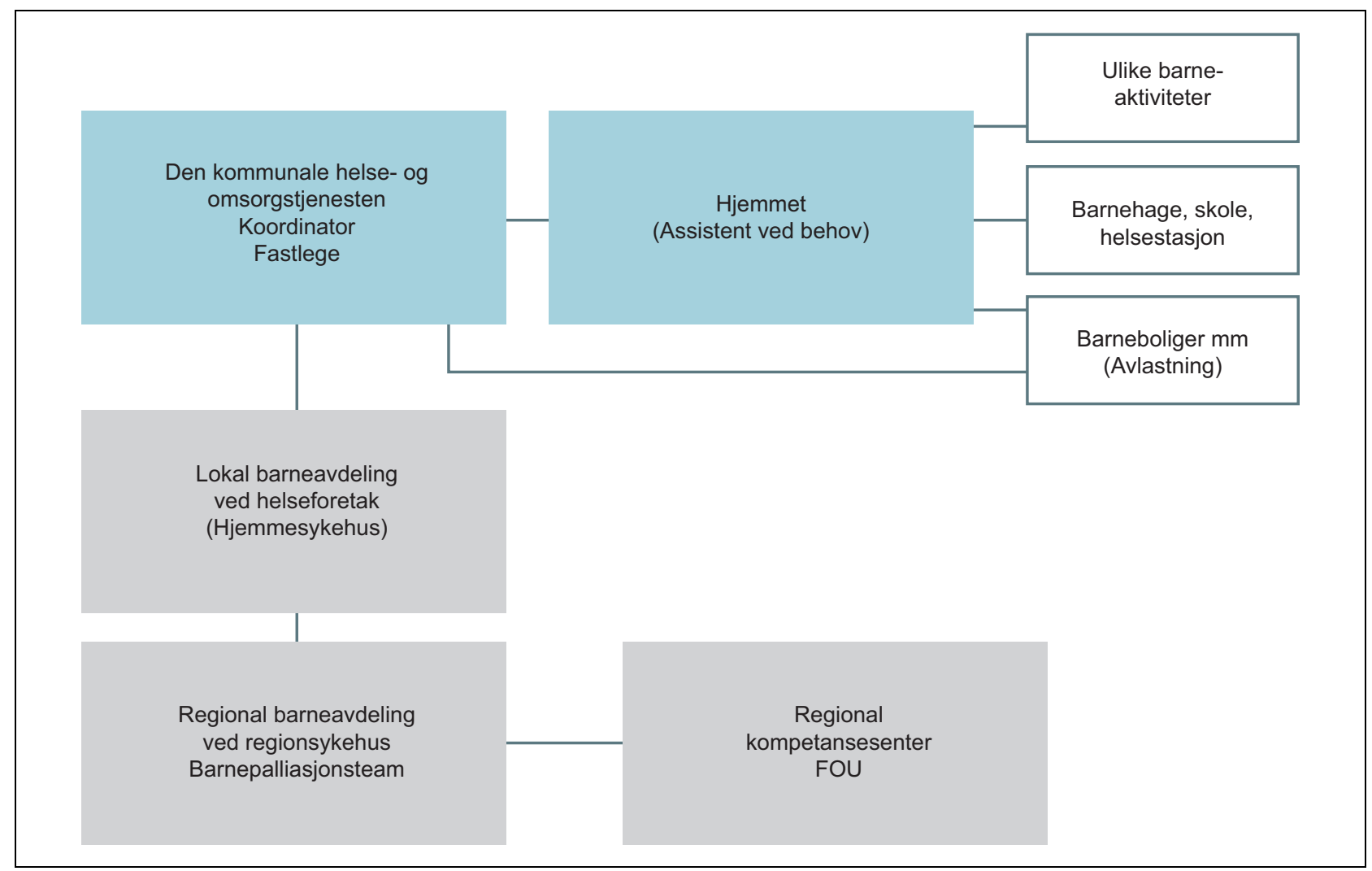

Figur 9.12 Organisering av barnepalliasjon i framtiden

tiltak overfor hjemmeboende barn når et barn har behov for palliasjon. Utvalget foreslår at erfaringer med palliative hjemmesykehus ved Oslo universitetssykehus, Akershus universitetssykehus og Stavanger universitetssjukehus evalueres for å vurdere nasjonal overføringsverdi.

Planene for hver enkelt pasient, beskrevet i de pasienttilpassede forløpene, basert på kommunal, lokal og regional kompetanse, bør være grunnstrukturen for barn også ved etablering av hjemmesykehus.

Utvalget er enige i at det ved region- og lokalsykehus skal etableres barnepalliative team, med en sammensetning som anbefalt $\mathrm{i}$ den nasjonale faglige retningslinjen om palliasjon til barn og unge uavhengig av diagnose (Helsedirektoratet, 2017), se figur 9.12. Størrelsen på teamene må avpasses geografi og befolkningstetthet. Alle større barneavdelinger bør ha et slikt palliativt team. Teamet bør ha lege med påbygningsspesialitet i palliativ medisin. På de største sykehusene må barnepalliasjon være hovedaktivitet.

På en barneavdeling skal det være egne palliative senger og leger og sykepleiere med spesialutdanning i palliasjon. For leger er det naturlig at de som grenspesialitet er pediater. FOU-delen i bar- neavdelingen samarbeider med og koordineres av det regionale senteret.

Ved en slik ordning forventer utvalget at samspillet mellom de tre nivåene i helsetjenesten blir utviklet også innen barnepalliasjon. Dette krever god planlegging, blant annet ved å utvikle de pasienttilpassede forløpene sammen med pasient og familien på et tidlig tidspunkt, og ved å ha nødvendig fleksibilitet.

Det er behov for å ha en særskilt oppmerksomhet rettet mot overgangen fra ungdom til voksen. Dette vil kreve forutsigbare og godt planlagte individuelle pasientforløp hvor det er tydeliggjort hvem som har hovedansvaret for pasienten til enhver tid. Når ungdom over 18 år har behov for spesialisthelsetjeneste og det er behov for innleggelse i sykehus, mener utvalget det er viktig å skape stabilitet ved at sykehuset sørger for at ungdom kommer til en fast avdeling ved sykehuset, og med størst mulig grad av fast personell å forholde seg til. Dette kan ivaretas ved at det nedfelles i en palliativ plan.

Barnet og familien kan ha behov for psykososial støtte i hele eller deler av sykdomsforløpet, og de har behov for å bli mott av personer med innsikt og forståelse som anerkjenner og normaliserer deres sorg og sorgreaksjoner. Noen velger å kalle denne 
sorgprosessen «ventesorg» (Foreningen for barnepalliasjon). Begrepet søker å understreke det normale i denne sorgprosessen, og gjøre den forståelig. Ventesorg er som annen sorg, med de samme symptomer, reaksjoner og variasjoner. For barnet kan sorgen omfatte depresjon, angst og frykt, sinne, isolasjon, ensomhet, frustrasjon, skyldfølelse og bekymringer.

Utvalget mener det er en oppgave for de palliative sentrene, i samarbeid med den kommunale helse- og omsorgstjenesten, å bidra til at alvorlig syke barn skal kunne være mest mulig hjemme og få dø hjemme. De må også ivareta samhandling, tilrettelegging og opplæring og for å trygge familier hjemme, og for å slippe innleggelse i sykehus. Det må være kontinuitet i ivaretakelsen av barnet og familien over tid. Utvalget mener det bør vurderes en særskilt finansiering for palliasjon til barn, alternativt at den palliative tilleggsrefusjonen kan brukes også for barn, og at de øvrige kravene for å få refusjon må være tilstede.

Det er utarbeidet en Nasjonal faglig retningslinje for palliasjon til barn og unge uavhengig av diagnose (Helsedirektoratet, 2017). Utvalget mener det er behov for å revidere denne retningslinjen og gi tydeligere føringer for integrasjon av palliasjon i pediatrien og føringer for organisering av palliative tjenester til barn og unge i den kommunale helse- og omsorgstjenesten og i spesialisthelstjenesten.

De palliative tilbudene for barn vil være mer varierende enn hos voksne. Barn med palliative behov kan leve i mange år med sykdommer som gradvis reduserer funksjonsnivået og hvor det palliative behovet vil endres og øke over mange år.

Når barn er døende kan det bli et større behov for hjemmetid sammen med familien og søsken. Barn med behov for palliative tjenester er volummessig lavt, men forløpene har høy kompleksitet. Det finnes ikke oversikt over antall barn med behov for palliasjon i Norge. Anslagene som brukes er basert på engelske tall. Selv i større kommuner vil man ha få barn per år, og det kan være utfordrende å ha tilstrekkelig kunnskap og kompetanse på dette feltet. Kommunen må derfor samarbeide tett med de palliative teamene i spesialisthelsetjenesten. Samarbeid mellom spesialisthelsetjenesten og den kommunale helse- og omsorgstjenesten må avtales basert på forhåndsbestemte retningslinjer.

Utvalget mener at den organisatoriske strukturen for barnepalliasjon i spesialisthelsetjenesten skal følge de samme hovedprinsippene som for voksne. Dette betyr at det ved alle regionale barneavdelinger skal etableres et barnepalliativt sen- ter med klinikk og FOU virksomhet på lik linje som ved palliative senter på sykehus. Etter at det er etablert barnepalliative sentere på regionsykehusnivå, skal dette også videreutvikles i på lokalsykehusnivå.

Utvalget understreker betydningen av et godt samarbeid mellom kommune og sykehus, slik at sykehuset kan være en støtte for kommunen som en klinisk kompetansebase. Kompetansesentrene må ha kompetanse om palliasjon til barn i større grad enn i dag og dele denne kompetansen med kommunene. Fastlegen bør være koordinator for familier med barn som har behov for palliativ behandling, pleie og omsorg.

Barn bør få leve og avslutte livet hjemme. Dersom dette ikke er mulig, bør barnet i størst mulig grad få være så nær hjemmet som mulig. Flertallet i utvalget, bestående av utvalgsleder Kaasa og utvalgsmedlemmene Andersen, Bahus, Broen, Farsund, Flovik, Hagerup, Husby, Schjødt og Slaaen mener at egne hospiceinstitusjoner for barn ikke er egnet til å ivareta dette formålet. Disse medlemmene mener at et eget barnehospice vil innebære at barn og familie må oppholde seg langt hjemmefra i en livssituasjon der vi vet at nærhet til familie, venner og nettverk er viktig. Det er for få innbyggere og for spredt bosetting i Norge til at egne barnehospice vil kunne ivareta barns behov for å være mest mulig hjemme sammen med familien. Flertallet i utvalget foreslår at det etableres tilbud integrert $\mathrm{i}$ den ordinære helse- og omsorgstjenesten som ivaretar barnet og hele familien som en enhet, og som tilbyr god oppfølging av familien etter barnets død. Dette bør gjøres i tilslutning til barneavdelingene, barnebolig, avlastningsbolig, barnehabilitering eller andre barne/familieinstitusjoner. For å få til dette, er det behov for å styrke kompetanse og kapasitet på barnepalliasjon både i den kommunale helse- og omsorgstjenesten og i spesialisthelsetjenesten.

Disse enhetene bør integreres sammen med den generelle palliative sengeenheten i kommunen, men skjermes fra enheter hvor det er urolige pasienter.

\section{Døden}

Døden er spesiell og sentral i palliasjon. Hospice som institusjon og hospice som en filosofi har hatt som mål å synliggjøre døden i helsetjenesten og $\mathrm{i}$ samfunnet generelt.

Ivaretakelse av døende mennesker og deres familie kan kreve særskilt kompetanse. Den grunnleggende kompetansen bør finnes innenfor 
alle de beskrevne organisasjonsmodellene i dette kapittelet, og anses som en sentral del i grunnleggende palliasjon.

For å videreutvikle kompetansen om den døende pasienten gjennom klinikk, klinisk og helserelatert forskning og utvikling og påse at de pasienttilpassede forløpene blir implementert i klinisk praksis for døende pasienter, mener utvalget at noen av de palliative sentre i Norge bør ha som hovedområde å ha oppmerksomhet på den døende pasienten. Ansvaret for å forske, generere ny erfaringsbasert kompetanse og videreutvikle de pasienttilpassede forløpene bør legges til noen dedikerte palliative sentere i Norge, både på region-, lokalsykehus- og kommunenivå. Pasientene skal ivaretas klinisk kompetansemessig nærmest mulig hjemmet.

De regionale kompetansesentrene får i oppgave å etablere interregionalt samarbeid med hovedansvar hos et av sentrene for den døende pasienten. Det bør også etableres tilsvarende hovedansvar til minst et palliativt senter på sykehus i hver helseregion.

\subsection{Tiltak}

- Det etableres kommunale palliative sentre i de største kommunene og som interkommunale sentre i mindre kommuner.

- Alle større lokalsykehus skal ha et fullverdig palliativt senter. Mindre lokalsykehus skal som et minimum ha palliativt team.

- Regionale palliative senter skal, i tillegg til et kompetansesenter, ha tre kliniske hovedaktiviteter: Pallitiv sengeenhet, palliativt team og palliativ poliklinikk.

- Regionale palliative sentre med en klinisk del og et kompetansesenter, skal organiseres som en enhet under en ledelse.

- Kompetansesenterdelen i de regionale palliative sentrene skal være atskilt fra den kliniske virksomheten og dekke de fire hovedopp- gavene: Undervisning, utarbeidelse og implementering av de pasienttilpassede forløpene, drift av nettverk og forskning - for hele regionen.

- Det nasjonale nettverket av de regionale palliative kompetansesentrene skal fordele regionale spisskompetanseområder seg imellom. Kompetansesentrene rapporterer i linjen til RHF-ene og samlet rapportering vurderes årlig av de regionale fagdirektørene.

- Det etableres barnepalliative sentre ved alle regionsykehus i Norge med samme struktur som palliativt senter i sykehus.

- Det etableres barnepalliative sentre på sykehus.

- Erfaringer med palliative hjemmesykehus for barn ved Oslo universitetssykehus, Akershus universitetssykehus og Stavanger universitetssjukehus skal evalueres.

- Den nasjonale faglige retningslinjen for palliasjon til barn og unge uavhengig av diagnose revideres for å gi tydeligere føringer for integrasjon av palliasjon i pediatrien og for organisering av palliative tjenester til barn og unge $\mathrm{i}$ den kommunale helse- og omsorgstjenesten og i spesialisthelsetjenesten.

- De regionale kompetansesentrene får i oppgave å etablere et interregionalt samarbeid for den døende pasient med hovedansvar hos ett av sentrene. Det etableres også tilsvarende hovedansvar i minst ett palliativt senter på sykehus i hver helseregion.

Kvalitet:

- Det utarbeides kvalitetsindikatorer innen palliasjon

- Nasjonale faglige retningslinjer:

- Palliative pasienttilpassede forløp inkluderes $\mathrm{i}$ alle relevante nasjonale faglige retningslinjer, også for andre sykdomsgrupper enn kreft. 


\section{Kapittel 10 \\ Pårørende}

\begin{abstract}
Pårorende representerer livgivende ressurser fordi de er mennesker som bryr seg, og som den syke har tillit til. Kjoerligheten fra dem som står noer påvirker motstandskraften og er en kilde til overlevelse.
\end{abstract}

Mads Gilbert

\subsection{Innledning}

Livstruende sykdom rammer ikke bare den som er syk, men også de som er nær. Å være pårørende til en som er alvorlig syk kan bidra til å knytte sterkere bånd, samtidig kan det også være belastende. Pårørende vil oftest støtte den syke, både fysisk og psykisk. Pårørendes tilstedeværelse og omsorg spesielt i hjemmet, men også på institusjon er viktig for pasientene. Det er vanligvis de pårørende som kjenner pasienten best $\mathrm{og}$ som kan bistå pasientene med å tydeliggjøre ønsker og behov når de ikke lenger klarer det selv. Det er derfor viktig å trekke pårørende inn tidlig i pasientforløpet. Pårørendes egne behov må også anerkjennes og ivaretas. Pårørende er klart definert i lovverket (se boks 10.1).

Pårørende har rett til informasjon om pasientens helsetilstand og den helsehjelp som gis, dersom pasient/bruker samtykker eller forholdene tilsier det, jfr. pasient- og brukerrettighetsloven $\S 3-3$. De samme reglene gjelder for pårørendes innsyn i journal, jfr. pasient- og brukerrettighetsloven $\S 5-1$.

\subsection{Dagens situasjon}

\subsubsection{Sentrale dokumenter og føringer}

NOU 2014: 12 Åpent og rettferdig - prioriteringer $i$ helsetjenesten anbefaler at pårørende får hjelp til å mestre livet med sykdom, og at de involveres i prioriteringsarbeid og arbeid med å utvikle helse- og omsorgstjenestene. Utredningen viser også til at

\section{Boks 10.1 Definisjon av pårørende}

I pasient- og brukerrettighetsloven § 1-3 første ledd bokstav b heter det at pårørende er: «Den pasienten oppgir som pårørende og nærmeste pårørende. Dersom pasienten er ute av stand til å oppgi pårørende, skal nærmeste pårørende være den som i størst utstrekning har varig og løpende kontakt med pasienten, likevel slik at det tas utgangspunkt i følgende rekkefølge: ektefelle, registrert partner, personer som lever i ekteskapslignende eller partnerskapslignende samboerskap med pasienten, barn over 18 år, foreldre eller andre med foreldreansvaret, søsken over 18 år, besteforeldre, andre familiemedlemmer som står pasienten nær, verge eller fremtidsfullmektig med kompetanse på det personlige området».

redusert belastning for pårørende kan gi helsegevinster.

Meld. St. 29 (2012-2013) Morgendagens omsorg foreslår et program for en aktiv og fremtidsrettet pårørendepolitikk. Etter at stortingsmeldingen ble lagt fram, ble programmet utviklet. Programmets (2014-2020) mål er blant annet å støtte pårørende som har krevende omsorgsoppgaver, bedre samspillet mellom den offentlige og uformelle omsorgen, legge til rette for å opprettholde pårørendeomsorgen på dagens nivå og gjøre det enklere å kombinere yrkesaktivitet med omsorg for barn og unge, voksne og eldre med alvorlig sykdom, funksjonsnedsettelse eller psykiske og sosiale problemer. Et av tiltakene i programmet er utviklingen av Veileder om pårorende $i$ helse- og omsorgstjenesten (Helsedirektoratet, 2017c). Veilederen beskriver pårørendes rettigheter og helse- og omsorgstjenestens plikter, og gir anbefalinger om god praksis. Veilederen omfatter 
alle pårørendegrupper, uavhengig av pasientens eller brukerens diagnose, og inkluderer eldre, voksne, ungdom og barn som pårørende.

I Meld. St. 26 (2014-2015) Fremtidens primoerhelsetjeneste - noerhet og helhet, Nasjonal faglig retningslinje for palliasjon til barn og unge uavhengig diagnose (Helsedirektoratet, 2017) og Nasjonalt handlingsprogram med retningslinjer for palliasjon $i$ kreftomsorgen (Helsedirektoratet, 2015b) framheves det at pårørende bør få en større og tydeligere plass i helse- og omsorgstjenestene. Pårørende som tar vare på sine nærmeste bør få veiledning, støtte og avlastning fra offentlige tjenester når de trenger det.

Beslutningsprosesser ved begrensning av livsforlengende behandling (Helsedirektoratet, 2013) beskriver blant annet pårørendes rolle og omtaler juridiske, etiske og kommunikative utfordringer og behovet for godt samspill mellom helsetjenesten, pasient og pårørende.

\subsubsection{Pårørende i et samfunnsperspektiv}

Befolkningsutviklingen viser at det i årene framover vil bli flere eldre med behov for hjelp fra den offentlige helse- og omsorgstjenesten. Pårørende utfører betydelige ansvars- og omsorgsoppgaver overfor sine nærmeste og utgjør på denne måten en sentral del av samfunnets totale omsorgsressurs. De bidrar i daglige gjøremål og praktiske oppgaver. Pårørende er ofte en del av pasientens naturlige nærmiljø og representerer stabilitet uavhengig av sykdomsutvikling og skifte av helsepersonell. De er en ressurs og en støtte for den som er syk, og kan gi viktig informasjon til helsepersonell (Helsedirektoratet, 2017c).

I 2008 ble det utført om lag 96000 årsverk i ulønnet omsorgsarbeid til syke, eldre og personer med nedsatt funksjonsevne i og utenfor husholdningen, mens det ble utført om lag 120000 årsverk i den kommunale helse- og omsorgstjenesten. 50 prosent av alle tjenestemottakere i den kommunale helse- og omsorgstjenesten mottok i 2016 en eller annen form for ubetalt privat hjelp. Andelen som mottar slik bistand varierer med ulike tjenestetyper (Statistisk sentralbyrå, 2017). Ektefeller er som regel langt viktigere omsorgspersoner enn voksne barn. Voksne barn bidrar ofte $\mathrm{i}$ omsorgen for sine foreldre når den eldre ikke har ektefelle i live. Kvinner utfører i større grad enn menn det uformelle, ubetalte omsorgsarbeidet. Det er en økende andel enslige i befolkningen og en stor andel av befolkningen er i arbeid. Dette er utviklingstrekk som påvirker muligheten til å gi uformell omsorg til alvorlig syke familie- medlemmer (Holmås, Kjerstad m.fl., 2016). Ønsket om palliativ behandling og omsorg i hjemmet i livets siste fase kan være vanskelig å imøtekomme hvis pasienten ikke har nære pårørende som bidrar i omsorgen.

Det er mangelfull kunnskap om hvordan etniske minoriteter opplever pårørenderollen $\mathrm{i}$ møte med helsepersonell i Norge. Mennesker fra ulike kulturer kan ha ulike tradisjoner som virker inn på pasientens preferanser i behandling og omsorg, og vil også påvirke pårørendes rolle. I den samiske befolkningen opplever mange at de ikke møter en omsorgstjeneste som er tilpasset deres språk og kultur. De blir dermed mer avhengige av hjelp fra pårørende både for å klare seg i hverdagen, og for å kunne hevde sine behov og rettigheter (Meld. St. 29 (2012-2013)). Kultursensitivitet er av stor betydning i møte med alvorlige syke og deres familie. Ritualer knyttet til død og hvordan man ser på sykdom kan være forskjellig fra kultur til kultur, men også fra person til person med samme kulturelle bakgrunn.

\subsubsection{Informasjon og veiledningsplikt}

Pasienter som trenger palliativ behandling kan i perioder være kognitivt svekket, utvikle en permanent kognitiv svikt og derfor ha begrenset samtykkekompetanse. Det følger av pasient- og brukerrettighetsloven $\S 3-3$, andre ledd at når en pasient over 16 år åpenbart ikke kan ivareta sine interesser på grunn av fysiske eller psykiske forstyrrelser, demens eller psykisk utviklingshemning, har både pasienten og nærmeste pårørende rett til informasjon om pasientens helsetilstand og den helsehjelp som gis.

Helsetjenesten har også en generell veiledningsplikt overfor pårørende (jfr. forvaltingsloven $\S 11)$. Generell informasjon, råd og veiledning til pårørende krever m.a.o. ikke samtykke fra pasient/bruker.

\subsubsection{Barn og unge som pårørende}

I 2010 ble det innført nye bestemmelser i helsepersonelloven $(\S 10$ a) og spesialisthelsetjenesteloven ( $3 \S 3-7$ a), som omhandler plikt til ivaretakelse av barn (0-18 år) som er pårørende «til pasient med psykisk sykdom, rusmiddelavhengighet eller alvorlig somatisk sykdom eller skade». Når barn 0-18 har behov for oppfølging eller informasjon pga. foreldrenes alvorlige somatisk sykdom, skal helsepersonell bidra til det. Dette kommer også til å gjelde barn som har alvorlig syke søsken (lovendring av 16. juni 2017 nr. 53). 
I møte med pasienter med alvorlig sykdom, skal helsepersonell søke kunnskap om pasienten har mindreårige barn. Helsepersonell skal i slike tilfelle snakke med pasienten om barnas behov for informasjon og oppfølging. Innenfor de rammene som taushetsplikten gir, skal helsepersonell bidra til at de som har omsorg for barnet får informasjon om pasienten. Helsepersonell skal også søke å få pasientens samtykke slik at de kan foreta den oppfølging av berørte barn som er hensiktsmessig.

Helseinstitusjoner skal ha barneansvarlig personell med ansvar for å fremme og koordinere oppfølging av barn til pasienter med alvorlig sykdom (jfr. spesialisthelsetjenesteloven $§ 3-7$ a). Dette er nærmere beskrevet i rundskriv IS-2010-5 (Helsedirektoratet, 2010). Når lovendring av 16. juni 2017 nr. 53 trår i kraft vil helsepersonell etter helsepersonelloven $\S 10 \mathrm{~b}$ ha en plikt til å ivareta mindreårige barn som er etterlatte etter foreldre eller søsken.

Multisenterstudien Barn som pårorende (Helsedirektoratet, 2015e) ga omfattende kunnskap om og innsikt i barnas situasjon, samt hvordan helse- og omsorgstjenesten fulgte opp sitt ansvar. Studien viste bl.a. at helsepersonell bare delvis fulgte opp plikten til å ivareta barn som pårørende. Helsepersonell skal ivareta barnets/barnas behov for informasjon og nødvendig oppfølging som barna har behov for etter tapet av foreldre eller søsken. Helsepersonell skal også tilby veiledning om aktuelle tiltak, og når det er nødvendig av hensyn til barna, innhente samtykke for å gi den oppfølgingen som er hensiktsmessig. Det er viktig at helsepersonell tilrettelegger informasjon for alle pårørende, uavhengig av kulturell bakgrunn, samtidig som de respekterer det kulturelle mangfoldet. Det vil være behov for en plan for hvordan informasjon til barnet og de barnet har rundt seg $\mathrm{i}$ hverdagen skal formidles.

Arbeidet med barn som pårørende i kommunen kan organiseres på ulike måter, for eksempel ved å opprette barneansvarlig personell, ved å legge spesiell kompetanse til familiesentre eller liknende, eller ved å legge ansvar og kompetanse til funksjoner som familiekoordinatorer (Helsedirektoratet, 2017c).

Mange foreldre opplever det som krevende å informere og involvere barna. Det er viktig at barn får tilpasset informasjon om foreldre eller søskens sykdom. Det er avgjørende å bidra til å trygge barna, og hjelpe dem til å opprettholde en mest mulig normal hverdag. Unge voksne har også behov for oppfølging, men er ikke sikret i lovverket i samme grad som barn.
Helse- og omsorgsdepartementet har opprettet et nasjonalt kompetansenettverk for barn som pårørende, BarnsBeste. Kompetansenettverket samler inn, systematiserer og formidler kunnskap og metodikk, med formål å forebygge og behandle problemer hos barn med foreldre som er rammet av sykdom og/eller rusproblemer. (BarnBeste, 2017)

\subsubsection{Pårørendes behov}

Det er en stor belastning å oppleve at et familiemedlem lider eller står i fare for å dø. Kortere liggetid på sykehus, lange sykdomsforløp, mer hjemmetid og et mål om at flere kan dø i eget hjem, fordrer mye av pårørende. Pårørende har økt risiko for å utvikle depresjon og søvnproblemer og de kan ha redusert livskvalitet (Helsedirektoratet, 2017c). En randomisert studie om tidlig palliasjon til pasienter med langtkommen kreft viste at tiltak for pasientene også førte til mindre depresjon og bedre livskvalitet for pårørende (El-Jawahri, Jackson m.fl., 2016). Vi vet at en av ti pårørende står i fare for å utvikle forlenget sorgreaksjon (Prolonged grief disorder, PGD) (Lundorff, Holmgren m.fl., 2017). Det bør tilbys støttesamtaler over tid for å gi støtte i psykososiale og åndelige/eksistensielle spørsmål. For å gi pårørende den informasjonen det har behov for, er det nødvendig med tverrfaglig samarbeid, der blant annet sosionom, psykolog og prest er viktige fagpersoner i tillegg til sykepleiere og leger. De vil også kunne formidle kontakt med andre hjelpeinstanser. Det bør være en systematisk oppfølging av pårørende etter dødsfallet.

Den palliative fasen vil kunne vare over en lengre periode for mange pasienter. Det kan være en stor utfordring å få hverdagslivet til å fungere når en nærstående er alvorlig syk og har behov for palliativ behandling. Familien kan få praktiske, økonomiske og sosiale utfordringer. Samtidig viser det seg at pårørende som klarer å ha et mest mulig normalt liv, i større grad enn andre vil opprettholde god helse (Stenberg, 2013). Situasjonen for pårørende $\mathrm{og}$ forholdet mellom pårørende $\mathrm{og}$ pasienten kan være spesielt utfordrende når det ikke er kontakt, er konflikter eller andre hendelser som vanskeliggjør forholdet.

Pårørende kan ha behov for å diskutere utfordringer de står i og møte andre som er i liknende situasjon. Enkelte kommuner har opprettet egne senter for pårørendearbeid. Larvik kommune har knyttet pårørendesenteret opp mot friskliv og mestring. Det finnes også nettressurser for pårørende med kunnskap, tips og råd, kontaktinforma- 
sjon til lokal hjelp samt oversikt over rettigheter for eksempel www.parorendesenteret.no. Pårørendealliansen er en frittstående paraplyorganisasjon som skal ivareta og forbedre pårørendes interesser og rettigheter, uavhengig av hvem man er pårørende til (www.parorendealliansen.no).

Ved alvorlig sykdom, både i hjemmet, på sykehjem og i sykehus, vil pasient og pårørende ha behov for råd og veiledning. Det er behov for kvalifisert og god bistand fra sosionom eller andre med relevant kunnskap for å få tilgang på aktuelle velferdsytelser som for eksempel pleiepenger, omsorgsstønad, samt praktisk bistand for å håndtere behov for barnehageplass, forsikringsordninger, testamente, arv, etterlattepensjon osv.

Forskning viser at pårørende opplever at deres behov for hjelp ikke alltid blir tatt på alvor i helsetjenesten og at det er vanskelig å få tilpasset hjelpen til behovene de har som familie. Pårørende kan vegre seg for å be om hjelp fra helse- og omsorgstjenestene (Aasbø, 2017). For å møte pårørendes behov er det nødvendig med en mer systematisk tilnærming til pårørendes utfordringer, behov og og omsorgsbyrde i hverdagen. The Carer Support Needs Assessment Tool (CSNAT), er et verktøy/skjema som kan brukes for å kartlegge pårørendes behov som omsorgsgivere ved alvorlig sykdom (Ewing, Grande, 2013).

Sorg er en normal prosess etter å ha opplevd et tap. Tilsvarende er ventesorg en normal sorg som oppstår når en pårørende over lang tid lever med en trussel om at en nærstående kommer til å dø. Det kan forekomme ved mange tilstander for eksempel ved alvorlig sykdom hos barn eller når en nærstående har fått diagnostisert demens. Ventesorg kan omfatte mange av de samme prosessene og symptomene som man opplever etter et dødsfall. (Foreningen for barnepalliasjon, 2017). Behov for støtte under det palliative forløpet og etter at pasienten er død, vil sannsynligvis være større og vare lengre når pasienten er et barn. Dette må det tas hensyn til ved å tilby kvalifisert hjelp over lengre tid (Kreicbergs, Valdimarsdottir m.fl., 2005).

\subsubsection{Når pasienten ønsker å være hjemme så lenge som mulig}

Å være samlet som familie og være sammen i hjemmet bidrar til å normalisere en hverdag i samsvar med livet familien har levd, noe det kan det være vanskelig å få til i en institusjon. Det er betydningsfullt å være $\mathrm{i}$ ro hjemme, og tid hjemme kan bidra til en verdifull avslutning på livet (Sørhus og Landmark, 2016). I noen tilfeller vil omsorg i hjemmet mot livets slutt ikke være mulig. Pasienten kan for eksempel ha funksjonsnedsettelser og symptomer som ikke kan lindres i hjemmet. Personer med demens bor ofte den siste delen av livet i sykehjem. For mange er dette hjemmet. Institusjonen må legge forholdene til rette for pårørende slik at de kan være sammen $\mathrm{i}$ livets siste fase når det er et ønske.

For å kunne bo hjemme så lenge som mulig, og kanskje også dø i hjemmet, er det viktig at pårørende føler seg kompetente og trygge på oppgavene som følger med. Mange pårørende ønsker å bidra med stell og omsorg selv om de ikke har noen tidligere erfaring med det (Grov, 2010). Det er en forutsetning at både pasient og pårørende kan stole på at de får tilgang på nødvendige helseog omsorgstjenester, og til teknisk utstyr og hjelpemidler. De fleste pårørende vil ha behov for opplæring og veiledning i rollen som omsorgsgiver. Involvering og god kommunikasjon mellom hjemmesykepleien og familiemedlemmer er viktig. Behovet for avlastning i hjemmet kan være stort når en i familien er i livets sluttfase, spesielt hvis det er barn eller ungdom i familien.

I planleggingen av de pasienttilpassede forløpene skal pårørende involveres sammen med pasienten. Dette er avgjørende når pasienten er hjemme. For å få til et godt forløp, må helsepersonell ha et tett og forutsigbart samarbeid med pårørende og være tilgjengelige hele døgnet. Ved akutte situasjoner, med forverring av sykdommen, pusteproblemer, smerter eller annet, kan pasient og pårørende oppleve raskt behov for hjelp. Det er nødvendig å ha et løpende samarbeid med pårørende for å tilpasse den offentlige omsorgen til familiens ønsker og behov vedrørende pleieoppgaver og tilbud om avlastning.

Noen pasienter velger selv å dø i institusjon fordi de vil skåne pårørende for den store belastningen det er å ivareta den alvorlig syke hjemme (MacArtney, Broom m.fl., 2015).

\subsubsection{Kontakten mellom pårørende og helse- og omsorgstjenestene}

Helsepersonell bør oppfordre pasienter til å ta med pårørende i møter med helse- og omsorgstjenesten hvor viktig informasjon skal gis. Det kan gjelde forverring av sykdommen, eller det å ta avgjørelser som vil ha store konsekvenser for familien. Eksempler på dette er hvordan man skal informere og ivareta barna når en $\mathrm{i}$ familien blir syk, eller å drøfte familiens ressurser og ønsker med hensyn til tilrettelegging for hjemmebasert omsorg. 
Kontakten mellom pasient, pårørende og helsepersonell bygger på gjensidig respekt og tillit. Tillit til helsepersonell oppnås når de har kunnskap på fagfeltet, møter pasienten og de pårørende «der de er», og når det er kontinuitet med hensyn til hvem pasient og pårørende møter. I spesialisthelsetjenesten er det etablert en ordning med kontaktlege (spesialisthelsetjenesteloven $\S 2$ $5 \mathrm{c}$, jfr pasient- og brukerrettighetsloven $\S 2-5$ a og https://helsedirektoratet.no/kontaktlege-i-spesialisthelsetjenesten). Samtidig vil pasienten ved innleggelse på sykehus måtte forholde seg til andre og nye behandlere og sykepleiere. Grundig kjennskap til sykehistorie og pasientens helhetlige situasjon er da av stor betydning. Pasienten kan også ha en sykepleier som primærkontakt.

En god overgang fra sykehus til hjem forutsetter at de pårørende deltar i planleggingen av utskrivelsen. Utskriving fra institusjon til hjemmet må være planlagt. Hjemmeforhold, pårørendes ressurser og behov bør være kartlagt forut for utskriving til hjemmet. Det må avklares om de pårørende har nødvendig kapasitet til å følge opp den syke hjemme med hjelp fra helsetjenesten.

Det bør gjennomføres tverrfaglige planleggingsmøter før utskrivning fra sykehus. Der kan pasient og pårørende delta, i tillegg til helsepersonell fra sykehusavdelingen, hjemmetjenesten og aktuelle faggrupper, som for eksempel fysioterapeut og sosionom. I noen tilfeller er også fastlegen til stede. På bakgrunn av møtet lages det en plan for videre behandling og det foretas en ansvarsavklaring mellom de to nivåene i helsetjenesten og samhandling med familien. Planleggingsmøtene bidrar til å sikre at pasientens og pårørendes behov blir ivaretatt.

Nasjonalt handlingsprogram for palliasjon $i$ kreftomsorgen (Helsedirektoratet, 2015b) har anbefalinger om kommunikasjon ved livstruende sykdom til pasient og pårørende. Helsedirektoratet har også publisert en pårørendeveileder som omtaler temaer i samtaler med pårørende i livets sluttfase. Det er videre utviklet lokale prosedyrer i helsetjenesten som sikrer kvaliteten i dialog med pårørende. Et eksempel er «Den døende pasient Pårørendesamtale»(Sykehuset Telemark, 2015).

\subsubsection{Pårørende til syke barn}

Det blir ofte mange ekstra omsorgsoppgaver for de pårørende til et alvorlig sykt barn, gjerne over mange år. Sykdom hos barnet medfører en rekke endringer for barnet og deres familier, overgangen fra å være frisk til å bli syk, flytting mellom hjem og sykehus, nye roller som må inntas - som å bli pleier ved siden av å være foreldre og overgangen fra en potensielt helbredelig til uhelbredelig sykdom.

Foreldre har liten eller ingen kontroll over utviklingen av sykdommen. Dette utfordrer deres rolle som forsørger. For foreldre representerer deres barns forverrede helse flere tap - tapet av det friske barnet og forventinger til barnets fremtid (Goldman, Hain, Lieben, 2016). Barnet og pårørendes ønske om å leve et mest mulig normalt familieliv gjør at omsorg og behandling bør tilrettelegges slik at den kan mottas i hjemmet fram mot livets avslutning. I perioder vil det være behov for institusjonsopphold (barnebolig og tilsvarende) for å gi avlastning til familien deres eller andre omsorgspersoner.

Syke barn som før hadde familien som nesten eneste hjelpekilde, har de siste årene fått omfattende bistand og assistanse fra den kommunale helse- og omsorgstjenesten. Dette har bidratt til å lette byrdene for mange pårørende (Meld. St. 29 (2012-2013)). På den andre siden har dreiningen fra institusjonsomsorg mot hjemmebaserte tjenester ført til at noen foreldre har fătt et større omsorgsansvar for barn med nedsatt funksjonsevne både når de er barn, men også etter at barnet er blitt voksent.

For å kunne gi god behandling og omsorg til alvorlig syke og døende barn, er ivaretagelse av familien til barnet av avgjørende betydning. God dialog mellom helse- og omsorgstjenesten, barnet og dets foreldre er svært viktig. For pårørende vil et kompetent og stabilt personell i den kommunale helse- og omsorgstjenesten og i spesialisthelsetjenesten bidra til trygghet. Det følger av pasient- og brukerrettighetsloven kapittel 3 at foreldre til barn med livstruende/livsbegrensende tilstand skal sikres rett til medvirkning og informasjon sammen med barnet ved gjennomføring av helsehjelpen. Informasjonen må være tilpasset og forståelig. Barns rett til å få informasjon og høres styrkes ved endringslov av 16. juni 2017 nr. 35 . Foreldre skal involveres som likeverdige i arbeidet med planlegging av omsorgen og valgene som gjøres når det gjelder behandlingstiltak og $\mathrm{i}$ arbeid med individuell plan.

Et sentralt mål er best mulig livskvalitet og som regel best mulig funksjon. Pårørende til pasienter med livsbegrensende sykdommer vil ofte samarbeide med mange forskjellige aktører slik som fastlege, barneavdelinger, habiliteringstjeneste, barneboliger og øvrige helse- og omsorgstjenester i kommunen. For å kunne gi god behandling og omsorg til alvorlig syke og døende barn, er støtte og samarbeid mellom helse- og 
omsorgstjenesten og barnet og dets foreldre svært viktig. For pårørende vil et kompetent og stabilt personell i den kommunale helse- og omsorgstjenesten og i spesialisthelsetjenesten bidra til trygghet.

I kommunene og i barne- og ungdomsavdelingene arbeides det med barn og familier med komplekse sykdommer. Dette gjelder både habiliteringsenheter og andre barnefagspesifikke seksjoner som hjerte, lunge, mage-tarm, onkologi, nyfødt, nevrologi m.m. Det mangler allikevel et system for helhetlig tilbud til barn med livsbegrensende tilstand og deres familier, og flere familier har følt seg alene med totalansvaret for barnet (Helsedirektoratet, 2017).

Tre barneavdelinger, Oslo universitetssykehus, Akershus universitetssykehus og Stavanger universitetssjukehus har utviklet en modell med «hjemmesykehus» for barn. Dette er avdelinger som legger forholdene til rette for omsorg og behandling i hjemmet og for hjemmedød hvor familiene ønsker dette. Dette er nærmere beskrevet i kapittel 9.

\subsubsection{Velferdsordninger for pårørende}

Pårørende bør rutinemessig få informasjon om muligheten for bistand i økonomiske eller trygdemessige spørsmål. Sentrale ytelser for pårørende til alvorlig syke er hjelpestønad, omsorgsstønad, pleiepenger og avlastningsopphold.

\section{Hjelpestønad}

Hjelpestønad ytes for å kompensere økonomisk der det foreligger et særskilt behov for tilsyn og pleie utover det som dekkes av offentlig hjelpeordning. Det er et vilkår at det foreligger et privat pleieforhold eller det må være slik at hjelpestønaden vil sette den pleietrengende i stand til å etablere et privat pleieforhold.

\section{Omsorgsstønad}

Omsorgsstønad skal gjøre det mulig for private omsorgspersoner å opprettholde særlig tyngende omsorgsarbeid for sine nærmeste. Stønaden er en kommunal økonomisk kompensasjon til personer som utfører omsorgsoppgaver som ellers ville vært utført av det offentlige. Det er den enkeltes behov for tjenester og den enkelte pårørendes muligheter, ressurser og ønsker som er utgangspunktet for tildeling av helsetjenester. Videre er det en forutsetning at den som har hjelpebehovet ønsker at privatpersonen skal stå for hjelpen og mener det er beste løsning. Kommunen må også vurdere hjelpebehovet slik at hjelp fra privatpersonen er det beste alternativet. Ordningen omfatter både omsorgsytere uten omsorgsplikt og foreldre som har omsorgsplikt for sine mindreårige barn. Omsorgsstønad er pensjonsgivende og skattepliktig inntekt. Blant ektefeller som mottar omsorgsstønad er kvinneandelen på 60 prosent og andel menn 40 prosent (NOU 2011: 17).

\section{Brukerstyrt personlig assistanse (BPA)}

Kommunen skal ha tilbud om praktisk bistand og opplæring, organisert som brukerstyrt personlig assistanse (Helse- og omsorgstjenesteloven § 3-2 første ledd nr. 6 bokstav b). BPA er en måte å organisere tjenestene på som gir alle personer med funksjonshemning mulighet til å leve et aktivt og mest mulig uavhengig liv. Brukerstyrt personlig assistanse er et viktig bidrag til likeverd, likestilling og samfunnsdeltakelse for personer med nedsatt funksjonsevne og stort behov for bistand.

Fra 1. januar 2015 ble BPA en lovfestet rettighet i pasient- og brukerrettighetsloven $\S 2-1 \mathrm{~d}$. Lovendringen gir rett til brukerstyrt personlig assistanse for personer under 67 år med langvarig og stort behov for personlig assistanse. Kommunene har også en plikt til å vurdere om det er hensiktsmessig å tilby BPA også til brukere som ikke fyller vilkårene $\mathrm{i}$ rettighetsbestemmelsen (Helseog omsorgstjenesteloven $\S 3-8$ ).

Når praktisk bistand og opplæring organiseres som en BPA-ordning, er det brukeren selv, eventuelt med bistand, som organiserer og leder arbeidet med assistentene.

Avlastningstiltak er et tilbud til personer og familier med særlig tyngende omsorgsarbeid. Avlastning gis ut fra ulike behov og kan organiseres på ulike måter. Formålet ved avlastning er å:

- hindre overbelastning hos omsorgsyter

- gi omsorgsyter nødvendig fritid og ferie

- gi omsorgsyter mulighet til å delta $\mathrm{i}$ vanlige samfunnsaktiviteter

Avlastningstiltak kan gis både som avlastning i eget hjem og som opphold i institusjon.

Personer med foreldreansvar for hjemmeboende barn under 18 år med nedsatt funksjonsevne har rett til avlastningstiltak.

\section{Pleiepenger}

Formålet med pleiepenger er å kompensere for bortfall av arbeidsinntekt for yrkesaktive med 
sykepengerett i forbindelse med barns sykdom, barns funksjonshemming og pleie av nære pårørende i livets sluttfase (Lov om folketrygd del IV. kap. 9).

I lov om folketrygd ble det i 2013 gjort en endring om at rett til pleiepenger ved alvorlig sykdom skulle gjelde nærstående og ikke kun pårørende. Ulike familiestrukturer og sterk tilknytning til venner og andre som tradisjonelt ikke er pårørende har ført til denne endringen.

\section{Pleiepenger i livets sluttfase}

Pleiepenger skal erstatte arbeidsinntekt når pleie av en nærstående i livets sluttfase krever at man er hjemme hos den syke (Folketrygdloven $§ 9$ 13). Det er en forutsetning at den pleietrengende bor hjemme, enten i sitt eget eller i hjemmet til den som søker om pleiepenger. Retten til pleiepenger opphører hvis den pleietrengende legges inn på institusjon eller dør. Det er den sykes eget ønske om hvem som skal pleie som er avgjørende for hvem som har rett til pleiepenger. Den pleietrengende må derfor samtykke i pleien. Hvis den pleietrengende er for syk til å gi samtykke, skal det gå fram av legeerklæringen i søknadsskjemaet. Pleiepenger gjelder når pasienten mottar pleie i hjemmet, inntil 60 dager.

Kvinner utgjorde 70 prosent og menn 30 prosent av de pårørende som mottok pleiepenger $\mathrm{i}$ livets sluttfase i 2016. Gjennomsnittlig varighet per tilfelle er 7 dager for menn og 6 dager for kvinner (Arbeids- og velferdsdirektoratet, 2017).

Fra og med 1. juli 2010 ble stønadsperioden utvidet til å gjelde fra 20 til 60 dager for hver pasi-

\section{Boks 10.2 Fakta om: Pleiepenger en nærstående i livets sluttfase Folketrygdloven § 9-13 (2016)}

- I 2016 ble det utbetalt 32.5 mill. kroner

- 1244 personer mottok pleiepenger for 4034 tilfeller

- Kvinner utgjorde 2837 av tilfellene (70 pst.) og

- menn 1197 av tilfellene (30 pst.)

- Bare 18 tilfeller var graderte $(0,4$ pst. av alle tilfeller)

- Gjennomsnittlig varighet per tilfelle er 7 dager for menn og 6 dager for kvinner

Kilde: Arbeids- og velferdsdirektoratet, 2017 ent. Det har vært en stor økning i bruk av ordningene, både sett i forhold til antall pasienter (380 i 2010 til 1244 i 2016) som pleiepengene har vært knyttet til og antall pårørende som har mottatt pleiepenger (706 i 2010 til 4034 i 2016), sammenliknet med tall fra 2010. Det har vært en endring $i$ utbetalingene fra 5,6 mill. kroner i 2010 til 32,5 mill. kroner i 2016. Det kan i noen grad forklares med at utvidelsen av pleiepengedager i 2010, men trolig også at ordningen har blitt bedre kjent $o g$ at flere velger å bruke den.

\section{Pleiepenger ved pleie av syke barn}

For foreldre med syke barn gir folketrygdlovens bestemmelser om pleiepenger og opplæringspenger økonomisk kompensasjon for bortfall av inntekt når barnet på grunn av sykdom har behov for kontinuerlig tilsyn og pleie, og medlemmet derfor må være borte fra arbeidet (Folketrygdloven $\S 9$ 10).

Pleiepengeordningen er utvidet med virkning fra 1.10.2017. Pleiepenger er en frikjøpsordning fra foreldrenes jobb når barn er alvorlig syke. Fra 1. oktober 2017 får foreldrene en kvote på 1300 dager. Ordningen medfører en endring ved at 100 prosent lønnskompensasjon gis kun 1 år, deretter går utbetalingen ned til 66 prosent av lønnen. Foreldrene kan velge om bare den ene bruker disse dagene, eller om begge bruker av kvoten samtidig. Utvalget er kjent med at det kan komme en mulig utvidelse av pleiepengeordningen for foreldre med omsorg for syke barn, da det er innvilget en økonomisk ramme for dette i statsbudsjettet 2018 .

\subsection{Vurdering og drøfting av dagens praksis}

En forutsetning for å møte pårørendes behov er at relasjonen mellom pasient, pårørende og helsepersonell er preget av tillit, samvalg, fleksibilitet og tilgjengelighet. Utvalget mener at en mer systematisk tilnærming til pårørende vil styrke pårørendes situasjon ved at:

- de pasienttilpassede forløpene inkluderer og avklarer pårørendes roller og oppgaver

- pårørende inkluderes, når pasienten planlegger og samtykker, i innholdet i de pasienttilpassede forløpene

- pårørendes situasjon og behov kartlegges systematisk og fortløpende 


\subsubsection{Kartlegging av pårørendes omsorgsbyrde}

Statens helsetilsyn fant i sin landsomfattende undersøkelse i 2010 at kommunene gjennomgående «ikke kartla og vurderte pårørendes omsorgsbyrde, situasjon og behov for avlastning», $o g$ at saksbehandlingen ved søknader om avlastning var mangelfull (Meld. St. 29 (2012-2013), s. 59). I en palliativ fase hvor behovet for støtte fra pårørende er stort, må det være systemer og rutiner som fanger opp de pårørendes omsorgsbyrde og behov.

1. oktober 2017 trådte lovendring av 2. juni 2017 nr. 34 om styrket pårørendestøtte i kraft med endringer i folketrygdloven, helse- og omsorgstjenesteloven og pasient og brukerrettighetsloven. Lovendringen presiserer at kommunen har plikt til å kartlegge pårørendes behov for støtte, og fatte vedtak om tiltak rettet mot pårørende: opplæring, veiledning, avlastning og omsorgsstønad. Dette gjelder også foreldre til syke barn.

Utvalget mener at The Carer Support Needs Assessment Tool (CSNAT) er et egnet og godt verktøy for å kartlegge situasjonen og behovene til pårørende til pasienter med alvorlig sykdom. Dette måleinstrumentet er oversatt til norsk og brukes i dag i flere prosjekter. Det har vært knyttet spesifiserte kriterier til innholdet i palliative tiltak i spesialisthelsetjenesten for at sykehuset har kunnet kreve palliativ refusjon, for arbeidet (Helsedirektoratet, 2017d). Blant annet heter det at «Virksomheten må kunne dokumentere systematisk arbeid med inklusjon og ivaretakelse av pårørende». Utvalget foreslår at det i tillegg står ... «f.eks. ved bruk av CSNAT».

\subsubsection{Velferdsordninger for pårørende}

Utvalget mener velferdsordningene for pårørende, skissert i kapittel 10.2.9, i hovedsak møter behovene de skal dekke. Utvalget har følgende vurderinger av velferdsordningene utover dette:

\section{Formidling av rettigheter og juridisk kompetanse}

For rettigheter etter trygdelovgivningen både til foreldre med barn som har behov for palliative behandling, og for voksne pasienter med et tilsvarende behov, er det slik utvalget har vurdert det særlig to aspekter som er viktige:

Det første er formidling av rettigheter til pårørende når behovet oppstår, slik at økonomiske bekymringer kan unngås og at rettigheter ikke går tapt på grunn av foreldelse.

Det andre er behovet for rettsriktighet som sikres ved tilstrekkelig juridisk kompetanse hos de som fatter vedtak. Avslag på feil grunnlag kan velte økonomien for pasienter og familier som er rammet av sykdom, og situasjonen kan gjøre at de ikke har de nødvendige ressurser til å klage på vedtak. I tillegg er det viktig at pasienter og foreldre til alvorlig syke barn har mulighet til å få bistand for å søke om aktuelle rettigheter, samt til å klage på eventuelle avslag, slik at deres ressurser når disse er begrensede kan brukes til å ivareta egen/barnas helse. Dagens praksis i helsetjenesten har langt svakere organisering av sosialfaglig kompetanse enn det nasjonale retningslinjer anbefaler (Helsedirektoratet, 2015b).

\section{Pleiepenger til nærstående i livets sluttfase}

Ordningen med pleiepenger gir mulighet for nærstående til å gi omsorg mot livets slutt i hjemmet til pasienten eller hos omsorgsgiver. Pleiepengeordningen brukes i forholdsvis liten grad sett opp mot det totale antall dødsfall. Det er sannsynlig at sykemelding av de pårørende brukes i stedet for pleiepengeordningen. Mulige årsaker til et antatt underforbruk av ordningen kan være mangel på kjennskap til pleiepengeordningen eller at en ordning med bruk av sykepenger oppleves enklere.

Fra helsetjenesten meldes det at pårørende ikke kan ta ut pleiepenger ved akutt innleggelse eller ved plutselige komplikasjoner som krever innleggelse. Pårørende følger ofte pasienten ved ikke planlagte, eventuelt akutte innleggelser for så å bistå pasienten igjen i hjemmet når situasjonen har stabilisert seg. Det kan være behov for at pårørende er med og støtter alvorlig syke pasienter på sykehuset og det kan da være særlig uheldig dersom den pårørende ikke har denne mulighetene på grunn av manglende økonomisk kompensasjon. En pårørende som gir omsorg i hjemmet over en lengre periode vil også kunne ha problemer med gå tilbake til sitt arbeidsforhold for et kortere tidsrom, spesielt når arbeidsplassen er $\mathrm{i}$ en annen landsdel enn der omsorgen gis.

Utvalget mener det bør åpnes for at de som har vedtak om pleiepenger også kan beholde/ta ut pleiepenger ved en kort akutt innleggelse $\mathrm{i}$ institusjon dersom det er en del av behandlingsforløpet og videre omsorg i hjemmet er planlagt eller pasienten er døende. 
Praktisk avlastning i hjemmet til familier med mindreårige barn.

For familier med barn hvor en forelder er syk kan det være behov for annen hjelp enn den som vanligvis tilbys av den offentlige helsetjenesten i kommunene. Bergen kommune har en «Familievikar»ordning som tilbyr praktisk bistand. Denne tjenesten kan tildeles småbarnsforeldre som har særlig behov for bistand. Fransiskushjelpen i Oslo har også sett behovet og har etablert en tjeneste, «Familiehjelperen», en tjeneste med frivillige som blant annet tilbyr leksehjelp, matlaging og aktiviteter med barna. Utvalget ser behovet for flere slike frivillige ordninger.

\subsection{Tiltak}

- The Carer Support Needs Assessment Tool, CSNAT, skal implementeres i de pasienttilpassede forløpene.

- Pleiepengeordningen utvides slik at voksne kan beholde dem under innleggelse av pasient i sykehus.

Utvalget mener at det bør åpnes for at de som har vedtak om pleiepenger også kan beholde/ta ut pleiepenger ved antatt kort, akutt innleggelse $\mathrm{i}$ institusjon dersom det er en del av behandlingsforløpet og videre omsorg i hjemmet er planlagt eller dersom pasienten er døende. 


\section{Kapittel 11 Frivillige}

\begin{abstract}
For society...volunteering is an expression of the caring community; it shows a connection between society and the terminally ill.

EAPC White Paper: Defining volunteering in hospice and palliative care in Europe, 2016.
\end{abstract}

\subsection{Innledning}

De demografiske fremskrivningene innebærer at behovet for frivillig innsats på helse- og omsorgsfeltet vil øke. Det må derfor legges til rette for rekruttering av frivillige og for et systematisk samarbeid mellom frivillige og helse- og omsorgs-

\section{Boks 11.1 TERMIK}

Stiftelsen TERMIK (terminal omsorg i kommunen) har utviklet metode for samarbeid mellom kommunens helse- og omsorgstjenester og frivillige på palliasjonsfeltet. Dette er kanskje en av de mest anerkjente metodene for samarbeid på dette området i Norge. TERMIK ble opprettet i Vefsn kommune i 1996. Frivillige avlaster og støtter alvorlig syke, døende og deres pårørende, enten hjemme, eller på institusjon. Tilbudet er spesielt beregnet for pasienter som har få eller ingen pårørende. I 21 år har stiftelsen TERMIK tilbudt hjemmebesøk til alvorlig syke, døende og deres pårørende. De har tilbudt besøk, våketjeneste og andre avtalte oppgaver ved institusjon er i 12 år. TERMIK har utviklet en modell for organisering av frivillig arbeid og en håndbok om hvordan å komme i gang med frivillig arbeid på palliasjonsfeltet. Flere kommuner, blant andre Grimstad, har gjort som Vefsn og opprettet en frivillighetstjeneste ved hjelp av TERMIKs verdigrunnlag og organisering. De frivilliges hjelp bestemmes ut fra den sykes og de pårørendes behov og livssituasjon. tjenestene i kommunen og i spesialisthelsetjenesten. Et godt systematisk samarbeid mellom frivillige og helse- og omsorgstjenesten kommer ikke av seg selv. Det må kontinuerlig arbeides for å legge til rette for at frivillige kan gjøre en innsats på palliasjonsfeltet. Pasientens behov skal være retningsgivende for den frivillige innsatsen på palliasjonsfeltet.

Den frivillige skal fylle en annen rolle enn helsepersonell. Frivillige kan gi av sin tid og kan bidra til å forebygge ensomhet, gi økt velvære og styrke livskvalitet, både hos pasient, pårørende og hos den frivillige selv. Frivilliges innsats er pasientsentrert og den kan bidra til å bedre pasientens fyiske, psykiske, sosiale og åndelige/eksistensielle behov. Frivillige kan også bidra til at pårørende opplever seg ivaretatt.

Gjennom den meningsfulle aktiviteten frivillig innsats er, kan den frivillige oppleve mestring og sosial inkludering. Flere kommuner samarbeider med frivillige som gjør en innsats overfor alvorlig syke og døende og deres pårørende.

\subsection{Dagens situasjon}

\subsubsection{Sentrale dokumenter og anbefalinger for frivillig innsats}

I St.meld. nr. 39 (2006-2007) Frivillighet for alle framgår det at regjeringen vil sikre en helhetlig frivillighetspolitikk gjennom bl.a. å sikre frivillighetens uavhengighet og mangfold, legge til rette for at alle kan delta i frivillig arbeid og øke kunnskapen og oppmerksomheten om frivillighetens rolle og betydning for samfunnet. Kulturdepartementet iverksatte i 2017 et arbeid med ny stortingsmelding om den statlige frivillighetspolitikken (regjeringen.no).

Det er utarbeidet en frivillighetserklaering mellom regjeringen og frivillig sektor. Frivillighetserklæringen inneholder grunnleggende prinsipper og overordnede målsettinger for regjeringens samspill med frivillig sektor. Plattform for samspill og samarbeid er en avtale mellom KS og Frivillig- 
het Norge (Frivillighet Norge er et samarbeidsforum for frivillige organisasjoner) (ks.no). Plattformen fastsetter prinsipper og handlinger for å styrke relasjonen mellom offentlig og frivillig sektor i Norge.

Et av hovedmålene i Meld. St. nr. 29 (20122013) Morgendagens omsorg er å «få kunnskap om, lete fram, mobilisere og ta i bruk samfunnets samlede omsorgsressurser på nye måter». I meldingen pekes det blant annet på de store mulighetene det ligger $\mathrm{i}$ å engasjere flere frivillige $\mathrm{i}$ helseog omsorgssektorens område.

Nasjonal strategi for frivillig arbeid på helse- og omsorgsfeltet (2015-2020) er utarbeidet i samarbeid mellom Helse- og omsorgsdepartementet, Frivillighet Norge og KS. Strategien skal bidra til å legge til rette for frivillig innsats, å rekruttere og beholde frivillige og styrke systematisk samarbeid mellom frivillig og offentlig sektor.

I utredningen NOU 1999: 2 Livshjelp - Behandling, pleie og omsorg for uhelbredelig syke og døende anbefales det at den frivillige innsatsen bør skje etter ønske fra pasienten. Større bruk av frivillige medarbeidere vil komme pasienter og pårørende til gode, og det må legges til rette for at frivillig innsats blir en naturlig del av helse- og omsorgstjenestene som tilbys pasient og pårørende. Frivillige medarbeidere må gis systematisk opplæring. Utredningen vurderer at bruk av frivillige krever både økonomiske og faglige ressurser.

Nasjonalt handlingsprogram for palliasjon $i$ kreftomsorgen, (Helsedirektoratet 2015b) anbefaler at frivillige kan inngå som et tilskudd til fagpersonell, men at de ikke skal delta i medisinskfaglig behandling, stell og pleie.

\section{Boks 11.2 Definisjon av frivillighet på pallisjonsfeltet}

I Defining volunteering in hospice and palliative care in Europe: an EAPC White Paper (2016) (EAPC, 2016; 23(4)) har EAPC utarbeidet en konsensusdefinisjon av frivillighet på palliasjonsfeltet: "Volunteering in hospice and palliative care is defined as the time freely given by individuals, with no expectation of financial gain, within some form of organised structure other than the already existing social relations or familial ties, with the intention of improving the quality of life of adults and children with life-limiting conditions and those close to them (family and others).

\subsubsection{Tradisjon for frivillig arbeid}

I Norge har vi lang tradisjon for frivillig arbeid. I løpet av et år deltar om lag halvparten av befolkningen i frivillig arbeid. Under $10 \%$ av det frivillige arbeidet skjer innenfor helse- og omsorgssektoren. Pårørende er ikke inkludert i dette estimatet. Frivilliges innsats på palliasjonsfeltet er begrenset. En kartlegging av palliative tilbud i 2012 viste at kun 5 av 34 palliative sentre i sykehus brukte frivillige, mens 14 av 30 kommunale lindrende enheter hadde frivillige tilknyttet seg (Sintef, 2016). Frivillige gjør en stor innsats på palliasjonsfeltet i mange land. I Storbritannia har frivillig sektor tradisjonelt tatt et stort ansvar for utvikling av palliative tjenester, særlig hospice.

Frivillige innen palliasjonsfeltet kan bidra som enkeltperson eller gjennom en frivillig organisasjon. Det er flere frivillige organisasjoner som arbeider for å bedre livskvaliteten til pasienter som trenger palliativ behandling og deres pårørende. I tillegg til TERMIK (se boks 11.1), arbeider Hospiceforum Norge, og frivillige fra Røde Kors og Fransiskushjelpen, for å styrke frivillige innsats overfor dem som er i livets siste fase. Hospiceforum Norge arbeider for å etablere hospice. Foreningen for barnepalliasjon har som mål å øke kunnskapen om barnepalliasjon, å arbeide for å styrke det palliative tilbudet til barn og deres familier, og å etablere barnehospice.Verdighetssenteret er en stiftelse som blant annet gir opplæring til frivillighetskoordinatorer. De frivillige og ideelle organisasjonene kan være viktige pådrivere for utvikling på palliasjonsfeltet.

Det gis midler over statsbudsjettet for å beholde og styrke frivillig innsats på helse- og omsorgsfeltet. Et eksempel er et kommunalt kompetanse- og innovasjonstilskudd (Prop. 1 S (20162017) Helse- og omsorgsdepartementet). Dette tilskuddet skal blant annet bidra til utvikling av nye tiltak og metoder for samspill med pårørende og frivillige $\mathrm{i}$ omsorgssektoren generelt og $\mathrm{i}$ demensomsorgen spesielt. Et annet eksempel er tilskudd til frivillige organisasjoners informasjonsarbeid på palliasjonsfeltet (Prop. $1 \mathrm{~S}$ (2016-2017) Helse- og omsorgsdepartementet).

\subsubsection{Livsberikelse og livsstøtte}

Med utgangspunkt i pasientens behov kan det være hensiktsmessig å dele frivillighet inn i kategoriene livsberikelse og livsstøtte (Johansen og Hagerup, 2017). Livsberikelse innebærer at de frivillige bidrar med kulturelle og andre estetiske opplevelser, lager gode, sosiale fellesskap eller 
hjelper til med praktiske handlinger. Livsstøtte betyr at de frivillige er direkte støtte- og omsorgspersoner, gjerne i en-til-en-situasjoner. Eksempler er nærvær ved sykesengen, følgetjeneste til sykehus, våketjeneste og avlastning for pårørende.

Til kategorien livsberikelse kan man i et lokalmiljø rekruttere enkeltpersoner eller grupper, gjerne i samarbeid med frivillige organisasjoner. Det viktigste er at frivillighetstjenesten er godt organisert $\mathrm{og}$ at de frivillige følges opp. Til kategorien livsstøtte bør det organiseres en tjeneste som innebærer at de frivillige er vurdert som egnet til oppgavene, får opplæring og kontinuerlig oppfølging og veiledning. Begge disse kategoriene er aktuelle for frivillige på palliasjonsfeltet. I praksis trenger det ikke være vanntette skott mellom de to formene for frivillighet.

Frivillige på palliasjonsfeltet kan utføre en rekke oppgaver, i pasientens eget hjem, eller i palliative enheter ved sykehjem eller i sykehus. Frivillige kan gjøre en innsats overfor pasienter og pårørende uavhengig av deres alder og sykdom. Frivillige kan bidra til bedre livskvalitet, både for personer som er kognivt fungerende og for personer med nedsatt kognitiv funksjonsevne.

Frivillige kan også være en likeperson, i denne sammenheng en person som selv har erfaring som pårørende til en nærstående som hadde en alvorlig sykdom med kort forventet levetid. Frivillige organisasjoner, som f. eks. Nasjonalforeningen for folkehelsen, gir opplæring til pårørende som ønsker å være likepersoner innenfor demensfeltet.

Rapport om tilbudet til personer med behov for lindrende behandling og omsorg mot livets slutt (Helsedirektoratet 2015a) påpeker at frivillig arbeid i palliasjon bør stimuleres og at våketjeneste bør vurderes etablert. Formålet med våketjeneste er å tilby nærvær, ro og trygghet til døende pasienter som ikke har pårørende til stede, hvor pårørende trenger avlastning eller ikke ønsker å være alene med den døende. Våketjeneste er etablert noen få steder, både i institusjon og i hjemmet, og kan i fremtiden være en viktig del av det frivillige tilbudet $\mathrm{i}$ palliasjon. Røde Kors, Fransiskushjelpen og Hospice Lovisenberg har våketjeneste av frivillige.

\subsubsection{Formelle forhold/rammer rundt frivillige}

I det frivillige arbeidet er det som regel tre parter: den/de frivillige, pasient og pårørende og det offentlige. Forholdet mellom disse tre må reguleres, bl.a. gjennom avtaler og regler. Samarbeidet med frivillige bør være systematisk og ha god forankring i helse- og omsorgstjenestene. Det bør foreligge tydelige samarbeidsavtaler mellom den frivillige eller den frivillige organisasjonen og virksomheten (kommune, sykehjem eller sykehus). Av samarbeidsavtalene bør det framgå regler om hva de frivillige, $i$ en formell, organisert ramme kan og eventuelt ikke kan gjøre. Mange kommuner og organisasjoner har slike avtaler i dag (Termik.no).

Det er behov for systemer eller rutiner for å selektere, kvalitetssikre, følge opp og gi tilstrekkelig kompetanse til den enkelte frivillige. Pasienter som mottar palliativ behandling er ofte i en kompleks situasjon rundt sykdomsforholdet. Det er derfor viktig for alle parter at de frivilliges rolle er tydelig overfor pasienten, pårørende og de profesjonelle tjenesteyterne. De frivillige må være egnet til oppgaven og ha evne til å lytte og kunne tåle å være nær et annet menneskes alvorlige livsskjebne og ha evne til samarbeid. Frivillige må beskyttes fra å bli involvert i sykdomsrelaterte forhold som krever profesjonell vurdering og bistand.

Helsepersonell bør få god informasjon om den frivillige innsatsen på deres arbeidsplass, om eventuelle arbeidsoppgaver knyttet til de frivilliges innsats og hvilke forventninger som stilles til helsepersonell i form av opplæring og informasjon. Dette innebærer at oppgavene som frivillige skal gjøre må være oversiktlige, tydelige og forutsigbare for alle involverte parter, og det må være en god og jevnlig kommunikasjon mellom alle. Det bør være et strukturert opplegg for de frivillige og alle bør få jevnlig oppfølging, undervisning og veiledning i tjenesten.

Frivillige bør etter utvalgets syn ha en like omfattende regulering av taushetsplikten, sammenlignbart med det som gjelder for helsepersonell. Jfr helsepersonelloven $\S 21$. I dag er det ikke lovhjemmel for å pålegge frivillige en slik taushetsplikt, og dette må derfor gjøres gjennom en avtale med den enkelte frivillige og den institusjonen (kommunen, helseforetak, annen offentlig virksomhet) som er ansvarlig for den frivillige. Utvalget mener at det ikke skal overlates til den enkelte pasient som mottar hjelpen å inngå avtale om taushetsplikt med den frivillige. Regulering av taushetsplikt bør gjøres på institusjonsnivå og brudd på taushetsplikten bør ha konkrete følger.

Utvalget er kjent med at noen kommuner har en frivillighetskoordinator, en funksjon som koordinerer og følger opp den frivillige innsatsen. Den eller de som har denne funksjonen må administrere og ha ansvar for den daglige driften av de fri- 
villige. Koordinatorfunksjonen kan ivaretas av en ansatt ved virksomheten eller av den frivillige organisasjonen. Om de frivillige organisasjonene selv drifter den frivillige aktiviteten, kan dette bidra til å unngå å øke arbeidsbyrden til helsepersonellet ytterligere.

Frivillig innsats på palliasjonsfeltet som oppleves som meningsfull kan, bidra til rekruttering og utvikling av frivillige. Vi må forutsette at de frivillige drives av et ønske om å være til nytte. For mange av de frivillige er det å få anledning til å bidra sannsynligvis en god verdi i seg selv. En studie fra 2014 som oppsummerte resultatene fra over 70 undersøkelser, fant at frivillig arbeid kunne knyttes opp mot redusert depresjon, bedre helhetlig helse, psykisk velvære og færre fysiske begrensninger hos voksne frivillige over 50 år (Andreson m.fl., 2014).

\subsection{Frivillighet i framtiden}

Behovet for frivillige på palliasjonsfeltet $\mathrm{i}$ framtiden er betydelige. For å ta vare på, rekruttere og utvikle den frivillige innsatsen på palliasjonsfeltet, er det en grunnleggende forutsetning at de frivillige oppleves som en samarbeidspartner og ikke som en ekstra belastning for helsepersonellet og/ eller pasient og pårørende. Det må skapes felles langsiktige og forutsigbare rammevilkår for frivillig sektor og det må samles kunnskap om frivillighet. Det må identifiseres samarbeidsområder og prinsipper for samarbeid. Frivillige organisasjoners rolle på palliasjonsfeltet bør utvikles i et nært samspill med de kommunale helse- og omsorgstjenestene. Frivillige organisasjoner kan ha erfaring, kompetanse og systemer for å rekruttere, lære opp, motivere og lede frivillige på palliasjonsfeltet. Økt samarbeid mellom offentlig og frivillig sektor på palliasjonsfeltet kan bidra til nye muligheter for hvordan palliativ behandling og omosorg kan ytes.

Selv om bruken av frivillige krever opplæring og oppfølging, vurderer utvalget at frivillige kan gjøre en viktig innsats på palliasjonsfeltet. Utvalget mener at palliasjon bør bli en del av kommunens helhetlige frivillighetspolitikk i fremtiden. Utvalget ser behov for forskning på frivilllige som gjør en innsats på palliasjonsfelter, og foreslår at dette inngår i tiltak om forskning, se kap. 8.

Behovet for frivillighet innen palliasjon i framtiden er stort, og det er behov for å skape langsiktige og forutsigbare rammevilkår for frivillig sektor. Det må samles kunnskap om frivillighet innen palliasjon og det må identifiseres samarbeidsområder $\mathrm{og}$ prinsipper for samarbeid. Utvalget mener frivillige organisasjoners rolle på palliasjonsfeltet bør utvikles i et nært samarbeid med den kommunale helse- og omsorgstjenesten.

\subsection{Tiltak}

- Det utvikles retningslinjer for å fremme frivillig innsats og samarbeid mellom kommunen, spesialisthelsetjenesten og frivillige på palliasjonsfeltet. 


\section{Kapittel 12 \\ Erfaringer fra andre land}

\subsection{Innledning}

Ifølge mandatet skal utredningen «også bygge på erfaringer fra andre land, for eksempel om hospice, og det må vurderes om erfaringene er relevante for Norge».

Verdens helseorganisasjon (WHO) og European Association for Palliative Care (EAPC) har gitt anbefalinger for organisering av palliasjon $\mathrm{i}$ sine medlemsland. Det finnes likevel mange organisatoriske modeller, da anbefalingene skal tilpasses de ulike lands helsesystemer. For Norge er det mest aktuelt å se på forholdene i Norden, og da særlig Danmark og Sverige. Utvalget har i tillegg innhentet informasjon fra Finland, Irland og Storbritannia.

Ulik organisering og finansiering av helsetjenesten kan gjøre det vanskelig å sammenlikne helsesystemer i ulike land. En gjennomgang av systemene $\mathrm{i}$ andre land vil likevel kunne være relevant for å vurdere endringsbehovet i Norge og hvordan eventuelle endringer bør utformes. Det er vanlig å skille mellom skattefinansierte helsesystemer (som i Norge og de andre nordiske landene) og helsesystemer som er finansiert med utgangspunkt i obligatoriske offentlige eller private sykekasser eller forsikringsordninger. Utfordringsbildet er i stor grad det samme; et økende antall eldre og kronisk syke, manglende koordinering mellom sykehus og primærhelsetjenesten, krav til effektivisering for å sikre økonomisk bæreevne, geografisk ulikhet i kvalitet og tilgjengelighet og et økende gap mellom behandlingsmuligheter og tilgjengelige budsjettrammer.

Utvalget ga Kompetansesenter i lindrande behandling Helseregion Vest i oppdrag å lage en oversikt over organiseringen av palliasjon i Danmark, Sverige, Finland, Storbritannia og Irland. Oversikten skulle inneholde:

- organisering på nasjonalt, regionalt og lokalt nivå, inkludert bruk av hospice

- tilbud til ulike pasientgrupper

- oppgavefordeling/samarbeid mellom offentlig og privat sektor samt frivillig arbeid
- finansieringsmodeller

- nasjonale planer, retningslinjer, standarder, registre, organisasjoner og foreninger

- integrering av palliasjon i de ulike medisinske spesialitetene

- utdanning av helse- og sosialfaglig personell i palliasjon

Senter for omsorgsforskning Øst har også bidratt. Kompetansesenteret har gjennomgått dokumenter og innhentet informasjon fra aktuelle kompetansemiljøer som Palliativt Kunskapscentrum i Stockholm og Palliativt Utvecklingscentrum i Lund, samt ved REHPA, Videncenter for Rehabilitering og Palliation i Danmark.

\subsection{Danmark}

Palliative tjenester bygger på nasjonale anbefalinger fra 2011 og deles i grunnleggende og spesialisert palliasjon. Det spesialiserte nivået utgjøres av palliative team, palliative avdelinger i sykehus og hospice. Danmark har 5,75 millioner innbyggere. De største dødsårsaksgruppene er kreft (29 pst.) og hjerte-og karsykdommer (20 pst.). Om lag 50 prosent av befolkningen dør på sykehus, 25 prosent i sykehjem, 20 prosent dør hjemme og 3 prosent på hospice. Danmark er ulikt Norge ved at alle innbyggerne har kort vei til et tettsted.

Danmark har en relativt desentralisert helsetjeneste der kommunalt/lokalt nivå har ansvar for førstelinjetjenesten, mens regionalt nivå har ansvar for andre- og tredjelinjetjenesten. De fem regionene har ansvar for sykehus, mens kommunen har ansvar for pleie- og omsorgstjenester. Regulering og kvalitetsovervåking skjer blant annet gjennom nasjonale og regionale retningslinjer, lisenssystemer for helsepersonell og nasjonale kvalitetsovervåkingssystemer. Danmark har et nasjonalt vitensenter (kompetansesenter) i palliasjon $\mathrm{og}$ en nasjonal palliativ database etablert $\mathrm{i}$ 2009 som er et register for spesialisert palliasjon 
på individnivå. I 2013 ble palliativ medisin godkjent som et medisinsk fagområde.

I Danmark er palliative tjenester organisert som en integrert del av den offentlige helse- og omsorgstjenesten. Det er lagt stor vekt på bruk av frivillige i hospicene.

\section{Det grunnleggende palliative tilbudet}

Grunnleggende palliasjon skal gis ved de fleste kliniske sykehusavdelinger, i sykehjem, i hjemmesykepleien, av fastlegene og av praktiserende fysioterapeuter og psykologer. På kommunalt nivå er det den enkelte kommune som har ansvar for et forsvarlig tilbud. I hver region inngås det en felles «sundhedsaftale» mellom regionrådet og de tilhørende kommunene. Avtalen skal sikre gode pasientforløp og har en del obligatoriske temaer, der innleggelse, utskrivning og hjelpemidler er særlig relevant for palliasjon. Ellers kan avtalen for eksempel innebære at kommunen skal lage en plan for det palliative arbeidet. I de nasjonale kreftplanene har planene for palliasjonsfeltet i stor grad gått ut på å styrke det grunnleggende nivået. Kræftplan IV (Sundhedsstyrelsen, 2016) har videreført denne linjen.

På samme måte som i Norge er det nettverk av ressurssykepleiere i flere regioner, såkalte «nøglepersoner i palliation». Danmark har etablert 44 palliative enheter i kommunen. Disse tiltakene kalles med en samlebetegnelse KISPK (kommunale institusjoner med særlig palliativ kompetanse). Noen av institusjonene kan betegnes som palliative sykehjem. Flere har samarbeid med det palliative teamet fra det spesialiserte nivået.

Det brukes frivillige i palliasjon på det kommunale nivået, både i sykehjem, som hjelpere ved tilstelninger og sosialt samvær og som «vågekoner» til å våke over døende.

\section{Det spesialiserte palliative tilbudet}

Det spesialiserte palliative tilbudet består av palliative team, palliative avdelinger i sykehus og hospice. I tillegg til klinisk virksomhet skal det spesialiserte nivået yte rådgivning til tjenesteytere på grunnleggende nivå, drive undervisning og etterutdanning samt forskning og utvikling. De spesialiserte tilbudene skal gi et tverrfaglig tilbud, definert som et personale med minimum fire ulike faggrupper. Lege og sykepleier skal alltid være ansatt, og de skal arbeide fulltid med palliasjon. De to øvrige faggruppene kan være ansatt i deltidsstilling. Det er et krav at palliative avdelinger og hospice har sykepleier til stede hele døgnet og tilgang til kvalifisert legehjelp. Palliative team har base ved sykehuset og yter tjenester til innlagte pasienter og til det kommunale nivået. Teamet kan også ha polikliniske konsultasjoner. Palliativt team kan ha base på hospice.

Danmark har 20 hospice med til sammen 250 sengeplasser. Hospice er et tilbud i pasientens siste levetid. Hospicene er selveiende institusjoner som har driftsavtale med regionene. Oppholdet er gratis, og med fritt sykehusvalg kan pasienter som fyller kriteriene for opphold selv velge hvilket hospice de vil komme til. Målgruppen er avgrenset til pasienter med behov for palliasjon som ikke har behov for å være på sykehus, men som ikke kan være hjemme. I Danmark er hospicetilbudet definert som en del av spesialisthelsetjenesten, og regulert $\mathrm{i}$ sundhedsloven og Bekendtgørelse om driftsoverenskomster mellem regionsråd og selvejende hospicer. Selv om hospicene hører til det spesialiserte nivået, er det ikke satt spesifikke krav til omfang og kvalitet av legetjenestene, slik at dette varierer betydelig. Gjennomsnittlig liggetid er 15 - 25 dager, og 10 15 prosent av pasientene skrives ut fra hospice. $\mathrm{Ca}$ 3 prosent dør på hospice. Tilbudet preges i høy grad av tverrfaglighet og mange frivillige. De frivilliges rolle er å bringe hverdagen inn i hospicet og skape en hjemlig og hyggelig atmosfære.

Hospice er kjent for å ha åpne dører ut mot lokalsamfunnet med blant annet felles arrangementer, konserter og åpne dager. De danske hospicebygningene er svært annerledes enn andre helse- og pleieinstitusjoner ved at utformingen skal ha et hjemlig preg og legge til rette for uformelle sosiale møter.

De nasjonale anbefalingene pålegger hospice å gi råd til det grunnleggende tilbudet og delta $i$ undervisning og forskning. Omfang av og innhold i undervisning varierer, og det er ingen tradisjon for selvstendig forskning på hospice.

Det er 22 palliative team som utgår fra sykehus, mens fire team utgår fra et hospice. Disse fire er lokalisert i Region Hovedstaden, som er delt inn i fire opptaksområder. Hvert område har ett hospice, en palliativ avdeling i sykehus, ett utgående hospiceteam og ett sykehusbasert palliativt team. De palliative teamene arbeider både som konsulenter og som direkte behandlingsansvarlige for den palliative behandlingen.

\section{Det palliative tilbudet til barn og unge}

I Danmark dør ca. 320 barn hvert år. Av disse dør om lag to tredeler i første leveår og en tredel før de er 18 år. De siste årene har barnepalliasjon fått 
økende oppmerksomhet i Danmark. Barneavdelingene har satset mer på palliasjon, og hver region har et tilbud innen barnepalliasjon. Et palliativt team i hver region skal ha spesialkompetanse innen barnepalliasjon og samarbeide med barneavdelingen. Teamene arbeider aktivt med kompetansebygging og utvikling av retningslinjer.

Det er etablert et barnehospice i Danmark, Lukashuset i København. Lukashuset ble etablert i 2015, og eies og finansieres av St. Lukas Stiftelsen. Hospicet har plass til fire barn/familier. I løpet av de første 11 månedene var 12 barn og deres familier innlagt. De kom alle fra Region Hovedstaden eller Sjælland. Lukashuset samarbeider med to regioner og seks sykehus.

Gjennomsnittlig belegg var 65 prosent og institusjonen har måttet avvise familier på grunn av kapasitetsproblemer. St. Lukas Stiftelsen ga Videncenter for rehabilitering og palliation i oppdrag å evaluere Lukashuset med sikte på å kvalitetssikre og videreutvikle den palliative innsatsen. Evalueringen viser blant annet at Lukashuset har bidratt til å øke familiens livskvalitet ved å skape ro omkring familien og yte en individuelt tilpasset innsats.

\section{Nasjonale planer, retningslinjer, standarder og registre}

På nasjonalt nivå er det først og fremst kreftplanene som har gitt retning for utbygging av palliasjon. I 2016 kom Kræftplan IV som inneholder en handlingsplan for å løfte grunnleggende palliasjon, men med få anbefalinger for å styrke det spesialiserte tilbudet. Dette har ført til en debatt i det palliative miljøet i Danmark. Hovedargumentet mot planen er at man ikke kan løfte det grunnleggende nivået uten også å styrke det spesialiserte. Danmark har vært et foregangsland for strukturerte pasientforløp og pakkeforløp. I 2012 ga Sundhedsstyrelsen ut Forløbsprogram for rehabilitering og palliation i forbindelse med krceft. I tillegg er Nationale anbefalinger for den palliative indsats (Sundhedsstyrelsen, 2012) en viktig nasjonal standard med definisjoner og anbefalinger for organisering av palliasjon. Disse anbefalingene er nylig revidert.

Videncenter for Rehabilitering og Palliation (REPHA) er et nasjonalt kompetansesenter, forankret ved Syddansk Universitet og Region Syd. Senteret arbeider for og koordinerer forskningsbasert kunnskap og praksis om rehabilitering og palliasjon til mennesker som er rammet av livstruende sykdom, og har skaffet oversikt over og sys- tematisert det palliative tilbudet i Danmark, både på grunnleggende og spesialisert nivå.

Nasjonal palliativ database drives av Dansk Multidiciplinær Cancer Gruppe - for Palliativ indsats (DMCG-PAL) og er et nasjonalt register på personnivå, opprettet i 2009. Databasen er det nærmeste man kommer en kvalitetsvurdering av det palliative tilbudet i Danmark. Databasen har tall for fem kvalitetsindikatorer: 1) andelen aktuelle og henviste pasienter som faktisk fikk et spesialisert palliativt tilbud, 2) andelen pasienter som fikk tilbud innen 10 dager etter henvisning, 3) andelen pasienter som fikk et spesialisert palliativt tilbud, av alle som døde av kreft, 4) andelen pasienter som ble screenet med European Organisation for Research and Treatment of Cancer Quality of Life Questionaire-Core-15-Palliative Care, 5) andelen pasienter som ble diskutert på et tverrfaglig møte. Databasen registrerer også kliniske og demografiske variabler.

\section{Utdanning}

Grunnutdanningene inneholder generelt lite palliasjon, særlig for legene. Det er utarbeidet kompetanseprogrammer for de fleste faggrupper som arbeider i palliasjon: sykepleiere, ergoterapeuter, prester, sosionomer, fysioterapeuter og social- og sundhedsassistenter. Palliativ medisin ble i 2013 godkjent som et medisinsk fagområde for leger i Danmark, en toårig påbygging for legespesialister. Dette tilsvarer det norske kompetanseområdet innen palliativ medisin, og kravene er stort sett de samme.

\subsection{Sverige}

Sverige har 10 millioner innbyggere. De største dødsårsaksgruppene er hjerte-og karsykdommer (35 pst.) og kreft (24 pst.). 42 prosent dør på sykehus, 38 prosent i «särskilda boenden» (omsorgsboliger, sykehjem og andre institusjoner) og knapt 18 prosent i eget hjem. Sveriges helsetjeneste er organisert og ledet på tre nivåer: nasjonalt, regionalt og lokalt. På nasjonalt nivå fastsettes prinsipper og retningslinjer for behandling og omsorg. Departementet, sammen med Socialstyrelsen og andre statlige organer, fører tilsyn med aktiviteter på de lavere nivåene, fordeler tilskudd og evaluerer tjenester for å sikre oppfølging av nasjonale mål. Et utbredt regionalt selvstyre begrenser detaljstyring fra departementet.

Sverige er delt inn i 21 län (fylker) der oppgavene styres av et landsting, et politisk folkevalgt 
organ. 13 landsting har fått utvidet ansvar for regional utvikling og har formell rett til å kalle seg regioner, selv om de formelt er landsting. Landstingets hovedansvar er helsetjenester, som står for 80 prosent av utgiftene. Landstinget styrer helsetjenesten både på primærhelsetjenestenivå, andrelinjenivå og tredjelinjenivå. Primærhelsetjenesten tilbys gjennom ca. 1000 helsesentre (vårdcentraler), andrelinjetjenesten består av fylkessykehus (länssjukhus) og lokalsykehus (länsdelssjukhus), mens de sju regionsykehusene er tredjelinjetjeneste. Sverige har 290 kommuner. Kommunene har ansvar for sosialtjenester og for pleie- og omsorgstjenester, både hjemmetjenester, omsorgsboliger og sykehjem, mens landstinget inngår kontrakter med fastlegene.

\section{Organisering av det palliative tilbudet}

På samme måte som i Norge og Danmark er de palliative tjenestene delt $i$ et grunnleggende og et spesialisert tilbud. I likhet med Norge og Danmark vektlegges kompetanse og tverrfaglighet $\mathrm{i}$ definisjonen av det spesialiserte palliative tilbudet, men i tillegg kreves døgnkontinuerlig virksomhet for å bli definert som et spesialisert tilbud. Dette er forskjellig fra Norge og Danmark. I praksis betyr dette at spesialisert palliasjon for en stor del tilbys i egne sengeavdelinger og $\mathrm{i}$ hjemmeomsorgsteam som opererer hele døgnet. I tillegg finnes det palliative rådgivningsteam som opererer på dagtid. Sverige har dermed heller ikke noe skarpt skille mellom primærhelsetjenesten og spesialisthelsetjenesten når det gjelder det palliative tilbudet; de spesialiserte virksomhetene kan være plassert på alle nivåer.

I likhet med Norge inngår ikke hospice som en egen organisatorisk enhet i de svenske anbefalingene, og hospice er ikke definert i retningslinjene.

Sverige har ikke hatt nasjonale planer for et nasjonalt eller regionalt kompetansesenter for palliasjon. Det er likevel etablert sentre fem steder i landet som fungerer som kompetansesentre.

\section{Det grunnleggende palliative tilbudet}

Det nasjonale handlingsprogrammet for palliasjon framhever at alle personer som befinner seg $\mathrm{i}$ livets sluttfase skal tilbys optimal omsorg uavhengig av grunnsykdom og oppholdssted. Dette betyr at grunnleggende palliasjon skal kunne tilbys overalt i helsetjenesten.
Palliasjon i Sverige er inndelt i allmänn (generell) palliativ vård hvor de fleste får et tilbud $\mathrm{i}$ eldreomsorgen, og specialiserad palliativ vård med Avancerad sjukvård i hemmet (ASIH), palliative enheter og hospice.

I sykehjem finnes en del steder palliative ombud, tilsvarende ressurssykepleiere i Norge. Det er også opprettet nettverk knyttet til tiltaksplan for døende (Liverpool Care Pathway) i sykehjem. Allmennlegene er ansatt ved helsesentre. Det er ikke noe krav at allmennlegene skal følge opp egne pasienter i hjemmet. Det er ingen kommunalt ansatt lege. Kommunene inngår kontrakter med allmennleger eller geriatere for legetjenester i sykehjem.

\section{Det spesialiserte palliative tilbudet}

Det finnes ca.120 registrerte spesialiserte palliative virksomheter. De er i hovedsak organisert som palliative sengeenheter og avancerad sjukvård i hemmet (ASIH). Det finnes også palliative rådgivningsteam, men få palliative team $\mathrm{i}$ sykehus. Alle virksomhetene organiseres i Palliativguiden, en nasjonal oversikt over virksomheter med spesialisert palliasjon. Palliativguiden driftes av Nationella Rådet för Palliativ vård.

\section{Stockholm}

Stockholm har 2,2 millioner innbyggere i hovedstadsområdet. Byen har 43 ulike ASIH-team og 20 ulike palliative enheter med til sammen 200 sengeplasser. 20,6 prosent av alle dødsfall er knyttet til et spesialisert tilbud. Dette er den høyeste andelen i landet. Stockholm ligger lavest på statistikken når det gjelder konsulentvirksomhet fra palliativt team til det grunnleggende nivået. Tidligere var kommunene i Stockholms län inndelt i geografiske soner som hver var dekket av et ASIH-team. Nå opererer flere team innen et større område. Bare to av de spesialiserte palliative tiltakene er drevet av Landstinget, resten er private aktører.

\section{Hospice}

I Sverige ligger de fleste palliative sengeenhetene utenfor akuttsykehusene. Noen enheter har valgt å bruke navnet hospice, totalt åtte. De fleste hospice er privat eid, men det finnes også kommunale hospice. Institusjonene har avtale med fylke eller kommune. 


\section{Det palliative tilbudet til barn og unge}

I Stockholm har palliative team i hjemmeomsorgen inkludert barn siden 1984. Spesialkompetanse er blant annet knyttet til særlig organiserte tjenester, slik som Astrid Lindgrens barnsjukhus ved Karolinska Universitetssjukhuset som har hatt en egen, spesialisert palliativ hjemmeomsorgstjeneste for barn (Sjukhusansluten Avancerad Barnsjukvård i Hemmet (SABH)). I resten av landet varierer det om barn blir inkludert i den spesialiserte palliative hjemmeomsorgen.

I Stockholm dør de fleste barn som har kreft, hjemme. Det er etablert et barnehospice i Sverige, Lilla Erstagården, som eies av Stiftelsen Ersta Diakoni. Lilla Erstagården ble etablert i 2010 og er en av flere avdelinger ved Ersta sjukhus. Målgruppen er barn og ungdom som trenger medisinsk hjelp og omsorg i livets sluttfase. Også barn (og deres familier) med kompliserte kroniske sykdommer eller skader er velkommen for hjelp og avlastning. Hospicet har fem enkeltrom. Barnet kan komme til hospicet etter henvisning fra lege, eller ved å kontakte hospicet direkte. Hospicet samarbeider tett med barneavdelingene i Stockholm. Stort sett alle familiene kommer fra Stockholmområdet. Personalet begrunner dette med at søsken skal ha tilgang til skole og nærmiljø.

Nasjonale planer, retningslinjer, standarder og registre

Det første nasjonale handlingsprogrammet for palliasjon (Nationellt vårdprogram) kom i 2012 og de første nasjonale retningslinjer året etter. Fem byer i Sverige har palliative sentre som driver utdanning, forskning og utviklingsarbeid og som dermed fungerer som kompetansesentre. Det Svenske palliativregistret ble etablert i 2005 og har som mål å registrere alle dødsfall i Sverige.

\subsection{Finland}

Finland har 5,5 millioner innbyggere. Om lag 85 prosent bor i tettsteder, med ca. 1 million i hovedstadsområdet. Den hyppigste dødsårsaken er hjerte- og karsykdommer (37 pst.), kreft (24 pst.) og demens (16 pst.). Det finske helsesystemet er delt inn i primær- og spesialisthelsetjenester. Primærhelsetjenestene utføres på kommunenes helsesenter (hälsovårdcentral). Her tilbys allmennlegetjenester, pleie- og omsorgstjenester og fore- byggende tjenester. Ofte har helsesentrene sengeenheter som kan betraktes som et lokalsykehus. Både grunnleggende og avansert hjemmesykepleie administreres fra helsesenteret.

Spesialisthelsetjenesten foregår stort sett på sykehus. Finland er delt inn i 20 helsedistrikter. Hver kommune tilhører et distrikt, og hvert distrikt har et sentralsykehus og flere andre sykehus. Finland har fem universitetssykehus. Landet er delt inn i fem områder, slik at hvert helsedistrikt har tilhørighet til et universitetssykehus (tilsvarende norske helseregioner).

\section{Organisering av palliative tjenester}

Det har vært etablert palliative tiltak i Finland siden 1982, men uten noen overordnet, nasjonal plan for organisering. De nasjonale anbefalingene fra 2010 skiller ikke klart mellom grunnleggende og spesialisert palliasjon, og det er stor variasjon $\mathrm{i}$ både tilbud og kvalitet. Hovedvekten i tilbudet har vært på omsorg ved livets slutt. Det pågår flere initiativ for å integrere palliasjon tidligere i sykdomsforløpet til kreftpasienter og utvide tilbudet til andre grupper. Alle de fem universitetssykehusene har et palliativt tilbud. Det finnes også palliative team ved åtte andre større sykehus. Finland har fem hospice. Palliasjon utøves ellers på helsesentrene og i hjemmeomsorgen, inkludert såkalte «hjemmesykehus». Finland har ikke noe kompetansesenter i palliasjon, men de har to professorater i palliativ medisin.

I $2010 \mathrm{kom}$ nasjonale anbefalinger for palliasjon utarbeidet av en gruppe eksperter, og disse anbefalingene gjelder fortsatt. De slår fast at hvert helsedistrikt skal lage en plan for palliasjon som grunnlag for mer detaljerte planer i hver kommune. Planene skal rapporteres til det finske helsedepartementet. I 2010-dokumentet står det blant annet at utbygging av palliativ hjemmesykepleie skal prioriteres, og at det er et stort behov for å utdanne leger og sykepleiere i palliasjon. Anbefalingene presenterer gode faglige palliative prinsipper, men Finland har hele tiden hatt sterkest fokus på omsorg ved livets slutt. Først de senere årene har det skjedd en dreining i retning av å inkludere palliasjon tidligere i sykdomsforløpet. Anbefalingene er ikke tydelige når det gjelder organisering og derfor har det palliative tilbudet $\mathrm{i}$ Finland utviklet seg ganske fritt, uten overordnede føringer, og uten noe klart skille mellom grunnleggende og spesialisert palliasjon.

Siden 2012 har det skjedd en betydelig utbygging av både sengeplasser og hjemmeomsorgstilbud i palliasjon. Helsedepartementet arbeider nå 
(2017) med kriterier for palliative plasser for å få lik tilgang og kvalitet. Kriteriene skal knyttes til pasientforløp for ulike diagnosegrupper, samt bygge på en behovskartlegging. Alle universitetssykehusene har egne spesialiserte palliative tilbud. Palliasjon i Finland har tradisjonelt vært nærmest utelukkende et tilbud til kreftpasienter. Nå pågår det flere initiativ for å utvide pasientgruppen, særlig mot eldre og personer med demens. Det er utarbeidet faglige retningslinjer for personalet $\mathrm{og}$ for pasienter $\mathrm{g}$ pårørende.

Universitetssykehuset i Helsinki har et palliativt senter. Teamet med konsulenttjeneste til sykehusets avdelinger og primærhelsetjenesten er tilgjengelig fem dager i uken. I tillegg er det en palliativ enhet med fire senger ved en av kreftpostene. Enheten er godkjent som utdanningssted til kompetanseområdet palliativ medisin. Det palliative senteret samarbeider med sentralsykehusene i området; Terhokoti hospice med 17 senger (i Helsinki), hjemmesykepleie, hjemmesykehus og flere palliative enheter i lokale helsesentre. Finland har ikke kompetansesenter for palliasjon. Det er utarbeidet faglige retningslinjer for personalet og for pasienter og pårørende.

\subsection{Storbritannia}

Storbritannia hadde i 2015 om lag 65 millioner innbyggere, hvorav 5,4 millioner i Skottland, 3 millioner i Wales og 1,9 millioner i Nord-Irland. Fordelingen mellom de viktigste dødsårsakene er ganske lik for de fire nasjonene i Storbritannia. I England og Wales er kreft årsaken til om lag 29 prosent av alle dødsfall, hjerte- og karsykdommer 28 prosent og demens 21 prosent. I Nord-Irland er tallene henholdsvis 29 prosent, 30 prosent og 14 prosent og i Skottland 30 prosent, 28 prosent og 13 prosent.

De fleste dødsfall i England skjer på sykehus (47 pst.), deretter følger død i eget hjem (23 pst.) og på sykehjem (22 pst,). 6 prosent av dødsfall $\mathrm{i}$ England skjer på hospice.

Helsetilbudet i Storbritannia er delt slik at England, Skottland, Wales og Nord-Irland har separate systemer. Helsetjenesten er statlig finansiert og er hovedsakelig organisert rundt National Health Service (NHS) i hvert enkelt land. Behandlingen gjennom NHS er kostnadsfritt for pasienter som bor i Storbritannia, med noen unntak.

\section{Det grunnleggende palliative tilbudet}

Det er i dag 223 hospice og palliative sengeenheter i Storbritannia, med til sammen 3200 senger. I tillegg har Storbritannia 291 hjemmetjenesteenheter, 129 «hospice-at-home»-tjenester, 275 palliative dagsentre og 346 palliative team i sykehus. Det er 43 palliative sengeenheter for barn, med i alt 338 senger. Videre finnes det 314 tjenestetilbud til etterlatte («bereavement services»).

Hospicesektoren bistår om lag 200000 personer med livsbegrensende og dødelige sykdommer hvert år, noe som tilsvarer ca. 40 prosent av anslått behov. 90 prosent av hospiceomsorgen skjer på dagtid eller i hjemmet, og mer enn 125000 personer arbeider frivillig på hospice hvert år. Liggetiden i hospice varierer lite fra år til år. Hovedtyngden av pasientene er innlagt $\mathrm{i}$ under to uker, mens en firededel blir bare i én til fire dager. Gjennomsnittlig lengde på hospiceopphold er rundt 14 dager.

\section{Det spesialiserte palliative tilbudet}

Både sykehus, hospice, dagsentre og andre institusjoner har spesialiserte palliative team. Disse består av legespesialister, sykepleiere, psykologer og koordinatorer (som for eksempel koordinerer kreftbehandling og palliativ behandling). Teamet kan også ha ernæringsfysiolog, logoped og prest tilgjengelig. Teamenes arbeidsområder ved forskjellige institusjoner er ofte overlappende, og spesialister i palliasjon har ofte kontrakter med både sykehus og hospice. Palliativ behandling i sykehus er likevel mer spisset mot akutte tilfeller, multisyke pasienter og koordinering med livsforlengende, sykdomsrettet behandling. Palliative team arbeider fleksibelt og kan følge opp der pasienten til enhver tid befinner seg. Palliasjon er en spesialitet for både leger og sykepleiere.

Det er ingen etablerte, formelle krav for å legges inn i hospice. En pasient kan for eksempel skrives inn en kort periode for å avlaste familiemedlemmer med store omsorgsoppgaver, eller på ubestemt tid når sykdomsforløpet er spesielt komplisert. Noen personer har opphold i hospice flere ganger i løpet av sykdomsforløpet, avhengig av personlige ønsker og omstendigheter, og vurderinger i samarbeid mellom fastlegen, familien og palliativt team. Opphold i hospice er gratis i Storbritannia.

I Storbritannia har frivillig sektor tradisjonelt tatt et stort ansvar for utvikling av palliative tjenester. Etter hvert er det i økende grad blitt utviklet 
en offentlig strategisk tilnærming til palliativ omsorg.

\section{Tilbud til ulike pasientgrupper}

Kreftpasienter utgjør den største gruppen av pasienter som får tilbud om palliativ behandling. Men to tredeler av befolkningen dør av andre sykdommer enn kreft. Behovet for palliasjon til alle andre pasientgrupper et derfor viktig for det palliative utviklingsarbeidet som pågår i hele Storbritannia. Siden 1990-tallet har arbeidet for et behovsprøvd tilbud vært stort, og dette har ført til mer likhet i tilgangen til tjenestene. Det offentlige har arbeidet for bedre tilgang til palliative tilbud for mindre velstående pasienter, pasienter i tynt befolkede områder og pasienter fra minoritetsgrupper.

Barn og unge er også en pasientgruppe som de senere årene har fått mer oppmerksomhet. Selv om de enkelte diagnosene kan være relativt sjeldne, utgjør barn til sammen en stor pasientgruppe, med særegne behov. Organisasjoner som «Rainbow Trust», «Together for Short Lives», og «Association for Paediatric Palliative Medicine» spiller alle en viktig rolle for utviklingen av og kvaliteten på omsorgen til syke barn og deres familier i Storbritannia. I 2017 er det 49 frittstående barnehospicer i Storbritannia. Videre har den sosiale og lovgivende innsatsen for barnepalliasjon og hospicebasert omsorg gjort store fremskritt i løpet av det siste 15 årene. Europeisk standard for barnepalliasjon ble utgitt i 2006 (European Assiciation of Palliative Care, 2006).

\section{Finansiering}

Allmennlegetilbudet, sykehus og sykehjem er hovedsakelig drevet av National Health Service (NHS) og er kostnadsfritt for pasienter som bor i Storbritannia. Samtidig spiller veldedighet og frivillighet en stor rolle $\mathrm{i}$ hospiceordningenn. Hospice for voksne pasienter mottar 30 prosent av finansieringen fra statlige midler, mens hospice for barn kun mottar 15 prosent av sin finansiering fra staten. Sistnevnte er dermed mye mer avhengige av donasjoner og lokal veldedighet.

\subsection{Irland}

Irland har 4,8 millioner innbyggere. De tre viktigste dødsårsakene i 2015 var hjerte- og karsykdommer (31 pst.), kreft (29 pst.) og lunge- og luftveislidelser (13 pst.). De fleste irer (74 pst.) sier de ønsker å dø i eget hjem, men bare 26 prosent gjør det. 43 prosent dør på sykehus, 25 prosent dør på langtidsavdelinger på sykehjem og 6 prosent dør ved hospice.

Den irske helsetjenesten, «Health Service Executive» (HSE), er organisert slik at primærhelsetilbudet er fordelt på ni regionale organisasjoner, mens spesialisthelsetjenesten (sykehus) er delt i seks regionale grupper. I tillegg er det en landsomfattende gruppe for barnesykehus.

Det generelle helsetilbudet i Irland er i utgangspunktet ikke gratis, men gjennom en rekke ordninger gjøres helsetjenesten økonomisk overkommelig. Hospice er kostnadsfritt for pasientene.

\section{Organisering av det palliative tilbudet}

Det palliative tilbudet i Irland har sitt utspring i den engelske hospicebevegelsen fra tiden etter andre verdenskrig. Mange av Irlands hospice er drevet av veldedighet og frivillig arbeid. I 1985 ble det første teamet opprettet som spesialiserte seg på pleie av døende i hjemmet, og i 1995 ble palliativ medisin en medisinsk spesialitet. Fra den tid har Irland fulgt en utvikling som likner utviklingen i Storbritannia, der palliasjon har gått fra å være en støttegrein for onkologi og nevrologi til å legge grunnlag for behandling av pasienter med et bredt spekter av diagnoser og behov. Som i Storbritannia er det i dag stor oppmerksomhet på at palliativ behandling skal være noe en først møter gjennom primærhelsetjenesten fra den allmennpraktiserende legen, hjemmesykepleien og så videre, med støtte fra spesialiserte team med spisskompetanse på feltet.

I Irland er det palliative team ved hospice, sykehus og dagsentre. Teamene jobber i samarbeid med fastlege og primærhelseteamet og andre medisinske spesialiteter etter samme modell som i Storbritannia.

Hjemmebasert omsorg med sykepleie og oppfølging av fastlegen er svært viktig i det helhetlige palliative tilbudet i Irland. Det er ønskelig at pasienten skal kunne være hjemme så lenge som mulig, og palliative team bidrar til å legge til rette for dette. Det er nesten ti ganger så mange som mottar pleie fra et hospiceteam i hjemmet, som i en seng på hospice. Et kort hospiceopphold kan ha som mål å justere symptomlindrende behandling eller avlaste pårørende før pasienten kan reise hjem igjen. Gjennomsnittlig liggetid $\mathrm{i}$ hospice er ni dager, mens pasienter i snitt mottar hjemmeomsorg i seks måneder.

Palliativ medisin er en spesialitet for leger i Irland. Spesialisering i palliasjon i sykepleierut- 
danningen er på masternivå. Det er også en spesialisering i palliativ omsorg for barn.

I 2010 lanserte helsedepartementet «Palliative care for children with lifelimiting conditions in Ireland - A national Policy», som gir anbefalinger om palliasjon til barn. Anbefalingene skal bidra til å sikre sammenhengende støtte og palliasjon til barn fra fødsel til ungdom og overgangen til voksne. Nasjonale helsemyndigheter har videre bidratt til et program for barn og unge med behov for palliasjon. Det er også ansatt en pediater med spesialisering i barnepalliasjon ved sykehuset $\mathrm{i}$ Crumlin. Irland har barnehospicet LauraLynn, som ble etablert i 2011, i Dublin. Barnehospicet ble til av innsamlede midler og består av åtte senger og fire familieboliger. De har siden oppstart gitt omsorg og støtte til over 355 familier. I 2014 etablerte barnehospice et program som heter Laura Lynn hjemmetjeneste, hospiceomsorg i hjemmet, i Nord- Dublin og i Sør-Dublin. I tillegg har også barnehospicet klinisk utdanning og et eget treningsprogram for barnepalliasjon.

I 2011 ble det første barnehospicet, LauraLynn, etablert i Irland.

\subsection{Oppsummering - hva kan vi lære av văre naboland?}

Gjennomgangen av organiseringen av palliasjon viser store variasjoner innad i Norden. Ingen av de andre nordiske landene har et så tydelig skille mellom den kommunale helse- og omsorgstjenesten og spesialisthelsetjenesten som Norge. Både Danmark og Sverige og til dels Finland, har hatt stor oppmerksomhet rettet mot organisering av et godt palliativt tilbud i de store byene. Dette er i kontrast til Norge, og utvalget mener at det er behov for et betydelig løft $\mathrm{i}$ det palliative tilbudet $\mathrm{i}$ de største byene.

Selv om de andre nordiske landene har valgt ulike modeller, og ikke alt passer inn i det norske helsesystemet, er oppmerksomheten på storbyorganisering noe vi kan lære av. Også i Norge er det utfordrende å organisere et godt palliativt tilbud i de største byene. God kapasitet av palliative team og enheter og behovet for klare henvisningslinjer og pasientforløp er tiltak som også bør tas i bruk i Norge.

Både Danmark og Sverige har flere tiltak innen barnepalliasjon. I Danmark er det en systematisk plan for å utvikle dette tilbudet, med organisering og opplæring av palliative team.

Erfaringene med barnehospice er at det er behov for et betydelig befolkningsgrunnlag og at familiene kommer fra nærområdet. Disse institusjonene fungerer altså i stor grad som avlastningshjem for nærboende. For norske forhold med store geografiske avstander mener utvalgets flertall det vil være mer hensiktsmessig å styrke tilbudene som allerede finnes, som barneavdelingene, barneboliger og avlastningsboliger.

Både Danmark og Sverige har opprettet et palliativt kvalitetsregister basert på utvalgte indikatorer. I Danmark omfatter registeret alle tiltak innen det spesialiserte palliative tilbudet. I Sverige ønsker man å registrere alle dødsfall. Begge registrene gir verdifull informasjon om kvalitet og kapasitet og gode muligheter for forskning.

I Sverige har de aller fleste medisinske spesialiteter innført et obligatorisk kurs i palliasjon i spesialistutdanningen.

Det er utstrakt bruk av frivillige knyttet til hospicevirksomheten både i Storbritannia og i Danmark. I begge land er det en aktiv sentral organisasjon som jobber for frivillige og for å støtte opp om de frivilliges arbeid, «Help the hospices» og «Hospiceforum Danmark» (Helsedirektoratet, 2015a).

Det vises til utvalgets forslag i de aktuelle kapitlene om organisering, struktur og kompetanse, kunnskap og frivillige. 


\section{Kapittel 13 \\ Balansen mellom helsepersonells inngrepsplikt og pasientenes selvbestemmelsesrett}

\subsection{Mandat}

Det følger av mandatet at «Utvalget skal utrede reglene om helsepersonells inngrepsplikt i helsepersonelloven $\S 7$ og pasienters rett til å nekte livreddende og livsforlengende behandling».

\subsection{Avgrensing}

Utvalgets arbeid skal ifølge mandatet avgrenses mot endringer i lovreglene om rett til nødvendig helsehjelp i pasient- og brukerrettighetsloven kapittel 2. Videre er det presisert at regjeringen er imot aktiv dødshjelp, og at utvalget ikke skal vurdere spørsmål om eutanasilovgivningen.

\subsection{Dagens lovregler om inngrepsplikt og selvbestemmelsesrett}

\subsubsection{Inngrepsplikt - hjemmelsgrunnlag}

Helsepersonells inngrepsplikt, eller hjelpeplikt følger av helsepersonelloven $\S 7$. Bestemmelsen har hatt sin nåværende form siden ikrafttredelsen i 2001. Bestemmelsen er en viktig pliktregel som pålegger helsepersonell å yte øyeblikkelig hjelp. Pasienter har - når vilkårene er oppfylt - krav på øyeblikkelig hjelp av helse- og omsorgstjenesten i kommunen med hjemmel i pasient- og brukerrettighetsloven $\S 2-1$ a første ledd, og av spesialisthelsetjenesten med hjemmel i samme lov 2-1 b første ledd. Plikt for kommunen og spesialisthelsetjenesten til å yte øyeblikkelig hjelp følger av henholdsvis helse- og omsorgstjenesteloven § 3-5 og spesialisthelsetjenesteloven $\S 3-1$.

Hjelpeplikten, som følger av helsepersonelloven $\S 7$, er en personlig hjelpeplikt som påhviler alt helsepersonell (Befring og Ohnstad, 2010). Generelt følger det en alminnelig hjelpeplikt i straffeloven $\S 287$ hvor det fremgår at man straffes med bot eller fengsel i inntil seks måneder der- som man unnlater «etter evne å hjelpe en person som er i åpenbar fare for å miste livet eller bli påført betydelig skade på kropp eller helse [...]» (lov om straff (2005)). Hjelpeplikten ble utvidet ved vedtakelsen av straffeloven av 2005 til å omfatte fare for betydelig skade på kropp og helse i tillegg til de situasjoner hvor det er fare for livet.

Helsepersonell har i dag en aktiv inngrepsplikt med lovhjemmel i helsepersonelloven $\S 7$. Bestemmelsens tre ledd lyder slik:

«Helsepersonell skal straks gi den helsehjelp de evner når det må antas at hjelpen er påtrengende nødvendig. Med de begrensninger som følger av pasient- og brukerrettighetsloven §4-9, skal nødvendig helsehjelp gis selv om pasienten ikke er i stand til å samtykke, og selv om pasienten motsetter seg helsehjelpen.

Ved tvil om helsehjelpen er påtrengende nødvendig, skal helsepersonell foreta nødvendige undersøkelser.

Plikten gjelder ikke i den grad annet kvalifisert helsepersonell påtar seg ansvaret for å gi helsehjelpen.»

\subsubsection{Inngrepsvilkåret «påtrengende nødvendig"}

Vilkåret for at hjelpeplikten etter helsepersonelloven $\S 7$ skal inntre, er at hjelpen må antas å være «påtrengende nødvendig». Vilkåret refererer både til pasientens helsetilstand, helsepersonellets mulighet til å gi adekvat hjelp og tidsperspektiv (Befring og Ohnstad, 2010). Hvorvidt helsehjelpen antas å være "påtrengende nødvendig» innebærer ifølge forarbeidene til helsepersonelloven (Ot.prp. nr. 13 (1998-99)) et visst skjønn. Det uttrykkes samme sted at det i vurderingen må legges vekt på «om det er fare for liv eller fare for alvorlig forverring av en helsetilstand.» Inngrepsvilkåret «påtrengende nødvendig» gir helsepersonell et visst spillerom. Terskelen for å gi øyeblikkelig hjelp fremheves som høy i lovens forar- 
beider, det skal ganske mye til for at plikten skal inntre med henvisning til ordlyden «påtrengende nødvendig». Det er videre uttrykt at: «Bestemmelsen om øyeblikkelig hjelp er ment å fange opp situasjoner som krever livreddende innsats og innsats for å avverge alvorlig helseskade for å hjelpe pasienten ut av en akutt situasjon.» Befring og Ohnstad uttrykker følgende om inngrepsvilkåret: «Som et alminnelig utgangspunkt omfatter plikten de situasjoner hvor det oppstår akutt behov for undersøkelse og behandling, for eksempel for å gjenopprette og/eller vedlikeholde vitale funksjoner, slik at man forhindrer eller begrenser alvorlig funksjonsnedsettelse som følge av skade eller sykdom». Det er det enkelte helsepersonell som må vurdere hvorvidt helsehjelpen antas «påtrengende nødvendig» i den konkrete situasjonen.

I den første setningen i helsepersonelloven $\S 7$ innebærer bestemmelsen at helsepersonell plikter å agere i alle situasjoner hvor det antas at hjelpen er «påtrengende nødvendig». Plikten hviler på alt helsepersonell (for eksempel tannleger, jordmødre, ambulansepersonell mv.), og gjelder døgnet rundt. Ifølge lovforarbeidene forventes det ulikt av helsepersonell relatert til hvilken kompetanse de har. Ordlyden i bestemmelsens første punktum «den hjelp de evner» skal gi uttrykk for dette (Ot.prp. nr.13 (1998-1999)). I straffeloven § 287 første ledd bokstav a følger det også av ordlyden at man «etter evne» plikter å hjelpe. I forarbeidene til straffeloven fremkommer det at «vedkommendes personlige forutsetninger og situasjonen som sådan må tas i betraktning».

Både somatiske og psykiske tilstander kan utløse hjelpeplikten, og helsehjelp kan være påtrengende nødvendig av hensyn til andres liv enn pasientens, for eksempel om pasientens psykiske tilstand utgjør en fare for andre (Befring og Ohnstad, 2010). Alvorlig smerte omfattes også av plikten til å gi øyeblikkelig hjelp ifølge lovforarbeidene, slik at den lidende skal få smertelindring.

Det fremheves i forarbeidene at det ligger en tidsavgrensning i formuleringen «påtrengende nødvendig». Når pasienten har fått tilstrekkelig hjelp og faren er over, opphører øyeblikkelig hjelp-plikten. Det samme gjelder når pasienten er døende, og det ikke kan ytes adekvat hjelp. (Ot.prp. nr.13 (1998-1999)).

Bestemmelsen i helsepersonelloven $\S 7$ annet punktum presiserer at i øyeblikkelig hjelp-situasjoner, det vil si i situasjoner hvor helsehjelpen er «påtrengende nødvendig», skal slik hjelp også gis i de situasjoner hvor pasienten ikke kan samtykke, og i de situasjoner hvor pasienten kan sam- tykke, men sier nei til helsehjelpen, eller på andre måter motsetter seg denne hjelpen med de begrensninger som følger av pasient- og brukerrettighetsloven $\S 4-9$. Det innebærer at øyeblikkelig hjelp-bestemmelsen setter til side alle samtykkebestemmelsene i pasient- og brukerrettighetsloven med unntak av $\S 4-9$. Sagt med andre ord så tilsier en naturlig tolkning av ordlyden i lys av lovens forarbeider at helsepersonelloven $\S 7$ gis anvendelse $i$ alle andre situasjoner enn de situasjoner som følger av pasient- og brukerrettighetsloven $\S 4-9$, når helsehjelpen antas å være påtrengende nødvendig, uavhengig av om pasienten er i stand til å nekte og gjør det. Det innebærer at bestemmelsen lovhjemler en omfattende hjelpeplikt.

\subsubsection{Unntak fra hjelpeplikten - begrepet "døende»}

I pasient- og brukerrettighetsloven $\S 4$ 4-9 følger det tre unntak fra hjelpeplikten i helsepersonelloven $\S 7$. De to første unntakene fremkommer av bestemmelsens første ledd, hvor det fremgår at pasienter kan nekte å motta blod eller blodprodukter samt å avbryte en pågående sultestreik på grunn av en alvorlig overbevisning. Det er fremhevet utfordringer ved begge bestemmelsene, men ingen av dem berører problemstillinger utvalget skal vurdere (Se Bahus og Førde, 2014 og Dahlberg og Dahl, 2015).

Det siste unntaket følger av pasient- og brukerrettighetsloven § 4-9 annet ledd hvor det fremgår at en døende pasient kan nekte å motta livsforlengende behandling. For pasienter med behov for palliativ behandling vil dette unntaket kunne ha betydning. En døende pasient er således ikke tvunget til å ta imot øyeblikkelig hjelp mot eget ønske. Hovedregelen om samtykke kommer igjen til anvendelse. Lovforarbeidene synes å legge til grunn en snever tolking av begrepet «døende» ved at det uttrykkes «at pasienten kan nekte å ta imot behandling der det ikke er utsikt til helbredelse eller bedring, men bare til en viss livsforlengelse som i realiteten er en forlengelse av en pågående dødsprosess» (Ot.prp. nr.12 (1998-1999)). En snever tolkning av begrepet døende gir liten selvstendig betydning da legene ikke har en plikt til å gi nytteløs behandling, og livsforlengende behandling av uhelbredelig syke og døende pasienter vil ofte fremstå som behandling uten nytte.

Det følger av lovforarbeidene at helsepersonell plikter å respektere pasientens behandlingsnektelse når pasienten er døende, «men har smerter som kan lindres med medisiner e.l.» Dette er en 
vesentlig presisering av selvbestemmelsesretten da pasientens ønske om bevissthetsnivå i møte med døden kan være kulturelt, åndelig og/eller religiøst motivert. Det følger videre av lovens forarbeider at nektelsen bare gjelder behandling, «ikke pleie og omsorg». Avgrensningen mot pleieog omsorg er kritisert med den begrunnelse at dette fremstår inkonsekvent, siden samtykkekravet i pasient- og brukerrettighetsloven $\S 4$-1, ifølge lovens forarbeider, gjelder alle former for hjelp som helsepersonell gir, også pleie og omsorg (Bahus, 2014). Påtvungen pleie og omsorg bør, i likhet med all annen tvang, så vidt mulig unngås. Samtidig kan det oppstå situasjoner hvor pleie og omsorg påtvinges under henvisning til andre grunnlag, også i situasjoner hvor pasienten ikke er døende.

En døende pasient vil alltid være alvorlig syk, men det er ikke mulig å si eksakt når en pasient går fra å være alvorlig syk til å være døende. Dette er også en grense i bevegelse ved at ny medisinsk teknologi gjør det mulig å holde liv i alvorlig syke pasienter over et lengre tidsrom enn det som var mulig tidligere. Dette gjør det krevende å anvende unntaket i pasient- og brukerrettighetsloven § 4-9 andre ledd.

Det er uttrykt at «dersom en progredierende og dødelig sykdom som amyotrofisk lateral sklerose (ALS) svekker vitale livsfunksjoner ugjenkallelig slik at pasienten behøver mekanisk ventilasjon for å leve, må vedkommende anses som døende, også i rettslig forstand» (Holmøy m.fl. 2009). Dette er kritisert blant annet fordi det tar lite hensyn til pasientens egen opplevelse av sin sykdom (Bahus m.fl., 2012). Dersom pasienten takker ja til behandling, for eksempel med hjemmerespirator, og får behandlingen til å fungere godt, kan pasienten leve en god stund til. Dersom man legger en fortolkning av «døende» til grunn, som er sammenfallende med et bestemt stadium av en sykdom, kan man risikere en for statisk tolking av begrepet ved at man ikke tar høyde for ny medisinsk teknologi eller pasientens oppfatning av sin egen situasjon.

Tidsintervallet fra en pasient er alvorlig syk til å være alvorlig syk og døende vil langt på vei være avhengig av om pasienten takker ja til behandling og responderer positivt på denne, eller om vedkommende velger å la sykdommen forbli ubehandlet. Ny teknologi kan med andre ord påvirke når enkeltpasienter eller grupper av pasienter er $\mathrm{i}$ en døende fase. Dersom man tar i bruk ny teknologi er man ikke døende, men ved ikke å ta den $\mathrm{i}$ bruk er man døende. Terminologien synes å endre seg i takt med dette ved at man i dag snak- ker om å «leve med en sykdom». Det kan virke lite naturlig å si at et menneske er «døende» i flere år, og man kan tenke seg at det kan være en uheldig belastning for et alvorlig sykt menneske å bli betegnet som «døende» i medisinsk og juridisk terminologi over flere år. Median levetid for flere diagnoser med dødelig utgang øker.

Man kan også tenke seg utfordringer ved at pasienten på svært kort tid går fra å ha mistanke om en diagnose, til å være døende. I situasjoner hvor sykdomsforløpet er raskt progredierende vil forskjellen mellom å være «alvorlig syk» (men ikke døende) og å være «alvorlig syk og døende,» komme særlig på spissen dersom pasienten er samtykkekompetent og nekter behandling. I det ene øyeblikket vil man da kunne påtvinge helsehjelp med hjemmel i helsepersonelloven $\S 7$, mens man i neste øyeblikk må respektere pasientens ønske.

Unntaket fra hjelpeplikten i pasient- og brukerrettighetsloven $\S 4$-9 annet ledd kan være vanskelig å anvende, og det er utfordringer både ved en vid og en snever tolkning av begrepet «døende».

\subsubsection{Pasientens selvbestemmelsesrett - pasientautonomi}

Pasienters rett til å takke ja eller nei til den behandlingen eller de behandlingsalternativene som tilbys, følger av pasient og brukerrettighetsloven $\S 4$-1. Selvbestemmelsesretten er negativt avgrenset, pasienten kan ikke selv bestemme hvilken behandling vedkommende ønsker, kun takke ja eller nei til tilgjengelige og forsvarlige behandlingsalternativer, jf. pasient- og brukerrettighetsloven $\S 3-1$. Denne retten til å velge mellom å avstå eller å ta imot tilbudt behandling kalles "pasientens selvbestemmelsesrett» eller «pasientautonomi». For at et samtykke skal være gyldig, må pasienten ha samtykkekompetanse og være tilstrekkelig informert, jf. pasient- og brukerrettighetsloven $\S \S 4-1,4-3$ og $\S 3-2$.

I pasient- og brukerrettighetsloven stilles det ikke noe krav om en rasjonell begrunnelse eller en kvalifisert årsak som vilkår for pasientens rett til å nekte eller avbryte behandling. Men den som yter helsehjelp, skal informere om betydningen av at helsehjelpen ikke gis, jf. pasient- og brukerrettighetsloven §4-1 annet ledd, annet punktum. Pasientens selvbestemmelsesrett er juridisk og etisk en sterkt vernet rett.

Den presenterte tolkingen av balansen mellom selvbestemmelsesretten og inngrepsplikten støttes av Høyesteretts flertall i Rt. 2010 side 612. I denne dommen, som er avsagt under dissens 3-2, 
handlet saken om en samtykkekompetent pleiepasient som nektet å vaske seg samt motta stell og pleie av infiserte sår. Dette medførte betydelige miljømessige utfordringer for sykehjemmet hvor mannen bodde. Spørsmålet for Høyesterett var om et kommunalt sykehjem kunne skifte sengetøy, utføre kroppsvask og skifte bandasjer på en pasient mot hans vilje, jf. pasientrettighetsloven $\S 4-1$. I denne forbindelse uttalte dommer Bårdsen som førstvoterende på vegne av flertallet at pasientens holdning gav sykehjemmet grunnlag for å si han opp, men at «det er enighet mellom partene om - at utskrivning nokså umiddelbart vil skape behov for øyeblikkelig hjelp, jf. helsepersonelloven $\S 7$. Slik hjelp skal etter den nevnte bestemmelsen gis «selv om pasienten motsetter seg» denne.»

\subsubsection{Alvorlig syke barn}

Foreldrenes utøvelse av barnets autonomi følger av pasient- og brukerrettighetsloven $\S 4-4$, første ledd. Bestemmelsen slår fast at: «Foreldrene eller andre med foreldreansvaret har rett til å samtykke til helsehjelp for pasienter under 16 år.» Det følger videre av andre ledd at det er tilstrekkelig at en av foreldrene (eller andre med foreldreansvaret) samtykker til helsehjelp, dersom denne regnes som en del av den daglige og ordinære omsorgen for barnet, eller fordi kvalifisert helsepersonell mener helsehjelpen er nødvendig for at barnet ikke skal ta skade. Men forelderen som ikke har samtykket, skal så vidt mulig høres først. Modifikasjoner i foreldrenes rett til å samtykke på vegne av barnet følger av barns selv- og medbestemmelsesrett og av prinsippet om barnets beste (Aasen, 2008). Er barnet mellom 16 og 18 år og mangler samtykkekompetanse, er det foreldrene eller andre med foreldreansvaret som samtykker, med mindre pasienten motsetter seg helsehjelpen, jf. pasient- og brukerrettighetsloven $\S 4-5$. Ved ikrafttredelse av lovendring av 16. juni $2017 \mathrm{nr}$. 53 vil barn mellom 12 og 16 år selv kunne samtykke til helsehjelp som foreldrene ikke er informert om eller det følger av tiltakets art. Hensynet til barnets autonomi vil ved den nevnte lovreguleringen være tydeligere regulert i pasient- og brukerrettighetsloven, og i samsvar med samfunnsutviklingen og rettsutviklingen ved at lovgivningen er på vei til å bli mer harmonisert med Barnekonvensjonen.

Pasient- og brukerrettighetsloven $\S 4$-4 må tolkes i lys av barnekonvensjonens regler, som er inkorporert via menneskerettsloven av 21. mai $1999 \mathrm{nr} .30 \mathrm{og}$ skal gis forrang foran norsk rett, jf. menneskerettslovens $\S 3$. Sentralt for barnets behov for palliativ behandling er prinsippet om barnets beste som følger av barnekonvensjonen artikkel 3. Helsepersonell, som representant for det offentlige, skal legge til grunn prinsippet om barnets beste ved vurderingen av barnets behov for palliativ behandling. Foreldre er forpliktet til det samme med hjemmel i barnelova $\S 30$ (Aasen, 2008). Dersom foreldrene ikke bidrar til nødvendige undersøkelser eller medisinsk behandling som barnet trenger, vil barnevernloven §4-10 kunne gi Fylkesnemnda for barnevern og sosiale saker lovhjemmel til å vedta at barnet skal gis nødvendig behandling, og dersom barnets medisinske behov ikke ivaretas av foreldrene, kan barneverntjenesten etter vedtak fra Fylkesnemnda for barnevern og sosiale saker overta omsorgen og samtykkekompetansen på barnets vegne, jf. barnevernloven $\S 4$-12 første ledd bokstav b (Syse, 2015).

Pasient- og brukerrettighetsloven $\S 4-4$ første ledd gir foreldrene rett til å samtykke til helsehjelp som tilbys. Foreldrenes rett til å samtykke får derfor særlig betydning når det foreligger et konkret valg mellom to eller flere behandlingsalternativ hvor det ene ikke utpeker seg som det beste alternativet. I det konkrete valget skal prinsippet om barnets beste være førende (Bahus, 2014).

Øyeblikkelig hjelp-bestemmelsen i helsepersonelloven $\S 7$ favner alle pasienter, også barn. Anvendelse av rettsreglene kan by på utfordringer i praksis, og et eksempel som ble fremhevet for utvalget var behandling av barn med alvorlige kromosomfeil som trisomi18. Det ble poengtert at dersom man velger å legge inn PEG-sonde (metode for å tilføre enteral ernæring (sondemat) direkte inn i magesekken), må man ha en plan for hvor lenge barnet skal ha enteral ernæring. I en slik kontekst vil barnet på et tidspunkt befinne seg i en øyeblikkelig hjelp-situasjon ved fjerning av sonden.

Utvalget mener at det bør gjennomføres forhåndssamtaler med foreldrene, og hvor det er forsvarlig bør barnet inkluderes i dialogen. I samtalen bør helsepersonell fra både kommune- og spesialisthelsetjenesten være med hvor det er hensiktsmessig. Resultatene av samtalene skal være med på å danne innholdet i de pasienttilpassede forløpene på lik linje med hvordan utvalget anbefaler at det skal være for voksene (se kapittel 4). 


\subsection{6 «Barnets beste» som et grunnleggende hensyn}

I følge barnekonvensjonen artikkel 3 og Grunnloven artikkel 104 andre ledd som bygger på FNs barnekonvensjon skal «barnets beste» være et grunnleggende hensyn ved alle handlinger som berører barn. FNs komité for barns rettigheter har i generell kommentar nr. 14 (2013) avsnitt 6 uttrykt at barnets beste er et tredelt konsept bestående av en selvstendig rettighet, et grunnleggende, fortolkende juridisk prinsipp og en prosedyreregel.

Barnets beste, både som et prinsipp, som rettighet og som prosedyreregel, skal være styrende for blant annet valg av helsehjelp, ved forhåndssamtaler, ved utformingen av behandlingsplaner, ved utskriving og overføring til den kommunale helse- og omsorgstjenesten, og ved enhver beslutning som tas av den behandlingsansvarlige for barnet. For foreldrene følger prinsippet om barnets beste av barnelova (Aasen, 2008). I barnelova $\S 30$ er det uttrykt at foreldreansvaret skal utøves ut fra barnet sine interesser og behov. Det følger også av barnekonvensjonen artikkel $18 \mathrm{nr}$. 1 at foreldre «har hovedansvaret for barnets oppdragelse og utvikling. Barnets beste skal for dem komme i første rekke».

For å tydeliggjøre at barnets beste skal være et grunnleggende hensyn i alle valg som gjøres både $\mathrm{i}$ spesialisthelsetjenesten og $\mathrm{i}$ den kommunale helse- og omsorgstjenesten, mener utvalget at «barnets beste» bør fremgå av både pasient- og brukerrettighetsloven og av helsepersonelloven. Dette vil innebære en ytterligere harmonisering med Barnekonvensjonen og være samsvarende med Grunnloven $\S 104$. Det vil i tillegg tydeliggjøre både helsepersonells personlige plikt til å vektlegge barnets beste i møte med og valg for det enkelte barn, men også sykehusledelsens ansvar for å tilrettelegge driften i samsvar med forpliktelsen til å la barnets beste være et grunnleggende hensyn.

For barn som trenger palliativ behandling vil «barnets beste» som et grunnleggende hensyn være særlig fremtredende, da fokus blir rettet mot det pasientsentrerte (pasienten med sykdommen) framfor kun det sykdomsrettede. Representasjonsreglene i pasient- og brukerrettighetsloven forutsetter at foreldrene eller andre med foreldreansvar vil ivareta barnets beste, men dette er en forutsetning som ikke nødvendigvis alltid vil være tilstede i den vanskelige overgangen fra kurativ til palliativ behandling, og i den krevende erkjennelsesprosessen av at barnet vil dø. En kodifisering av hensynet til barnets beste vil i større grad sikre helsepersonell forståelsen av at de alltid må se hen til barnets behov, et pasientsentrert fokus, $i$ de beslutninger som fattes, også når foreldrene strever med å akseptere at helbredelse ikke lenger er mulig. Utvalget mener at ved utforming av ny lovtekst bør samme formulering som følger av den norske oversettelse av barnekonvensjonen artikkel 3 nr. 1, samt Grunnlovens $\S 104$ andre ledd, benyttes for å unngå motstrid i tolkningsinnhold.

\subsubsection{Folkerettslige forpliktelser}

Flere folkerettslige bestemmelser som Norge har forpliktet seg til å følge berører reglene om selvbestemmelsesrett og hjelpeplikt, og får således betydning for tolkingen av samtykkereglene og hjelpeplikten i norsk rett.

I mai 2014 fikk vi en ny grunnlovsbestemmelse (Grunnloven $§ 102)$ som langt på vei speiler Den europeiske menneskerettighetskonvensjon (EMK) artikkel 8, og sikrer rett til respekt for privatliv og familieliv og den personlige integritet. I 2014 ble også Grunnloven $\S 92$ endret, og pålegger nå statens myndigheter å «respektere og sikre menneskerettighetene slik de er nedfelt i denne Grunnlov og i for Norge bindende traktater om menneskerettigheter». Ifølge Jens Edvin A. Skoghøy pålegger denne bestemmelsen «blant annet domstolene å håndheve ikke bare de menneskerettighetene som er nedfelt i Grunnloven, men også andre internasjonale menneskerettsforpliktelser, og å sørge for at eventuelle menneskerettsbrudd blir reparert» (Skoghøy, 2015).

Norge har inkorporert fem viktige menneskerettskonvensjoner med tilleggsprotokoller ved vedtakelsen av lov om styrking av menneskerettighetenes stilling i norsk rett av 21. mai 1999 (menneskerettsloven). Ved motstrid mellom nasjonale lovbestemmelser og konvensjonenes bestemmelser skal sistnevnte ha forrang, jf. menneskerettsloven $\S 3$.

Pasienters selvbestemmelsesrett er vernet av Den europeiske menneskerettighetskonvensjon artikkel 8. Retten for en pasient til å nekte behandling, også når dette kan resultere $\mathrm{i}$ at vedkommende dør, ble slått fast av Den europeiske menneskerettighetsdomstolen (EMD) i en dom av 29. april 2002 (Pretty mot Storbritannia). Siden 2002 er det fastholdt fra domstolen at den enkeltes fysiske og psykiske integritet er vernet av menneskerettighetskonvensjonens artikkel 8, slik at inngrep i en pasient er i strid med artikkel 8 nr.1 med mindre det foreligger samtykke. I en dom av 
5. desember 2013 (Arskaya mot Ukraina) uttalte domstolen følgende: «the Court notes that the freedom to accept or refuse specific medical treatment is vital to the principles of self-determination and personal autonomy» med henvisning til sak av 10. juni 2010 (Jehovah's Witnesses of Moscow and others mot Russland). I saken Jehovah's Witnesses of Moscow and others mot Russland fremhevet domstolen betydningen av å kunne ta en beslutning i samsvar med eget syn og verdier uavhengig av hvor lite rasjonelt valget fremstår for andre og viste til den tidligere dommen fra 2002 (Pretty mot Storbritannia).

«Kroppen konstituerer den viktigste grensen mellom individet og omverdenen, og er derfor blant de mest beskyttelsesverdige goder» (NOU 2005: 1). Ethvert inngrep i et menneske uten samtykke må kunne rettferdiggjøres i henhold til artikkel 8 (2).

På den andre siden verner menneskerettighetskonvensjonen artikkel 2 prinsippet om livets ukrenkelighet. I Arskaya mot Ukraina uttalte domstolen at prinsippet om livets ukrenkelighet («the principle of sanctity of life») er særlig tydelig for en lege som gir medisinsk behandling for å redde liv og som skal handle i pasientens beste interesse. Under henvisning til Haas mot Sveits (dom av 20. januar 2011) slår domstolen fast at artikkel 2 forplikter statene til å forhindre at mennesker tar sitt eget liv dersom beslutningen ikke er tatt av fri vilje og med full forståelse av hva som er implisert. Domstolen uttrykker også at en av hovedutfordringene med å avgjøre om en pasient kan nekte behandling eller ikke er relatert til pasientens samtykkekompetanse.

FN-konvensjonen om sosiale og politiske rettigheter (SP) som også er gjort til gjeldende norsk rett, beskytter i artikkel 17 inngrep i privat- eller familieliv i likhet med Den europeiske menneskerettighetskonvensjon artikkel 8. SP artikkel 7 første punktum har samme ordlyd som menneskerettighetskonvensjonens artikkel $3 \mathrm{om}$ at ingen må utsettes for umenneskelig eller nedverdigende behandling.

Barnekonvensjonen som er gjeldende norsk rett, bestemmer i artikkel 3 at barnets beste skal være et grunnleggende hensyn ved enhver beslutning. I artikkel 6 fremgår barnets rett til liv og til å vokse opp, og i artikkel 12 fremgår barnets rett til med- og selvbestemmelsesrett. I artikkel 24 anerkjennes barns rett til å nyte godt av den høyest oppnåelige helsestandard og til behandlingstilbud for sykdom og rehabilitering.

Oviedo-konvensjonen (konvensjonen om menneskerettigheter og bioetikk) «er den første folke- rettslige konvensjonen som er særskilt innrettet mot å ivareta individets rettigheter $\mathrm{i}$ forbindelse med biomedisinsk behandling og forskning» (NOU 2005: 1). Den skal sikre at vitenskapelige og medisinske fremskritt ikke går på bekostning av menneskerettighetene. «Konvensjonen etablerer grunnleggende menneskerettigheter på det biomedisinske området, herunder kravet om individets frie og informerte samtykke, retten til privatliv og regler for beskyttelse av personer med redusert eller manglende samtykkekompetanse» (NOU 2005: 1). Norge undertegnet konvensjonen i 1997 og ratifiserte den 13. oktober 2006. Oviedokonvensjonen (og tilleggsprotokollen om biomedisinsk forskning) er bindende i landene der den er ratifisert. «En viktig del av statenes forpliktelse ligger i å vedta og implementere nasjonal lovgivning i overensstemmelse med de internasjonale forpliktelser» (NOU 2005: 1). Oviedo-konvensjonen er ikke gjort til norsk lov, men det følger av presumsjonsprinsippet at norsk rett må antas å være i overensstemmelse med Norges folkerettslige forpliktelser. Det innebærer at norske regler, så langt som mulig, skal tolkes slik at det ikke oppstår konflikt med konvensjonens bestemmelser (NOU 2005: 1). Menneskerettslovens formål, å styrke menneskerettighetenes stilling i norsk rett, som følger av $\S 1$, vil sammen med Grunnloven $\S 92$, også ha selvstendig betydning for forståelsen av hvilken vekt Oviedo-konvensjonen har i norsk rett.

Formålet med Oviedo-konvensjonen som slås fast i artikkel 1, er blant annet å beskytte alle menneskers verdighet og identitet samt å respektere deres integritet og rettigheter og fundamentale friheter ved anvendelse av biologi og medisin. Oviedo-konvensjonen slår i artikkel 2 fast prinsippet om at hensynet til den enkelte går foran hensynet til vitenskapens og samfunnets interesser. Det fremgår av konvensjonen artikkel 5 at informert samtykke er den klare hovedregelen. Artikkel 5 er lik pasient- og brukerrettighetsloven $\S$ 4-1 $\mathrm{i}$ innhold. I konvensjonens artikkel 8 fremgår hjelpeplikten. Ordlyden er: "When because of an emergency situation the appropriate consent cannot be obtained, any medically necessary intervention may be carried out immediately for the benefit of the health of the individual concerned». I motsetning til norsk lovgivning skal øyeblikkelig hjelp kun gis til personer hvor man ikke kan få tak i pasientens samtykke.

Det følger av Explanatory Report to the Convention for the protection of Human Rights and Dignity of the Human Being with regard to the Application of Biology and Medicine: Convention 
on Human Rights and Biomedicine punkt 57 første punktum at muligheten til å gi øyeblikkelig hjelp er begrenset til krisesituasjoner hvor helsepersonell er forhindret fra å få tak i pasientens samtykke. Det følger videre av samme sted siste punktum at selv i øyeblikkelig hjelp-situasjoner skal helsepersonell gjøre enhver fornuftig innsats for å fastlegge hva pasienten ville ha ønsket. Man må derfor kunne anta at hjelpeplikten i henhold til Oviedo-konvensjonen ikke omfatter den situasjonen hvor pasienten mangler samtykkekompetanse, men har et kjent forhåndsønske for den oppståtte situasjonen.

\subsection{Nordisk lovgivning}

Lovregulering i land som det er naturlig å sammenlikne oss med kan gi veiledning i forhold til alternative måter å regulere balansen mellom pasienters selvbestemmelsesrett og helsepersonell inngrepsplikt. De nordiske land står i en særstilling som sammenlikningsgrunnlag fordi vi har mange historiske og kulturelle likhetstrekk. De menneskerettslige forpliktelsene er imidlertid til en viss grad ulikt inkorporert i de nordisk land. For eksempel har Sverige ikke ratifisert Oviedokonvensjonen.

\subsubsection{Finsk rett}

Den finske pasientrettighetsloven av 17.8. 1992 følger pasienters selvbestemmelsesrett av lovens $\S 6$ (svensk oversettelse): «Vården och behandlingen skall ges i samförstånd med patienten. Om patienten vägrar ta emot en viss vård eller behandling, skall den i mån av möjlighet och i samförstånd med honom ges på något annat sätt som är godtagbart från medicinsk synpunkt» (http:// www.finlex.fi/sv/laki/ajantasa/1992/19920785).

Finsk rett har, i motsetning til norsk rett, en regel om stedfortredende samtykke for det tilfellet at pasienten har mistet sin samtykkekompetanse. For det tilfellet at pasienten ikke har en stedfortreder, skal prinsippet om pasientens beste interesse legges til grunn. Det følger av $\S 6$ annet ledd: «Om en patient som har uppnått myndighetsåldern på grund av mental störning eller psykisk utvecklingsstörning eller av någon annan orsak inte kan fatta beslut om vården eller behandlingen, skall hans lagliga företrädare, en nära anhörig eller någon annan närstående person höras före ett viktigt vårdbeslut $i$ avsikt att utreda hurdan vård som bäst motsvarar patientens vilja. Om detta inte kan utredas, skall patienten vårdas på ett sätt som kan anses vara förenligt med hans bästa». Bestemmelsen om stedfortredende samtykke utdypes i bestemmelsens tredje ledd. For barn tar finsk lovgivning utgangspunkt i barnets rett til med- og selvbestemmelse. Det følger av $\S 7$ : «En minderårig patients åsikter om en vårdeller behandlingsåtgärd skall utredas, om det med beaktande av patientens ålder eller utveckling är möjligt. Vården av en minderårig patient skall ske i samförstånd med patienten, om han med beaktande av ålder eller utveckling kan fatta beslut om vården». For barn som ikke kan ta egne beslutninger, følger det av $\S 7$ annet ledd at foreldre eller andre med foreldreansvar skal ta beslutningen sammen med barnet. Pasientens rett til øyeblikkelig hjelp (brådskande vård) følger av lovens $\S 8$ hvor det tydelig fremgår at man ikke skal gi øyeblikkelig hjelp til pasienter som har uttrykt at de ikke ønsker helsehjelp i den oppståtte situasjonen: «Patienten skall beredas den vård som behövs för avvärjande av fara som hotar hans liv eller hälsa även om hans vilja på grund av medvetslöshet eller av någon annan orsak inte kan utredas. Har patienten tidigare på ett giltigt sätt uttryckt sin bestämda vilja i fråga om vården, får han dock inte ges vård som strider mot hans viljeförklaring.

Det finske sosial- og helsedepartementet har uttrykt at artikkel 8 har blitt behandlet flere ganger etter at loven trådte i kraft i mars 1993. For eksempel, hvis en person har skrevet sitt livstestament (living will) for lenge siden, er det mulig at den teknologiske utviklingen har forandret prognosen av sykdommen som pasienten har. Det må da vurderes om pasienten ville ha endret sitt livstestament dersom vedkommende ville ha kjent til den nye utviklingen. I Finland kan en person legge sitt livstestament $\mathrm{i}$ et nasjonalt arkiv for helsevesenet (en såkalt oma-KANTA).

\subsubsection{Svensk rett}

Svensk pasientrettighetslov (Patientlag) trådte i kraft 1. januar 2015. Samtykkereglene følger av lovens kapittel 4. «Samtycke». Det følger av $§ 1$ at: «Patientens självbestämmande och integritet ska respekteras». Videre følger det av $\S 2$ tilnærmet tilsvarende regel som pasient- og brukerrettighetsloven $\S 4-1$ om informert samtykke og § 4-2 om krav til samtykkets form: «Hälso- och sjukvård får inte ges utan patientens samtycke om inte annat följer av denna eller någon annan lag. Innan samtycke inhämtas ska patienten få information enligt 3 kap. Patienten kan, om inte annat särskilt följer av lag, lämna sitt samtycke skriftligen, munt- 
ligen eller genom att på annat sätt visa att han eller hon samtycker till den aktuella åtgärden. Patienten får när som helst ta tillbaka sitt samtycke. Om en patient avstår från viss vård eller behandling, ska han eller hon få information om vilka konsekvenser detta kan medföra.» Vedrørende samtykke på barns vegne er også rettstilstanden ganske lik den norske, særlig når lov av 16. juni 2017 nr. 53 trår i kraft og styrker barns medvirkningsrett og rett til å bli hørt. Det fremgår av $\S 3$ i lovens kapittel fire følgende: «När patienten är ett barn ska barnets inställning till den aktuella vården eller behandlingen så långt som möjligt klarläggas. Barnets inställning ska tillmätas betydelse i förhållande till hans eller hennes ålder och mognad».

Pasienters rett til øyeblikkelig hjelp følger av $\S 4$ hvor det fremgår følgende: «Patienten ska få den hälso- och sjukvård som behövs för att avvärja fara som akut och allvarligt hotar patientens liv eller hälsa, även om hans eller hennes vilja på grund av medvetslöshet eller av någon annan orsak inte kan utredas». Bestemmelsen skiller her mellom personer som kan uttrykke sin vilje, og pasienter som ikke kan. Ordlyden tilsier at alvorlig syke pasienter som ennå ikke er døende, vil få respektert et uttrykt ønske om ikke-behandling i en øyeblikkelig hjelp-situasjon. Dette vil også gjelde i de øyeblikkelig hjelp-situasjoner hvor pasienten er bevisstløs, men hvor man kan utrede hva pasienter ønsker, viljen «kan utredas».

Rettsavdelingen i den svenske socialstyrelsen har uttrykt følgende om rettstilstanden: «Rent generellt kan sägas att svensk hälso- och sjukvård bygger på frivillighet. Enligt svensk grundlag är var och en gentemot det allmänna skyddad mot påtvingat kroppsligt ingrepp (regeringsformen (1974:152) 2 kap. 6 §). Hälso- och sjukvården ska bygga på respekt för patientens självbestämmande och integritet (hälso- och sjukvårdslagen (2017:30) 5 kap. $1 \S 3$ p.) och patientens integritet och självbestämmande ska respekteras (patientlagen (2014:821) 4 kap. 1 §). Huvudregeln är att samtycke krävs för att ge en patient hälso- och sjukvård, vissa undantag finns dock (patientlagen 4 kap. 2 §). För att samtycket ska vara giltigt måste det ha föregåtts av relevant information (patientlagen 4 kap. 2 §). Informationsskyldigheten regleras i patientlagen $3 \mathrm{kap}$.

Patienten ska få den hälso- och sjukvård som behövs för att avvärja fara som akut och allvarligt hotar patientens liv eller hälsa, även om hans eller hennes vilja på grund av medvetslöshet eller av någon annan orsak inte kan utredas (patientlagen
4 kap. $4 \S)$. Denna bestämmelse är också tillämplig när en person som mer varaktigt får anses sakna beslutsförmåga befinner sig $\mathrm{i}$ en nödsituation. Under den tid ett akut eller i övrigt nödvändigt omhändertagande pågår får en nödsituation anses vara för handen. När så inte längre är fallet kan vård inte längre ges med stöd av denna bestämmelse, även om patienten fortfarande inte är $\mathrm{i}$ stånd att uttrycka sin vilja. Bestämmelsen ska således inte tillämpas för att t.ex. fortlöpande kunna bereda en person som är varaktigt beslutsoförmögen hälso- och sjukvård som inte är av akut karaktär. I dessa fall torde stöd för vården även fortsättningsvis få hämtas i den allmänna nödbestämmelsen i 24 kap. 4 § brottsbalken (1962:700) (prop. 2013/14:106 s. 120-121). Vidare ska hälso- och sjukvården, i den mån det är möjligt, utföras och genomföras i samråd med patienten (patientlagen 5 kap. $1 \S$ samt patientsäkerhetslagen (2010:659) 6 kap $1 \S)$.

Angående den palliativa vården mer specifikt så gäller samma regler där. Givetvis kan läkarens uppgift att alltid försöka bota och lindra sjukdomar hamna i konflikt med patientens autonomi om patienten tackar nej till livsuppehållande behandling. Men ingen hälso- och sjukvård får ges mot patientens vilja, så patienten har alltså rätt att tacka nej till sådan behandling samt att avbryta pågående behandling. Patientens rätt till självbestämmande väger således tyngre än läkarens vilja att hjälpa. Undantag från denna regel kräver lagstöd, se exempelvis $3 \S$ lagen (1991:1128) om psykiatrisk tvångsvård.

En patient som önskar avsluta en livsuppehållande behandling har således rätt att göra detta. Vid en sådan begäran ska emellertid patientens vårdkontakt göra följande:

- försäkra sig om att patienten och närstående har fått individuellt anpassad information,

- göra en bedömning av patientens psykiska status, och

- förvissa sig om att patienten förstår informationen, kan inse och överblicka konsekvenserna av att behandlingen inte inleds eller fortsätter, haft tillräckligt med tid för sina överväganden samt står fast vid sin inställning (Socialstyrelsens föreskrifter och allmänna råd om livsuppehållande behandling SOSFS 2011:7). I nämnda föreskrift rekommenderar Socialstyrelsen även att patientens vårdkontakt i den här typen av situation redogör med andra yrkesutövare som deltar i eller har deltagit i patientens vård. Det är dock endast en rekommendation och inget som är bindande för vårdpersonalen att följa. 
Om livsuppehållande behandling inte ska sättas in eller inte ska fortsätta ingår det i god palliativ vård att ge till exempel smärtlindrande och ångestdämpande behandling.»

\subsubsection{Dansk rett}

Den danske sundhedsloven trådte i kraft 1. januar 2007. I dansk rett har man de samme tre særreglene som i Norge om retten til å nekte livsforlengende behandling, og behandling med blod, samt retten til å sultestreike (sundhedsloven $§ \S 23-25$ ). Danmark har imidlertid ikke en lovregel tilsvarende helsepersonelloven $\S 7$, og sunhedsloven forutsetter at pasienten formodes å ville ønske behandlingen gjennomført. Pasienters selvbestemmelsesrett følger $\S 15$ og er langt på vei identisk med den norske om at all behandling krever et informert samtykke, med mindre det foreligger et gyldig rettsgrunnlag. Ordlyden er som følger: «Ingen behandling må indledes eller fortsættes uden patientens informerede samtykke, medmindre andet følger af lov eller bestemmelser fastsat i henhold til lov eller af $\S \S 17-19 »$. I dansk rett har pasientene i tillegg via en ordning med livstestamenter mulighet til å tilkjennegi et ønske om fremtidig fravalg av livsforlengende behandling etter sundhedsloven $\S 26$. Dersom pasienten er uavvendelig døende er et ønske om fravalg av livsforlengende behandling bindende for helsepersonell (sundhedspersonen).

Den helserettslige myndighetsalderen er 15 år i Danmark, og fra dette tidspunkt kan barnet selv ta avgjørelser i helsespørsmål. Foreldre eller andre med foreldreansvar skal samtidig få informasjon, jf. $\S 17$. For pasienter som varig mangler evne til å gi samtykke, kan de nærmeste pårørende gi informert samtykke på pasientens vegne, jf. $\S 18$. Videre er det i $\S 18$ bestemmelser om verge, om de situasjoner hvor nærmeste pårørende eller vergen tar beslutninger som er åpenbart til skade for pasienten eller behandlingsresultatet, og helsepersonells behandlingsmulighet når pasienten mangler nærmeste pårørende eller verge.

For at helsepersonell skal gi øyeblikkelig hjelp etter sundhedsloven $\S 19$ kreves også et informert samtykke, med mindre pasienten midlertidig eller varig mangler evnen til å gi informert samtykke eller er under 15 år. I sistnevnte situasjon kan helsepersonell starte eller fortsette en behandling uten samtykke fra pasienten eller fra de med foreldreansvaret, nærmeste pårørende eller verge dersom pasienten «befinder sig i en situation, hvor øjeblikkelig behandling er påkrævet for patien- tens overlevelse eller for på længere sigt at forbedre patientens chance for overlevelse eller for et væsentligt bedre resultat af behandlingen».

Danmark har to faglige veiledninger som omhandler valg og fravalg av livsforlengende behandling.

Den 6. september 2017 ble det inngått en politisk avtale om blant annet å styrke pasienters fravalg av behandling, herunder livsforlengende behandling. Forslag til lov om endring av sundhedsloven ble sendt på høring 8 . september til 10.oktober 2017. Det uttales blant annet i forslaget: «Regeringen ønsker at styrke mulighederne for, at enhver patient - uanset diagnose og forventet levetid - kan fravælge sundhedsfaglig behandling. Dette gælder både fravalg af, at en behandling indledes, og fravalg af fortsættelse af en igangværende behandling. Regeringen ønsker endvidere at styrke patienters muligheder for på forhånd at tage stilling til, om de ønsker livsforlængende behandling i specifikke situationer, der måtte finde sted i fremtiden på et tidspunkt, hvor patienten ikke længere er i stand til at udøve sin selvbestemmelsesret. Regeringen foreslår på den baggrund en udvidelse af de muligheder for fravalg af livsforlængende behandling, som allerede findes i livstestamenteordningen. Denne foreslås omlagt til en behandlingstestamente-ordning. Forslaget omfatter en udvidelse af patientgruppen, for hvem udøvelsen af selvbestemmelse via et behandlingstestamente vil kunne blive relevant. Forslaget betyder endvidere, at alle tilkendegivelser $\mathrm{i}$ et behandlingstestamente gøres bindende for sundhedspersonen, i modsætning til i dag, hvor tilkendegivelser i livstestamentet kun er bindende for så vidt angår uafvendeligt døende patienters ønsker om fravalg af livsforlængende behandling.» Det understrekes at forslaget ikke legaliserer aktiv dødshjelp.

Pasienters selvbestemmelsesrett styrkes gjennom følgende fem punkter i det danske lovforslaget:

1. Samtykkekompetente pasienter kan selv om de ikke er døende kreve en påbegynt livsnødvendig behandling avbrutt selv om det resulterer $\mathrm{i}$ at pasienten dør

2. Pasientgruppen som kan opprette livstestamenter (som endrer betegnelse til behandlingstestamenter) utvides fra å kun gjelde uavvendelig døende og vegetative pasienter til ikke uavvendelig døende pasienter hvor behandling kan føre til overlevelse men hvor de fysiske konsekvensene av sykdommen eller av behandlingen vurderes å være veldig alvorlige og lidelsesfulle. 
3. Alle tilkjennegivelser om fravalg av behandling i behandlingstestamentet gjøres bindende. I dag er de kun bindende for døende pasienter.

4. En ikke-døende pasient får en valgfri sikkerhetsgaranti hvor vedkommende kan tilkjennegi at beslutningen om fravalg av livsforlengende behandling forutsetter de pårørendes, vergens eller fremtidsfullmektigens aksept. (Danmark har en liknende ordning fra organdonasjonsområdet).

5. Pasienten kan $i$ behandlingstestamentet bestemme at lov om anvendelse av tvang ved somatisk behandling av varig inhabile ikke skal anvendes dersom de blir varig inhabile.

For Danmark krever punkt 1. en endring i veiledningen på området. For Norge vil det kreve en endring av helsepersonelloven $\S 7$ ved opprettholdelsen av en tradisjonell tolking av bestemmelsen. I Norge har ikke livstestamenter rettslig status og vil dersom de er kjent inngå i en vurdering av hva pasienten ville ha ønsket om pasienten ikke er samtykkekompetent og utenfor en øyeblikkelig hjelp situasjon. Danmark har med dagens lovregulering en sterkere selvbestemmelsesrett og en svakere inngrepsplikt enn den som følger av norsk rett. Det er derfor av interesse for utvalget at Danmark vurderer å styrke pasienters selvbestemmelsesrett ytterligere.

\subsubsection{Islandsk rett}

Det følger av den Islandske pasientrettighetsloven (Patients' Rights Act, No. 74/1997) artikkel 7 første ledd at pasientens rett til å bestemme om han eller hun vil godta behandlingen skal bli respektert. Det følger av siste ledd $\mathrm{i}$ artikkel 7 at ingen behandling kan gis uten samtykke fra pasienten. Samtykket skal være skriftlig når det er mulig, og oppgi den informasjon som er gitt til pasient og om pasient har forstått denne. Et unntak fra kravet om samtykke følger av artikkel 9 hvor det fremgår at dersom en pasient er bevisstløs og pasientens tilstand er slik at det ikke er mulig for vedkommende å uttrykke sin vilje når det gjelder akutt behandling, så skal samtykke antas med mindre man har sikker kunnskap om at pasienten ikke ønsker behandling.

I lovens artikkel 24 reguleres behandling av døende pasienter, og her fremgår det at en terminal pasient har rett til å dø med verdighet. Hvis en terminal pasient entydig indikerer at han eller hun avslår videre livsforlengende behandling, eller gjenopplivningsarbeid, skal legene respektere pasientens beslutning. Dersom en terminal pasi- ent er mentalt eller fysisk for syk til å ta del i en beslutning om behandling, skal legen forsøke å konsultere pasientens slektninger og egne kollegaer før det bestemmes om behandlingen skal videreføres eller opphøre.

I likhet med den norske pasient- og brukerrettighetsloven så er det foreldrene i henhold til artikkel 26 som samtykker på barnets vegne frem til barnet blir 16 år. Barnet skal så langt det er mulig tas med i beslutningen og når det er fylt 12 år skal det alltid høres. Dersom barnets foreldre nekter å samtykke til nødvendig behandling, så skal legen eller annet helsepersonell få bistand fra barnevernsmyndigheter. Dersom det ikke er tid til å kontakte barnevernsmyndighetene og det gjelde akutt livsopprettholdende behandling for et sykt barn så skal barnets helse være avgjørende og den nødvendige behandlingen skal startes umiddelbart. Den samme løsningen følger av norsk rett når man ser pasient- og brukerrettighetsloven i sammenheng med barnelova, barnevernloven og barnekonvensjonen.

Den islandske pasientrettighetsloven har i tillegg en egen bestemmelse om lettelse av lidelse og nærvær av familie og venner i artikkel 23, hvor det fremgår at pasientens lidelse skal lindres så godt som medisinskfaglig mulig. Det følger videre av samme artikkel at en pasient har rett til å motta støtte fra familie, slektninger og venner mens behandlingen pågår og under sykehusoppholdet. Det er også lovfestet at pasienten og dennes nærmeste slektninger har rett til psykisk, sosial og religiøs støtte.

Juridisk rådgiver i det islandske velferdsdepartementet bekrefter at islandsk rett krever et informert samtykke for å gi øyeblikkelig hjelp med mindre pasienten er ute av stand til å tilkjennegi eget ønske, og man i tillegg ikke har positiv kunnskap om at pasienten motsetter seg behandlingen.

\subsubsection{Oppsummering av nordisk rettstilstand}

Finsk, svensk, dansk og islandsk rett praktiserer en annen balanse mellom helsepersonells inngrepsplikt og pasientenes autonomi enn den som følger av norsk rett, ved at pasienters selvbestemmelsesrett har et sterkere vern enn etter norsk rett og at helsepersonells inngrepsplikt er tilsvarende svakere. En tradisjonell tolking av helsepersonellovens $\S 7$ gir med andre ord helsepersonell en sterk inngrepsplikt på bekostning av pasienters selvbestemmelsesrett som vi ikke finner igjen i tilsvarende grad i de øvrige nordiske land. 
Lovteknisk har samtlige nordiske naboland valgt å ha øyeblikkelig hjelp-bestemmelsen i samme lov som samtykkereglene.

\subsection{En vurdering av om dagens lovregler innebærer en riktig grensedragning mellom helsepersonellets inngrepsplikt og pasienters rett til å nekte livreddende og livsforlengende behandling}

\subsubsection{Mandat}

Utvalget skal vurdere om dagens lovregler innebærer en riktig grensedragning mellom helsepersonellets hjelpeplikt og pasientenes autonomi, blant annet når pasienten motsetter seg helsehjelpen. Utvalget skal også vurdere om dagens regler bør videreføres, eller foreslå nødvendige endringer.

Utvalget har konkludert med at helsepersonelloven $\S 7$ griper inn i og kan sette til side samtykkebestemmelsene i pasient- og brukerrettighetsloven kapittel 4, med unntak av $\S 4-9$. Først og fremst griper helsepersonelloven $\S 7$ inn i hovedregelen i pasient- og brukerrettighetsloven $\S 4-1$ om at all helsehjelp trenger pasientens samtykke, og uten slikt samtykke mangler helsepersonell et rettslig grunnlag for å behandle pasienten. Bestemmelsen griper også inn i pasient- og brukerrettighetsloven $\S 4-6$ annet ledd, som omhandler pasienter over 18 år som mangler samtykkekompetanse, siden man ikke behøver å vurdere hvorvidt pasienten ville ha samtykket til helsehjelpen som ytes. Ifølge sistnevnte bestemmelse må helsehjelpen både være i pasientens interesse, og det må være sannsynlig at pasienten hadde gitt tillatelse til helsehjelpen, dersom helsepersonell skal ha et rettslig grunnlag for å behandle pasienten. Pasient- og brukerrettighetsloven $\S 4-4$, som bestemmer at foreldre samtykker på vegne av barn under 16 år, og $\S 4-5$ som gjelder foreldres rett til å samtykke på vegne av barn mellom 16 og 18 år som mangler samtykkekompetanse, kan også settes til side i øyeblikkelig hjelp-situasjoner.

Balansen mellom hjelpeplikten og selvbestemmelsesretten kan illustrerer ved følgende modell:

Modellen er utviklet av jurist og lege Jørgen Dahlberg og den tydeliggjør at helsepersonells inngrepsplikt er omfattende, særlig siden den også favner de tilfellene hvor pasienten er samtykkekompetent og motsetter seg helsehjelpen (situasjon 2). I situasjoner hvor pasienten kan uttrykke seg, men samtidig oppfattes som veldig forvirret, $\mathrm{i}$ sjokktilstand, eller på andre måter gir et tydelig inntrykk av å være i en unormal mental tilstand, kan det fremstå legitimt å behandle pasienten også mot hans eller hennes uttrykte vilje da pasienten i slike situasjoner trolig mangler tilstrekkelig samtykkekompetanse til å ta et informert valg. Det er vanskeligere å begrunne etisk og juridisk at helsehjelp skal gis i de situasjoner hvor pasienten er samtykkekompetent, fremstår rasjonell når det gjelder egen situasjon og motsetter seg helsehjelpen selv om denne er "påtrengende nødvendig».

Å hjelpe en pasient som har mistet samtykkekompetansen, og som ikke har et kjent ønske for den oppståtte situasjonen, følger allerede av den hjelpeplikten som påhviler enhver, jf. straffeloven $\S 287$ (situasjon 3). Man vil i slike situasjoner anta eller presumere at pasienten ville ha samtykket til den hjelp som gis. Dersom pasienten har et kjent ønske for situasjonen kan man imidlertid ikke legge en antagelse om presumert samtykke til grunn. Det kan også være vanskelig å begrunne hvorfor en pasient som har mistet samtykkekompetansen varig eller midlertidig, skal påtvinges øyeblikkelig hjelp i situasjoner hvor pasienten $\mathrm{i}$ bevisst tilstand ved journalførte forhåndssamtaler eller ved skriftlige nedtegnelser på andre måter

\begin{tabular}{|l|l|l|}
\hline Samtykkekompetanse & $\begin{array}{l}\text { Pasienten er ikke i stand til } \\
\text { å samtykke }\end{array}$ & $\begin{array}{l}\text { Pasienten er i stand til } \\
\text { å samtykke }\end{array}$ \\
\hline Handlingsalternativer & 1 & 2 \\
\hline $\begin{array}{l}\text { Pasienten motsetter seg } \\
\text { behandling }\end{array}$ & 3 & 4 \\
\hline $\begin{array}{l}\text { Pasienten motsetter seg ikke } \\
\text { behandling }\end{array}$ & & \\
\hline
\end{tabular}

Helsepersonell har inngrepsplikt

Figur 13.1 Modell for handlingsalternativer i øyeblikkelig hjelp-situasjoner 
har gitt klart uttrykk for ikke å ønske den aktuelle behandlingen (situasjon 1). Situasjon 4 er uproblematisk mens situasjon 1,2 og 3 innebærer en krenkelse av pasientens integritet.

Pasienter som tas hånd $\mathrm{om}$ av den norske helse- og omsorgstjenesten, kan, med henvisning til blant annet Den europeiske menneskerettighetskonvensjon (EMK) artikkel 8, nekte enhver form for behandling. Det innebærer at øyeblikkelig hjelp-bestemmelsen i helsepersonelloven $\S 7 \mathrm{i}$ utgangspunktet griper inn i konvensjonens artikkel 8 (1) når pasienter behandles mot eget uttalte ønske. Det har vært reist spørsmål om det å påtvinge øyeblikkelig hjelp på tvers av en samtykkekompetent pasients ønsker, «selv om pasienten motsetter seg helsehjelpen», er i strid med EMK artikkel 8 (2). I vurderingen av spørsmålet uttrykkes det at helsepersonelloven $\S 7 \mathrm{i}$ utgangspunktet krenker EMK artikkel 8 (1), men at vilkårene i EMK artikkel 8 (2) er oppfylt for akutte kriser som var vanskelig eller umulig å forutse, for eksempel en person som holder på å blø i hjel i forbindelse med en bilulykke (betegnet som «egentlige» øyeblikkelig hjelp-situasjoner). Når det gjelder forventede kriser i forløpet av en progressiv dødelig sykdom (betegnet som «uegentlige» øyeblikkelig hjelp-situasjoner), fremheves det at samfunnet ikke har tilsvarende interesse i å bevare liv på bekostning av selvbestemmelsesretten. Helsepersonelloven $\S 7$ favner, ifølge konklusjonen, for vidt til å oppfylle vilkårene i EMK artikkel 8 (2) slik at man unngår motstrid med EMK artikkel 8 (1), ved å inkludere situasjoner hvor pasienten er klar, og på en rasjonell og konsekvent måte tilkjennegir et ønske om ikke-behandling. Samlet konkluderes det med at øyeblikkelig hjelp-bestemmelsen går utover det som er nødvendig $i$ et demokratisk samfunn, $o g$ at kravet om proporsjonalitet kun synes oppfylt for «egentlige» øyeblikkelig hjelp-situasjoner.

For pasienter med behov for palliativ behandling har sondringen mellom forventede kriser i forløpet av en progressiv dødelig sykdom («uegentlige» øyeblikkelig hjelp-situasjoner) og akutte kriser som det er vanskelig å forutse («egentlige» øyeblikkelig hjelp-situasjoner), stor betydning da denne pasientgruppen forventes å rammes av førstnevnte og således får sin selvbestemmelsesrett betydelig innskrenket. For å unngå at pasienter med progressive dødelige sykdommer behandles mot sin vilje, er man derfor etter gjeldende rett avhengig av at begrepet døende tolkes vidt. I klinisk praksis vil også de aller fleste pasienter når de er døende eller ha kort forventet levetid være samtykkekompetente.
Det er et klart behov for en pliktbestemmelse som gir helsepersonell lovhjemmel til å agere i øyeblikkelig hjelp-situasjoner, og utvalget er av den oppfatning at man må opprettholde bestemmelsen for å sikre pasienter hjelp i øyeblikkelig hjelp-situasjoner. Etter utvalgets oppfatning er det imidlertid behov for å tolke øyeblikkelig hjelpbestemmelsen innskrenkende slik at den fanger opp situasjoner hvor pasienten blir vurdert av helsepersonell som ikke samtykkekompetent, og hvor det ellers ikke er uttrykt et klart forhåndsønske som bør respekteres for den oppståtte situasjonen.

Bestemmelsen «skal bidra til trygghet for at befolkningen får nødvendig hjelp i uventede situasjoner som krever livreddende innsats og innsats for å avverge alvorlig helseskade» (Befring og Ohnstad 2010). Det folger videre av lovens forarbeider at «Inngrepsplikten kan begrunnes med at samfunnet har en særlig interesse i å opprettholde respekten for livet, og at dette legitimerer innskrenkninger i den enkelte pasients autonomi» (Ot.prp. nr.13 (1998-1999)). En innskrenkende tolkning av øyeblikkelig hjelp-bestemmelsen til «egentlige» øyeblikkelig hjelp-situasjoner gir befolkningen trygghet for at de får nødvendig hjelp i uventede situasjoner, og den ivaretar samfunnets interesse for å bevare liv. For at innskrenkninger i den enkeltes autonomi skal legitimeres, må inngrep ikke gå lengre enn nødvendig for å være i samsvar med EMK artikkel 8 (2). En innskrenkende tolkning er også i bedre samsvar med Oviedo-konvensjonen, jf. artikkel 5 og 8, enn en ordlydsbasert tolkning.

Det er uttrykt at «Argumentet om at det er i samfunnets interesse å bevare liv (prinsippet om livets ukrenkelighet) og sikre at befolkningen får nødvendig hjelp i uventede situasjoner, fremstår som utilstrekkelig i møte med uegentlige øyeblikkelig hjelp-situasjoner. Tvert om kan det hevdes at samfunnet ikke har noen grunn til å begrense samtykkekompetente pasienters selvbestemmelsesrett ved uegentlige øyeblikkelig hjelp-situasjoner [...]. I slike situasjoner bør pasienten kunne velge, selv om vedkommende ikke er å anse som døende og derved omfattet av pbrl. § 4-9 annet ledd» (Bahus, 2014).

Begrunnelsen for bestemmelsen i helsepersonelloven $\S 7$ tilsier derfor en innskrenkende tolkning av øyeblikkelig hjelp-bestemmelsen til «egentlige» øyeblikkelig hjelp-situasjoner. En innskrenkende tolkning av øyeblikkelig hjelpbestemmelsen sikrer selvbestemmelsesretten til pasienter som er døende i et langt sykdomsforløp, og hvor det er uklart når pasienten går fra å være 
alvorlig syk til å være alvorlig syk og døende. Utvalget mener derfor at det er uheldig å sette et juridisk skille mellom det å være «alvorlig syk» og det å være «alvorlig syk og døende» for mennesker med alvorlig sykdom som de vil dø av. Mange pasienter i denne gruppen vil være døende dersom de takker nei til behandling, mens de vil være alvorlig syke, men ikke døende, med behandling (for eksempel cellegift, dialyse etc.). Behovet for å tolke begrepet «døende» utvidende for å sikre at pasienter med progressive dødelige sykdommer har selvbestemmelsesrett ved forventede kriser i sykdomsforløpet, bortfaller ved en innskrenkende tolkning av øyeblikkelig hjelp-bestemmelsen.

Utvalget mener at en innskrenkende tolkning av øyeblikkelig hjelp-bestemmelsen i helsepersonelloven $\S 7$ vil sikre uhelbredelig syke pasienter en rett til å møte døden på sin egen måte. Det kan være at de vil velge mest mulig behandling ved et sykehus, eller at de vil ha mer livskvalitet på bekostning av livslengde. Kanskje vil de ha mer hjemmetid og, dersom det praktisk lar seg gjennomføre, få mulighet til å dø i eget hjem. Pasienten eier sin sykdomsopplevelse og må, slik utvalget ser det, selv kunne velge hva som skal aksepteres av behandling ved en forventet medisinsk krise.

Ved å snevre inn hjelpeplikten til de situasjoner hvor pasienten ikke kan uttrykke et klart ønske, enten på grunn av bevisstløshet eller fordi personen ellers fremstår å være $\mathrm{i}$ en unormal mental tilstand, og ved å styrke pasienters selvbestemmelsesrett uavhengig av om de er «døende» eller bevisst på behandlingstidspunktet, mener utvalget at det gis større rom for å utarbeide behandlingsplaner, uten å komme i konflikt med hjelpeplikten. Utvalget mener at dette vil bidra til at man reduserer krenkende situasjoner for pasient og pårørende som kan følge av intervenerende behandling, særlig når behandlingen ikke er ønsket. Videre mener utvalget at man ved en innskrenkende tolkning av øyeblikkelig hjelpbestemmelsen til «egentlige» øyeblikkelig hjelpsituasjoner gir helsepersonell rettslig ryggdekning for å kunne avstå fra å behandle når pasienten ikke ønsker behandlingen, selv om helsehjelpen fremstår som «påtrengende nødvendig». En annen side av dette er at man kan unngå at legene opplever at de går for langt $\mathrm{i}$ å intervenere medisinsk i pasientens liv. En innskrenkende tolkning av øyeblikkelig hjelp-bestemmelsen kan også medføre mindre uheldig bruk og kanskje misbruk av ressurser.

\subsubsection{Lovtekniske betraktninger}

Lovteknisk følger samtykkebestemmelsene av pasient- og brukerrettighetsloven kapittel 4, men helsepersonells inngrepsplikt følger av helsepersonelloven kapittel 2. Det innebærer at lovreglene kan være vanskelig å finne fram i og få oversikt over, særlig for ikke-jurister. I praksis er det også i stor utstrekning helsepersonell, ikke jurister, som skal anvende bestemmelsene i det daglige. Dette tilsier at man bør flytte bestemmelsen om hjelpeplikt til pasient- og brukerrettighetsloven. Det som taler imot å flytte bestemmelsen i helsepersonelloven $\S 7$ til pasient- og brukerrettighetsloven kapittel 4, er at helsepersonell er kjent med bestemmelsen i helsepersonelloven, og at begge lover har virket parallelt med et system hvor de $\mathrm{i}$ stor grad speiler hverandre i over 15 år. Det følger også en rett til øyeblikkelig hjelp for pasient og bruker i pasient- og brukerrettighetsloven $\S \S 2-1$ a og 2-1 b, begge første ledd. Utvalget har etter avveining av ulike hensyn kommet fram til å opprettholde dagens system.

\subsubsection{Utvalgets vurderinger av om dagens regler bør videreføres}

Utvalget skal vurdere om dagens regler bør videreføres eller foreslå nødvendige endringer.

Utvalget mener at det bør sikres en reell (juridisk) rett til å bestemme over egen kropp for alvorlig syke pasienter som har en sykdom de vil dø av, uavhengig av om de er «døende». Utvalget anbefaler, i samsvar med vurderingen i punkt 3.1.1, at samtykkekompetente pasienter som er i «uegentlige» øyeblikkelig hjelp-situasjoner bør få utøve sin selvbestemmelsesrett uavhengig av om pasienten anses som døende. Pasient- og brukerrettighetsloven $\S 4-9$, andre ledd første punktum, vil ved en innskrenkende tolking av helsepersonelloven $\S 7$ kun ha selvstendig betydning ved «egentlige» øyeblikkelig hjelp situasjoner. Videre er utvalget av den oppfatning at pasienter som har uttrykt klart og konsekvent at de ikke ønsker behandling ved en forventet krise skal få sitt ønske respektert også om de har mistet samtykkekompetansen på det tidspunktet krisen og derved behovet for helsehjelp materialiserer seg, med mindre det klart fremgår at pasientens forhåndsønsker ikke lenger kan gjøres gjeldende. Et klart og konsekvent ønske kan fremkomme gjennom forhåndssamtaler eller på andre dokumenterbare måter, for eksempel et livstestament. Et klart og konsekvent ønske som er dokumenterbart bør derved være avgjørende og tre istedenfor den vur- 
deringen som ellers skal gjøres etter pasient- og brukerrettighetsloven $\S 4-6$ og helsepersonelloven $\S 7$ avhengig av om det foreligger en øyeblikkelig hjelp-situasjon eller ikke.

Utvalget mener at den foreslåtte tolkingsendringen er i samsvar med endringen i rettskildebildet, og behov som følger av den medisinsk teknologiske utviklingen. Helsepersonelloven $\S 7$ som hjemler helsepersonells inngrepsplikt, og pasientog brukerrettighetslovens $\S 4-1$ som hjemler pasientenes selvbestemmelsesrett, har stått uendret i innhold siden 2001. Det øvrige rettskildebildet, herunder rettspraksis fra EMD, har i samme periode hatt en klar utvikling i retning av å slå fast betydelig vekt på pasienters selvbestemmelsesrett på bekostning av helsepersonells inngrepsplikt. Videre synes EMD i dommen av 5. desember 2013 (Arskaya mot Ukraina) å skille tydelig mellom pasienter som har samtykkekompetanse fra pasienter som mangler samtykkekompetanse og ellers ikke har et klart uttrykt forhåndsønske basert på korrekt informasjon om sin helsemessige tilstand.

I norsk rett er betydningen av samtykkekompetanse nylig hensyntatt ved at manglende samtykkekompetanse nå er inntatt som et vilkår for å anvende tvang etter psykisk helsevernlov. Se endring til psykisk helsevernlov $\S 3-2$ første ledd nr. 3 av 10. februar $2017 \mathrm{nr}$. 6. Det samme vilkåret om manglende samtykkekompetanse følger av pasient- og brukerrettighetsloven kapittel 4 A ved bruk av tvang til pasienter som motsetter seg somatisk helsehjelp. Harmoni i lovverket tilsier at man ved anvendelse av helsepersonelloven $\S 7$ ikke kan se bort fra at pasienten er samtykkekompetent og nekter helsehjelp som i situasjonen er påtrengende nødvendig. Menneskerettighetenes plassering i Grunnloven i 2014, herunder Grunnloven $\S 102$, og som i tid kom etter høyesteretts dom i Rt. 2010 side 612, kan også sies å utgjøre en del av det endrede rettskildebildet i retning av økt vekt på å respektere pasienters selvbestemmelsesrett. Økt vekt på selvbestemmelse på bekostning av inngrepsplikten støttes også av reelle hensyn. Nye medisinskteknologiske løsninger gjør det mulig å holde i live pasienter lenger enn før, også når livet ikke lenger har nødvendig livskvali- tet for den enkelte pasient. Det gjør behovet for å kunne bestemme og planlegge siste fase av en sykdom i et behandlingsforløp økende, og det øker ikke bare behovet for å kunne respektere pasienters selvbestemmelsesrett, men også behovet for at et klart og konsekvent forhåndsønske skal respekteres. Vi ser at Danmark nå tar konsekvensene av den medisinske utviklingen ved å fremme lovendringsforslag for å øke selvbestemmelsen til pasienter i forhold til fravalg av behandling.

En tolkingsendring som foreslått vil også innebære at plikten til å yte øyeblikkelig hjelp blir mer i samsvar med eget opprinnelig formål uten å gå lengre enn nødvendig. Plikten til å yte øyeblikkelig hjelp bidrar til trygghet for at befolkningen får nødvendig helsehjelp i uventede situasjoner som krever livreddende innsats og innsats for å avverge alvorlig helseskade.

En tolkningsendring vil, i motsetning til en lovendring, ikke fremgå av lovteksten i helsepersonelloven $\S 7$. Utvalget foreslår derfor at man $\mathrm{i}$ grunnutdanning, i videre- og etterutdanning for leger og i utvalgte spesialistutdanninger tematiserer balansen mellom helsepersonells inngrepsplikt og pasientenes selvbestemmelsesrett. Videre mener utvalget at det vil være av stor betydning at avdelingsoverlegene ved avdelinger med pasienter som har behov for palliativ behandling, får særlig opplæring i de nevnte lovbestemmelsene.

\subsubsection{Tiltak}

- For å tydeliggjøre helsepersonells og helse- og omsorgstjenestenes plikt til å legge vekt på «barnets beste» som et grunnleggende hensyn ved alle avgjørelser som angår barn, bør denne forpliktelsen fremgå både av formålsbestemmelsen i pasient- og brukerrettighetsloven og av helsepersonelloven $\S 4$.

- For å sikre kompetanse blant behandlende leger om alvorlig syke pasienters selvbestemmelsesrett, bør undervisning i grunnutdanningen og i videre- og etterutdanningen innlemme dette temaet. 


\section{Kapittel 14 \\ $\emptyset$ konomiske og administrative konsekvenser}

\subsection{Innledning}

Utvalget vil i dette kapittelet gi en overordnet vurdering av de økonomiske og administrative konsekvensene av de viktigste tiltakene i NOUen. Utvalget har fått i mandat å utrede økonomiske, administrative og andre vesentlige konsekvenser av sine forslag. Minst ett av forslagene skal baseres på uendret ressursbruk.

Utfordringsbildet som beskrives, viser at det er behov for en systematisk styrking av kompetansen og implementering av et palliativt tilbud til pasienter og pårørende både i spesialisthelsetjenesten og i den kommunale helse- og omsorgstjenesten. Det er særlig behov for et kompetanse- og kapasitetsmessig løft i kommunene. Flere av forslagene medfører økte kostnader, men vil på sikt gi samfunnsmessig gevinst ved et bedre og mer fleksibelt samarbeid mellom 1 . og 2. linjetjenesten og en bedre utnyttelse av de samlede ressursene $i$ spesialisthelsetjenesten og $\mathrm{i}$ den kommunale helse- og omsorgstjenesten. Å prioritere palliasjon er ikke bare et verdivalg som vil bedre omsorgen for alvorlig syke og døende, det vil også kunne være med å balansere forventningene til effekter av øvrig helsetjeneste og slik bidra til bedre ressursutnyttelse.

\subsection{Uendret ressursbruk}

Enkelte av utvalgets forslag kan realiseres uten økt ressursbruk for kommuner og helseforetak. Samarbeidsavtaler om pasientforløp for palliasjon som en del av de avtalene sykehus og kommuner skal inngå, er et eksempel på dette. Det samme gjelder utvalgets forslag til lovendringer, blant annet en tydeliggjøring av palliasjon i helse- og omsorgstjenesteloven. Palliativ behandling følger i dag av kommunenes «sørge for-ansvar» i helseog omsorgstjenesteloven $\S 3$-2. En tydeliggjøring av kommunenes ansvar for palliasjon vil kunne bidra til at flere pasienter med palliative behov vil få palliative tjenester i kommunen. Strukturert, proaktiv palliasjon rettet mot funksjon hos pasienten kan bidra til forebygging av problemer og komplikasjoner (EU, 2014). Dette kan samlet sett være ressursbesparende for kommunen.

Utvalgets forslag vil samlet sett gi et løft for pasienter som har behov for palliative tjenester. Mange av forslagene er knyttet til økt kompetanse innen palliasjon både i den kommunale helse- og omsorgstjenesten og i spesialisthelsetjenesten, med en særlig innsats rettet mot palliasjon i kommunene. Bedre organisering på begge nivåer vil gi en bedre utnyttelse av de samlede ressursene.

Utarbeidelse av mal for pasientforløp må ses i sammenheng med Helsedirektoratets arbeid med nasjonale faglige retningslinjer og vil kunnes gjøres innenfor Helsedirektoratets gjeldende ramme. Det samme gjelder utarbeidelse av retningslinjer for å fremme frivillig arbeid innen palliasjon og revidering av den nasjonale faglige retningslinjen for palliasjon til barn og unge uavhengig av diagnose. Utarbeidelse av kvalitetsindikatorer innen palliasjon må sees i sammenheng med Helsedirektoratets arbeid med utvikling av kvalitetsindikatorer for helse- og omsorgstjenesten. Kvalitetsindikatorer kan innføres innenfor gjeldende systemer og økonomiske rammer.

Bruk av pasientsentrerte kartleggingsverktøy (Patient Reported Outcome Measures (PROMs) og Patients Reported Experience Measures (PREMS)) både for pasienters behov og for pårørendes omsorgsbyrde kan bidra til å forebygge sykdom hos pårørende og redusere risikoen for at pårørende selv kan få behov for helse- og omsorgtjenester.

\subsection{Forslag som omhandler den kommunale helse- og omsorgstjenesten}

Det kommunale tilbudet vil omfatte tilbud både i institusjon, $\mathrm{i}$ hjemmet og ambulant virksomhet $\mathrm{i}$ samarbeid med spesialisthelsetjenesten. Det stilles kapasitets-, kompetanse- og bemanningskrav 
til tilbudet, samt krav til samarbeidsavtaler og etablering av kommunale palliative team, og økte krav til forskning og undervisning.

Uavhengig av hvordan kommunen har organisert sitt palliative tilbud må tilbudet til alvorlig syke og pasienter i livets sluttfase være av god kvalitet, uavhengig av diagnose og alder. For å oppnå dette, må kapasiteten og den faglige kvaliteten styrkes. Dette krever en målrettet oppbygging av det palliative tilbudet i kommunene. Utvalget mener at en økt innsats innen palliasjon i kommunene er en forutsetning for å kunne løfte omsorgen til alvorlig syke og døende til et reelt godt tilbud som ivaretar både brukere og deres pårørende.

\section{Etablering av kommunale palliative sentre}

Utvalget foreslår at det etableres kommunale palliative sentre på sykehjem med en grunnstruktur som på lokalsykehus, men uten poliklinikk. Sentrene skal inneholde en tverrfaglig palliativ sengeenhet og et tverrfaglig kommunalt palliativt team som virker innad på sykehjemmet, mot andre sykehjem i kommunen og mot pasientens hjem. Sentrene skal være en kompetansebase for palliasjon i kommunen. Størrelsen på enheten med palliative senger vil variere ut fra kommunens størrelse og behovene i kommunen. Det er ikke anslått i hvilken grad forslaget vil utløse behov for flere legestillinger eller stillinger for annet helsepersonell i kommunene. Utvalget foreslår at det kommunale palliative teamet skal være tverrfaglig sammensatt på samme måte som i spesialisthelsetjenesten. Tverrfagligheten kan delvis imøtekommes ved å knytte til seg faggrupper som allerede er obligatoriske $\mathrm{i}$ den kommunale helse- og omsorgstjenesten. Samlet personellbehov på landsbasis er ikke beregnet. Utvalget legger til grunn at etablering av kommunale palliative team vil kreve en omstrukturering av dagens ressurser, i tillegg noe ressursøkning.

\section{Forskning og undervisning}

For å ivareta utvikling og implementering av pasienttilpassede forløp i den kommunale helse- og omsorgstjenesten, foreslår utvalget at det bør være palliative sentre i kommunene som kan drive forskning og utvikling, eller samarbeide med den sentrale FOU-enheten i kommunen. I helse- og omsorgstjenesteloven fra 2012 tydeliggjøres kommunenes ansvar for å medvirke til og tilrettelegge for forskning innen den kommunale helse- og omsorgstjenesten. I § 8-3 står det: «Kommunen skal medvirke til og tilrettelegge for forskning for den kommunale helse- og omsorgstjenesten». Målet er å stimulere til praksisnær forskning og bidra til at tjenestene sprer og tar i bruk ny kunnskap i møte med framtidige utfordringer.

Mange kommuner har ikke selv kompetanse og kapasitet til å gjennomføre forskningsprosjekter. Samarbeid med etablerte forskningsinstitusjoner, regional høgskole/ universitet eller et nasjonalt eller regionalt kompetansesenter er ofte en forutsetning for egen forskning, men kan også være en fordel i arbeidet når en skal medvirke til og tilrettelegge for forskning. Aktuelle samarbeidspartnere kan være høgskole eller universitet, helseforetak, forsknings- og kompetansesentre, utviklingssentrene for sykehjem og hjemmetjenester og instituttsektoren (Senter for omsorgsforskning Sør og Senter for omsorgsforskning Vest, 2014). Samlede kostnader på landsbasis er ikke beregnet. Utvalget forutsetter at forskning knyttet til det kommunale palliative senteret gjøres innenfor kommunenes eksisterende økonomiske rammer. Forskning er i stor grad eksternt finansiert, det vil si at det konkurreres om forskningsmidler fra nasjonale eller internasjonale kilder. For å kunne skrive gode søknader, blant annet for å kunne få EU-midler, kreves det kompetanse, tid og forskningssamarbeid. Dette kan i stor grad innhentes fra universiteter og høyskoler.

\subsection{Forslag som omhandler spesialisthelsetjenesten}

Videreutvikling av den eksisterende palliative modellen

Forslag til organisatoriske tiltak i spesialisthelsetjenesten bygger på modellen i Nasjonalt handlingsprogram for palliasjon i kreftomsorgen (Helsedirektoratet, 2015b). Utvalget foreslår en videreutvikling av denne modellen ved at større lokalsykehus skal ha fullverdige palliative sentre med palliativt team og sengeenhet, minimum et palliativt team på mindre sykehus. Videre foreslår utvalget følgende kliniske oppgaver lagt til det regionale palliative senteret: sengeenhet, palliativt team og poliklinikk. De regionale kompetansesentrene har allerede i dag forsknings- og utviklingsoppgaver. I tillegg til disse foreslår utvalget at kompetansesentrene fordeler spisskompetanseoppgaver seg i mellom. Utvalget foreslår også hvordan det regionale palliative senteret skal organisere og ledes. Noen av disse organisatoriske endringene kan dekkes innenfor de eksisterende rammer i helse- 
foretakene. Utvalget foreslår at de regionale palliative kompetansesentrene skal få mer omfattende oppgaver enn i dag ved at palliasjon skal gis til flere diagnosegrupper, de vil måtte bidra enda mer til kompetanseheving, de vil få en bredere forskningsportefølje, og de vil få større oppgaver rettet mot den kommunale helse- og omsorgstjenesten. Utvalget legger til grunn at disse økte oppgavene vil kreve en ressursøkning.

\section{Tilleggsrefusjon ved palliativ behandling}

Dagens tilleggsrefusjon ved organisert palliativ behandling i spesialisthelsetjenesten har bidratt til oppbyggingen av det pallitive kliniske tilbudet $\mathrm{i}$ spesialisthelsetjenesten. Utvalget forutsetter at dagens ordning med tilleggsrefusjon for palliativ behandling videreføres på minst samme nivå.

Den palliative tilleggsrefusjonen er i hovedsak rettet inn mot pasienter i spesialisthelsetjenesten, men kan også benyttes dersom det palliative teamet i spesialisthelsetjenesten tilbyr ambulant behandling i pasienetens hjem. Utvalget ønsker å styrke de palliative teamenes rådgivende funksjon overfor den kommunale helse- og omsorgstjenesten. Denne virksomheten dekkes ikke av den palliative tilleggsrefusjonen i dag. Utvalget er kjent med at det er foreslătt en endring $i$ finansiering av palliasjon i spesialisthelsetjenesten fra 2018.

\subsection{Utdanning}

Videreutdanning i palliasjon på masternivå

Utvalget foreslår en utvidelse til masterløp for de mest aktuelle videreutdanningene. Utvalget legger til grunn at det vil være behov for en viss ressursøkning til videreutdanning innen palliasjon.

\section{Palliativ medisin som egen påbyggingsspesialitet}

Dette tiltaket henger sammen med at det vil være behov for flere leger med spesialistkompetanse i palliativ medisin. For å nå dette målet må det etableres en ny spesialistutdanning i palliativ medisin, samt opprettes flere utdanningsstillinger. Dette vil kreve flere ressurser. På den annen side vil økt legekompetanse i klinisk praksis kunne bedre effektiviteten og kvaliteten på de kliniske tjenester i et samfunnsøkonomisk perspektiv og på den måten være ressursbesparende. Utvalget har ikke foretatt en beregning av de økonomiske konsekvensene av dette tiltaket.
Opprette kliniske utdanningsstillinger for påbyggingsspesialiteten palliativ medisin

Utvalget anslår at det i en startfase vil være behov for omlag 40 nye utdanningsstillinger. Ansatte i disse stillingene vil være i utdanning under spesialiseringen og samtidig gjøre en klinisk jobb. Det er utgifter knyttet til å etablere utdanningsstillinger, men stillingene gir også inntekt siden utdanningskandidaten behandler pasienter og deltar i det kliniske arbeidet og gir bistand til de kommunale helse- og omsorgstjenestene. Dette er med på å øke kvaliteten på tilbudet til pasienter med behov for palliasjon, redusere reinnleggelser og gi en bedre rekruttering til faget. Utvalget har ikke foretatt beregninger av de økonomiske konsekvensene av dette tiltaket.

Opprette LIS stillinger for utdanning innen palliativ medisin for relevante spesialiteter

For å nå målet om mer palliativ medisinsk utdanning i relevante spesialiteter, mener utvalget at de regionale kompetansesentrene, sammen med Helsedirektoratet, helseforetak og eventuelt andre bør utvikle et kurstilbud som del av de forskjellige spesialistutdanningen. Med unntak av kapasitetsøkning i de regionale kompetansesentrene og i de akademiske institusjonene for å bidra til dette, vil dette tilbudet ikke føre til store økte kostnader.

LIS-stillingene vil delvis kunne være en del av de eksisterende LIS-stillingene ved at legene får 6 måneders tjeneste i sin LIS-tid på en palliativ enhet. Dette kan delvis kompenseres ved interne omprioriteringer. Utvalget mener at for å få til det nødvendige kompetanseløftet innen palliasjon, må det også opprettes nye LIS-stillinger i palliasjon. Økonomiske konsekvenser av å opprette LIS-stillinger for relevante spesialiteter er ikke beregnet. Det er vanskelig å forutse hvor mange utdanningsstillinger som vil bli etablert, men utvalget legger til grunn at en økning av et visst omfang vil kreve en ressursøkning.

\subsection{Forskning}

\section{Forskningsprogram om palliasjon}

Forskning er avgjørende for å bygge opp solid kunnskap, og for å bringe faget videre. Palliasjon er et relativt nytt felt innen forskning. Mesteparten av eksisterende kunnskap har blitt utviklet ganske nylig, og er fortsatt begrenset på flere måter. Sammenlignet med studier av forebygging og helbredelse av livsbegrensende sykdommer 
som kreft, kols, hjertesvikt eller nevrodegenerative sykdommer, har de tilgjengelige økonomiske ressursene for å studere palliasjon vært svært begrensede.

Optimal integrering av evidensbaserte palliative tjenester for alle mennesker som lider av kroniske og livsbegrensende sykdommer, vil kun være mulig dersom nasjonale og internasjonale finansieringskilder inkluderer forskning på palliasjon som en av sine prioriteringer. Disse prioriteringene bør omfatte både observasjonelle- og intervensjonsstudier som er store nok og kan være tilstrekkelig konklusive for å bedre klinisk praksis. Det er nødvendig med forskning innenfor flere store sykdomsgrupper. Det er også nødvendig med forskning for å utvikle palliative helsetjenester både i spesialisthelsetjenesten og i den kommunale helse- og omsorgstjenesten. Forskning på palliative populasjoner innebærer mange metodiske utfordringer og etiske problemstillinger. Det betyr at slike studier ofte er krevende i form av grundige forberedelser og komplekse evalueringer.

Behovet for frivillighet innen palliasjon i framtiden er stort, og det er behov for å skape langsiktige og forutsigbare rammevilkår for frivillig sektor. Det må samles kunnskap om frivillighet innen palliasjon og det må identifiseres samarbeidsområder og prinsipper for samarbeid. Utvalget mener frivillige organisasjoners rolle på palliasjonsfeltet bør utvikles i et nært samarbeid med den kommunale helse- og omsorgstjenesten.

Utvalget foreslår et det opprettes et eget 10årig forskningsprogram i Forskningsrådet til palliativ forskning for å støtte kliniske studier innen palliasjon med særskilt vekt på pasientens siste leveår og hvordan palliasjon kan integreres i helsetjenesten i alle deler av pasientforløpene, også under livsforlengende behandling. Et sentralt tiltak her er å støtte etablering av ett eller flere sentre innen palliativ fremragende forskning (SFF). Forskningsprogrammet skal bidra til palliativ forskning i den kommunale helse- og omsorgstjenesten og i spesialisthelsetjenesten, og det skal legges særskilt vekt på tverrfaglighet.

Utvalget foreslår at det settes av midler i størrelsesorden 100-120 mill. kroner per år over 10 år til et slikt forskningsprogram, en økonomisk ramme som er på linje med andre etablerte forskningsprogrammer i Forskningsrådet av tilsvarende varighet.

\section{Kvalitetsregistre innen palliasjon}

Utvalget foreslår å opprette egne diagnosespesifikke kliniske kvalitetsregistre innen palliasjon, herunder et eget register for barn. Det foreslås videre å opprette et eget register som kan brukes for å kvalitetssikre pasienters siste levemåneder. Økonomiske konsekvenser av å opprette de foreslåtte kvalitetsregistre er ikke beregnet. Utvalget legger til grunn at etablering og drift av kvalitetsregistre vil kreve ressursøkning.

\section{Evaluering av hjemmesykehus for barn}

Det er etablert en modell med hjemmesykehus for barn enkelte steder. Utvalget har ikke tatt stilling til om hjemmesykehus for barn er en ønsket modell, men foreslår at det igangsettes en ekstern evaluering for å innhente erfaringer med palliativt hjemmesykehus ved Oslo universitetssykehus, Akershus universitetssykehus og Stavanger universitetssykehus. Utvalget mener denne evalueringen kan finansieres gjennom forskningsmidlene til de regionale helseforetakene.

\subsection{Barn og unge}

Barn og unge med behov for palliasjon skal få mulighet til å være mest mulig hjemme og leve et så normalt liv som mulig. Utvalget foreslår at spesialisthelsetjenesten og den kommunale helse- og omsorgstjenesten legger til rette for dette, slik at opphold på sykehus eller en annen institusjon reduseres til et nødvendig minimum. Utvalget foreslår at det etableres barnepalliative sentre både regionalt og lokalt, med integrasjon av palliasjon og palliative team/ kompetanse på barneavdelinger både regionalt og lokalt, samt palliative team i kommunene. De palliative teamene på sykehusene både regionalt og lokalt må sannsynligvis ta et større ansvar for tiltak til barn med behov for palliasjon som bor hjemme. Utvalget har ikke beregnet kostnader ved etablering av barnepalliative team, men legger til grunn at en utvidelse av tilbudet av noe omfang vil kreve ressursøkning. 


\section{Kapittel 15 \\ Oversikt over tiltak}

\begin{tabular}{|c|c|}
\hline Kapittel & Tiltak \\
\hline & $\begin{array}{l}\text { - Alle sykehus skal ha en plan for å forebygge overbehandling mot livets slutt. Planen } \\
\text { bør være en del av de pasienttilpassede forløpene. } \\
\text { - } \quad \text { Det etableres nasjonale indikatorer for å fange opp overbehandling mot livets slutt. } \\
\text { - } \quad \text { Det utvikles en nasjonal metodikk for forhåndssamtaler. Forhåndssamtalene skal } \\
\text { være en obligatorisk del av av de pasienttilpassede forløpene. }\end{array}$ \\
\hline $\begin{array}{l}\text { Pasienttilpas- } \\
\text { sede forløp }\end{array}$ & $\begin{array}{l}\text { - Det skal være samarbeidsavtaler mellom kommuner og sykehus om felles utvikling } \\
\text { og bruk av pasienttilpassede forløp innen palliasjon. } \\
\text { - } \quad \text { For å få utløst palliativ refusjon i spesialisthelsetjenesten stilles det krav om at palliativ } \\
\text { team skal veilede den kommunale helse- og omsorgstjenesten om felles pasienter. } \\
\text { - } \quad \text { Det utarbeides en nasjonal mal for palliativt pasientforløp som omfatter både spesia- } \\
\text { listhelsetjenesten og den kommunale helse- og omsorgstjenesten. } \\
\text { - For å tydeliggjøre kommunens «sørge for» ansvar for palliativ behandling bør denne } \\
\text { forpliktelsen framgå av helse- og omsorgstjenesteloven (hol) paragraf 3-2 første ledd } \\
\text { nr. } 5 \text { ved at begrepet palliasjon inntas i lovteksten. } \\
\text { - Pasienter skal delta i utarbeidelse av pasienttilpassede forløp, blant annet gjennom } \\
\text { bruk av forhåndssamtaler. } \\
\text { - Det skal igangsettes en nasjonal evaluering av pasientforløpet Livets siste dager. }\end{array}$ \\
\hline $\begin{array}{l}\text { Palliasjon i } \\
\text { utdanningene }\end{array}$ & $\begin{array}{l}\text { - Palliativ medisin etableres som en egen påbyggingsspesialitet. } \\
\text { - Det opprettes kliniske utdanningsstillinger for påbyggingsspesialiteten palliativ medi- } \\
\text { sin. } \\
\text { - Det opprettes LIS stillinger for utdanning innen palliativ medisin for relevante spesia- } \\
\text { liteter. } \\
\text { - Videreutdanning i palliasjon på masternivå for relevante helsefagprofesjoner utvides } \\
\text { og formaliseres. } \\
\text { - Bør tilsvare } 60 \text { studiepoeng, ha minimum } 6 \text { ukers veiledet praksis og harmonise- } \\
\text { res i innhold } \\
\text { - Innholdet bør følge internasjonale anbefalinger (f.eks. EAPCs White Paper, 2013) } \\
\text { - Utdanningene kan være monofaglige og/eller tverrfaglige } \\
\text { - Videreutdanningene bør være på masternivå } \\
\text { - Det anbefales masterprogram som kvalifiserer for videre PhD-program }\end{array}$ \\
\hline
\end{tabular}




\begin{tabular}{ll}
\hline Kapittel & Tiltak \\
\hline Forskning & $-\quad$ Det opprettes et eget forskningsprogram i Forskningsrådet for palliativ forskning for \\
& å støtte store, gode kliniske studier innen palliasjon. \\
- & De regionale helseforetakene skal styrke den regionale palliative forskningen ved å \\
& bygge opp og støtte lokale og regionale palliative forskningsgrupper som skal ha \\
& nasjonale og internasjonale samarbeidspartnere. \\
- & Det etableres en nasjonal finansiering for palliative sentre for fremragende forskning. \\
- & De regionale palliative sentrene får likelydende oppdrag om forskningsoppgaver fra \\
& Helse- og omsorgsdepartementet via de regionale helseforetakene, og det rapporte- \\
& res årlig (se kapittel 9). \\
- & Det opprettes egne diagnosespesifikke kliniske kvalitetsregistre innen palliasjon, her- \\
& under et eget register for barn.
\end{tabular}

Organisering, - Det etableres kommunale palliative sentre i de største kommunene og som interkomstruktur og munale sentre i mindre kommuner.

kompetanse - Alle større lokalsykehus skal ha et fullverdig palliativt senter. Mindre lokalsykehus skal som et minimum ha palliativt team.

- Regionale palliative sentre skal, i tillegg til et kompetansesenter, ha tre kliniske hovedaktiviteter: Palliativ sengeenhet, palliativt team og palliativ poliklinikk.

- Regionale palliative sentre med en klinisk del og et kompetansesenter, skal organiseres som en enhet under en ledelse.

- Kompetansesenterdelen i de regionale palliative sentrene skal være atskilt fra den kliniske virksomheten og dekke de fire hovedoppgavene: Undervisning, utarbeidelse og implementering av de pasienttilpassede forløpene, drift av nettverk og forskning - for hele regionen.

- Det nasjonale nettverket av de regionale palliative kompetansesentrene skal fordele regionale spisskompetanseområder seg imellom. Kompetansesentrene rapporterer i linjen til RHF-ene og samlet rapportering vurderes årlig av de regionale fagdirektørene.

- Det etableres barnepalliative sentre ved alle regionsykehus i Norge med samme struktur som ved palliativt senter i sykehus.

- Det etableres barnepalliative sentre på sykehus.

- Erfaringer med palliative hjemmesykehus for barn ved Oslo universitetssykehus, Akershus universitetssykehus og Stavanger universitetssjukehus skal evalueres.

- Den nasjonale faglige retningslinjen for palliasjon til barn og unge uavhengig av diagnose revideres for å gi tydeligere føringer for integrasjon av palliasjon i pediatrien og for organisering av palliative tjenester til barn og unge i den kommunale helse- og omsorgstjenesten og i spesialisthelsetjenesten.

- De regionale kompetansesentrene får i oppgave å etablere et interregionalt samarbeid for den døende pasient med hovedansvar hos et av sentrene. Det etableres også tilsvarende hovedansvar i minst ett palliativt senter på sykehus i hver helseregion.

- Det utarbeides kvalitetsindikatorer innen palliasjon.

- Palliative pasienttilpassede forløp inkluderes i alle relevante nasjonale faglige retningslinjer, også for andre sykdomsgrupper enn kreft.

Pårørende 1. The Carer Support Needs Assessment Tool, CSNAT, skal implementeres i de pasienttilpassede forløpene.

2. Pleiepengeordningen utvides slik at voksne kan beholde dem under innleggelse av pasient i sykehus.

Frivillige _ - Det utvikles retningslinjer for å fremme frivillig innsats og samarbeid mellom kommunen, spesialisthelsetjenesten og frivillige på palliasjonsfeltet. 
NOU 2017: 16

Kapittel Tiltak

Balansen mel- - For å tydeliggjøre helsepersonells og helse- og omsorgstjenestens plikt til å legge vekt lom helsepersonells innpå «barnets beste» som et grunnleggende hensyn ved alle avgjørelser som angår grepsplikt og pasientenes selvbestembarn, bør denne forpliktelsen fremgå både av formålsbestemmelsen i pasient- og brukerrettighetsloven og av helsepersonelloven $\S 4$.

- For å sikre kompetanse blant behandlende leger om alvorlig syke pasienters selvbemelsesrett stemmelsesrett, bør undervisning i grunnutdanningen og i videre og etterutdanningen innlemme dette temaet. 


\section{Litteraturliste}

Advance care planning. Hentet fra www.advancecareplanning.org.nz/

Andreson, m.fl., 2015. I Organisering og ledelse av uorganiserte frivillige $i$ helse- og omsorgstjenestene $i$ norske kommuner. Rapport fra RO. Hentet fra http://ro.no/wp-content/uploads/ 2015/04/rapport_organisering_ledelse_uorganiserte_frivillige_helse.pdf

Arbeids- og velferdsdirektoratet. 2017. Pleiepenger noer pårorende (FTL §9-12). Innhentet statistikk fra Statistikkseksjonen, Kunnskapsavdelingen NAV, november 2017.

Arskaya mot Ukraina. EMDs dom av 5. desember 2013. Hentet fra https://hudoc.echr.coe.int/ app/conversion/pdf/

Bahus, M., Førde, R., Steen, P. A. 2012. Law, ethics and clinical judgment in end-of-life decisions How do Norwegian doctors think? Resuscitation, 83: 1369-1373. Hentet fra https:// www.ncbi.nlm.nih.gov/pubmed/22542767

Bahus, M. 2014. Beslutningsprosessen ved liv/dødavgjørelser. Doktoravhandling. Oslo: Universitetet i Oslo.

Bahus, M. og Førde, R. 2014. Når pasienter nekter blodoverføring. Tidsskrift for Den norske legeforening, 2014; 850-851.

Barnelova. 1981. Lov om barn og foreldre av 8. april $1981 \mathrm{nr}$. 7. Hentet fra https://lovdata.no/dokument/NL/lov/1981-04-08-7?q=barnelova

Barnevernloven. 1992. Lov om barneverntjenester av 17. juli $1992 n$ r. 100. Hentet fra https://lovdata.no/dokument/NL/lov/1992-07-17-100

BarnsBeste, Nasjonalt kompetansenettverk for barn som pårørende. 2017. Sørlandet sykehus. Hentet fra https://sshf.no/helsefaglig/kompetansetjenester/barnsbeste/

Basch, E., Deal, A.M. m.fl. 2017. Overall Survival Results of a Trial Assessing Patient-Reported Outcomes for Symptom Monitoring During Routine Cancer Treatment. JAMA. 2017; 318 (2): 197-198.

Befring, A. K., Ohnstad, B. 2010. Helsepersonelloven med kommentarer. Fagbokforlaget.

Birkestrand, T., Otterstad, H. K. 2010. Samhandlingsreformen. Store forskjeller $i$ eldres bruk av sykehus. Sykepleien. 30.11.2010. Hentet fra https://sykepleien.no/en/node/4625

Blix, B.H. 2016. Helse- og omsorgstjenester til den samiske befolkningen $i$ Norge, Omsorgsbiblioteket. Hentet fra http://www.helsebiblioteket.no/omsorgsbiblioteket/samisk-befolkning Brattheim, B. J., Hellesø, R. m.fl. 2017. Elektronisk meldingsutveksling ved utskriving av pasienter fra sykehus til kommune. 27.6.2017. Sykepleien. Hentet fra https://sykepleien.no/forskning/ 2016/02/elektronisk-meldingsutveksling-vedutskriving-av-pasienter-fra-sykehus

Dahlberg, J., Dahl, V. 2015. Sultestreikende asylsøker - hvor langt går pasientens rett til å nekte behandling? Tidsskrift for Den norske legeforening, 2015; 45-47. Hentet fra http://tidsskriftet.no/2015/01/helse-og-jus/sultestreikende-asylsoker-hvor-langt-gar-pasientensrett-til-nekte-behandling

Den europeiske menneskerettighetskonvensjon (EMK) av 4. november 1950.

Departementene. 2016. Regjeringens strategi for ungdomshelse 2016-2021. Hentet fra https:// www.regjeringen.no/contentassets/ 838b18a31b0e4b31bbfa61336560f269/ungdomshelsestrategi_2016.pdf

Direktoratet for e-helse. Nasjonal e-helsestrategi og handlingsplan 2017-2022. Hentet fra www.ehelse.no

Dødsårsaksregisteret. 2017. Hentet fra www.fhi.no

Edmonton Symptom Assessment system (ESAS). Hentet fra www.helsebiblioteket.no

Eide, K., Rugkåsa, M. m.fl. 2009: Over profesjonelle barrierer. Et minoritetsperspektiv $i$ psykososialt arbeid med barn og unge. Gyldendal akademisk.

El-Jawahri, A., Jackson, V. A. m.fl. 2016. Effect of early integrated palliative care on family caregivers $(F C)$ outcomes for patients with gastrointestinal and lung cancer. Journal of Clinical Oncology, 34, no. 26_suppl (October 2016) 234234. Hentet fra http://ascopubs.org/doi/ 10.1200/jco.2016.34.26_suppl.234. 
EU. 2014. EU-erklæring om Palliasjon, 2014. http://palliativecare2020.eu/declaration/ no.php

Europarådet. 1997. Explanatory Report to the Convention for the protection of Human Rights and Dignity of the Human Being with regard to the Application of Biology and Medicine: Convention on Human Rights and Biomedicine. Hentet fra https://rm.coe.int/16800ccde5

Europarådets konvensjon om menneskerettigheter og biomedisin (Oviedo-konvensjonen) av 4 april 1997. European Association for Palliative Care. 2017. Definition and recommendations for advance care planning: an international consensus supported by the European Association for Palliative Care. Lancet Oncol 2017; 18(9):e543e551.

European Association for Palliative Care. 2006. Standards for paediatric palliative care in Europe. Hentet fra www.eapc.eu

European Association for Palliative Care. 2009. White Paper on standards and norms for hospice and palliative care in Europe: part 1. 16 (6). Hentet fra http://www.eapcnet.eu/ LinkClick.aspx?fileticket=f63pXXzVNEY\%3D\&tabid=735

European Association for Palliative Care. 2013. Core Competences for education in Paediatric Palliativ Care. Hentet fra http://www.eapcnet.eu/LinkClick.aspx?fileticket=6elzOURzUAY\%3d\&tabid=1432

European Association for Palliative Care. 2014. White paper defining optimal palliative care in older people with dementia: A Delphi study and recommendations from the European Association for palliative care.

European Association for Palliative Care. 2016. Defining volunteering in hospice and palliative care in Europe.

European Association for Palliative Care. 2017. White paper on advance care planning.

European Pathway Association. 2017. Hentet fra http://e-p-a.org/care-pathways /

Ewing, G., Grande, G. 2013. Development of a $\mathrm{Ca}$ rer Support Needs Assessment Tool (CSNAT) for end-of-life care practice at home: a qualitative study. Palliat Med. 2013 Mar;27(3):244-56. Hentet fra https://www.ncbi.nlm.nih.gov/pubmed $/ 22450160$

Fastlegeforskriften. 2012. Forskrift om fastlegeordning $i$ kommunene. Hentet fra https://lovdata.no/dokument/SF/forskrift/2012-08-29842

Fearon, K., Strasser, F., Anker, S. D., Bosaeus, I., Bruera, E., Fainsinger, R. L., m.fl. 2011. Defini- tion and classification of cancer cachexia: $A n$ international consensus. Lancet Oncol;12:489495. Hentet fra https:// www.ncbi.nlm.nih.gov/pubmed/21296615

Finsk pasientrettighetslov. Lag om patientens ställning och rättigheter. Hentet fra http://www.finlex.fi/sv/laki/ajantasa/1992/19920785

FNs konvensjon om barnets rettigheter (barnekonvensjonen) av 20. november 1989. Hentet fra https://www.regjeringen.no/no/dokumenter/fns-barnekonvensjon/id88078/

FNs konvension om sivile og politiske rettigheter (SP) av 16. desember 1966. Hentet fra www.fn.no >Om-FN > Avtaler > Menneskerettigheter

Folkehelseinstituttet. (2016). Halvparten av oss dør $i$ sykehjem.Hentet fra https://www.fhi.no/ nyheter/2016/halvparten-av-oss-dor-i-sykehjem/Folkehelseinstituttet

Foreningen for barnepalliasjon. 2017. Hentet fra https://barnepalliasjon.no/ventesorg-om-avente-pa-doden /

Forskrift om habilitering og rehabilitering, individuell plan og koordinator. 2011. Hentet fra www.lovdata.no

Forskrift om kommunal betaling for utskrivningsklare pasienter 2012. Hentet fra https:// lovdata.no/forskrift/2011-11-18-1115

Forvaltningsloven. 1967. Lov om behandlingsmåten i forvaltningssaker (forvaltningsloven).

Hentet fra https://lovdata.no/dokument/NL/ lov/1967-02-10

Fransiskushjelpen. www.fransiskushjelpen.no

Fremstedal, R. 2008. Håp belyst ut fra Kant og Kirkegaard. Omsorg - Nordisk tidsskrift for palliativ medisin. 2008. Nr. 3/2008.

Friis, P., Førde R. 2015. Forhåndssamtaler med geriatriske pasienter. Tidsskr Nor Legeforen 2015, 135:233-5.

Friis, P., Førde, R. 2017. Forhåndssamtaler $=a d-$ vance care planning. Tidsskr Nor Legeforen $2017 ; 137: 462$.

Gaertner, J. m.fl. 2017. Effect of specialist palliative care services on quality of life in adults with advanced incurable illness in hospital, hospice, or community settings: systematic review and meta-analysis. BMJ. 2017 Jul 4;357:j2925. doi: 10.1136/bmj.j2925. Hentet fra https:// www.ncbi.nlm.nih.gov/pubmed/28676557

Gawande, A. 2016. A vore dødelig. Om legekunst og livskvalitet. Nordli

Gilbert, M. 2016. Til deg som er pårorende, Kreftforeningen. Hentet fra https://kreftforeningen.no/globalassets/brosjyrer/parorende/tildeg-som-er-parorende-juli16-w.pdf 
Gjerberg, E., Lillemoen, L., Weaver, K., Pedersen, R., Førde, R., 2017. Advance care planning in Norwegian nursing homes. Tidsskr Nor Legeforen; $137(6): 447-450$.

Goldman, A., Hain, R., Lieben, R. 2016. Grunnbok $i$ barnepalliasjon. Kommuneforlaget.

Gran, S. V., Grov, E. K. m.fl. 2013. Smertekartlegging og medikamentell smertebehandling av eldre pasienter $i$ sykehjem. Sykepleien forskning. Hentet fra https://brage.bibsys.no/xmlui/bitstream/handle/11250/142425/VitenskapeligGran2013.pdf?sequence $=1 \&$ isAllowed $=\mathrm{y}$

Grov, E. K. 2010. Pårørende. Reitan A. M. \& Schjølberg T. K. (Red.). Kreftsykepleie: Pasient - Utfordring - Handling (3. utg.). Oslo: Akribe Forlag.

Haas mot Sveits, EMDs dom av 20. januar 2011.

Hadorn, D. C., Baker, D., Hodges J. S., Hicks N. 1996. Rating the quality of evidence for clinical practice guidelines. J Clin Epidemiol 1996;49:749 54 . Hentet fra https:// www.ncbi.nlm.nih.gov/pubmed/8691224

Helse Bergen HF. 2016. Hentet fra www.helse-bergen.no

Helse Bergen HF. 2017. Livets siste dagar - plan for lindring $i$ livets sluttfase. Hentet fra www.helse-bergen.no

Helsedirektoratet. 2010. Barn som pårørende. Rundskriv IS-5/2010. Hentet fra https://helsedirektoratet.no/publikasjoner/barn-som-parorende

Helsedirektoratet 2011a. Handlingsplan for forebygging og behandling av kronisk nyresykdom (2011-2015). IS-1884.

Helsedirektoratet 2011b. Nasjonal faglig retningslinje for utredning, behandling og oppfolging av personer med samtidig ruslidelse og psykisk lidelse - ROP-lidelser. Sammensatte tjenester samtidig behandling.

Helsedirektoratet 2012. Kols: nasjonal faglig retningslinje og veileder for forebygging, diagnostisering og oppfølging. IS - 2029. Hentet fra www.helsedirekoratet.no/publikasjoner/

Helsedirektoratet 2012a. Velferdsteknologi. Fagrapport om implementering av velferdsteknologi $i$ de kommunale helse- og omsorgstjenestene 2013-2030.

Helsedirektoratet. 2013. Beslutningsprosesser ved begrensning av livsforlengende behandling. IS 2091. https://helsedirektoratet.no/Lists/ Publikasjoner/Attachments/67/IS-2091-Beslutningsprosesser-ved-begrensning-av-livsforlengende-behandling.pdf

Helsedirektoratet. 2015. Samlet rapport for Omsorgsplan 2015. Oppsummering og vurdering av resultater for hele planperioden 2007-2015. IS-2605.

Helsedirektoratet. 2015a. Rapport om tilbudet til personer med behov for lindrende behandling og omsorg mot livets slutt - å skape liv til dagene. IS-2278. Hentet fra https://helsedirektoratet.no/Lists/Publikasjoner/Attachments/892/ Rapport_lindrende\%20behand-

ling\%20og\%20omsorg\%20ved\%20livets\%20slutt_IS-2278.pdf

Helsedirektoratet. 2015b. Nasjonalt handlingsprogram for palliasjon $i$ kreftomsorgen, IS-2285. Hentet fra https://helsedirektoratet.no/Lists/ Publikasjoner/Attachments/918/Nasjonalt\%20handlingsprogram\%20for\%20palliasjon\%20i\%20kreftomsorgen-IS-2285.pdf

Helsedirektoratet. 2015c. Organisering og drift av tverrfaglige smerteklinikker. Veileder IS-2190. Hentet fra https://helsedirektoratet.no/Lists/ Publikasjoner/Attachments/873/Veileder-Organisering-og-drift-av-tverrfaglige-smerteklinikker-IS-2190.pdf

Helsedirektoratet. 2015d. Forsøksordningen kompetanseområde palliativ medisin. Rapport IS2279. Hentet fra https://helsedirektoratet.no/ Lists/Publikasjoner/Attachments/804/Prosjektrapport $\% 20 \mathrm{Fors} \% \mathrm{C} 3 \% \mathrm{~B} 8 \mathrm{ksordning}$-Kompetanseomr\%C3\%A5de-\%20palliativ-\%20medisin-IS-2279.pdf

Helsedirektoratet. 2015e. Barn som pårorende Resultater fra en multisenterstudie, IS-0522. Hentet fra https://helsedirektoratet.no/publikasjoner/barn-som-parorende-resultater-fraen-multisenterstudie

Helsedirektoratet. 2016. Nøkkeltall for helse- og omsorgssektoren. Hentet fra https://helsedirektoratet.no/Lists/Publikasjoner/Attachments/1177/Nøkkeltall\%202016\%20IS2464.pdf

Helsedirektoratet. 2016b. Palliativ medisin som kompetanseområde. Hentet fra https://helsedirektoratet.no/autorisasjon-utdanning-og-godkjenning/palliativ-medisin-som-kompetanseomrade-

Helsedirektoratet. 2017. Nasjonal faglig retningslinje for palliasjon til barn og unge uavhengig av diagnose. IS 2599. Hentet fra https://helsedirektoratet.no/Retningslinjer/Palliasjon\%20til\%20barn\%20og\%20unge.pdf

Helsedirektoratet 2017a. Veileder om rehabilitering, habilitering, individuell plan og koordinator, IS-2651. Hentet fra https://helsedirektoratet.no/Retningslinjer/Rehabilitering,\%20habilitering,\%20individuell\%20plan\%20og\%20koordinator.pdf 
Helsedirektoratet, 2017b. Veileder om kommunens oppfølging av pasienter og brukere med store og sammensatte behov. Hentet fra https://helsedirektoratet.no/Retningslinjer/Kommunens\%20oppf\%C3\%B8lging\%20av\%20pasienter\% $20 \mathrm{og} \% 20 \mathrm{bru}-$

kere $\% 20$ med $\% 20$ store $\% 20$ og\%20sammensatte\%20behov.pdf

Helsedirektoratet. 2017c. Veileder om pårorende $i$ helse- og omsorgstjenesten. IS-2587. Hentet fra

https://helsedirektoratet.no/Retningslinjer/Pårørendeveileder.pdf

Helsedirektoratet. 2017d. Innsatsstyrt finansiering. IS-2568. Hentet fra https://helsedirektoratet.no/Lists/Publikasjoner/Attachments/ $1265 /$ Innsatsstyrt $\% 20$ finansiering $\% 202017 \% 20$ IS-2568.pdf

Helsedirektoratet. 2017e. Utviklingssenter for sykehjem og hjemmetjenester. Hentet fra https:// helsedirektoratet.no/tilskudd/utviklingssenter-for-sykehjem-og-hjemmetjenester\#mål-forordningen

Helse Midt-Norge RHF 2017. Årsrapport 2016. Hentet fra https://stolav.no/Documents/ Kreftklinikken/KLB_Aarsrapport2016_FINAL.pdf

Helse Nord RHF 2017. Årsrapport fra Lindring i Nord fås ved kontakt til dette kompetansesenteret.

Helsenorge.no. Hentet fra www.helsenorge.no/ rettigheter/samvalg

Helse- og omsorgsdepartementet. 2010. Veileder til Forskrift om godkjenning av sykehus, bruk av betegnelsen universitetssykehus og nasjonale tjenester $i$ spesialisthelsetjenesten, 2010. Hentet fra https://www.regjeringen.no/globalassets/ upload/hod/sykehus/nasjonaletjenester/veileder_nasjonale_tjenester_mai_2014.pdf?id=2171971

Helse- og omsorgsdepartementet. 2013. Likeverdige helse- og omsorgstjenester for alle. Nasjonal strategi om innvandreres helse 2013-2017.

Helse- og omsorgsdepartementet. 2013. NCD-strategi 2013-2017. For forebygging, diagnostisering, behandling og rehabilitering av fire ikkesmittsomme folkesykdommer; hjerte- og karsykdommer, diabetes, KOLS og kreft. Hentet fra https://www.regjeringen.no/contentassets/ e62aa5018afa4557ac5e9f5e7800891f/ncd_strategi_060913.pdf

Helse- og omsorgsdepartementet. 2013a. Sammen mot kreft. Nasjonal kreftstrategi 2013-2017.

Helse- og omsorgsdepartementet 2014. HelseOmsorg21. Et kunnskapssystem for bedre folkehelse. Nasjonal forsknings- og innovasjonsstra- tegi. Hentet fra https://www.regjeringen.no/ contentassets/ 8ab2fd5c4c7746dffb51e3f64cd4d71aa/helseomsorg21_strategi_web.pdf?id=2266705

Helse- og omsorgsdepartementet. 2015. Oppdragsdokument 2017. Hentet fra www.regjeringen.no

Helse- og omsorgsdepartementet. 2015a. Demensplan 2020. Et mer demensvennlig samfunn.

Helse- og omsorgsdepartementet. 2015b. Delplan til Omsorgsplan 2015. Nevroplan 2015. Hentet fra https://www.regjeringen.no/contentassets/cca646be99be45af96eaec07a7739234/ nevroplan2015.pdf

Helse- og omsorgsdepartementet, KS og Frivillighet Norge. 2015. Nasjonal strategi for frivillig arbeid på helse- og omsorgsfeltet.

Helse- og omsorgsdepartementet. 2016. Oppdragsdokument 2017. Hentet fra www.regjeringen.no

Helse- og omsorgstjenesteloven. 2011. Lov om kommunale helse- og omsorgstjenester m.m Hentet fra https://lovdata.no/dokument/NL/ lov/2011-06-24-30?q=helse- og omsorgstjenesteloven

Helsepersonelloven. 1999. Lov om helsepersonell m.v. Hentet fra https://lovdata.no/dokument/ NL/lov/1999-07-02-64?q=helsepersonelloven

Helse Sør-Øst, RHF. 2012. Retningslinje for etablering, organisering og finansiering av regionale kompetansetjenester $i$ Helse Sør-Øst.

Helse Sør-Øst RHF. 2017. Årsrapport fra kompetansesenter for lindrende behandling.

Hentet fra https://oslo-universitetssykehus.no/ .../kompetansesenter...lindrende-behandlinghelser

Helse Vest RHF, 2003. Regionale kompetansesentre $i$ Helse Vest. Arbeidsgrupperapport 2003. Hentet fra https://helse-vest.no/seksjon/styresaker-arkiv/Documents/2003/17.02.2003/ Sak\%2001603\%20B\%20Vedlegg\%2011\%20Kompetansesentre\%20vedlegg.pdf

Helse Vest RHF. 2017. Årsapport fra det regionale kompetansesenteret $i$ lindrende behandling og omsorg. Arsrapport 2016. Hentet fra https:// helse-bergen.no/seksjon/KLB/.../arsrapport_2016_KLB_kortversjon.pdf

Helse-Vest RHF. 2017. Nasjonalt register over palliative virksomheter. PallReg. Hentet fra www.pallreg.no

Helsetilsynet, 2010. Rapport 2/2010. Oppsummering av landsomfattende tilsyn $i 2009$ med kommunale sosial- og helsetjenester til barn i barneog avlastningsboliger; "Det vil helst gå bra..." Hentet fra https://www.helsetilsynet.no 
Helsetilsynet 2015. Oppsummering av landsomfattende tilsyn $i 2015$ med samhandling om utskrivning av pasienter fra spesialisthelsetjenesten til kommunen. Hentet fra www.helsetilsynet.no

Heløe, L. A. 2012. Fra paternalisme til pasientrettigheter. Tidsskr Nor Legeforen 2012132:4346.

Hestnes, K. 2014. Nasjonal kartlegging av palliative tiltak [Sceroppgave $i$ medisinstudiet]. Bergen: Det medisinsk-odontologiske fakultet, Universitetet i Bergen. (Helsedirektoratet, 2015a).

Hjelde, K. H., Guribye, E., Magnussen, M.-L., Ali, W. Oppfølging av barn som pårorende i familier med innvandrerbakgrunn. 2015. (NAKMI rapport nr. 3, 2015). Nasjonalt kompetansesenter for migrasjons- og minoritetshelse, NAKMI. Hentet fra http://www.nakmi.no/publikasjoner/dokumenter/hjelde-et-al-2015-barn-sominnvandrerbakgrunn-nakmi-rapport-nr-32015.pdf

Holmøy, T., Aarrestad, S., Engstrand, P., Ottesen, S., Syse, A., Førde, R. 2009. Avslutning av respiratorbehandling ved amyotrofisk lateral sklerose. Tidsskr.Nor Lægeforen., 129, (7) 628-631.

Holtan, A., Aass, N., Nordøy, T. m.fl. 2007. Prevalence of pain in hospitalised cancer patients in Norway: a national survey. Palliative Med; 21: 7-13. Hentet fra https:// www.ncbi.nlm.nih.gov/pubmed/17169954

Holmås, T. H., Kjerstad, E., Monstad, K. 2016. Kommunale pleie- og omsorgstjenester - en studie av eldre med og uten noere pårorende, (Notat 1-2016), Uni Researce Rokkansenteret. Hentet fra http://uni.no/media/manual_upload/Notat_1-2016_Monstad_Kjerstad_Holmaas.pdf

Hui, D., Bruera, E. 2016. Integrating palliative care into the trajectory of cancer care. Nat Rev Clin Oncol. 2016 Mar; 13(3): 159-171. https:// www.ncbi.nlm.nih.gov/pmc/articles/ PMC4772864/

Høvik, M., Kienlin, S., Berg, G. 2017. Palliative forløp. Sykepleien Forskning. Hentet fra https://sykepleien.no/forskning/2017/08/ palliative-forlop-kan-gjores-bedre

Islandsk pasientrettighetslov. Patients' Rights Act, No. 74/1997. Hentet fra https://eng.velferdarraduneyti.is/media/acrobat-enskar_sidur/Patients-Rights-Act-No-74-1997.pdf

Jackman, D. M., Zhang, Y. m.fl. 2017. Cost and Survival Analysis Before and After Implementation of Dana Farber Clinical Pathways for Pa- tients With Stage 4 Non Small Cell Lung Cancer. PubMed Apr 13(4) e346-e352.

Jansen, K., Haugen, D. F., Pont, L., Ruths, S. 2017. Safety and Effectiveness of Palliative Drug Treatment in the Last Days of Life-A Systematic Literature Review. J Pain Symptom Manage. Hentet fra https://www.ncbi.nlm.nih.gov/pubmed/28803078

Jehowah's witnesses of Moscow and others mot Russland, 2010. EMDs dom av 10. Juni 2010.

Joffe, S., Manocchia, M., Weeks, J. C., Cleary, P. D. 2003. What do patients value in their hospital care? An empirical perspective on autonomy centred bioethics.2003. J Med Ethics 2003:,29: 103-108.

Johansen, I. E. og Hagerup, V. 2017. Tid som gave. Frivillighetsprosjekt $i$ Sandefjord kommune. Hentet fra www.sandefjordkommune.no

Jordhøy, M. S. m.fl. 2000. A palliative-care intervention and death at home: a cluster randomised trial. The Lancet vol. 356, 2000. Hentet fra https://www.ncbi.nlm.nih.gov/pubmed/ 11036893

Journal of Palliative Medicine 2010. Cassel, B., Webb-Wright, J., Holmes J., Lyckholm L., Smith, T. J. Clinical and financial impact of a palliative care program at a small rural hospital Journal of Palliative Medicine, 13(11): 1339-1343. Hentet fra http://online.liebertpub.com/doi/abs/10.1089/jpm.2010.0155

Journal of Palliative Medicine. 2013. Rabow, M., Kvale, E., Barbour, L., Cassel, J. B,. Cohen, S., Jackson, V., Luhrs, C., Nguyen, V., Rinaldi S., Stevens, D., Spragens, L., Wessman, D. Moving Upstream: A Review of the Evidence of the Impact of Outpatient Palliative Care. Journal of Palliative Medicine, 16 (12): 1540-1549. Hentet fra http://online.liebertpub.com/doi/abs/ 10.1089/jpm.2013.0153

Journal of Palliative Medicine. 2014. May, P., Normand, C., Morrison R. S. Economic Impact of Hospital Inpatient Palliative Care Consultation: Review of Current Evidence and Directions for Future Research., Journal of Palliative Medicine, 17(9): 1054-1063. Hentet fra http://online.liebertpub.com/doi/abs/10.1089/ jpm.2013.0594

Kaasa, S., Haugen, D. F., 2006. Fagfeltet palliativ medisin. Medisin og Vitenskap. No.3,26. januar 2006, 126:326-8. http://tidsskriftet.no/ sites/default/files/pdf2006-326-8.pdf

Kaasa, S. og Loge, J. H. 2016. Palliasjon. Nordisk lærebok. Gyldendal.

Kalseth, J., Theisen, O. M. 2017. Trends in place of death: The role of demographic and epidemiolo- 
gical shifts in end-of-life care policy. Hentet fra. www.ncbi.nlm.nih.gov

Kavalieratos, D. m.fl. 2016. Association Between Palliative Care and Patient and Caregiver Outcomes: A Systematic Review and Meta-analysis. JAMA. 2016 Nov 22;316(20):2104-2114. doi: 10.1001/jama.2016.16840. Hentet fra https://www.ncbi.nlm.nih.gov/pubmed/ 27893131

Komiteen for barns rettigheter: Generell kommentar nr. 14 (2013) om barnets rett til at hans eller hennes beste skal være et grunnleggende hensyn (art. 3, para. 1).

Kommunenes sentralforbund (KS). 2017. Hentet fra http://www.ks.no/fagomrader/helse-ogvelferd/helse-og-omsorg/kommunale-helsetjenester/kunnskapsloft-for-kommunene/

Kongeriket Norges Grunnlov av 17. mai 1814.

Kongsgaard, U., Kaasa, S. m.fl. 2005. Lindring av smerter hos kreftpasienter (Rapport fra Kunnskapssenteret Nr 9-2005). Hentet fra http:// www.kunnskapssenteret.no/publikasjoner/ lindring-av-smerter-hos-kreftpasienter

Kreftforeningen. 2017. Kreftforeningens forskningsinnsats. Hentet fra https://kreftforeningen.no/

Kreftregisteret. 2017. Årsapport 2016. Hentet fra https://www.kreftregisteret.no/globalassets/ publikasjoner-og-rapporter/arsrapporter/publisert-2016/krg_aarsrapport-2016.pdf

Kreicbergs, U., Valdimarsdóttir, U., Onelöv, E., Björk, O., Steineck, G., Henter, J. I. 2005. CareRelated Distress: A Nationwide Study of Parents Who Lost Their Child to Cancer, Journal of Clinical Oncology 2005 23:36, 9162-9171. Hentet fra https://www.ncbi.nlm.nih.gov/pubmed/ 16172455

Kunnskapssenteret. (2014). Livets sluttfase - om $\stackrel{1}{a}$ finne passende behandlingsnivå og behandlingsintensitet for alvorlig syke og døende. (Systematisk oversikt. Rapport fra Kunnskapssenteret nr. 18-2014)-Hentet fra http:// www.kunnskapssenteret.no/publikasjoner/livets-sluttfase-om-a-finne-passende-behandlingsniva-og-behandlingsintensitet-for-alvorligsyke-og-doende

Legeforeningen. 2006. Rom for etisk refleksjon $i$ utdanningen. Legeforeningens policy nr.2/2006 - Profesjonsetikk. Hentet fra http://legeforeningen.no/PageFiles/28909/Legeforeningens\%20poicy\%20nr.\%2022006.pdf

Lekven, B. E. L. 2016. Nasjonal kartlegging av palliative tiltak 2013-2014. Særoppgave i medisinstudiet, Det medisinsk-odontologiske fakultet, Universitetet i Bergen.
Lov om folketrygd. Del IV. Ytelser ved sykdom m.m. Kapittel 9. Stonad ved barns og andre noerståendes sykdom. Hentet fra https://lovdata.no/dokument/NL/lov/1997-02-28-19/KAPITTEL_55\#KAPITTEL_5-5

Lundorff, M., Holmgren, H., Zachariae, R., Farver-Vestergaard, I., O'Connor, M. 2017. Prevalence of prolonged grief disorder in adult bereavement: A systematic review and meta-analysis. J Affect Disord. 2017, 212 (1):138-149. doi: 10.1016/j.jad.2017.01.030. Epub 2017 Jan 23. Hentet fra https://www.ncbi.nlm.nih.gov/pubmed/28167398

MacArtney, J. I., Broom, A., Kirby, E., Good, P., Wootton, J., Adams, J. 2015. Locating care at the end of life: burden, vulnerability, and the practical accomplishment of dying. Sociology of Health \& Illness, n/a-n/a. doi:10.1111/14679566.12375. Hentet fra https:// www.ncbi.nlm.nih.gov/pubmed/26547139

Melberg, H. O. 2013. Sykehusutgifter mot livets slutt. Tidsskrift for Den norske legeforening. No. 8, 133:841-4. DOI: 10.4045/tidsskr.12.0802. Hentet fra http://tidsskriftet.no/2013/04/originalartikkel/sykehusutgifter-mot-livets-slutt

Meld. St. 30 (2011-2012). Se meg! - alkohol narkotika - doping. Hentet fra https://www.regjeringen.no/no/dokumenter/meld-st-3020112012/id686014/

Meld. St. 10 (2012-2013). God kvalitet - trygge tjenester. Kvalitet og pasientsikkerhet $i$ helse- og omsorgstjenesten. Hentet fra https://www.regjeringen.no/contentassets/ b9f8d14c14634c67a579a1c48a07c103/no/ $p d f s / s t m 201220130010000 d d d p d f s . p d f$

Meld. St. 29 (2012-2013). Morgendagens omsorg. https://www.regjeringen.no/contentassets/ $34 \mathrm{c} 8183 \mathrm{cc} 5 \mathrm{~cd} 43 \mathrm{e} 2 \mathrm{bd} 341 \mathrm{e} 34 \mathrm{e} 326 \mathrm{dbd} 8 / \mathrm{no} /$ pdfs/stm201220130029000dddpdfs.pdf

Meld. St. 26 (2014-2015). Fremtidens primorhelsetjeneste - noerhet og helhet. https://www.regjeringen.no/contentassets/d30685b2829b41bf99edf3e3a7e95d97/no/pdfs/stm201420150026000dddpdfs.pdf

Meld. St. 11 (2015-2016), (2016-2019). Nasjonal helse- og sykehusplan. Hentet fra https:// www.regjeringen.no/contentassets/ 7b6ad7e0ef1a403d97958bcb34478609/no/ pdfs/stm201520160011000dddpdfs.pdf

Meld. St. 34 (2015-2016). Verdier i pasientens helsetjeneste - Melding om prioritering. Hentet fra https://www.regjeringen.no/no/dokumenter/meld.-st.-34-20152016/id2502758/

Meld. St. 29 (2016-2017). Perspektivmeldingen 2017. Hentet fra https://www.regjeringen.no/ 
contentassets/aefd9d12738d43078c-

bc647448bbeca $1 /$ no/pdfs/st-

m201620170029000dddpdfs.pdf

Menneskerettsloven. (1999). Lov om styrking av menneskerettighetenes stilling $i$ norsk rett av 21. mai 1999 nr. 30. Hentet fra https://lovdata.no/ dokument/NL/lov/1999-05-21-30

Miller, R. G., Jackson, C. E. m.fl. 2009. Practice parameter update: the care of the patient with amytrophic lateral schlerosis: drug, nutritional, and respiratory therapies (an evidence-based review: report of the Quality Standards Subcommittee of the American Academy of Neurology. Neurology. 2009 Oct 13;73(15):122733. Hentet fra https://www.ncbi.nlm.nih.gov/ pubmed/19822873

Nasjonalt kunnskapssenter for helsetjenesten. 2014. Livets sluttfase - om å finne passende behandlingsnivå og behandlingsintensitet for alvorlig syke og døende. (Systematisk oversikt. Rapport fra Kunnskapssenteret nr. 18-2014)Hentet fra http://www.kunnskapssenteret.no/ publikasjoner/livets-sluttfase-om-a-finne-passende-behandlingsniva-og-behandlingsintensitet-for-alvorlig-syke-og-doende

Nasjonalt råd for prioritering i helse- og omsorgstjenesten. (2009). Sak 08/1347. Vedtak 08.06.2009. Hentet fra www.prioritering.no

Nasjonalt senter for distriktsmedisin. (2017). Samhandling om utskrivningsklare pasienter. Hentet fra http://arkiv.nsdm.no/filarkiv/File/rapporter/Rapport\%205\%20april\%202017.pdf

Nordisk institutt for studier av innovasjon- NIFU, forskning og utdanning. 2016.

Wiig, O., Rørstad K., Børing, P. Forskning og innovasjon knyttet til kommunale helse- og omsorgstjenester: Kartlegging av ressursinnsats og resultater. (Rapport 2016:32). Hentet fra https:// brage.bibsys.no/xmlui/handle/11250/ 2423142

Norges Forskningsråd. 2016. Evaluering av samhandlingsreformen. Hentet fra www.forskningsradet.no

Norges Høyesterett. Rt. 2010 side 612

Norsk helseinformatikk. Informasjon om hjerneslag. Hentet fra www.nhi.no

Norsk Palliativ Forening. Hentet fra www.palliativ.org

Norsk Palliativ forening. 2017. Begreper med tilknytning til palliasjon. Hentet fra http://legeforeningen.no/spesial/Norsk-forening-for-palliativ-medisin/Nyheter/Begreper-med-tilknytning-til-palliasjon/

Norsk sykepleierforbund/Analysesenteret. 2010. Utskrivningsklare pasienter - hvem er de og hvor hører de hjemme? Hentet fra https:// www.nsf.no/Content/417818/Rapport\%20Utskrivningsklare\%20pasienter\%20aug\%202010\%20(2).pdf

NOU 1984: 30. (1984). Pleie og omsorg for alvorlig syke og døende mennesker. Hentet fra https:// www.nb.no/items/URN:NBN:no-nb_digibok_2007071600018

NOU 1997: 20. (1997). Omsorg og kunnskap! Norsk kreftplan. Hentet fra https://www.regjeringen.no/no/dokumenter/nou-1997-20/ id141003/

NOU 1999: 2. (1999). Livshjelp - Behandling, pleie og omsorg for uhelbredelig syke og døende. Hentet fra https://www.regjeringen.no/no/dokumenter/nou-1999-2/id141460/

NOU 2005: 1.(2006). God forskning - bedre helse. Oslo: Sosial- og helsedepartementet. Hentet fra https://www.regjeringen.no/no/dokumenter/ nou-2005-01/id389605/

NOU 2011: 17. (2011). Når sant skal sies om pårørendeomsorg. Departementenes servicesenter Informasjonsforvaltning: Oslo. Hentet fra https://www.regjeringen.no/contentassets/ 405c4c2d84704979a84027741d237338/no/ pdfs/nou201120110017000dddpdfs.pdf

NOU 2014: 12. (2014). Åpent og rettferdig - prioriteringer $i$ helsetjenesten. Hentet fra https:// www.regjeringen.no/no/dokumenter/NOU2014-12/id2076730/

NOU 2016: 17. (2016). På lik linje. Åtte left for å realisere grunnleggende rettigheter for personer med utviklingshemming https://www.regjeringen.no/contentassets/b0baf226586543ada7c530b4482678b8/no/pdfs/

NTNU. Helseundersøkelsen $i$ Nord-Trøndelag (HUNT). Hentet fra www.ntnu.no/hunt

Helsepersonelloven. Ot.prp.nr.13 (1998-1999) Om lov om helsepersonell m.v. (helsepersonelloven). Hentet fra https://www.regjeringen.no/ no/dokumenter/otprp-nr-13-1998-99-/ id159428/

Pallion. Nasjonalt forskningsprosjekt om palliasjon. Hentet fra www.pallion.no

Patientlag (2014: 821). https://www.riksdagen.se/sv/dokument-lagar/dokument/ svensk-forfattningssamling/patientlag2014821_sfs-2014-821

Pasient- og brukerombudet. 2016. Årsmelding. Hentet fra https://helsenorge.no/pasient-og-brukerombudet/arsrapporter

Pasient- og brukerrettighetsloven. 1999. Lov om pasient- og brukerrettigheter. Hentet fra https:/ /lovdata.no/dokument/NL/lov/1999-07-02-63 
Pubmed. 2017. Søkt 20.11.2017 på palliative care/ palliative care cancer. Hentet fra https:// www.ncbi.nlm.nih.gov/pubmed/? palliative+carehttps://www.ncbi.nlm.nih.gov/pubmed/?term=palliative+care+and+cancer

Pretty mot Storbritannia, EMDs dom av 29. april 2002.

Psykisk helsevernloven. 1999. Lov om etablering og gjennomforing av psykisk helsevern av 2. juli 1999 nr. 62. Hentet fra https://lovdata.no/dokument/NL/lov/1999-07-02-62

Regional kompetansetjeneste for lindrende behandling, Helse Sør- Øst. 2017. Kartlegging av pårørendes behov som omsorgsgivere CSNAT. Hentet fra https://oslo-universitetssykehus.no/kartlegging-av-parorendes-behovsom-omsorgsgivere-csnat

Riksrevisjonen, 2015. Dokument 3:5 (2015-2016) Riksrevisjonens undersøkelse av ressursutnyttelse og kvalitet $i$ helsetjenesten etter innforingen av samhandlingsreformen.

Romøren, M., Pedersen, R., Førde, R. 2016. How do nursing home doctors involve patients and next of kin in end-of-life decisions? A qualitative study from Norway. BMC Med Ethics 2016; 14;17:5.

Romøren, M., Pedersen, R., Førde, R. 2017. Én pasient, to verdener - samhandling mellom sykehjemsleger og sykehusleger. Tidsskr Nor Legeforen 2017 137:193-7. Hentet fra: http://tidsskriftet.no/2017/02/originalartikkel/en-pasient-verdener-samhandling-mellom-sykehjemsleger-og-sykehusleger

Sandsdalen, T. 2016. Quality in palliative care from the patient perspective: Instrument development, perceptions of care received and the importance of care. Doctorial thesis. Karlstad University Studies. 2016:48. Hentet fra https:/ /www.diva-portal.org/smash/get/ diva2:1044098/FULLTEXT02.pdf

Sandsdalen, T., Hov, R., Høye, S., Rystedt, I., Wilde-Larsson, B. 2015. Patients' preferences in palliative care: A systematic mixed studies review. Palliat Med. 2015 May;29(5):399-419. doi: 10.1177/0269216314557882. Epub 2015 Feb 13. Hentet fra https:// www.ncbi.nlm.nih.gov/pubmed/25680380

Sigurdardottir, K. R., Haugen D. F., van der Rijt, C. C. D., Sjøgren, P., Harding, R., Higginson, I. J., Kaasa, S. 2010. Clinical priorities, barriers and solutions in end-of-life cancer care research across Europe. Report from a workshop. European Journal of Cancer; 46(10), 1815-1822. Hentet fra https://www.ncbi.nlm.nih.gov/pubmed/20456947
Sigurdardottir, K. R., Haugen, D. F., Bausewein, C., Higginson, I. J., Harding, R., Rosland, J. H., Kaasa, S. 2012. A pan-European survey of research in end-of-life cancer care, Support Care Cancer; 2012; 20:39-48. Hentet fra https:// link.springer.com/content/pdf/ 10.1007\%2Fs00520-010-1048-x.pdf

SINTEF Teknologi og samfunn, (2016). Melby, L., Das, A., Halvorsen, T., Steihaug, S. Evaluering av tjenestetilbudet til personer med behov for lindrende behandling og omsorg. Rapport, SINTEF, Hentet fra https://helsedirektoratet.no/ Documents/Nyheter/A27799\%20Rapport\%20lindrende\%20behandling_revidert\%202017.pdf

Skoghøy, J. E. Menneskerettighetenes stilling etter grunnloven, LOV OG RETT, vol. 54, 4, 2015, s. 195-196

Spesialisthelsetjenesteloven. Lov om spesialisthelsetjenesten m.m. 1999. Hentet fra www.lovdata.no

Statistisk sentralbyrå. 2015a. Spesialisthelsetjenesten. Hentet fra https://www.ssb.no/helse/ statistikker/speshelse/aar/2016-06-23

Statistisk sentralbyrå. 2015b. Kommunehelsetenesta. Hentet fra https://www.ssb.no/helse/statistikker/helsetjko/aar/2016-06-28?fane=tabell\&sort=nummer\&tabell=271492

Statistisk sentralbyrå. 2017. Kommunale helse- og omsorgstjenester 2016. Statistikk om tjenester og tjenestemottakere. (Rapporter 2017/26, 2017). Hentet fra https://www.ssb.no/helse/artiklerog-publikasjoner/_attachment/ 318105 ? ts $=15 \mathrm{dcac} 9 \mathrm{dff} 0$

St.meld. nr. 25 (2005-2006). 2006. Mestring, muligheter og mening. Framtidas omsorgsutfordringer. Hentet fra https://www.regjeringen.no/contentassets/16e39820de5c485da382fd99165afaf7/no/pdfs/stm200520060025000dddpdfs.pdf

St.meld. nr. 39 (2006-2007). Frivillighet for alle.

St.meld. nr. 47 (2008-2009). Samhandlingsreformen. Rett behandling - på rett sted- til rett tid. Hentet fra https://www.regjeringen.no/no/ dokumenter/stmeld-nr-47-2008-2009-/ id567201/

St.prp. nr.61 (1997-1998). Om nasjonal kreftplan og plan for utstyrsinvesteringer ved norske sykehus. Hentet fra https://www.regjeringen.no/ no/dokumenter/stprp-nr-61-1997-98-/ id201900/

St.prp.nr.1 (1998-1999). Helse- og omsorgsdepartementet.

St.prp.nr.1 (2016-2017). Helse- og omsorgsdepartementet. Hentet fra https://www.regjerin- 
gen.no/contentassets/ d64fc8298e1e400fb7d33511b34cb382/no/ pdfs/prp201620170001hoddddpdfs.pdf

Stortinget, Innst.379 S (2014-2015). Innstilling fra helse- og omsorgskomiteen om representantforslag fra stortingsrepresentantene Olaug $V$. Bollestad, Hans Olav Syversen og Line Henriette Hjemdal om en plan for å sikre retten til livshjelp ved livets slutt.

Straffeloven. Lov om straff av 20. mai 2005 nr. 28 (straffeloven), www.lovdata.no. Hentet fra https://lovdata.no/dokument/NL/lov/200505-20-28

Strømskag, K. E. 2012. Og nå skal jeg dø-Hospicebevegelsen og palliasjonens historie $i$ Norge. Oslo: Pax forlag A/S.

Sunnhedsloven, LBK nr 1188 af 24/09/2016. Hentet fra https://www.retsinformation.dk/ forms/r0710.aspx?id=183932

Sundhedsstyrelsen. 2017. Kroeftplan IV. Hentet fra www.sst.dk

Sundhedsstyrelsen 2017. Forløbsprogram for rehabilitering og palliation i forbindelse med kroeft. Hentet fra www.sst.dk

Sykehuset Telemark. 2015. Den døende pasient Pårorendesamtale. Hentet fra https:// www.sthf.no/SiteCollectionDocuments/palliasjonsnettverk/Den-døende\%20pasient-Pårørendesamtale.pdf

Syse, A. 2015. Pasientrettighetsloven med kommentarer, 4. reviderte utg.

Syse, A., Moshina, N. 2015. Kreftkoordinatorers rolle $i$ samhandlingsarbeidet $i$ kreftomsorgen $i$ norske kommuner. Nordisk Tidsskrift for Helseforskning nr. 1-2015, 11 årgang. Hentet fra http://septentrio.uit.no/index.php/helseforsk/article/view/3476

Stenberg, U. 2013. Living close to a patient with cancer - Challenges in support and caregiving. Doktorgradsavhandling, Universitetet i Oslo.

Sørhus, G. S., Landmark, B., Grov, E. K. 2016. Ansvarlig og avhengig - Pårorendes erfaringer med forestående død $i$ hjemmet, Klinisk Sygepleje 02/2016 (Volum30). Hentet fra https:// www.idunn.no/klinisk_sygepleje/2016/02/ansvarlig_og_avhengig_paaroerendes_erfaringer_med_forestaae?languageId=2

Temel J. S. m.fl. 2010. Early palliative care for patients with metastatic non-small-cell lung cancer. New England Journal of Medicine. 363:73342. Hentet fra https://www.ncbi.nlm.nih.gov/ pubmed/20818875

Termik. 2017. Hentet fra www.vefsn.termik.no
Teunissen, S. C., Wesker, W., Kruitwagen, C., de Haes, H.C., Voest, E. E., de Graeff, A. 2007. Symptom prevalence in patients with incurable cancer: a systematic review. J Pain Symptom Manage. 34:94-104. Hentet fra: https:// www.ncbi.nlm.nih.gov/pubmed/17509812

Tingvold, L., Sogstad, M. 2012. Lindrende behandling. Erfaringsoppsummering - tilskudd til lindrende behandling og omsorg ved livets slutt. (Rapportserie nr. 9/2012). Høgskolen i Gjøvik. Senter for omsorgsforskning. Hentet fra http:/ /brage.bibsys.no/xmlui/bitstream/id/ 101811/Rapport\%209-2012.pdf

Tromsø kommune. 2017. Helsehuset i Tromsø. Hentet fra www.tromso.kommune.no

US Department of Health and Human Services. Agency for Health Care Policy and Research. 1993. Acute pain management: operative or medical procedures and trauma. Clinical Practice Guideline No. 1. AHCPR Publication No. 92-0023. Rockville, MD: The Agency, 1993: 107-107.

Videncenter for rehabilitering og palliation. Hentet fra www. Rehpa.dk

WHO (1998). Who Definition of Palliative Care. Hentet fra www.who.int

WHO (2017). Definition of Palliative Care. Hentet fra http://www.who.int/cancer/palliative/definition/en/

Williams, C. M., Wilson, C. C. m.fl. 2005. Dying, death, and medical education: student voices. $\mathrm{J}$ Palliativ Med. 2005;8(2):376.

Zimmermann, C. m.fl. 2004. Early palliative care for patients with advanced cancer: a clusterrandomised controlled trial, The Lancet, May 17, 2014. Hentet fra https:// www.ncbi.nlm.nih.gov/pubmed/24559581

Aasbø, G. 2014. Kols sliter ut pårørende. Hentet fra https://forskning.no/helsepolitikk-helsetjeneste-helseadministrasjon-royking/2014/11/ kols-oppfattes-dramatisk-de

Aasbø, G. 2017. Affected and responsible: A qualitative study of family caregivers in interaction with chronically ill persons and health care professionals. Doktorgradsavhandling. Oslo: Universitetet i Oslo. Hentet fra https:// www.duo.uio.no/bitstream/handle/10852/ 55527/PhD-Aasboe-DUO.pdf?sequence $=1 \&$ isAllowed $=\mathrm{y}$

Aasen, H. S. 2008. Barns rett til selvbestemmelse og medbestemmelse $i$ beslutninger om helsehjelp. Tidsskrift for familierett, arverett og barnevernrettslige spørsmål, (1) 4-28. 


\section{Barnepalliasjon}

\section{Dissens fra utvalgsmedlem Natasha Pedersen}

Dissensen og forslag til tiltak må sees i sammenheng med de problemstillingene og utfordringene som er tatt opp i NOUens kapittel 1 - Organisering, struktur og kompetanse og i sammenheng med dissens til utvalgsmedlem Astrid Rønsen.

Utvalget mener at egne hospice institusjoner for barn ikke er egnet til å ivareta dette formålet, noe som ikke er blitt fremlagt faktagrunnlag eller evidens på. Internasjonalt er det evidens på at antall barn i behov for palliasjon er økende. Det henvises til de Nasjonal faglig retningslinje for palliasjon til barn og unge uavhengig av diagnose (Helsedirektoratet, 2016) som ikke sier noe om den kommunale organiseringen. Barnepalliasjon er et økende behov i vårt samfunn som i dag har utilstrekkelige løsninger.

Barnehospice som en organisatorisk modell, er grunnstenen i utviklingen av barnepalliasjon som fagområde og det er et økende antall barnehospice som blir etablert i hele verden, siden oppstarten av det første som var et frittstående barnehospice, Helen House og ble åpnet i Oxford, England i 1982 med sengeplasser til åtte pasienter og deres familier.

I denne dissens vil jeg først redegjøre noe for det faktagrunnlaget jeg bygger min dissens på:

\section{Korte fakta om barnehospice}

Familier som har et barn som skal dø befinner seg i en ekstremsituasjon. Cicely Saunders som var en pioner for palliasjon til voksne, sa «Måten en pasient dør på, lever som minner for de som er igjen» For barn og unge vil både måten de lever og dør på, leve videre som minner. Et barnehospice har fokus på livet og ikke bare på døden. Det handler om å hjelpe barnet og familien til å kunne leve best mulig selv om man har en livstruende eller livsbegrensende tilstand, uavhengig av diagnosen og selv om man vet at det blir et forkortet livsløp, enten det er dager, måneder eller år.

Tjenestene på et Barnehospice søker å forbedre denne ekstremsituasjonen. Målet for tjenestene på et barnehospice er å hjelpe barnet og deres familier til å leve livet fullt ut mens det er mulig, og ta vare på barnet og familien når barnet dør og være tilstede for familien i tiden etterpå. Både fysisk og psykisk.

Hospicetjenestene innebærer en helhetlig eller holistisk omsorgstanke til barnet og familien for å avhjelpe behov og utfordringer av fysisk, psykisk, sosial, åndelig og eksistensiell karakter som er forbundet med livstruende sykdommer og alvorlige tilstander.

På dette grunnlaget vil derfor dette medlem peke på følgende:

\section{Vi bør ha barnehospice som organisatorisk modell i Norge}

Barnehospice bør inngå som en naturlig organisatorisk modell og som en del av totalløsning innen barnepalliasjon i Norge. I dag kan i prinsippet hvem som helst starte et barnehospice. Ved å foreslå barnehospice som modell allerede nå, har offentlige myndigheter mulighet til å legge noen tydelige føringer for kvalitet og innhold for barnehospice som en integrert del av norsk helsetjeneste.

\section{Dagens situasjon}

Det som særlig kjennetegner dagens tjenester $\mathrm{i}$ Norge knyttet til barnepalliasjon er et fravær av organisering, kunnskap og av familieperspektiv. Det er manglende spisskompetanse innen barnepalliasjon samt fravær av organiserte, døgnbaserte og fleksible tjenester for denne gruppen. Dagens tilbud for denne målgruppen fremstår med andre ord som utydelig, fragmentert, lite fleksibelt og uforutsigbart.

Dette medlem vil peke på følgende hovedargumenter for barnehospice:

Det finnes en rekke argumenter for hvorfor det er formålstjenelig med barnehospice som en organisasjonsmodell også i Norge. Jeg presenterer likevel her kun hovedargumentet - helhetlig familieperspektiv og pårørendeomsorg - samt et 


\section{Boks 1.1 Barnehospice bidrar til at en ekstremsituasjon blir en styrket situasjon}

\section{Barnehospice er på familienes premisser}

Omsorgen på et Barnehospice er individuelt tilpasset hvert barn og deres familier. Det er en høyst personlig og individuell tilpasset omsorg som evalueres kontinuerlig slik at skiftende behov som er i endringer, blir møtt og ivaretatt.

\section{Barnehospice omslutter omsorgen for hele familien}

Tjenestene på et Barnehospice er familie -sentrert og -fokusert. Familier og søsken har sammensatte behov som trenger å bli vurdert og håndtert riktig. Dedikerte barnehospicer gir en bedre løsning enn sykehus for barn som får palliativ omsorg.

\section{Barnehospice kjennetegnes ved}

Trygghet fordi barnet og familien får kvalifisert hjelp av kompetente personer med spesialistkunnskap innen barnepalliasjon.

Fleksibilitet ved at barnet og familien får relevant hjelp ut fra skiftende og ulike behov.

Forutsigbarhet ved at den syke og de nærmeste vet at hjelpen er der over tid, og når de trenger det.

\section{Omgivelsene i et Barnehospice}

Er minst mulig sykehuspreget med stor vekt på livsglede og livskvalitet. Arkitektur, interiør og estetikk og en atferd hos personalet som styrker verdighet og respekt, lindrer lidelse og gir trøst og støtte i prosessen frem mot døden og i etterkant av den.

\section{Livssyn og kulturelle behov}

Tjenestene som Barnehospice gir, er til familier fra alle trosretninger, kulturer og etnisk bakgrunn, og de legger vekt på å respektere betydningen av familienes religiøse skikker og kulturelle behov som er avgjørende for det daglige livet til hver familie.

\section{Barnehospice er innovasjon innen helsetjenesten}

Er en del av en bevegelse som er med på å produsere radikal innovasjon innenfor institusjon, tjenester og verdier.

\section{Hospice tema}

Mange barnehospicer har utviklet seg til flerfaglige team, blant annet med lekespesialister, kunsterapeauter og familieterapeuter. Hospiceteam arbeider utelukkende med barnepalliasjon og har de ferdighetene og den erfaringen som er nødvendig for å ha tilsyn med barn med livsbegrensende og komplekse pleiebehov. Hospiceteam tilbyr valg med hensyn til sted for pleie når livet går mot slutten. Teamene bygger ofte opp langvarige forhold til familier som besøker hospicet for jevnlige og korte opphold gjennom sykdomsforløpet.

\section{Terminalpleie eller dødsfall}

Selv når det ikke er mulig for barnet å dø hjemme, kan familien være i stand til å bringe ham eller henne hjem eller til et barnehospice etter døden.

Mange Hospice har en sorgsuite med en innebygd kjølingsenhet der et barn kan være etter at det har dødd og der familien fortsatt kan få støtte. Kontinuerlig sorgstøtte er et vanlig tilbud til individer eller grupper og til søsken og foreldre uavhengig om barnet dør på hospice eller ikke.

\section{Avlastning i Barnehospice}

De fleste sengene i barnehospicer benyttes til avlastning for å gi familien en pause i den daglige rutinen og belastningen. Mange av disse familiene lever i en ekstrem situasjon over måneder og år. De fleste Hospice tilbyr et bestemt antall avlastningsdøgn per år fordi det er så vanlig å benytte denne tjenesten. I tillegg tilbyr mange Hospice, avlastning i krisesituasjoner, som når en forelder er syk eller et søsken må på sykehus eller etter langvarig sykehusinnleggelse. Fleksibiliteten er særlig viktig for å forebygge at familier bryter sammen eller får unødvendige innleggelser på sykehus. Avlastning kan gis barnet alene eller til barnet og barnets familie eller venner. Det gir familier muligheter til å tilbringe tid med barnet utenfor hverdagslige gjøremål og letter ansvaret for deres daglige pleieoppgaver. For tenåringer tilbyr avlastningsperioder verdifull uavhengighet fra familien og en mulighet for å tilbringe tid med venner og andre unge mennesker i lignende livssituasjoner. Avlastningsperioder kan også gi familien verdifull tid til å gjøre ting som rett og slett ikke ville ha vært mulig ellers, som en utenlandsferie eller å kunne være sammen med sine andre barn i vissheten om at barnet deres er i trygge hender. 
par tilleggsargumenter i forhold til finansiering og det holdningsskapende aspektet knyttet til alvorlig sykdom, død og behandling.

\section{Helhetlig familieperspektiv og pårørendeomsorg - "To know better, but let the family decide».}

Barnepalliasjonens utøvelse i et barnehospice er et godt eksempel på pasientens helsetjeneste $\mathrm{i}$ forhold til dagens tjenester for barn og unge. Dette fordi tjenestene tar utgangspunkt i, og er individuelt tilpasset til, hele familiens behov der fokuset på omsorg er vel så viktig som den medisinske behandlingen. Med andre ord rett hjelp til rett tid, fra spesialisert personell $\mathrm{i}$ trygge og verdige omgivelser når $\mathrm{du}$ trenger det - alle nødvendige tjenester samlet under ett tak 24 timer i døgnet. Dette handler samtidig om forebyggende helse og livsmestring for hele familien (eksempel bereavement-support). Mange familier lever med barn og unge med livsstruende og livsbegrensende tilstander over lengre tid. Det betyr at familiene trenger et «fristed/hvilested» underveis. Den ekstrautfordringen det er å leve med krevende omsorgsansvar og oppgaver over år, krever noe ekstra av alle i familien også søsken. Barnehospice vil da kunne tilby og representere kompetanse i et miljø som er innrettet på alvorlig syke barn og familier, og representerer derfor den rammen disse familiene trenger for å leve med sine særskilte utfordringer. Dette gir fornyet energi til å fortsette på en god måte $\mathrm{i}$ sine egne liv hjemme. Det fellesskapet som disse familiene kan skape på tvers mellom ulike familier og personell på disse stedene, blir grunnmuren som bærer dem gjennom utfordringer over flere år.

\section{Dette medlem vil også peke på to tilleggsargumenter knyttet til holdninger og finansiering:}

\section{Påvirke samfunnets holdninger knyttet til døden og overbehandling:}

Barnehospice vil kunne være et viktig bidrag til at døden får en mer naturlig plass i samfunnet. Dette fordi barnehospice er tydelig på sitt oppdrag, sin filosofi, fysiske lokasjon og innhold av tjenester. Barnehospice har med sin profil gjennom 45 år i store deler av verden skapt oppmerksomhet, samfunnsengasjement og goodwill. Dette konkret gjennom medieomtale, organisert frivillighet og fundraising.

\section{Barnehospice blir $i$ stor grad finansiert av privat sektor $i$ andre land:}

Det er dokumentert at barnehospice internasjonalt, både etablering og drift, delvis finansieres av det private gjennom innsamlede midler. Barnehospice har i Storbritannia vist seg å få mye mere støtte en voksenhospice, der $59 \%$ av midlene gis gjennom funding og kun $15 \%$ gjennom det offentlige.

Selv om barnehospice sikkert vil kunne få betydelig støtte fra private innsamlede midler også i Norge er det viktig med offentlig finansiering. En verdig død for barn og unge skal ikke være avhengig av innsamlede midler. Disse må gjerne komme i tillegg, bidra til å heve kvaliteten i virksomheten, men den grunnleggende virksomheten må finansieres av offentlig midler.

\section{Hospice som en viktig del av integrasjonen av barnepalliasjon i Norge}

I mange land er barnehospice en høyst integrert modell innenfor barnepalliasjon. Dette blant annet i land som det bør være naturlig for Norge å sammenligne seg med; Tyskland, Irland, New Zealand, Storbritannia, Sverige og Danmark. Med dette som bakgrunn, samt barnehospice sitt tydelige fokus og merverdi på familieperspektivet og pårørendeomsorg, er det fristende å stille seg spørsmålet: Hvorfor bør vi ikke ha barnehospice som organisatorisk modell i Norge?

\section{Dette medlemmet mener derfor at:}

- Det skal være reelle valgmuligheter for ønsket sted å dø. Det må legges til rette for at barnehospice må være en del av det palliative tilbudet til alvorlig syke og døende barn og unge også i Norge.

- Med barnehospice i denne sammenheng menes en egen selvstendig institusjon, den skal ikke være en del av et sykehus, et sykehjem eller lignende institusjoner. Barnehospice skal samarbeide nært med hele den øvrige helsetjenesten. Barnehospice står ikke i motsetning til god barnepalliasjon i helsetjenesten forøvrig, men kommer i tillegg.

- Et barnehospice vil også bidra til å utvikle et fravær og manglende frivillighet innen barnepalliasjon.

- Et barnehospice bidrar og vil være et egnet sted for organisert og strukturert likemannsarbeid.

- Barnepalliasjon må være integrert $\mathrm{i}$ alle deler av helsetjenesten. Og tjenestene må tilby kontinuitet $\mathrm{i}$ omsorgen og være tilgjengelige døgnet rundt, enten hjemme, på sykehus, i hocpice eller $\mathrm{i}$ andre institusjoner som avlastningsboliger eller barneboliger.

- Spesielle avlastningstiltak i kommunene bør utvikles for barn og deres familier med pallia- 
tive behov. Opprettelse av barnehospice vil kunne tilby dette.

- Et barnehospice vil også fungere som et viktig sted for å utvikle kompetansen innen barnepalliasjon og sørge for formidling av denne. Det vil og gi muligheter for klinisk virksomhet, utredning av palliative behov og eventuelt terminal omsorg.

Dette medlemmet forstår at det ikke umiddelbart kan besluttes å bygge flere barnehospice rundt omkring i landet. Tilbudet vil representere betydelige kostnader, og det er behov for å gjøre seg erfaringer med barnehospice også i den norske helsetjenesten.
Dette medlemmet mener imidlertid at en raskt må komme i gang med forsøk. Det beste vil være om det snarest etableres et barnehospice i Oslo, og foreslår rent konkret at politiske myndigheter i Oslo og på regjeringsnivå i samarbeid med frivillige organisasjon(er) tar initiativ til dette.

Dette medlem mener også at en slik etablering sannsynligvis ikke vil representere nye store kostander for helsevesenet all den tid at alternativet til at barn og unge dør på et barnehospice oftest vil være død på et sykehus. Et barnehospice vil representere en hel rekke fordeler ut fra dagens organisering eller mangel på organisering. Se figur 1.1.

\section{OMSORG FOR BARN OG UNGE}
1. Barnet er ofte isolert
2. Bruddstykker, og tilfeldig behandling med store hull i behandlingen
3. Tilgang til barnepalliasjon fraværende
4. Fokuset er raskt og akutt behandling

1. Barnet og familien som enhet for behandling

2. Organisert håndtering i kontinuerlig form og utstrakt service

3. 24-timers rådighet til å håndtere problemer

4. Fokuset er å gi støtte til å ha barnet i sitt nærmiljø

\section{OMSORG FOR FAMILIEN}
1. Familiene er perifere
2. Familiene i krise
3. Familiene må håndtere vanskelige beslutninger
4. Arbeidsuro og-støy fra avdelingen
5. Høye sosiale utgifter

1. Familien som enhet for behandling

2. Utstrakt støtte til familien og søsken

3. Familien er ikke alene i en vanskelig situasjon

4 Støtteservice for å redusere stress og sammenbrudd

5. Forebyggende tjenester - bedre samfunnsøkonomi, redusere misbruk av alkohol og stoff, reduksjon av sykdommer og utvikling av andre sykdommer i familien og tenåringsproblemer for søsken. Komme i forkant av uløste sorgproblemer. Ventesorg.

\section{BEDRE BRUK AV RESSURSER}

1. Krisedriftet økonomi

2. Unødig sykehusinnleggelse fordi det ikke fins alternative tilbud

3. Squeezes pennies to lose dollars

4. Kvalifikasjon på bakgrunn av økonomi hindrer ikke økende kriser
1. Makroledelse

2. Service på enheter eller i hjemmet reduserer sykehuskostnader

3. Regulert bruk av ressurser gir mer for pengene

4. Tilgang til servicer når det er nødvendig og behov for ressurser. Mindre kostnader.

\section{TILFREDSTILLELSE/UTFALL}

1. Familier tynget med sorg og skyldfølelse

2. Familien "tvunget" til å ta avgjørelser ut fra feil grunnlag

3. Barna mottar mangelfull smertebehandling og symptomlindring

4. A dø i et uegnet miljø med forstyrrelse, forvirring og omgitt av stress og skyldfølelse og fornektelse
1. Familiene blir tilbudt kontinuerlig og tilpasset støtte, oppfølging og informasjon.

2. Familiene får ta avgjørelser som er til det beste for barnet

3. Barna og de unge får møtt sine behov gjennom sykdomsforløpet og behandlet smerter og symptomer som endrer seg.

4. Verdig avslutning av livet i verdige omgivelser med støtte underveis, også til familiene i etterkant så lenge det er behov.

Figur 1.1 
Forslagstiller Natasha Kjærstad Pedersen

Støttet av Astrid Rønsen

Medlemmer i Palliasjonsutvalget

\section{Kilder og vedlegg}

Foreningen for barnepalliasjon FFB, Informasjons og opplysningshefte i barnepalliasjon. 2014

Fraser et al. Life-Limiting Conditions in Children in the UK, Division of Epidemiology, University of Leeds, 2011

Cochrane H., Liyanage S., Nantambi R. Palliative Care Statistics for Children and Young Adults. Health and Care, Partnerships Analysis. Department of Health (utgiver)

Palliative Care Needs Assessment for Children. Department of Health and Children, the Irish Hospice Foundation (utgiver),

2005.

Psychological interventions for children and youth with serious somatic illness in primary care

Livets sluttfase - om å finne passende behandlingsnivå $\mathrm{og}$ behandlingsintensitet for alvorlig syke og døende

Som alle andre? Søsken til barn og unge med funksjonsnedsettelser https://samforsk.no/Publikasjoner/Som\%20alle\%20andre\%20WEB.pdf

Prevalence, Trends and Custody Among Children of Parents with Intellectual Disabilities in Norway http://onlinelibrary.wiley.com/doi/ 10.1111/jar.12304/abstract?systemMessage $=$ Wiley + Online + Library+will+be+unavailable+on+Saturday+17th+December+2016+at+09:00+GMT/+04:00+EST/ $+17: 00+$ SGT+for+4hrs+due+to+essential+maintenance.Apologies+for+the+inconvenience

Emotional Experiences Among Siblings of Children With Rare Disorders

Communication of illness related experiences of chronically ill children and the effect of Sisom, a computerized symptom assessment tool. Doktoravhandling Torun M Vatne .2011

https://parorendealliansen.no/2017/parorendeundersokelsen-2016-resultater-raske-fakta/ https://sykepleien.no/meninger/innspill/2016/ 01/ditt-barn-er-uhelbredelig-og-dodelig-syk

The state of hospice services in England 2014 to 2017 Findings from CQC's initial programme of comprehensive inspections of hospice services

http://www.ffo.no/globalassets/rapporter/generelt-om-likemannsarbeid.pdf

Abu-Saad Huijer H., Benini F., Cornaglia Ferraris P., Craig F., Kuttner L., Wood C., Zernikow B. (European Association of Palliative Care Taskforce for Palliative Care in Children). IMPaCCT: Standards for paediatric palliative care in Europe. European Journal of Palliative Care, 2007; 14:2-7.

A Palliative Care Needs Assessment for Children. The Irish Hospice Foundation (red.), Department of Health and Children, Ireland, 2005. Lastet ned 22. oktober 2007 fra www.dohc.ie/ publications/needs_assessment_palliative.html

Hynson J.L., Gillis J., Collins J.J., Irving H., Trethewie S.J. The dying child. How is care different? Medical Journal of Australia, 2003; 179:S20-S22.

Independent Review of Palliative Care Services for Children and Young People. Economic Study. Independent Review Team, Health Economics Consortium/Department of Health York, Storbritannia, 2007; Sluttrapport fra www.york.ac.uk/inst/yhec/downloads/ Final \%20Report- may07v1.pdf

Eaton, N. Children community nursing services. Models of care delivery. A review of the United Kingdom literature. Journal of Advanced Nursing, 2000; 32:49-56.

Ramnarayan P., Craig F., Petros A., Pierce C. Characteristics of death occurring in hospitalized children: changing trends. Journal of Medical Ethics, 2007; 33: 255-260.

A. Goldman, R. Hain, S. Lieben, Grunnbok i barnepalliasjon, 2016 Kommuneforlaget. 


\title{
Vedlegg 2
}

\section{Hospice som tiltak}

\author{
Dissens fra utvalgsmedlem Astrid Rønsen
}

\section{Utgangspunkt for dissensen}

Denne dissensen omhandler hospice som tjenestetilbud. Hospice-tilbud rettet mot pasienter og deres nærmeste i sen palliativ fase er tenkt som et supplement til ordinær helsetjeneste. Forslaget støttes av utvalgsmedlem Natasha Pedersen.

Dissensen og forslag til tiltak må ses i sammenheng med de problemstillingene og utfordringene som er tatt opp i denne NOUen i sin helhet, og retter seg særskilt mot kapittel 9 Organisering, struktur og kompetanse, kapittel 8 Palliasjon $i$ utdanning og kapittel 11 Frivillighet. Vi vil trekke fram følgende momenter i mandatet som vi knytter dissensen til:

Utredningen skal også bygge på erfaringer fra andre land, for eksempel om hospice, og det må vurderes om erfaringene er relevante for Norge.

Utvalget skal gi forslag til hvordan vi kan inkludere brukeres, pårørendes og frivilliges erfaringer og kunnskap for å tilrettelegge for individuelle behov gjennom hele sykdomsforløpet.

Barn og unge som pårørende skal inngå $\mathrm{i}$ utredningsarbeidet. Barn og unge er sårbare grupper, og må få en spesiell oppmerksomhet $\mathrm{i}$ utvikling av tjenestene. ${ }^{1}$

Innenfor rammen av palliative tjenester skal utvalget også drøfte når disse pasientene bør regnes for utskrivningsklare eller ikke, slik at man unngår uverdige utskrivninger motivert $\mathrm{i}$ en kommunal betalingsplikt.

På eget initiativ kan utvalget også reise spørsmål og foreslå tiltak med sikte på å styrke helse- og omsorgstjenestene til personer med behov for lindrende behandling og omsorg.

Utvalget legger som en felles premiss at hospicefilosofi skal danne grunnlaget for praksis i pallia-

1 Hospice for barn og deres familier blir fremsatt i egen dissens og blir derfor ikke omtalt særskilt i denne dissensen. sjonsfeltet. Utredningen tar utgangspunkt i Verdens helseorganisasjons definisjon av «palliative care», jf. kapittel 4 Verdier. Hele utvalget slutter seg også til framstillingen av manglene i dagens tjenestetilbud og de utfordringene vi står overfor $i$ framtida som samfunn og helsetjeneste, jf. kapittel 5 Perspektiv. Det er også bred enighet om utredningens forslag til tiltak for å styrke tilbudene på palliasjonsområdet $\mathrm{i}$ den ordinære spesialist- og kommunehelsetjenesten. Hele utvalget mener det er nødvendig for å nå vårt felles mål om bedre behandling og omsorg for denne utredningens målgruppe.

Det som ligger til grunn for denne dissensen, er uenighet om virkemidler. Forslagsstiller har ikke fătt flertall for følgende tiltak: À bygge opp intermediære strukturer og innhold (hospice) som retter seg mot pasienter og deres nærmeste $\mathrm{i}$ sen palliativ fase, hvor den kroniske inkurable sykdomstilstanden har medført stort hjelpebehov av både praktisk, pleiemessig, mellommenneskelig og behandlingsmessig art.

I kapittel 9 Organisering, struktur og kompetanse står følgende tekst, som er noe av grunnlaget for denne dissensen:

Palliative tjenester bør være en del av de ordinære helse- og omsorgstjenestene for å sikre helhetlige og koordinerte forløp og likeverdig behandling. De palliative tjenestene, herunder palliasjon i livets aller siste fase, anbefales ikke organisert som en særomsorg organisert på siden av de ordinære helse- og omsorgstjenestene.

Slik vi forstår flertallsinnstillingen, hører ikke egne hospiceinstitusjoner inn $\mathrm{i}$ den «norske modellen» (jf. kapittel 9). Vi mener at det er urimelig å utdefinere alle tilbud fra frivillige ideelle organisasjoner, da vi i Norge har lang tradisjon for å integrere mange slike tilbud både organisatorisk og finansielt. Til forskjell fra flertallsinnstillingen, som i all hovedsak bygger på tiltak innen rammene av spesialist- og kommunehelsetjenesten, mener forslagsstiller til denne dissensen at det vil være formålstjenelig med særskilte organisasjoner/institusjoner som supplerer tilbudene i 
øvrig helsetjeneste. Frittstående hospice med hjemmehospice, dag- og døgnfunksjon vil kunne gi pasienter og pårørende større valgfrihet og bidra til mer individuelt tilpassede og fleksible tilbud. Slike organisasjoner vil samtidig kunne fungere som kompetansesentre med særlig ansvar for erfaringsbasert kunnskapsutvikling og deling/formidling rettet mot kommunesektoren.

\section{Hva er hospice?}

Hospice som filosofi og idé har sin opprinnelse i omsorg for døende og deres nærmeste. Internasjonalt knyttes hospice til tjenestetilbud for pasienter og pårørende i nettopp denne fasen (jf. kapittel 13). I dissensen brukes betegnelsen hospice om konkrete behandlings- og omsorgstilbud som er forpliktet til å virkeliggjøre tekningen som denne filosofien bygger på:

1) Å dø er først og fremst en menneskelig prosess som berører den som er døende og de nærmeste: Hospice er person- og familiesentrert. Det er deres livshistorie, verdier og håp - det som gir mening, som er utgangspunktet for våre tjenester uansett hvor pasienten måtte befinne seg. Å legge til rette for at pasienter og de nærmeste får være der de ønsker å være den siste tiden, blir dermed viktig.

2) Hospice bygger på humanistiske verdier hvor en helhetlig forståelse av mennesket, og en forståelse av mennesket som en del av sin «familie», er utgangspunkt og rettesnor for hjelpen som ytes.

3) Døden er ikke medisinsk. Slik sett avviker hospice fra tradisjonell helsetjeneste som ofte er styrt av biomedisinsk logikk, hvor den tradisjonelle tenkemåten er bygd på å definere problemer for så å løse disse.

4) Det sentrale i hospice er å møte, romme og om mulig bidra til å lindre pasientens lidelse uavhengig av diagnose. Lidelse er mer enn et symptom - det være seg fysisk, emosjonelt, sosialt, eksistensielt eller åndelig betinget og lidelsen har mange uttrykk (total pain). Et hospice skal ha en solid tverrfaglig kompetanse og bevisst bygge en tverrfaglig kultur som kan møte pasienter og pårørendes individuelle behov.

5) Kompleksiteten med hensyn til pleieutfordringer i kombinasjon med sykdomsplager er varierende og gjør at særskilt kompetanse kan være nødvendig i sen palliativ fase. Solid symptomlindringskompetanse basert på helhetsforståelse og tverrfaglighet er et kjennetegn ved hospicekulturen.
6) Livskvalitet er en uttalt intensjon innen «palliative care». Knyttet til omsorg for døende kan dette spesifiseres som:

1. å lindre sykdomsplager/plagsomme symptomer

2. om mulig å forebygge tilleggsproblemer og

3. å øke pasientens velvære

Hva som bidrar til lindring, mening og velvære er høyst individuelt, og en bred tilnærming er derfor avgjørende for å møte pasienten og familiens ønsker og behov.

7) Døden har og tar sin tid. Det innebærer at støtte underveis fra omgivelsene (eget nettverk, profesjonelle og frivillige hjelpere) må organiseres slik at de kan møte familier med kortere og lengre forløp. Finansieringsordninger må sikre kontinuitet som trygger de berørte. Hospice må samspille aktivt med andre eksisterende tjenestetilbud.

8) For å gi hverdagen meningsinnhold og ivareta pasienter og de nærmeste underveis, er det viktig å understøtte hverdagslivets aktiviteter, det å opprettholde rutiner, vaner og interesser for å styrke personens indentitet og rolle. Frivillig innsats et viktig og avgjørende bidrag i samspill med profesjonell kompetanse. Frivillige bringer det normale livet inn i hospice og bidrar til å normalisere døden ute i samfunnet.

9) Sanselighet og livsutfoldelse, betydningen av fysiske rammer, kultur og estetikk er en vesentlig del av omgivelsene som tilbys pasienter og deres nærmeste når de ikke kan være i sine egne hjem. Behov for fellesskap og behov for private rom er forhold som også må tas hensyn til når hospice som bygg skal utformes.

10) Kronisk syke pasienter har sammensatte erfaringer. Å bidra til at pasienter opplever å gjenvinne og bevare sin integritet kan være avgjørende for hvordan den siste tiden leves. Det er i møte med sine nærmeste og profesjonelle og frivillige hjelpere dette kan være mulig.

11) Støtte til de nærmeste etter dødsfallet er en naturlig del av den helhetsforståelsen som kjennetegner hospice.

(Kirk, 2014, Rønsen og Jakobsen, 2016)

\section{Hjemmehospice, dag- og døgnhospice}

Det har vært en uttalt premiss fra regjeringens side (jf. mandatet for dette NOU-arbeidet), at flere ikke bare ønsker å tilbringe mer tid hjemme, men at flere også ønsker å dø i eget hjem. For å imøtekomme dette trengs betydelige tiltak for å trygge pasienter og pårørende. Her mener forslagsstiller 
at hospicetilbud som kan supplere de ordinære tjenestetilbudene, vil kunne spille en viktig rolle. Hospicetilbud vil kunne bidra til at flere får mulighet til å være hjemme lenger enn i dag, ved at tilbud fra hjemmesykepleie/fastlege suppleres av hospicetjenester. Hjemmebaserte hospicetjenester vil også kunne gi hjelp og støtte til pasienter og deres pårørende som er innstilt på og føler seg trygge nok til å fortsette helt til slutt. I mange tilfeller vil relativt enkle hjelpetilbud kunne avverge uønskede og unødvendige sykehusinnleggelser og sykehjemsplassering av pasienter som aller helst ville vært hjemme.

Liggetid på sykehus har blitt stadig kortere, og dette er også i tråd med dagens helsepolitiske mål. Samtidig som sykehusene tilbyr mer behandling (kurativt, livsforlengende og palliativt), skrives det ut pasienter med mer kompliserte pleieog behandlingsutfordringer. Dette medfører stort press på hjemmetjenestene og sykehjemmene (Trier, 2017, Svendsen, 2017). Hospice med dagog døgntilbud vil kunne bidra til å gi noen av de mest ressurskrevende pasientene et mer fullverdig tilbud mot slutten av livet. Hospicetilbudene vil kunne sørge for god behandling og pleie for pasienter med ulike grunnsykdommer som kreft, progredierende nevrologiske tilstander og kroniske hjerte- og lungelidelser i sen fase. Hospice vil både basere seg på anerkjent kunnskap om symptomlindring og individualisert omsorg der det tilrettelegges for de særskilte ønskene og behovene som pasienter og deres nærmeste har.

\section{Tverrfaglighet og frivillighet}

Et kjennetegn ved hospice er en tverrfaglig omsorgskultur hvor frivillige har en selvfølgelig plass og funksjon. I denne NOUen vises det til at frivillighet ennå ikke har fått betydelig plass innen det palliative feltet i Norge (if. kapittel 11). Vi har imidlertid noen gode eksempler knyttet til omsorg for døende i Norge. Organisasjonen Termik, har organisert frivillige til alvorlig kronisk syke og deres pårørende. Deres opplegg for frivillige har vært et eksempel for andre og fătt «avleggere» flere steder i landet. Fransiskushjelpen, som er tilknyttet den katolske kirke i Oslo, har vel 110 frivillige knyttet til sin virksomhet. Røde Kors har både gjennom Verdighetssenteret i Bergen og «våkekone»-prosjekter bidratt til frivillighet innen feltet. Dette er alle gode eksempler på at frivillige organisasjoner har klart å skape og vedlikeholde slike tilbud, som kan spille på lag med og supplere det ordinære offentlige tjenestetilbudet. Mangel på bidrag fra frivillige er imidlertid ikke et pro- blem i vestlige land hvor hospice har hatt sin selvfølgelige plass innen omsorg for alvorlig syke og døende. Eksempelvis er det 125000 personer som arbeider frivillig på hospice i Storbritannia (if. kapittel 13). Erfaringer fra Danmark viser at frivillighet har gode vekstvilkår innen hospiceinstitusjoner også der (Hospice Forum Danmark, 2012).

Vi har ikke klart godt nok å etablere en tverrfaglig kultur i det palliative fagfeltet i Norge. Dette er en mangel som er særlig merkbar i de delene av kommunehelsetjenesten som har ansvar for tilbud til pasienter som bor i eget hjem eller i kommunal boenhet. Hospiceorganisasjoner med tverrfaglig bemanning supplert med frivillig innsats, vil kunne bistå den kommunale helsetjenesten med opplæring av frivillige. Hospicene vil også kunne fungere som hospiteringsarenaer for sykepleiere, leger, fysioterapeuter, ergoterapeuter og prester/ livsynsveiledere og andre som møter pasienter og pårørende i livets siste fase.

\section{Hospice er kostnadseffektivt og gir god kvalitet}

Dette dissensforslaget om at det bør satses på frittstående hospice, er begrunnet med vekt på både behandlings- og omsorgsfilosofien, men også med at denne typen institusjoner vil kunne drive mer kostnadseffektivt enn lindrende enheter i ordinære sykehjem. En rapport fra Oslo Economics (se vedlagt trykt vedlegg) viser at døgnprisen i frittstående hospice ligger lavere enn døgnopphold på lindrende enheter på sykehjem, og betydelig lavere enn opphold i sykehus.

Det har vist seg vanskelig å opprettholde virksomhet med god måloppnåelse ved mange lindrende enheter i sykehjem (Rundhovde, 2011). Noe av forklaringen kan være at det dreier seg om små enheter der det er vanskelig å sikre stabilt kjernepersonale. Det har også vist seg vanskelig å integrere og sikre tilgang til ønsket tverrfaglig kompetanse i små lindrende enheter i ordinære sykehjem. Små lindrende enheter i sykehjem og palliative senger blir lite robuste. Stikkord her er manglende tverrfaglighet, varierende legedekning og en sårbarhet fordi sykepleierressursene ikke står i forhold til de komplekse palliative faglige utfordringene. En generell sykepleiermangel i sykehjem fører også til at sykehjemmets behov for kompetanse og ressurser må dekkes opp internt. For sykehjemsledelsen vil det være vanskelig å skjerme en liten enhet når det er stort press på ressursene $\mathrm{i}$ andre deler av sykehjemmet.

Hospice har vist seg å få tilgang til dedikerte fagpersoner. Hospicevirksomhet har et klart og 
avgrenset fokus som gjør at personalet kan konsentrere seg om pasienter og pårørende i en spesiell livssituasjon. Ifølge tilsynsrapport som omhandler kvalitet på hospicetilbud i England, er det personalet som er den viktigste kvalitetsindikatoren. Hospice, der personalet har «mengdetrening» og evner å møte krevende situasjoner sammen med pasient og pårørende, framheves som et kjennetegn ved hospice i Storbritannia, og som en av grunnene til at hospice skårer så høyt på kvalitetsundersøkelser knyttet til «end-of-life care». I denne tilsynsrapporten ble tilbudet til 25 prosent av hospicene bedømt som «outstanding» og 70 prosent som «good» (Care Quality Commission, 2017). Til sammenlikning ble tilbudet ved kun 6 prosent av sykehusene og 2 prosent av sykehjemmene bedømt som «outstanding». Hospice bedømmes høyt når det gjelder pasienters tilfredshet også knyttet til norske forhold (Sandsdalen, 2016).

\section{Hospice som tyngdepunkt for kompetanse til} kommunene

Det har vist seg at det har vært vanskelig å nå samhandlingsreformens intensjon om sammenhengende tjenester for pasienter med sammensatte lidelser og behov for tjenester på ulike nivåer i helse- og omsorgstjenesten. Mye kan tyde på at kommunehelsetjenesten ikke har evnet å bygge opp den nødvendige kompetansen og de tjenestetilbudene som reformen forutsetter. All erfaring tilsier at gjennomgripende endringer i den samlede norske helsetjenesten i beste fall vil være en tidkrevende prosess, og med mange feilskjær underveis. Det kan ta lang tid før nye mål og ambisjoner på palliasjonsområdet blir realisert på lokalt nivå. Vi mener at en skrittvis satsing på hospicetilbud vil kunne tilføre mer dynamikk i utviklingen av palliative tjenester i kommunehelsetjenesten. Fullt utviklede hospiceorganisasjoner vil både kunne bidra med konkrete, pasientrettede tilbud, utvikling av erfaringsbasert kunnskap, opplæring og annen formidling. Det understrekes av forslagsstiller at hospice ikke er ment til fortrengsel for tilbud i den ordinære offentlige helsetjenesten. Vi mener at hospice vil kunne samspille med andre tilbud og bidra til at flere får gode tilbud på en kostnadseffektiv måte.

Betydning av frivillige ideelle organisasjoner i norsk helsetjeneste

Utvalget har gjennom utredningen vist at vi har stor ambisjoner med hensyn til å utvikle og løfte det palliative feltet på alle nivåer i hele landet. Palliasjon har vært et satsingsområde gjennom et drøyt tiår. For å nå ønsket målsetting, må vi tenke løsninger både på kortere og lengre sikt. For å lykkes bedre, ser forslagsstiller av dissensen det som vesentlig å satse på miljøer som har lykkes med å skape gode kulturer. Her mener forslagsstiller at hospicetjenester drevet av private ideelle organisasjoner kan virke som en katalysator på en utvikling som helsetjenesten og samfunnet trenger. Et godt eksempel er Fransiskushjelpens hjemmehospice i Oslo, som bygger på 40 års erfaring med å være et supplement til det ordinære offentlige tjenestetilbudet i kommunen. De har en kjernegruppe av profesjonelle medarbeidere, som sammen med 110 frivillige driver Norges største sorgstøttearbeid, tilbyr familiehjelp og har frivillige som avlaster pårørende til pasienter som bor hjemme i siste del av livet. A bygge videre på disse erfaringene og videreutvikle det til også å omfatte et utvidet døgntilbud i Oslo, er viktig og nødvendig. I Oslo er eksempelvis sengekapasiteten for spesialisert døgntilbud til alvorlig syke i siste del av livet knapt en tredel av det som anbefales internasjonalt.

Det finnes flere miljøer med engasjement og pågangsmot som ønsker å etablere hospicetilbud i andre byer og på mindre steder i Norge. Disse miljøene representerer et potensial og er en uforløst ressurs som det norske samfunnet og helsetjenesten trenger.

\section{Tiltak}

- Etablere hospice ulike steder i landet med forsterket hjemmetilbud, dag- og døgnfunksjon 250 døgnplasser innen 5-10 år

- En del av spesialisthelsetjenesten (statlig finansiert), men lagt utenfor sykehusets organisering og lokalisering, avtale via helseregionene

- Prøve ut ulike modeller som skal evalueres

- Utvikle egnede finansieringsordninger

- Hospice som «fyrtårnfunksjon» skal fungere som utviklings- og kompetansesenter, aktivt samarbeide med kommunale tjenester; hospiteringsfunksjon, utviklings- og forskningsprosjekter

\section{Litteratur}

Care Quality Commission (2017): The state of hospice services in England 2014-2017, 2017.

Hospice Forum Danmark (2012): Frivillige på hospice. Nordisk Frivilligprosjekt. Arco Grafisk $\mathrm{A} / \mathrm{S}$. 
Kirk J.W. og Jennings, B. (red.) (2015): Hospice Etichs: Policy and practice in palliative care. Oxford University Press.

Oslo Economics (2017): En kostnadsanalyse av hospice i Norge. Oslo: Oslo Economics.

Rønsen, A. og Jakobsen, R. (2016): Å fullføre et liv. Oslo: Gyldendal Akademisk.

Runhovde, G. (2011): «Skjørt og personavhengig»: tverrfaglig samarbeid på tvers av profesjonelle grenser. En undersøkelse ved palliative enheter på sykehjem. Masteravhandling. Fredrikstad: Høgskolen i Østfold.

Sandsdalen, T. mfl. (2016): Patients' perceptions of palliative care quality in hospice inpatient care, hospice day care, palliative units in nursing homes, and home care: a cross-sectional study, BMC Palliative Care 15(1):79.

Svendsen, S J et al. (2017): Døende pasienter i sykehjem: Sykepleiere gjør «mer av alt» og er «alene om alt», Sykepleien

Trier, Ellen Lykke (2017): «Hospice møter døendes helhetlige behov», Sykepleien

\section{Undervedlegg 1}

\section{En kostnadsanalyse av hospice i Norge}

\section{Utarbeidet av Oslo Economics}

\section{Om Oslo Economics}

Oslo Economics utreder økonomiske problemstillinger og gir råd til bedrifter, myndigheter og organisasjoner. Våre analyser kan være et beslutningsgrunnlag for myndighetene, et informasjonsgrunnlag i rettslige prosesser, eller et grunnlag for interesseorganisasjoner som ønsker å påvirke sine rammebetingelser. Vi forstår problemstillingene som oppstår i skjæringspunktet mellom marked og politikk.

Oslo Economics er et samfunnsøkonomisk rådgivningsmiljø med erfarne konsulenter med bakgrunn fra offentlig forvaltning og ulike forsknings- og analysemiljøer. Vi tilbyr innsikt og analyse basert på bransjeerfaring, sterk fagkompetanse og et omfattende nettverk av samarbeidspartnere.

\section{Helse og velferd}

Oslo Economics tilbyr helseøkonomiske analyser og samfunnsøkonomisk utredning for departe- menter, direktorater, helseforetak, organisasjoner $o g$ industrien.

Vi kjenner offentlige veiledere og har vi bred erfaring med å identifisere og vurdere virkninger av ulike tiltak. Vi prissetter nyttevirkninger og kostnader, eller vurderer virkninger kvalitativt dersom prissetting ikke lar seg gjøre.

\section{Problemstilling og metode}

På oppdrag fra Hospiceforum Norge har Oslo Economics utarbeidet et notat for å synliggjøre konsekvensene av å utvikle et regionalt tilbud av hospicesentre for pasienter i livets sluttfase. Hospice utgjør et supplement til den øvrige palliative omsorgen i primær- og spesialisthelsetjenesten og øke pasientenes valgfrihet.

Hospiceforum Norge er en frivillig livssynsnøytral organisasjon som arbeider for å bedre rammene for alvorlig syke, døende og deres nærmeste.

Vurderingene $\mathrm{i}$ analysen er basert på publisert litteratur, offentlig tilgjengelig statistikk og rapporter, samt intervjuer med fagressurser. Hovedformålet med denne analysen har vært å fremskaffe bedre informasjon om de økonomiske virkningene av palliativ omsorg i primær- og spesialisthelsetjenesten i Norge.

Det finnes i dag lite detaljert informasjon om kostnader og ressursbruk i palliativ omsorg i Norge. I denne rapporten har vi likevel gjort et forsøk på å utarbeide anslag basert på de få datakildene som finnes. Vi understreker at anslagene er beheftet med usikkerhet og at termen hospice benyttes for tjenester med ulik form og bemanningsgrad. Hospiceforum Norge anser hospice som sentra som består av dag, døgn og ambulant tjeneste. I denne rapporten er det særlig sett på kostnadene for ulike varianter av døgnfunksjonen.

Analysene er utarbeidet av Erik Magnus Sæther (prosjektleder), Christoffer Bugge og Ivar Sønbø Kristiansen i perioden oktober - primo november 2017.

\section{Hva er hospice og hvem er det relevant for?}

\subsection{Hospice som tjeneste og filosofi}

De behov mennesker har i livets sluttfase kan dekkes ulike steder: sykehus, sykehjem/institusjon, hospice eller i hjemmet. Vi vet at en del av de som dør i sykehus og sykehjem, ville ha ønsket å dø hjemme eller i en annen omsorgsform. En utfordring med dagens tjenestetilbud er derfor at pasienter og pårørende ikke i stor nok grad kan velge den omsorgsform de ønsker for livets sluttfase. 
Konsekvensen blir ofte omsorg i somatiske akuttsykehus som både er unødvendig kostbare og mindre egnet. Sykehusenes primæroppgave er knyttet til utredning og behandling, og en sluttfase der kan lett medføre mer diagnostikk og teknologisk behandling enn det pasienten egentlig ønsker. Et alternativ til innleggelse i sykehus eller sykehjem kan være hospice-omsorg i livets sluttfase.

Et hospice er et hjem for kronisk syke eller døende pasienter. Behandling på hospice kjennetegnes av at den hverken tar sikte på å fremskynde eller utsette døden, men derimot på å avhjelpe behov og problemer både av fysisk, psykisk, sosial og åndelig karakter hos den døende og de pårørende. Fravær av fokus på diagnostikk og teknologisk behandling og fokus på pasientens opplevde behov er karakteristisk.

I møtet med livsavslutning og død skal den enkelte pasient og de pårørende møtes med respekt for egne verdier og livsforståelse, der det legges til rette for livsutfoldelse, samvær, fellesskap og aktivitet etter pasient og pårørendes egne valg.

Hospice legger vekt på bruk av frivillige medarbeidere som kan supplere de ansatte i den samlede innsats, ikke minst i sosiale aktiviteter og fellesskap.

Et hospice innehar en gjennomtenkt arkitektur og estetikk, der livet kan leves i størst mulig frihet for pasienter og pårørende i egnede rom for fellesskap, aktivitet, stillhet og refleksjon. Målet er i henhold til Hospiceforum ${ }^{2}$ at pasienten, sammen med deres nærmeste, skal få en så god avslutning på livet som mulig. Dette innebærer trygghet for at man får kvalifisert hjelp av kompetente perso-

2 Se ytterlige beskrivelse på www.hospiceforum.no ner; fleksibilitet, ved at vi får relevant hjelp ut fra skiftende og ulike behov; og forutsigbarhet, at vi som syke og pårørende vet at hjelpen er der når vi trenger det, og at den er der over tid. Flere peker på at disse prinsippene også er til god hjelp for de pårørende og bidrar til at de takler både den siste tiden før døden og tiden etterpå, med retur til hverdagen og arbeidslivet på en bedre måte.

Et hospice kan ha ulikt innhold både mellom institusjoner i samme land og mellom land. I USA dekker de offentlige forsikringssystemene Medicare og Medicaid så vel som mange private poliser «hospice services». Tjenestene kan imidlertid bli tilbudt i sykehus, sykehjem og egne hospiceenheter. Danmark har i dag hospice i alle amt, altså fylker. Uhelbredelig syke kreftpasienter har en lovfestet rett til opphold på hospice. Danmark arbeider for å doble antall hospiceplasser, slik at pasientgruppene med alvorlig hjerteog lungesyke også kan bli inkludert. I Danmark har arkitekter, pasienter, pårørende og fagfolk sammen skapt modellen for «Det Gode Hospice i Danmark». Hospiceforum Norge anser hospice som sentra som består av dag, døgn og ambulant tjeneste. Som nevnt ser vi i denne rapporten særlig sett på kostnadene for ulike varianter av døgnfunksjonen.

I Norge har vi hospice i kommunehelsetjenesten som Hospice Stabekk og i spesialisthelsetjenesten som Hospice Lovisenberg. Institusjonene har noe ulike pasientgrupper, ulik liggetid og ulike budsjettrammer. Bemanningsfaktor og bemannings-sammensetningen $i$ de flerfaglige teamene har for eksempel stor betydning for kostnaden.

I bemanning av hospice argumenteres det for verdien av flerfaglighet og en robust bemanning. Det pekes på at hospice fordrer optimal tverrfag-

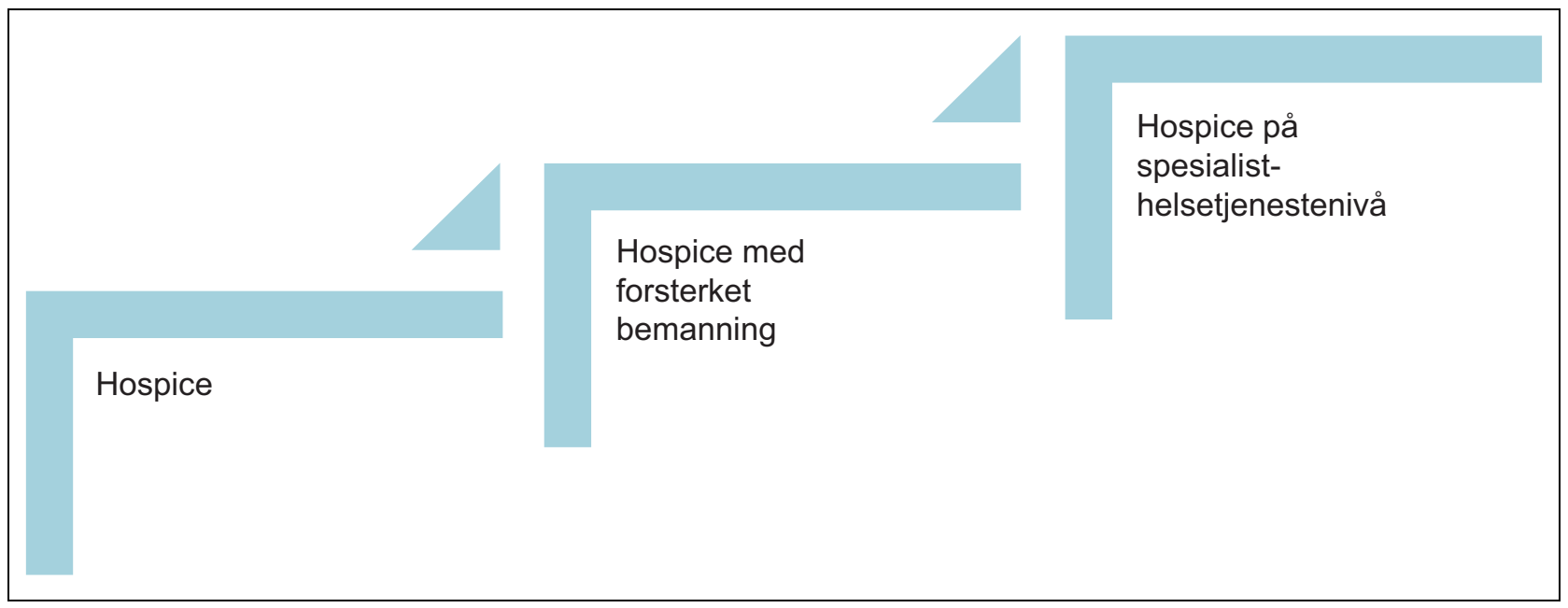

Figur 2.1 Hospice kan ha ulike roller og bemanningsnivå 
lig kompetanse, omfattende både medisin, sykepleie, psykologi, sosialt arbeid, interesse for og vekt på pasientens interesser og ressurser, fysioterapi, ernæring, teologi/religion, sosiologi, kunst og kultur. Dette har konsekvenser for kostnadene og en slik bredde i tilbudet er ikke lagt inn i varianten til venstre, men i mellomalternativet, hospice med forsterket bemanning. I eksempelcaset (beskrives senere) løste man de utvidede funksjonene ved å knytte til seg andre tjenester og benytte frivillige. I varianten til høyre styrkes tilbudet med helsetjenester på spesialisthelsetjenestenivå. Dette kan være aktuelt i en mer begrenset tidsperiode og for pasienter med særlige behov.

\subsection{Omsorgsformer i Norge}

I Norge dekkes behovet for omsorg i livets sluttfase på ulike måter. Et betydelig antall pasienter dør i vanlig sykehusavdeling eller sykehjemsavdeling. I Helsedirektoratets rapport (IS-2278, 2015) beskrives dagens tjenester og finansieringen av disse.

\subsubsection{Kommunal helse-og omsorgstjeneste}

Grunnleggende palliasjon er integrert i virksomheten i kommunens helse- og omsorgstjenester, og dekkes derfor via virksomhetenes vanlige finansieringsordninger. Det finnes ingen spesifikk finansieringsordning for palliativ behandling i sykehjem. Det er dermed opp til den enkelte kommune å prioritere et eget palliativt tilbud. Kommunal frihet ved utformingen av omsorgstjenesten betyr stor variasjon i palliative tjenester fra kommune til kommune. I alt 44 sykehjem hadde i 2015 en lindrende enhet, totalt er det 272 senger. I tillegg er det 82 sykehjem som hvert har tre lindrende senger eller mindre, i alt 130 lindrende senger. Ved mindre lindrende enheter kan det være et problem å sikre en stabil bemanning og å holde på kompetansepersonell. De får ikke den «mengdetrening» som hospice eller en stor palliativ enhet gir og det gir en slitasje å være alene om ansvaret. Videre er det er vanskeligere å skjerme de ansatte fra å måtte dekke opp behovet på andre poster ettersom de i utgangspunktet har en bedre bemanning enn andre sykehjemsposter.

Mer enn 200 kommuner har kreftkoordinator i regi av Kreftforeningen. Hertil kommer noen sykepleiere som i ren kommunal regi er koordinatorer i lindrende omsorg/kreft.

Palliative enheter i sykehjem er dyrere å drifte enn vanlige sykehjemsavdelinger. Drift av en lin- drende enhet krever mer og bedre kvalifisert personell, inkludert økte legetjenester, enn en ordinær sykehjemspost. I tillegg kan medikamenter, smertekassetter, infusjonsutstyr og andre forbruksvarer medføre store kostnader. Beregninger utført i 2006 viste at en seng i en palliativ sykehjemsenhet var ca. dobbelt så dyr som en vanlig seng i sykehjem (Helsedirektoratet IS-2278, 2015). En kartlegging gjort i forbindelse med fagrapporten (Grunnlag for IS-2278) viser det samme. Noen lindrende enheter, både kommunale og interkommunale, er definert som halvannenlinjetjeneste og mottar delfinansiering fra det lokale helseforetaket.

\subsubsection{Spesialisthelsetjeneste}

I sykehus er grunnleggende palliasjon en del av den ordinære virksomheten og dekkes av de vanlige finansieringsordningene.

Helsedirektoratets fagrapport IS-2278 anfører at 40 helseforetak har et palliativt senter hver med ambulerende palliativt team. Disse teamene har en viktig funksjon i samhandlingen mellom nivåene $\mathrm{i}$ helsetjenesten. 21 av de palliative sentrene har også palliativ enhet, med til sammen 113 senger.

Spesialisert palliasjon får en tilleggsfinansiering per pasientopphold gjennom en egen tilstandskode, «Behandling ved palliativt senter» (kode Z51.50) (117). Betingelsene for å bruke denne koden er at sykehuset har opprettet et eget, organisert palliativt tilbud i form av et palliativt senter med et palliativt team, eventuelt en palliativ enhet, $o g$ at senteret fyller gitte kriterier i oppfølgingen av pasientene. Tilstandskoden kan brukes både ved innleggelser og ved dagbehandling, men ikke ved polikliniske konsultasjoner. Under visse betingelser kan koden også brukes ved tilsyn i pasientens hjem. Koden kan benyttes uavhengig av om pasienten er innlagt på en av sykehusets «vanlige» avdelinger og får tilsyn fra teamet, eller om pasienten er innlagt på den palliative enheten.

\subsubsection{Frivillige}

Helsedirektoratet (IS-2278, 2015) peker på at frivillige kan benyttes både $\mathrm{i}$ institusjons- og hjemmebasert omsorg. Frivillige skal være et supplement til fagpersonell og skal ikke delta i medisinskfaglig behandling, stell eller pleie. Frivillige skal ha opplæring og oppfølging i tjenesten. Selv om mange virksomheter innen lindrende behandling benytter frivillige, er muligheter for en større 


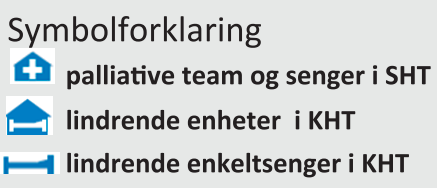

Figur 2.2 Oversikt over palliative team og palliative senger (121)

Kilde: Figur hentet fra Helsedirektoratet (IS-2278)

satsning til stede. Frivillige er med på å få «normaliteten» og «verden» inn i institusjonene og bærer med seg viktige erfaringer ut i samfunnet. Å være frivillig for alvorlig syke og døende kan være både utfordrende og meningsfylt. For eksempel har Hospice Stabekk i Bærum kommune 10-15 frivillige som følges opp av en sykepleier med ansvar for gruppen.

I kostnadsanalysen har vi ikke regnet arbeidsinnsatsen fra de frivillige som en kostnad for samfunnet. Dette fordi det er individer som søker om å få være frivillig, og vi legger derfor til grunn at det er slik de ønsker å benytte fritiden sin.

\section{3 Økonomisk evaluering av hospice}

Helsedirektoratets fagrapport IS-2278 er basert på systematisk søk i forskningslitteraturen, men sier lite om effekt og kostnadseffektivitet. En oversiktsartikkel om den internasjonale litteraturen, konkluderer at hospice gir mer tilfredse pasienter og pårørende enn alternative omsorgsformer (B Candy. Hospice care delivered at home, in nursing homes and in dedicated hospice facilities: A systematic review of quantitative and qualitative evidence. Int J Nurs Stud 2011; 48: 121-33). Kvaliteten på forskningen var imidlertid moderat.
I en amerikansk studie av pasienter med terminal føflekkreft fant forfatterne at hospice care økte levetiden og reduserte «end-of-life» costs (J Huo et al. Survival and cost-effectiveness of hospice care for metastatic melanoma patients. Am J Manag Care 2014; 20: 366-73). Da amerikansk helsetjeneste er svært forskjellig fra norsk, kan konklusjonen neppe overføres til norske forhold.

Stortinget behandlet i 2017 Stortingsmelding 34 (2015-16) - Verdier i pasientens helsetjenesteMelding om prioritering. Meldingen slår fast at effekten av et helsetiltak, tiltaket kostnader og tilstandens alvorlighet skal avgjøre om den offentlige helsetjeneste skal tilby tiltaket. Effekten av tiltaket skal som hovedregel måles i såkalte kvalitetsjusterte leveår (engelsk: quality adjusted life years - QALYs). Et helsetiltak kan ha effekt både ved at pasienten lever lengre og/eller får høyere livskvalitet. Hospice skal per definisjon ikke påvirke livslengde, men forbedre livskvalitet. Sistnevnte effekt er imidlertid kortvarig da oppholdet typisk varer fra dager til noen uker. Effekten målt i QALYs blir derfor liten. Den engelske filosofen Hughes hevder derfor at hospice-tjenester aldri vil være kostnadseffektive i snever forstand, men argumenterer for at en holistisk («atomic») tilnærming gjør det økonomiske paradigmet irrelevant 
(Hughes-H. Palliativ care and the QALY problem (Health Care Analysis 2005; 13: 289-301). De amerikanske økonomene Tony Yang og Margaret Mahon argumenterer derimot med at «palliative care» har lavere kostnader enn «non-palliative care» fordi sistnevnte betyr mindre bruk av cellegift, billeddiagnostikk og tekniske intervensjoner (Yang-YT, Mahon-MM. Palliative care for the terminally ill in America: the consideration of QALYs, costs and ethical issues. Med health care and philos 2012; 15: 411-16). Dersom dette skulle være tilfelle når man sammenligner hospice med andre typer omsorg ved livets slutt, vil hospice kunne fremstå som «kostnadseffektivt».

\subsection{Pasienter i Norge}

I dag dør de fleste i sykehus, på en pleie-/omsorgsinstitusjon eller hjemme (fig. 2.3). Av de totalt 40
686 dødsfallene i Norge i 2015 døde 12798 (31\%) på sykehus, mens 19373 (48\%) døde i en pleie-/ omsorgsinstitusjon. Bare 5830 (14\%) mennesker døde i eget hjem i 2015 (fig. 2.4).

I motsetning til i Norge avslutter i Danmark mange livet på egne hospice. Danmark har i dag i overkant av 250 hospiceplasser. Danmark har også en betydelig høyere andel død i hjemmet enn i Norge (24\% mot $14 \%$ i Norge). I figuren under er hospice inkludert i kolonnen for sykehus for Danmark. Vi har ikke tilgang til tilsvarende inndeling av statistikken for Norge.

De fleste ønsker å være hjemme ved alvorlig sykdom og å dø hjemme (Helsedirektoratet IS2278, 2015). Medisinske, pleiemessige og bostedsmessige forhold kan imidlertid hindre at ønskene blir realisert. Sykehus og sykehjem har begrensninger ved at den døende og de nærmeste

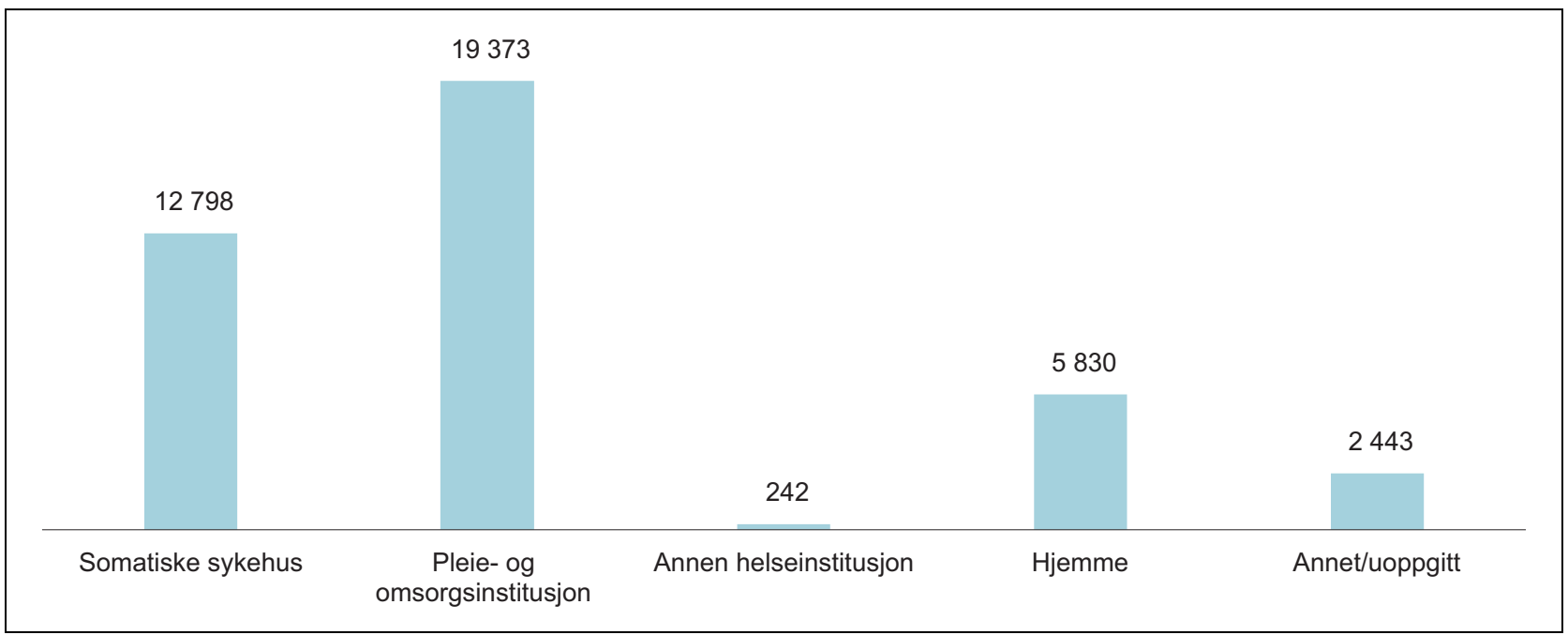

Figur 2.3 Antall dødsfall i Norge etter dødssted, 2015

Kilde: Dødsårsaksregistret (FHI)

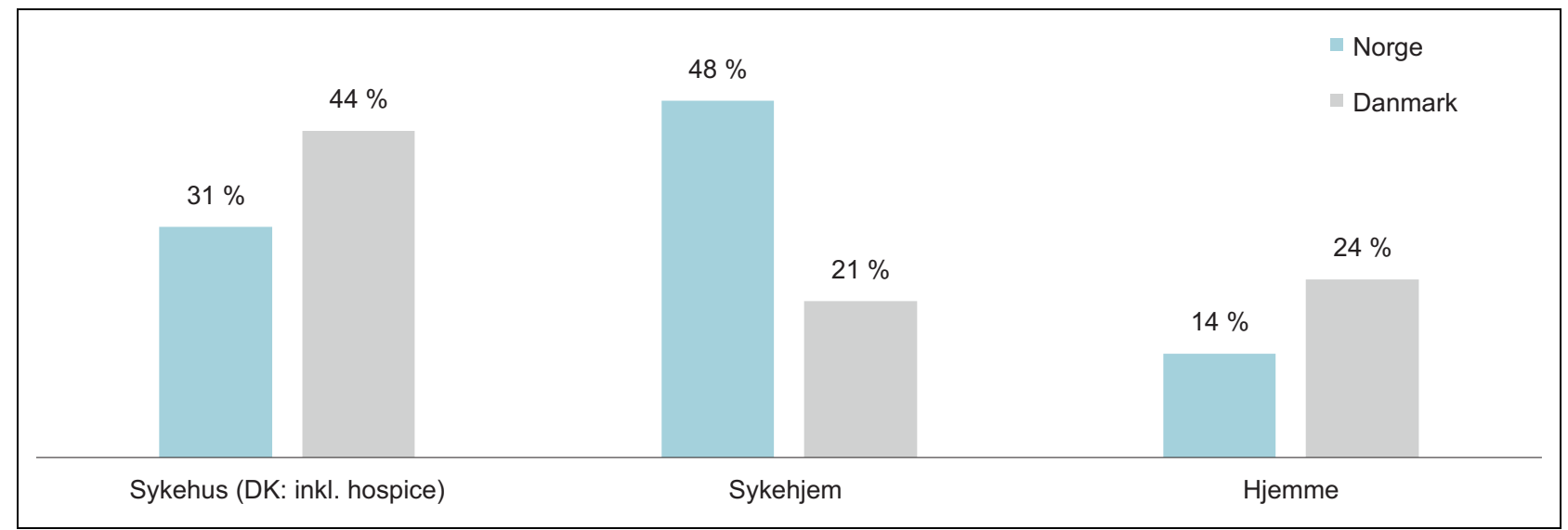

Figur 2.4 Fordeling av dødssted i Norge og Danmark, 2015

Kilde: Dødsårsaksregistret (FHI) og Dødsårsagsregisteret (Sundhedsdatastyrelsen) 


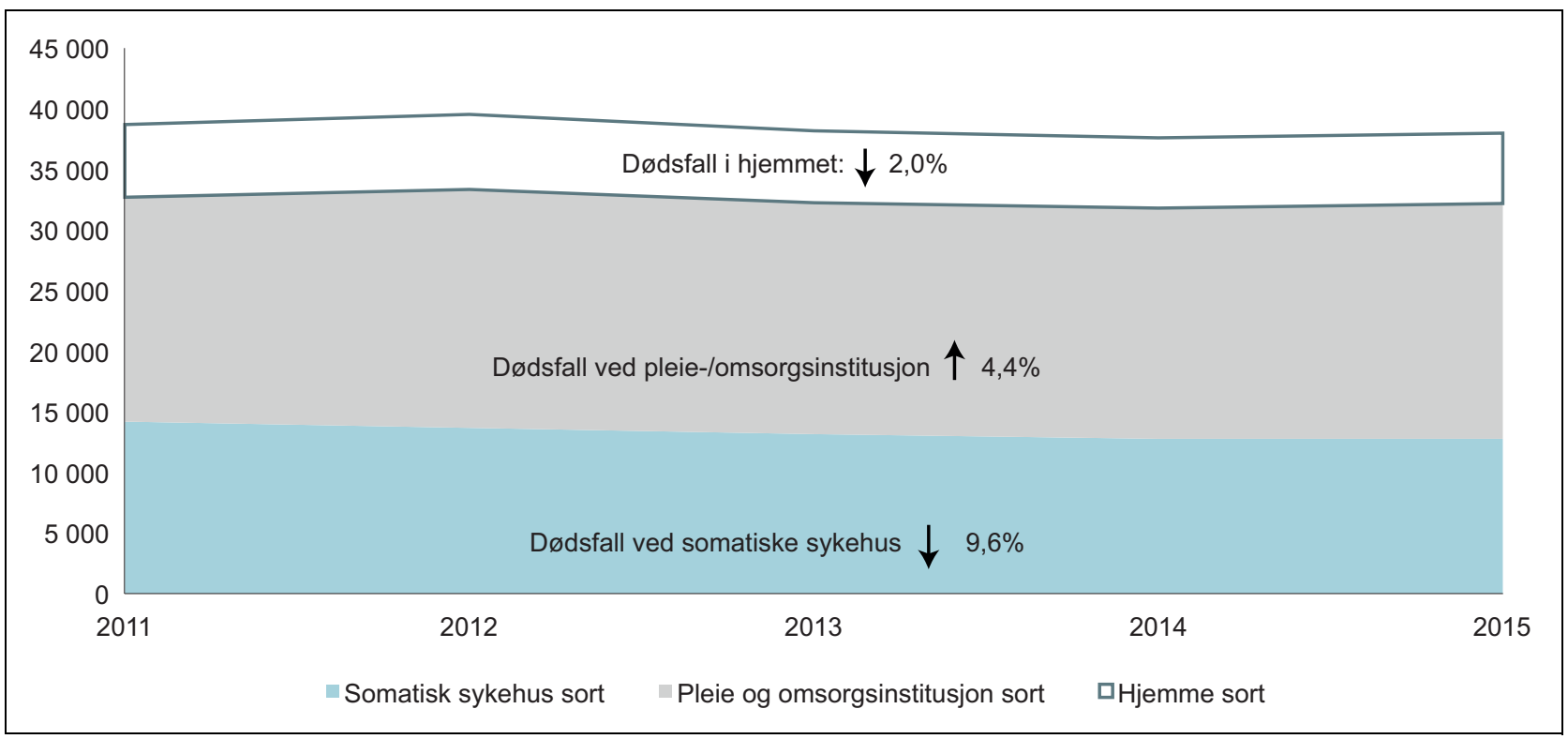

Figur 2.5 Antall dødsfall i Norge etter dødssted, 2011-2015

Kilde: Dødsårsaksregistret (FHI)

er lite skjermet for annen aktivitet og har begrensede muligheter til å trekke seg tilbake.

Over tid har antall dødsfall i Norge ved somatiske sykehus og i hjemmet falt. Ser vi på perioden 2011-2015 falt antall dødsfall ved somatiske sykehus med 9,6 prosent, mens tilsvarende tall for død i hjemmet var 2,0 prosent. I samme periode økte antall dødsfall ved en pleie-/omsorgsinstitusjon med 4,4 prosent. Det er verdt å merke seg at $\mathrm{i}$ denne perioden falt også antall dødsfall i Norge ifølge data fra Dødsårsaksregistret fra 41346 til 40686 (1,6\%). Trendene beskrevet over er også gjeldene om man ser på dataene over en lengere tidsperiode (for eksempel fra år 2000).

\subsection{Hva vet vi om pasienter og pårørende?}

Antallet pasienter som lever med alvorlig kronisk sykdom eller er døende i Norge vil øke fordi de store fødselskullene fra etterkrigstiden nå er blitt pensjonerte og nærmer seg livets sluttfase. Kreft og hjerte- og karsykdom er de to vanligste årsakene til død i Norge, og især kreft karakteriseres ved et langtrukkent forløp med økende funksjonssvikt og symptombyrde. Forbedringer i behandling av hjertesykdom har bidratt til at denne sykdomsgruppen kan få et mer langtrukkent forløp. Dette betyr at etterspørselen etter tilbud for alvorlig kronisk syke eller dødende pasienter øker, noe som igjen betyr økte kostnader for samfunnet. Det

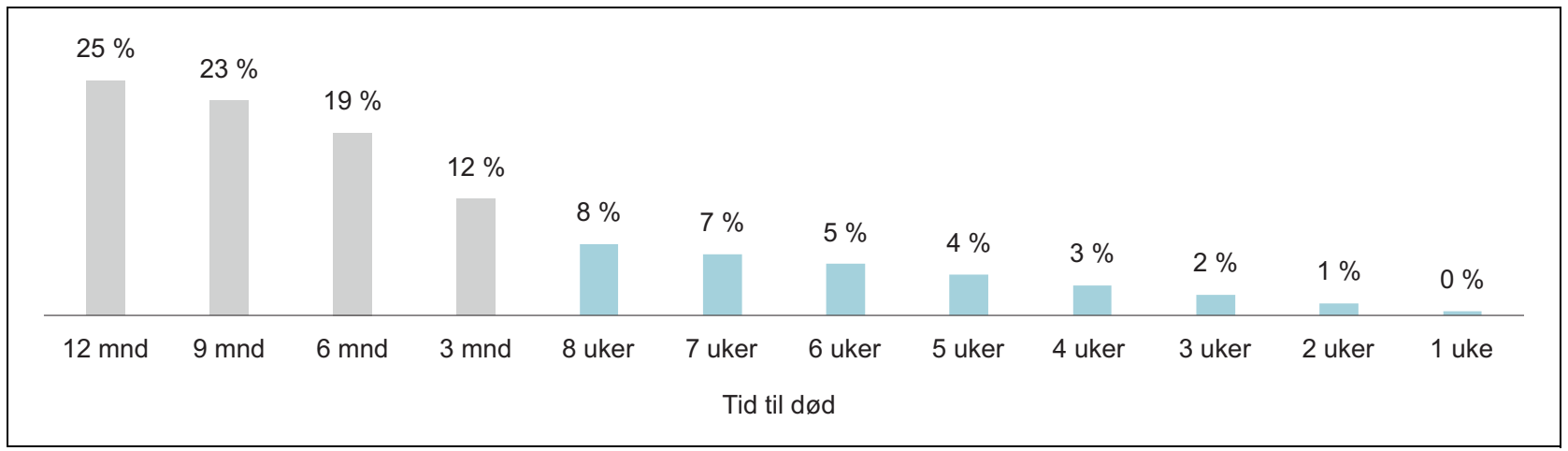

Figur 2.6 Prosentandel* av kreftpasienter som blir behandlet med intravenøs antineoplastisk behandling i tiden før død, 2009-2014

Kilde: NPR, Analyse Oslo Economics *Andel av pasienter som er registret som døde og har mottatt kjemoterapi i perioden 20092014 
er derfor viktig å utrede hvordan samfunnets ressurser kan utnyttes slik at pasientene får best mulig tilbud og ressursbruken likevel holdes på et rimelig nivå.
2.5.1 Hva kjennetegner pasienter som er relevante for hospice?

Å avslutte livet på hospice vil være en aktuell løsning for noen pasienter, men ikke alle. Det er sær-

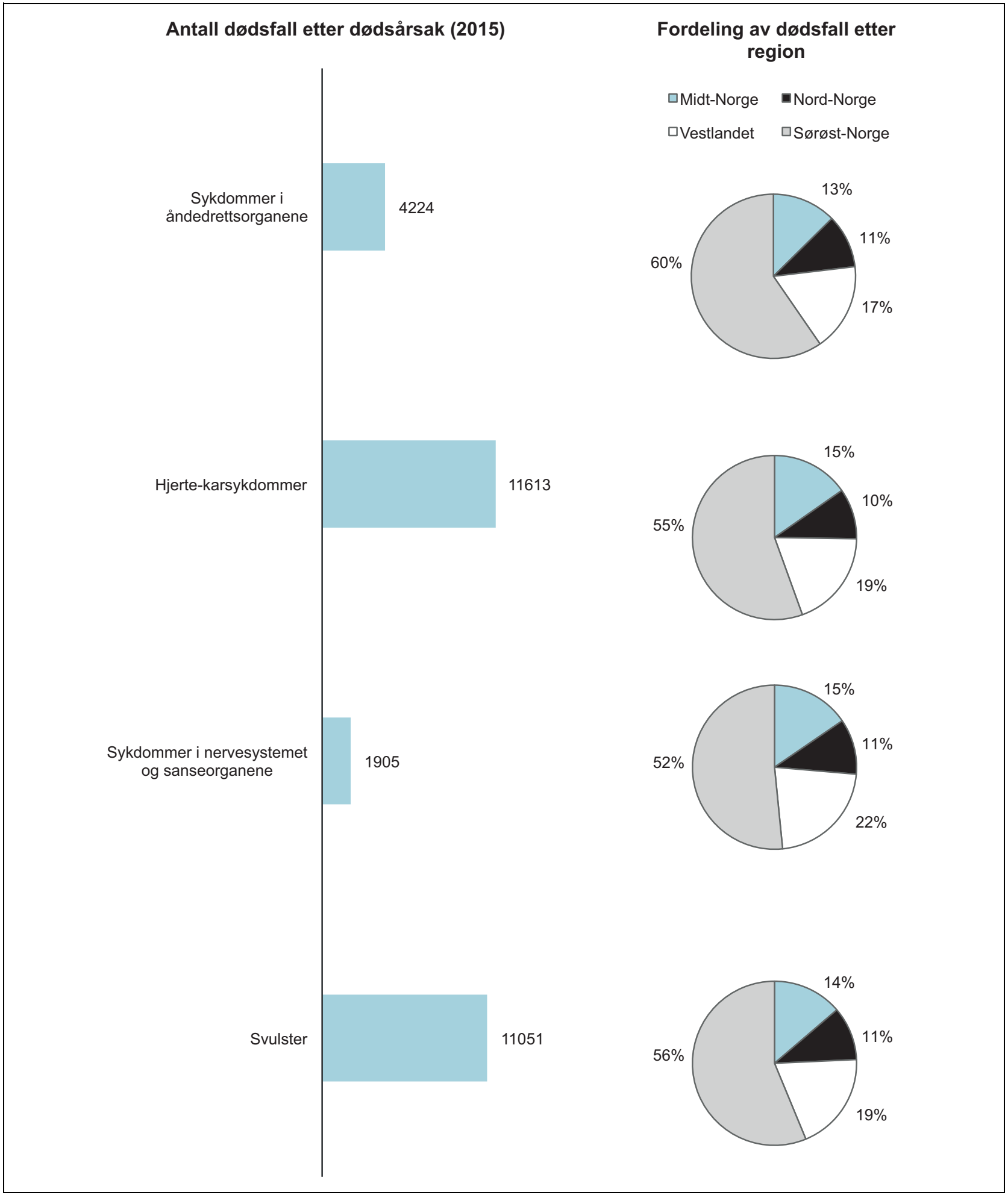

Figur 2.7 Dødsfall i Norge etter dødsårsak og region, 2015

Kilde: Dødsårsaksregisteret (FHI) 


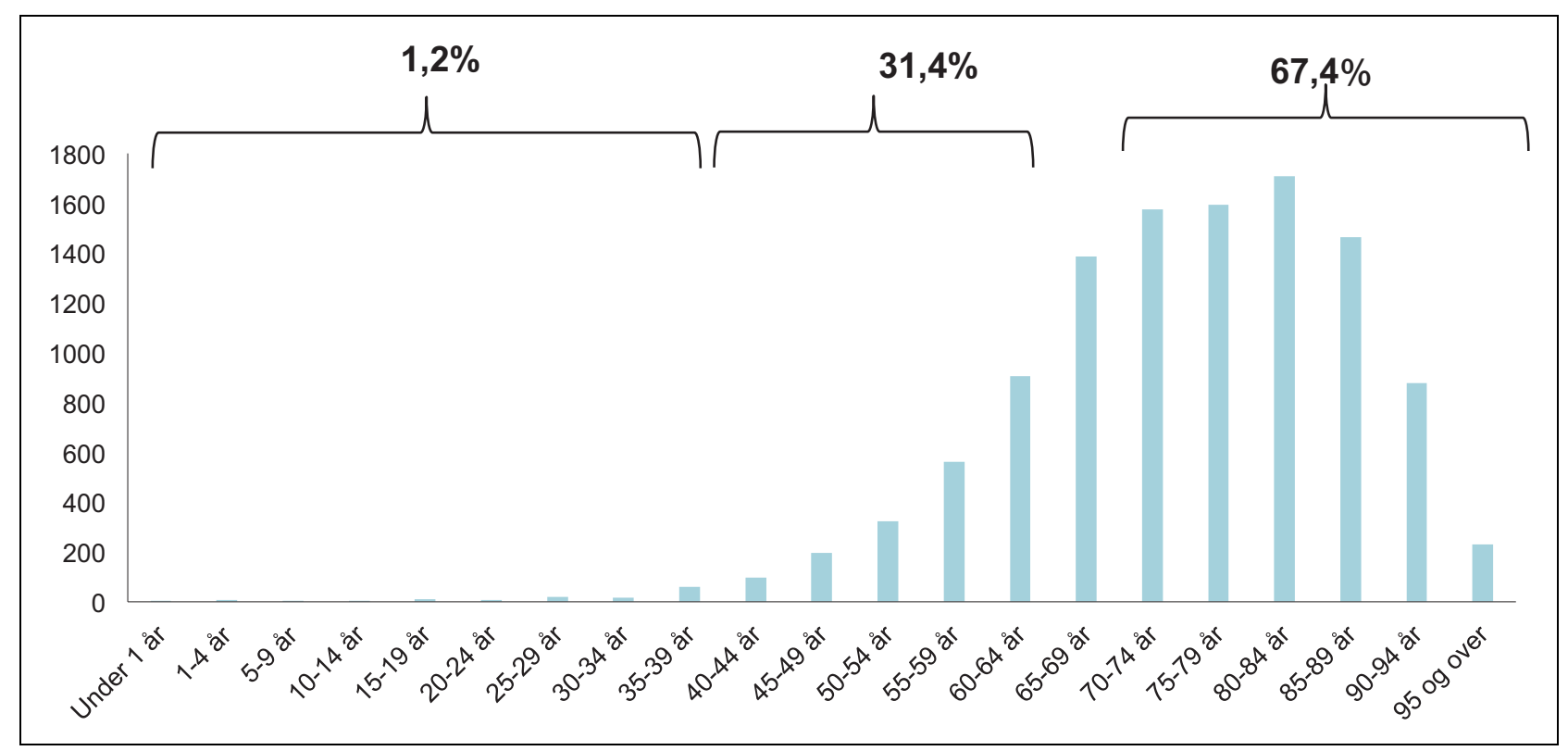

Figur 2.8 Antall dødsfall forårsaket av svulster i Norge etter alder, 2015

Kilde: Dødsårsaksregisteret (FHI)

lig noen kjennetegn ved pasientgruppen som vil ha nytte av en slik type omsorg i livets sluttfase:

- Pasientene har en svært alvorlig sykdom med lav forventet gjenværende levetid (under 6 måneder)

- Pasientene er ikke blant de eldste i befolkningen $(70+)$

- Enkelte har en annen kulturell bakgrunn

- En livssituasjon preget av at pårørende har behov for avlastning (f.eks. yngre barn)

- Pasientene har spesielle behov

Hospice er først en aktuell tjeneste når pasientene har lav forventet levetid (under 6 måneder). Pasienter med alvorlige sykdommer, som for eksempel enkelte former for kreftsykdommer og sykdommer i nervesystemet, sanseorganene eller åndedrettsorganene er derfor særlig aktuelle.

I dag vet vi at en rekke kreftpasienter får livsforlengende behandling i ukene før død. Behandlingen er ofte ressurskrevende og kan gi betydelige bivirkninger.

Kreft representerte den nest vanligste dødsårsak i Norge i 2015. Totalt 11051 pasienter var registret i dødsårsaksregistret med svulst som dødsårsak. Den andre viktigste dødsårsaken i Norge, nemlig hjerte- og karsykdom, stod for 11613 dødsfall samme år.

Omtrent $95 \%$ prosent av pasientene på hospice er pasienter med en kreftdiagnose. Kreft er en sykdom først og fremst rammer eldre pasienter, og som nevnt tidligere er ikke hospice et til- bud som er tenkt å primært dekke behovene til de aller eldste pasientene i samfunnet. Ser vi på aldersfordelingen for pasienter som døde av en kreftsykdom i Norge i 2015 gjaldt 67 prosent av dødsfallene pasienter over 70 år. Pasientene mel$\operatorname{lom} 40 \mathrm{og} 70$ år utgjorde omtrent 30 prosent.

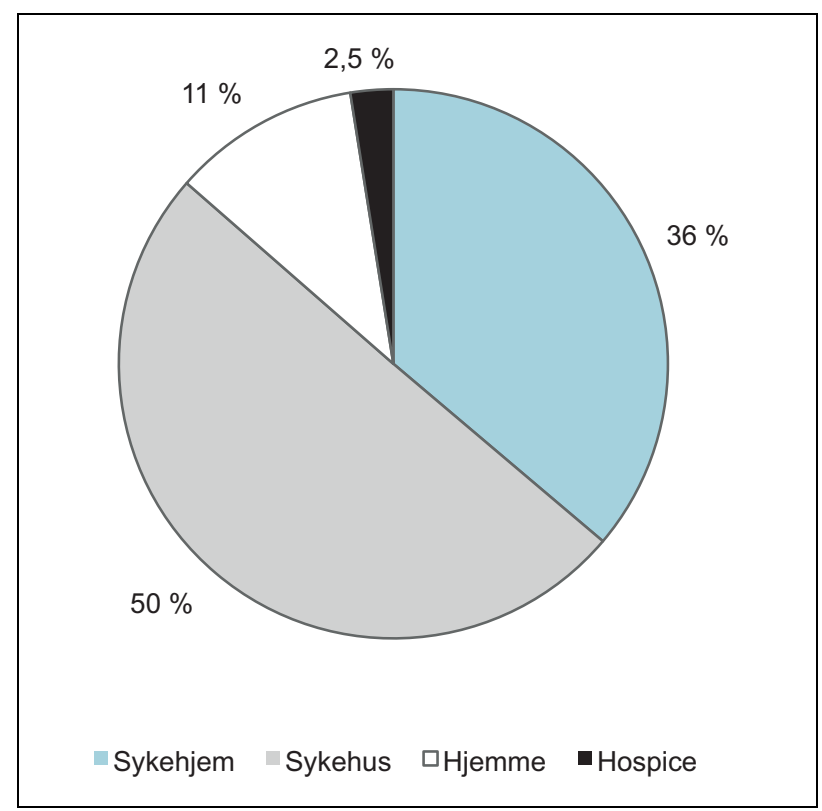

Figur 2.9 Fordeling av dødssted for kreftpasienter i Norge, 2012

1 https://www.lorenskog.kommune.no/_f/ic1e1dbb6-185245c8-ba06-63d7aa4ab020/nina_borge_loerenskog_141014.pdf Kilde: Referert i presentasjon av Nina Hauge ${ }^{1}$ 
Blant kreftpasienter er andelen som dør i sykehus større enn for de øvrige sykdomsgrupper. Bare 2,5 prosent av kreftpasientene døde i hospice i 2012 .

\subsection{Kostnader i hospice}

Som for sykehus og sykehjem utgjør personal- og lønnskostnader den største kostnadskomponenten i et hospice. Et hospice har behov for ulike typer personell, som leger, sykepleiere/spesialsykepleiere, helsefag-arbeidere/hjelpepleiere, ergo/fysioterapeuter og ernæringsspesialister.

Lonnskostnadene inkluderer lønn med ulike tillegg, vikarer og ekstrahjelper og sosiale kostnader. Andre løpende driftskostnader vil blant annet være knyttet til legemidler, mat og servering til brukere og annet medisinsk forbruksmateriell.

I Danmark er det anslått at et nytt hospice (med 12 plasser) koster mellom 42 og 50 millioner kroner å etablere i hovedstadsregionen (Hospiceforum.dk). Kvadratmeterprisen for et hospice er, $\mathrm{i}$ likhet med sykehusbygg, noe høyere enn tradisjonelle bygg. Dette skyldes blant annet at byggene er spesialtilpasset til formålet. Eksempelvis vil et hospice ha behov et integrert oksygenanlegg i veggene. Levetiden på mye av utstyret tilhørende bygget er også begrenset.
Med utgangspunkt i regnskapsinformasjon fra et norske hospice, og erfaringstall fra Danmark, har vi utarbeidet et grovt anslag for kostnadene i et hospice (fig 2-10). Anslagene er utarbeidet for et eksempelhospice med 22 plasser, uten dagtilbud eller utadrettet virksomhet. Videre er det lagt til grunn en levetid på bygget på 20 år. Lonn- og personalkostnader er som nevnt den viktigste kostnadskomponenten, og antas å utgjøre 70-80 prosent av de årlige kostnadene. I anslaget i figuren under har vi illustrert kostnadene for to situasjoner, en hvor hospicet har bemanning som i dag, og en hvor bemanningen er utvidet.

Beregningene over tar utgangspunkt $i$ et hospice med 22 plasser. Dette er i norsk sammenheng et stort hospice, som trolig vil kunne utnytte stordriftsfordeler i større grad enn et hospice med 5-12 plasser. Ved beregning av kostnader per plass for et gjennomsnittshospice i Norge (se under) har vi derfor lagt til grunn at kostnadene er 20 prosent høyere enn i dette eksempelhospicet.

\subsection{Hjemmesykepleie, ambulante team, dagsenter og hjemmedød}

Både i primær- og spesialisthelsetjenesten arbeides det målrettet for at pasienter kan bo så lenge hjemme som mulig. Kommunene tilbyr hjemme-

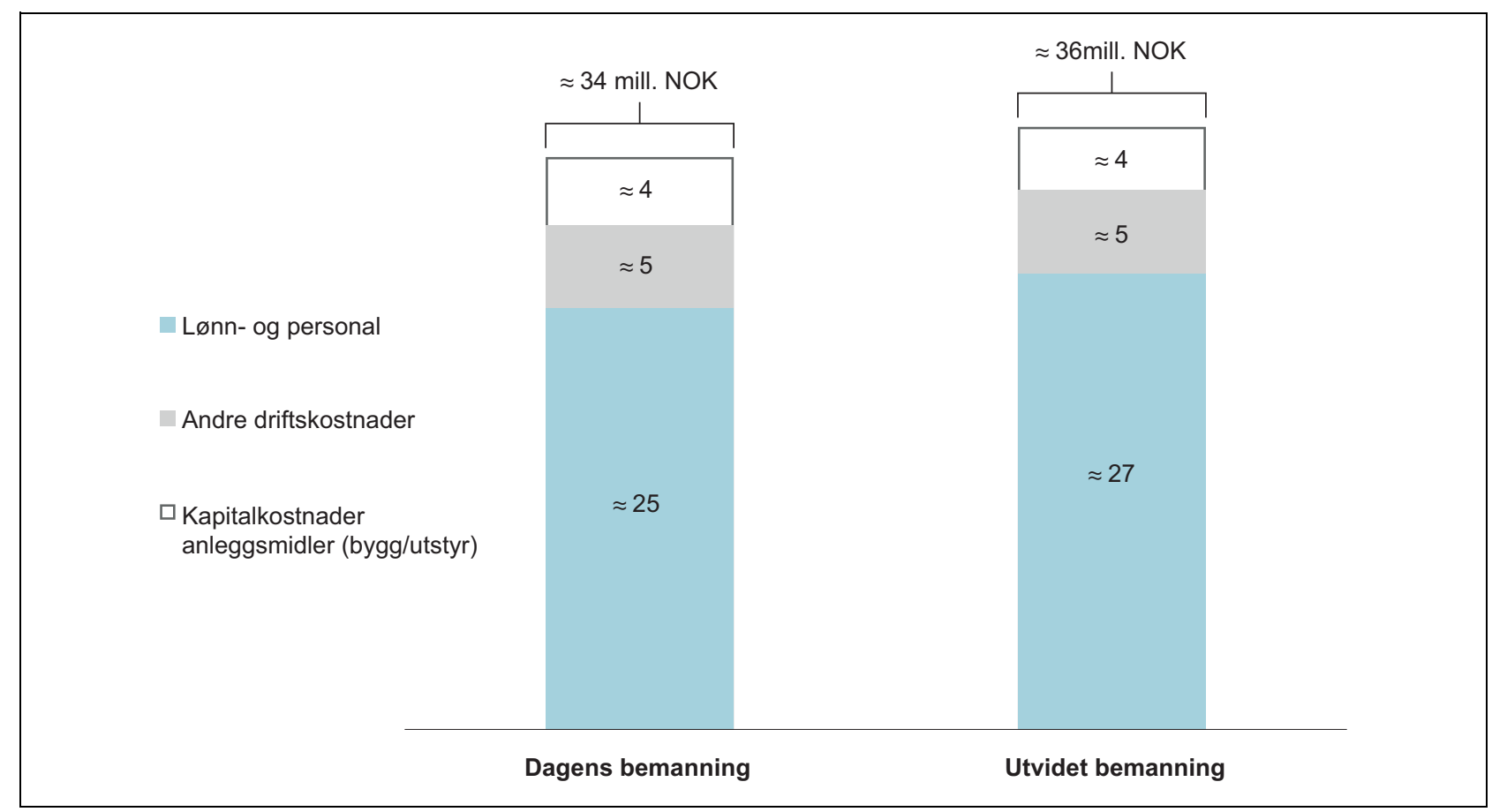

Figur 2.10 Anslag for årlig kostnad hospice uten dagtilbud eller utadrettet virksomhet (22 plasser), mill. NOK

Figurforklaring: Figuren illustrerer omfanget av de viktigste kostandene i et hospice uten dagtilbud eller utadrettet virksomhet med 22 plasser. Kostnadene er vist i to situasjoner: en hvor hospicet har noe underdekning i bemanning, og en hvor det er full dekning. 
sykepleie, oppfølging fra kreftsykepleier og støtte fra kreftkoordinator. I spesialisthelsetjenesten er det palliative team som tilbyr ambulant virksomhet. Jo bedre man klarer å skape et godt tilbud i hjemmet jo mindre behov er det for institusjonsplasser og sykehusopphold.

Hospicefilosofien søker på tilsvarende måte å legge til rette for å bo lengst mulig hjemme og å kunne dø hjemme der dette oppleves riktig for pasienter og pårørende. Hospiceforum Norge anser hospice som sentra som består av dag, døgn og ambulant tjeneste.

Dagsenter kan styrke livskvaliteten og avlaster pårørende $\mathrm{og}$ hjemmetjenesten $\mathrm{og}$ slik gjør det mulig å bo lengre hjemme. Vi har ikke inkludert en kostnadsanalyse av et slikt tilbud i denne rapporten.

For ambulante tjenester kan man tenke seg at hospicene selv stiller med ansatt personell og frivillige som understøtter eller erstatter de eksisterende tjenestene. Dette er en utbredt modell i flere andre land, men er særlig egnet i områder med høy botetthet slik at reisetiden begrenses. Videre vil det måtte kreve avklaringer om ansvarsforhold og finansiering. I Oslo gjør for eksempel Fransiskushjelpen et viktig arbeid med oppfølging av pasienter i siste fase i deres hjem. En variant er at hospice i større befolkningssentra kan være et kompetansesenter for regionen og understøtte de eksisterende tjenestene i kommunen og spesialist- helsetjenesten som legger til rette for pleie i livets sluttfase for denne pasientgruppen.

I de videre analysene har vi lagt til grunn at pasientene følges opp hjemme så lenge dette er mulig. For å begrense kompleksiteten har vi konsentrert kostnadsanalysen om institusjonsopphold for pasienter der hjemmedød ikke er et alternativ. Institusjonsopphold er normalt dyrere enn omsorg i hjemmet. En styrket kompetanse i hjemmetjenesten i kombinasjon med andre tjenester som dagsenter og ambulante team fra hospice og spesialisthelsetjenesten kan utsette institusjonsopphold og slik sett redusere omsorgskostnadene, samtidig som det kan gi økt livskvalitet for pasienter og pårørende.

\section{Enhetskostnader for ulike behandlingstilbud}

Det finnes lite offentlig, norsk kostnadsstatistikk for omsorg i livets sluttfase. Enhetskostnadene nedenfor bygger på det som finnes av offentlig tilgjengelig statistikk og rapporter, erfaringstall fra Norge og Danmark, DRG-satser og egne vurdering. Dette gir grunnlag for overordnede anslag for døgnkostnaden for ulike behandlingssteder for pasienter som er relevante for behandling på hospice (fig. $2.11 \mathrm{og}$ tabell 2.1), men tallene må vurderes med varsomhet. For de ulike behandlingsalternativene har vi beregnet enhetskostnader i form av døgnpris knyttet til drift (per plass).

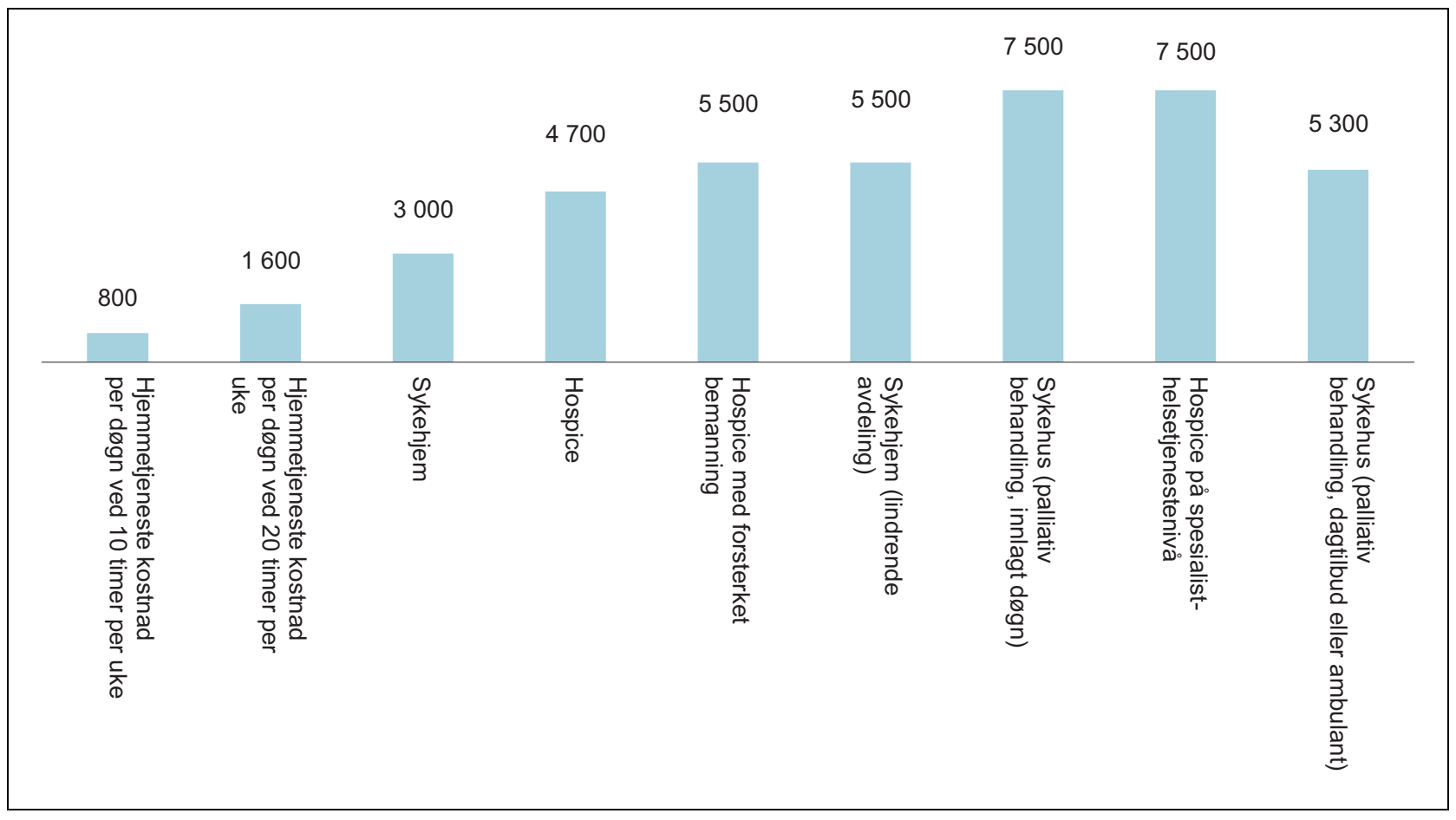

Figur 2.11 Anslag for kostnad per døgn ved ulike behandlingssteder, 2017-kroner

Merknad: Kapitalkostnader er holdt utenfor anslagene. 
Tabell 2.1 Oppsummering av anslag for driftskostnader ved ulike behandlingssteder, 2017-kroner

\begin{tabular}{|c|c|c|c|c|}
\hline Behandlingssted & $\begin{array}{r}\text { Beste anslag } \\
\text { kostnad (NOK) }\end{array}$ & Lav & Нøу & Kilde/forutsetning \\
\hline $\begin{array}{l}\text { Hjemmetjeneste kostnad per døgn } \\
\text { ved } 10 \text { timer per uke }\end{array}$ & 800 & 700 & 1100 & $\begin{array}{l}\text { Modell for beregning av enhets- } \\
\text { kostnader i hjemmetjenesten } \\
\text { (Virke mfl. 2013) }\end{array}$ \\
\hline $\begin{array}{l}\text { Hjemmetjeneste kostnad per døgn } \\
\text { ved } 20 \text { timer per uke }\end{array}$ & 1600 & 1400 & 2200 & $\begin{array}{l}\text { Modell for beregning av enhets- } \\
\text { kostnader i hjemmetjenesten } \\
\text { (Virke mfl. 2013) }\end{array}$ \\
\hline Sykehjem (per plass per døgn) & 3000 & 2800 & 3200 & $\begin{array}{l}\text { Gjennomsnittlig sykehjems- } \\
\text { plass (Statistisk sentralbyrå) }\end{array}$ \\
\hline Hospice (per plass per døgn) & 4700 & 3900 & 5500 & $\begin{array}{l}\text { Erfaringstall fra større hospice i } \\
\text { Norge, med korreksjon for stor- } \\
\text { driftsfordeler }\end{array}$ \\
\hline $\begin{array}{l}\text { Hospice med forsterket bemanning } \\
\text { (per plass per døgn) }\end{array}$ & 5500 & 4500 & 6500 & $\begin{array}{l}\text { Kostnad som for sykehjem } \\
\text { lindrende avdeling }\end{array}$ \\
\hline $\begin{array}{l}\text { Hospice på spesialist-helsetje- } \\
\text { nestenivå (per plass per døgn) }\end{array}$ & 7500 & 7000 & 8000 & $\begin{array}{l}\text { Kostnadsanslag basert på DRG } \\
\text { for palliativ behandling og døgn- } \\
\text { opphold medisinsk avdeling }\end{array}$ \\
\hline $\begin{array}{l}\text { Sykehjem, lindrende avdeling (per } \\
\text { plass per døgn) }\end{array}$ & 5500 & 4500 & 6500 & $\begin{array}{l}\text { Statistisk sentralbyrå og Helse- } \\
\text { direktoratet }\end{array}$ \\
\hline $\begin{array}{l}\text { Sykehus (palliativ behandling, innlagt } \\
\text { døgn) (per plass per døgn) }\end{array}$ & 7500 & 7000 & 8000 & $\begin{array}{l}\text { Kostnadsanslag basert på DRG } \\
\text { for palliativ behandling og døgn- } \\
\text { opphold medisinsk avdeling }\end{array}$ \\
\hline $\begin{array}{l}\text { Sykehus (palliativ behandling, dagtil- } \\
\text { bud eller ambulant) }\end{array}$ & 5300 & 4800 & 5800 & DRG 959W \\
\hline
\end{tabular}

Merknad: Kapitalkostnader er holdt utenfor anslagene.

Som illustrert i figuren er det knyttet usikkerhet til anslagene.

Ikke overraskende er prisen per døgn lavest for pasienter som oppholder seg i egen bolig med bistand fra de kommunale hjemmetjenester. Tall fra Statistisk sentralbyrå viser at gjennomsnittlig antall timer med hjemmesykepleie og praktisk bistand for alle aldre i 2015 var 8,9 timer i uken. Pasientene det her er snakk om har antas å ha et større pleiebehov enn en gjennomsnittspasient. Dersom vi legger til grunn at pasientene får 10 timer hjemmetjenester i uken vil kostnaden per døgn for kommunene være omtrent 800 kroner. Selv om 20 timer hjemmetjenester i uken vil hjemmetjenester være et relativt rimelig alternativ. En del pasienter kan nok få adskillig mer enn 20 timer pleie per uke.

Med data fra Statistisk sentralbyrå har vi beregnet gjennomsnittlig døgnkostnad for et sykehjem i Norge i 2015 til i underkant av 3000 kroner.

Palliative enheter i sykehjem er også langt dyrere å drifte enn vanlige sykehjemsavdelinger. Lindrende enheter krever mer og bedre kvalifisert personell og mer legetjenester enn en ordinær sykehjemspost. I tillegg kommer medikamenter, smertekassetter, infusjonsutstyr og andre forbruksvarer. I en rapport fra Helsedirektoratet (IS-2278, 2015) var en seng i en palliativ sykehjemsenhet omtrent dobbelt så dyr som en vanlig seng i sykehjem. Døgnkostnaden for en seng på lindre enhet på sykehjem er derfor anslått til 5500 kroner. De faktiske kostnadene vil avhenge av driftsmodell og bemanning i den enkelte kommune.

Måten et hospice innrettes på har betydning for døgnkostnaden. I figuren over har vi illustrert dette ved å legge til grunn tre ulike modeller. Bemanningsgraden, antall senger og hvor hospicet er lokalisert er sentrale drivere for døgn- 
kostnaden i et hospice. Døgnprisen ved et hospice er anslått til å være 4700 kroner, noe som er betydelig høyere enn en gjennomsnittlig sykehjemsplass. Dette anslaget bygger på erfaringstall fra et større hospice i Norge, og er justert for at mindre hospice trolig i mindre grad klarer å ta ut stordriftsfordeler i driften.

Flere ønsker en mer omfattende bemanning enn i det hospicet vi har tilgang til regnskapstall for. Vi har derfor anslått kostnadene for et hospice med forsterket bemanning basert på en forutsetning om at ressursbruken legges på nivå med lindrende enhet ved sykehjem eller et døgn i spesialisthelsetjenesten.

Sammenlignet med palliativ behandling ved sykehus er kostnaden til disse typene hospice (og sykehjem) lavere. Kostnaden er beregnet til 7500 kroner basert på data fra Helsedirektoratet (DRG, NPR).

Ikke alle pasienter er innlagt, og enkelte mottar dagbehandling. Kostnaden knyttet til palliativ behandling i sykehus som dagtilbud eller ambulant er anslått til å være 5300 kroner (basert på tilhørende DRG).

Vi har videre illustrert et hospice i spesialisthelsetjenesten og lagt til grunn at kostnadene her er som for spesialisthelsetjenesten. Vi har ikke detaljerte kostnadsinformasjon om denne varianten av hospice. Trolig vil de ha noe ulike sammensetning av personellet som kanskje kan gi en lavere døgnkostnad, men samtidig muligheter for noe lengre liggetid enn for en palliativ enhet. Vi har derfor lagt vårt anslag på tilsvarende nivå.
I tabellen under er kostnadsanslagene oppsummert, og intervaller som illustrerer usikkerheten.

Kapitalkostnader er holdt utenfor beregningene av kostnaden per dag over. Generelt er det grunn til å tro at hospice vil ha lavere kapitalkostnader enn sykehus, mens de trolig vil ligge på nivå eller høyere enn sykehjem. Vi har lagt til grunn at kapitalkostnadene utgjør følgende andel av driftskostnadene:

- Vanlig sykehjemsavdeling: 10,6\%

- Hospice og lindrende avdeling sykehjem: $12,0 \%$

- Sykehus: $13,0 \%$

Anslagene for kapitalkostnadene er basert på statistikk fra Statistisk sentralbyrå, SAMDATA og egne vurderinger.

\section{Hvilken plass kan hospice ha i det norske behandlingstilbudet?}

Som nevnt er hospice et tilbud for pasienter med en alvorlig sykdom (ofte en kreftsykdom) og kort restlevetid, og som ofte spesielle behov (typisk knyttet til smertelindring). Hospiceforum Norge anser hospice som sentra som består av dag, døgn og ambulant tjeneste. I denne analysen konsentrerer vi oss om døgntilbudet og har vi lagt til grunn at hospice erstatter deler av dagens behandlingstilbud, men at hovedvekten av tilbudet fortsatt vil bli gitt i sykehus og sykehjem. Hospice vil være aktuelt etter pasientene har fått en diagnose, og behandlingen er gjennomført i sykehus.

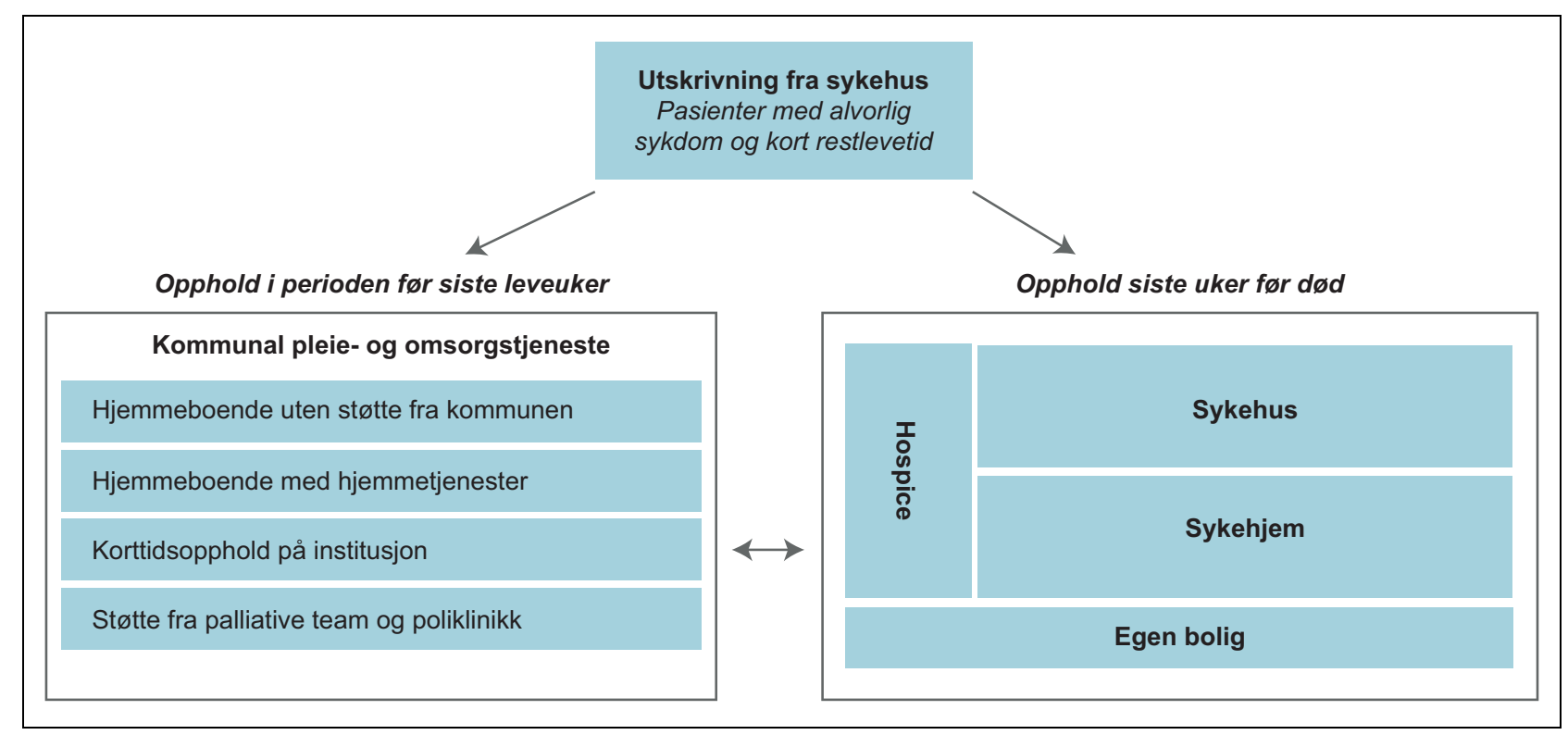

Figur 2.12 Plass i behandlingstilbudet 
En mulig modell man kan tenke seg er å etablere hospice i større befolkningssentra, så kan man tilby tjenesten de de pasientene som ønsker det som et alternativ til døgnopphold på sykehus eller sykehjem. I våre analyser har vi som en illustrasjon lagt til grunn 100 plasser fordelt på flere sentra. Det er som kjent et økende behov i årene som kommer og dette kan bygges ut som et alternativ til en utbygging av kapasiteten i sykehus eller på sykehjem.

Figur 2.12 illustrerer hospice som del av behandlingstilbudet. Etter utreding og eventuell livsforlengende behandling ved sykehuset vil ansvaret for enkelte pasienter overføres til den kommunale pleie- og omsorgstjenesten. I perioden før de siste leveukene vil mange pasienter kunne bo i egen bolig, med eller uten hjelp fra hjemmetjenesten, korttidsopphold på institusjon og/eller støtte fra palliative team og poliklinikk. Når pasientene nærmer seg livets slutt vil flere kunne bli lagt inn på sykehus, sykehjem eller hospice. Andre pasienter har så kort restlevetid etter utredning og behandling at de vil forbli på sykehuset til de dør, eller overføres til sykehjem i lives siste leveuker. Også for disse kan hospice være et alternativ.

\subsection{Kostnader for ulike behandlingsforløp}

Pasienter som er aktuelle for hospice vil naturlig ha svært ulike behandlingsforløp. Det kan imidlertid være nyttig å se på kostnadene av et «typisk» behandlingsforløp, og hvordan de varierer per dag avhengig av hvilken behandling pasientene mottar. Forenklet kan vi se for oss to type behandlingsgrupper:

- Pasienter som etter livsforlengende behandling på sykehus mottar hjemmetjenester en periode før palliativ behandling siste leveuker (behandlingsforløp 180 dager)

- Pasienter som etter livsforlengende behandling på sykehus ikke er i stand til å bo hjemme og har behov for palliativ behandling siste leveuker (behandlingsforløp 21 dager)

\subsubsection{Illustrasjon av et behandlingsforløp med hjemmetjenester}

For pasienter som etter livsforlengende sykehusbehandling flytter hjem og mottar hjemmetjenester i perioden før livets sluttfase vil kostnadene per dag tidlig i behandlingsforløpet trolig ikke avhenge av om pasientene avslutter livet på hospice, i sykehus eller ved sykehjem. Et typisk kostnadsforløp vil være som illustrert i fig. 2.13. Kostnaden per dag er høy når pasienten er under

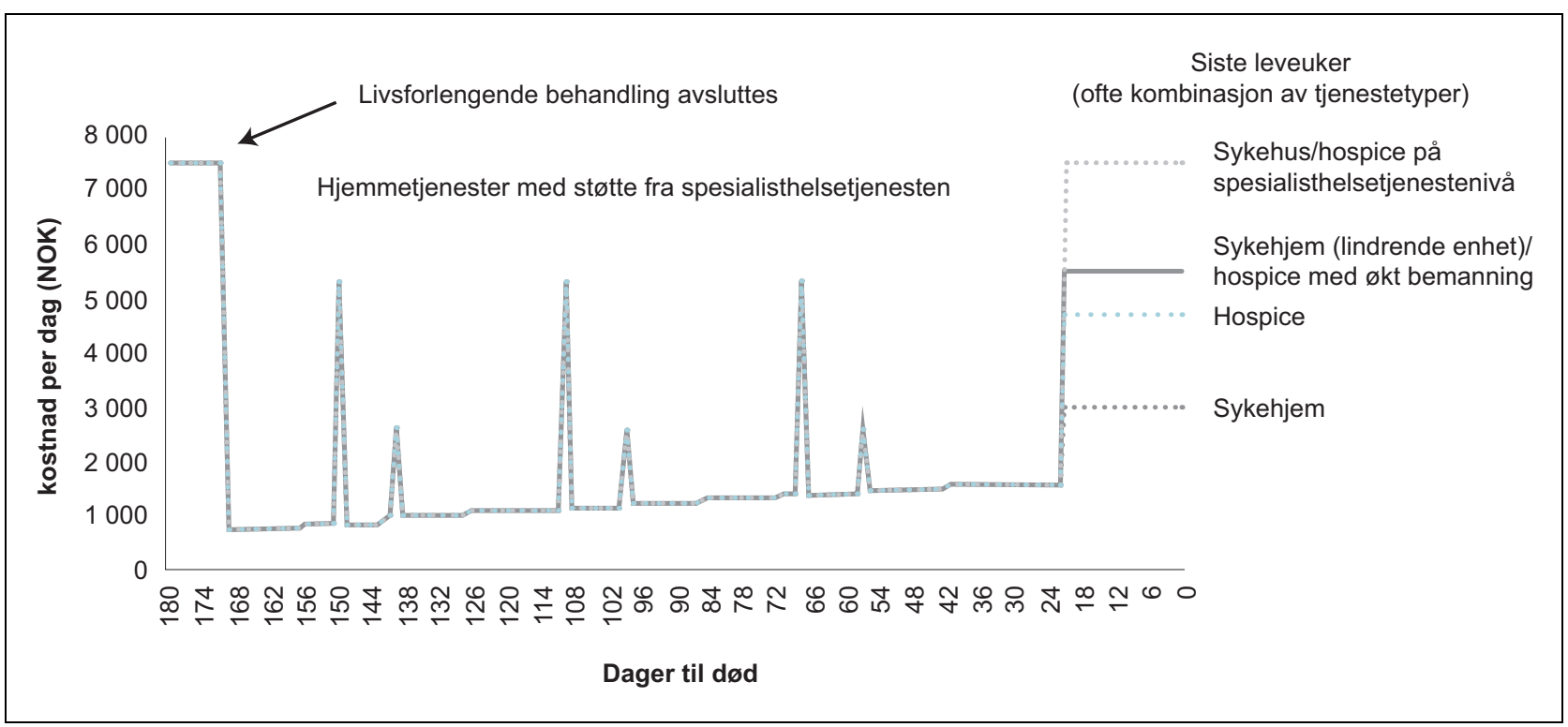

Figur 2.13 Illustrasjon av kostnad per dag for pasienter med økende hjemmetjenester før palliativ behandling i livets sluttfase (siste 180 levedager), NOK

Figurforklaring: Figuren illustrerer kostnaden per dag over et forløp på 180 dager. Når livsforlengende behandling avsluttes og pasienten flytter hjem faller kostnaden (venstre i figuren). Videre får pasienten gradvis mer hjemmetjenester (illustrert med de små økningene i kurvene), og pasienten kan ha opphold på sykehus eller behandling på poliklinikken. Sistnevnte vil innebærer en betydelig økning i døgnkostnaden (illustrert med de store sprangene i kurvene). Frem til livets sluttfase antas kostnaden å være uavhengig av hvor pasienten avslutter livet. I livets sluttfase (her illustrerte som siste 3 uker) antas det at pasienten må ha fulltidspleie på sykehus, sykehjem eller hospice. Ofte vil pasienten motta en kombinasjon av tjenester fra primær- og spesialisthelsetjenesten. 
livsforlengende behandling i sykehus, før den faller betydelig når pasienten blir skrevet ut. Med økende pleiebehov øker kostnadene knyttet til hjemmetjenester når pasienten nærmer seg livets avslutning. I tillegg vil mange pasienter ha behov for dagbehandling i spesialisthelsetjenesten. Når pleiebehovet er så stort at pasienten ikke lenger kan bo hjemme vil dagskostnaden igjen øke. Som illustrert i figuren vil kostnaden per dag i pasientens siste levedager variere avhengig av hvor pasientene avslutter livet. Pasientene vil kunne bevege seg mellom sykehus, sykehjem og eventuelt hospice i denne perioden. Hvor de oppholder seg, og hvor lenge, vil ha stor betydning for de samlede kostnadene.

Av figur 2.14 ser vi at kostnadene per dag i løpet av pasientens siste leveuker er betinget på hvor pasienten befinner seg. Av figuren ser vi at kostnadene per dag er høyest dersom pasienten avslutter livet på sykehus, mens pleie i en standard sykehjemsavdeling er minst ressurskrevende. Pasienter kan også flyttes mellom en vanlig sykehjemsplass, til en dyrere plass ved lindrende enhet i sykehjem. Kostnaden forbundet med hospice ligger mellom en vanlig sykehjemsplass og behandling ved lindrende enhet i sykehjem.

\subsubsection{Illustrasjon av et behandlingsforløp uten hjemmetjenester}

For enkelte pasienter er pleiebehovet så stort etter at livsforlengende behandling ved sykehuset er avsluttet at de ikke kan bo hjemme. Disse vil i dag typisk bli liggende på en palliativ avdeling ved sykehuset eller overføres til lindrende avdeling ved et sykehjem. Hospice vil være et alternativ for disse pasientene. Kompetansen på et hospice er høyere enn ved en vanlig sykehjemsavdeling, og fasilitetene er bedre lagt til rette for pasienter med spesielle behov. Dette gjør at pasienter i enkelte tilfeller kan skrives ut fra sykehuset tidligere. Det samme vil gjelde en lindrende avdeling ved sykehjem. Som illustrert i figur 4-3 vil dette bidra til at dagsprisen faller tidligere.

\section{2 Økonomiske konsekvenser av større hospice- tilbud}

Hvilke økonomiske konsekvenser økt hospicebruk vil ha, avhenger av hvilken omsorgsform de har i dag og hvor lenge de har denne omsorgsformen var. Særlig fordelingen av hvor pasientene oppholder seg i livets sluttfase er avgjørende (sykehus, lindrende enhet sykehjem eller vanlig sykehjemsavdeling) har betydning. I vår beregning av økonomiske konsekvenser legger vi til

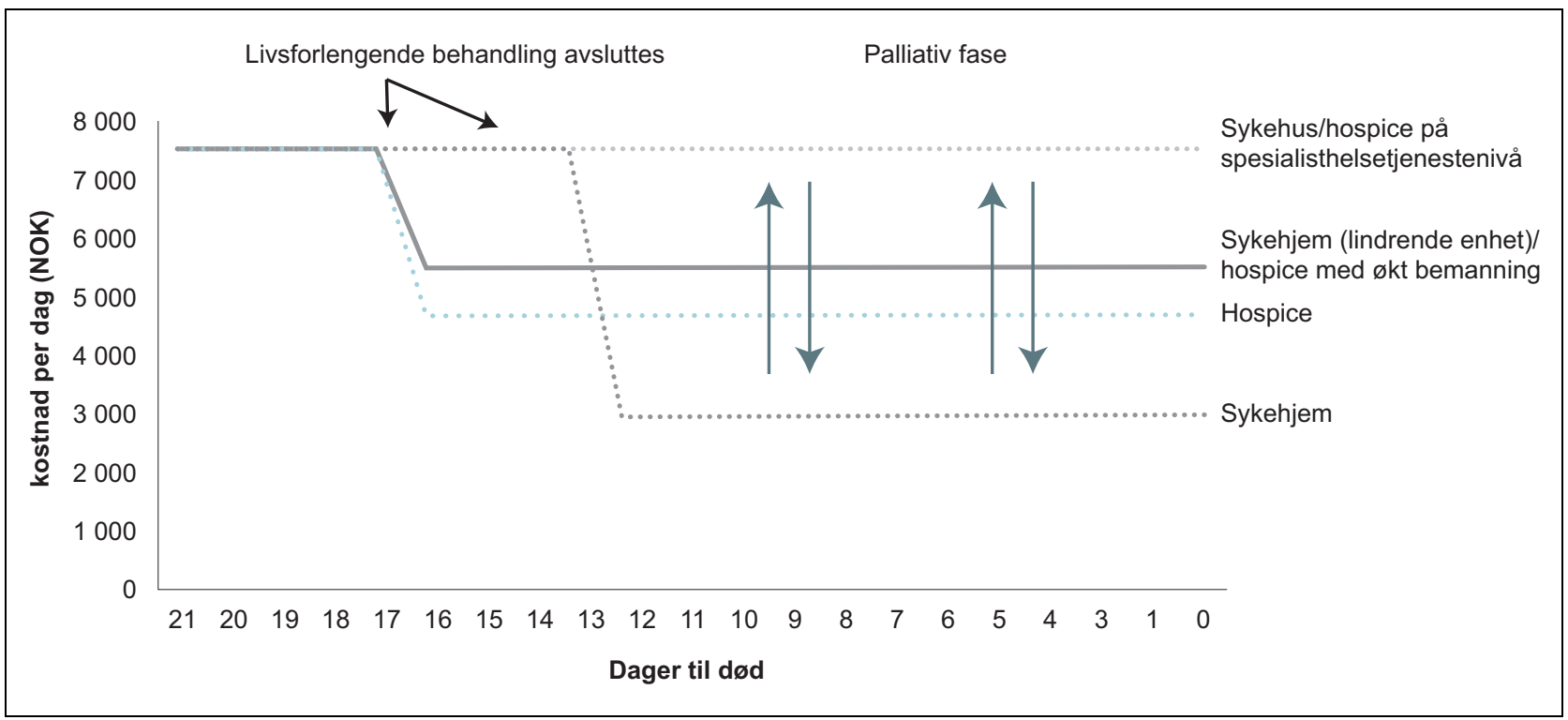

Figur 2.14 Illustrasjon av kostnad per dag for pasienter som etter livsforlengende sykehusbehandling har behov for heldags palliativ behandling (siste 21 levedager), NOK

Figurforklaring: Figuren illustrerer kostnaden per dag for pasienter som ikke kan bo hjemme etter at livsforlengende behandling er avsluttet. Etter livsforlengende behandling kan pasienten fortsette oppholdet på sykehus eller bli overført til sykehjem/hospice. I enkelte tilfeller kan behandlingen på sykehus avsluttes tidligere hvis pasientene skal på en lindrende enhet (sykehjem) eller hospice, sammenlignet med situasjonen hvor pasienten skal på en vanlig sykehjemsavdeling. I palliativ fase vil mange pasienter flytte seg mellom behandlingstedene (illustrert med piler). For eksempel vi enkelte pasienter som er på sykehjem ha ett eller flere korttidsopphold på sykehus. 
Tabell 2.2 Anslag på fordeling av døgnplasser for tjenester som erstattes av hospice

\begin{tabular}{lrrr}
\hline & Basisanslag & $\begin{array}{r}\text { Gitt større bruk av } \\
\text { palliative plasser i dag }\end{array}$ & $\begin{array}{r}\text { Gitt mindre bruk av } \\
\text { palliative plasser i dag }\end{array}$ \\
\hline Sykehus & $20 \%$ & $30 \%$ & $10 \%$ \\
Sykehjem & $30 \%$ & $15 \%$ & $50 \%$ \\
Sykehjem lindrende & $50 \%$ & $55 \%$ & $40 \%$ \\
\hline
\end{tabular}

Tabellforklaring: Tabellen over viser anslag for hvilke døgnplasser hospice antas å erstatte. Pasientene vil oppholde seg ulik tid på sykehus eller sykehjem i perioden de alternativt kunne vært på hospice. Med antakelsene over (basisanslag) vil eksempelvis pasienter som i livets sluttfase ikke er på lindrende avdeling i sykehjem, ligge $40 \%(20 /(20+30)$ ) av tiden på sykehus og $60 \%$ (30/ $(20+30))$ av tiden på sykehjem (vanlig avdeling). Kolonne nummer tre viser anslag hvor pasientene tilbringer lite tid på vanlig sykehjemsavdeling, og mer tid i palliative plasser. I kolonne fire er det lagt til grunn at pasientene (samlet sett) tilbringer mer tid i en vanlig sykehjemsavdeling.

Tabell 2.3 Anslag for økonomiske konsekvenser av hospice, 2017-kroner. Merk: anslagene bygger på forutsetninger som er usikre.

\begin{tabular}{lrrr}
\hline & Basisanslag & $\begin{array}{c}\text { Gitt større bruk av } \\
\text { palliative plasser i dag }\end{array}$ & $\begin{array}{r}\text { Gitt mindre bruk av } \\
\text { palliative plasser i dag }\end{array}$ \\
\hline $\begin{array}{l}\text { Per plass: } \\
\text { Tilbud uten hospice }\end{array}$ & 577000 & 643000 & 497000 \\
Tilbud med hospice & 526000 & 526000 & 526000 \\
Differanse & 51000 & 117000 & -29000 \\
Per år: & & & 181000000 \\
Tilbud uten hospice & 211000000 & 235000000 & 192000000 \\
Tilbud med hospice & 192000000 & 192000000 & -11000000 \\
Differanse & 19000000 & 42000000 &
\end{tabular}

Tabell 2.4 Anslag for økonomiske konsekvenser av hospice med økt bemanning, 2017-kroner. Merk: anslagene bygger på forutsetninger som er usikre.

\begin{tabular}{lrrr}
\hline & Basisanslag & $\begin{array}{r}\text { Gitt større bruk av } \\
\text { palliative plasser i dag }\end{array}$ & $\begin{array}{r}\text { Gitt mindre bruk av } \\
\text { palliative plasser i dag }\end{array}$ \\
\hline $\begin{array}{l}\text { Per plass: } \\
\text { Tilbud uten hospice }\end{array}$ & 577000 & 642000 & 497000 \\
Tilbud med hospice & 616000 & 616000 & 616000 \\
Differanse & -39000 & 27000 & -118000 \\
Per år: & & & \\
Tilbud uten hospice & 211000000 & 235000000 & 181000000 \\
Tilbud med hospice & 225000000 & 225000000 & 225000000 \\
Differanse & -14000000 & 10000000 & -43000000 \\
\hline
\end{tabular}


grunn at hospice erstatter opphold på sykehus (20\%), opphold på vanlig sykehjemsavdeling (30\%) eller lindrende avdeling på sykehjem (50\%). Fordelingen er basert på antall lindrede døgnplasser i spesialisthelsetjenesten og i sykehjem. I tillegg har vi anslått antall døgnplasser i vanlige sykehjemsavdelinger som vil bli erstattet av hospice gitt at vi legger til grunn 100 hospiceplasser.

Basert på forutsetningene nevnt over, og enhetskostnadene anslått i kapittel X blir de økonomiske konsekvensene per plass og per år som presentert i tabell 2.3.

Behandlingspraksis for disse pasientene er uklar i dag og av stor betydning for de økonomiske konsekvenser ved en overføring av pasientene til hospice. I en situasjon hvor hospice $\mathrm{i}$ hovedsak erstatter behandling i sykehus eller lindrede enhet ved sykehjem, og enhetskostnadene er som beregnet i kapittel 3, vil innføringen av hospice gi store besparelser. Dersom det på en annen side er slik at 50 prosent av plassene hospice erstatter er tradisjonelle sykehjemsplasser (kolonne $4 \mathrm{i}$ tabellen) vil innføringen av hospice trolig være mer kostnadskrevende enn dagens situasjon.

I tabell 2.3 over har vi lagt til grunn at en hospiceplass koster 4700 kroner per plass per døgn. Dersom vi legger til grunn kostnaden for et hospice med styrket bemanning (5 500 kroner) blir de økonomiske konsekvensene som i tabell 2.4 .

\subsection{Finansiering og budsjettkonsekvenser}

Dagens finansieringsordning gir noen incentiver for omsorg i sykehus ved at staten dekker ca. 50 prosent av de stipulerte kostnader ved opphold i sykehus mens sykehusene må bruke sin basisbevilgning for å dekke de øvrige kostnader. Kommunene får derimot ikke statlig tilskudd utover de statlige basisbevilgninger. For kommunene fremstår det som en økonomisk fordel at pasientene tilbringer livets sluttfase i sykehus.

I henhold til Helsedirektoratets rapport (IS2278 2015) opplever en del palliative enheter fare for nedleggelser i forbindelse med de årlige budsjettforhandlingene i kommunen. Fra fagfeltet rapporteres det om bekymring blant personalet og befolkningen for at et tilbud som har vært bygget opp over tid skal raseres på grunn av manglende prioritering i kommunen. Rapporten peker videre på at uten et tilstrekkelig palliativt tilbud i kommunene, vil palliative enheter ved sykehus stå i fare for å måtte fungere som erstatning for syke- hjem, noe som ikke er i tråd med samhandlingsreformens intensjon, ikke kostnadseffektivt og ikke tilpasset brukerens behov.

En mulig løsning kan, som beskrevet i denne rapporten, være å etablere hospice i de større befolkningssentra og knytte hele eller deler av finansieringsansvaret til spesialisthelsetjenesten. Da sikrer man et tilbud med en lavere kostnad enn i spesialisthelsetjenesten samtidig som man ivaretar eller styrker kvaliteten og kontinuiteten i tjenesten. Å helt overføre finansieringsansvaret til spesialisthelsetjenesten vil gi uheldige incentiver for kommunene som vil søke å flytte flest mulig inn i hospice, også de som strengt tatt ikke trenger denne type tilbud. En mellomløsning kan være at finansieringsansvaret splittes mellom partene. Gitt at de løpende driftsutgiftene for hospice er lavere enn i situasjonen uten hospice, bør man utvikle finansieringsløsninger som gjør at både stat og kommune vil kunne redusere sine løpende utbetalinger.

Utbygging av flere hospiceplasser vil også kreve investeringer i bygg med relativt høy teknisk standard. Erfaringstall fra Danmark viser at et hospice med 12 senger koster mellom 42-50 millioner kroner. Nyere sykehjemsbygg med 100 plasser (i Norge) antas å koste mellom 500-700 millioner kroner. Ettersom hospicene vil ha færre plasser per enhet, vil investeringskostnaden per plass trolig være høyere enn et sykehjemsbygg med 100 plasser. Det er derfor naturlig å forvente at investeringskostnaden i Norge vil ligge mellom 600 og 1000 millioner (gitt 100 plasser). Netto budsjettkonsekvens vil imidlertid være mindre, ettersom behov for bevilgninger til utbygging av sykehjem og palliative enheter blir lavere. Dersom hospice i stor grad erstatter plasser på sykehus vil nettokostnaden knyttet til investeringer bli negativ. Dette fordi helseforetakene kan få redusert sine investeringer i sykehusbygg (som er dyrere å bygge enn hospice) .

\section{Drøfting og anbefaling}

Lindrende behandling og omsorg for døende har fått økende oppmerksomhet de siste 30 år. Helsedirektoratets fagrapport IS-2278 gir en god oversikt over de mange utredninger som har blitt publisert. Fagrapporten viser at helsetjenesten i dag søker å dekke behovene med en lang rekke ulike tilbud både $\mathrm{i}$ spesialisthelsetjenesten og kommunehelsetjenesten. Den store variasjonen i tilbud kan neppe forklares ved at pasient og pårørende har ulike ønsker i ulike sykehusområder og kommuner. Den må ha andre forklaringer. Enkelt- 
personers eller gruppers engasjement og tro på et spesielt tiltak kan medvirke til at ulike kommuner og sykehusområder har ulike tilbud. Budsjettmessige hensyn og oppfatninger om hva ulike typer tilbud koster, kan også ha betydning. Sist, men ikke minst kan helsepersonell, frivillige, administrativt ansatte og politikere være usikre på eller endog uenige om hvilke tilbud som er best.

Det synes å være enighet om at vanlige akuttavdelinger i sykehus eller vanlige sykehjemsplasser ikke er velegnet for lindrende behandling, men spørsmålet er hva samfunnet ellers kan tilby og hva de ulike løsninger koster. Helsedirektoratets fagrapport ga lite informasjon om kostnader ved den anbefalte «styrking» av lindrende behandling. De konkrete forslagene gjaldt små eller uspesifiserte bevilgninger til mer evaluering av omsorgstyper, mer forskning, mer utdanning av personell, mer bruk av ambulante tjenester fra sykehusene, bedre implementering av retningslinjer mv.

Når det er mangelfull kunnskap om hva som er de beste eller mest kostnadseffektive tilbud for lindrende behandling og omsorg ved livets slutt, er det grunn til å ta vare på tilbud som fungerer godt. Helsedirektoratets fagrapport peker på hospice som en god modell, og sier at «hospicefilosofien, som hadde sitt arnested på Cicely Saunders' hospice, har .....blitt retningsgivende for all palliasjon». Rapporten gir også eksempler på at hospice kan gi pasientene gode tilbud.

Våre økonomiske analyser tyder på kostnadene kan være nokså forskjellige ved de ulike omsorgsmodeller. Samfunnets tilbud må nødvendigvis ta hensyn til kostnadene fordi helsetjenestens budsjetter er begrensede. Dette betyr likevel ikke at de billigste løsningene som hovedregel skal velges. Hjemmepleie forutsetter at pasienten ønsker denne omsorgsform og at den syke og døende har pårørende som kan og vil delta i omsorgen. Den krever også erfarne og kompetente ansatte. Disse forhold legger nødvendigvis viktige begrensninger på bruken av hjemmepleie. Omsorg i sykehus, hva enten det gjelder palliative enheter/senger eller vanlige akuttsenger, vil vanligvis ha de høyeste kostnadene, men denne type omsorg kan være nødvendig når medisinske eller tekniske forhold krever det. Omsorg i hospice og sykehjem kommer kostnadsmessig i en mellomklasse og utgjør det viktigste tilbudet tallmessig.

Stortinget har sluttet seg til prinsippene i Prioriteringsmeldingen. Effekt, kostnad og alvorlighet skal være de sentrale elementer ved prioritering. Alvorlighet må nødvendigvis være høy i livets sluttfase. Effekten av god omsorg i livets sluttfase ligger ikke i livsforlengelse, men i livskvalitet og verdighet. Hensynet til kostnader vil da trolig bli tillagt mindre vekt. De som har «sørge-for-ansvaret» må nødvendigvis ta hensyn til budsjettbegrensninger, men antall aktuelle pasienter vil $\mathrm{i}$ alle fall ha moderat økning de nærmeste 10-15 år.

For mange vil frihet til å velge omsorgsform være viktig for pasient og pårørende i livets sluttfase. Per Fugelli som nå er død, sa at vi «bør ta døden tilbake» fordi «den er en dypt personlig eiendel». Og videre: «Har du vært et myndig menneske på jorden så skal du for faen føre også i siste dans». Underforstått: pasienten skal styre. Hospice med bidrag fra frivillige kan være ett av flere tilbud og som erfaringen viser så foretrekker mange pasienter og pårørende denne tjenesteprofilen.. Opphold her kan ha verdier som vanskelig kan tallfestes i en økonomisk analyse.

En modell man kan prøve ut er hospice med døgnplasser i større befolkningssentra. Disse kan også inneholde døgntjenester, dagplasser og ambulante team, samt fungere som kompetansesenter med ansvar for regionen. Jo bedre man får fulgt opp pasientene hjemme jo mindre behov er det for mer kostbare opphold i spesialist-helsetjenesten. Vi må bygge ut kapasiteten for å møte det økte behovet som kommer i årene fremover. Det kan være verdt å prøve ut hospice i større skala, i kombinasjon med en evaluering av tilbudet. 


\section{Flertallsmerknad til dissensene til utvalgsmedlemmene Rønsen og Pedersen}

Utvalgets flertall, bestående av de øvrige medlemmene, ved utvalgsleder Kaasa og utvalgsmedlemmene Andersen, Bahus, Broen, Farsund, Flovik, Hagerup, Husby, Schjødt og Slaaen, ønsker å ha en flertallsmerknad til dissensene til utvalgsmedlemmene Rønsen og Pedersen.

Flertallet ønsker å presisere at et samlet utvalg er enige om målsettingene: å styrke det palliative tilbudet til personer som trenger palliativ behandling. Et samlet utvalg stiller seg videre bak forståelsen av utfordringsbildet og samtlige tiltak utvalget foreslår, med unntak av to tiltak.

Uenigheten omhandler to konkrete tiltak:

1. Etablere frittstående hospice ulike steder i landet - med forsterket hjemmetilbud, dag- og døgnfunksjon. Det foreslås dekning mht døgnplasser på 250 plasser innen 5-10 år, og at hospice skal være en del av spesialisthelsetjenesten (statlig finansiert), men lagt utenfor sykehusets organisering og lokalisering, avtale via RHF. Det foreslås at ulike modeller skal prøves ut og evalueres. Det foreslås at egnede finansieringsordninger skal evalueres. I tiltaket heter det videre at «Hospice som «fyrtårnfunksjon» - skal fungere som utviklings- og kompetansesenter, aktivt samarbeide med kommunale tjenester; hospiteringsfunksjon, utviklings/forskningsprosjekter». Dette tiltaket er fremmet av utvalgsmedlem Rønsen, og støttes av utvalgsmedlem Pedersen.

2. Barnehospice bør inngå som en naturlig organisatorisk modell og som en del av totalløsning innen barnepalliasjon i Norge. Dette tiltaket er fremmet av utvalgsmedlem Pedersen og støttet av utvalgsmedlem Rønsen.

Flertallet ønsker å peke på to negative forhold som etablering av ovennevnte hospiceløsninger vil kunne føre til:

Norsk helsetjeneste er tuftet på et grunnleggende prinsipp om at alle pasienter skal få et likeverdig tilbud uansett hvor de bor i landet. Ved å gi et likeverdig tilbud i våre helse- og omsorgstjenester har man på svært mange områder oppnådd at Norge innen de fleste sektorer ligger på et høyt internasjonalt nivå. Innen palliasjon vil prinsippet om likeverdighet være sentralt (se ref). Dette gjelder spesielt for behandling, pleie og omsorg for døende pasienter. Vi ser fra Danmark at pasienter som mottar spesialisert palliasjon er pasienter med lang utdannelse og bedre inntekt og at denne forskjellen var enda større for dem som mottok hospice tjenester tilsvarende den modellen som mindretallet foreslår. Flertallet frykter at at hospiceetablering utenfor den etablerte helsetjenesten, med særlige avtalevilkår, vil bidra til ulikheter blant annen basert på sosioøkonomisk status. De to tiltakene foreslått av Rønsen og Pedersen vil kunne bidra til forskjellsbehandling, da langt fra alle $i$ et langstrakt Norge kan reise til hospice som typisk vil være sentralisert i større byer. Et tilbud organisert utenom de faglige og akademiske miljøene i Norge vil heller ikke kunne følge med i kunnskapsfronten og heller ikke bidra til ny kunnskap innenfor rammen av større nasjonale og internasjonale samarbeidsprosjekter. I Storbritania og Canada, som et eksempel, har man sett både klinisk og akademisk at hospice i dag blir en integrert del av helse- og omsorgstjenestene.

For å oppnå et likeverdig palliativt tilbud har utvalget lagt til grunn at tjenestene skal tilbys innenfor de eksisterende strukturer både innen spesialisthelsetjenesten og den kommunale helseog omsorgstjenesten.

Utvalget erkjenner at kvaliteten innen palliasjon i dag ikke er god nok. Det foreslås derfor en rekke tiltak både innen organisering av tjenestene, for å øke den faglige kompetansen, for å bedre kunnskapen gjennom forskning og for å arbeide med sentrale verdier innen palliasjon spesielt og norsk helsetjeneste generelt.

Manglende integrasjon i den øvrige helsetjenesten: Mange pasienter får i dag god livsforlengende behandling over lang tid. Det har skjedd store endringer de siste 10 årene for mange store sykdomsgrupper. For å kunne gjennomføre denne behandlingen, som gir flere år med god 
livskvalitet for mange pasienter, på en trygg og god måte, kreves det spisskompetanse innen medisin og sykepleie. Dette gjelder for alle pasienter men spesielt for barn. Livsforlengende behandling mot livets slutt er utfordrende og det kan føre til overbehandling. Derfor mener flertallet $\mathrm{i}$ utvalget at palliasjon må integreres inn $\mathrm{i}$ alle deler av de pasienttilpassede forløpene både i spesialisthelsetjenesten og i den kommunale helseog omsorgstjenesten og at den palliative medisinske kompetansen er tilstede $\mathrm{i}$ de tverrfaglige møtene. Samhandlingen mellom nivåene $\mathrm{i}$ helseog omsorgstjenestene vil også være en sentral oppgave for de palliative teamene som utvalget foreslår å fulletablere i spesialisthelsetjenesten og nyetablere i den kommunale helse- og omsorgstjenesten.

Nasjonalt og internasjonalt er det også erkjent at palliasjon bør være en integrert del av det generelle helsetilbudet. Det er i flere store konkluderende studier vist at en slik integrasjon gjør at pasientene får bedre livskvalitet, at de har bedre psykisk og fysisk helse og i noen tilfeller lever de også lengere.

Et av hovedtiltakene flertallet i utvalget derfor foreslår er en tydeligere og mer forutsigbar, plass av palliasjon inn i de pasientsentrerte forløpene. Dette vektlegges gjennom hele det palliative forløpet, men også spesielt når pasientene er døende.

Flertallet mener at etablering av egne hospice enheter for voksne og barn, slik Rønsen og Pedersen foreslår, vil gi en særomsorg for enkeltgrupper som flertallet mener kan ivaretas på en god måte innenfor dagens system - med de tiltakene et samlet utvalg foreslår.

Samlet sett mener flertallet at den løsningen flertallet foreslår søker å få til best mulig likebehandling ved å styrke behandlingstilbudet til pasienter med behov for palliativ behandling i alle deler av Norge.

Ved iverksetting av tiltakene slik et samlet utvalg foreslår, vil dette bidra til å gi gode palliative tjenester til dem som trenger det, der de er, også i hjemmet,spesielt til personer i livets siste fase og barn og unge som har behov for palliasjon. Palliasjon på et høyt internasjonalt nivå kan ivaretas på en god måte innenfor dagens system - forutsatt at de tiltakene et samlet utvalg foreslår blir implementert.

\section{Referanse}

Referansen fra Madrid EAPC konferansen 2017:Best Abstract/Mejor Abstract Social Inequalities in Admission to Specialist Palliative Care. A Nationwide Study from the Danish Palliative Care Database. Adsersen M.1, Thygesen L.C.2, Groenvold M.1,31Department of Palliative Medicine, Bispebjerg Hospital, Research Unit, Copenhagen, Denmark; 2National Institute of

Publich Health, University of Southern Denmark, Copenhagen, Denmark; 3Department of Publich Health, Copenhagen

University, Copenhagen, Denmark 
Bestilling av publikasjoner

Offentlige institusjoner:

Departementenes sikkerhets- og serviceorganisasjon Internett: www.publikasjoner.dep.no

E-post: publikasjonsbestilling@dss.dep.no

Telefon: 22240000

Privat sektor:

Internett: www.fagbokforlaget.no/offpub

E-post: offpub@fagbokforlaget.no

Telefon: 55386600

Publikasjonene er også tilgjengelige på www.regjeringen.no

Trykk: 07 Media AS - 12/2017 